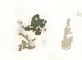

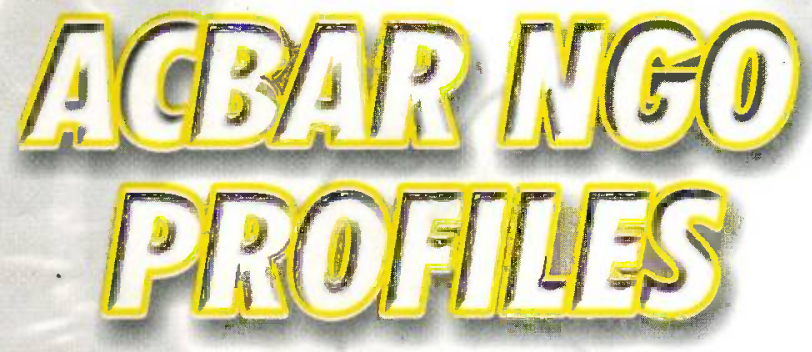

PROFILES \& OPERATIONAL DATA OF HUMANITARIAN AGENCIES WORKING IN AFGHANISTAN

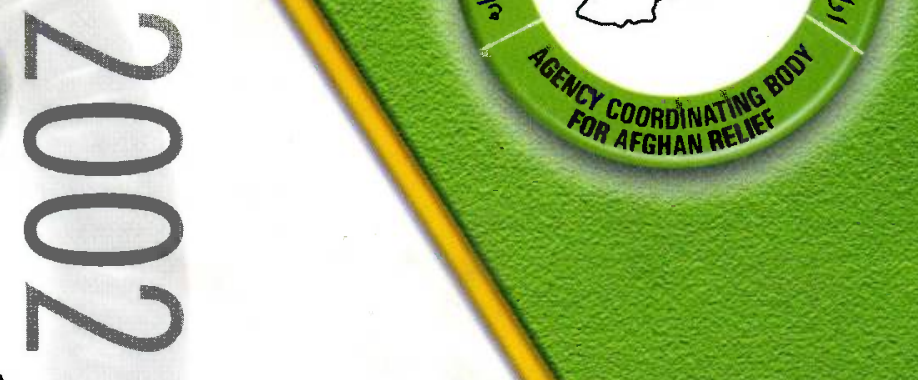




\section{AREA OFFICES}

\section{KABUL}

HERAT

JALALABAD

KANDAHAR

\section{PESHAWAR}

\section{Kabul.}

12 Jami Watt, Shahr-e-Now, Kabul, Afghanistan.

Tel: 0093-(0) 20-290136

Mob:0093-(0)70282090

E-mail: info@acbar.org

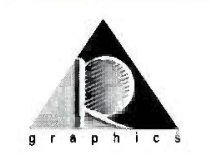

AL-REHMAN GRAPHICS

Jangi Street, Inside Kabuli Gate, Peshawar.

091-2564302, Mob:0300-5931437

E-mail:alrehman72@hotmail.com 


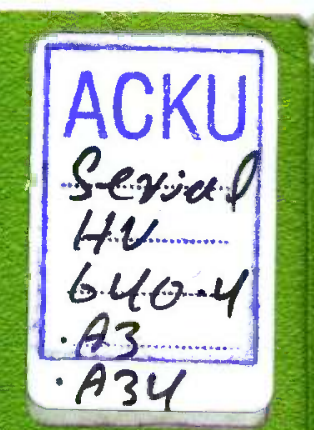




\section{INTRODUCTION}

I have the pleasure to introduce the 2002 edition of ACBAR's "Directory of NGOs working for Afghans". This is the $15^{\text {th }}$ edition and contains details on some 245 NGOs who have taken the effort to complete the forms.

While the survey does not include the totality of NGOs registered with the Government ${ }^{1}$, it does, with two or three exceptions, include the most meaningful actors of the NGO community here.

As is usual the details are presented in a standard format which facilitates the reading and provides a degree of NGO profiling and comparison. It also includes respective sectors of activity as well as contact details which we hope will be useful for programming purposes.

The survey was carried out during August and September 2002 through ACBAR's regional offices (Kabul, Peshawar, Herat, Mazar, and Jalalabad), and through 2 mobile teams deployed to Bamyan and Badakshan. The southern region and Baluchistan was surveyed between ACBAR's new Kandahar office and with much cooperation from SWABAC, whom I would like to thank very much here. I also wish to thank all the ACBAR staff who was so active in collecting and compiling this information.

In addition to this volume, we are printing the Database of NGO activities, derived from the same survey, and which contains some 2500 ongoing projects. We also will share the data with AIMS to enable the merging with UN project information and mapping of a comprehensive picture of the aid assistance to Afghanistan in 2002.

I hope that the various users, including agencies, donors, government officials and all others who are interested in the Afghanistan aid operations will find the data informative and useful.

Rafael Robillard Executive Director

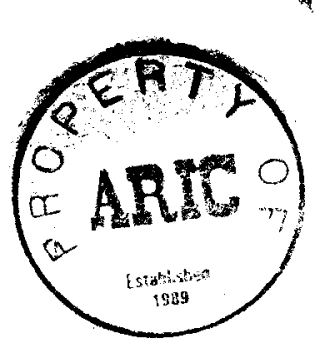

\footnotetext{
${ }^{1}$ Which at the time of writing sum no less than 1,060 .
} 


\section{Map of Afghanistan}

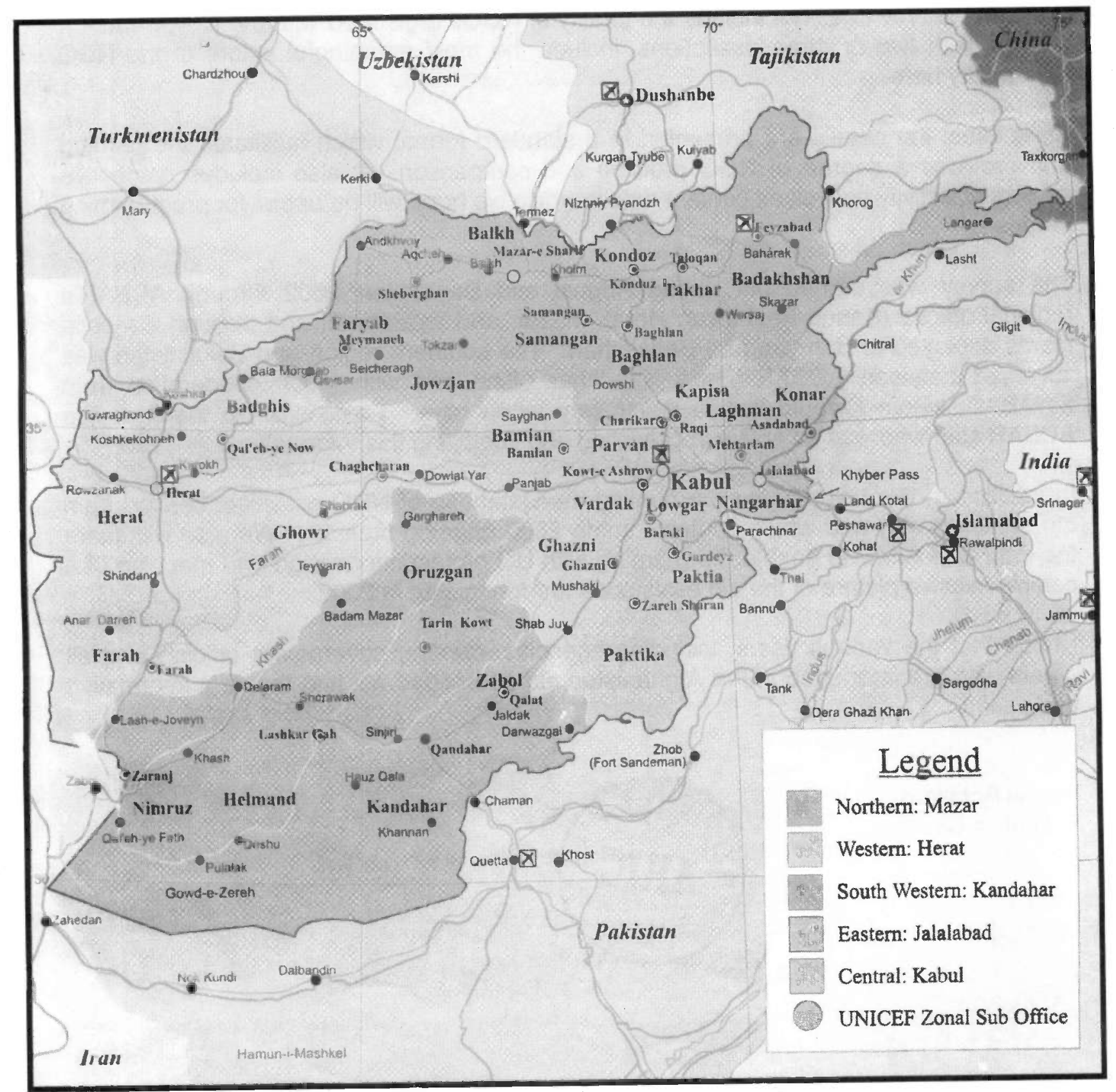




\section{STASTICAL SUMMARY}

\section{NGO's Activities per Sector}

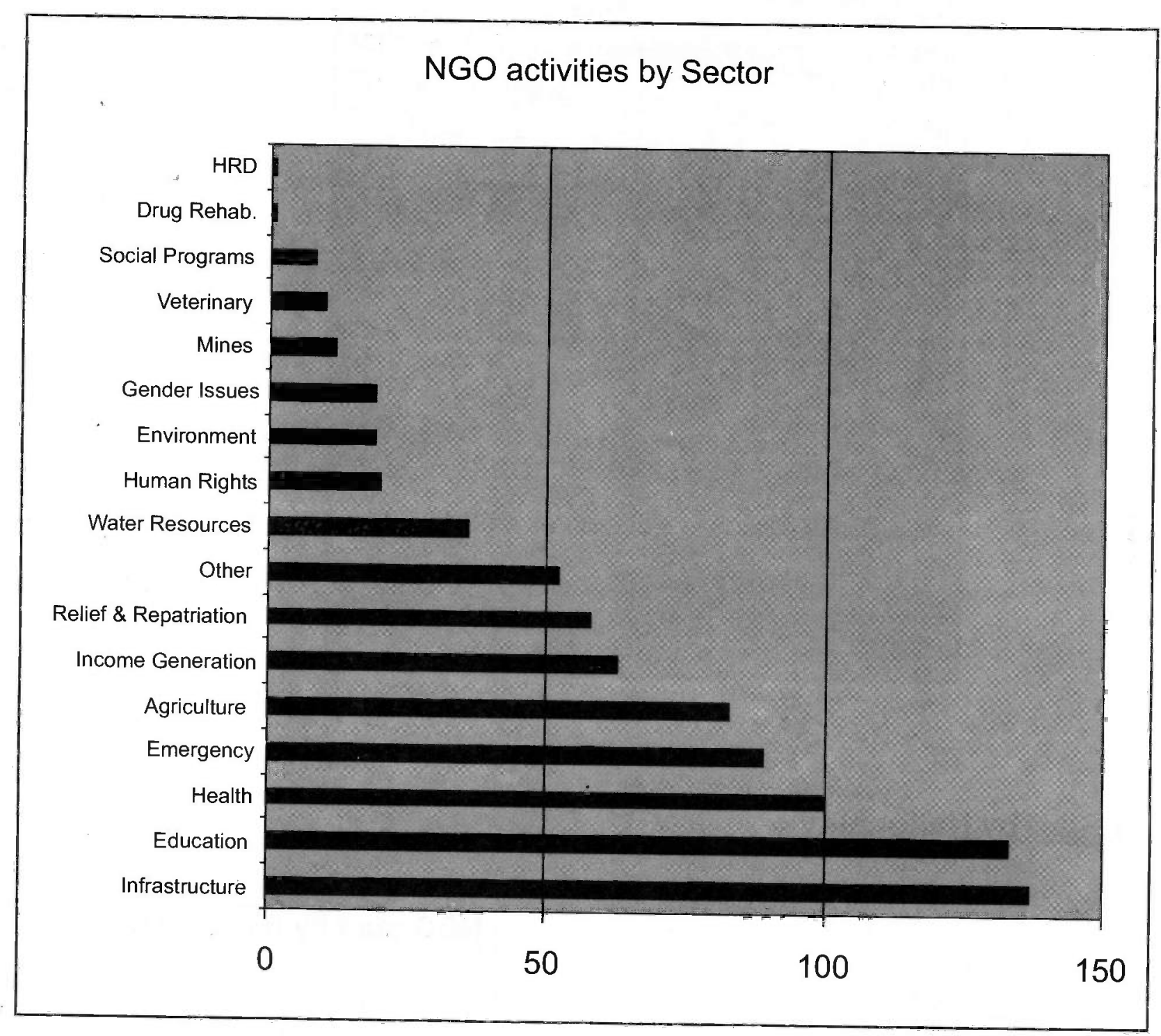


NGO's Activities per Sector

\begin{tabular}{|c|c|c|}
\hline \multicolumn{3}{|c|}{ NGO's activities per Sector } \\
\hline Sector & NGOS & \\
\hline Infrastructure & & 137 \\
\hline Education & & 133 \\
\hline $\begin{array}{l}\text { Health } \\
\text { Emergency }\end{array}$ & & $\begin{array}{r}100 \\
89\end{array}$ \\
\hline Agriculture & & 83 \\
\hline Income Generation & & 63 \\
\hline Relief \& Repatriation & & 58 \\
\hline Other & & 52 \\
\hline Water Resources & & 36 \\
\hline Human Rights & & 20 \\
\hline Environment & & 19 \\
\hline Gender Issues & & 19 \\
\hline Mines & & 12 \\
\hline Veterinary & & 10 \\
\hline Social Programs & & 8 \\
\hline Drug Rehab. & & 1 \\
\hline HRD & & $\frac{1}{1}$ \\
\hline Grand Total & & 841 \\
\hline & & \\
\hline
\end{tabular}

\section{NGO Staff by Nationality}

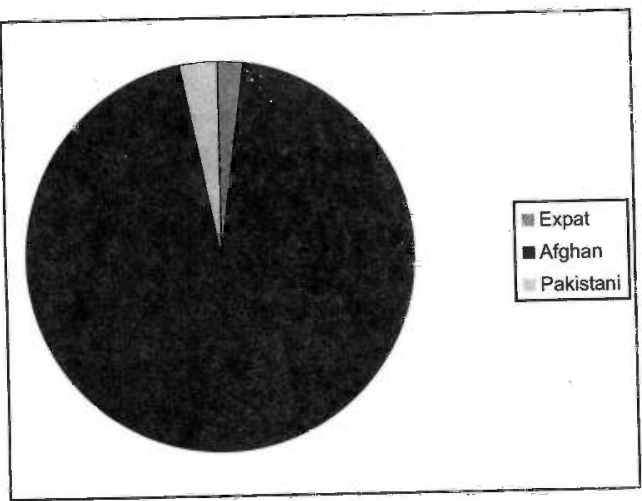

\begin{tabular}{|lll|l|}
\hline \multicolumn{3}{|l|}{ NGO staff by nationality } & \\
\hline & & & Total \\
\hline Expat & Afghan & Pakistani & \\
\hline 577 & $24907 \quad 816$ & $\mathbf{2 6 3 0 0}$ \\
\hline
\end{tabular}




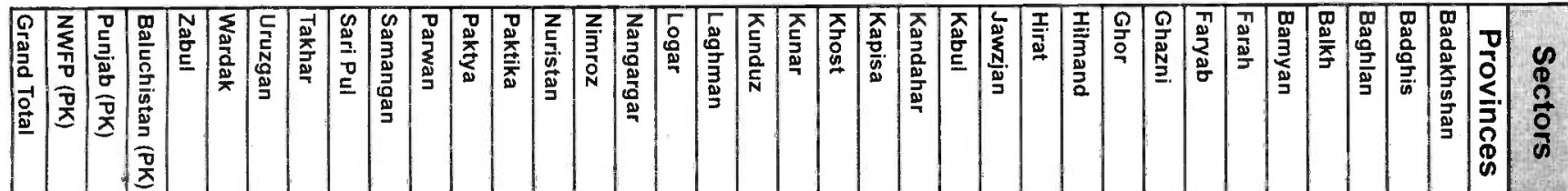

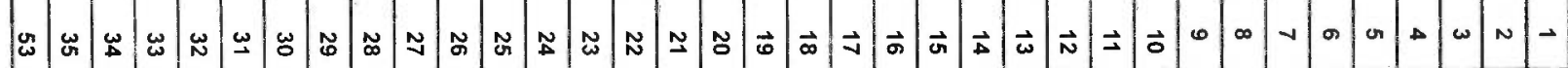

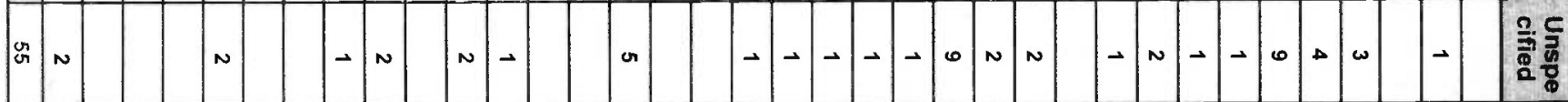

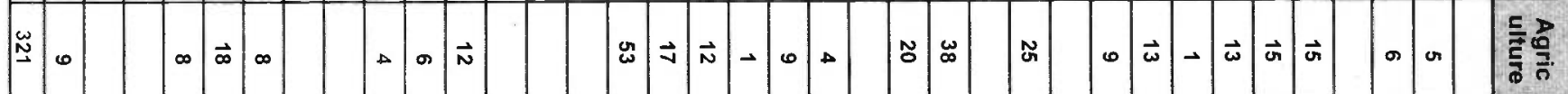

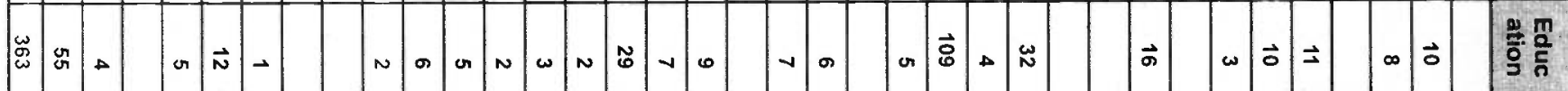

$\vec{\AA}$

N $\quad$ N O

$\omega$

ถึำ

n N

A

$\omega$

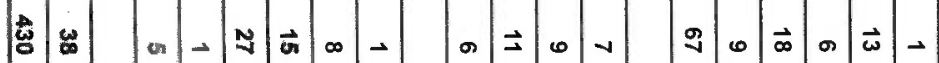

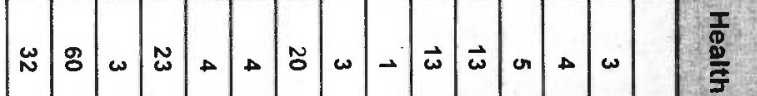

- $\rightarrow-$

N

4

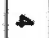

$\rightarrow \omega$

$\rightarrow \rightarrow-n$

끔ㅍ

$\because \infty$

$\rightarrow \quad \rightarrow \omega$

ज्ञ

$\omega \rightarrow \Delta N$

$\rightarrow 0 N$

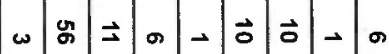

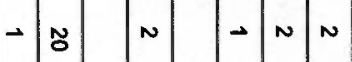

$\sin n \rightarrow-$

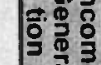

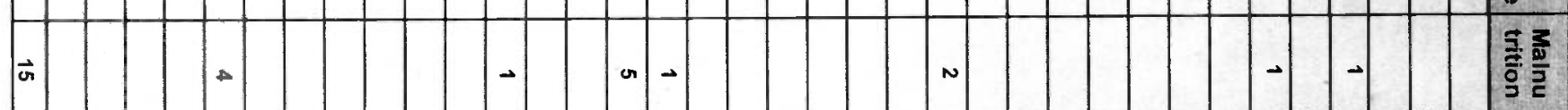

苔

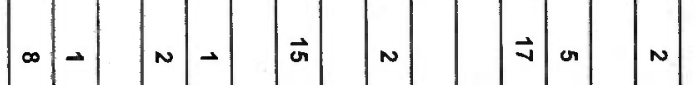

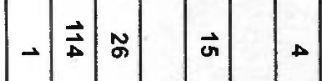

$\omega \vec{\omega}$

$\vec{\sigma}$ N

v N

$\rightarrow \rightarrow$

节

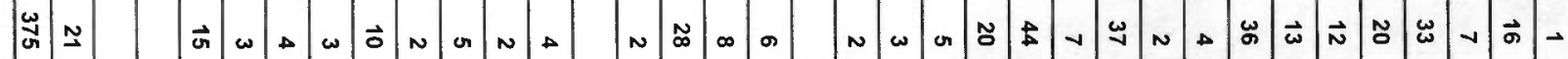

ก N

$\vec{\sigma} \quad \vec{\sigma}$

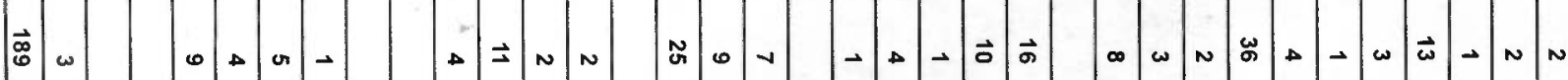

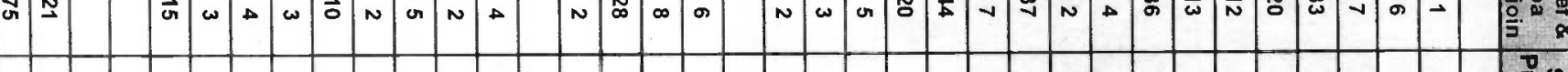

$\rightarrow \quad$ n

$n \rightarrow \rightarrow$

- or $\omega$

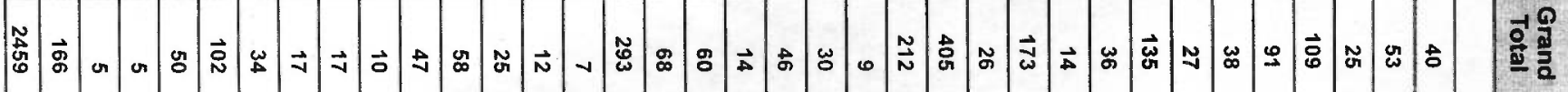




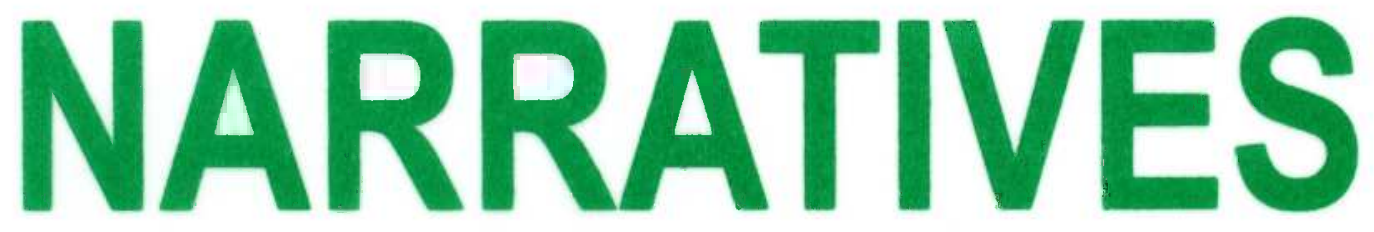

OF NGOs 


\section{AABRAR (Afghan Amputee Bicyclists for Rehabilitation Recreation)}

AABRAR was founded in July 1992 in Peshawar, Pakistan as a center providing rehabilitation, physiotherapy services and vocational training for landmine victims, polio victims, cerebral palsy victims, other people with disabilities, orphans, and disabled women and girls. It was officially inaugurated on 25 August 1992 in Jalalabad, Afghanistan.

AABRAR started its activities with the help of a UK based organization, Afghan Refugees Fund (ARF), following the successful completion of an ARF supported project. AABRAR has received grants from the Asio Foundation (AF), the European Union (EU) through IRC/RAP, the United Nations Comprehensive Disabled Afghans Project (CDAP/UNOPS) and UNICEF.

Curiently most of AABRAR's activities are funded by Caritas, Diakonie Emergency Fund, and Medico International e.v.Germany, and the World Food Programme.

\section{Afghanaid}

AA (Afghan Aid)

Afghan Aid is a British NGO, registered in the UK as a company limited by Guarantee number 3034888 and registered in the UKas Charts number 1045348.

Afghan Aid endeavors to assist the impoverished rural Afghan communities by building their capacity to enhance their economic and social development in a sustainable and equitable manner. Afghan Aid aims to give special attention to the basic needs of those members of the community who tend to be socially or economically marginalized.

Afghan Aid activities are mainly divided into two sectors:

1. Community Development program.

* Village Organization (VOs); = Women Group Organization (WGO's)

* $\quad$ Productive Community Infrastructure (PCI) = Micro finance (Micro credit). = Health education (HBD, TBA and H/for Women).

* $\quad$ Training (Staffand beneficiaries training), Agriculture

* Demonstration plots $>$ seed multiplication (Food sector). Water shed Management $>$ Agriculture > Animal Health <treatment and vaccination > Child Advancement Program (Peer Group) > Women Resource Centers (WRC). (Carpet weaving, tailoring, embroidery, knitting, literacy, > Health education.

2. Road Rehabilitation:

Main roads, bridges, retaining wall, road related all kinds of structures, we have pipe foundation factory etc...

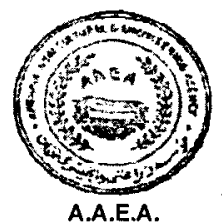

\section{AAEA (Afghan Agriculture and Engineering Agency)}

The Afghan Agriculture and Engineering Agency (AAEA) is a local Afghan NGO working in different sectors since 1993 for the reconstruction of Afghanistan. It is registered with the Ministry of Planning and has completed over 90 projects including projects in the agriculture and construction sectors. AAEA has 18 experienced staff who working on projects. 


\section{ABADY.ARDO (Afghanistan Rehabilitation \\ \& Development Organization)}

$A B A 4 D Y$ was established and registered on 4 November 1998 with the Ministry of Planning, as an Afghan non-profit, non-partisan, non-political and non-government humanitarian organization. It services the needs of the Afghan community and helps to rehabilitate and reconstruct Afghanistan in an environmentally appropriate manner.

$A B A D Y$ has experienced and skilled, technical and administrative staff committed to the ethical implementation of their projects. The organization is overseen by an Executive Board and managed by $a$ Director. Technical issues are controlled and evaluated by ABADY's Technical and Scientific Board.

Since the establishment of $A B A D Y$ it has functioned mostly in the vocational and education sector. It has implemented educational programs for girls, boys and adults, carpet weaving, literacy, calligraphy, foreign language training (English, German, French, and Arabic), computer software and school subjects for girls and boys whose education was disrupted during the Taliban regime.

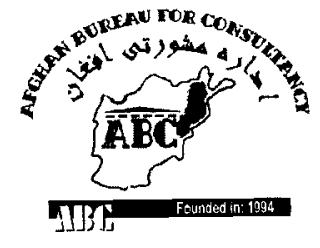

\section{ABC (Afghan Bureau for Consultancy)}

The Afghan Bureau for Consultancy ( $A B C$ ) is an Afghan non-governmental, nonpolitical, non-profitable humanitarian organization established in 1994.

$A B C$ 's mission is to create conditions conducive to sustain repatriation, improve the social infrastructure and provide health services to the Afghan community, especially for women and children. ABC has an emphasis on primary health training within the Afghan community through a range ofactivities including:

1. Reconstruction of public utilities

* school construction

* $\quad$ reconstruction of irrigation systems

* $\quad$ construction of drinking water supplies.

2. Women's health Development

* $\quad$ training of community health workers

* VHWtraining

* $\quad$ pre and post-natal care.

3. Income generation

* poultry production

* cheese production

* tailor training

$A B C$ is committed to full and complete accountability to the communities it services, local authorities and donor agencies. local authorities and donor agencies.

\section{ABC (Afghan Building Construction)}

The Afghan Building Construction ( $A B C$ ) is an independent, non-governmental, non-political, non-profit organization. It has close contact with other organizations working for the reconstruction and rehabilitation of Afghanistan. ABC was established in 1993.

The purpose and objective of $A B C$ is in rehabilitation and reconstruction activities. It emphases the sustainability of its projects for vulnerable groups it works with in different parts of Afghanistan. 


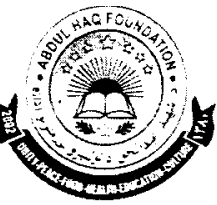

\section{Abdul Haq Foundation}

The Abdul Haq Foundation is a non-political, non-profit and non-governmental organization that promotes national unity, peace, democracy, prosperity and equality for all people in Afghanistan.

The Foundation is committed to caring for the national and Islamic identity of Afghanistan.

The Foundation supports the special groups in the Afghan community such as widows, orphans and the disabled.

The following areas also come under its operations.

1. Agriculture and irrigation

2. Education

3. Health

4. Security, women rights

5. Vocational training

6. Capacitybuilding

7. Rehabilitation

8. Cultural affairs.

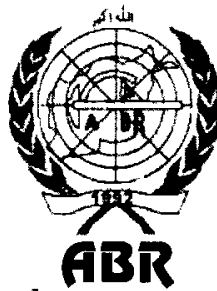

ABR (Afghan Bureau for Reconstruction)

The Afghan Bureau for Reconstruction (ABR) was established in 1992 to take part in the rehabilitation, reconstruction and development of Afghanistan. It is supported by the United Nations High Commission for Refugees (UNHCR), the World Food Program (WFP), United Nations Children's Fund (UNICEF), and the United Nations Office for Project other organizations in the private sector.

The organization is registered with the Ministry of Planning of Afghanistan. It has site offices in Nangarhar, Kabul and if required will open offices in more provinces.

$A B R$ is a non-governmental, non-political and non-profit organization. ABR is a technically oriented organization with the goal of reconstructing and developing Afghanistan. The nature of ABR's work is competitively based. ABR works either as an individual organization or in partnership with other organizations. The organization accepts orders from individuals, government departments and other organizations for projects. ABR implements proposals identified as needed by communities, and after completion of preliminary technical aspects will submit a proposal to donor agencies for funding.

$A B R$ operates purely on a humanitarian basis to organize various departments that shall function together to assist the people of Afghanistan by under taking various projects in different sectors to build the war torn infrastructures of the country. ABR coordinates and develops projects by cooperating with organizations having similar objectives and with donor organizations. ABR accepts grants and gifts from a wide range of sources, including governments, agencies, authorities, public bodies, corporations, companies and private donors.

\section{AC (AFGHAN CONNECTION)}

The Afghan Connection ( $A C$ ) is a small United Kingdom based charity that comprises individuals who in the past have been involved in a number of medical projects in Afghanistan. For example, orthopedic field teams in the 1980s, a mother and child clinic in Rokha, Panjshir in conjunction with the Swedish Committee of Afghanistan.

The current health project is to provide equipment, training and in conjunction with Pharmaciens Sans Frontieres, essential drugs to the pediatric intensive care unit, of the Indira Gandhi Hospital in Kabul under 


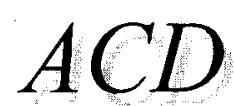

Afghan Committee for Development

\section{ACD (Afghan Committee for Development)}

The Afghan Committee for Development (ACD) is a public utility institution initiated in 1996. It activities are to promote the handicrafts and traditional products of Afghanistan in order to finance the organization's education projects.

We have 20,000 students (girls and boys) in 100 ACD home based schools in all districts of Kabul city. With the establishment of the Islamic Interim Administration of Afghanistan the home based schools were brought under the authority of the Ministry of Education.

Most of ACD's activities are related to education, as the organization sees that it is the first step towards building a civil society. It is the key to the fulfillment of human rights and is the heart of all development.

$A C D$ has received support The United Nations International Childrens Educational Fund (UNICEF), the International Committee of the Red Cross (ICRC), the United Nations High Commission for Refugees (UNHCR) and Children in Crisis (CiC) in its educational work.

$A C D$ also provides vocational courses for orphans, street children, returnees and disabled people in carpentry, carpet weaving, knitting and shoe making. Through such courses ACD aims to make such groups self-sufficient.

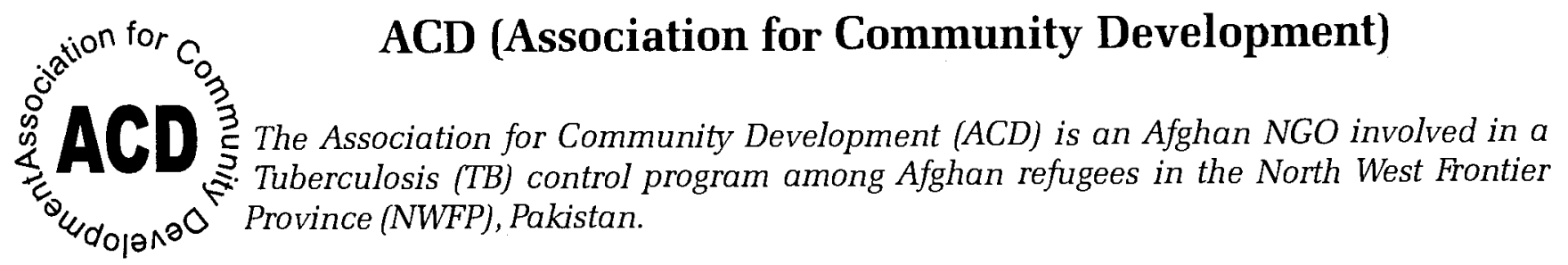

It is registered with the Government of NWFP and is managed by a team of technical experts who have worked in the NWFP for the health of Afghan refugees since 1985. ACD came into existence at the end of 2000 when ICD completed its activities.

$A C D$ works in closed liaison with the provincial and national TB control programs in Pakistan, especially in the areas of training and monitoring needs assessments. The organization supports the World Health Organization (WHO) and national and provincial TB program preparedness exercises.

ACD in partnership with Health Net International (HNI) is implementing TB control programs among Afghan refugees in collaboration with the United Nations High Commission for Refugees (UNHCR) and 12 national and international NGOs. The organization supports 100 basic health centers and 45 field laboratories. ACD/HNI provide technical support in needs assessment, protocol development, implementation, monitoring, evaluation, and capacity building for TB programs and case management. Additionally, ACD/HNI supports its partners in setting up laboratories for TB diagnosis.

\section{ACDO (Afghan Community Development Organization)}

The Afghan Community Development Organization (ACDO) is a non-governmental, non-political, nonprofit, voluntary and humanitarian organization founded 1 January, 1991.

The two and a half decades of war and its consequences, neglect and deprivation have ravaged Afghanistan's natural resources, caused pollution, the existence of millions of land mines and rapid population growth combined with damage to the environment, rehabilitation and the compromising of health and living standards. The country's valuable old growth forests, woodlands and systems essential 
for productive land have been destroyed or seriously depleted. Museums, archives and historical relics as well as other resources have been damaged or looted.

$A C D O$ is an Afghan managed and operated organization dedicated to sustainable activities for the rehabilitation of engineering, agriculture, health, income generation, infrastructure and relief efforts for Afghanistan. ACDO will function in line with and within the laws and regulations of the government of Afghanistan and is registered with Ministry of Planning. It is registered with the Government of Pakistan.

ACDO's main tasks are to assist Afghan people in Afghanistan and Pakistan in the following sectors

$\begin{array}{ll}\text { 1. } & \text { Education } \\ \text { 2. } & \text { Health } \\ \text { 3. } & \text { Incomegeneration } \\ \text { 4. . } & \text { Construction } \\ \text { 5. } & \text { Irrigation } \\ \text { 6. } & \text { Agriculture. }\end{array}$

\section{ACLU(Afghan Construction Logistics Unit)}

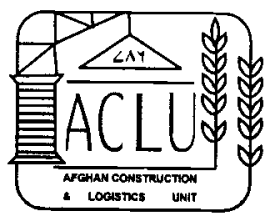

The Afghan Construction and Logistics Unit (ACLU) was established in October 1988 with the direct financial support of USAID. The initial aim was to provide transport for commodities and arrange for the transportation of refugees returning to Afghanistan and to repair and rebuild the damaged roads and bridges of the country.

At the end of June 1993 when US financial aid ceased in Afghanistan. ACLU was converted to a non-governmental, non-political and self-financing NGO, with its main headquarters in Peshawar.

ACLU has over 300 pieces of heavy and light construction equipment and machinery and employs only qualified and experienced engineers and staff for its projects. Since its establishment, ACLU has completed over 152 projects of various types, including

- nearly 60 bridges

- more than $1400 \mathrm{kms}$ of road works

- 100,000 square feet of completed buildings

- $160 \mathrm{kms}$ of irrigation canels

- more than 20 tube wells, three intakes, six water supply and sanitation schemes

- implementation of more than 10 emergency relief projects.

ACLU also transports materials for other NGOs and rents its equipment to other organizations when it is not being used by $A C L U$.

\section{ACRU (Ariana Construction \& Rehabilitation Unit)}

Ariana Construction and Rehabilitation Unit (ACRU) is an Afghan non-governmental, non-political, non-profitable and humanitarian voluntary organization established in 1991. Its aim is to oversee and implement projects for the rehabilitation of Afghanistan, in the sectors of irrigation, transportation, agriculture resources, poultry and educational programs.

The main office is located in Kabul, Afghanistan with five regional offices in Logar, Mazar-e-Sharif, Badakhshan, Kapisa, Paktika and one liaison office in Peshawar. ACRU has been carrying out its activities and services in Kabul, Logar, Khost, Paktia, Paktika and Badakhshan provinces in the sectors of 
construction and rehabilitation of roads, bridges, water supply (pipe schemes, shallow wells, drawing points), shelter, irrigation, poultry, food production, capacity building, emergency and free distribution.

A five-member board of directors governs ACRU.

$A C R U$ is committed to providing its employees with adequate benefits and facilities to enable them to perform their duties satisfactorily and enjoy a good working atmosphere.

peace

\section{ACSF (Afghan Civil Society Forum)}

The Afghan Civil Society Forum (ACSF) was launched by Swiss Peace Afghan Civil Society Forum (Swiss Peace Foundation) based on suggestions from participants at the Afghan Civil Society Meeting, held in 2001 in Bad Honnef, Germany held parallel to the un-sponsored meeting of political factions. ACSF began its work in February 2002. ACSF is currently a project within Swiss Peace, but the next aim is to make it into an independent Afghan organization within the next one to three years.

Swiss Peace was founded in 1988 as an independent action-oriented peace research institute with an international reputation for research on peace and conflict. The major goal of Swiss Peace's scientific and practical activities is a general and lasting reduction in organized violence between and within states and thus the prevention and transformation of armed conflicts.

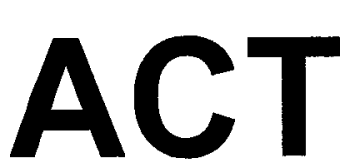

ACT (Agency for Construction and Training)

The Agency for Construction and Training (ACT) is an off-spring of the Pak-Germany Technical Training program which commenced vocational training to Afghan refugees and Pakistanis in September 1995. ACT is a non-governmental, non-political, non-sectarian and non-profit organization.

ACT aims to reach a large number of illiterate, less educated, unskilled and semi skilled Afghan youths to train them in different market oriented trades and to assist them to enter the open market to enable to become either employed or self employed and eventually self reliant. ACT also aims to provide skilled labor to the local Afghan economy and to improve the capacity of the workforce to meet further challenges of development and open market competition.

ACT specializes in teacher training programs and vocational training in the areas of masonry, tinsmith, welding, carpentry, plumbing, electrics and carpet weaving.

\section{Action Aid \\ actıonaid afghanistan \\ Action Aid's work in Afghanistan concentrates primarily on local level capacity building and community mobilization, as designated under Pillar I of the National Development Framework. Key activities include community empowerment and development training, both at the village level and within local NGOs.}

The program also aims to establish a strong policy network, and to disseminate relevant information at the community level.

Finally, Action Aid hopes to facilitate a process of interaction between policy makers and local civil society. The overall aim of the program is to construct a channel through which the voices of the country's poor will be heard and listened to. 


\section{ADA (Afghan Development Association)}

The Afghan Development Association (ADA) was founded 31 October, 1990. After it was established ADA consulted with various donors to obtain support to work inside Afghanistan.

A needs assessment survey was completed in 11 Districts of Afghanistan in 1991 and a One Year Plan for an integrated Rural Development Project was implemented successfully. In 1992 ADA built the capacity of its staff and maintaining good relations with the community and donors. A three-year plan for the development of different donors on a partial basis supported this project.

$A D A$ has played a significant role in improving the living conditions of Afghan people through implementing integrated rural development and refugee resettlement projects. Since its inception it has worked with individuals, communities and villages to enable them to take charge of their own destiny and become less vulnerable.

\section{ADEA}

\section{ADEA (Afghanistan Development and EngineeringAgency)}

Afghanistan Development and Engineering Agency (ADEA) is a local Afghan NGO which has been working in different sectors for the rehabilitation of Afghanistan. This organization has been established since 1996. It has twenty three skilled staff who are busy working and implementing of projects.

So the two projects are currently running in Sahak Village and Qaria Tangai Village of Puli Charkhi.

\section{ADEB ADEB (Afghan Development and Emergency Bureau)}

Afghan Development and Emergency Bureau (ADEB) is a non-governmental, non-religious, non-political, Kabul based agency with its sub-office in the Khost province. The agency was established in 1997 and it is registered with the Ministry of Planning in Kabul, Afghanistan.

ADEB has implemented a number of projects in partnership with WFP, Canada Fund, AusAID, and DFID/CARE International in both Khost and Paktya provinces of Afghanistan.

$A D E B$ is trying to expand its geographical area as well as its donor base in the current year.

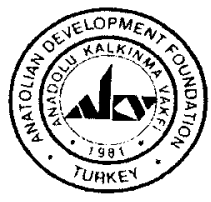

\section{ADF (Anatolian Development Foundation)}

Anatolian Development Foundation (ADF) is the biggest implementing partner of UNHCR in Turkey and is a member of ICVA. In order to respond to the situation in Afghanistan, it started to work under the umbrella of the Joint Relief Afghanistan Consortium (ADF- DiakonieCaritas-HEKS). Since early October, 2001 ADF and its partners have been in Pakistan. As of August 2002, the Consortium's total value of support reached to USD $\$ 3,728,138$ and up until now, its Islamabad office has complete 6 projects through the distribution of 2,750 winter tents, 5,500 blankets, 5,000 winter clothes sets for children, 7,500 children winter jackets and 500 food items for homeless Afghan refugee families. The office is planning to rehabilitate 35 schools in Kandahar, and to distribute 1,250 kerosene heaters, 500 wind up radios, and 25,000 educational stationary bags inside Afghanistan and Pakistan to needy Afghans during the year 2002. For the time being, the Islamabad office is running a capacity building project for a local NGO, an educational publication project for refugee children and a rehabilitation project for 5 schools in Nangarhar. 
With offices in Islamabad Pakistan, Kabul and Kandahar Afghanistan and a temporary presence in Iran, the Consortium is well prepared to respond to existing needs. Qualified staff, administrative structures and technical equipment are in place.

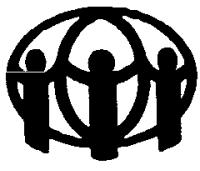
ADRA

\section{ADRA (Adventist Development and Relief Agency)}

The Adventist Development and Relief Agency (ADRA) is the worldwide humanitarian aid organization of the Seven-day Adventist Church. It fulfills its primary purpose of teaching individuals and communities to help themselves and disaster relief without regard as to race, gender, political or religious affiliation.

ADRA operates in five core portfolio activities: Food security, economic development, primary health, disaster response and preparedness and basic education.

ADRA is a network of independent country offices in more than 120 countries. ADRA is a recently registered international NGO in Afghanistan.

In the future, ADRA is determined to continue helping the people of Afghanistan to recover from the effects of over 20 years of war.

\section{AFRANE AFRANE (Amitie Franco-Afghane)}

Amitie Fraco-Afghane (AFRANE) started its activities in Afghanistan in 1980. From 1980 to 1985, it carried out every year emergency help missions in Kunar, Kabul, Logar, Badghis, Faryab, Ghazni, Badakhashan, Baghlan, Kandahar, Kunduz and Zabul provinces, thanks to the generosity of private donors. The yearly budgets of these humanitarian missions increased from US\$18000 in 1980 to US\$240000 in 1985. From 1986, AFRANE started to focus its activities on rural development activities, funded by private donations and IRC/RAP.

Many projects on irrigation systems rehabilitation, seed improvement and distribution, fertilizer proper rates finding and distribution, mechanization, fruit trees nurseries and support to schools were implemented between 1987 and 1994 in the above provinces. At the same time, the funding sources diversified with funding received from private donations, IRC/RAP, Secours catholiqe, UNHCR, WFP, FAO, EU, UNDP and the French Government. During this period, the yearly budget oscillated between US\$100,000 and US\$1,050,000. In 1994 and 1995, AFRANE funded by ECHO, implemented large sanitation and water supply projects in Kabul.

From 1996 to 1999 AFRANE decreased its rural activities, keeping only one office in Peshawar (closed in 1998) and two sub offices in Logar and Ghazni Provinces. At the same time it increased its education activity in Jalalabad, Kabul, Chaharikar and Hazzarajat, through French Government funding sources, private donations and self fund raising in France. AFRANE is publishing a magazine called "Les Nouvelles d'Afghanistan" in France. The educational activities consisted of supporting the Isteqlal schools with salaries to the teachers, stationary and pedagogical support.

From 2000 to date, AFRANE wanted to restart its rural activities and implemented several karez rehabilitation projects in Logar province, submitted many other projects for Ghazni and Logar provinces, and continued to develop its educational program through the rehabilitation and construction of schools, pedagogical support and the provision of stationary. 


\section{AFS (Agency for Farming Support)}

The Agency for Farming Support (AFS) is an independent non-political and non-profit organization. It was established in 1991 with its headquarters in Kabul and brunch offices in Jalalabad and Peshawar, Pakistan.

$A F S^{\prime}$ mission is to contribute in reconstruction and rehabilitation, and work for the sustainable development of Afghanistan.

The agency is registered with the government in Afghanistan. AFS is an active member of the coordinating bodies and officials in Afghanistan and Pakistan has endorsed its activities.

AFS' target areas include but are not limited to central, eastern and southern Afghanistan.

AFS has received funds from UN agencies, IRC and NCA, and is being supported by several other international organizations. AFS has experience and interest in the provision of the following activities and services both inside Afghanistan and for the Afghan refugees in Pakistan:

Basic Human Needs: to support education, primary health care, income generation, nutrition, safe drinking water, sanitation, shelter and family planning services for the least privileged and needy segments of the Afghan population.

Women in Development: to raise their economic and social status and work for their participation in the development of the Afghan society human resource development and work opportunity.

Infrastructure Development: to build agriculture related infrastructure with the purpose of contributing towards food security and sustainable agriculture.

Environmental Protection: to protect the environment through tree planning and greenery activities, preventing soil erosion and degradation, biodiversity conservation and to provide environmental hygiene awareness in the country.

AFS has a strong team of professionals who have been able to successfully implement programs under difficult circumstances and are ready to continue in the future for a better of life of the miserable segment of Afghan society.

AFS undertakes planning, designing and execution of project aimed at help the people to help themselves through individual and community participation.

Altogether 45 projects, mainly in infrastructure development, women development, income-generation, environment including water and sanitation, agriculture inputs and services in six provinces and Afghan refugee camps in NWFP, Pakistan.

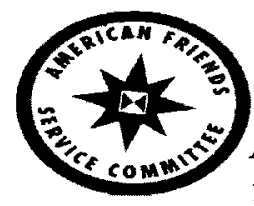

\section{AFSC (American Friends Service Committee)}

American Friends Service Committee (AFSC) is an independent Quaker organization which was founded in 1917 to provide conscientious objectors with an opportunity to aid civilian victims during World War I. Today it carries on programs of service development, social justice and peace education in 22 foreign countries and 43 places in the United States. It works in many troubled regions of the world to promote peace, justice and reconciliation.

Its work is based on Quaker belief in the dignity and worth of every person and on faith in the power of love and non violence to bring about social change. AFSC received the Noble Peace Prize in 1947. 


\section{AG BAS-ED (Afghan German Basic Education)}

Afghan German Basic Education (AG BAS-ED) was established in June 1996 to revive and reinstate the education system of Afghanistan. AG BAS-ED is now active in 8 provinces of Afghanistan providing education facilities to more than 30,000 students, both boys and girls and a total of 700 teachers have been trained by the project.

AG BAS-ED also provides health education for females aged between 15-50 and adult literacy for males and females. $A G$ BAS-ED is an active member of ACBAR, ANCB and has registered with Ministry of Planning of the Afghan Government. AG BAS-ED has officially signed the cooperation protocol with the Ministry of Education in Kabul as well as with the provincial education departments.

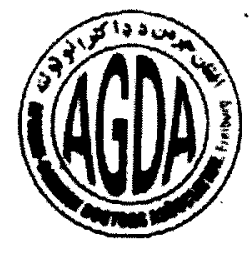

\section{AGDA (Afghan German Doctors Association)}

Afghan German Doctors Association (AGDA) was established in 1997 in Freeburg, Germany by Afghan and German Doctors. This organization works in the health sector and started its activity in April, 1999 in Jalalabad, Afghanistan.

AGDA has a MCH clinic in Jalalabad city as well as helping several public hospitals such as the Nangarhar Public Health Hospital, Nangarhar Medical Faculty Teaching Hospital and the Wazir Akbar Khan Hospital in Kabul. ADGA decided to establish a one year ultrasound training program for Afghan doctors in Kabul.

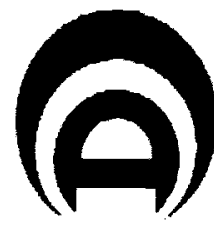

\section{AGHCO (Afghan/German Help Coordination Office)}

Afghanistan.

Afghan/German Help Coordination Office (AGHCO) is a non-government, non-political and non-profitable organization which was established in 1991 to assist in the rehabilitation of Afghanistan and to secure the operation of relief and rehabilitation activities inside

This organization originated from Afghanistan Nothilfe (ANH-Germany) in 1991. AGHCO was cooperating with ANH-Germany from 1986 to 1991.

AGHCO by having sufficient capability of executing operational, financial, management and implementation, started its efforts for rehabilitation of Afghanistan in the sectors of health, construction, irrigation, water and sanitation, income generation and reliefand emergency.

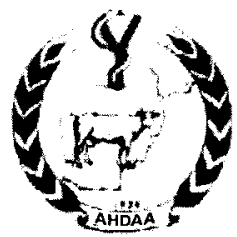

\section{AHDAA (Animal Husbandry and Development Association for Afghanistan)}

Animal Husbandry and Development Association for Afghanistan (AHDAA) was founded on 29th March, 1996 and was registered in the Representative Office of the Ministry of Foreign Affairs in Herat on $16^{\text {th }}$ August, 1996. On $17^{\text {th }}$ December, 1996 the organization was registered with UONHA and with the Ministry of Planning on $5^{\text {th }}$ June, 2000.

This is a charitable organization working for the welfare and development of the Afghan society. This is non political, non-governmental organization and its board consists of nine members.

Some of the important projects which are implemented by AHDAA include pipe scheme drinking water reservoir in Gulran district, agriculture farm power and training workshop, emergency food program, 
emergency distribution of non-food items, emergency distribution of wheat seed and farm power, emergency distribution of chickpea and fertilizer, rehabilitation of karezes, construction of Ziragi retaining
wall. These are all funded by different donors.

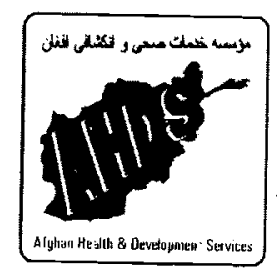

\section{AHDS (Afghan Health and Development Services)}

AHDS is a non-profit, non-governmental and non-political organization founded by Afghans on $7^{\text {th }}$ April, 1990 to address the health care needs of the Afghan population. AHDS is registered in Afghanistan as a national NGO, in Pakistan as an Afghan NGO, and in the USA as a tax-exempt organization. AHDS has concerned itself in the rehabilitation of Afghanistan's health infrastructure and in providing comprehensive primary health care services to the needy Afghan population.

Projects:

- Primary Health Care through the establishment and operation of 18 health facilities in the provinces of Logar, Nangarhar and Wardak (handed over)

Primary Health Care through the establishment and operation of 39 health facilities in the provinces of Kandahar and Uruzgan

Reconstruction of physical infrastructures of 18 totally or partially destroyed health facilities of the Ministry of Public Health (complete)

- Capacity building through the Regional Training Center in Kandahar City for community health workers, traditional birth attendants, and other male and female health staff

- Community mobilization through the establishment of community health committees

Supplementary feeding program through 10 MCH centers in Kandahar and Uruzgan

Water and sanitation in Uruzgan province

Expansion of PHCs in remote areas of Kandahar, Uruzgan and Samangan.

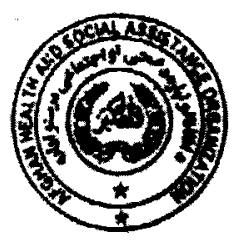

\section{AHSAO (Afghan Health and Social Assistance Organization)}

Afghan Health and Social Assistance Organization (AHSAO) was established in June, 1985 by the Late Dr.M.Nasim Ludin in Peshawar, Pakistan. It is an Afghan NGO registered with the Government of Pakistan and Afghanistan. AHSAO is a member of ACBAR and ANCB.

This organization started its activities by establishing a 40-bed Childrens Hospital and Out Patient Department (OPD) in Peshawar, Pakistan for Afghan refugees. This organization is implementing projects in various parts of Afghanistan with the following aims:

- To take an active part in the rehabilitation of Afghanistan in different sectors.

- To provide income generation and employment opportunities to the people of Afghanistan.

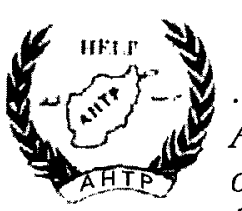

\section{AHTP (Afghan Help \& Training Program)}

Afghan Help \& Training Program (AHTP) is a non-governmental, non-profitable Afghan organization which was established in 1993. AHTP is engaged in providing services in the fields of health care, health education, veterinary, agriculture and emergency relief. AHTP manages its programs through a main office in Peshawar and sub offices in Kabul and Nangarhar provinces. AHTP has registration with the Ministry of Planning; Afghan High Commissioner in Peshawar and SAFRON in Islamabad.

The main objective of AHTP is to take part in capacity building at national, organizational and community level; restoration of the existing economic resources; and eradication of poverty through implementing of 
the projects in the field of health care, health education, veterinary, agriculture and emergency relief. AHTP seeks to contribute in establishing a peaceful and calm environment in Afghanistan in order to repatriate the Afghan refugees. Ongoing projects are UNHCR and cattle feeding projects which is funded by CORDAID.

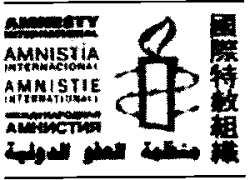

AI (Amnesty International) AMNESTI INTERNATIONAL grave abuses of the rights to physical and integrity, freedom of conscience and expression, and freedom from discrimination, within the context of its work to promote all human rights. Amnesty International addresses governments, intergovernmental organizations, armed political groups, companies and other non- state actors. Amnesty International seeks to disclose human rights abuses accurately, quickly and persistently. It systematically researches the facts of individual cases and patterns of human rights abuses. These findings are publicized, and members, supporters and staff mobilize public pressure on governments and others to stop the abuses.

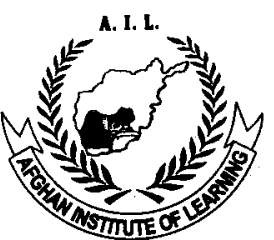

\section{AIL (Afghan Institute of Learning)}

The Afghan Institute of Learning (AIL) is an Afghan nongovernmental organization which was founded in 1995 in Pakistan by Professor Sakena Yaccobi, to assist Afghan women and children. The organization works to empower Afghan who are needy and oppressed by expanding their educational and health opportunities and by fostering self reliance and community participation. It is run entirely by Afghan women and they are one of the largest employees of Afghan women.

AlL has offices in Peshawar Pakistan, Jalalabad, Kabul and Hirat, Afghanistan. It provides comprehensive education and health services to about 300,000 Afghan women and children annually by:

$\varnothing$ providing equal educational opportunities through preschools, primary and secondary schools, enrichmentclasses, a newly opened university and women's learning centers,

$\varnothing$ supporting home literacy classes and income generation training projects for needy women,

$\varnothing$ training female teachers (5,000 trained to date) and developing teacher training curricula,

$\varnothing$ providing leadership and human rights training for Afghan women,

$\emptyset$ providing health education and basic health services to thousands of women and children,

$\varnothing$ training health educators, vaccinators and other health professionals, and

providing advanced software and hardware computer training.

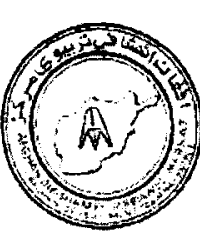

\section{AITM (Afghan Inkishaafee Tarbiawee Markaz)}

Afghan Inkishaafee Tarbiawee Markaz (AITM) was initially established as the Save the Children Fund (UK) Training Unit which was based in Peshawar and provided health and some community development.

AITM since its establishment in 1989 up to the end of 2001 succeeded in training around 4500 staff members from 160 Afghanistan and Pakistan based Afghan NGOs, International NGOs and UN organizations. The trainees are involved in the implementation of reconstruction, rehabilitation, voluntary repatriation and rural development. Courses were held in Ghor, Nuristan, Hirat, Kandahar, Ghazni, Khost, Gardez, Kabul, Jalalabad, Badakhshan and Peshawar in management, training and community participating skills. An important advantage of the organization is the training of women with over $30 \%$ of the course participants being women. 


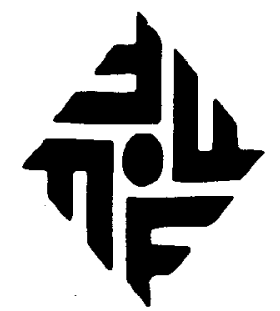

\section{AKDN (Aga Khan Development Network)}

The Aga Khan Development Network (AKDN) is a group of private, non-denominational development agencies and institutions that seek to empower communities and individuals, often in disadvantaged circumstances, to improve living conditions and opportunities. Established by the Ismaili Imamat (office of spiritual leadership) and working in over 20 countries, the Network's underlying impulse is the ethic of compassion for the vulnerable in society and its agencies and institution's work for the common good of all citizens, regardless of origin, gender or religion.

AKDN has a long-term commitment to Afghanistan and the central Asian region. From its long-standing work in Pakistan, Tajikistan and other areas of central Asia, AKDN can draw on substantial experience in post-conflict reconstruction, communal conflicts, high mountain societies, community-based social and economic development, cultural rehabilitation and revival, and support to public sector reform and to the private sector. AKDN has had a presence in Afghanistan since 1996 through one of its affiliated agencies Focus Humanitarian Assistance.

A substantial logistical infrastructure has been built to provide humanitarian assistance, agriculture rehabilitation and support to basic education and health predominantly in the northeast of the country. With the support of the Aga Khan Foundation and other agencies, FOCUS manages an integrated agricultural rehabilitation and development program that aims to achieve sustainable food security and peace. This program is currently concentrated in Darwaz, Shekay, Sheghnan, Ishkhashem, Zebak, Wakhan, Vardooj, Baharak, Jurm Yomgan, Kuran-wa-Munjan, Darayem, Yaftalha and Agro. Over the last four years, the AKDN humanitarian program has grown from \$67,000 in 1996 to a larger integrated program of around $\$ 11$ million in 2001.

AKDN is a family of agencies, created by His Highness the Aga Khan, with distinct, yet complementary mandates. AKDN agencies address three main areas of activity: social development, culture and economic development.

The key institutions working social development include Aga Khan Foundation (AKF), Aga Khan University, University of Central Asia, Aga Khan Health Services (AKHS), Aga Khan Education Services (AKES), and Aga Khan Planning and Building Services (AKPBS).

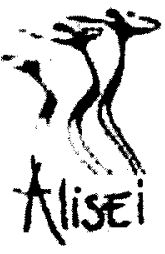

\section{Alisei}

Alisei is an Italian NGO involved in development and humanitarian assistance in more than 20 countries world wide. Alisei has gained considerable experience and capacity which is recognized by major donors (ECHO, UNHCR, Italian Cooperation, DFID).

Alisei established its presence in western Afghanistan since last January, setting up a main office in Heart and three field offices in Badghis province (Qalai-naw, Bale Moyhob, Ghormach). Our activities are strictly related to the ongoing reintegration program in the region and concerns shelter, road repair, water and sanitation, agriculture, rehabilitation of schools and health center. Alisei is also in charge of the Ghormach Way Station on behalf of IOM. 


\section{AMRAN (Afghan Mobile Reconstruction Association)}

Afghan Mobile Reconstruction Association (AMRAN) is a local Afghan NGO which was established in 1991. The aim of the organization is to assist and contribute towards the improvement of social and economic conditions of Afghan males and females. The NGO had successfully implemented a number of projects in partnership with several $U N$ and other foreign donor organizations in different areas of Afghanistan and Pakistan. The Agency has acquired vast experience in the field of embroidery, tailoring, carpet weaving, lacework, leatherwork, training, reconstruction, irrigation, agriculture and many more projects and established links with the business community. This NGO employs 17 permanent staff in its main office in Peshawar and 28 permanent staff in its offices inside Afghanistan.

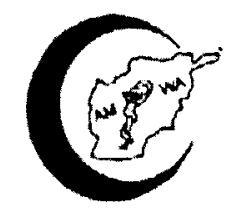

\section{AMWA (Afghan Medical Welfare Association)}

Afghan Medical Welfare Association (AMWA) has been serving the welfare of Afghan refugees since 1998 in the health field by providing them preventive and curative health services. Presently AMWA is providing health services to a population of approximately 60,000 refugees settled in the Jalozai Camp in Nowshera district, NWFP and it is financed by UNHCR through two basic health units and one mobile unit. In addition to this, AMWA is providing EPI coverage to the Afghan refugees residing in the Zadran, Gul Aghaand Malik Azim Paktiawal camps.

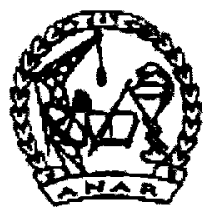

\section{ANAR (Afghanistan National Association for Rehabilitation)}

Afghanistan National Association for Rehabilitation (ANAR) is a non-governmental, nonpolitical organization comprising of experienced doctors, agriculturists and journalists. ANAR was established in December, 1993 but it started its work in 1994 after obtaining the necessary funds. Our main goals are to rehabilitate the vital systems of the country such as construction; health, education, publication and struggle against drug abuses.

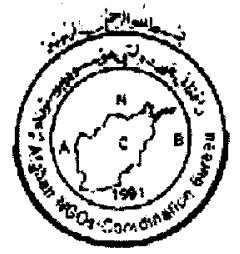

\section{ANCB (Afghan NGOs Co-ordination Bureau)}

Afghan NGOs Co-ordination Bureau (ANCB) was established on the 27th November, 1991 and it is a non-governmental, non-political and non-profitable coordinating body operative to function as an advocacy network to:

$\varnothing$ coordinate the activities of 170 Afghan NGOs

$\varnothing$ establish good working relations between Afghan NGO, provincial \& central government

$\emptyset$ provide a place for meetings for member NGOs and support those NGOs in data collection, conducting research, developing norms/standards, and to ensure uniformity

$\oslash$ conduct capacity building

$\emptyset$ make efforts to link the international community and Afghan NGOs in order to sort out the vexing calamities noticed effectively and efficiently and find out proper ways and means of cooperation and in long term solutions to the crisis. This will bring about a good'problem solving and cooperative ground at an international level with new ideas and approaches.

ANCB consists of its main office in Kabul, a liaison office in Peshawar and its sub office in Jalalabad. 
Afghanistan National Construction Coordination (ANCC) was established in Pakistan in 1994 to work for the most vulnerable people and for the rehabilitation and reconstruction of Afghanistan. Its main office is located in Kandahar with branch offices in Zabul.

ANCC is registered with the Planning Department of South West zone in Kandahar as well as the Ministry of Planning of the government of Afghanistan. ANCC is also registered with UNOCHA and is an active
member of SWABAC. ANCC is working in infrastructure, irrigation, food aid, emergency, road construction, vocational training
and water and sanitation sectors.

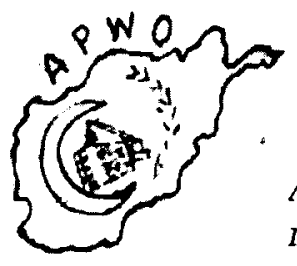

\section{APWO (Afghan Public Welfare Organization)}

Afghan Public Welfare Organization (APWO) is a non-governmental, non-political and non-profitable organization established in 1989.

Its vision is to achieve peace in Afghanistan through community involvement. APWO's fields of activities include relief, construction, road rehabilitation, irrigation, shelter and water and sanitation.

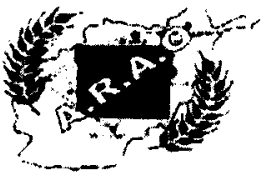

\section{ARAO (Afghan Rehabilitation and Agricultural Organization)}

Afghan Rehabilitation and Agricultural Organization (ARAO) is an Afghan local NGO. This construction, irrigation system implements several different projects such as water supply, agriculture, engineers and the other personnel in the Kabul, Herat, Badghis and Ghor provinces. It has also cooperated with other organizations such as SFL, IOM, WV, HELP, CHLC, ATI and GTZ.

ARAO has offices in Kabul, Herat, Badghis, and Ghor provinces.

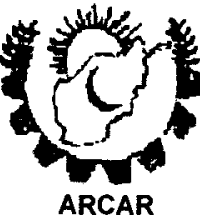

\section{ARCAR (Ariana Rehabilitation Committee for Afghanistan}

ARCAR

Ariana Rehabilitation Committee for Afghanistan Reconstruction (ARCAR) is a nongovernmental, a non-political, non-profit organization established in 1991. The main sectors of ARCAR's activities include engineering, health, education and training. ARCAR has implemented over 40 projects inside Afghanistan with the assistance of UNOPS, UNHCR, WFP, UNDP, CIDA, and UNDCP, Japanese Embassy, IOM, URF/KFW and other humanitarian agencies.

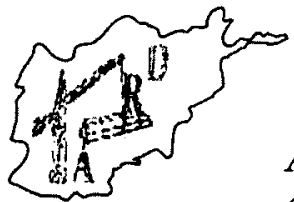

\section{ARD (Amo Rehabilitation and Development)}

Amo Rehabilitation and Development (ARD) was established in 2001 and is still operating. It is registered with the Ministry of Planning and has its main office in Kabul. ARD has implemented projects in many provinces such as Paktika, Ghazni, and Khost and Parwan. It has well-educated, technical and experienced staff who are experienced in construction, shelter, water supply, agriculture, health, training courses and many other fields. ARD also plans to work in Bamyan, Ghazni,
Parwan and Kapisa provinces 


\title{
ARDC
}

\author{
ARDC (Afghanistan Rehabilitation \\ and Development Center )
}

Afghanistan Rehabilitation and Development Center (ARDC) was founded on $1^{\text {st }}$ September, 1993. It is non-governmental, non-political and non-profitable organization formed to assist the people of Afghanistan in the rehabilitation of the rural economy by implementing and establishing various multi sectarian projects. ARDC also aims to encourage the repatriation of refugees and help in their resettlement.

$A R D C$ works in the following sectors: construction, engineering, public health, education and agriculture.

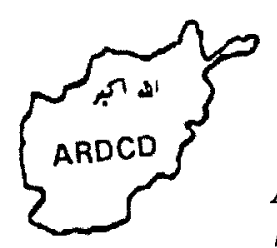

\section{ARDCD (Afghanistan Reconstruction and Drug Control Department)}

Afghanistan Reconstruction and Drug Control Department (ARDCD) was founded in 1992 by M. Tahir Khalil. It was registered with UNOCHA in March, 1992 and later on with Afghan NGOs Co-ordinating Bureau (ANCB).

The organization's first project was seed and fertilizers distribution. ARDCD has successfully completed different projects with UNDP and IRC and it is serving Afghanistan and the Afghan nation to the best of its ability.

\section{ARE}

\section{ARE (Afghanistan Reconstruction Consultants)}

Afghanistan Reconstruction Consultants (ARE) started the activities in '1994 in Mazar, Afghanistan. It has experienced staff who work in engineering, architecture, reconstruction, agriculture and education in Saripul, Jawzjan, Maymana, Balkh and Samangan areas. ARE works in different sectors with various UN agencies such as WFP, UNICEF, UNHCR and also international NGOs.

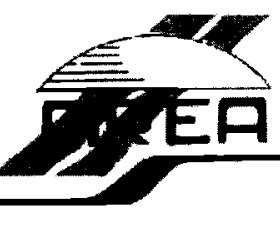

\section{AREA (Agency for Rehabilitation Energy Conservation in Afghanistan)}

Agency for Rehabilitation Energy Conservation in Afghanistan (AREA) is a nongovernmental, non-political and non-profit humanitarian and development organization. AREA has been established to save the interested of the people of Afghanistan and enable them to build a sustainable livelihood.

AREA has four regional offices in addition to its headquarters inside Afghanistan and Pakistan. The regional offices are located in Mazar, Kabul, Hirat and Jalalabad. 


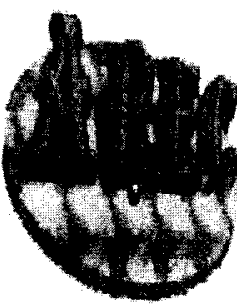

\section{AREC (Afghanistan Reconstruction and Engineering Committee)}

Afghanistan Reconstruction and Engineering Committee (AREC) is a non-political, nonprofitable and non-governmental organization which is registered with the Government of Afghanistan and is a member of ANCB. It is also member of the education subcommittee of $A C B A R$ and the Interagency Network of Education in Emergency (INEE). Since its inception AREC has implemented a number of projects which have been funded by international communities. For the past four years the organization has been directly involved in the education of Afghan refugees' children.

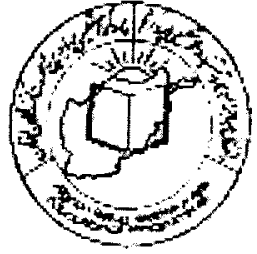

\section{AREP (Afghan Refugees/Returnees Educational Programs)}

The Afghan Refugees/Returnees Educational Programs (AREP) is an Afghan nongovernmental, non-political organization that was founded in 1994 and is run entirely by Afghans. The organization is registered with the governments of Pakistan and Afghanistan. AREP is currently involved in educational and rehabilitation activities and it has gained the confidence of the donors and has proved to be the only Afghan organization providing maximum assistance in the field of education.

\section{ARO ARO (Afghanistan Relief Organization)}

Afghanistan Relief Organization (ARO) is a non-political and non-profit humanitarian organization of volunteers, based in Canoga Park, CA USA. Its sole purpose is to serve the needy people inside Afghanistan as well as those in the refugee camps in the neighboring countries. ARO's mission is to deliver aid and guarantee the distribution of all the contributions to Afghanistan's needy. Since 1997, ARO has been operating in the United States by being actively involved in fund raising and collecting donated goods. The $A R O$ is managed and operated by a board of directors, members and community volunteers. It has distributed food, medicine and winter relief supplies in previous efforts.

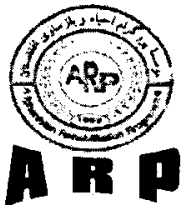

\section{ARP (Afghanistan Rehabilitation Program)}

Afghanistan Rehabilitation Program (ARP) is an Afghan non-political, non-governmental agency which was established in 1999. It is staffed by professional, well educated, honest and competent engineers. ARP has several different donors and already has 10 current projects in various parts
of Afghanistan.

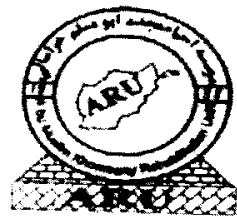

\section{ARU (Abu Muslim Korasany Rehabilitation Unit)}

Abu Muslim Korasany Rehabilitation Unit (ARU) conducts agriculture training courses in Gardez city and Zurmat districts of Paktya province; Sorabia shelter in Kabul province; rapid emergency surveys for returnees in Ghor district of Ghazni province; karez cleaning in Ghor district of Ghazni province; shelter programs in Nawur district of Ghazni province; and tailoring training courses for widows in Dih Sabz district of Kabul province. 


\section{ARU (Aryana Reconstruction Unit)}

Aryana Reconstruction Unit (ARU) started its activities in 1994 in Mazar, Afghanistan. It operates in different sectors such as construction, agriculture, education and public health and has experienced staff who work in these fields. ARU has projects in various provinces of northern Afghanistan such as Saripul, Jawzjan, Balkh, Maymana and Samangan and has worked in conjunction with WFP, UNICEF, UNHCR and some international NGO's. ARU has completed over 20 different projects and is registered with the Ministry of Planning.

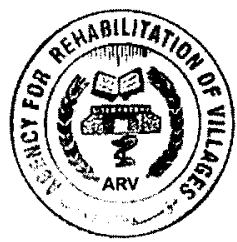

\section{ARV (Agency for Rehabilitation of Villages)}

Agency for Rehabilitation of Villages (ARV) has been established for the coordination of humanitarian assistance of international agencies for rehabilitation of war torn Afghanistan. ARV is a non-government organization and its main objective is to assist with the promotion of sub-regional economic recovery, improve living conditions and alleviate poverty of vulnerable rural households through the rehabilitation of work in the following sectors: construction, water supply, transportation, health, agriculture, education and handicrafts.

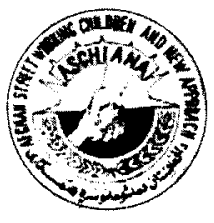

\section{ASCHIANA (Afghan Street Working Children and New Approach)}

Afghan Street Working Children and New Approach (ASCHIANA) is a non-governmental Afghan organization assisting the war affected and traumatized street working children. The beneficiaries of this organization are the poor children who otherwise do not have the opportunity to receive an education. There are five centers located in different parts of Kabul which the children attend and they are provided with basic literacy education, health education, mine awareness, drug awareness and personal hygiene education. The children also receive vocational training such as calligraphy, painting, drawing, carpentry, wood engraving, tailoring, embroidery and flower making. The family members of the street working children are also provided with assistance.

ASCHIANA's main aim is to help the children refrain from working on the streets as it is worthless and harmful and it is neither good for the children nor for the national and international communities.

\section{ASO (Afghan Solidarity Organization)}

Afghan Solidarity Organization (ASO) was established by Mr Essa M., an eminent social worker and honorable sympathizer of the poor and vulnerable in 1999. It of course has he objective to provide assistance to varied walks of life. It now serves the Afghan people by providing them with food, portable water, construction facilities for schools, refugee transit and encashment centers, facilities for youths and adults to be trained, carpentry, automechanics and literacy training. ASP has also carried out systematic surveys and identified the needs of the community.

\section{ASSAD (Afghan Society Scientific Association for Development}

Afghan Society Scientific Association for Development (ASSAD) commenced their activities in 1997 and is still working in the south west of Afghanistan. Since then ASSAD has been implementing projects, mainly in construction but its hopes to commence activities in Kabul in 2003. 


\section{ASSO (Afghan Social Service Organization)}

Afghan Social Service Organization (ASSO) has been established since 1993 and is registered with the Ministry of Planning and is a member of ANCB. It has received funding from UNHCR, WFP and UNDP and also from ISAF in a project of rehabilitating a kindergarten. ASSO has a partnership with Care.

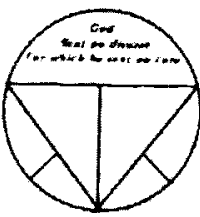

\section{ATA/AP \\ (Anti Tuberculosis Association Afghanistan Program)}

Anti Tuberculosis Association Afghanistan Program (ATA/AP) was established in 1990 with a view to combat Tuberculosis (TB) in Kunar and so a clinic was established in Asadabad. In 1994 the clinic was upgraded to a hospital by adding a ward. Tuberculosis control centers and Health education center were also established in various districts of Kunar. In 1998 two more Tuberculosis clinics, Tuberculosis control centers and health education centers were established,.one being at Bargi Matal, Nuristan province and the other at Mihtarlam, Laghman province. In 1999 a Culture Laboratory, specific to TB was also established to carry out culture and sensitivity tests of Multi Drug Resistant (MDR) cases of $T B$. The laboratory also became a training institute for training microscopists and lab assistants. The same year a TB Clinic, TB control center and five health education centers were also established in Khogyani, Nangarhar. Every year the hospitals and clinics of ATA/AP in Afghanistan treat from 1,500 to 2,000 TB patients. It is covering almost $80 \%$ of the population in health education.

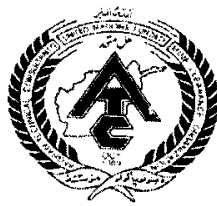

\section{ATC (Afghan Technical Consultants)}

Afghan Technical Consultants (ATC) is the oldest, largest, non-political, well-disciplined and well-organized agency of the humanitarian mine/UXO clearance NGOs and are the implementing partners of the Mine Action Program for Afghanistan (MAPA) which itself forms part of UNMACA. ATC undertakes this project within the framework of the MAPA, based on clearly identified priorities established in consultation with local people and aid agencies delivering support to the
region.

ATC started demining operations in early 1990 with an initial staff of 35 . Since then, it has undergone significant changes and expansion. Demining operations were expanded to other provinces in eastern, central and northern regions. To date, ATC has completed demining of priority areas in the provinces of Kunar, Kunduz, Takhar, Bamyan and Laghman. ATC has development into a highly organized and effective NGO employing almost 1,500 personal in its demining and non-demining projects

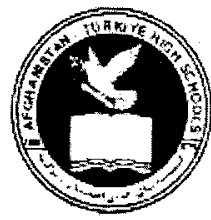

\section{ATCE (Afghan-Turk CAG Educational)}

Afghan-Turk CAG Educational has stared education projects through building up and reconstructing secondary schools, bringing international volunteer teachers and educating Afghan children since 1995. A combination of an international and national curriculum is used. English is taught in the first year as a preparatory class for the $8^{\text {ih }}$ grade students which will enable them to take physics, chemistry, biology, maths and computer lessons n future years as these are conducted in English. ATCE focuses on providing education to students from rural areas through its boarding schools. Since 1995 ACTE has reconstructed 6 schools in 6 provinces being Kabul, Maymana, Mazar, Kandahar
and Samangan. 
technical and logistical aid in humanitarian programs.

Based in Kabul and Peshawar, ATLAS Logistique is established in both countries and has developed networks to achieve all of the humanitarian logistic challenges that the Afghanistan/Pakistan mission is offering.

Now as a partner of ECHO, ATLAS can provide to other NGOs who are funded by ECHO: - transport of humanitarian freight from Pakistan to Afghanistan

- transport of humanitarian freight all over Afghanistan

- computer maintenance

- computer training

- purchase assistance

\section{AWC (Afghanistan Women Council)}

Afghanistan Women Council (AWC) is a non-governmental, non-political, non-profit, non-sectarian organization founded in 1986 by the efforts of Ms. Fatema Sayed Qailani and a group of Afghan women with the aim to assist Afghan women and children. The predominant objective of the organization is to enlighten women, improve their living conditions and strengthen their socio-economic status in society by their multi-lateral involvement in development activities.

AWC is running a high school, teacher training institute, mother and child health clinic in Peshawar. Since 1992 AWC has also been running a hospital in Kabul.

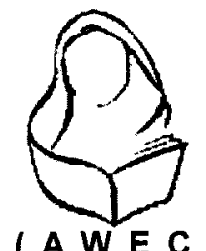

\section{AWEC (Afghan Women's Education Center)}

Afghan Women's Educational Center (AWEC) is a non-profit, non-political and nongovernmental organization which works for the promotion of rights, self-sufficiency and empowerment among Afghan women and children through education, health and socioeconomic development projects.

AWEC was established in 1991 in Islamabad and describes itself as the first resource center for Afghan refugee women. Expanding in response to acute needs, AWEC opened its own high literacy school in 1993. AWEC's key activities include literacy programs, health education, skills development (sewing, English language, advanced computer and management training). A study group was formed for women's rights in Islam and support networks. In 1998 AWEC created a center for street children and women in Peshawar. The center offers income generation activities, literacy, informal education, medical referrals, counseling services, job placement, network support, skill development and education. AWEC plans to work inside Afghanistan in the city and rural areas.

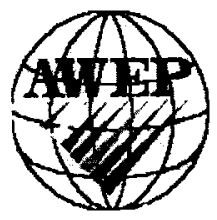

\section{AWEP (Afghan Women Empowerment Program)}

AWEP is a non-profit and non-political NGO and its main objective is empowering women and children in different sections of health, education, capacity building and income generation. It started functioning in 1988 in Peshawar through the cooperation of a group of Afghan women. As a result of the changes which have occurred during past years in the country, the women have gradually lost their mental abilities, educational opportunities and their income providing 
sources, due to these reasons at present they are unable to participate in social activities as equal as men. As a result of this $A W E C$ 's center aims to improve the talent of women, restore their courage and skills and guide them on how to make good use of their knowledge.

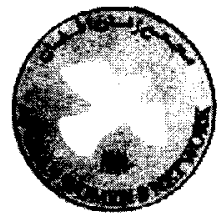

\section{AWN (Afghan Women's Network)}

Afghan Women's Network (AWN) was established in 1996 following seven Afghan women attending the United Nations fourth World Conference on Women in Beijing, China. At present there are 24 NGO's and 800 individuals who are members of AWN in Peshawar and 5 NGO's and 90 individuals who are members in Kabul.

AWN's goal, is to provide a voice for women.

Afghan Women's Network is nonpartisan coordinating body, promoting the rights of Afghan women and children at national and international levels.

Objectives:

$>\quad$ Advocacy and lobbying for women and children's rights

$>$ Create awareness about women's and children's rights

$>$ Provide a co-ordination structure between women's NGOs and other organizations (government, donors, international NGO's etc)

Activities:

$>\quad$ Information dissemination through newsletters and website

$>$ Capacity building and training for Afghan women and women's organizations

Coordination and liaison between Afghan women's NGOs and other organizations

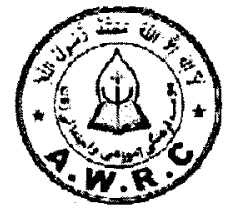

\section{AWRC (Afghan Women's Resource Center)}

The Afghan Women's Resource Center (AWRC) is a non-governmental, non-political, indigenous, humanitarian aid organization, working for Afghan women in the NWFP, Pakistan since October 1989. Its main aim since its inception has been to serve as a focal point for Afghan women from all walks of life, including those living in refugee camps and in the urban parts of Peshawar. For the past thirteen years AWRC has served as an educational and vocational training center for over 7500 Afghan women, and aims at empowering them with the skills and knowledge they need to support themselves and their families, and contribute actively to the rebuilding of Afghanistan. On $19^{\text {th }}$ May 2002, AWRC was registered with Ministry of Planning, Afghanistan and has started its activities in Kabul since $2^{\text {ntl }}$ August.

AWRC is also registered with the Afghan Commissionerate, NWFP and SAFRON, Islamabad, Pakistan.

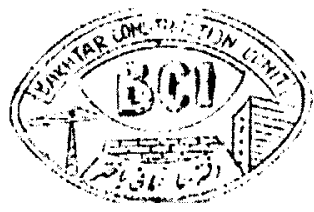

\section{BCI (Bakhtar Construction Unit)}

Bakhtar Construction Unit (BCI) was established in 1994 and renamed from BCU to $B C I$ in 1995. BCI implemented construction projects after receiving donations from UNOPS, UNCHR and WFP. It was originally established in Jalalabad but relocated and has worked in different provinces. BCI is now working for the rehabilitation of Afghanistan. 


\section{BRR (Bureau for Rural Rehabilitation)}

(MI) Bureau for Rural Rehabilitation (BRR) is an Afghan, indigenous, non-political and nongovernmental agency that has been working on behalf of the poorest in Afghanistan since 1990. Since 1990, BRR has implemented different projects in different areas of Afghanistan. BRR works to create conditions conducive to sustained repatriation through a range of different activities, as follows:

1. Rehabilitation of irrigation systems

2. Construction and repair of village roads

3. Construction of secondary schools

4. Repair and reconstruction of flood protection structures

5. Drinking water supply (shallow wells and gravity fed pipeline)

6. Income generation projects

7. Upgrading of community knowledge and their initiatives

The personnel of BRR are well qualified, having sufficient knowledge in the different aspects of reconstruction, rehabilitation, repatriation and development issues of Afghanistan. BRR staff have previously worked in the international agencies as well as in the government of Afghanistan.

\section{B.R.T}

\section{BRT (Bashar Dost Rehabilitation Team)}

Bashar Dost Rehabilitation Team (BRT) is a national NGO which has been established since January, 2000. It is a non-governmental, non-political and non-profit organization which has implemented several projects.

\section{CAFE (Central Asian Free Exchange)}

Central Asian Free Exchange (CAFE) is a USA based NGO focused on central Asia. CAFE's main work and office is located in Uzbekistan and has been there since 1991. CAFÉ is primarily a development organization boasting staff from over 20 countries. CAFE's original focus was primarily education development, but over the years it has gained expertise in $\mathrm{C} \cdot \mathrm{A} \cdot \mathrm{F} \cdot \mathrm{E}$ focus was primarily education development, but over the years

CAFE is largely funded by private donors but also receives funds from several governments and other international humanitarian and agencies. CAFE's regional focused allows its staff to gain a better understanding of the cultural and political climate of the area and thus design sustainable and appropriate projects.

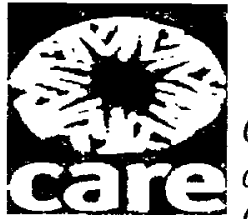

\section{CARE (Care International)}

CARE is one of the world's largest international humanitarian agencies founded in 1945 after World War II. CARE helps people and communities achieve lasting solutions to poverty. CARE seeks a world of tolerance and social justice, where people have overcome poverty and live in dignity and security.

CAFE established its mission in Afghanistan in 1961. Its first project focused on medical training and improving health care service delivery. The 1979 the Soviet invasion made it necessary for CARE to suspend its operations from 1980 until 1989. In 1989, CARE restarted its first relief and rehabilitation project in Kunar province. Staff-wise, CAREAfghanistan is now the third largest CARE mission in the world. 
CARE runs various programmes in the rural and urban areas of seven provinces of southeast Afghanistan to fight the prevailing poverty. During the 2002 financial year, CARE directly assisted more than two million people through water supply, basic schooling and education, road, irrigation, and emergency and relief projects. CARE also helps the poor through local partners in five additional provinces. CARE focuses its approach at the family and community levels.

\section{Caritas Caritas (Caritas Germany)}

Caritas Germany has been working in Afghanistan since 1994.

Main activities are:

$>$ Education (school programs for girls, winter school programs)

$>$ Carpentry and metalwork training for war orphans

$>$ Rehabilitation of schools

$>$ Constriction of roads, bridges and schools in the southern Hazaradjat

The major focal point in 2003 will be the assistance to disabled and handicapped people.

\section{CAWC (Central Afghanistan Welfare Committee)}

Since 1989, Central Afghanistan Welfare Committee (CAWC) has built up its own implementing capacities in the field of agriculture, irrigation, construction, education, health, handicrafts and some emergency programs in some specific areas of Afghanistan, so as to help the people from every possible aspect and help them lessen their miseries.

CAWC is a non-governmental and non-political organization and it has focused all its efforts and struggles in the purpose of development and relief of the most poor and vulnerable people of Afghanistan, free from
any discrimination.

\section{CCA (Cooperation Center for Afghanistan)}

CCA was established in 1990 and was temporarily based in Peshawar. In the first year it provided emergency relief assistance to war and natural disaster affected people in the central highlands areas and also in the north. In 1994 due to the decline of the human rights situation, CCA launched its human right programme. The main components of its human rights program include advocacy, awareness raising, human rights monitoring and investigation. CCA has organized several seminars, conferences, and training workshops on different human rights issues. CCA also maintains its regular and non-periodical publication in Dari, Pashtu, and English.

\section{CDU (Country Development Unit)}

Country Development Unit (CDU) is an Afghan organization established in 1992 in Peshawar, Pakistan. CDU is non-governmental, non-political and non-profitable organization which is registered with the Ministry of Planning, Afghanistan and is a member of ANCB. CDU has implemented various projects inside the country and introduced its staff for training to achieve the aim of development. 


\section{CIC (Children in Crisis)}

Children in Crisis (CIC) was founded in the UK by the Duchess of York. Its mission is to improve the lives of children around the world affected by conflict, deprivation, poverty or other hidden crisis, by working with local communities to provide education, healthcare and in crisis protection.

CIC began work in Afghanistan in 1997 through support to the Indira Ghandi Childrens Hospital, homebased schools and Tahia Maskan and Alluaddin Orphanages. Currently it focuses on teacher training and education for vulnerable groups (IDPS and street working children). It would like to expand support to vulnerable groups further, particularly the street working children and possibly through orphan reunification.

\section{CoAR (Coordination of Afghan Relief)}

CoAR Coordination of Afghan Relief (CoAR) is an independent, non-government, non-political and non-profitable organization, created on the initiation of a group of Afghans in December 1989 in order to contribute in the rehabilitation process of Afghanistan. Since its establishment, COAR's strategy has evolved from providing cross-border, short-term emergency relief services to long term development efforts, which stress community involvement and project sustainability and facilitate the gradual return of refugees. CoAR provides support to communities through the promotion of agriculture, water provision, environment, livestock, rural engineering, health, women development programs, education, infrastructure related to agriculture and emergency programs in 23 districts of eight provinces of Afghanistan (Wardak, Ghazni, Logar, Herat, Mazar, Saripul, Bamyan and Kabul).

Since its establishment this organization has implemented programs with support of different donor agencies, such as Norwegian Church Aid (NCA), Catholic Relief Services (CRS), International Rescue Committee (IRC), Food and Agriculture Organization (FAO), World Food Program (WFP), Save the Children United States (SC/US), Peace Winds Japan (PWI), Netherlands Development Assistance (NEDA), USAID, European Union (EU), SV, WCC and has kept strong mutual and intimate bilateral relations with all of them.

CoAR Rural Development Centers (RDCs) based on its objectives of strategic planning, exerts efforts to establish firm ties with the community through Participatory Rural Appraisal (PRA) and local Shuras. Therefore the community will be mobilized to seek their proprieties in the implementation of projects and to take an active part in project implementation, planning and monitoring of our programs.

\section{CORDAID (Catholic Organization For Relief and Development Aid)}

\section{(ordaid)}

Cordaid, the Dutch member of the Caritas Confederation, is a signatory to the

"Code of Conduct for the International Red Cross and Crescent Movement and NGOs in Disaster Relief" and is a pilot agency of the "Sphere Group". The Cordaid Department for Emergency and Rehabilitation has been supporting Cordaid's long-standing local partner organizations in their response to emergency situations in Bosnia, Albania, Yugoslavia, Mozambique, India, and El Salvadorand also in Afghanistan.

So far Cordaid has worked with local Afghan partner organizations including IbnSina, EPPP, VARA, NPO/RRAA, HAFO, WRO, BRO, SARA, LKRO, RAFA, AWRC, AHTP, MRCA and AHDS. Cordaid is at present broadening its partner network in Afghanistan, in order to respond better to both the present crisis as well as the urgent rehabilitative needs. 


\section{CPAU (Co-operation for Peace and Unity)}

Co-operation for Peace and Unity (CPAU) is an Afghan NGO working for restoration of a sustainable peace in Afghanistan. It came to existence in October, 1996 through the efforts of some committed Afghan development and aid workers. Since then CPAU is trying its best to promote peace in the community level. CPAU works hard to replace the culture of violence, prevailing in Afghanistan, with the culture of peace, equality, social justice and celebration of diversity. $C P A U$ believes that violence is not the solution to any problem and Afghans should try to demonstrate mutual respect and patience to find peaceful solutions to their problems.

Vision: $C P A U$ is committed to work towards the creation of an environment free of violence of any nature (free of physical, structural and cultural violence).

Mission: To facilitate the process of peace building and sustainable development through systematic and comprehensive capacity development and various programmatic interventions leading to the creation of an enabling environment for Afghan communities so that they can actively participate in the promotion of social justice, development and peace building in Afghanistan.

\section{CPHA (Committee for the Promotion of Medical and Humanitarian Aid to Afghanistan)}

Committee for the Promotion of Medical and Humanitarian Aid to Afghanistan (CPHA) is a small, privately organized German NGO which was founded in 1993. It has 25 members. The only project is the Chak-e-Wardak Hospital in Afghanistan which is a 50 bed province hospital run by the German nurse Karla Schefter since 1989. The focus is on supplying medical aid to women and children plus providing training facilities for Afghan women (TBA'S, ORT, health educators, vaccinators, nurses, rehabilitation field workers). Since 2002, CPHA is also supporting the Langar Orphan Boarding School in Chak district.

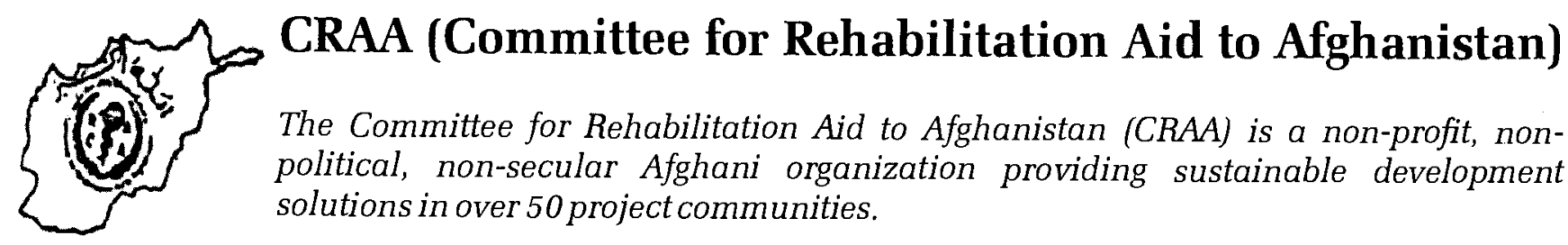

With over 20 years experience in 8 provinces throughout Afghanistan, the work of CRAA has reflected a balanced mix of health and sanitation, agriculture, forestry, animal husbandry, education, maternal and infant care, narcotics awareness, flood control, and income generation activities.

The organization aims to provide adequate resources, public services and an economic infrastructure based largely in agriculture to facilitate the repatriation of refugees and to rehabilitate the sectors of Afghan society that have suffered the most severe losses.

More than 100 projects have been undertaken with major development and relief organizations, all adhering to a strict code of sustainability maintained by CRAA.

The organization's most substantial work at present is with Heifer Project International (HPI), teaching people to care for livestock in a sustainable program of environmentally responsible agricultural practices. CRAA has trained 52 village-level veterinarians to provide basic veterinary services on a fee-basic.

CRAA has supported project communities through the introduction of sustainable public health systems 
comprised of medical skill training, the provision of clean water and sanitation facilities, midwifery and community-level care training, and the construction of multi-purpose structures for public use.

The organization maintains offices in Kabul, Jalalabad and Charparhar with a main representative office in Peshawar, Pakistan. Presently the organization employs about 85 field staff and 20 administrative personnel.

CRAA is registered with UNOCHA, ACBAR, ANCB, NWFP, Home Department, Commissioner for Afghan Refugees, Afghani and Pakistani Government authorities and holds non-profit status under US 501-c-3 for its US division.

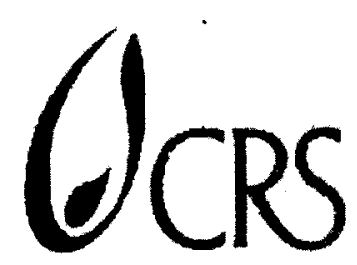

\section{CRS (Catholic Relief Service)}

Founded in 1943 as the overseas relief and development of the United States Catholic Conference of Bishops, CRS today works in more than 85 countries with a program value approaching $\$ 400$ million per annum. CRS is an original subscriber to the Humanitarian Charter, and seeks to promote equitable and durable, community based programs which meet the felt needs of target populations. The agency provides such support for the most vulnerable, poor and marginalized, regardless of creed, nationality, ethnicity, race, gender or political affiliation. The CRS Afghanistan Program is headquartered in Kabul with sub offices in Kandahar and Hirat. CRS has been working in Afghanistan for more than five years as part of the Caritas Consortium supporting education for girls. Since November, 2001 CRS has programmed $\$ 7$ million in relief assistance inside of Afghanistan through its network of Afghan partners. Presently, CRS aims to intensify its involvement in relief activities in Afghanistan. The focus will be in the areas of reliefaid and food security, education, agriculture recovery, water resource management, health, infrastructure reconstruction and income generation.

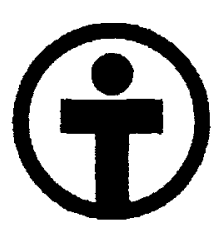

\section{CWS-P/A (Church World Service-Pakistan/Afghanistan)}

CWS-P/A is a non-governmental organization working in working in Pakistan and Afghanistan for the development relief of marginalized communities since 1954. The organization is a member of Church World Service USA locally rooted through its advisory board and regional networks. It operates through seven offices in Pakistan and Afghanistan.

The organization is providing service to more than 350 partner organizations under the aegis offollowing three programs:

1. Social Development Program, which offers financial assistance to NGOs, CBOs, church bodies, groups and individuals

2. Capacity Building Program, that aims to enhance the institutions and organizational capacity of our partners issue-based

3. Disaster Response Program to reduce the risk of the vulnerable sectors of the disaster prone segments.

\section{DAC (Danish Afghanistan Committee)}

OAC

Danish Afghanistan Committee (DAC) is a Danish NGO which works in the health sector in the Hirat province since 1998. DAC supports a primary health care program in Guzara district with a population of 200,000. It also comprises of a district hospital with all standard primary care activities plus an OT, patient's wards and a delivery ward from surrounding sub clinics and health posts. 
Similar support has been recently introduced in the neighbouring districts of Pashtun Zarghun and Obe. DAC also supports the PHC unit of the MoPH and the intermediate nursery school. Education and training of staffat all levels is an important part of the programme.

\section{DACAAR (The Danish Committee for Aid to Afghan}

The Danish Committee for Aid to Afghan Refugees (DACAAR) is an apolitical, humanitarian, nongovernment organization. The Association was founded in 1984 with the purpose of providing support to Afghan refugees. The members are Danish People's Aid, Danish Refugee Council, and MS-Danish Association for International Co-operation.

\section{Objectives}

To objective of the association are: To support rehabilitation and development in Afghanistan so that Afghan refugees and internally
displaced persons can return and participate in their local community.

- To support Afghan refugees in the countries around Afghanistan until they are able to return to Afghanistan and rebuild their lives.

\section{Strategies}

The association seeks to realize it objectives by:

- Supporting sustainable development in local areas through involvement of the population in the planning and implementation of its own development, including projects and activities.

- Supporting development of human resources and capacity in Afghanistan.

\section{Basic principles}

DACAAR's strategy relies on community participation in project identification, planning, implementation, maintenance and evaluation. DAACAR places great emphasis on political neutrality. The programme is implemented on the basic of a respect for Afghan culture and universally accepted human rights.

\section{DAFA (De-mining Agency for Afghanistan)}

The De-mining Agency for Afghanistan (DAFA) was established in June, 1990. This agency is a non-profitmine clearance agency working under the umbrella of the United Nations Mine Action Programme (UN-MAP) in Afghanistan. DAFA employs manual and mechanical techniques for de-mining operations. Its main objective is to save the lives of the Afghan people from the threat of mines, and clear mind areas inside Afghanistan. The most remarkable achievement to date has been the clearance of vast areas of agricultural, grazing, canal, residential areas and public transportation routes, allowing for the repatriation of refugees and the resumption of essential socioeconomic activities in Afghanistan. Mine clearance operations are in various provinces of Afghanistan such as Badghis, Nimroz, Kandahar, Zabul and Ghazni. When minefields are identified by $M C P A$ and local authorities and are given priority, DAFA is called to carry out clearance operations. DAFA conducts field clearance tasks for six hours daily, it regulates its work on the basis of the information provided by the MCPA. Site Operation Officers submit daily reports of operations to the Planning Officer, weekly and monthly reports on operations are prepared and a copy is forwarded to the DAFA Head Office, the AMAC and MACA. 


\section{DCA (Dutch Committee for Afghanistan)}

Dutch Committee for Afghanistan (DCA) was established in 1988 in Peshawar, Pakistan. In the beginning it was supported and financed by the Dutch Government. From 1990 to 2000 it was financed by Novib. From March 2001 the European Union provided the necessary funds to DCA for 2 years.

$D C A$ is working in veterinary aspects. Since 1988 nearly 600 paravets have been trained by DCA. Most of the paravets presently are working in animal clinics.

DCA's main office is located in Peshawar. It is indeed a support center and sub offices are located in Kabul and Hirat. The Kabul office is a training center and the Hirat office basically is working in field units with 4 provinces.

\section{DHSA (Development and Humanitarian Services for Afghanistan)}

Development and Humanitarian Services for Afghanistan (DHSA) is an Afghan NGO established in 1992 in Afghanistan by a group of young Afghan intellectuals of different skills and origins. It is a non-political and non-sectarian organization and its activities of spread towards Kabul and central regions of the country. Later, when necessity arose, the organization started working in the northern parts of Afghanistan. So far DHSA has implemented more than 250 small and large-scale projects in twelve provinces of the country.

One section of DHSA, called Irfan Cultural Center, deals with art and culture. It prepares, publishes and distributes a weekly magazine Killid (the key) with 16,000 issues per week. A quarterly magazine by the name of Sapida, dealing with literature and history is also published.

\section{DS (Darul Shefa)}

Darul Shefa (DS) is a non-profit, non-political and a non-governmental organization established in 1996. It is registered with the Government of Pakistan and Afghanistan and its mission is to reach the neediest and most deserving Afghan refugees and local population in Pakistan and Afghanistan. DS provides assistance in following fields:

Food: Emergency food provision and distribution primarily to Afghan refugees in different refugee camps

Shelter: Provision of shelter to refugees 
Health: Provision of health services and free medicine to Afghan refugees and local population in Afghanistan and Pakistan through the establishment of basic health units, free medical camps, mobile medical clinics and the establishment of hospitals.

Education: Provision of basic education to children of refugees and Afghans through establishing schools in refugee areas, supporting established schools and providing students with books and other materials.

Social Development: Assisting skilled Afghans to restart their profession, establishment of community centers, initiation of food for work projects and the establishment of training and work centers for the physically disabled.

\section{EDHI (Edhi Welfare Center)}

EDHI Home and Welfare Center can assist those people who are injured as a result of an emergency such as an earthquake, mine explosion and fighting and refer them to a hospital. EDHI can also assist the children of the injured and find accommodation and support for them.

\section{EMDAD (Engineering and Medical Department for Afghanistan)}

Engineering and Medical Department for Afghanistan Development (EMDAD) was established in 1999 to take part in rehabilitation, reconstruction and development of war torn Afghanistan. So far, EMDAD has been supported by United Nations High Commission for Refugees (UNHCR), World Food Program (WFP), and some other organization and private sectors.

The organization is registered with Ministry of Planning of Afghanistan, Eastern provinces and the Islamic Shura in the south of Khost in Gardize.

EMDAD is non-governmental, non-political and non-profit organization. EMDAD is a technical oriented organization having the goal to take part in construction, reconstruction and development of Afghanistan. The nature of EMDAD's work is open-competitive based. EMDAD can accept orders from individuals, government departments and other organizations. EMDAD can create proposals identified by the communities as proper needs, after the completion of technical aspects.and this will be submitted to donor agencies for funding. EMDAD operates purely on humanitarian basis to organize various departments, which shall function together to assist the people of Afghanistan by undertaking various projects in different sectors to build the war torn infrastructures of the country. EMDAD can survey, plan, design and implement rehabilitation, reconstruction and development projects and activities in Afghanistan. EMDAD can coordinate and develop projects by establishing cooperation with organizations having similar objectives and with donor organization. EMDAD can accept grants from any governments, agencies, authorities, public bodies, corporations, companies or individuals, movable properties, donations, gifts, subscriptions, devices, and other assistance with a view of promoting the objectives of the society in receiving any gift of property to take the same either unconditionally or subject to special conditions prescribed in writing by the donors. 


\section{EPPP (Environment Protection and Promotion Program)}

The (EPPP) is non-partisan, non-governmental consultant and implementers agency independently established in 1996. Its mission is to provide rehabilitation services for the Afghan community. It is committed to the improvement of living standards especially those of women and children with the emphasis on cost effective rehabilitation concepts and approaches, intervention and capacity building within the Afghan community at national, organizational and community level, therefore helping Afghans to help themselves. It seeks to contribute to the establishment of a peaceful and stable environment in Afghanistan, through its input in rehabilitation and development activities and thus further assist the repatriation of Afghan Refugees.

\section{ERO (Ehsan Rehabilitation Non Government Organization)}

Ehsan Rehabilitation Non Government Organization (ERO) is an Afghan local NGO that has been registered with the Ministry of Planning since 1998. During the Taliban period between 1998 to 2001 ERO's work and activities ceased. In February, 2002 ERO recommenced their work and started the reconstruction of Jamal Mina, Shiwaki, Kalakan, Shakaradara and Amana High Schools.

\section{FECO (Fayez Engineering and Construction Organization)}

FECO was established in 1993 and has experienced technical staff members in construction, agriculture, health and other sectors. The main office of FECO is in Mazar-eSharif and there are sub offices in Kabul, Jawzjan and Faryab provinces.

Since its establishment, FECO has successfully implemented more than 43 different types of projects and 6 projects are in progress.

\section{FFO (Farhad Ferdows Organization)}

Farhad Ferdows Organization (FFO) was previously known as Lalestan Pamir. This organization performed several kinds of construction activities in 1996 in the Herat province and it also performed some construction activities under the name of Ferdows Co. Thirty five unit culverts have been surveyed in Guzara district which has been submitted to DACAAR for implementation. Also several proposals have been prepared for clinics in Guzara, Rodat Sangi and Islam Qala with WHO. FFO has also been involved in preparing and performing a survey for a dam in Ab Kamari village in Badghis province. Due to the political situation, FFO has only recommenced its activities four months ago under its current name. 


\section{FRDO (Female Rehabilitation and Development Organization)}

Female Rehabilitation and Development Organization (FRDO) Organization was established in 1995 in the historical city of Mazar-e-Sharif. At the time it was registered with the Presidency of Foreign Affairs, UNHCR, WFP and OPC. FRDO completed some projects such as carpet weaving in Shiberghan, biscuit making in Hairatan, carpentry in Kunduz and TBA for Tajik refugees in Ali Abad. All of the project of this organization were mainly feminine based and were for the help of the vulnerable and needy Afghan women, widows, orphans and unguarded girls. FRDO's main office was located in Jamhori Gate of Mazare-Sharif but due to some political unrest, it was set ablaze and looted. As a result a new office was established in Peshwar, Pakistan in 1999. FRDO has now completed a number of projects in tailoring, embroidery, carpet weaving, health education and literacy. It is currently running nine projects in carpet weaving, health education and literacy in the new Shamshato refugee camp.

\section{Feed The ChILDREN \\ INTERNATIONAL (UK)}

\section{FTCI (Feed the Children International UK)}

FTCI (UK) is a registered charity in the UK and is affiliated to Feed The Children, a nonprofit organization in the USA. FTCI is a non-denominational organization that responds to humanitarian crises world wide, no matter what the religion, creed or belief of the beneficiaries. Feed the children commenced operations in Haiti in 1979, since that time it has commenced country programs in 20 other countries

FTCI (UK) has experiences in the following sectors: nutrition, health, education, shelter, water and sanitation, agricultural seeds and tools, community development, fisheries, micro finance, particularly with women's groups and finally emergency aid response.

\section{FTH (Construction and Reconstruction Committee)}

FTH Construction and Reconstruction Committee began its activities in 1374 and it focused on construction, agriculture, improvements and education. FTH has completed six projects in the Balkh province and its office is situated in Mazar. It aims to help the people in all sections of the
community.

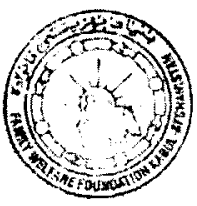

\section{FWF (Family Welfare Foundation)}

Family Welfare Foundation (FWF) is a non-governmental, non-political and non-profitable organization which was established in 1994 to provide development, infrastructure, educational and vocational training in order to improve the standard of living of the people.

In addition, FWFs activities aim at ensuring the rights of all women and disable individuals by improving their capacity and drive them to participate in all of life's activities. Aimed at better implementing the disables rights, particularly the hearing impaired, FWF established the Hearing Impaired Foundation of Afghanistan (HIFA), which is an independent department of FWF. HIFA provides educational and vocational training for hearing impaired individuals, both male and female without any discrimination. FWF/HIFA always tries to stand by these aims and brings them into practice by providing opportunities of training, equality and employment support. 


\section{FWO (Falahat Welfare Organization)}

Falahat Welfare Organization (FWO) is a humanitarian agency that was established in 1994 for the purpose of humanitarian assistance to Afghans in Pakistan and Afghanistan. This organization commenced its activity in quilt making in Kabul city in 1996. Due to the situation of Kabul city, FWO focused its activities on construction and income generation projects for vulnerable women. In 2002 , this organization launched a number of projects including women tailoring training, construction of schools and shelter projects in different parts of Afghanistan.

\section{DEUTSHE WELTHUNGERHILFE \\ German Agro Action}

\section{GAA (German Agro Action)}

German Agro Action was founded in 1962 as the national committee for the "Freedom from Hunger Campaign" of the Food and Agricultural Organization of the United Nations (FAO) by the Federal German President at the time, Heinrich Lubke. Today it is one of the biggest private aid organizations in Germany. Non-profit, non-aligned and non-denominational, the organization works under a voluntary board of directors and the patronage of the Federal President.

Donations from the population finance the work in Africa, Asia and Latin America. In addition, German Agro Action receives grants from the Federal German Government, the European Union and the United Nations. The frugal and transparent use of financial resources is annually checked by the Central German Institute for Social Issues (DZI) and confirmed by their "donation seal".

Local partner organizations, committed, competent and reliable, carry out the projects. Where there is no independent partner organization the emergency aid projects are implemented with our staff. The target groups are the poorest of the poor: the landless; small farmers; women; children and youth; people who have lost everything as a result of war or environmental disasters; people who need start-up aid to live in safety and dignity.

The project work concentrates on agriculture and food security, emergency aid and rehabilitation, children and youth, basic social infrastructure, crafts and commerce and the promotion of project holders.

In 2001 GAA's worldwide budget amounted to 79 million Euros, out of which 14.8 million Euros was allocated to interventions in Afghanistan and other neighboring countries in Central Asia (Tajikistan, Uzbekistan and Kirgistan).

\section{GHO (Goharshad Humanitarian Organization)}

Goharshad Humanitarian Organization (GHO) is aiming to help the poor community of Afghanistan to some extent. The assistance as we have planned will be providing by the provision of health services, education, vocational training and supporting the orphan children. One of the other objectives of GHO is to pave the way for employment of Afghan experts living aboard. We are also aiming to raise the capacity and cultural level of the population.

GHO is at the initial stages of being established and therefore is yet not equipped with the essential facilities. GHO is a national NGO and is open to service and work in the region, without any religious conflict or affiliation. The best members are women. 


\section{GOAL}

GOAL is an international humanitarian organization founded in Ireland 25 years ago. It is a non-denominational, non-governmental and non-political organization. GOAL works towards ensuring that the poorest and most vulnerable people in our world, and those affected by humanitarian crises, have access to the fundamental needs and rights of life; food, water shelter, medical attention and primary education. GOAL is operational in 19 countries worldwide and has its biggest program in Northern Afghanistan. The team here consists of 17 international staff and over 200 national staff. The key focus of this program is rural rehabilitation where GOAL's engineering, agriculture, food distribution and IDP teams are implementing projects to ultimately provide food security for the Afghan people.

\section{GRCO (Ghor Rehabilitation and Construction Organization)}

Ghor Rehabilitation and Construction Organization (GRCO) is a non-governmental, nonpolitical, non-profitable and charitable organization, which has been established and has initiated its activities since 1992. This organization has carried out some activities in the sectors of: agriculture, water sanitation, food distribution, reconstruction and rehabilitation. These projects have been funded by WFP, FAO, IRC, DACAAR and MADERA.

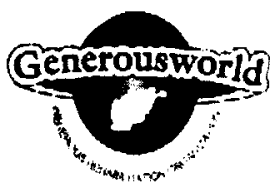

\section{GRO (Generous Rehabilitation Organization)}

Generous Rehabilitation Organization (GRO) was established in 1999 and is still working. GRO is registered in Ministry of Planning and has its main office in Shahr-enow, Kabul. It has implemented projects in many provinces such as Paktika, Ghazni, Parwan and Kapisa. GRO is registere in UNHCR, WFP, CARE, UNOPS and ISAF.

GROs logo, which is a map of Afghanistan in the heart of Asia, shows construction rehabilitation and development of Afghanistan.

\section{GRSP (Ghazni Rural Support Program)}

Ghazni Rural Support Program (GRSP) is a non-governmental, non-political and non-partisan Afghan NGO funded in 1993 and it promotes sustainable integrated rural development activities inside Afghanistan. GRSP is seeking sustainability, using the strategy of social organization, saving and capacity development for encouraging community participation and ownership. GRSP focuses on involving the people in the project cycle.

GRSP is strongly committed to both national and international values, Afghan tradition and culture, human rights, gender equity and environmental issues.

GRSP works in the following sectors: agriculture/animal husbandry, irrigation/construction, primary health care, income generation activities, education/training and emergency relief.

\section{HAFO (Helping Afghan Farmers Organization)}

Helping Afghan Farmers Organization (HAFO) began its functioning as an offshoot from the Dutch Committee for Afghanistan (DCA). When DCA ceased to continue certain programs, Afghans cooperating with the agency committed themselves to continue the mission through 
the formation of HAFO in 1990. Since its establishment HAFO has grown considerably and developed its own policies and strategies, taking into account the present requirements of Afghan society and global trends.

HAFO is determined to remain a humanitarian, non-profit and non-governmental organization to better serve the common cause of the Afghan people who need assistance. It works in construction, irrigation, agriculture and vocational training.

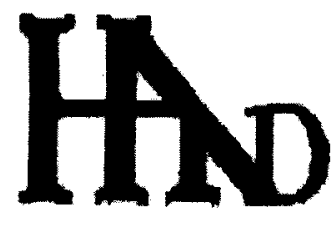

\section{HAND (Humanitarian Assistance Network and Development)}

Humanitarian Assistance Network and Development (HAND) is a non-governmental, non-profit and non-political Afghan NGO which was founded in 1995 in Kabul for the purpose of rehabilitation and reconstruction of Afghanistan.

The main sectors of HAND's work includes:

* Construction: reconstruction and rehabilitation of schools, bridges, clinics, hospitals and Vocational training, rotated the filed.

* Agriculture: improvement of seeds, fruit and forest nurseries, poultry

* Education and development: supporting of women development through vocational training and professional training centers

\section{HAPA (Humanitarian Action for People of Afghanistan)}

Humanitarian Action for People of Afghanistan (HAPA) is a local NGO which has been registered with the UN since 1994 and the Planning Department since 1996. HAPA has also been registered with SWABAC since 1995. Since then it has implemented 12 different projects and is ready to continue with more.

\section{HAS (Humanitarian Assistance Society)}

Humanitarian Assistance Society (HAS) is a non-political and non-governmental organization established on the $10^{\text {th }}$ of October 2001 by a number of social welfare workers to address the man made and natural crises faced by humanity especially by war stricken Afghans, who have lost almost every thing in the last two decades or more of civil war. The main office of the society is situated in Kabul and other regional offices are in Kandahar, Jalalabad and Baghlan. In Pakistan there are also regional offices in Peshawar and Quetta. HAS is registered with the Ministry of Planning Afghanistan Government and the Afghan Commissionerate Government of Pakistan. It is also a membership of ANCB.

\section{Objectives:}

- To uphold the human values and promote the services of man for the benefit of larger human community.

- To provide opportunities for living in a developed community, where the human rights is respected.

- To empower man in order to walk on the path of self-sufficiency.

- To improve the living standards of those who struggle to overcome poverty.

\section{Main Field of Activities:}

- Reconstruction and development programs

- Vocational training programs 
- Relief programs in emergencies

- Education

- Health

- Water supplyschemes

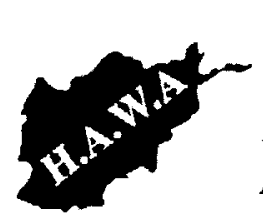

\section{HAWA (Humanitarian Assistance for Welfare of Afghans)}

Humanitarian Assistance for Welfare of Afghans (HAWA) is a non-governmental, nonpolitical and non-profitable organization established in 1995 to assist in the rehabilitation of Afghanistan. It was also established for the secure operation of relief and rehabilitation activities inside Afghanistan through the direct cooperation with existing local residents, authorities, shuras and donors.

\section{HAWCA (Humanitarian Assistance for the Women and Children of Afghanistan)}

Humanitarian Assistance for the Women and Children of Afghanistan (HAWCA) was established in January 1999, as a non-political and non-profit making organization. It is working in several fields such as education, health care, emergency relief, income generation and the sponsoring of widows and orphans. HAWCA operates in seven provinces of Afghanistan as well as Peshawar.

The aim of HAWCA is to encourage women for their active participation in the process of reconstruction and development of Afghanistan.

\section{HCI (Human Concern International)}

Human Concern International (HCI) is a Canadian relief and development organization working for the cause of needy people, to alleviate human suffering through sustainable developmental projects.

HCI was established in 1980 for the cause of Afghan refugees, since then HCI has implemented numerous projects for the welfare of Afghan refugees in Pakistan and has successfully completed a variety of projects and programs inside Afghanistan.

HCI is a multi-sectoral organization, working in health, education, relief, reconstruction and rehabilitation ofinfrastructure in Afghanistan

\section{HELP (Hilfe Zur Selbsthlife e.V.)}

HELP

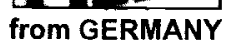

Help is an international relief organization with its headquarters in Bonn, Germany. It is operational worldwide, mainly the Balkans, Caucasus, central Africa, central America and central Asia. It is funded by the German Government, ECHO, EU and the UN.

The organization was founded in 1981 in the context of the Afghan refugee crisis and was operative until 1997. HELP recommenced its activities in November, 2001 and now mainly works in western Afghanistan in infrastructure, rehabilitation, construction, education, demining, water and sanitation and relief. 


\section{HEWAD Reconstruction Health and Humanitarian Assistance}

HEWAD is a non-governmental, non-profitable and non-political organization established in 1994 with the aim of assisting Afghan in various sectors by upgrading their knowledge and skills. HEWAD also aims to play a positive role in the implementation of projects to raise the capacity of Afghans to an effective level to help reconstruct and rehabilitate war ravaged Afghanistan. HEWAD presently has several ongoing projects inside Afghanistan as well as in Peshawar.

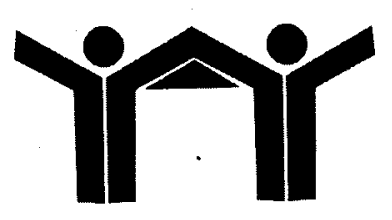

\section{HFHI (Habitat for Humanity International)}

Habitat for Humanity International (HFHI) is a not for profit, international nongovernmental organization based in the United States. HFHI works for the elimination of poverty housing and homeless throughout the world in partnership with the poor, their governments and other organizations. HFHI works in 83 countries around in the world with 23 counters being the Asia-Pacific region. The organization has built over 100,000 houses for families throughout the world. HFHI responds to natural disasters and complex emergencies through its Disaster Response Office .

\section{HQPE} HOPE WW (HOPE Worldwide)

world wide

HOPE Worldwide's mission is to provide hope to a hurting world. In Afghanistan HOPE Worldwide seeks to achieve its mission by improving the levels of health and education amongst men, women and children, primarily through the establishment and support of health facilities (including $\mathrm{MCH}$ clinics and hospitals) and the rehabilitation of schools. HOPE Worldwide's comparative advantage emanates from its ability to respond quickly to emergency situations and from its network of experienced professionals and volunteers across the world (over 100,000). Currently HOPE worldwide has projects in over 100 countries.

HOPE Worldwide registered with the MOP, MOFA and MOPH in Kabul in May 2001.

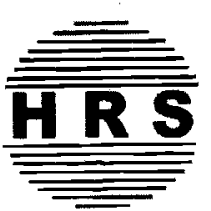

\section{HRS (Hewad Reconstruction Service)}

Hewad Reconstruction Service (HRS) is a national NGO which was established in 1993. The main objective of HRS is to play an active and positive role in raising the quality of life pf the Afghan communities. Being a national NGO, HRS does not have its own funding and it mostly has implementing partners. HRS has pursued to be a perfect training camp for engineers, doctors, nurses, computer operators, field supervisors and drivers. HRS has the credit to be only active NGO throughout us bombing in October to November, 2001 in Hirat.

\section{HT (The Halo Trust)}

The Halo Trust (HT) is a non-political, non-religious British registered charity (No. 1001813) that specializes in the removal of debris of war. Halo (Hazardous Areas Life Support Organization was founded in 1988. Since then, Halo has cleared over a million mines and unexploded ordinances (UXO). Halo has over four thousand de-miners working in 6 countries.

Halo has a simple Mission Statement: "Getting mines out of the ground, now" 
Serving the People Afghanistan LAM is a development organization that has worked in Afghanistan for over 36 years. International staff come from over 15 countries. LAM currently has projects in the sectoral areas of health, education, rehabilitation and economic development.

\section{IBNSINA (IBNSINA Public Health Programme for Afghanistan)}

IbnSina is active in 13 provinces of Afghanistan, providing health care for a population of more than 3 million people.

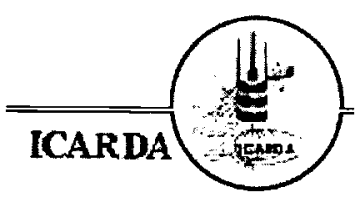

\section{ICARDA (International Center for Agricultural Research in the Dry Areas)}

International Center for Agricultural Research in the Dry Areas (ICARDA) is based in Syria. Its main objective is to rehabilitate agricultural research stations in Afghanistan. ICARDA plans to work on cereals and horticultural crops to obtain new improved varieties. It has distributed about 3,500 metric tons of improved spring wheat seeds in the northern provinces of Afghanistan. For the year 20022003 ICARDA plans to collect 6,000 metric tons of improved spring wheat seeds from the farmers. After processing it should be redistributed to the farmers along with fertilizers. ICARDA has also selected $25 b$ progressive farmers in Nangarhar province for training in order to produce good quality potatoes.

\section{NC M/C ICMC (International Catholic Migration Commission)}

ICMC serves underserved refugees, IDPs and migrants.

Goals and objective:

1) To provide a referral for, and direct provision of, immediate care for refugees, IDPs and migrants

2) To provide integration and healing in migration impacted communities

3) To provide durable solutions and sustainable livelihoods for vulnerable refugees, IDPs and migrants.

\section{IDRO (International Development \& Relief Organization)}

International Development and Relief Organization (IDRO) is registered with the Government and is working on poverty programs in the Jalozai, Adizai, Utmanzai and Khorasan refugee camps. It is assisting the vulnerable Afghan families by providing them 6 weeks old layer chicks for raising inside their homes in order to generate income to improve their family economics. According to a written agreement between IDRO and the recipients of the chicks, the families are bound to spend some money out of the generated income towards the maintenance of their family's health. IDRO also works in the Pak communities by providing chicks and 10 fruits trees. IDRO covers income generation, health education, environmentand training. It has so far distributed 96,920 chicks amongst 3,231 families. 


\section{IF Hope (International Foundation of Hope)}

International Foundation of Hope (IF Hope) is a non-governmental, non-political, nonreligious and non-profit charity based organization based in Colorado, USA. IF Hope is registered in the USA, Afghanistan and Pakistan. We are presently involved in health care, education, construction projects, relief, agriculture and income generating projects.

\section{International IIII CROIIn IHRLG (International Human Rights Law Group) Human Rights LIIUU International Human Rights Law Group (IHRLG) is a non-profit and non-governmental organization of human rights and legal professionals engaged in human rights advocacy, litigation and training around the world. The Law Group was established over twenty years ago. Its mission is to support the promotion and protection of human rights and to support the human rights activists around the world. Since 1978 the Law Group has worked in over 88 countries of the world to help local leaders and organizations addressing human rights abuses. The Law Group started the Women Rights Advocacy Program (WRAP) for Afghan refugee women in Pakistan in 1999 and is currently working on human rights education in Pakistan.}

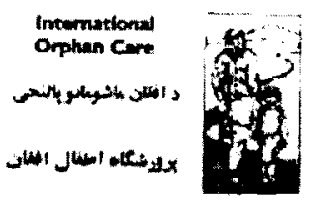

\section{IOC (International Orphan Care)}

In 1993 the International Orphan Care (IOC) was established by Americans and those Afghans who are living in USA including:

1. J.Preston Darby M.D, F.A.C.P. (President)

2. Honorable Richard J. Riordan (former Mayor of City of Los Angeles).

3. Dr. Abdullah Osman M.D (Director of Operations, Afghanistan)

Ambassador Peter Tomsen (former special Envoy to Afghanistan

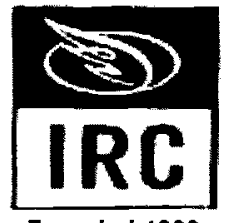

Founded 1933

\section{IRC (International Rescue Committee)}

dignity and self-reliance. This comn rehabilitation services, resettlement assistance and advocacy of refugees.

IRC started its program for Afghanistan in 1980 in Pakistan. In 1988 IRC initiated its program inside Afghanistan providing assistance in the sectors of agriculture, education, small business assistance, health, micro-grants, irrigation and road construction.

\section{ISRA (Islamic Relief-Agency)}

ISRA is an international nongovernmental org that is more than two decades old. ISRA is assisting vulnerable and poor families in Afghanistan and in Pakistan. Keeping the aim and motto of the organization in mind, ISRA carries out its programs quite successfully. In Pakistan, where much other relief assistance exists, ISRA identified that orphans needed more assistance. Generous support was extended to enable them to enjoy an improved standard living. 
As defined in its objective, ISRA shall remain committed to serve the vulnerable segments of society in the field of health, agriculture, education, social, welfare and rural development.

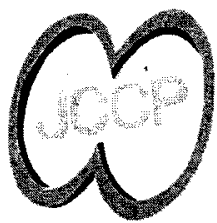

\section{JCCP (The Japan Center for Conflict Prevention)}

In the $21^{\text {st }}$ century, Japan will have to play a role in fields other than economics, that is in the fields pursuing peace and security. In July, 1999 JCCP, "formally termed as JCPD", was was elected as the first Chairman of JCCP.

Being concerned with the frequent outbreak of regional and ethnic conflicts, JCCP aims to strengthen the contribution of the Japanese non-government sector to the prevention of conflict in the world. To accomplish this mission, a series of initiatives are being undertaken as well as the establishment of overseas sub-offices in Sri Lanka, Cambodia and the Middle East. In March, 2002 a JCCP representative office was established in Afghanistan and programs began for the reintegration of soldiers into society and peace building workshops in Kabul and the surrounding areas.

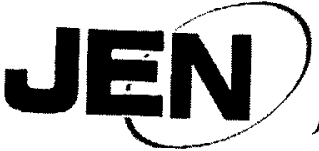

Japan Emergency NGO

\section{JEN (Japan Emergency NGO)}

Japan Emergency NGO (JEN) was established in 1994 and has been working in the former Yugoslavia region (Croatia, Bosnia and Herzegovina, Yugoslavia) for seven years. JEN has also worked in Chechenya, India and Mongolia for short operations and have performed emergency operations for Afghan refugees in Pakistan and Afghanistan.

JEN supports mental and economical'self-reliance of the people and communities that are affected by conflict and natural disasters. JEN is experienced in emergency relief operations such as temporary education, vocational train, emergency relief distribution and also in rehabilitation operations such as formed partnerships with UNHCR, UNICEF, WFP, UNDP and the Japanese Government.
fial past JEN has

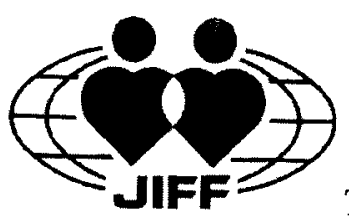

\section{JIFF (Japanese International Friendship \& Welfare Foundation)}

The JIFF Physiotherapy Center was established on $18^{\text {th }}$ August, 1991 in Peshawar to provide physiotherapy and follow-up therapy to Afghan refugees and victims of war that had undergone surgical treatment. After one year of successful activities in Peshawar, the Government of Japan commenced its financial assistance to this project.

The JIFF Medical Center was established on 7th September, 2002 in Kabul to provide food for malnourished children and medical assistance to those children, which due to war and drought did not receive proper food or medical assistance. The Medical Center has a Children O.P.D, Malnutrition program, X-ray machines, dispensary, female health education and laboratory all free of charge.

The Medical Center has provided services to the following number of patients:

O.P.D for children: 300 patients/day

Malnutrition: 50 patients/day

Dispense Medicine: 300 patients/day

$X$-rays: 20 patients/day

Laboratory: 25 patients/day

Female Health Education program: 300 patients/day 


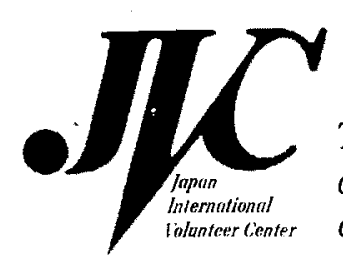

\section{JVC (Japan International Volunteer Center)}

The medical project is implemented jointly with OMAR International. The project is divided into two schemes, a mobile clinic and a basic health center, both of which are composed of OPD, health and nutrition education, nutrition programs and EPI. The mobile clinic targets IDPs but in the progress of IDP's repatriation, the target has been shifted to the population in rural areas where health services are not accessible for people. The Basic Health Center in Jalalabad functions mainly as a base for the mobile activities. Those activities will be evaluated in January, 2003 and adjusted according to the change in situation.

\section{JWA (Jacob's Well Appeal)}

The Jacob's Well Appeal (JWA) is a British based medical charity with operations in Afghanistan, Romania, Poland, Kosovo and Pakistan. The Jacob's Well Appeal was established in 1988 in Afghanistan and has been active through all the political changes in Afghanistan.

The JWA supplies medicines and hospital equipment to 8 big hospitals in Kabul other provinces. The JWA has been running a mother and child clinic in Kabul since 1988. The clinic provides free medical treatment and ante natal screening with ultrasound for all pregnant women attending the clinic.

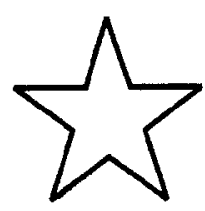

\section{KCF (Khorasan Community Forum)}

A community forum is a system through which people are empowered to address their problems and seek local solutions. Once communities are organized and systems are established, local resources, both financial and social can be mobilized so that people can become the agent of change in development of their community. The community therefore becomes the driving force in planning and implementing projects for infrastructure repair as well as social recovery. These projects include the rehabilitation of drainage canals, the establishment of systems for solid waste, the establishment of education courses and environmental improvement.

The most important thing is that the community goes through a transparent process of electing their representatives, who are working in voluntary basis. These representatives are called the Consultative Board (CB) and they have a responsibility to liaise with the community members and consult with them on a regular basis through open public meetings on different issues.

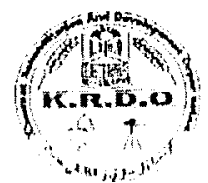

\section{KRDO (Khadmat Rehabilitation and Development Organization)}

Khadmat Rehabilitation and Development Organization (KRDO) was established in 2001 in Takhar and Badakhshan. In February, 2002 an office was opened in Kabul. In April, 2002 the organization was registered with the Ministry of Planning. The main areas KRDO works in includes education, construction, health, emergency and refugees. The organization is also planning to combat narcotics. 


\section{LEPCO (Leprosy Control Organization)}

During the last years of the 1970's and 80's, large numbers of Afghan refugees arrived in Pakistan as a result of the war in Afghanistan. Among these refugees, there were many leprosy patients, the vast majority from one ethnic group, the Hazaras. The Hazaras are from Hazarajat, an isolated and mountainous area in central Afghanistan.

In 1984, due to the high number of leprosy patients amongst the Hazara refugees, Dr Ruth Pfau at that time in charge of Marie Adelaide Leprosy Center in Pakistan went into Afghanistan with two Afghans who had been trained as leprosy technicians. Not only did they find many leprosy patients, they also found out that in large parts of Hazarajat general health care was virtually non existent.

A clinic was opened in Malestan and later another one in Sheikh Ali. Gradually the program was expanded. At present are ten LEPCO clinics, eight in Hazarajat, one in Sayadabad, Wardak and one in Mazar. Leprosy control remains the first priority for the LEPCO clinics but in the absence of general healthcare facilities they have had to treata lot of general patients as well. In 1994, a Tuberculosis (TB) control component was added to the program. In recent years there has been some reduction in the leprosy caseload and more general health facilities have become available in Hazarajat. As much as possible $L E P C O$ now tries to hand over general health care tasks to other organization and focuses on TB and leprosy control only. TB control has now become the mainstay of activities in the LEPCO clinics.

\section{LKRO (Loy Kandahar Reconstruction Organization)}

Loy Kandahar Reconstruction Organization (LKRO) is an independent, non-governmental organization which was established in 1992. It seeks to promote sustainable economic and social development by working with local communities through relief and development programmes.

LKRO is a registered NGO with UNOCHA, SWABAC and the Ministry of Planning of Afghanistan. It is a multisectoral, institutional development NGO and it has a full presence in Zabul, Helmand, Uruzgan and Kandahar provinces. LKRO has implemented prevalent emergency and development programmes.

\section{LROA (Lmar Rehabilitation Organization for Afghanistan)}

Lmar Rehabilitation Organization for Afghanistan (LROA) is a non-profitable, nongovernmental and non-political national NGO which was established in July, 1999. The organization has been involved in the strengthening of economic, social and health sectors of the war ravaged Afghanistan. 


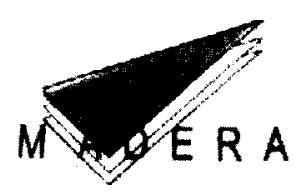

\section{MADERA (Mission d'Aide au Development des Economies Rurales)}

Mission d'Aide au Developpement des Economies Rurales (Madera) - Support to Development of Rural Economy Mission is a European organization under French Law.

Madera has been working since 1988 in the various provinces of Afghanistan to contribute to the recovery of rural economies devastated by years of war, and to favour the resettlement of village communities, mostly from neighbouring countries.

Madera is conducting activities in agriculture, livestock, forest protection, rehabilitation of water systems and road reconstruction. The activities are supported by the European Commission, United Nations and the French Ministry of Foreign Affairs.

The Main Office is in Jalalabad and there are offices in Laghman, Nangarhar, Kunar, Wardak, Hazarajat, Ghor and Hirat provinces.

\section{Malteser}

\section{Malteser (Malteser Foreign Aid Department)}

Malteser Foreign Aid Department is engaged in humanitarian aid worldwide since 1966. The head office is based in Cologne, Germany and has about 30 full time employees. Around 60 expatriates care for the projects worldwide.

In 2000, Malteser's turnover was about 20 million US dollars with approximately $50 \%$ of the turnover acquired from private donations and the other $50 \%$ being from grants from public donors (ECHO, UNHCR and the German Foreign Ministry).

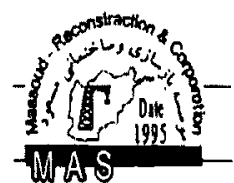

\section{MAS (Massoud Reconstruction and Corporation)}

Massoud Reconstruction and Corporation (MAS) was established in 1995 in Mazar. This organization contains experienced engineers and technical staff and has worked on different projects with WFP, UNHCR and GOAL. MAS' projects includes repairing roads, school and hospitals.

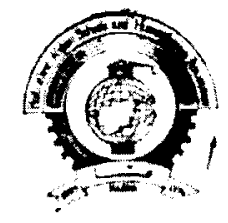

\section{MASHA (Multi-ethnic Afghan Schools and Humanitarian Assistance)}

Multi-ethnic Afghan Schools and Humanitarian Assistance (MASHA) is a nongovernmental, non-political and non-profitable organization which started functioning in 1997. It is registered with the Ministry of Planning, UN agencies and international NGOs working in Afghanistan. During the past years MASHA had worked in several sectors such as education, construction, agriculture, irrigation, water supply, sanitation, income generation activities and emergency programs. The funds for these activities were provided by UN agencies and some international NGOs. 
Mawlanai Balkh Rehabilitation Foundation (MBR) is a non-government organization with its purpose to service the people and reconstruct the country.

Since its foundation, $M B R$ has undertaken the following activities:

1. Construction of four bridges in Balkh district with UNHCR

2. Food distribution, Graveling and road repairing in Marmul district with WFP

3. Food distribution in the $5^{\text {th }}$ area of Mazarprovince with WFP

4. Food distribution, road graveling and digging in Marmul district with WFP.

5. Survey of schools and literacy courses in Marmul, Chahar Kint and Sholgara districts with WFP.

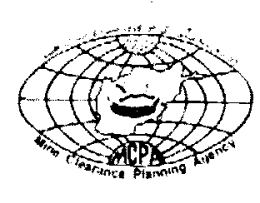

\section{MCPA (Mine Clearance Planning Agency)}

Mine Clearance Planning Agency (MCPA) is an Afghan NGO which was established in early 1990 as an implementing partner of the United Nations Mine Action Programmed for Afghanistan. The organization is operating with 46 five-man survey teams through its headquarters in Kabul and sub offices in Kabul, Jalalabad, Kandahar, Herat and Mazar. The overall goal of MCPA is to contribute toward the goals and objectives of the UN Mine Action Programme which is to reduce the threat of mines and other unexploded ordinances from the priority areas to allow mine area clearance, the safe return of refugees and local capacity building in mine action activities.

MCPA is involved in the following activities: general surveys, technical surveys, mine awareness, campaigns for achieving a total ban on landmines, post-conflict contamination assessments and victim surveys. 


\section{MDC (Mine Detection and Dog Center)}

Mine Detection and Dog Center (MDC) is a non-governmental, politically neutralized organization functioning under the supervision of the United Nations Mine Action Program for Afghanistan. MDC specialize in the fields of mine dog breeding, mine dog training and mine dog operations.

This organization was established in 1989 after receiving a donation of 14 trained mine detection dogs from the King of Thailand and it was the beginning of the development of this project. The presence of hundreds of cleared minefields by $M D C$ is the evidence of the successful operations. The output rate of MDC minefield clearance operations is higher than any other NGO involved in mine action. At the moment MDC produces around 40 to 45 percent of all mine action minefield clearance outputs in Afghanistan.

MDC operates in two phases:

1. Minefield clearance operations (by deployment of Mine Dog Groups)

2. Supporting minefield survey operations

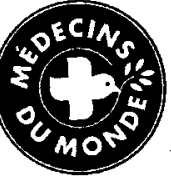

\section{MDM (Medecins Du Monde)}

Medecins Du Monde (MDM) is an international humanitarian association which relies on the voluntary commitment of the health care providers who are its members. For almost twenty years, it has brought relief to the most vulnerable populations, throughout the world and in France.

MDM France has worked in Afghanistan since 1982. MDM France currently supports MCH Clinics in Kabul as well as in Herat, two clinics in Maslakh IDP camp, a hospital in Chaghcharan city and clinics near Taywara in Ghorprovince.

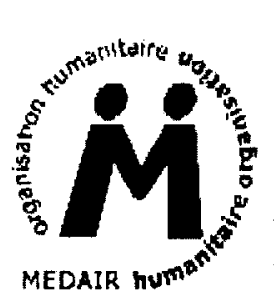

\section{MEDAIR}

Medair's headquarters are in Switzerland, although the agency is also registered in the UK, the Netherlands, France and Germany. The organization was founded in 1998 and has since worked in 19 countries in Africa, the Caucasus, the Balkans and Asia. The mission statement of Medair is "to respond to human suffering in emergency and disaster situations by implementing multisectorial relief and rehabilitation projects, in a compassionate and serving attitude inspired by its Christian ethos. Medair attempts to identify a people group or region that is particularly hit by a crisis and meet the needs of this community by providing appropriate aid. This may be in the area of health, shelter, water, clothing, food or other, helping the affected group to re-establish a more sustainable way of life. Medair has previously run TB control programmes in Somalia and Southern Sudan. Funding for project is received from various institutional donors and private supporters.

Medair has been working in Afghanistan since October 1996. It has implemented non-food item relief distributions, water and sanitation assistance, shelter projects for returning refugees, food-for-work for urban vulnerable families, drought relief and medical programmes. The medical programmes have included hospital support and health education amongst the poorer communities in Kabul; mobile clinics for IDP affected communities; a baselines health survey and an immunization campaign in a remote district of Badakhshan province and the support of the National TB Institute. 


\section{MERLIN}

Merlin is a UK-based charity, providing healthcare for people in crises and disaster situations around the world. We specialize in reaching the poorest countries; the most difficult environments and in complex emergencies; and supporting vulnerable people when the local infrastructure has broken down.

Our work saves lives and alleviates suffering. Visit our website www.merlin.org.uk to find out more about our work.

Merlin is registered charity in the UK(1016607) and US (31-1626535).

\section{MeRU (Medical Relief Unit)}

Medical Relief Unit (MeRU) is an international NGO which was started in 1998. It has a history of sending emergency missions to Kosovo (1999), Tokaimura (1999) and the Indian earthquake (2001) with the field of activities is related to health and emergency rescue.

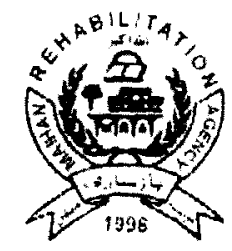

\section{MRA (Maihan Rehabilitation Agency)}

Maihan Rehabilitation Agency (MRA) is a non-governmental, non-political and nonprofitable agency established in March, 1995. The main office is located in Jalalabad with a

The objectives of MRA include:

- To plan and undertake projects for rural development

- To improve the living standards of the Afghan community through development programmes

- To secure the operation of reliefactivities in the target areas

\section{Fing R.A.A}

\section{MRAA (Mailan Rehabilitation Association for Afghanistan)}

Mailan Rehabilitation Association for Afghanistan (MRAA) was established in the year 2000 and it is mainly concerned with the rehabilitation and reconstruction in the areas of education, health, agriculture, technical and industrial projects. MRAA is involved in reliefand emergency situations.

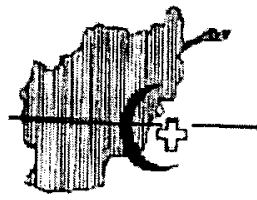

\section{MRCA (Medical Refresher Courses for Afghans )}

Medical Refresher Courses for Afghans (MRCA) is a European (French) NGO, entirely health oriented organization, which was established in 1985. MRCA has been providing medical assistance in terms of curative and preventive services and training programs in different health categories to Afghan refugees in Peshawar Pakistan as well as to Afghans inside Afghanistan. MRCA's main funding sources are the EU, ECHO and the French Government.

1. MRCA's Refugee program in Pakistan: 
MRCA is the only European NGO providing appropriate inpatient health services to Afghan refugees and services as a referral hospital to other facilities dedicated to Afghan refugees inside the refugee camps and around Peshawar.

2. MRCA's program in Afghanistan:

MRCA runs a 20-bed Rehabilitative Surgery Unit in the previous Plastic Surgery Department of Maiwand Hospital in Kabul. MRCA also operate the Charikar Civil Hospital in Parwan.

\section{MRORA (Maruf Relief Organization for Reconstruction of}

MarufReliefOrganization for Reconstruction of Afghanistan (MRORA) was established in 1998 in Pakistan to work for the needy people of Afghanistan. It is registered with the Ministry of Planning and UNOCHA. MRORA's main office is located in Kabul and its regional office is in Kandahar. It is a member of SWABAC and it has implemented many projects in Afghanistan in the areas of infrastructure, irrigation, agriculture, vocational training, water supply and others.

\section{MRS (Marja Rehabilitation Shura)}

Marja Rehabilitation Shura (MRS) was established on $28^{\text {th }}$ February, 1992 in Pakistan to work for the needy people of Afghanistan. It is registered with the Ministry of Planning and it is a member of SWABAC. MRS' main office is located in Kandahar with a sub office in Helmand province. It has implemented many projects in the south western zone of Afghanistan and works in water supply, agriculture, education, construction and other sectors.

\section{MSH (Management Sciences for Health)}

MSH MANGGEMENT SCENCES FOR HEATH

Management Sciences for Health (MSH) is collaborating with the MOPH, key NGOs, and other donors to conduct a survey of health facilities, workers and other potential providers of health services, such as shops and pharmacies throughout the country. Local Afghan teams will map the location of facilities, workers and services throughout the country.

Assistance will be provided to Afghan health authorities at the national and regional levels to enable them to:

- Being re-establishing governance of health care

- Set priorities and policies for community health services

- Develop management systems to support the health system

MSH will also work with the MOPH at the national level to guide NGOs working in the country, and will assist, as needed with the coordination of donor and NGO services delivery programs.

\section{NBR (Naw Bahar Balkh Reconstruction)}

Naw Bahar Balkh Reconstruction (NBR) commenced its activities in 1994 in the northern provinces of Afghanistan. It has previously undertaken projects in reconstructions, roads, agriculture, education and health with both UN agencies and international NGOs. Since its commencement, NBR has completed more than 20 projects in Jawzjan and Balkh provinces. It aims to assist in the reconstruction and rehabilitation of Afghanistan. 


\section{NC (Nejat Center)}

Nejat is an Afghan NGO which was established in 1991 and has been active in drug rehabilitation, HIVIAIDS prevention and awareness raising and education of street children with facilities for 20 patients. Namps near Peshawar. Nejat runs a residential program for heroin addicts refugee camps. The Nejat organisation has also been active in Badahug rehabilitation program in two expected that Nejat will soon be active in health, drug rehabilitation and education projects in 1995. It is Province.

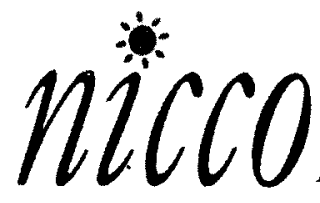

\section{NICCO (Nippon International Cooperation for Community}

NICCO was founded on the principles of world peace and the creation of economic and purposes, NICCO has posted its staff members in stricken people in developing countries. For these principles NICCO is, and has been since its establishment dedicated. According to its humanitarian regardless of the recipients racial, religious, political or factionalbeliefs.

\section{NIDA (National Industrial Development for Afghanistan)}

Since establishment in 1988, NIDA has focused on rehabilitation programs in different development sectors from its branch office in Peshawar. Decades of war and its consequences have led to great neglect and deprivation. The destruction of Afghanistan's natural recourses and widespread pollution are also significant problems facing the Afghan community. Consequently, the rehabilitation process has been impeded, affecting the health and living standards of the people.

The impact of these events has been felt all across the country. Valuable old growth forests, woodlands, and irrigation systems have been destroyed indiscriminately seriously depleting Afghanistan's natural resource base. Museums, archives and historical relics and other resources have been heavily damaged or
looted.

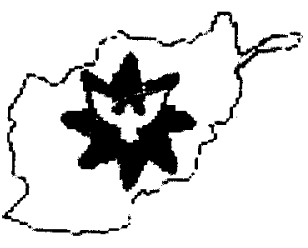

\section{NPO/RRAA (Norwegian Project Office Rural Rehabilitation Association for Afghanistan)}

Norwegian Project Office Rural Rehabilitation Association for Afghanistan NPO/RRAA of NPO, and has been registered in 1990 as an Afghan NGO. It is registered in Pakistan under the name regional offices and 7 sub offices in Afghanisth the Ministry of Planning since 1994. NPO/RRAA has four Jan Mosque Shar-e-now Kabul, since April 15, 2002. The main office operating near Sitara Hotel Shaboobo Irrigation, Health, Construction, Emergency and Training.

NPO/RRAA also undertakes activities in Pakistan in refugee camps in the North West Frontier Province of Pakistan. These projects include Income generation, Literacy, Scales Training and Health Education.

With the recent political changes in Afghanistan that has led to formation of interim government, NPO/RRAA has reviewed its strategic plan to ensure that it best meets the needs of the present situation. 


\section{NRO (Noor Rehabilitation Organization)}

Noor Rehabilitation Organization is a non-governmental, non-profitable and non-political organization. NOOR has been involved in the strengthening of economic, social and health sectors of war ravaged Afghanistan. Established in Dec 2000, NOOR has successfully completed many different projects in a variety of sectors.

\section{Ockenden International}

Ockenden International is a British based, secular NGO working with displaced people and refugees. Work is primarily focused on developing access and opportunities for community self help and self-sufficiency in often difficult and insecure environments. Ockenden has been fulfilling this role in Afghanistan since 1997 and in Pakistan since 1984. Ockdendens's regional office is based in Islamabad with country offices in Kabul, Tehran and Peshawar and program offices in Herat, Badghis, Farah, Nimroz, Helmand and Ghazni (Afghanistan) Mashad (Iran) and in Hangu (Pakistan).

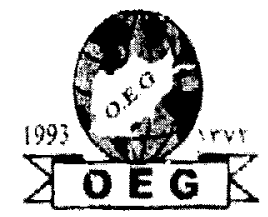

\section{OEG (Omulblad Engineering Group)}

Omulblad Engineering Group (OEG) was established in 1993 as a non-government organization carrying. Activities are carried out according to the rules/regulations of charity organizations, NGO's and the government of Afghanistan. Omulblad Engineering Group [OEG] is registered with the Afghan Government, UNWFP, UNHCR, HNICEF, IOM, ACT, HIA ass well as the USARMY in Mazare-Sharif. Omulblad Engineering Group (OEG) has implemented more than 24 different projects inside Afghanistan.

\section{ORA (Orphans Refugees and Aid)}

ORA was founded in Germany in 1981 and presently works in over forty countries in Asia, Africa, South America and Eastern Europe. From the beginning, ORA's mandate has been to assist vulnerable groups worldwide including refugees, orphans and the poor. ORA encourage development towards selfsufficiency.

ORA International has been supporting refugees since 1983. In 1991 ORA Central Asia was established in Peshawar. Over the past few years, ORA's projects have grown to encompass many areas of community development. We are focused on drug addict rehabilitation, health education, HIVIAIDS education and awareness, and education programs among Pakistanis and Afghans living in both Peshawar and Afghanistan. In 2001 ORA employed 96 local staff and 10 ex pat staff working in Pakistan and Afghanistan. Our staff are strengthened by ORA's commitment to serve the disadvantaged in a spirit of love and compassion.

\section{ORDA (Organization Rehabilitation Disables Afghanistan)}

Organization Rehabilitation Disables Afghanistan (ORDA) is working in 6 areas which includes reconstruction, education, handcrafts, agriculture, veterinary and health. It is working in Samangan, Kandahar, Takhar, Baghlan and Faryab areas of Afghanistan. 
OxfamGB has been working in Afghanistan since 1991. Current activities in Afghanistan consist of a large operation programme in Hazarajat and a smaller operation programme in Badakhshan province.

Oxfam's involvement in Badakhshan began after the massive earthquake hit the western District of Shahre-Buzurg on the $30^{\text {th }}$ of May 1998, killing some 2400 people and leaving many more injured and homeless. Oxfam launched an emergency program consisting of water supply, sanitation and shelter construction projects in the worst hit villages. Following the closure of that program Oxfam decided to continue its activities in the District, responding with a stronger focus on development. This was initiated through the implementation of an integrated rural recovery program including health education and livelihood programs.

\section{PACEE}

\section{PACTEC (Partners in Aviation \& Communications Technology)}

Parners in Aviation \& Communictions Tectinology Partners in Aviation \& Communications Technology (PACTEC) has worked in Afghanistan since 1998 providing essential air transport and 'life link' radio/e-mail services on a first comelfirst serve NGO priority based system. We also offer secluded charter flight services to all over Afghanistan.

At present, PACTEC services over 100 registered NGO organizations. Old air strips are currently being repaired and new air trips are being organized to facilitate the expanding aid effort in the remotest areas of Afghanistan .

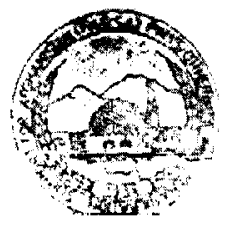

\section{PARSA (Physiotherapy and Rehabilitation Support for Afghanistan) \\ t}

Parsa (Physiotherapy and Rehabilitation Support for Afghanistan) is an American NGO that has been working inside Afghanistan since 1996. Its aim and goal is to provide the means for Afghans, especially widows and poor women, to make a livelihood with which to support their families and themselves. This in turn assists in generating a household income and revitalizing the economy

PARSA's activities cover five areas: The Gift Shop encourages female artisans by buying their best embroideries and clothing and then selling them. The vocational skills training program has enabled 130 sons of widows and poor adolescents to provide for their families as electricians, plumbers and Jewelers. The women's wool co-operatives have helped nearly 100 very poor, illiterate women to learn and secure an income in the wool business. PARSA's home schools have educated nearly 1200 girls during the Taliban repression and now continues to educate 280 girls and women in rural Paghman. Lastly, PARSA is committed to assisting the disabled through its rehabilitation and physical therapy center where it has helped thousands of people over the past year to recover from pain and disability.

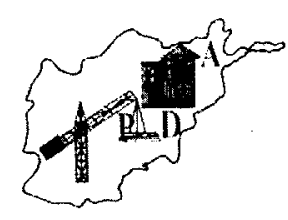

\section{PDA (Pamir Development Authority)}

Pamir Development Authority PDA is an Afghan non governmental, non - political Agency. Established in 1993 in Peshawar PDA is staffed with professional, experienced engineers/agrarians. PDA is an organizational and for the rehabilitation of Afghanistan Through its operational and financial capacity, PDA works towards the rehabilitation of Afghanistan, 
undertaking reliefand rehabilitation activities in its operational areas.

PDA has implemented several projects in partnership with UNHCR, WFP, Canada Fund and ECHO. PDA also maintains good relationships with local shuras.

\section{PHO (Polish Humanitarian Organization)}

The mission of the Polish Humanitarian Organization is to help victims of war and natural disasters and the victims of poverty both abroad and in Poland, and to assist refugees coming into our country. PHO, which was established in 1992, supports activities that contribute to the development of an open and responsible society, which is capable of selfdetermination.

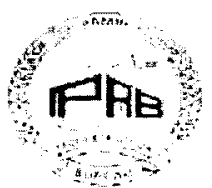

\section{PRB (Pamir Reconstruction Bureau)}

Pamir Reconstruction Bureau (PRB) is an Afghan NGO founded in 1990. PRB has a main office and five field offices inside Afghanistan and Pakistan. PRB is engaged in relief, reconstruction and development activities in rural and urban areas of northern and central Afghanistan. $P R B$ provides services in the areas of civil engineering $\&$ construction, animal health and livestock production, agriculture, skills training, income generation projects, community development and relief.

PRB has successfully implemented over 151 projects in 14 provinces in the sectors of animal \& livestock, engineering $\&$ construction, agriculture and relief. It receives funding from NCA, IRC, IDRF, CIDA, AGRP, the UN and other private donations from North America. The annual budget of the agency reaches around US $\$ 1,200,000$.

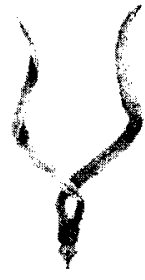

\section{PSD (Partners for Social Development)}

Partners for Social Development (PSD) has been working for a brighter future for the Afghans. PSD has completed various multi-sectoral projects in nine provinces of the country during the pre-Taliban government, but during the Taliban times, work was concentrated on the education sector only. The Taliban seized PSD offices and properties all over the country in August and September 1998. During the Taliban ruling, PSD changed the names of the formal schools to madressa, but most of the schools in Ghazni had been functioning under a co-education system. PSD is in the process of reviving its pre-Taliban activities in various sectors.

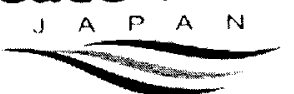

\section{peace winds}

\section{PWJ (Peace Winds Japan)}

Peace Winds Japan (PWJ) established in 1996, is a Japanese nongovernmental organization that provides assistance to individuals threatened by armed conflict and poverty. PJW's work has a strong focus on areas where assistance is not readily available due to poor security, political and economic circumstances. Our activities have neither political nor religious interest, and currently cover Asia and the Middle East. While our primary focus is on emergency humanitarian assistance, we also work on reconstruction and development projects. 


\section{QRCO (Qutb Rehabilitation and Construction Organization)}

QRCO is a nongovernmental, non political and nonprofit organization which was established in January, 2002. Currently, QRCO has several projects in operation including 2 Zeropoint of Islam Qala . agriculture projects and one construction project at the refugee gathering center at

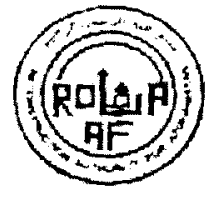

\section{RAFA (Reconstruction Authority for Afghanistan)}

Reconstruction Authority for Afghanistan (RAFA) is nongovernment and nonprofit public welfare based Afghan NGO staffed by well educated and experienced staff. RAFA was founded in early 1988 after the signing of Geneva accord on Afghanistan for the purpose of to assist, undertake and facilitate humanitarian, technical and economic assistance for the repatriation of over five million refugees. RAFA also participates in the rehabilitation and reconstruction of basic rural infrastructure in war ravaged Afghanistan. The organization strives for the maximum participation of community members in project identification, planning and implementation with no prejudice to religion

\section{RDO (Rehabilitation and Development Organization)}

$R D O$ is a non-governmental, non-profitable and non-political agency, which aims to assist the neediest Afghan people irrespective of their ethnic, political and other affiliations. RDO contributes to the rebuilding and development of Afghanistan through planning and designing vocational training programs and by focusing on rehabilitation, education, agriculture, health and other relief projects and programs. The organization strives for international support and seeks financial and technical assistance for the rehabilitation, development and prosperity of Afghanistan. The organization is committed to community participation and contributions as a must in all project interventions.

\section{RELIEF}

\section{RI (Relief Rehabilitation \& Development)}

INTERNATIONAL Relief International (RI) is a humanitarian non-profit agency that provides emergency $_{\text {relief, rehabilitation, and development assistance to vulnerable communities }}$ worldwide. RI conducts multi-sectoral humanitarian assistance programs that bridge the gap between reliefand development. RI was established in 1990 and is based in Los Angeles, California, USA.

RI was active in Afghanistan during the mid-1990s, providing emergency medical care to internally displaced persons. Current activities include: Primary Health Care and Maternal \& Child Health, Schools Construction and Rehabilitation, Rural Development including Road Rehabilitation, Irrigation and other public works and the establishment of Women's Development Centers.

\section{ROAD/DARIA (Reconstruction Organization for Afghanistan Development)}

ROAD/DARIA was registered with the Ministry of Planning in 1997 and has since worked in close collaboration with UNHCR and ICRC in providing clothes, shelter and assistance to returning refugees. Work has previously been undertaken in the Wardak and Kabul provinces and this year, 300 shelters will be
established in Jabal-sarajDistrict, Parwan Province. 


\section{RSSA (Reconstruction and Social Services for Afghanistan)}

Reconstruction and Social Services for Afghanistan (RSSA) is a non-political and nonprofitable Organization, with qualified and experienced personal in the sectors of engineering, agriculture and in women's activities. RSSA was established in December 1990 and since then has been engaged in the reconstruction/rehabilitation of Afghanistan. RSSA is registered with ANCB, Government of Pakistan, Government of Afghanistan, ACBAR, WFP, UNAMA and has maintained close relations with all UN and Afghan NGO's.

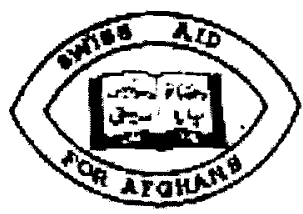

\section{SAA (Swiss Aid for Afghans)}

Swiss Aid for Afghans (SAA) is a registered NGO working since 1987 in Pakistan as well as in Afghanistan in the fields of education, reliefand income generation. In the field of education SAA has extended many services to the Afghan people.

In Pakistan, 7 primary and 4 secondary level schools for girls and boys have been established. SAA is also delivering cost free textbooks and other necessary stationery items to the students and pupils. In Kabul, SAA is running two sewing courses for 28 widows under the Ministry of Women. Two new colleges (Economy $\&$ Administration College and Teachers' Training College) are now operating in Jalalabad City this year.

\section{SAB (Solidarities Afghanistan Belgium)}

Solidarities Afghanistan Belgium (SAB) is non-government organization based in Liege Belgium. It works exclusively with Afghans, in both Pakistan and Afghanistan.

Founded in 1982 out of a desire to assist Afghans in the reconstruction of their war-torn country, SAB has grown to specialize in education, an area that it considers crucial for the sustainable development of Afghanistan. Within formal education, $S A B$ has developed its expertise in Basic Education for primary school teachers. Within informal education, it has chosen to concentrate on vocational and literacy training in order to provide illiterate Afghans with skills that enable them be competitive in the labor market and improve their livelihood. SAB's field activities started in 1984 in Pakistan, in refugee's camps in the district of Peshawar. In 1992, it was able to start implementing similar activities in the eastern region of Afghanistan. In addition, $S A B$ now intends to expand its activities of basic education and vocational training in 2002 to the other provinces such as Kabul, Logar and Paktia

\section{SC/UK (Save the Children-UK)}

Save the Children UK

Save the Children (UK) is a UK charity working in over 70 countries, including the $U K$, to create a better world for children. The principal underlying our work is derived from the UKConvention on the Rights of the Child

SC-UK has been working in Afghanistan since 1976 when it established and supported health clinics on the periphery of Kabul. Following the Soviet invasion, SC-UK established primary health care services and training for refugee's population in Pakistan. With the end of Soviet war and the return in 1994 of refugee's to Afghanistan, SC-UK closed this program and re-established operations inside Afghanistan. Initial activities in and around Herat were suspended following the Taliban take over of that region, and operations were subsequently relocated to Mazar-Sharif in the north.

At present, SC-UK is supporting MoPH to run 15 PHC clinics in the north. A Resource center for working street children in Mazar city will provide literacy training, life skills education, recreational space and vocational training. A Child-Focused Health Education (CFHE) program has been operational since 1997. 


\section{SC/US (Save the Children-US)}

Save the Children-US has been working in Afghanistan since 1989 and in refugee villages in Pakistan since 1985 In Afghanistan, Save the Children USA (SC/US) works in the program areas of education, health, food security and livelihood support. SC/US works in partnership with the Afghan government and local NGOS to help strengthen their capacity. Nearly two million people benefit from Save the Children's programs in Pakistan and Afghanistan.

\section{Save the Children}

children in developing

countries in such critical areas as survival, development, protection and participation through its programming and advocacy activities.

Save the Children works for:

- a world which respects and values each child

- a world which listens to children and learns

- a world where all children have hope and opportunity

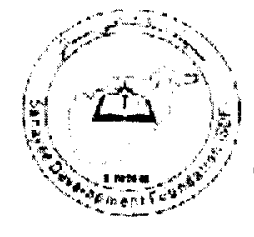

ayee Development Foundation (SDF) is an indigenous Afghan NGO, established in 1990 from a small educational center called the Kabul English Language Center (KELC). The chief aim of KELC was to promote education for the needy people of Afghanistan both in Afghanistan and Pakistan.

$S D F$ is run by qualified Afghan staff, who have a comprehensive understanding of their country, culture and the needs of their people. SDF works in the fieIds of education, peace building, income generation, skill development, capacity building and emergency assistance projects in both Afghanistan and Pakistan.

\section{SDP (Samandar Development Programme)}

Samandar Development Programme (SADP) is a local non-government organization, which was established in 1998 with the intention of rehabilitation and participation in public utility works. SADP was registered at the planning ministry and planning department of the west zone, and is also an implementing partner of the UN, international organizations as well as being a nonofficial member of ACBAR. SDP implements various activities in the sectors of construction, education, public health, agriculture and handicrafts in coordination with its donor agencies agencies, SADP believes in taking effective steps towards the development and rehabilitation of this war torn country. 


\section{SERVE (Serving Emergency Relief \& Vocational Enterprises)}

The purpose of SERVE is to express God's love and bring hope to Afghanistan's people by assisting vulnerable people and addressing personal, social and environmental needs.

SERVE is a Christian charity registered in the UK and has been working with Afghan refugees in Pakistan since 1980. SERVE has gradually moved both its projects into Afghanistan and is currently relocating its main office to Kabul. Serve's projects emphasize community development principles, education and vocational training for Afghans with disabilities, and public health/nutrition education.

SERVE is committed to helping the Afghan people become active and independent members of their society, and aims to empower local communities for their long-term sustainability. SERVE is registered with the government of Afghanistan and Pakistan and works in cooperation with UN bodies and other local international reliefand development organization.

\section{SFAO (Save the Forest Animals Organization)}

SFAO is a non-governmental organization established approximately two years ago with head offices in Kabul and Kandahar, as well as a sub office in Herat province. SFAO works in close consultation with the UN and International NGO's to identify and act on current problems, with expert staff ready to carry out specific projects. SFAO has carried out projects in agriculture, and surveying sections and at present has construction and water supply projects in the southwest of Afghanistan.

\section{SGAA (Sandy Gall's Afghanistan Appeal)}

Sandy Gall's Afghanistan Appeal was set up the British journalist, Sandy Gall, in 1984 to help disabled Afghans. SGAA was first based at Lady Reading Hospital in Peshawar where it ran an orthopedic center providing prostheses (artificial limbs) and orthoses (calipers and braces) for disabled Afghans and Pakistanis. SGAA has also set up training centers for Afghan physiotherapists and technicians in Pakistan and Afghanistan. Physiotherapy graduates work all over Afghanistan for other specialist organizations. Currently SGAA has its main center in Jalal Abad, where it serves three provinces in the Eastern region and maintains a women and child physiotherapy clinic in Khair Khana in northern Kabul.

Over 13000 disabled are assisted every year with physiotherapy treatment. Orthopedic appliances and mobility aids such as wheelchairs, crutches, walking frames and special chairs. A health disability awareness programme is also run through health clinics, schools and health workers to make local communities aware of how disabilities can be helped and prevented. 


\section{SHA (Shafaq Reconstruction Organization)}

Shafaq reconstruction Organization is a non-government organisation which aims to help war and drought affected people. Registered as an NGO in 1993, SHA.it is committed to the rehabilitation and repair of buildings, roads and bridge as well as cultivation and livestock work. Finally, Shafaq Reconstruction Organization is determined to rehabilitate the villages ofour country, helping them to become independent citizens.

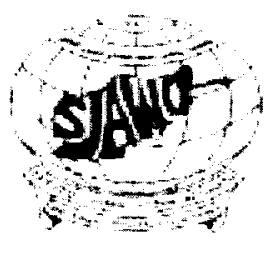

\section{SJAWO (Sayyed Jamaluddin Afghan Welfare Organization)}

SJAWO was established in 1989 following the Russian invasion and has since endeavored to help rebuild Afghanistan through planning, designing and implementing vocational training programs and construction activities for the Afghan people. SJAWO has also carried out projects in the fields of irrigation, agriculture, education, rehabilitation of horticulture and public buildings, flood protection works, relief programs and health units in different parts of Afghanistan.

SJAWO also undertakes programs in refugee camps in Pakistan. It has been implementing several vocational skills training projects in different trades skills as well as computer science and office management. Currently, 200 disabled Afghan students are receiving technical skill training in carpentry, welding, tin works, masonry and leather work at new Shamshatoo Afghan Refugee camp.

Similarly 170 vulnerable female students are receiving training in carpet weaving. tailoring and embroidery at the same camp.

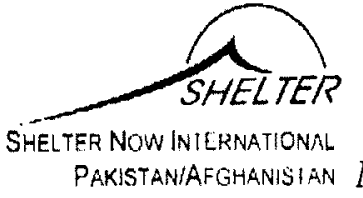

\section{SNI (Shelter Now International)}

Pakistan/Afghanisian Mawlanai Balkh Rehabilitation Foundation (MBR) is a non-government organization with its purpose to service the people and reconstruct the country.

Since its foundation, MBR has undertaken the following activities:

1. Construction of four bridges in Balkh district with UNHCR

2. Food distribution, Graveling and road repairing in Marmul district with WFP

3. Food distribution in the $5^{\text {th }}$ area of Mazar province with WFP

4. Food distribution, road graveling and digging in Marmul district with WFP.

5. Survey of schools and literacy courses in Marmul, Chahar Kint and Sholgara districts with WFP.

\section{SOLIDARITIES}

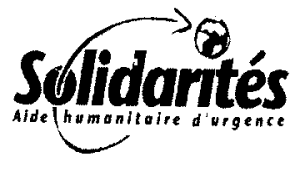

Solida rites is a humanitarian association established with the goal of providing emergency relief to countries where populations are dispossessed due to war or natural disasters.

Solidarities also collects and disseminates information about the population it assists. In 2002, Solidarites has eight missions throughout the world. From 1980 to 1990, emergency aid was brought to Afghanistan in the form of food or cash along with more long-term development programmes in education and agriculture. Emphasis was given to the re-establishment of the country's physical and social infrastructure. Today, humanitarian, rehabilitation and development assistance in Afghanistan is offered in agriculture, infrastructure, and emergency relief.

The agency hopes to improve the condition of the most vulnerable people and participate in the restoration of a civil society, through economic reconstruction and development, and capacity building in close collaboration with the authorities in Afghanistan. 


\section{SRA (Shendend Reconstruction Agency)}

A

Shendend Reconstruction Agency (SRA) began its work in 1997 with activities in Farah, Herat and Badghis provinces. SRA has received assistance from the UNHCR and UNICEF for some of its projects. SRA is working in Qaleh New (ATI School).

\section{SRO (Sadaqat Rehabilitation Organization)}

Sadaqat Rehabilitation Organization (SRO) is a non-governmental, non-political and completely impartial organization.

The main objectives of SRO include:

- to perform medical and health services in rural areas through treatment

- development of industry and handicraft by offering vocational training and technical services

- development of education oforphaned children

- development and extension of agricultural centers, cleaning of canals

- active participation in the reconstruction of Afghan houses

- struggle against the cultivation and trafficking of opium

\section{SRO (Sherzaad Reconstruction Organization)}

Sherzaad Reconstruction Organization (SRO) was established in 2001 in Herat province and has since worked in Badghis and Ghor provinces. In 2001 SRO implemented food and shelter projects in Herat and a health/rehabilitation clinic which was funded by IRC Office. With an agreement signed with the UNHCR, SRO is now implementing a shelter project for IDP's, returnees, as well as reconstructing schools, water supply and irrigation systems in five districts of Herat Province.

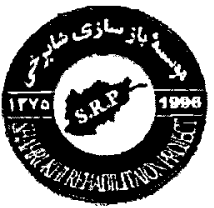

\section{SRP (Shahrukhi Rehabilitation Project)}

SRP is supported by 15 experienced staff members and has been a successful partner for several UN agencies (WFP, GOAL, NUICHA, UNCIF and UNOPS). Since its establishment, SRP has successfully implemented 11 project in the northern provinces of Afghanistan.

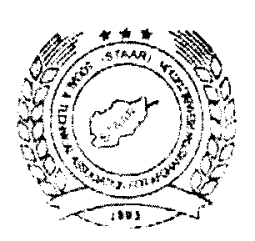

\section{STAAR (Social and Technical Association for Afghanistan Rehabilitation)}

STAAR is a non-political, non-government and non-profit organization set up to provide humanitarian assistance through a variety of projects determined by the Afghan Government and donor agencies. STAAR is primarily concerned with providing humanitarian assistance to all Afghans and for the rehabilitation of Afghanistan's economical capacity.

STARR is an Afghan NGO undertaking reconstruction, reliefand repatriation efforts for refugees and needy people, providing technical expertise for the planning and implementation of architectural, civil, agricultural, health and irrigation project. 


\section{SVF (Social Volunteers Foundation)}

Social Volunteers Foundation (SVA) works in the field of education and vocational trainings for boys, girls and widows. At present, a total of 60 widows, 90 street working children and 70 girls over 13 years who have been deprived of education are being assisted.

SVA has worked with such organisations as SCS (Save the Children Sweden) in providing education centers and stationary supplies. An agreement with Ministry of Education has been signed through which students were given certificates for their work.

\section{$\mathrm{T}^{\text {The Asia }}$ Foundation}

organization committed to the development of a peaceful, prosperous, and open Asia-Pacific region. The Foundation supports programs in Asia that help improve governance and law, economic development and reform, women's participation and international relations. The Foundation gives priority to strengthening leadership and capacity of local organizations, as well as improving public policy. Foundation grants are given for education and training, technical assistance, exchanges, policy research and educational materials. Founded in 1954, The Asia Foundation is headquartered in San Francisco, has 16 offices in Asia, and an office in Washington DC. The Asia Foundation established its Afghanistan office in 1956. This office functioned until the end of 1979. In early 1980, the office was closed. A Foundation office was opened in Peshawar in the 1980s to work on programs with Afghan refugees in Pakistan. The Asia Foundation re-established its program in Afghanistan in early 2002 .

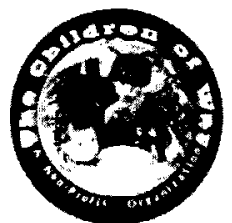

\section{TCOW (The Children of War)}

The Children of War (TCOW) organization has made great progress since it first began in 1994. TCOW has provided assistance to Afghans in refugee camps (Pakistan, Iran, and Afghanistan) generally with donations from Afghans living in the United States and partly from Canada. A training school for Afghan children has been established in Kabul and Peshawar providing basic level education, stationery and uniforms. Finances have also been provided for food distribution and education projects.

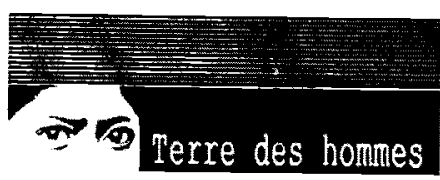

\section{TDH (Terre des homes)}

Terre des hommes is a Swiss based NGO working in Afghanistan for the past eight years, assisting mothers and children. TDH is a private, non-profit, international children's movement, free of religious, political or ethnic bias. TDH headquarters is located in Lausanne, Switzerland. TDH was founded in 1960 and now works in more than 40 countries, bringing direct aid and assistance to abandoned or impoverished children and their families

\section{TRÓCAIRE}

\section{TROCAIRE}

Working for a just Wrold

Trocaire has been involved with Afghanistan since 1994. It started its operational activities in Afghanistan and Pakistan shortly after the American intervention in the area in October 2001. At this time, Trocaire focused its activities on emergency reliefboth within Afghanistan and with the refugee communities in Pakistan. By February, with the worst of the emergency over, and the prospect of some sort 
Trocaire works through local Afghan NGOs partners, and does not implement any projects itself. Trocaire works in the areas of peace building, livelihood support and human rights. Trocaire's main Afghan partners are $A R E A, A D A$, and CPAU. Trocaire funds for Afghanistan originate from the Irish public and from the Irish Government.

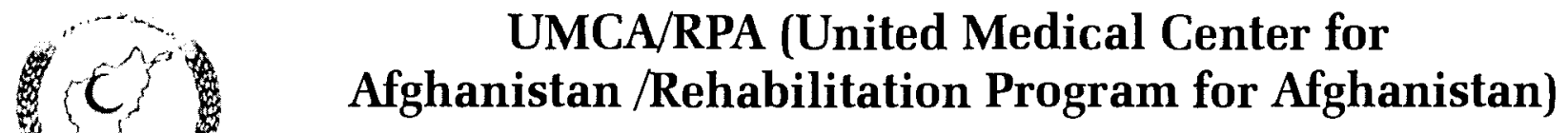

$U M C A / R P A$ is a non-political, non-governmental and non-profit humanitarian organization established in 1987 (RPA was added to UMCA in 1996). It aims to offer help to needy Afghans through the humanitarian assistance program and actively participates in the rehabilitation and development programs for Afghanistan.

The sectors of operation include health, education, construction, emergency assistance, income generation programs and water and sanitation.

UMCA/RPA has implemented many projects in side Afghanistan and in Pakistan for Afghan refugees and various proposals for health, vocational training, education and construction have been submitted to donors.

\section{UMCOR (United Methodist Committee for Relief)}

UMCOR's mission is to alleviate human suffering with open hearts to all religions and open doors to all people. It is a humanitarian, non-proselytizing agency of the United Methodist Church. UMCOR-NGO provides transitional development and relief assistance internationally by working collaboratively with local communities to assist then in restoring social stability, revitalizing community structures, and empowering their members to retake control of their lives.

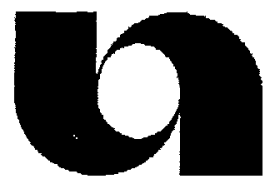

\section{UNO/ARRENA (University of Nebraska at Omaha/Americas' Rapid Response to Education Needs in Afghanistan)} of Afghanistan by taking part in the rehabilitation of education programs.

Objectives of the program are:

1. To revise Afghan schools' textbooks regarding to the new changes and development of education system in Afghanistan.

2. To provide and deliver more than 10 million primary and secondary revised textbooks for Afghan schools.

3. To print more than 30,000 instructional materials and teacher training kits.

4. To train male and female teachers and conducting of refreshing courses for primary schools and teachers.

UNO is a center for Afghanistan Studies and was opened in 1972. It was the contractor of USAID's higher education project at Kabul University from 1974 to 1978. It was an implementer for several training 


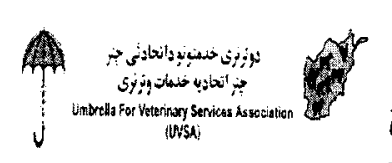

\section{UVSA (Umbrella for Veterinary Services Association)}

Umbrella for Veterinary Services Association (UVSA) is a non-governmental and non-political organization established since June, 1996. Since its establishment UVSA has been preparing assistance to the owners of animals inside of Afghanistan by providing them medicine, vaccines, molasses blocks and veterinary equipment through regional VSAs and VFUs.

The main objective is to bring Afghan veterinarians together to follow up a single sustainable policy for delivering veterinary services to the Afghan farmers and to ensure the supply of quality veterinarian medicines and vaccines at regional centers and at competitive prices for the VFUs without making a profit.

UVSA has 639 members and 7 regional VSAs in Nangarhar, Kabul, Kandahar, Ghost, Herat, Balkh and Kunduz provinces.

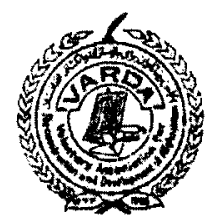

\section{VARDA (Voluntary Association for Reconstruction)}

Voluntary Association for Reconstruction and Development of Afghanistan was established in 1998 and is officially registered with the Ministry of Planning. After registration we started an income generation project with our own capital. It is a carpet weaving project providing jobs for about 2000 people for the last 4 years.

We have completed the following rehabilitation and construction projects.

1. Rehabilitation of Zarghoona high school

2. Rehabilitation of Aina Media center

3. Rehabilitation of Place $9^{\text {th }}$ station for Turkish ISAF

4. Rehabilitation of a building in Hood Khail for Turkish ISAF

5. Construction of 3 new buildings in ISAFOH-Q

6. Rehabilitation Teacher training Collage

7. Rehabilitation of Yaka Toot High school

8. Rehabilitation of Karte-Se girls high school

9. Construction of a guest house for IOM

\section{VWO (Voice of Women Organization)}

Voice of Women Organization (VWO) serves for widows and vulnerable women by giving them tailoring, computer and English language lessons as well as literacy courses, women rights and professional training.

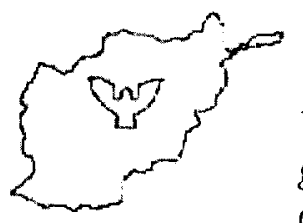

\section{WAA (Women Assistance Association)}

Women Assistance Association (WAA) was established as a non-profit, nongovernmental, humanitarian organization in 2000. Since its inception, the organization has been involved in implementing projects that generate change in the lives of the poor women that live in the society.

Since its establishment the organization has been involved in delivering both emergency and rehabilitation interventions in Afghanistan. 
After the fall of the Taliban and formation of transit government in Afghanistan, the organization shifted its main office from Peshawar to Kabul. At present the organization is involved in offering training to women and conducting sessions in health education for about 5000 individuals in Butkhak village of Baghram district. These projects are funded by Norwegian Church Aid (NCA).

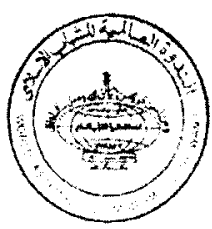

\section{WAMY (World Assembly Muslim Youth)}

The World Assembly of Muslim Youth (WAMY) is an independent, international organization working for needy communities around the world. WAMY's headquarters are based in Riyadh, Saudi Arabia.

WAMY has regional as well various branches in and outside Saudi Arabia. Established in 1972, it has a presence in 55 countries and associate membership of over 500 youth organization around the world. WAMY is a member of the United Nations NGOs and is recognized for its vast scope of humanitarian and relief work that encompasses about $60 \%$ the Muslim World.

WAR child

\section{WC (WAR CHILD)}

War Child was founded in 1993 in response to the higher incidents of children caught in the war in former Yugoslavia. War Child aims to provide immediate, effective and variable aid to war affected children and their families. War Child works independently or in partnership with other agencies to provide effective aid. Projects cover the areas of nutrition, rehabilitation, emergency relief, medical care, food provision, education and social welfare programmes.

\section{WRO (Watan Reconstruction Organization)}

Watan Reconstruction Organization is a non-governmental and non-political organization It does not belong to any party and is not involved in any politician activities. The main objective of WRO is to develop, rehabilitate and reconstruct Afghanistan by using funds from both national and international cooperative organizations.

\section{WSTA (Watan's Social \&Technical Service Association)}

Watan's Social \& Technical Service Association (WSTA) is a humanitarian agency, established in 1992 for the purpose of humanitarian assistance to Afghans in Pakistan \&Afghanistan. This organization started its activity as a small leather craft income-generating unit. Within a short period of time this organization sold its leather products successfully not only in Pakistan, but also in other countries. Apart form bringing income to the organization, this unit provides employment to Afghans working in the unit. Success in production and marketing of leather products enabled this organization to expand its activities in other projects such as construction, bakery establishment, training $\&$ educational courses, tailoring \& embroidery courses, literacy projects, carpet weaving \& school constructing and shelter projects. 
Women's Unity For Rebulilitation WUR is a non-governmental, non-profitable and non-political organization engaged in the improving the conditions for Afghan Refugees and women in Afghanistan. Since its establishment it has endeavored to keep good and co-operative relations with all agencies working for women. Relations with donor agency are exemplary. Its good track record has always tempted donors who wish to fund result-oriented projects to give priority in funding to WUR. The projects this agency has successfully implemented has changed the lives of allot of vulnerable, poor and handicapped Afghan women. This agency has expert staff in imparting knowledge on income generation and handicrafts skill that donors have always praised and appreciated its excellent performance. This agency is always ready to implement women focused projects which could produce a quick impact and encourage women to get training allowing them to earn theirown living.

\section{World Vision}

WVA (World Vision Afghanistan) supported programs serving over 75 million impoverished men, women and children worldwide. During the last three years, World Vision Inc (i.e. World Vision/United States) has received and administered over 150 contracts, grants and cooperative agreements with the US Government.

In terms of the project proposed here, WV Afghanistan will have ready access to expertise in all aspects of programming, financial /administrative management and grant compliance from WVIs global, regional and nearby country offices. Experts in qualitative assessment methodologies, project design tools, monitoring and evaluation, reconstruction and rehabilitation, and community mobilization are easily accessible. This expertise is shared through regional and international workshops and training; the frequent sharing of key staff between programs and with $W V$ 's regional and international offices; and the production and sharing of publications, methodologies, best pratices, lessons learned and research.

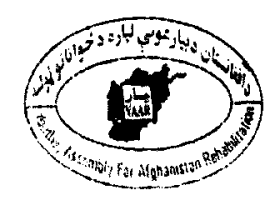

\section{YAAR (Youth Assembly for Afghanistan Rehabilitation)}

YAAR is a non-political, non-governmental and not profitable organization, rendering all its services without discrimination. As an implementing organization YAAR will obey all the laws of government, donor agencies and coordinating NGOs and will organize its activities according to these laws. YARR shall implement reliefand rehabilitation activities through mutual understanding and direct cooperation with existing, local residents, authorities and shuras.

\section{YARA (Youth Association for Rehabilitation of Afghanistan)}

School rehabilitation and the distribution ofbooks and other facilities to schools in different provinces have been under taken to help the education of school children by YARA. YARA will endeavor to execute suitable projects to decrease dependency upon outside support and encourage seed reliance in the community. YARA is registered with the Ministry of Planning of the Government of Afghanistan and is a member of Afghan NGOS coordination Bureau (ANCB) 


\section{(YRO) Yama Rehabilitation Organization}

Yama Rehabilitation Organization (YRO) started work in 1994 in the northern province of Afghanistan in Mazar city with engineers, agriculture experts, medical doctors and education experts. Areas worked include Jawzjan, Baghlan and Balkh in sectors such as reconstruction, agriculture, education and free food distribution with different UN offices (WFP, UNHCR, UN/OPS, UNICEF) and international NGOs. With 15 different projects completed, YRO currently has a project in Jawzjan province in Aqcha district.

\section{Zuflucht}

Zuflucht supports the Leprosy Control Program in Afghanistan by providing:

- A social support program for Leprosy patients who are rejected and isolated from their families or communities.

- Health eduçation and early case finding survey to find unknown and hiding Leprosy patients.

- A home for Homeless and Handicapped, including non-leprosy patients in Yakawlang, Bamyan.

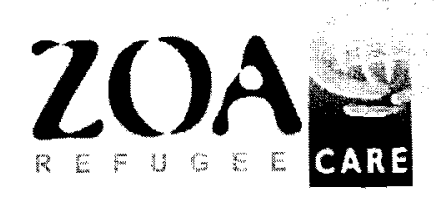

\section{ZOA (ZOA REFUGEE CARE)}

ZOA Refugee Care is a Dutch based NGO. It has implemented humanitarian assistance projects for refugees and internally displaced persons in many countries during the past twenty years. In Asia the programs cover Cambodia, Thailand, Lao PDR, Sri Lanka and, since 2000, Afghanistan.

ZOA Refugee Care implements projects in Afghanistan aimed to enable potential refugees and IDP's to stay in their villages and to encourage refugees in Pakistan to return to these villages in Afghanistan.

The projects evolve around rehabilitation of agriculture and basic healthcare in close co-operation with the people. Project areas in Afghanistan are Khake-jabar district of Kabul province and Sozma-Qala district of Saripul province. 


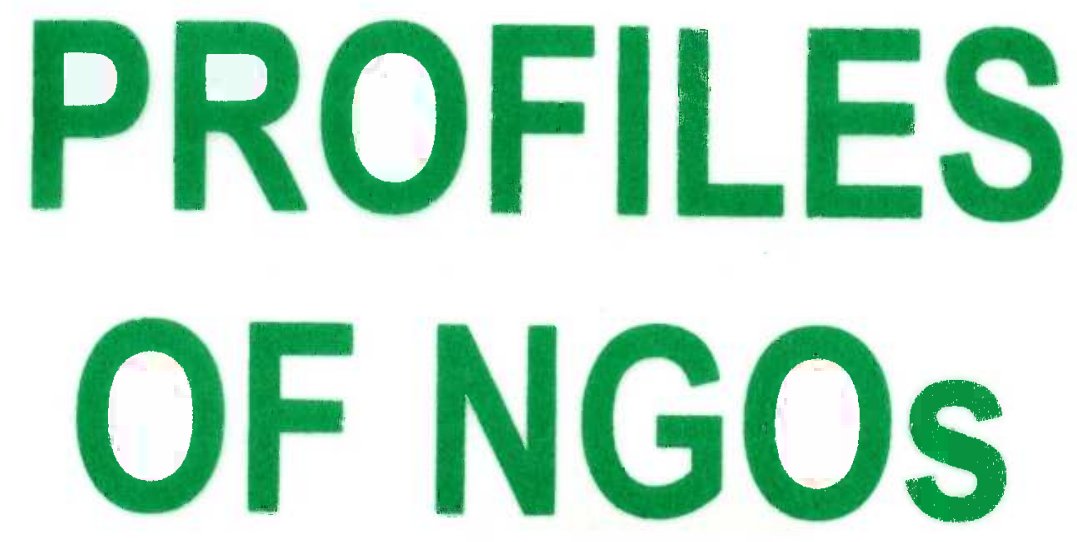




\begin{tabular}{|c|c|c|c|c|}
\hline Membership & ANCB & & Country of Affiliation & Afghanistan \\
\hline Address & Commu & cation & Key Staff & Position \\
\hline \multirow{3}{*}{$\begin{array}{l}\text { C/O:KJRC Jamrud Road, } \\
\text { University Town, } \\
\text { PO BOX 782, } \\
\text { Peshawar-Pakistan }\end{array}$} & Phone: & 844078 & Abdul Baseer & Director \\
\hline & Fax: & $8405 \mathrm{ZI}$ & Haji Omara Khan & Assistant Director \\
\hline & $\begin{array}{l}\text { E-mail: } \\
\text { Web: }\end{array}$ & aabrarps@psh.paknet.com.pk & Mr. Razaqul & Administrator \\
\hline
\end{tabular}

\begin{tabular}{|l|}
\hline Afghan \\
\hline \hline Pakistani \\
\hline Expatriates \\
\hline Total \\
\hline
\end{tabular}

\section{Personnel}

Budget In US \$

\begin{tabular}{|l|}
\hline Administrative \\
\hline Support \\
\hline Technical \\
\hline Total \\
\hline
\end{tabular}

\begin{tabular}{|c|c|c|c|c|c|}
\hline & 1998 & 1999 & 2000 & 2001 & 2002 \\
\hline Afghanistan & 100,000 & 10,000 & 43,000 & 54,000 & 74,410 \\
\hline Pakistan & 0 & 0 & 0 & 0 & 0 \\
\hline Total & $100,000.00$ & $10,000.00$ & $43,000.00$ & $54,000.00$ & $74,410.00$ \\
\hline
\end{tabular}

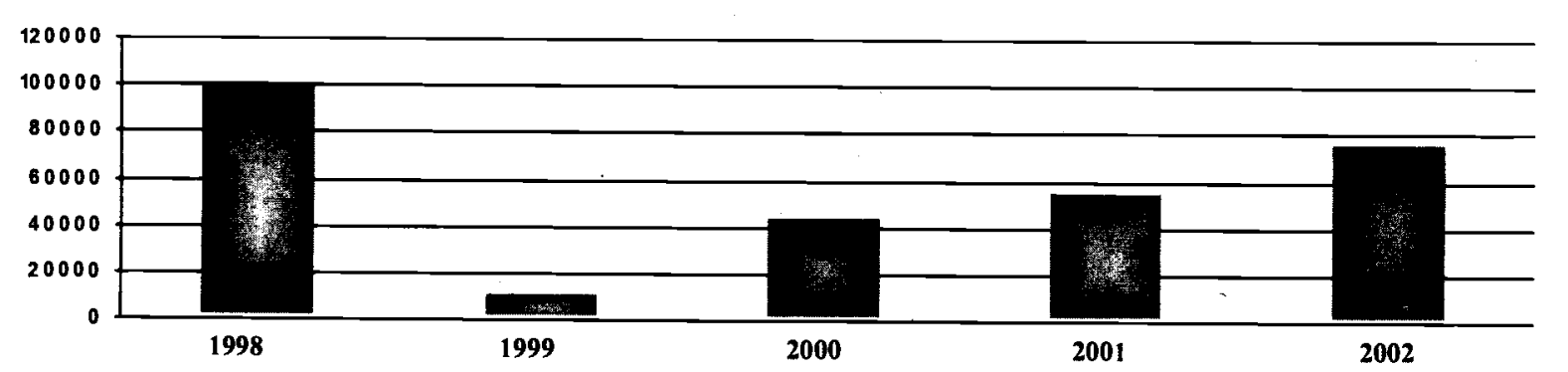

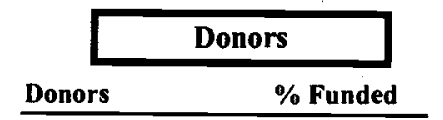

Caritas

Diakonic

Medico Int

Trocaire

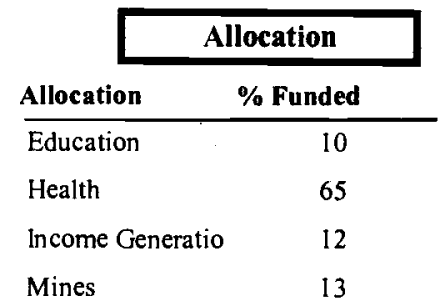

Sub Offices

\begin{tabular}{lll}
\cline { 2 - 3 } Province & \multicolumn{2}{c|}{ Targeted Provinces } \\
\hline Kabul & Sector & \% Targeted \\
Kabul & Mines & 3 \\
Kabul & Income Generation & 4 \\
Nangarhar & Education & 4 \\
Nangarhar & Health & 65 \\
Nangarhar & Education & 6 \\
Nangarhar & Mines & 10 \\
& Income Generation & 8
\end{tabular}

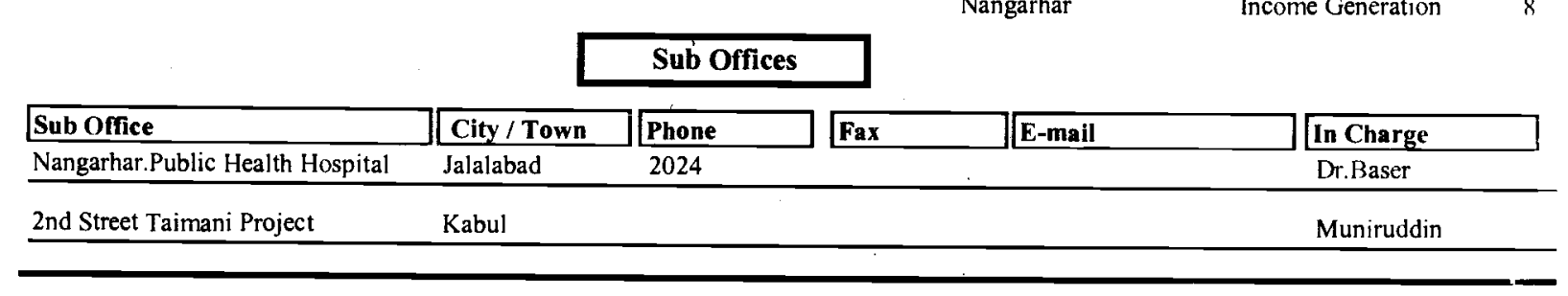




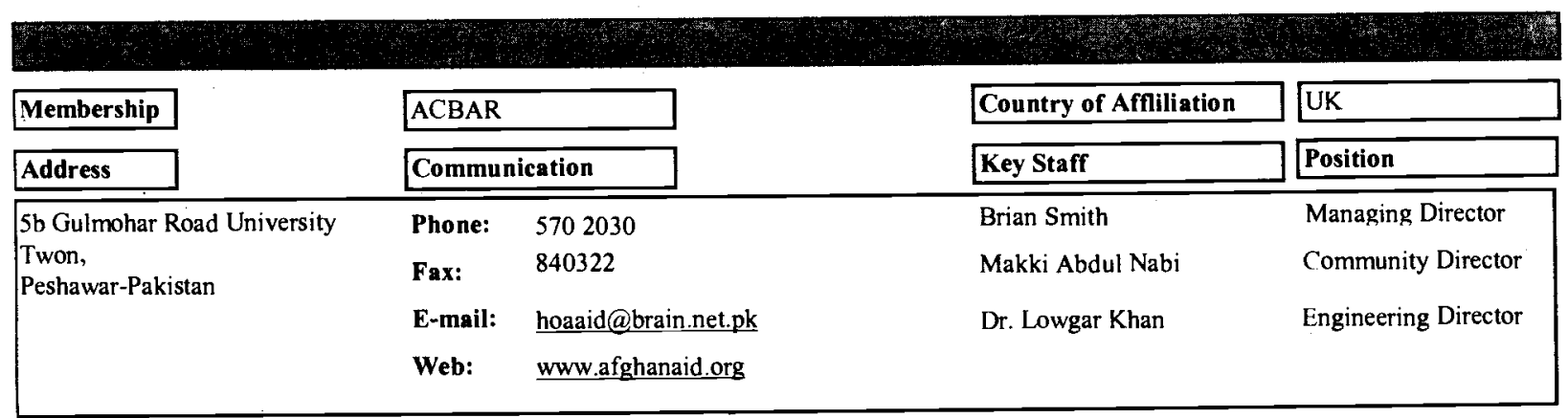

\begin{tabular}{|c|c|c|c|c|c|c|}
\hline & \multirow{2}{*}{\multicolumn{2}{|c|}{391}} & Personnel & & & \\
\hline Afghan & & & & Administrative & & 60 \\
\hline$\longdiv { \text { Pakistani } }$ & \multicolumn{2}{|c|}{7} & & Support & & 70 \\
\hline Expatriates & \multicolumn{2}{|c|}{2} & & Technical & & 270 \\
\hline \multirow[t]{3}{*}{$\overline{\text { Total }}$} & \multirow{2}{*}{\multicolumn{2}{|c|}{400}} & & Total & & 400 \\
\hline & & & Budget In US \$ & & & \\
\hline & 1998 & 1999 & 2000 & 2001 & \multicolumn{2}{|l|}{2002} \\
\hline Afghanistan & \multirow{2}{*}{$\begin{array}{l}2,100,000 \\
0\end{array}$} & $2,100,000$ & $3,000,000$ & $4,500,000$ & \multicolumn{2}{|l|}{$5,800,000$} \\
\hline Pakistan & & 0 & 0 & 0 & 0 & \\
\hline Total & $2,100,000.00$ & $2,100,000.00$ & $3,000,000.00$ & $4,500,000.00$ & $5,800,000.00$ & \\
\hline
\end{tabular}

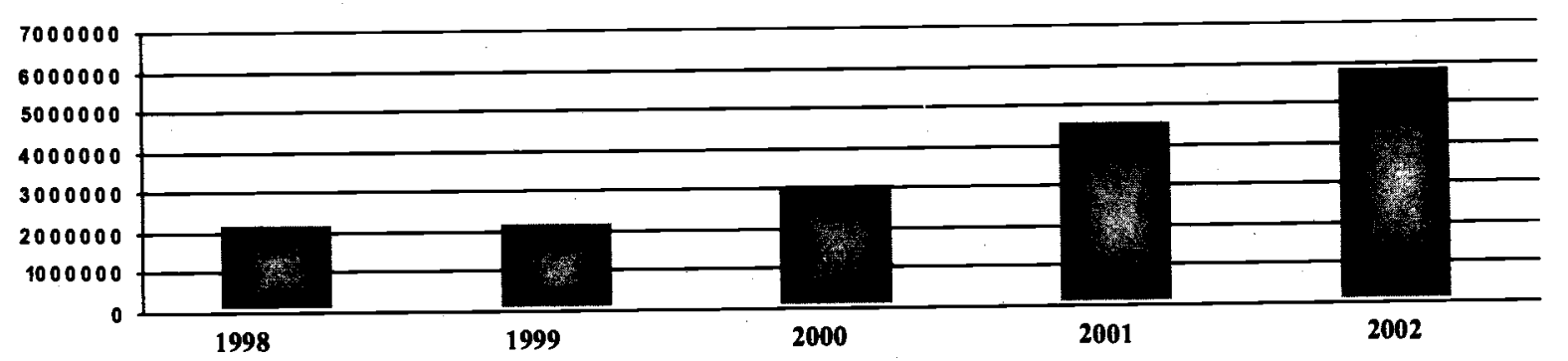

\begin{tabular}{|c|c|c|c|c|c|c|c|}
\hline \multicolumn{2}{|c|}{ Donors } & & ocation & \multirow[b]{2}{*}{ Province } & \multicolumn{3}{|c|}{ Targeted Provinces } \\
\hline Donors & $\%$ Funded & Allocation & $\%$ Funded & & Sector & $\% \mathrm{Ta}$ & \\
\hline DFID & 16 & Agriculture & 38 & Badakhshan & Rura & ment & 42 \\
\hline $\mathrm{EC}$ & 52 & Emergency & 2 & Ghor & Rura & oment & 40 \\
\hline Private & 2 & Health & 2 & Nuristan & Rura & pment & 18 \\
\hline UK Foundation & 10 & Income Generatio & 5 & & & & \\
\hline UNAMA & 2 & Infrastructure & 50 & & & & \\
\hline WFP & & Veterinary & 3 & & & & \\
\hline
\end{tabular}

Sub Offices

\begin{tabular}{|c|c|c|c|c|c|}
\hline Sub Office & City / Town & \begin{tabular}{|l|} 
Phone \\
\end{tabular} & Fax & E-mail & In Charge \\
\hline Kabul.Karte- Parwan & Kabul & & & & Murwarid Ziayee \\
\hline FaizAbad & Badakhshan & & & aadbdk@brain.net.pk & Ghulam Dastagir \\
\hline Hirat & Hirat & & & & Nazari \\
\hline Ghor & Kamen & & & & Abdul Khalid \\
\hline Nuristan & Kamoo & & & aadnur@brain.net.pk & Babrek Hamidi \\
\hline
\end{tabular}




\begin{tabular}{|c|c|c|c|}
\hline \begin{tabular}{|l} 
Membership \\
\end{tabular} & & Country of Affiliation & Afghanistan \\
\hline Address & Communication & Key Staff & Position \\
\hline \multirow{4}{*}{$\begin{array}{l}\text { Street No } 4 \text { Kochi Gul Frushi, } \\
\text { Shahr-e- Now, } \\
\text { Kabul-Afghanistan }\end{array}$} & Phone: & Dr.S.Hamayon & Director \\
\hline & Fax: & Eng.Ab.Latif & Project Manager \\
\hline & E-mail: & Eng.A.Qahar & Admin/Accounts \\
\hline & Web: & & \\
\hline
\end{tabular}

\begin{tabular}{|l|}
\hline Afghan \\
\hline \hline Pakistani \\
\hline Expatriates \\
\hline Total \\
\hline
\end{tabular}

Personnel

\begin{tabular}{|c|c|c|c|c|c|}
\hline rotal & & & & Total & \\
\hline & , & & Budget In US \$ & & \\
\hline & 1998 & 1999 & 2000 & 2001 & 2002 \\
\hline Afghanistan & 100,000 & 61,658 & & & \\
\hline Pakistan & 0 & 0 & & & \\
\hline Total & $100,000.00$ & $61,658.00$ & & & \\
\hline
\end{tabular}

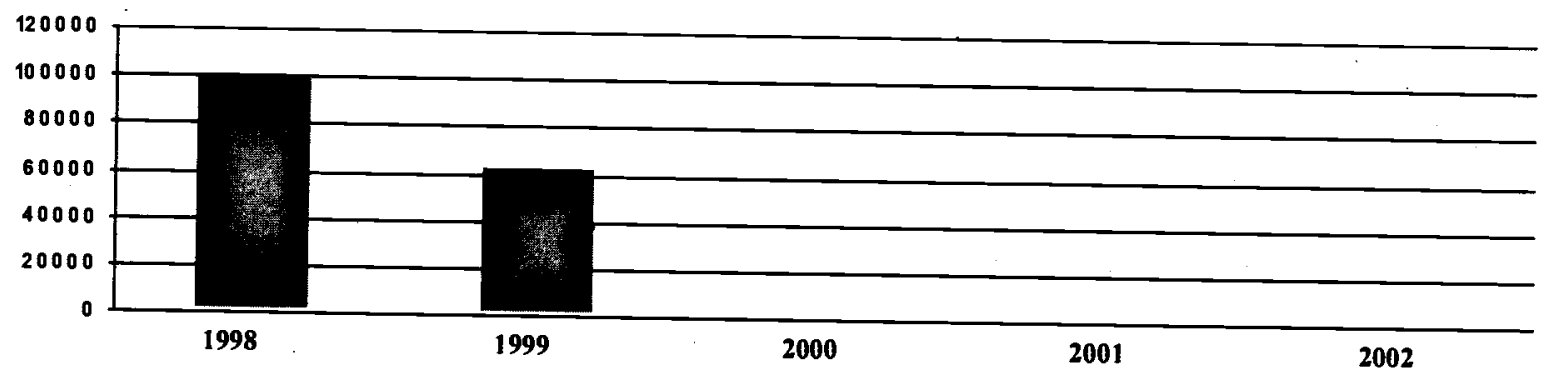

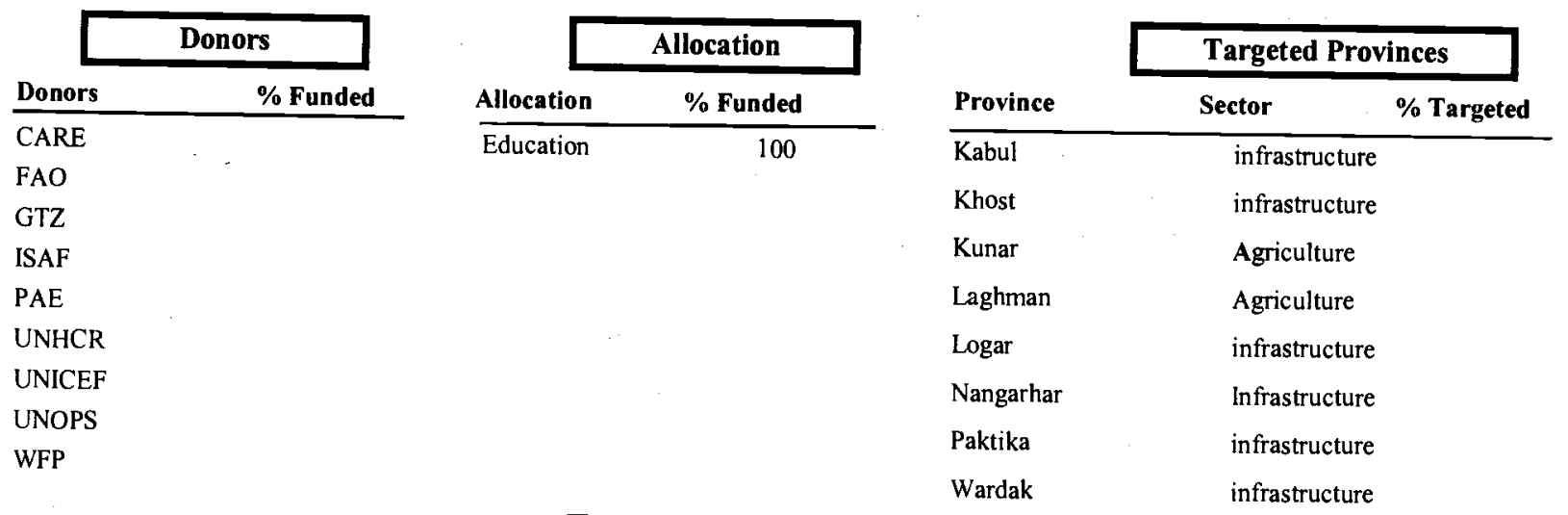

Sub Offices

\begin{tabular}{|c|c|c|c|c|}
\hline Sub Office & City / Town & Phone & E-mail & In Charge \\
\hline Kapisa.Oshter Gram & Kohistan & & & AbLatif \\
\hline Nangarhar & Jalalabad & & & Eng.Fahim \\
\hline Bandar Khan & Kunduz & & & Eng.A. Hamid \\
\hline Shahr-e- Pulikhumry & Baghlan & & & Dr. Norulhaq \\
\hline
\end{tabular}




\begin{tabular}{|c|c|c|c|}
\hline Membership & & Country of Affliliation & Afghanistan \\
\hline Address & Communication & Key Staff & Position \\
\hline \multirow{4}{*}{$\begin{array}{l}\text { Charahi-e-Haji Yaqoob, } \\
\text { Shar-e-Naw, } \\
\text { Kabul-Afghanistan }\end{array}$} & $30081 / 070277542$ & Abdul Jamil Sarwary & Director \\
\hline & & Abdul Jalil Bashir & Deputy Director \\
\hline & E-mail: abady@hotmail.com & Haji Noor Ahmad Zadran & Finance Manager \\
\hline & Web: & & \\
\hline
\end{tabular}

\begin{tabular}{|c|c|c|c|c|c|}
\hline & & & Personnel & & \\
\hline Afghan & \multicolumn{2}{|c|}{12} & & Administrative & 4 \\
\hline Pakistani & \multicolumn{2}{|c|}{0} & & Support & 2 \\
\hline Expatriates & \multicolumn{2}{|c|}{0} & & Technical & 6 \\
\hline \multirow[t]{3}{*}{ Total } & & & . & Total & 12 \\
\hline & . & & Budget In US S & & \\
\hline & 1998 & 1999 & 2000 & 2001 & 2002 \\
\hline Afghanistan & 1,550 & 2,795 & 2,960 & 1,000 & \\
\hline Pakistan & 0 & 0 & 0 & 0 & \\
\hline Total & $\overline{1,550.00}$ & $2,795.00$ & $2,960.00$ & $1,000.00$ & \\
\hline
\end{tabular}

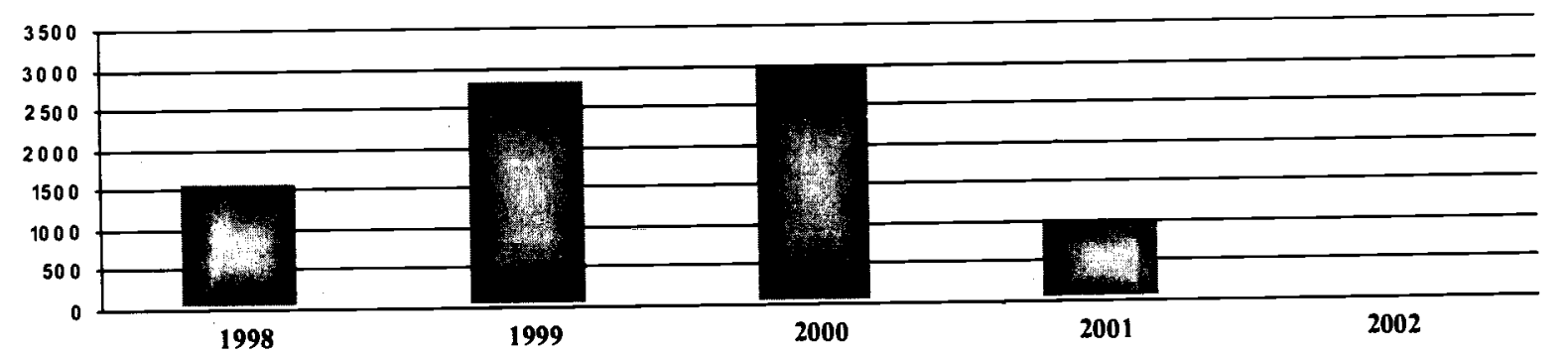

\begin{tabular}{|c|c|c|c|c|c|c|}
\hline \multicolumn{2}{|c|}{ Donors } & & llocation & \multirow[b]{2}{*}{ Province } & \multicolumn{2}{|c|}{ Targeted Provinces } \\
\hline Donors & $\%$ Funded & Allocation & $\%$ Funded & & Sector & $\%$ Targeted \\
\hline ABADY Members & 13 & Agriculture & 8 & Kabul & Education & 82 \\
\hline \multirow[t]{3}{*}{ Self Funding } & 87 & Education & 52 & Wardak & Health & 18 \\
\hline & & Health & 10 & & & \\
\hline & & Income Gen & 30 & & & \\
\hline
\end{tabular}

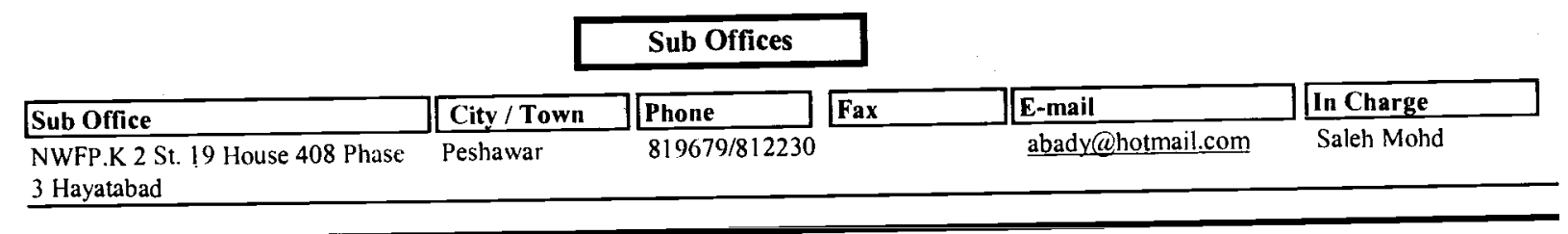




\begin{tabular}{|c|c|c|c|}
\hline Membership & ANCB & Country of Affiliation & Afghanistan \\
\hline Address & Communication & Key Staff & Position \\
\hline \multirow{4}{*}{$\begin{array}{l}\text { Share-e-Now House 196, } \\
\text { In Front of Sitara Hotel, } \\
\text { Kabul-Afghanistan }\end{array}$} & $070278706 / 34391$ & Latifa Afzali & Executive Director \\
\hline & & Mustafa Amarkhil & Deputy Director \\
\hline & ana@hotmail.com & Hedayatullah & Technical Advisor \\
\hline & Web: & & \\
\hline
\end{tabular}

\begin{tabular}{|c|c|c|c|c|c|c|}
\hline & & & Personnel & - & & \\
\hline Afghan & \multicolumn{2}{|c|}{47} & & Administrative & & 15 \\
\hline Pakistani & \multicolumn{2}{|c|}{0} & & Support & & 20 \\
\hline Expatriates & \multicolumn{2}{|c|}{0} & & Technical & & 12 \\
\hline \multirow[t]{3}{*}{ Total } & \multirow{2}{*}{\multicolumn{2}{|c|}{47}} & & Total & & 47 \\
\hline & & & Budget In US \$ & & & \\
\hline & 1998 & 1999 & 2000 & 2001 & \multicolumn{2}{|l|}{2002} \\
\hline Afghanistan & 60,500 & 142,300 & 220,000 & 250,000 & \multicolumn{2}{|l|}{309,071} \\
\hline Pakistan & 0 & 0 & 0 & 0 & \multicolumn{2}{|l|}{0} \\
\hline Total & $60,500.00$ & $142,300.00$ & $220,000.00$ & $250,000.00$ & \multicolumn{2}{|l|}{$309,071.00$} \\
\hline
\end{tabular}

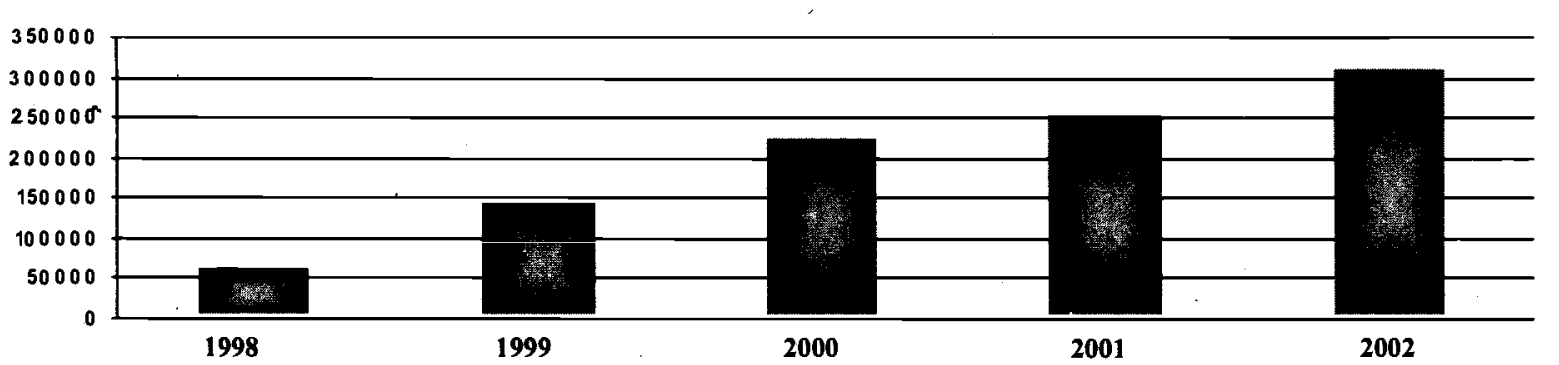

\begin{tabular}{|c|c|c|c|c|c|c|}
\hline & & & & & Targeted Provinces & \\
\hline Donors & $\%$ Funded & Allocation : & nded & Province & Sector & \\
\hline CORDAID & 20 & Health & 10 & Baghlan & Income Generation & 5 \\
\hline GTZ & 80 & Income Generatio & 30 & Balkh & Income Generation & 5 \\
\hline & & Other & 60 & Bamyan & Income Generation & 5 \\
\hline & & & & Hirat & Income Generation & 5 \\
\hline & & & & Kabul & Health & 8 \\
\hline & & & & Kabul & Income Generation & 22 \\
\hline & & & & Kabul & Infrastructure & 35 \\
\hline & & & & Kandahar & Income Generation & 5 \\
\hline & & & & Logar & Agriculture & 10 \\
\hline
\end{tabular}

Sub Offices

\begin{tabular}{|c|c|c|c|c|}
\hline Sub Office & City / Town & \begin{tabular}{|l} 
Phone \\
\end{tabular} & E-mail & In Charge \\
\hline $\begin{array}{l}\text { Balkh.Darwaza Jamhoriat in front } \\
\text { of } 200 \text { Bestar Hospital }\end{array}$ & Mazar & 2341 & & Dr. Wahidullah \\
\hline Baghi Murad House 17 & Hirat & & & Hamidullah \\
\hline Chouki Shaida St 7 House 154 & Kandahar & & & Eng. Masehullah \\
\hline
\end{tabular}




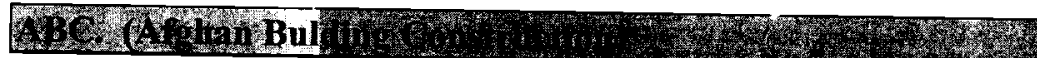

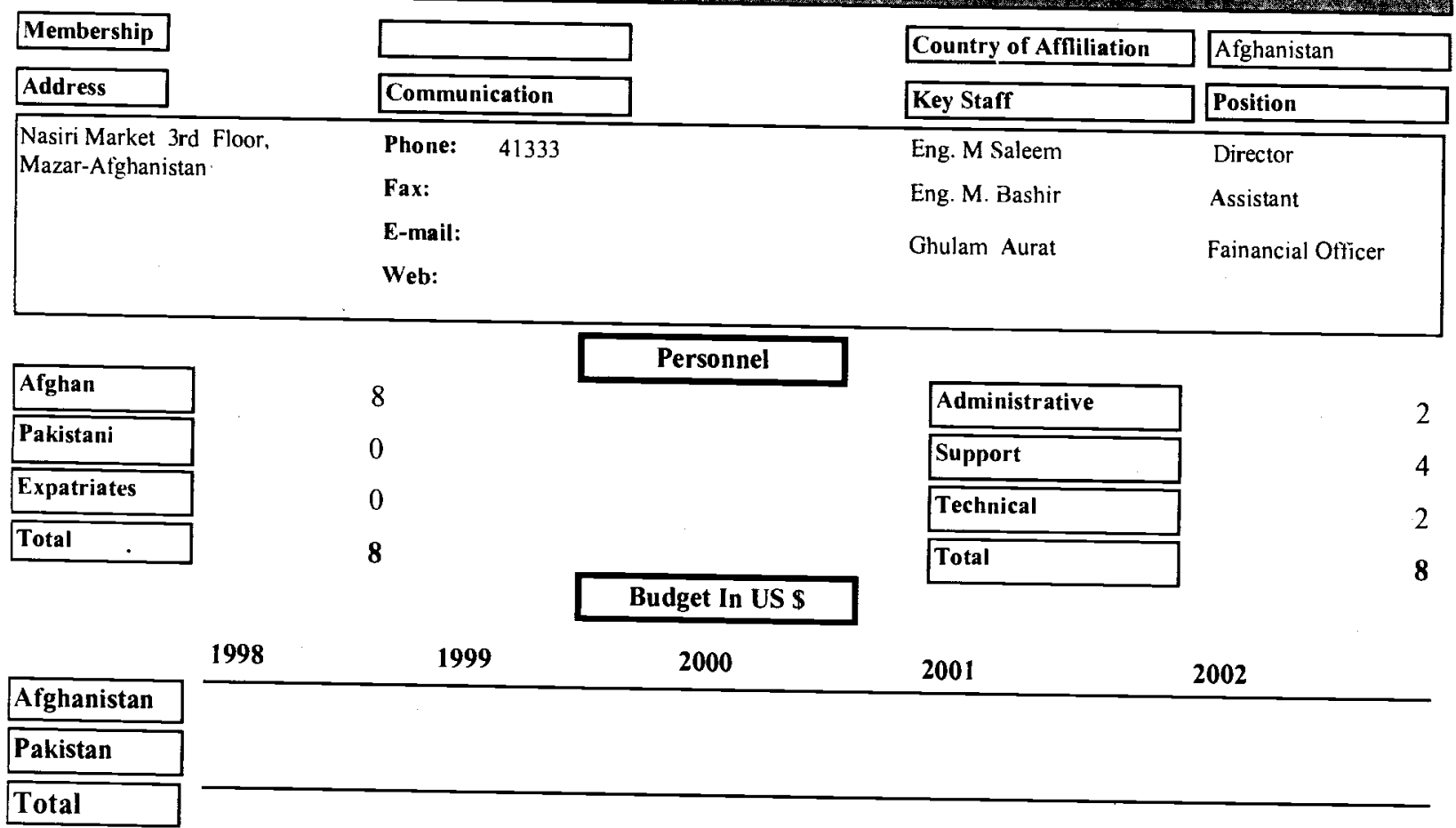

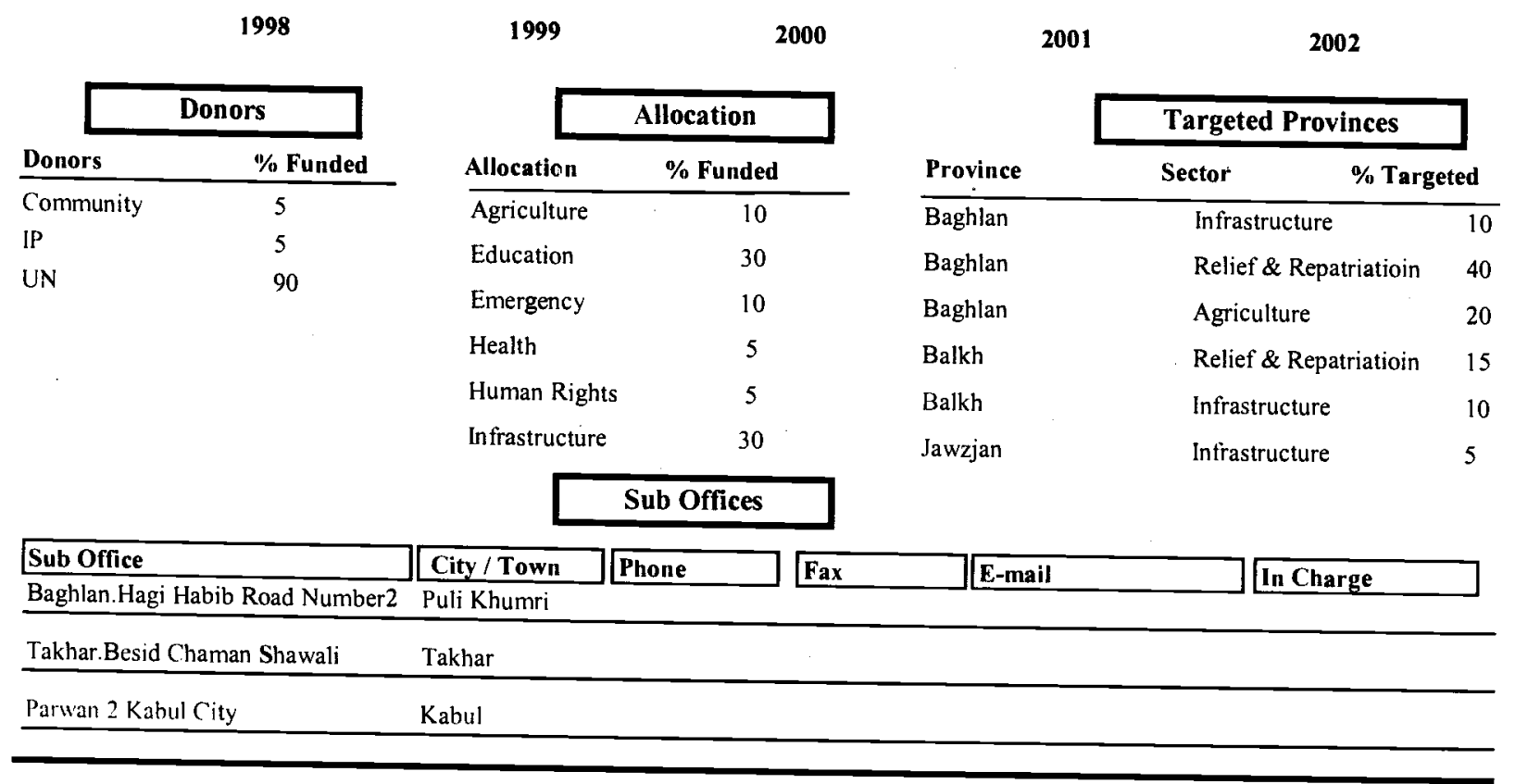




\begin{tabular}{|c|c|c|c|c|}
\hline Membership & & & Conntry of Affliliation & Afghanistan \\
\hline Address & \multicolumn{2}{|c|}{ Communication } & Key Staff & Position \\
\hline \multirow{4}{*}{$\begin{array}{l}\text { House } 7 \text { Phase } 1 \text { Hayatabad, } \\
\text { Peshawar-Pakistan }\end{array}$} & Phone: & 816120 & Nasrullah Bargalai & Exective Director \\
\hline & Fax: & 814700 & Mia Sham-s-ul-haq & Administrator \\
\hline & E-mail: & abdulhaqfoundation@hotmail.com & Eng.Tahsilder & Chief Engineer \\
\hline & \multicolumn{2}{|r|}{$2-2$} & & \\
\hline
\end{tabular}

\begin{tabular}{|l|}
\hline Afghan \\
\hline Pakistani \\
\hline Expatriates \\
\hline Total \\
\hline
\end{tabular}

Personnel

\begin{tabular}{|l|}
\hline Administrative \\
\hline Support \\
\hline Technical \\
\hline Total \\
\hline
\end{tabular}

\begin{tabular}{|l|}
\hline Afghanistan \\
\hline Pakistan \\
\hline Total \\
\hline
\end{tabular}

1998

1999

2000 2001 2002 120,000 0 $120,000.00$

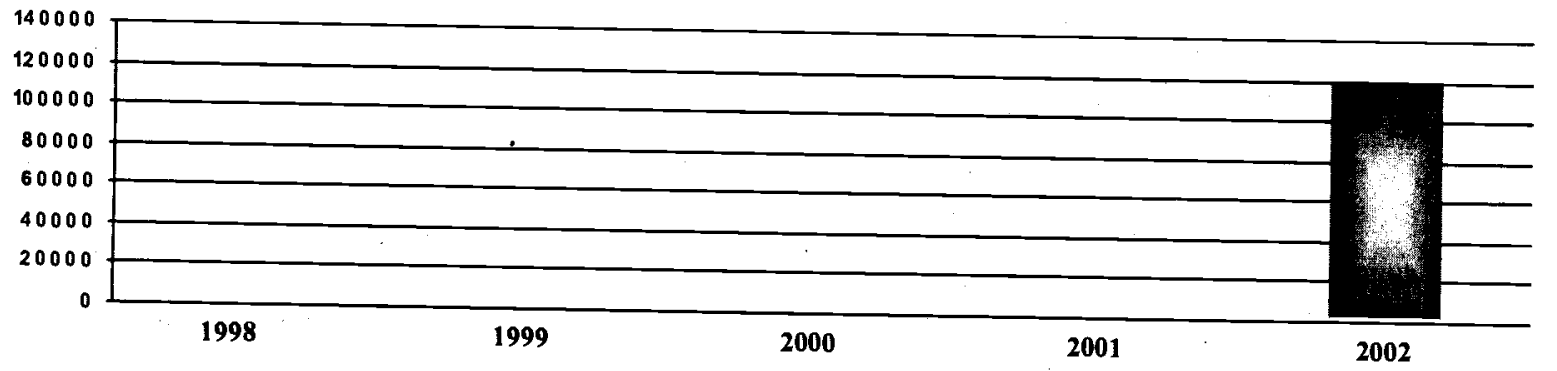

\begin{tabular}{lc|}
\multicolumn{2}{c|}{ Donors } \\
Donors & \% Funded \\
\hline US ARMY & 100
\end{tabular}

\begin{tabular}{lc|}
\cline { 2 - 2 } & \multicolumn{2}{c|}{ Allocation } \\
Allocation & \% Funded \\
\hline Agriculture & 20 \\
Education & 20 \\
Health & 10 \\
Infrastructure & 40 \\
Relief \& Repatria & 5
\end{tabular}

\section{Snb Offices}

\begin{tabular}{lll} 
& \multicolumn{2}{c|}{ Targeted Provinces } \\
\cline { 2 - 3 } Province & Sector & \% Targeted \\
\hline Kabul & Relief \& Repatriatioin & 5 \\
Nangarhar & Human Rights & 5 \\
Nangarhar & Health & 10 \\
Nangarhar & Education & 20 \\
Nangarhar & Infrastructure & 40 \\
Nangarhar & Agriculture & 20
\end{tabular}

\begin{tabular}{|c|c|c|c|c|}
\hline Sub Office & City / Town & Phone & E-mail & In Charge \\
\hline Charhi Torabazkhan, Shahr-e-Now & Kabul & & & Mumtaz \\
\hline Nangarhar. Near Kama Bus Stand & Jalalabad & & & - \\
\hline Khost City & Khost & & & \\
\hline
\end{tabular}




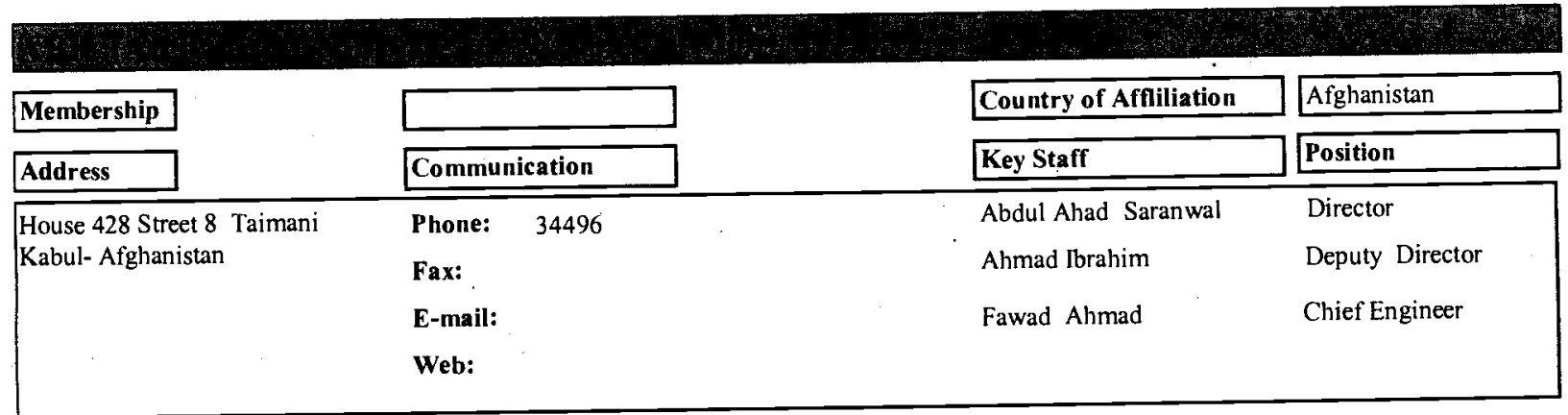

\begin{tabular}{|c|c|c|c|c|c|}
\hline & & & Personnel & & \\
\hline Afghan & \multicolumn{2}{|c|}{21} & & Administrative & 3 \\
\hline Pakistani & \multicolumn{2}{|c|}{0} & & Support & 4 \\
\hline Expatriates & \multicolumn{2}{|c|}{0} & & Technical & 14 \\
\hline \multirow[t]{3}{*}{ Total } & \multirow{2}{*}{\multicolumn{2}{|c|}{21}} & & Total & 21 \\
\hline & & & Budget In US \$ & & \\
\hline & 1998 & 1999 & 2000 & 2001 & 2002 \\
\hline Afghanistan & 90,000 & 197,000 & 84,550 & 167,204 & 199,592 \\
\hline Pakistan & 0 & 0 & 0 & 0 & 0 \\
\hline Total & $\overline{90,000.00}$ & $197,000.00$ & $84,550.00$ & $167,204.00$ & $199,592.00$ \\
\hline
\end{tabular}
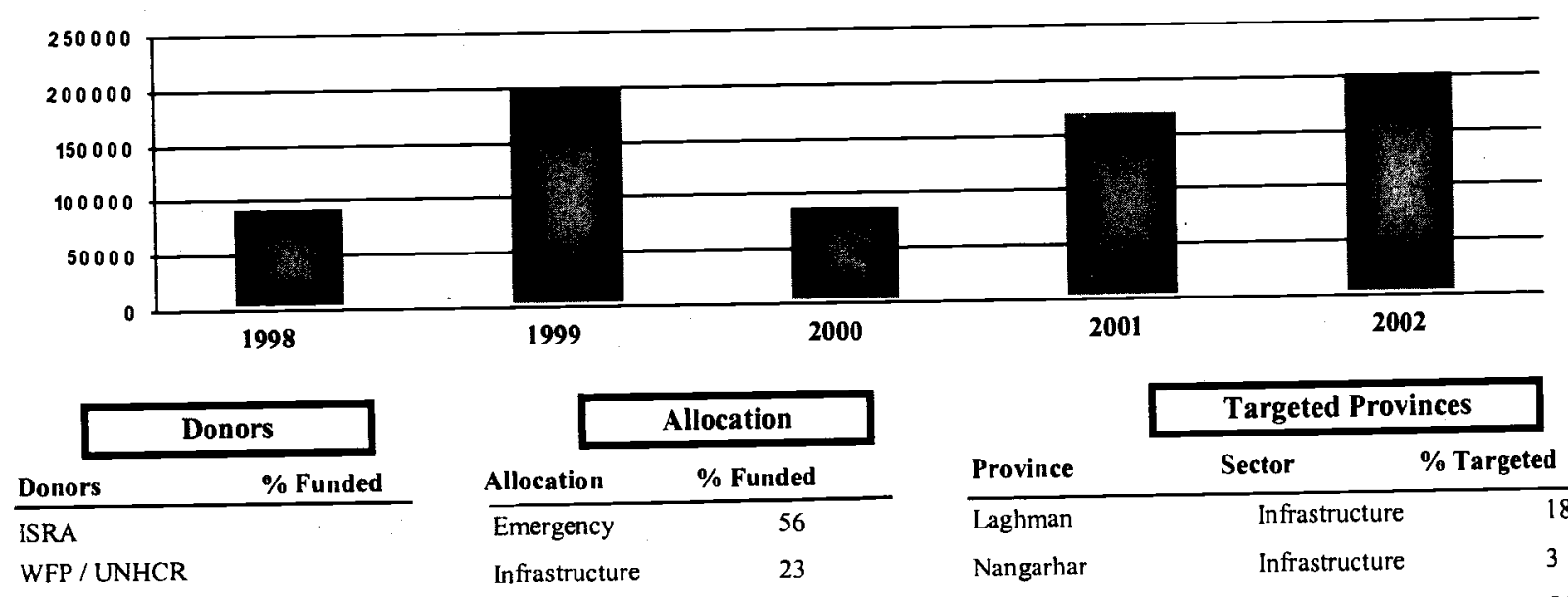

\begin{tabular}{lc}
\multicolumn{1}{c|}{ Allocation } \\
\hline Allocation & \% Funded \\
\hline Emergency & 56 \\
Infrastructure & 23 \\
Other & 21
\end{tabular}

\begin{tabular}{lcc} 
& \multicolumn{2}{c|}{ Targeted Provinces } \\
\cline { 2 - 3 } Province & Sector & $\%$ Targeted \\
\hline Laghman & Infrastructure & 18 \\
Nangarhar & Infrastructure & 3 \\
Paktika & Emergency & 56 \\
Wardak & Infrastructure & 23
\end{tabular}

\begin{tabular}{l|l|l|l|l|} 
& & & \\
\end{tabular}




\begin{tabular}{|c|c|c|c|}
\hline Membership & & Country of Affiliation & UK \\
\hline Address & Communication & Key Staff & Position \\
\hline \multirow{4}{*}{$\begin{array}{l}\text { De la beche aldworth berkshire } \\
\text { United Kingdom }\end{array}$} & Phone: & \multirow[t]{4}{*}{ Dr. Sarat Fane } & \multirow[t]{4}{*}{ Head of Organization } \\
\hline & 00441 & & \\
\hline & E-mail: $\quad \underline{\text { sarahf }}$ & & \\
\hline & Web: & & \\
\hline
\end{tabular}

\begin{tabular}{|l|}
\hline Afghan \\
\hline \hline Pakistani \\
\hline \hline Expatriates \\
\hline Total \\
\hline
\end{tabular}

Personnel

\begin{tabular}{|c|c|c|c|c|c|}
\hline Total & & & & Total & 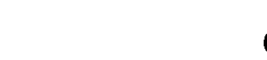 \\
\hline & 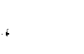 & & Budget In US S & & \\
\hline & 1998 & 1999 & 2000 & 2001 & 2002 \\
\hline Afghanistan & & & & & 40,000 \\
\hline Pakistan & & & & & 0 \\
\hline Total & & & & & $40,000.00$ \\
\hline
\end{tabular}
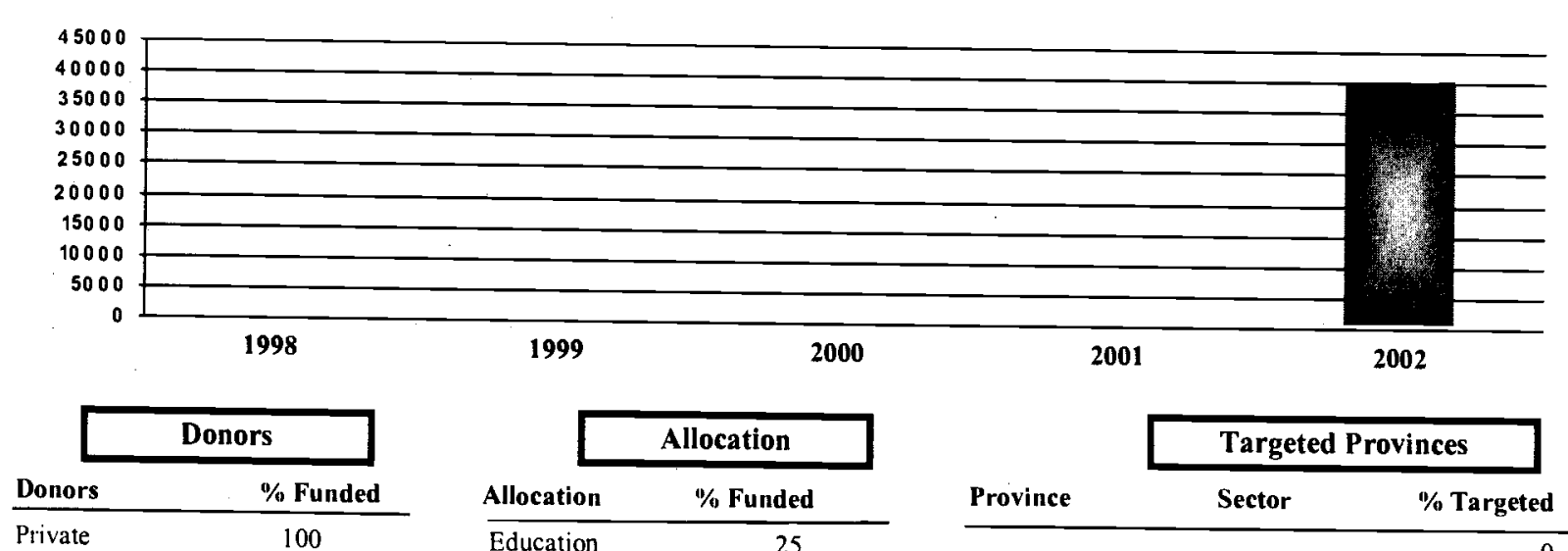

\begin{tabular}{lc} 
& \multicolumn{1}{c|}{ Allocation } \\
Allocation & $\%$ Funded \\
\hline Education & 25 \\
Health & 75
\end{tabular}

\begin{tabular}{llr} 
& \multicolumn{2}{c|}{ Targeted Provinces } \\
\cline { 2 - 3 } Province & Sector & \% Targeted \\
\hline & & 0 \\
Kabul & Education & 25 \\
Kabul & Health & 75
\end{tabular}




\begin{tabular}{|c|c|c|c|}
\hline Membership & & Country of Affiliation & Afghanistan \\
\hline Address & Communication & Key Staff & Position \\
\hline \multirow{4}{*}{$\begin{array}{l}\text { Haji Yaqhob Square, } \\
\text { Shahr-e-Now, } \\
\text { Kabul-Afghanistan }\end{array}$} & Phone: & Azimullah Hafizi & General Director \\
\hline & Fax: & Amanullah & Deputy Director \\
\hline & E-mail: & Rollah & Admin Officer \\
\hline & Web: & & \\
\hline
\end{tabular}

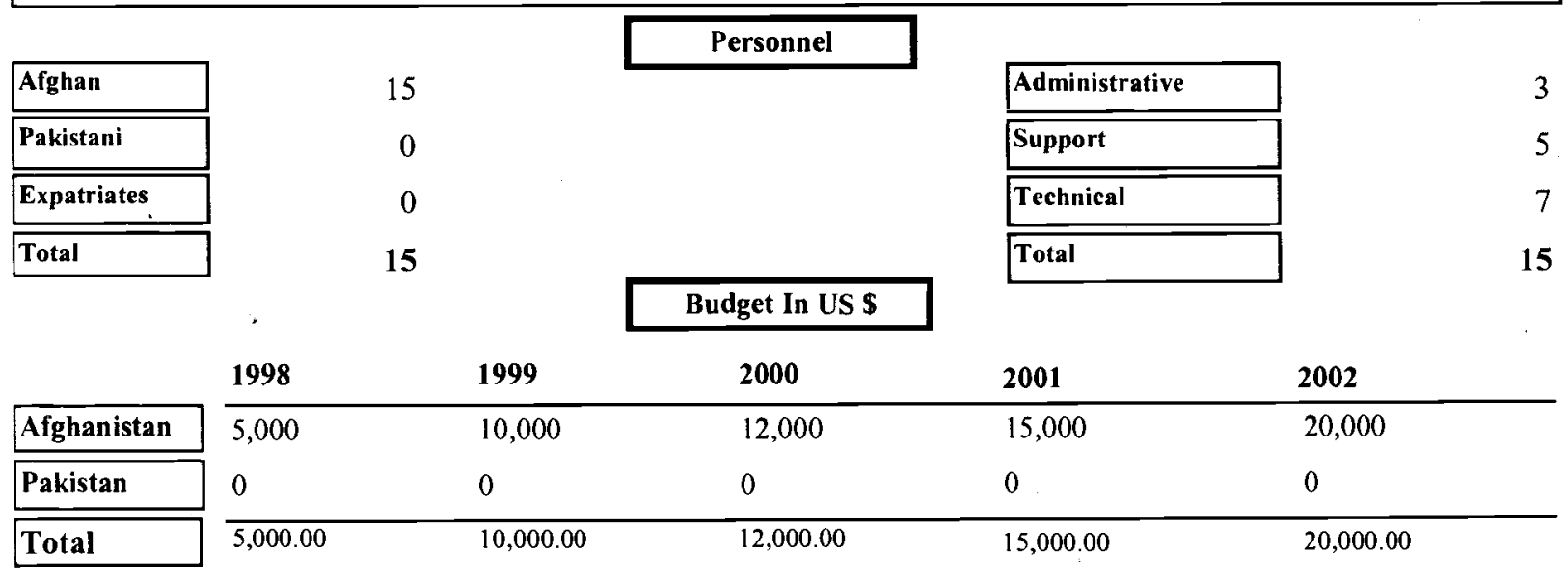

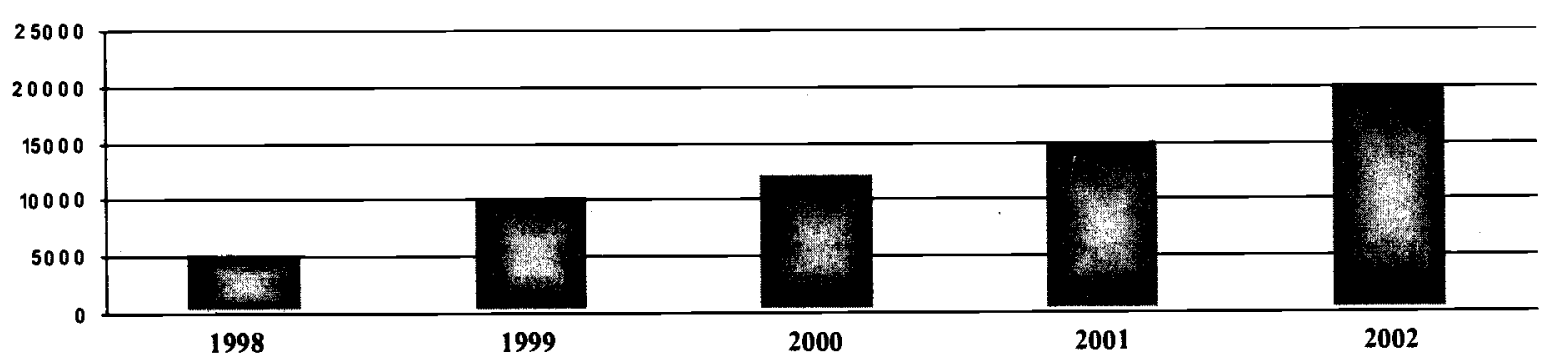

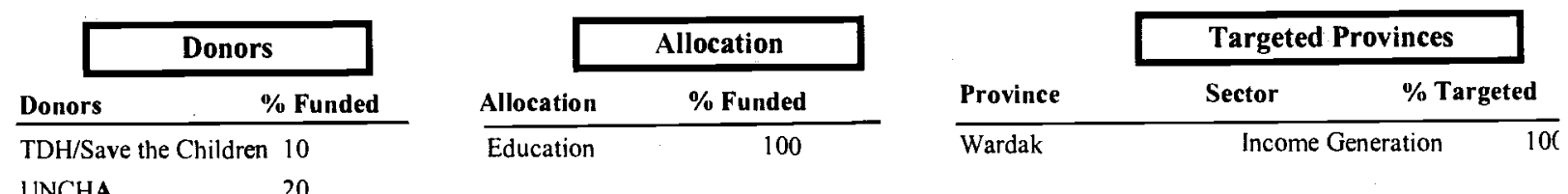

UNCHA 20

UNDP 30

UNICEF $\quad 40$ 


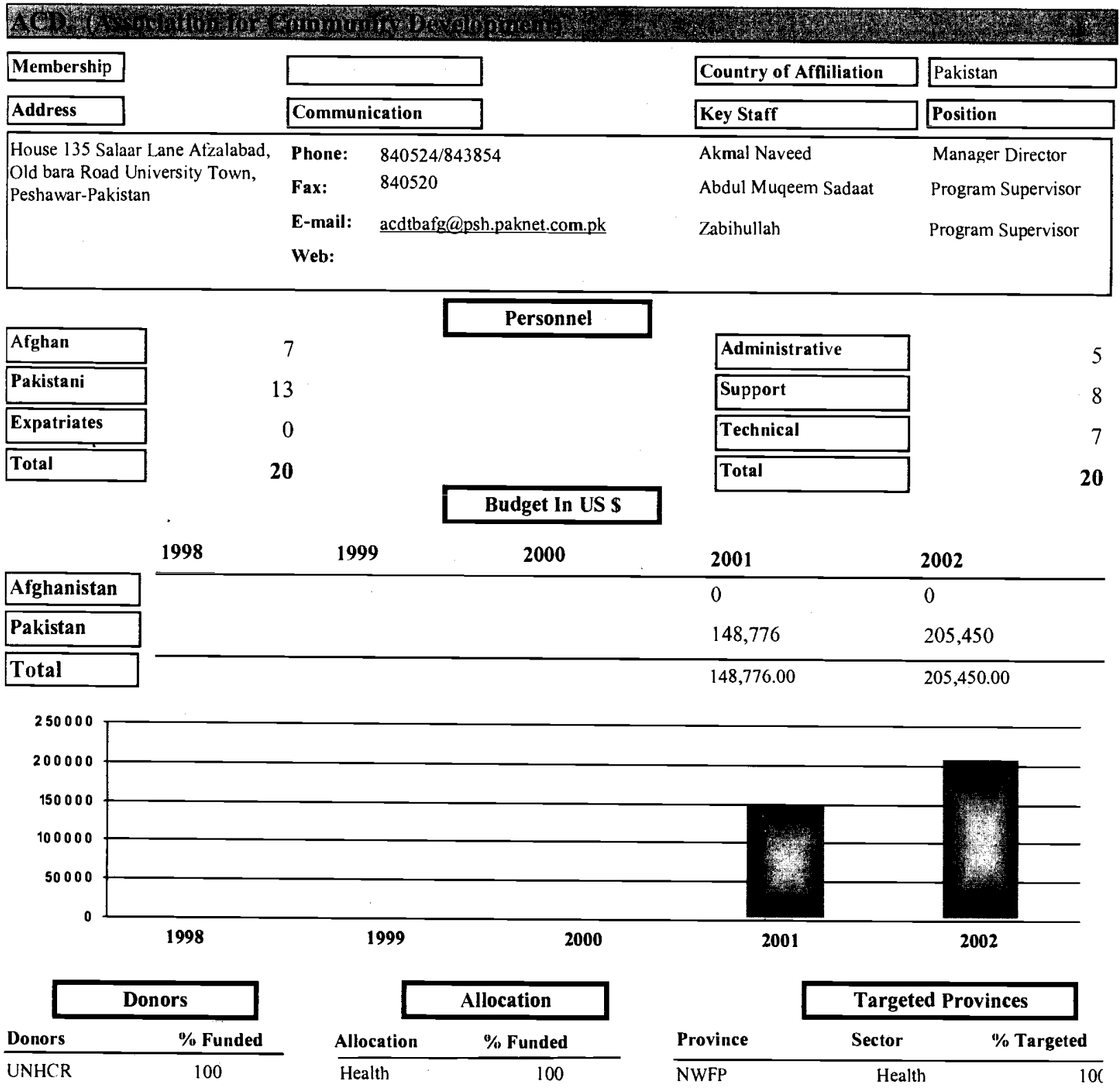

\section{Sub Offices}




\begin{tabular}{|c|c|c|c|}
\hline Membership & & Country of Affliliation & Afghanistan \\
\hline Address & Communication & Key Staff & Position \\
\hline \multirow{4}{*}{$\begin{array}{l}\text { l0th Street Taimani Watt, } \\
\text { Kabul-Afghanistan }\end{array}$} & $31952 / 070281991$ & Gul Waiz Kaka & Executive Director \\
\hline & Fax: & Dr. Matiullah Zahiri & Deputy Director \\
\hline & E-mail: & Abdul Qadar & Finance / Admin \\
\hline & Web: & & \\
\hline
\end{tabular}

\begin{tabular}{|l|}
\hline Afghan \\
\hline Pakistani \\
\hline Expatriates \\
\hline Total \\
\hline
\end{tabular}

\section{Personnel}

\begin{tabular}{|l|}
\hline Administrative \\
\hline Support \\
\hline Technical \\
\hline Total \\
\hline
\end{tabular}

Budget In US \$

\begin{tabular}{|c|c|c|c|c|c|}
\hline & 1998 & 1999 & 2000 & 2001 & 2002 \\
\hline Afghanistan & 44,000 & 67,000 & 95,000 & 423,823 & $1,457,664$ \\
\hline Pakistan & 20,000 & 32,390 & 29,700 & 15,000 & 9,860 \\
\hline Total & $64,000.00$ & $99,390.00$ & $124,700.00$ & $438,823.00$ & $1,467,524.00$ \\
\hline
\end{tabular}

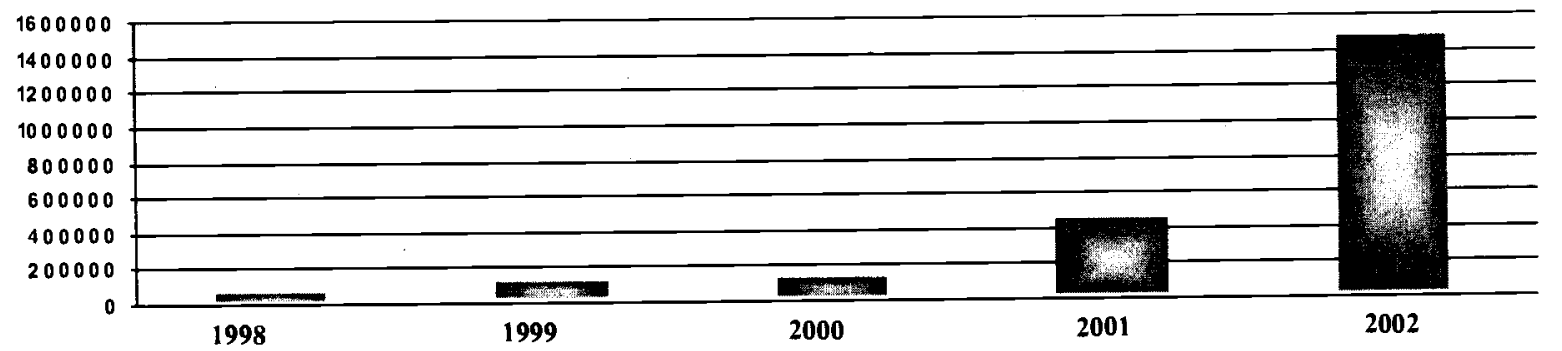

\begin{tabular}{|c|c|c|c|c|c|c|}
\hline \multicolumn{2}{|c|}{ Donors } & \multicolumn{2}{|c|}{ Allocation } & \multirow[b]{2}{*}{ Province } & \multicolumn{2}{|c|}{ Targeted Provinces } \\
\hline Donors & $\%$ Funded & Allocation & $\%$ Funded & & Sector & $\%$ Targeted \\
\hline $\mathrm{AACA}$ & 5 & Agriculture & 30 & Ghazni & Emergency & 5 \\
\hline CIDA & 20 & Education & 10 & Kabul & Emergency & 20 \\
\hline DFID & 5 & Emergency & 30 & Kapisa & Emergency & 25 \\
\hline UNKLE: & 30 & Environment & 10 & Khost & Agriculture & 10 \\
\hline $\begin{array}{l}\text { UNOPS } \\
\text { WFP }\end{array}$ & 30 & Health & 5 & Nangarhar & Water Supply & 5 \\
\hline WHO & 5 & Infrastructure & 5 & Paktika & Emergency & 5 \\
\hline & & Water Resources & 10 & Paktya & Emergency & 5 \\
\hline & & & & Parwan & Emergency & 25 \\
\hline
\end{tabular}

Sub Offices

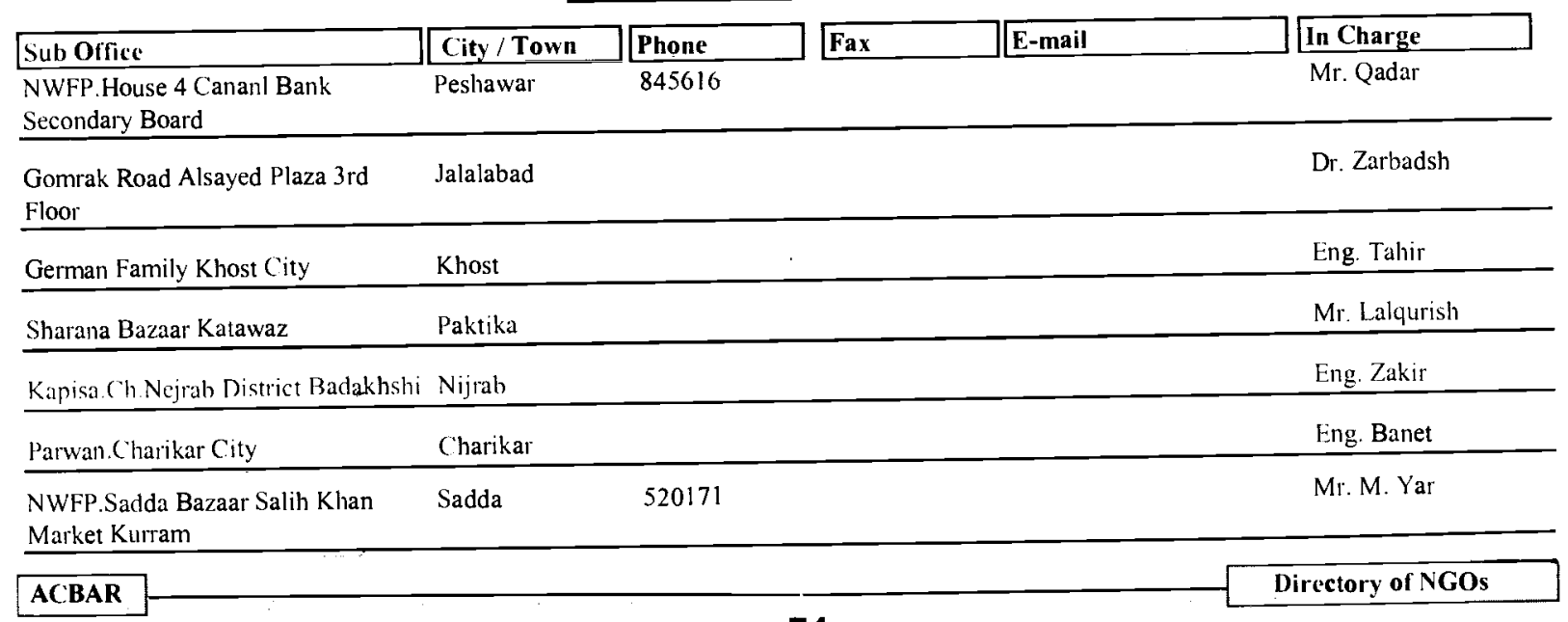




\section{ACLU (Arghan Construction \& Logistic Uni)}

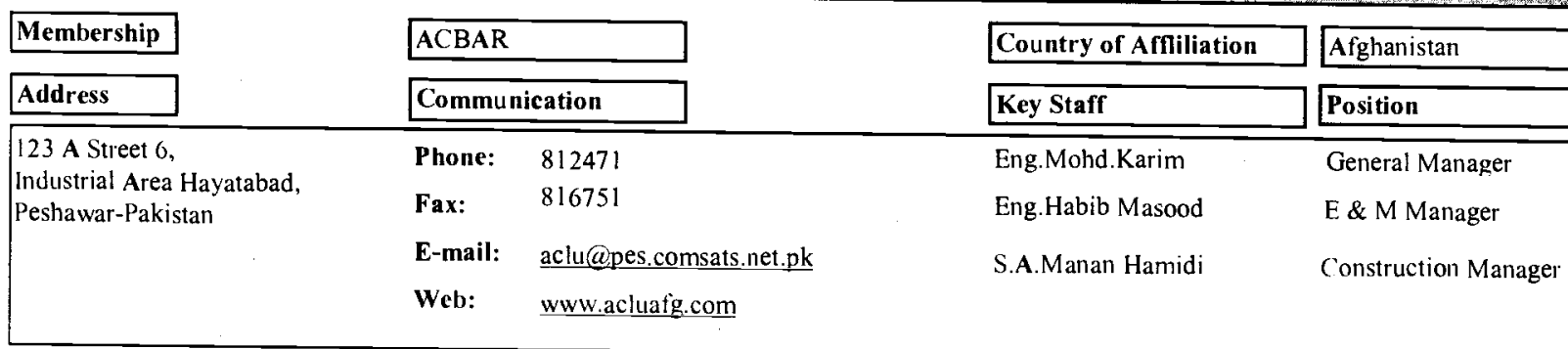

\begin{tabular}{|l|}
\hline Afghan \\
\hline Pakistani \\
\hline Expatriates \\
\hline Total \\
\hline
\end{tabular}

\section{8}

34

0

192

Personnel

\begin{tabular}{|l|}
\hline Administrative \\
\hline Support \\
\hline Technical \\
\hline Total \\
\hline
\end{tabular}

Budget In US \$

\begin{tabular}{|c|c|c|c|c|c|}
\hline & 1998 & 1999 & 2000 & 2001 & 2002 \\
\hline Afghanistan & 126,200 & 180,000 & 305,074 & 50,000 & 381,000 \\
\hline Pakistan & 0 & 0 & 0 & 0 & 0 \\
\hline Total & $126,200.00$ & $180,000.00$ & $305,074.00$ & $50,000.00$ & $381,000.00$ \\
\hline
\end{tabular}

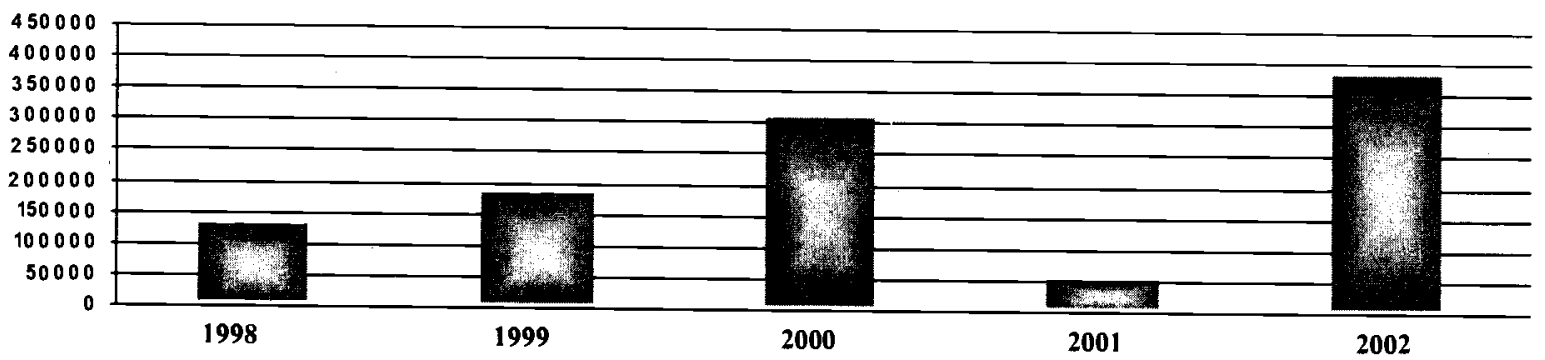

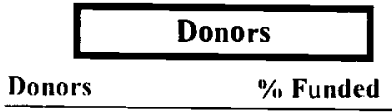

Afghan Govt.

Intersos.

IRC

Japan Embassy

Other

UNAMA

UNHCR

UNOPS

WFP

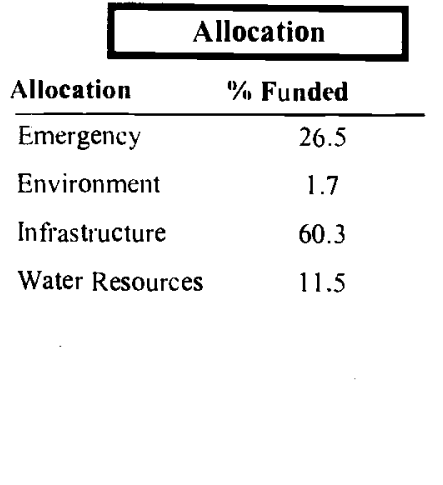

Sub Offices

\begin{tabular}{lll} 
& \multicolumn{1}{c|}{ Targeted Provinces } \\
\cline { 2 - 3 } Province & Sector & \multicolumn{1}{c}{ \% Targeted } \\
\hline Balkh & Water Resources & 4.3 \\
Balkh & Income Generation & 0.0 \\
Balkh & Relief \& Repatriatioin & 2.8 \\
Ghazni & Water Resources & 0.8 \\
Ghazni & Relief \& Repatriatioin & 0.5 \\
Hilmand & Relief \& Repatriatioin & 0.2 \\
Kabul & Infrastructure & 1.6 \\
Kabul & Water Resources & 0.7 \\
Kunar & Infrastlucture & 7.0 \\
Laghman & Water Resources & 5.1 \\
Laghman & Infrastructure & 0.3 \\
Nangarhar & Infrastructure & 7.1 \\
NWFP & Water Resources & 1.3 \\
NWFP & Infrastructure & 59. \\
NWFP & Environment & 1.7 \\
Paktya & Infrastructure & 5.2
\end{tabular}




\begin{tabular}{|c|c|c|c|c|}
\hline Sub Office & City / Town & Phone & E-mail & In Charge \\
\hline $\begin{array}{l}\text { Shah Darak Charahi Saheed Beside } \\
\text { Army Club }\end{array}$ & Kabul & 070274905 & & Eng.Maroof \\
\hline $\begin{array}{l}\text { Nangarhar. Chowk Sehat-eAma End } \\
\text { of Street }\end{array}$ & Jalalabad & & & Habib Rehman \\
\hline $\begin{array}{l}\text { Kandahar.Shahri Now Near Muslim } \\
\text { Chowk }\end{array}$ & Kandahar & & & Eng.Rahimullah \\
\hline Balkh.Near Mazar Hotel & Mazar & & & Mir A. Ghafoor \\
\hline
\end{tabular}


ANCB

Country of Affiliation

Afghanistan

\section{Address}

Communication

Batween Haji Yaqoob \& Shahid

Phone: 070226481

Square

Phone: 070226481

Fax:

Now

Kabul-Afghanistan

E-mail: acru@psh.paknet.com.pk

Web:

Key Staff

Position

Baryalai Omarzai Director

Eng. M. Zaman Deputy Director

Ab. Razeq Program Manager

\begin{tabular}{|l|}
\hline Afghan \\
\hline Pakistani \\
\hline Expatriates \\
\hline Total \\
\hline
\end{tabular}

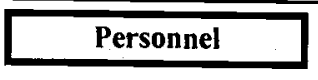

\begin{tabular}{|l|}
\hline Administrative \\
\hline Support \\
\hline Technical \\
\hline Total \\
\hline
\end{tabular}

Budget In US \$

\begin{tabular}{|c|c|c|c|c|c|}
\hline & 1998 & 1999 & 2000 & 2001 & 2002 \\
\hline Afghanistan & 25,350 & 94,350 & 55,680 & 68,500 & 56,750 \\
\hline Pakistan & 0 & 0 & 0 & 0 & 0 \\
\hline Total & $25,350.00$ & $94,350.00$ & $55,680.00$ & $68,500.00$ & $56,750.00$ \\
\hline
\end{tabular}

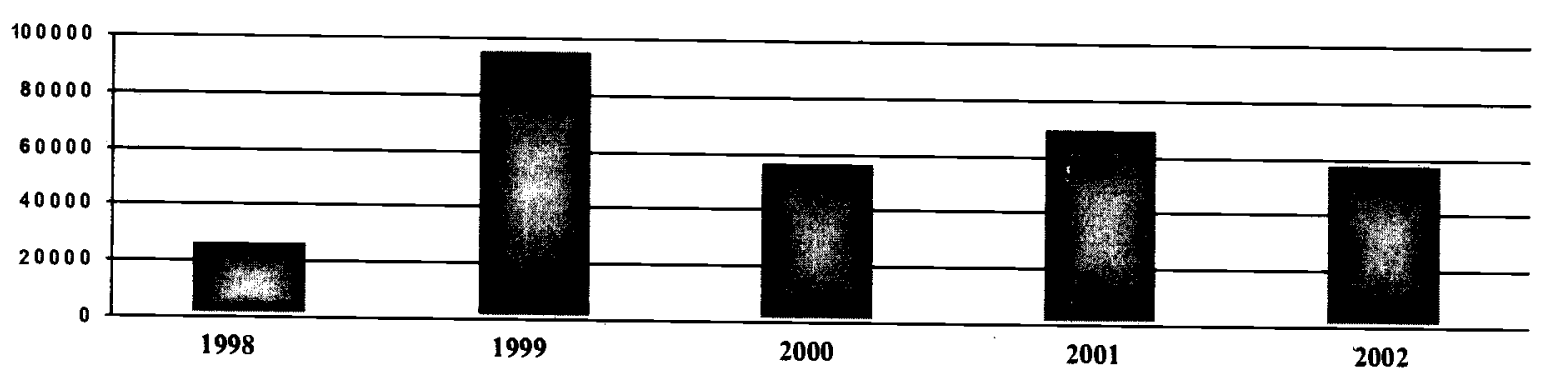

\begin{tabular}{|c|c|c|c|c|c|c|c|}
\hline \multicolumn{2}{|c|}{ Donors } & & location & \multirow[b]{2}{*}{ Province } & \multicolumn{3}{|c|}{ Targeted Provinces } \\
\hline Donors & $\%$ Funded & Allocation & $\%$ Funded & & Sector & $\%$ Tar & \\
\hline Canada Fund & & Education & 19 & Badakhshan & Wate & & 8 \\
\hline DFID & & Infrastructure & 58 & Ghazni & Relie & triation & 3 \\
\hline $\begin{array}{l}\text { FAO } \\
\text { ICRC }\end{array}$ & & Other & 23 & Kabul & Educ & & 25 \\
\hline UNDP & & & & Logar & Wate & & 10 \\
\hline UNHCR & & & & Paktia & Water & & 34 \\
\hline UNOPS & & & & Paktika & Infras & & 20 \\
\hline
\end{tabular}

World Bank

Sub Offices

\begin{tabular}{|c|c|c|c|c|}
\hline Sub Office & City / Town & Phone & E-mail & In Charge \\
\hline Paktika. Godi Khail & Zmari Kot & & & Yousef Khil Sujauddin \\
\hline $\begin{array}{l}\text { Balkh.Mazar-e-Sharif Behind } \\
\text { Stadim }\end{array}$ & Mazar & & & M.Arif \\
\hline $\begin{array}{l}\text { Kapisa. Gulbahar Near Textil mil of } \\
\text { Gulbahar }\end{array}$ & Kohistan & & & Eng. Younus \\
\hline Badakhshan.Kishim Bazar & Kishim & & & Bilal \\
\hline NWFP.Murad Abad, Board & Peshawar & 851205 & & Zabihullah \\
\hline Zabul.Shahjoy Bazar & Shahjoy & & & Bilal \\
\hline
\end{tabular}




\section{ACST SWISSPEACE (Afghan Civil Society torum)}

\begin{tabular}{|c|c|c|c|}
\hline Membership & & Country of Affliliation & Switzerland \\
\hline Address & Communication & Key Staff & Position \\
\hline \multirow{4}{*}{$\begin{array}{l}\text { Sannenberg Strasse } 17 \mathrm{CH}-3000 \\
\text { Berne } 7 \\
\text { Switzerland }\end{array}$} & $+41(0) 313301212$ & Susanne Schmeidl & Coordinator \\
\hline & $+41(0) 313301213$ & Rahim Ataze & Office Manager \\
\hline & acsf@swisspeace .ch & Masood Karokhail & Asst.Coordinator \\
\hline & www.swisspeace.ch & & \\
\hline
\end{tabular}

\begin{tabular}{|l|}
\hline Afghan \\
\hline \hline Pakistani \\
\hline Expatriates \\
\hline Total $\cdot$ \\
\hline
\end{tabular}

Personnel

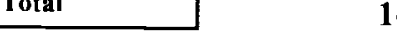

Budget In US S

\begin{tabular}{|l|}
\hline Administrative \\
\hline Support \\
\hline Technical \\
\hline Total \\
\hline
\end{tabular}

0

1

14

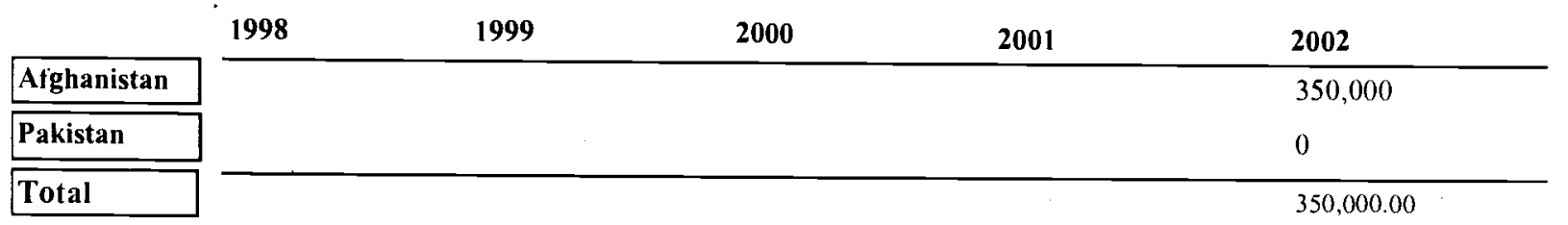

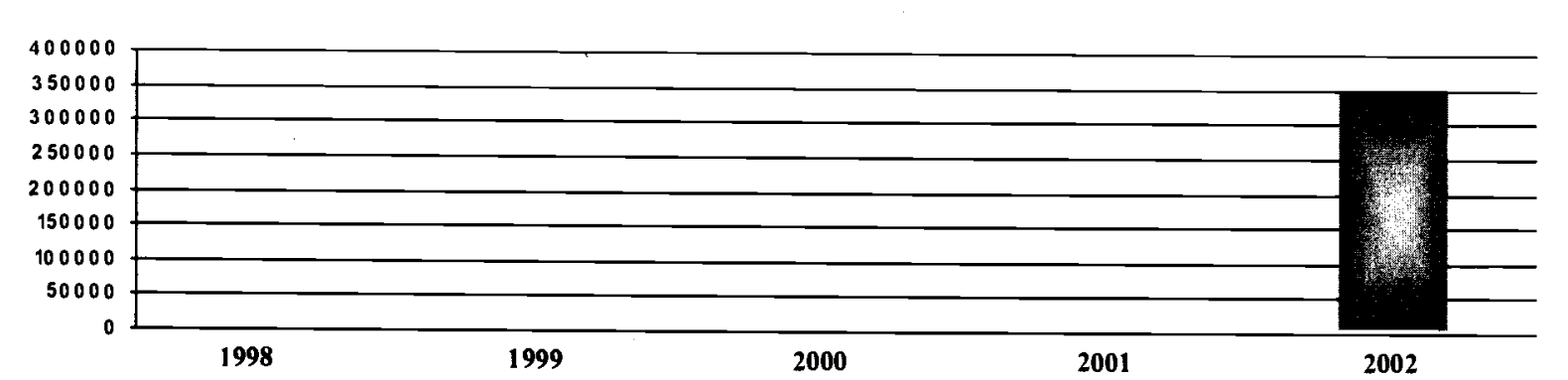

\begin{tabular}{lcccc}
\hline \multicolumn{2}{c|}{ Donors } & & \multicolumn{2}{c|}{ Allocation } \\
Donors & $\%$ Funded & & Allocation & \% Funded \\
\cline { 1 - 1 } German Govt. & 33 & & Social Programs & 100 \\
Swiss Govt. & 67 & &
\end{tabular}

Targeted Provinces

\section{Sub Offices}

\begin{tabular}{|c|c|c|c|c|c|}
\hline Sub Office & City / Town & Phone & Fax & E-mail & In Charge \\
\hline $\begin{array}{l}\text { Shahrara Watt House } 45 \text { Across } \\
\text { form Malalai Hospital }\end{array}$ & Kabul & 2201061 & & $\begin{array}{l}\text { acsf- } \\
\text { kabul } @ \text { swisspeace.ch }\end{array}$ & Susanne Schmeidl \\
\hline
\end{tabular}




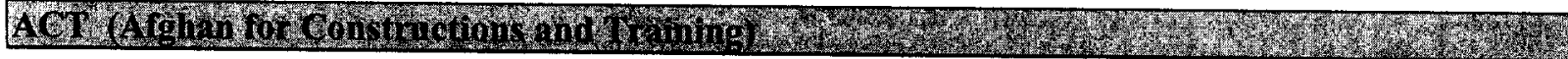

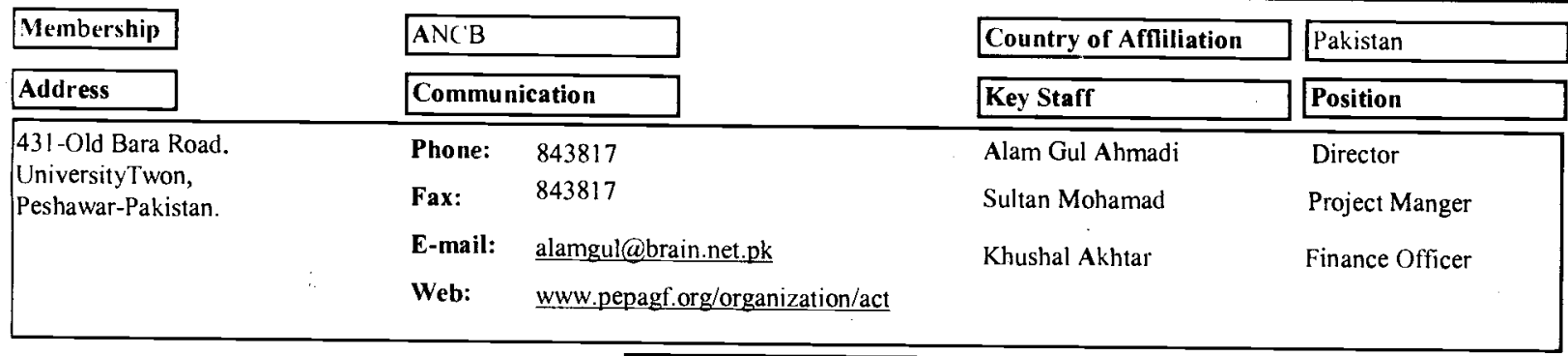

\begin{tabular}{|l|}
\hline Afghan \\
\hline Pakistani \\
\hline Expatriates \\
\hline Total \\
\hline
\end{tabular}

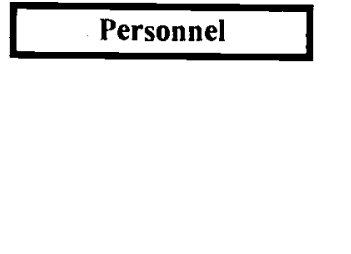

\begin{tabular}{|l|}
\hline Administrative \\
\hline Support \\
\hline \hline Technical \\
\hline Total \\
\hline
\end{tabular}

Budget In US \$

1998

1999

2000

2001

2002

\begin{tabular}{|l|}
\hline Afghanistan \\
\hline Pakistan \\
\hline Total \\
\hline
\end{tabular}

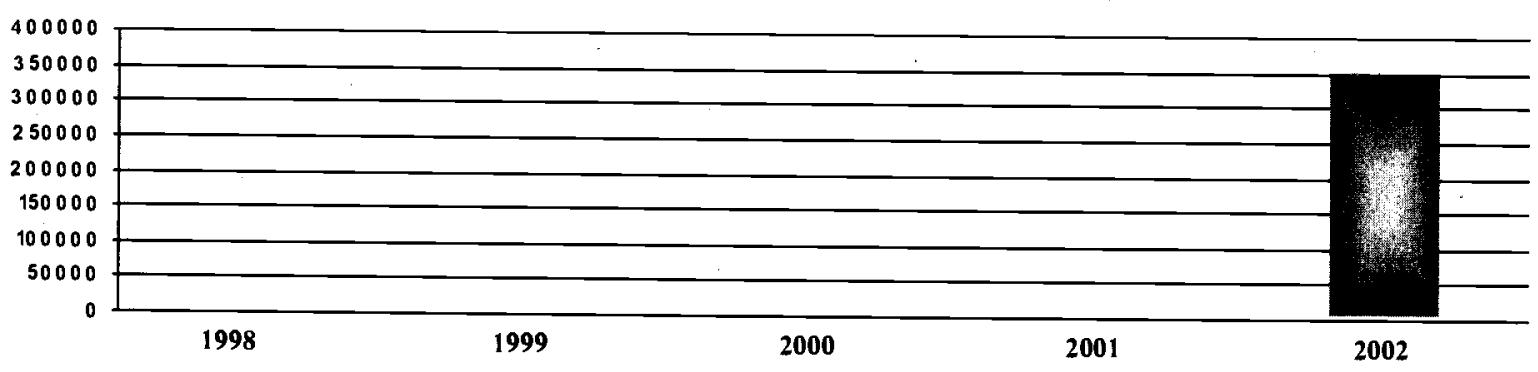

\begin{tabular}{lcccc|}
\hline \multicolumn{2}{c|}{ Donors $\cdot$} & & & \multicolumn{2}{c|}{ Allocation } \\
\cline { 1 - 1 } Donors & \% Funded & & Allocation & \% Funded \\
\cline { 1 - 1 } GTZ & 54 & & Education & 54 \\
UNHCR & 46 & & Infrastructure & 46
\end{tabular}

Targeted Provinces

\section{Sub Offices}

\begin{tabular}{|c|c|c|c|c|c|}
\hline Sub Office & City / Town & Phone & Fax & E-mail & In Charge \\
\hline $\begin{array}{l}\text { Kartai Mamorin Opp. Kabul } \\
\text { Polytechnic }\end{array}$ & Kabul & 07021495 & & alamgul@brain.net.pk & Alam Gul \\
\hline Wardak. V.T.C. Sheikh Abad Distt. & Saydabad & & & & Abdul Wahab \\
\hline Wardak. T.T.P Malmal Distt & Saydabad & & & & Sayed Ateeq \\
\hline VTC Ghazni Market & Ghazni & & & & Izatullah \\
\hline VTC Khwaja Umarai Marbooti & Ghazni & & & & Zafar Khan \\
\hline VTC Lycee Sanaie & Kabul & & & & M. Kabir \\
\hline VTC Takhnikum Kabul & Kabul & & & . & Anar Gul \\
\hline
\end{tabular}




\section{AetionAid (Action 1 Tou)}

\begin{tabular}{|c|c|c|c|}
\hline Membership & & Country of Affiliation & UK \\
\hline Address & Communication & Key Staff & Position \\
\hline \multirow{4}{*}{$\begin{array}{l}\text { House \# } 79 \text { Lane -1, } \\
\text { Street-15 Wazir Akbar Khan, } \\
\text { Kabul-Afghanistan }\end{array}$} & $2301288 / 070275491$ & Bijay Kumar & Country Representative \\
\hline & +873763036550 & Noor Klaan Haidari & Finance Manager \\
\hline & E-mail: bijayk@actionaidasia.org & Philippa Sackett & Policy \& Devlop. Office \\
\hline & Web: & & \\
\hline
\end{tabular}

\begin{tabular}{|l|}
\hline Afghan \\
\hline \hline Pakistani \\
\hline Expatriates \\
\hline Total \\
\hline
\end{tabular}

Personnel

\begin{tabular}{|c|c|c|c|c|c|}
\hline & & & Budget In US \$ & & \\
\hline & 1998 & 1999 & 2000 & 2001 & 2002 \\
\hline Afghanistan & & & & & 400,000 \\
\hline Pakistan & & & & & 0 \\
\hline Total & & & & & 400.000 .0 \\
\hline
\end{tabular}

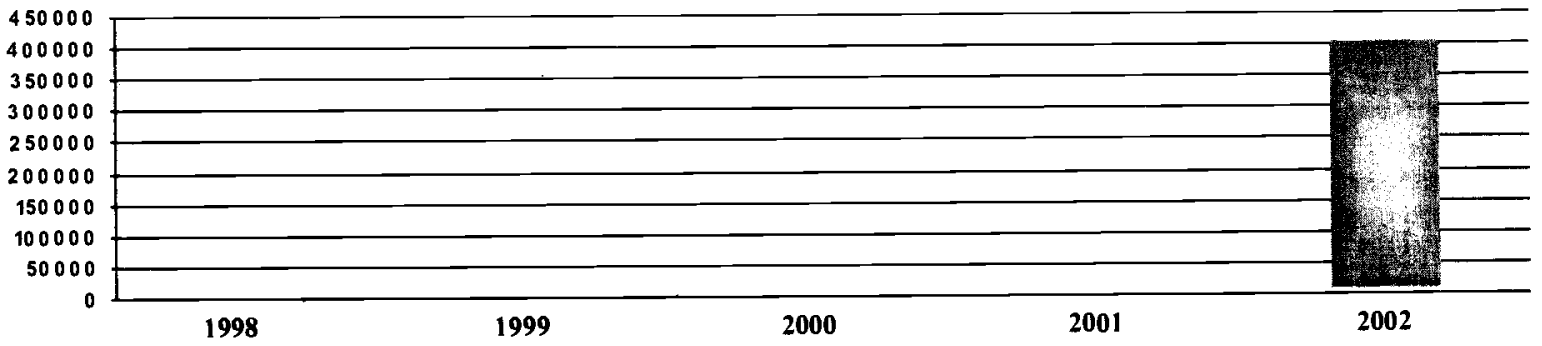

\begin{tabular}{lc}
\multicolumn{2}{c|}{ Donors } \\
\hline Donors & $\%$ Funded \\
\hline ACTIONAID & 70 \\
UNAMA & 30
\end{tabular}

\begin{tabular}{lc}
\multicolumn{2}{c|}{ Allocation } \\
Allocation & \% Funded \\
\hline HRD & 30 \\
Human Rights & 5 \\
Other & 25 \\
Social Programs & 40
\end{tabular}

\begin{tabular}{llr} 
& \multicolumn{2}{c|}{ Targeted Provinces } \\
\cline { 2 - 3 } Province & \multicolumn{2}{c}{ Sector } \\
\hline Balkh & Social Programs & 0 \\
Jawzjan & Social Programs & 0 \\
Kabul & Other & 0 \\
Kabul & HRD & 0 \\
Samangan & Social Programs & 0
\end{tabular}

Sub Offices 


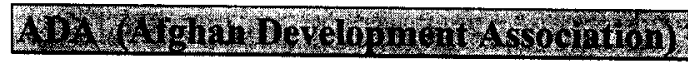

\begin{tabular}{|c|c|c|c|}
\hline Membership & $\mathrm{ACBAR}$ & Country of Affliliation & Afghanistan \\
\hline Address & Communication & Key Staff & Position \\
\hline \multirow{4}{*}{$\begin{array}{l}\text { Frokhi Watt House } 8 \text { Street } 6 \text {, } \\
\text { Opp Shalir-e-Naw Park. } \\
\text { Kabul-Afghanistan }\end{array}$} & Phone: & Ab.Razique Samadi & Managing Director \\
\hline & 00929145296 & Eng.Mohd.H lassan & Field Coordinator \\
\hline & afgdevas@brain.net.pk & Eng.Esmat Haidry & Planning Director \\
\hline & www.atgdevas.org & & \\
\hline
\end{tabular}

\begin{tabular}{|l|}
\hline Afghan \\
\hline \hline Pakistani \\
\hline Expatriates \\
\hline Total \\
\hline
\end{tabular}

\begin{tabular}{|l|}
\hline Administrative \\
\hline Support \\
\hline Technical \\
\hline Total \\
\hline
\end{tabular}

Budget In US \$

\begin{tabular}{|c|c|c|c|c|c|}
\hline & 1998 & 1999 & 2000 & 2001 & 2002 \\
\hline Afghanistan & $1,865,306$ & $1,595,002$ & $1,324,373$ & $1,684,521$ & $3,773,371$ \\
\hline Pakistan & 0 & 0) & 0 & 0 & 39,300 \\
\hline Total & $1,865,306.00$ & $1.595,002.00$ & $1,324,373,00$ & $1,684,521.00$ & $3,812,671.00$ \\
\hline
\end{tabular}

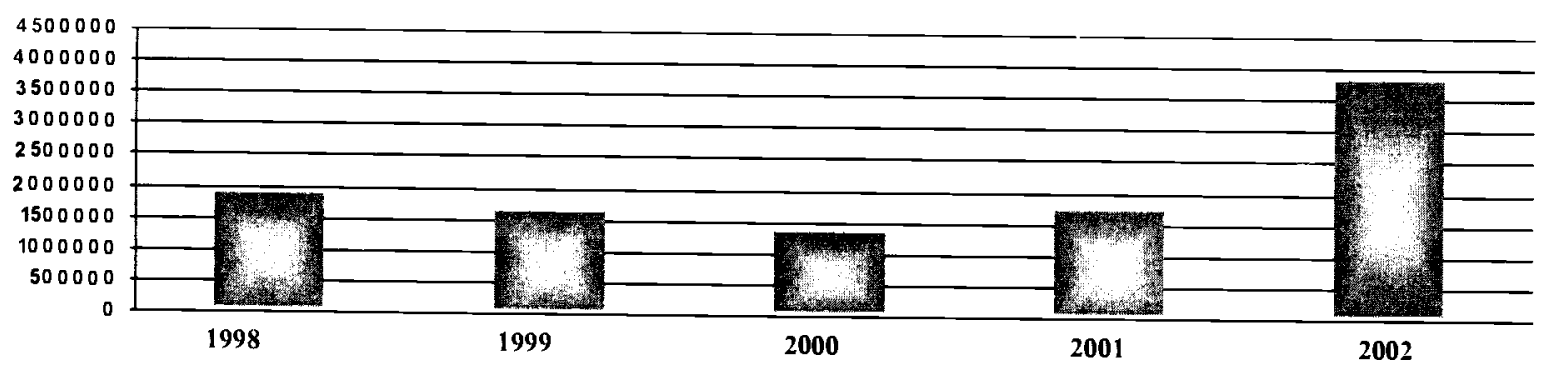

\begin{tabular}{lc|}
\cline { 2 - 2 } & \multicolumn{2}{c|}{ Donors } \\
Donors & \% Funded \\
\hline ADA & 5.98 \\
CA & 0.19 \\
DFIL) & 10.16 \\
EU & 36.47 \\
IRC & 0.29 \\
Japan & 0.07 \\
NCA & 19.62 \\
NOVIB & 13.95 \\
OFDA & 0.09 \\
SAFE & 0.53 \\
Trocaire & 2.87 \\
UNICEF/FAO & 0.20
\end{tabular}

\begin{tabular}{lc|}
\hline & Allocation \\
\hline Allocation & $\%$ Funded \\
\hline Agriculture & 19.68 \\
Fducation & 0.76 \\
Energency & 7.69 \\
Health & 0.76 \\
Incone Generatio & 4.55 \\
Infrastructure & 6.07 \\
Other & 21.31 \\
Relief \& Repatria & 1.92 \\
Water Resources & 37.27
\end{tabular}

\begin{tabular}{llr} 
& \multicolumn{2}{c|}{ Targeted Provinces } \\
\cline { 2 - 3 } Province & Sector & \% Targeted \\
\hline Balkh & Other & 21. \\
Farah & Infrastructure & 0.0 \\
Ghazni & Water Resources & 37. \\
Hirat & Emergency & 7.6 \\
Kabul & Reliet \& Repatriatioin & 1.9 \\
Logar & Income Generation & 4.5 \\
Uruzgan & Agriculture & 19. \\
Wardak & Health & 7.6 \\
Zabul & Education & 0.7 \\
& &
\end{tabular}

\section{Sub Offices}

\begin{tabular}{|c|c|c|c|c|c|}
\hline Sub Office & City / Town & Phone & Fax & E-mail & In Charge \\
\hline Kandahar.Sora lama Shar-e-Naw & Kandahar & 0022216 & & & M.A.Karimi \\
\hline Farah. Near Frah Petrol Pump & Farah & & & & M.M.Zehigar \\
\hline Wardak. Mangali, Shsh qala Region & Chack & & & & Saduddin \\
\hline $\begin{array}{l}\text { Mazar. Masmall Strect sultan Razia } \\
\text { Rd. }\end{array}$ & Mazar & 40240 & & & Eng.Hamidullah \\
\hline $\begin{array}{l}\text { NWFP. House 17FA-1 Khushal } \\
\text { Khan K.Road University Town }\end{array}$ & Peshawar & 845212 & & afgdevas@brain.net.pk & Razia Samadi \\
\hline
\end{tabular}




\begin{tabular}{|c|c|c|c|}
\hline Membership & & Country of Affliliation & Afghanistan \\
\hline Address & Communication & Key Staff & Position \\
\hline \multirow{4}{*}{$\begin{array}{l}\text { Street } 4 \text { Kochi Gul Froshi, } \\
\text { Shahr-e-Now, } \\
\text { Kabul-Afghanistan }\end{array}$} & Phone: & Eng. M. Younos & Director \\
\hline & Fax: & Eng. Mashoq & Project Manager \\
\hline & E-mail: & A. Wase & Admin / Account \\
\hline & Web: & & \\
\hline
\end{tabular}

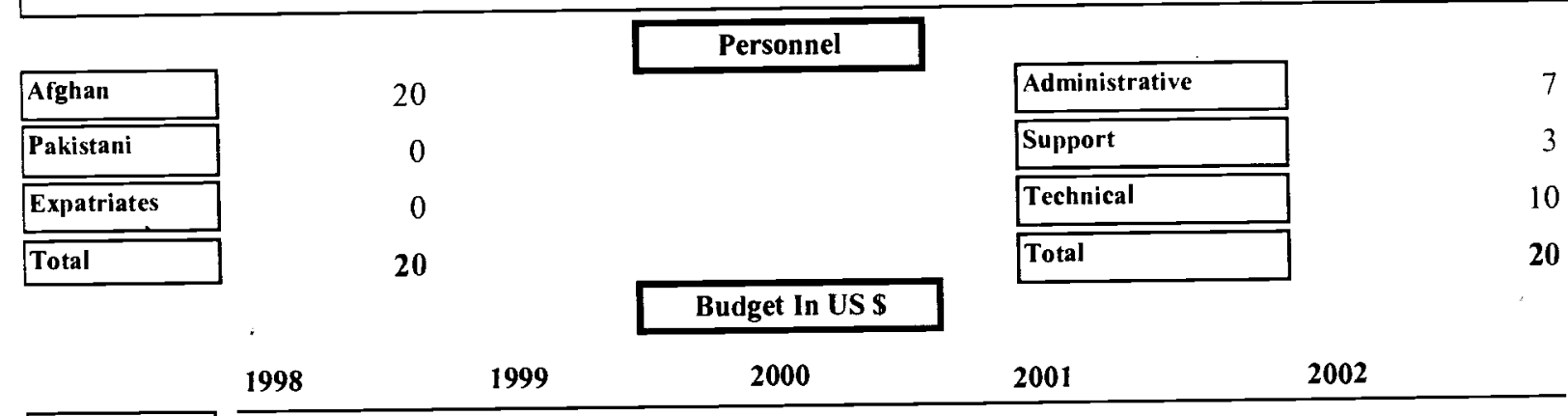

\begin{tabular}{|l|}
\hline Afghanistan \\
\hline \hline Pakistan \\
\hline Total \\
\hline
\end{tabular}

1998

\begin{tabular}{l}
\multicolumn{2}{c|}{ Donors } \\
Donors \\
\hline CARE \\
ISAF \\
WFP \\
WFP
\end{tabular}

1999

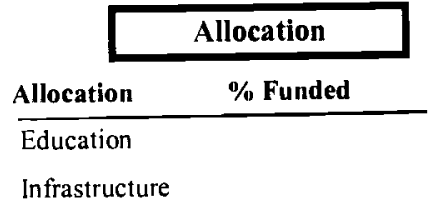

Sub Offices
2000

\begin{tabular}{|c|c|c|}
\hline \multirow[b]{3}{*}{ Province } & \multicolumn{2}{|c|}{2002} \\
\hline & \multicolumn{2}{|c|}{ Targeted Provinces } \\
\hline & Sector & $\%$ Targeted \\
\hline Ghazni & \multicolumn{2}{|c|}{ Education } \\
\hline Kabul & \multicolumn{2}{|c|}{ Infrastructure } \\
\hline Kapisa & \multicolumn{2}{|c|}{ Education } \\
\hline Logar & \multicolumn{2}{|c|}{ Education } \\
\hline
\end{tabular}

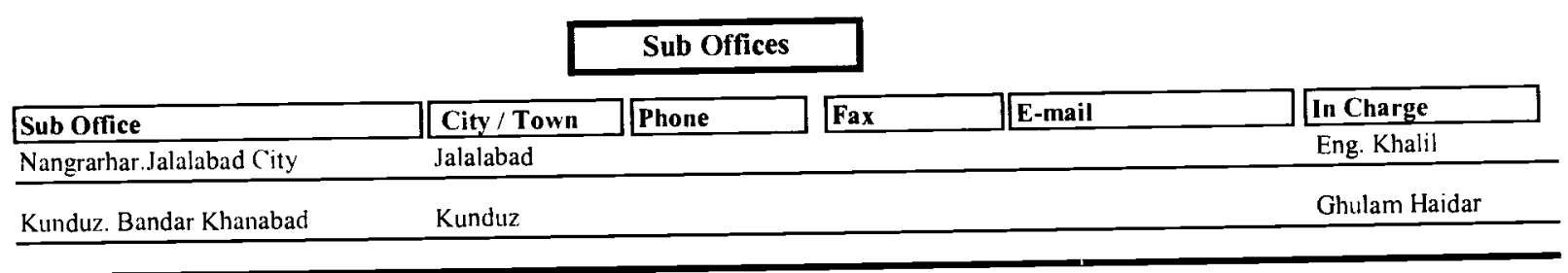




\begin{tabular}{|c|c|c|c|}
\hline Membership & Other & Country of Affiliation & Afghanistan \\
\hline Address & Communication & Key Staff & Position \\
\hline \multirow{4}{*}{$\begin{array}{l}\text { Khair Khana } 1 \text { Saraki Awal Bus } \\
\text { Stop, } \\
\text { Block } 55 \text { 3rd Floor Near to WFP } \\
\text { WareHouse, } \\
\text { Kabul-Afghanistan }\end{array}$} & $2400264 / 070283473$ & Eng.Mir Jamal & Director \\
\hline & Fax: & Eng.Mahboob & Deputy Director \\
\hline & E-mail: & & \\
\hline & Web: & & \\
\hline
\end{tabular}

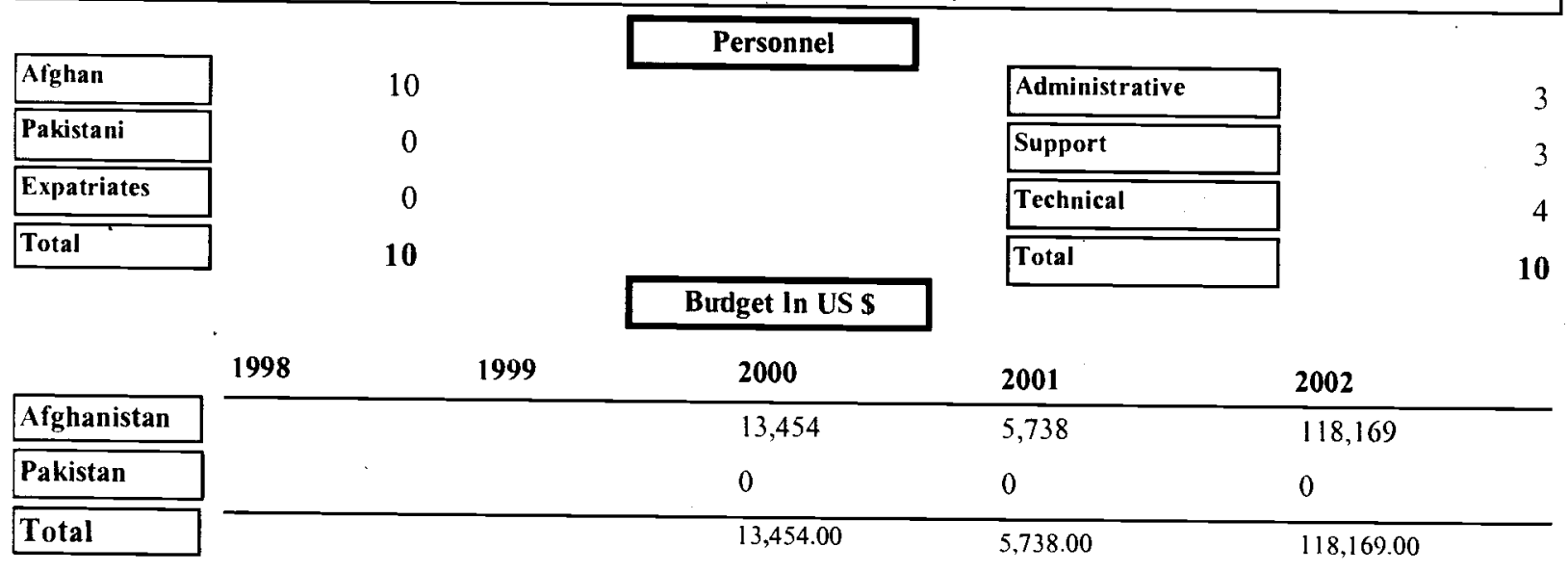

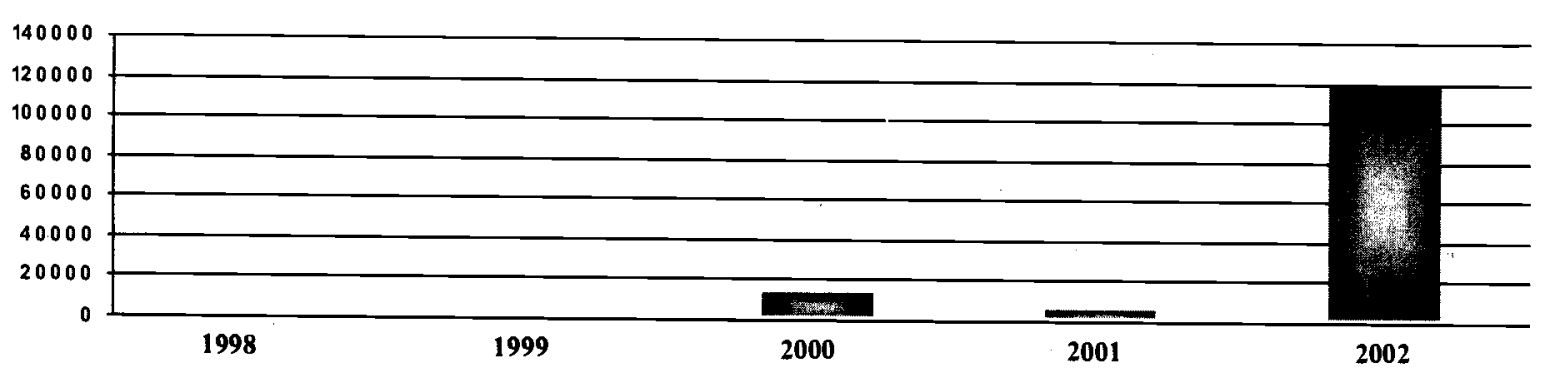

\begin{tabular}{|c|c|c|c|c|c|c|}
\hline \multicolumn{2}{|c|}{ Donors } & & location & \multirow[b]{2}{*}{ Province } & \multicolumn{2}{|c|}{ Targeted Provinces } \\
\hline Donors & "\% Funded & Allocation & $\%$ Funded & & Sector & Targeted \\
\hline Canada Fund & 23.8 & Other & 31 & Khost & Infrastructure & 39 \\
\hline CARE & 15.74 & Water Resources & 69 & Khost & Water Resources & 24 \\
\hline $\begin{array}{l}\text { DFID } \\
\text { WFP }\end{array}$ & $\begin{array}{l}15.22 \\
45.24\end{array}$ & & & Paktya & Water Resources & 45 \\
\hline
\end{tabular}

Sub Offices

\begin{tabular}{|c|c|c|c|c|c|}
\hline Sub Office & City / Town & Phone & Fax & E-mail & In Charge \\
\hline Khost City Opposite Qabail School & Khost & & & & Eng.Qadeer \\
\hline
\end{tabular}




\begin{tabular}{|c|c|c|c|}
\hline Membership & ICVA & Country of Affliliation & Turkey \\
\hline Address & Communication & Key Staff & Position \\
\hline \multirow{4}{*}{$\begin{array}{l}\text { Ataturk Bulvari 121/818, } \\
\text { O6640 Bakanliklar, } \\
\text { Ankara -Turkey }\end{array}$} & +903124257804 & Ahmet Akyurek & President \\
\hline & +903124176728 & Endei Baskaya & Vice President \\
\hline & akv@marketweb.net.tr & Ali Eroghlu & Project Manager \\
\hline & www.akv.org.tr & & \\
\hline
\end{tabular}

\begin{tabular}{|l|}
\hline Afghan \\
\hline Pakistani \\
\hline Expatriates \\
\hline Total \\
\hline
\end{tabular}

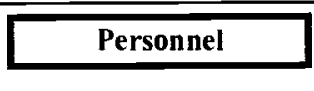

\section{8}

\begin{tabular}{|l|}
\hline Administrative \\
\hline Support \\
\hline Technical \\
\hline Total \\
\hline
\end{tabular}

Budget In US \$

\begin{tabular}{|c|c|c|c|c|c|}
\hline & 1998 & 1999 & 2000 & 2001 & 2002 \\
\hline Afghanistan & & & & $1,770,000$ & $1,610,000$ \\
\hline Pakistan & & & & 295,000 & 60,000 \\
\hline Total & & & & $2,065,000.00$ & $1,670,000.00$ \\
\hline
\end{tabular}

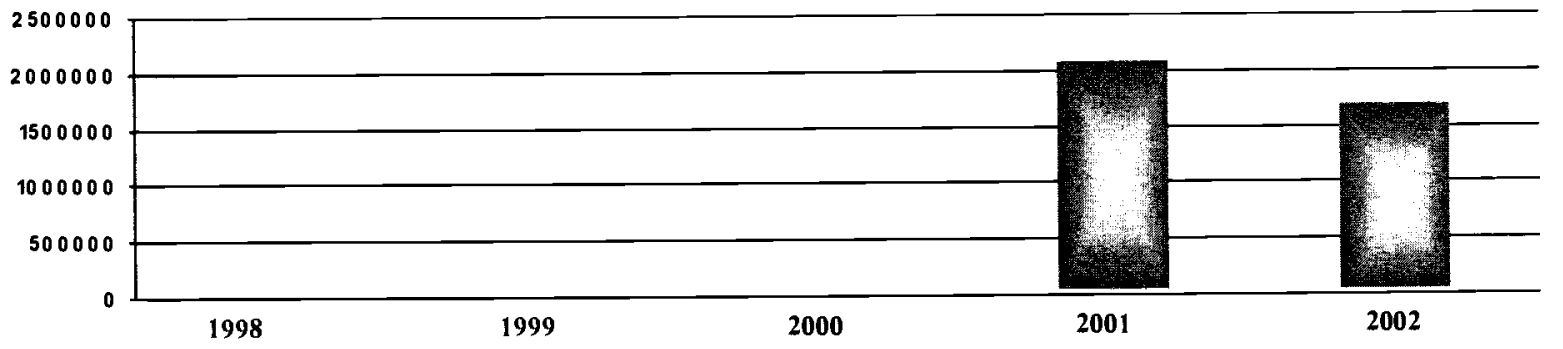

\begin{tabular}{|c|c|c|c|c|c|c|}
\hline \multicolumn{2}{|c|}{ Donors } & & location & \multirow[b]{2}{*}{ Province } & \multicolumn{2}{|c|}{ Targeted Provinces } \\
\hline Donors & $\%$ Funded & Allocation & $\%$ Funded & & Sector & $\%$ Targeted \\
\hline CARITAS Germany & 35 & Agriculture & 10 & Balochistan & Emergency & 5 \\
\hline Diakonic Germany & 40 & Education & 20 & Kandahar & Emergency & 70 \\
\hline \multirow[t]{3}{*}{ Heks Switzerland } & 25 & Emergency & 25 & Nangarhar & Emergency & 25 \\
\hline & & In frastructure & 20 & & & \\
\hline & & Relief \& Repatria & 25 & & & \\
\hline
\end{tabular}

\begin{tabular}{|c|c|c|c|c|c|}
\hline & & Sub Offices & & & \\
\hline Sub Office & City / Town & Phone & Fax & E-mail & In Charge \\
\hline Islamabad. H.No. 1/A, St.63, F7/3. & Isłamabad & +923008579789 & $051-2820432$ & $\begin{array}{l}\text { adf- } \\
\text { pakistan }(\text { hhotmail.com }\end{array}$ & Asadullah Dagar \\
\hline H.No. 87 , Charahi Haji Moh.Dad & Kabul & 202200119 & 2031875 & $\begin{array}{l}\text { adt: } \\
\text { afghanistan@ohotmail.co } \\
\underline{m}\end{array}$ & A. Thsan Shengul \\
\hline Grish Adda Stadium Road & Kandahar & +882162277079 & & $\begin{array}{l}\text { adf- } \\
\text { kandahar@hotmail.com }\end{array}$ & Tommy Bouchiba \\
\hline Nangrarhar.Joe 7 St. 4 Road 1 & Jalalabad & +882162277079 & & $\begin{array}{l}\text { adf- } \\
\text { nangarhar@hotmail.com }\end{array}$ & Eng.Amanullah \\
\hline Tehran & Tehran/Iran & +989132165196 & & adf-iran@hotmail.com & Eng.Mirkhani \\
\hline
\end{tabular}




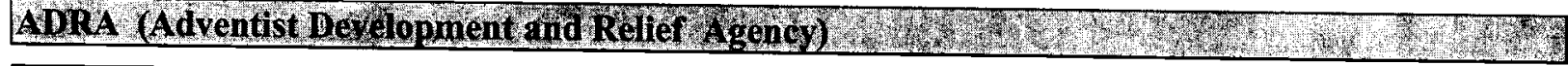

\begin{tabular}{|c|c|c|c|}
\hline Membership & ACBAR & Country of Affliliation & USA \\
\hline Address & Communication & Key Staff & Position \\
\hline \multirow{3}{*}{$\begin{array}{l}\text { House } 124 \text { St } 5 \text { District } 4, \\
\text { Shahr-e-Naw Belind Hirati } \\
\text { Mosque. } \\
\text { Kabul-Afghanistan }\end{array}$} & $070274601 / 070283905$ & Peter Jaggi & Country Director \\
\hline & Fax: & Juregen Amold & Programs Director \\
\hline & $\begin{array}{l}\text { E-mail: atghanistan@adra.euruaficica.org } \\
\text { Web: }\end{array}$ & Clerstice Arnold & Accountant \\
\hline
\end{tabular}

\begin{tabular}{|l|}
\hline Afghan \\
\hline Pakistani \\
\hline Expatriates \\
\hline Total \\
\hline
\end{tabular}

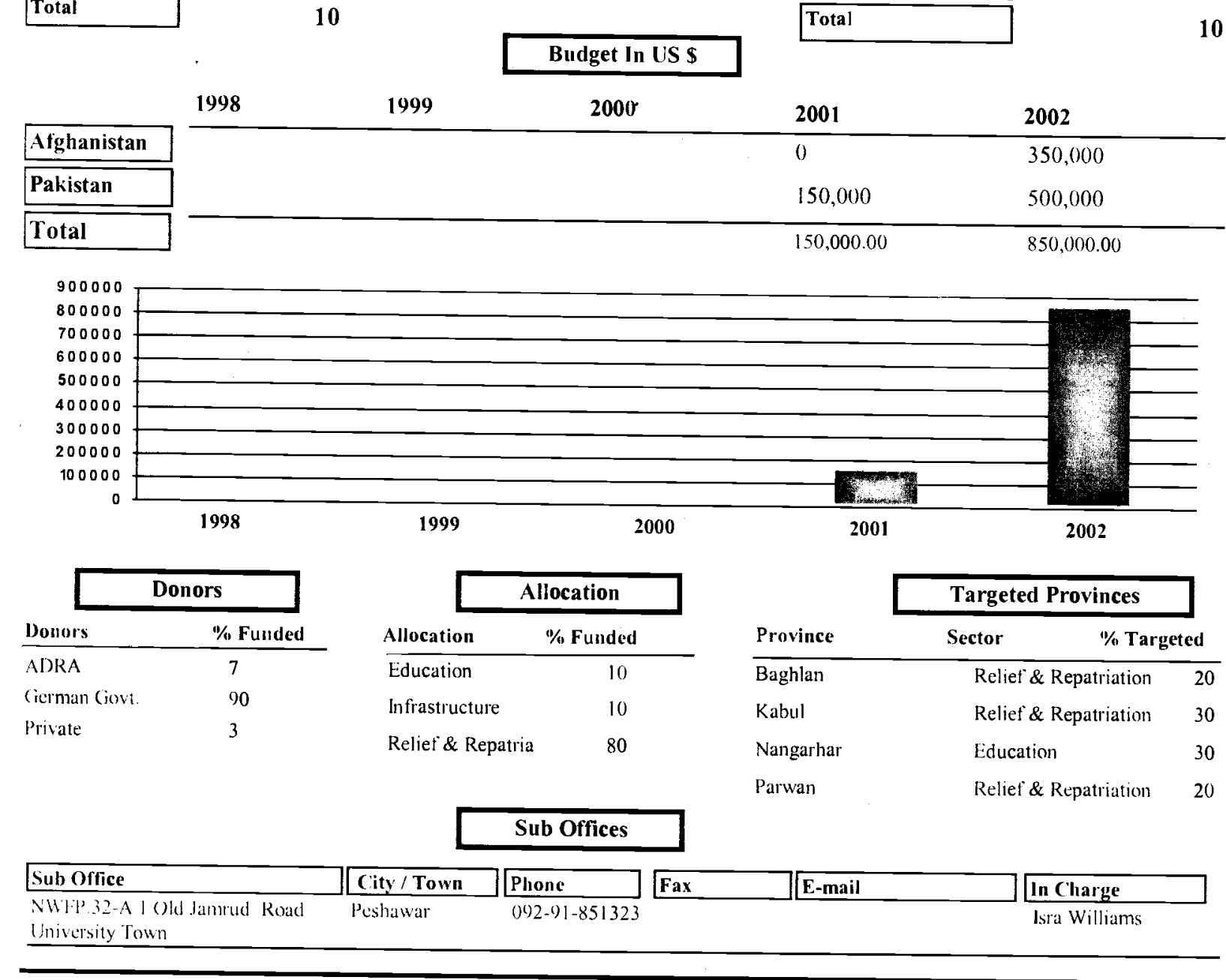

Personnel

0

5

0

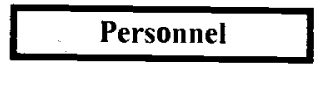

\begin{tabular}{|l|}
\hline Administrative \\
\hline Support \\
\hline Technical \\
\hline Total \\
\hline
\end{tabular}




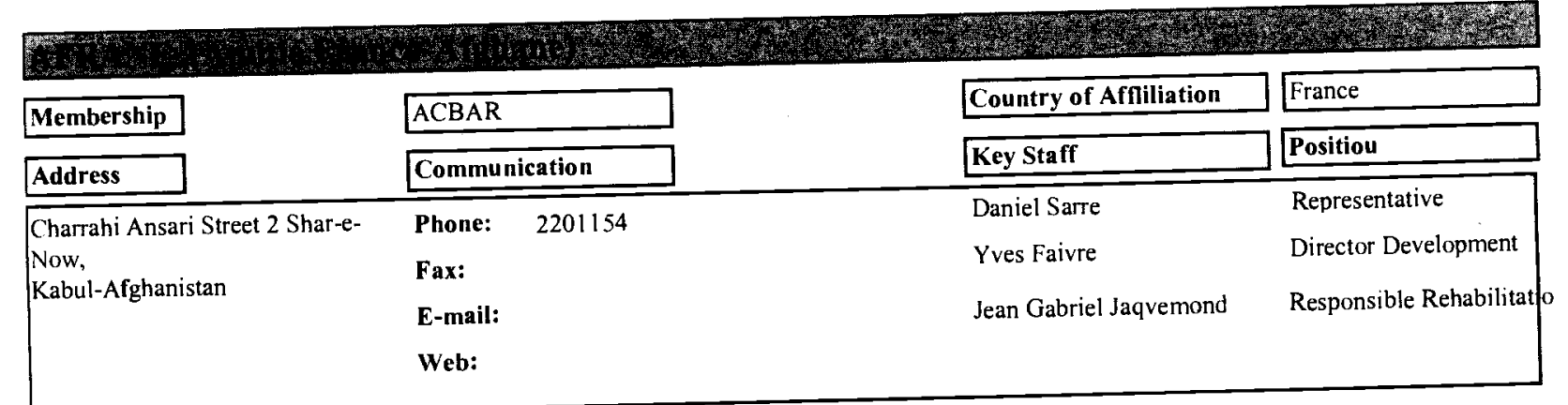

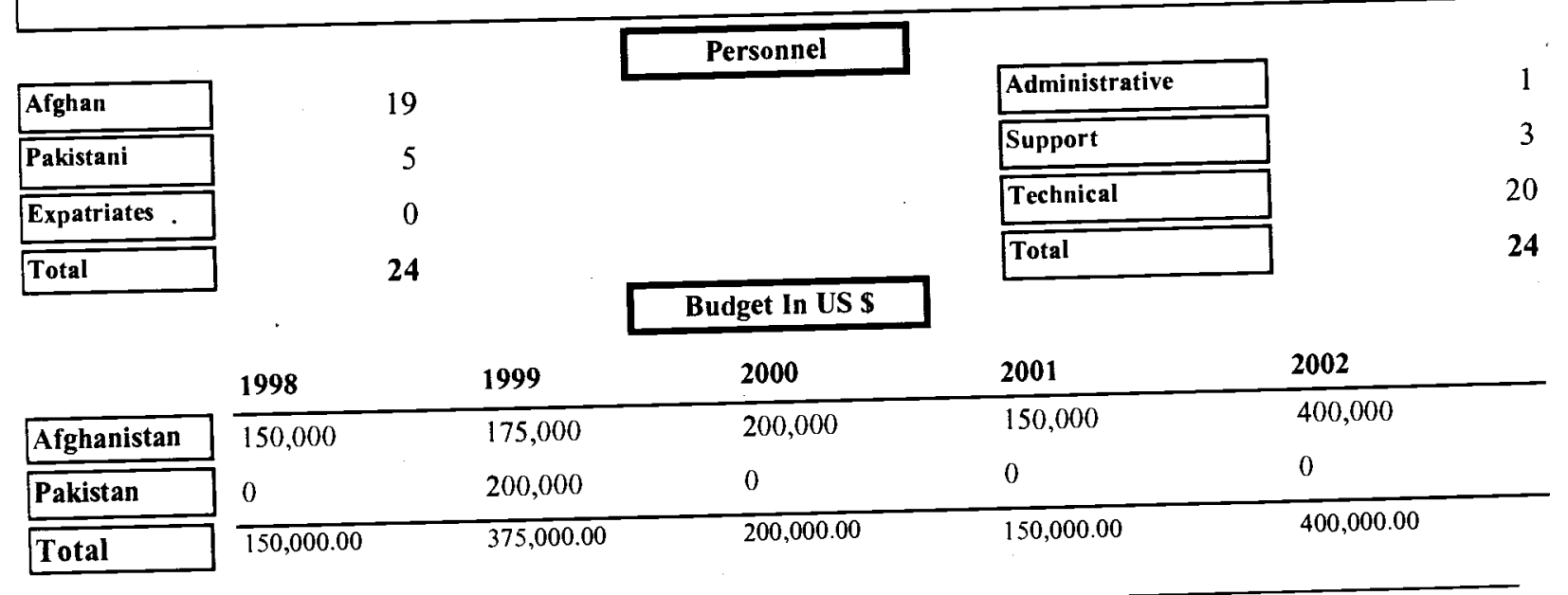

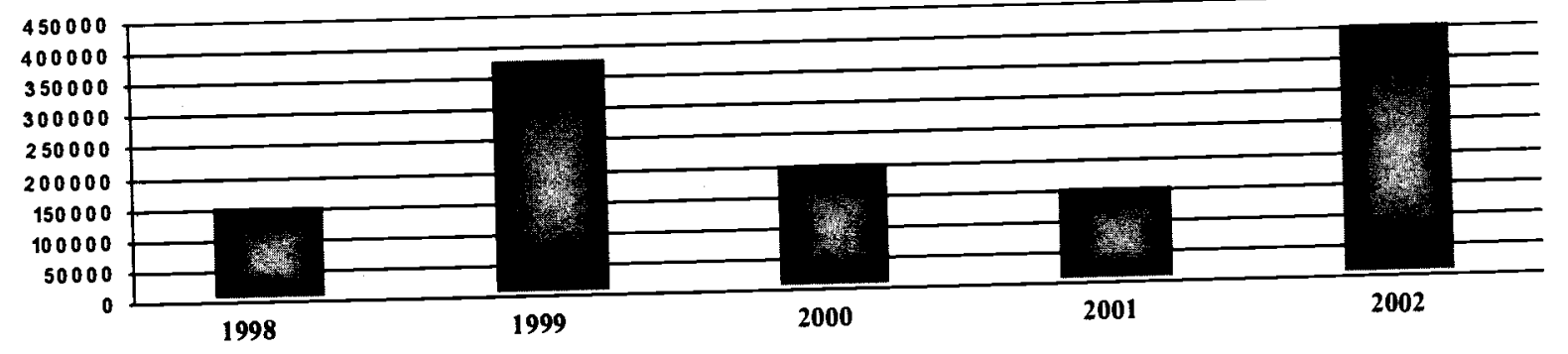

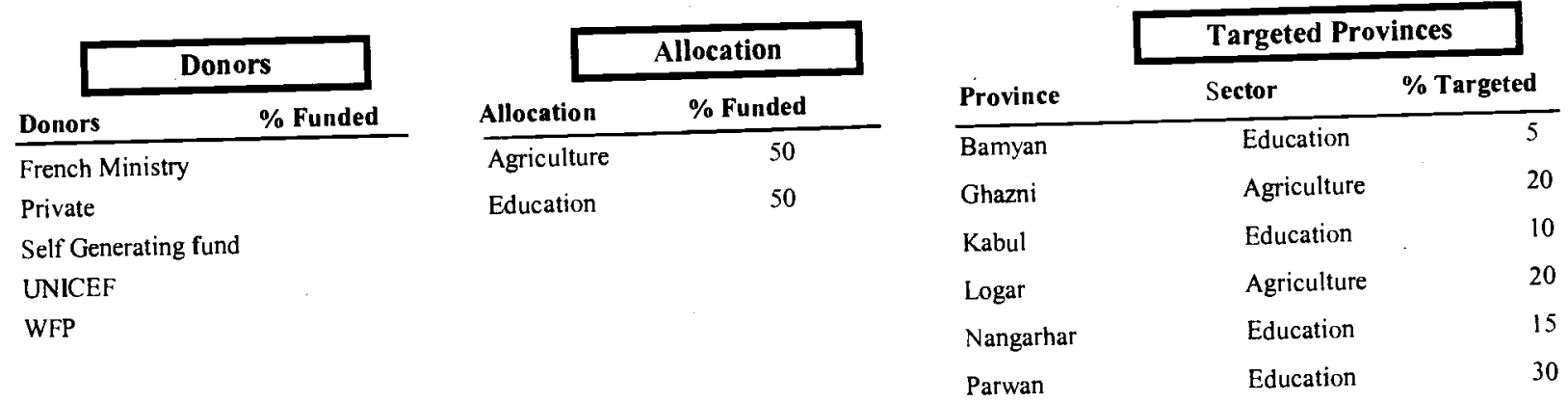

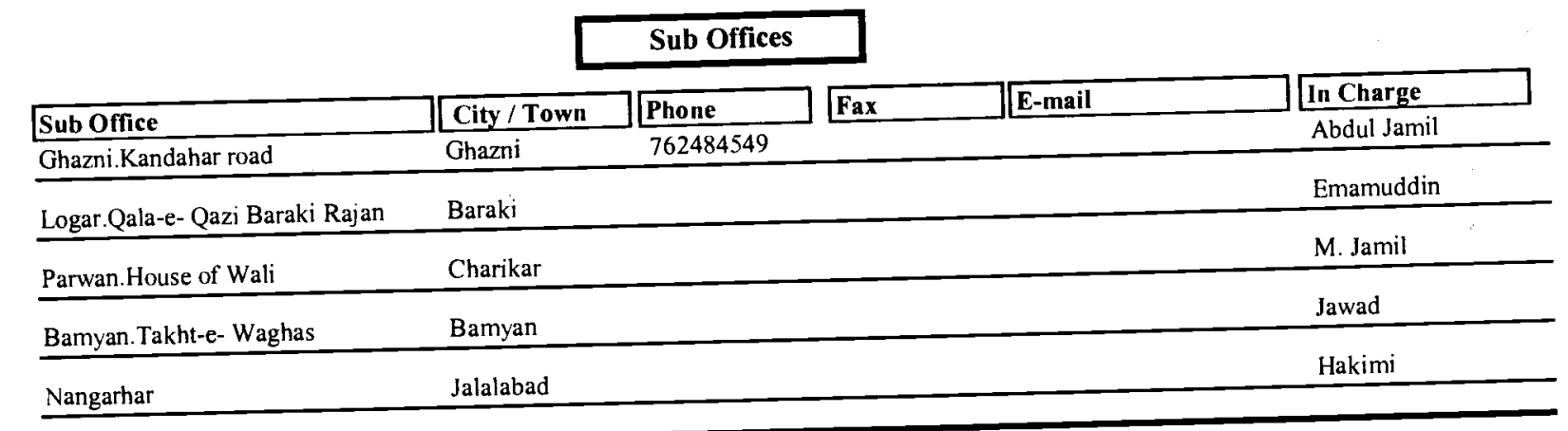




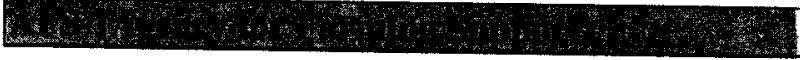

\begin{tabular}{|c|c|c|c|}
\hline Membership & ANCB & Country of Affiliation & Afghanistan \\
\hline Address & Communication & Key Staff & Position \\
\hline \multirow{3}{*}{$\begin{array}{l}\text { Street l House } 183 \text { Shashdarak, } \\
\text { Behind ACLU office, } \\
\text { East of club-e-Askari, } \\
\text { Kabul-Afghanistan }\end{array}$} & Phone: & Abdul.Aziz Oriakhil & Director \\
\hline & Fax: & Dr.Ebrahim & Deputy Director \\
\hline & E-mail: afs876@yahoo.com & Eng. Koshistani & Administrator \\
\hline
\end{tabular}

\begin{tabular}{|l|r|}
\hline Afghan & 29 \\
\hline \hline Pakistani & 0 \\
\hline Expatriates & 0 \\
\hline Total & 29 \\
\hline
\end{tabular}

Personnel

\begin{tabular}{|c|c|c|c|c|c|}
\hline Total & & & & Total & 29 \\
\hline & & & Budget In US \$ & & \\
\hline & 1998 & 1999 & 2000 & 2001 & 2002 \\
\hline Afghanistan & & 25,000 & 25,000 & $\overline{0}$ & 21,000 \\
\hline Pakistan & & 25,000 & 0 & 50,000 & 50,000 \\
\hline Total & & $50,000.00$ & $25,000.00$ & $50,000.00$ & $71,000.00$ \\
\hline
\end{tabular}

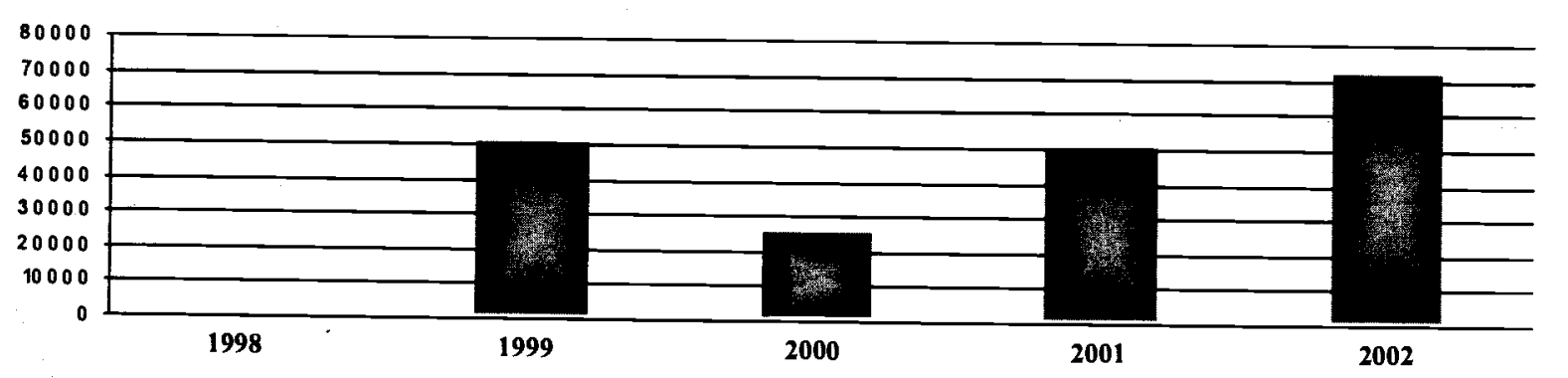

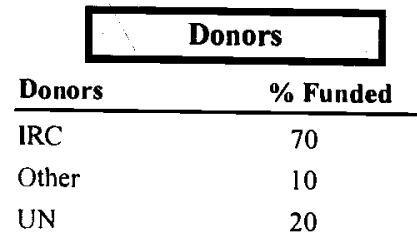

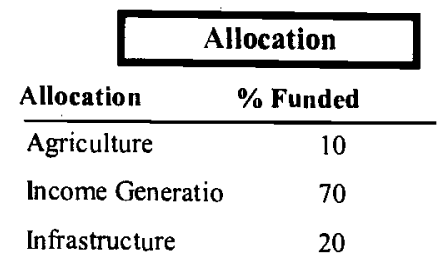

Sub Offices

\begin{tabular}{|l|}
\hline Administrative \\
\hline Support \\
\hline Technical \\
\hline Total \\
\hline
\end{tabular}

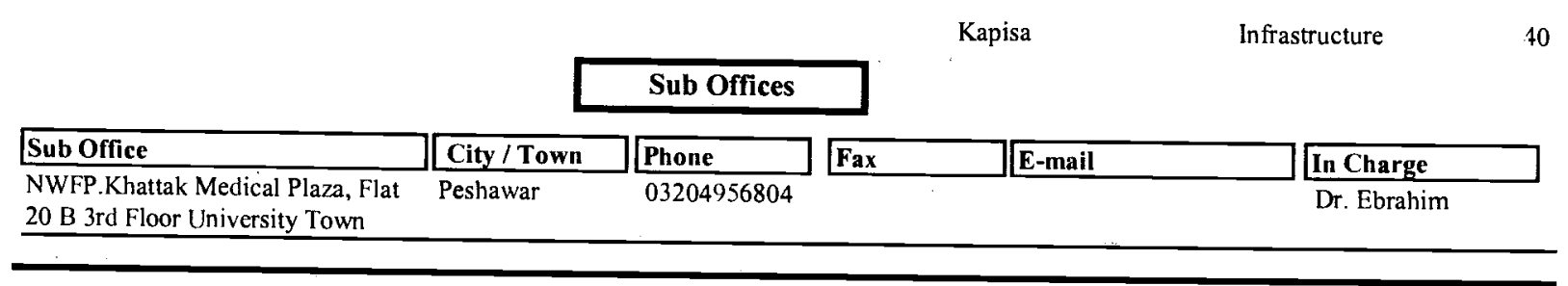




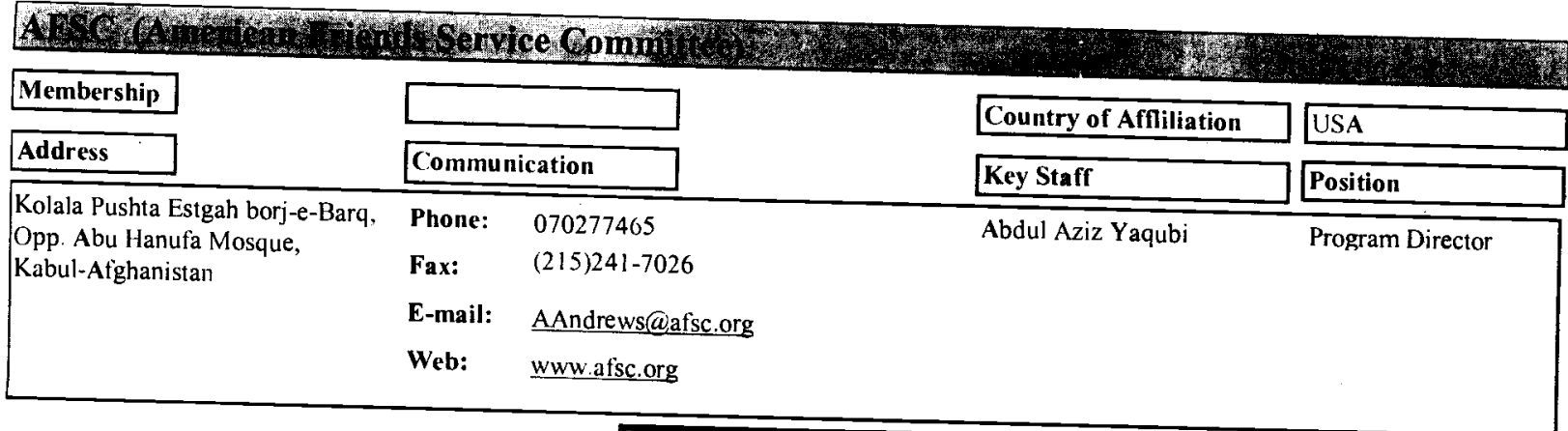

\begin{tabular}{|l|}
\hline Afghan \\
\hline \hline Pakistani \\
\hline Expatriates \\
\hline Total \\
\hline
\end{tabular}

Budget ln US S

\begin{tabular}{|l|}
\hline Administrative \\
\hline Support \\
\hline Technical \\
\hline Total
\end{tabular}

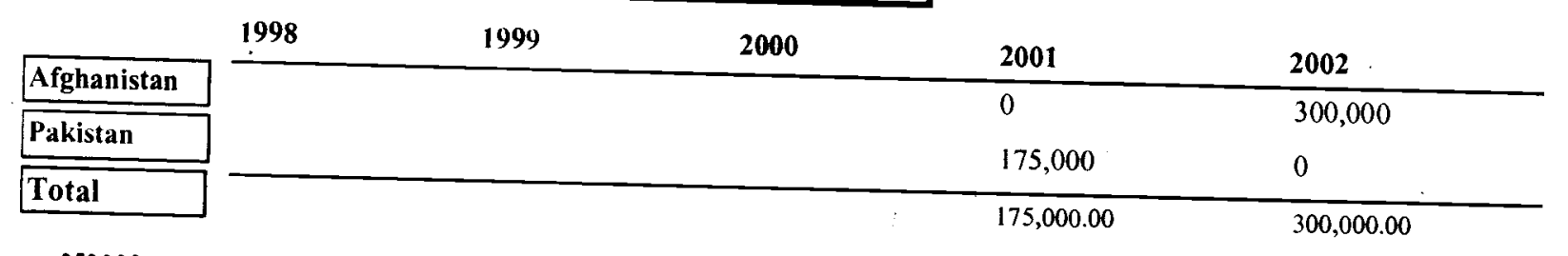
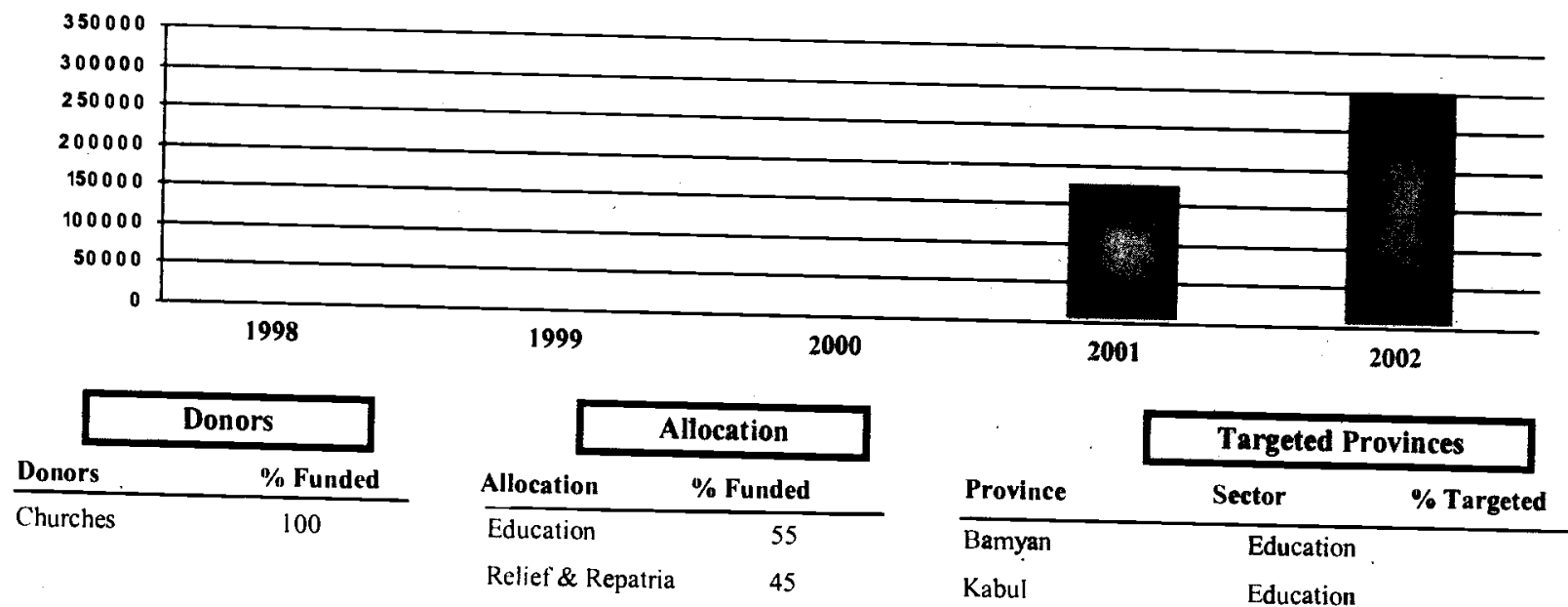

\section{Sub Offices}

\begin{tabular}{lc|} 
& \multicolumn{2}{c|}{ Targeted Provinces } \\
\cline { 2 - 2 } Province & Sector \\
\hline Bamyan & \%durgeted \\
Kabul & Education \\
Nangarhar & Education \\
Parwan & Education
\end{tabular}

\begin{tabular}{|c|c|c|c|c|}
\hline Sub Office & City / Town & Phone & E-mail & In Charge \\
\hline $\begin{array}{l}\text { NWFP.D o/II Park Ave.Rd } \\
\text { University Town }\end{array}$ & Peshawar & 5700366 & & A.Aziz Yaqubi \\
\hline
\end{tabular}




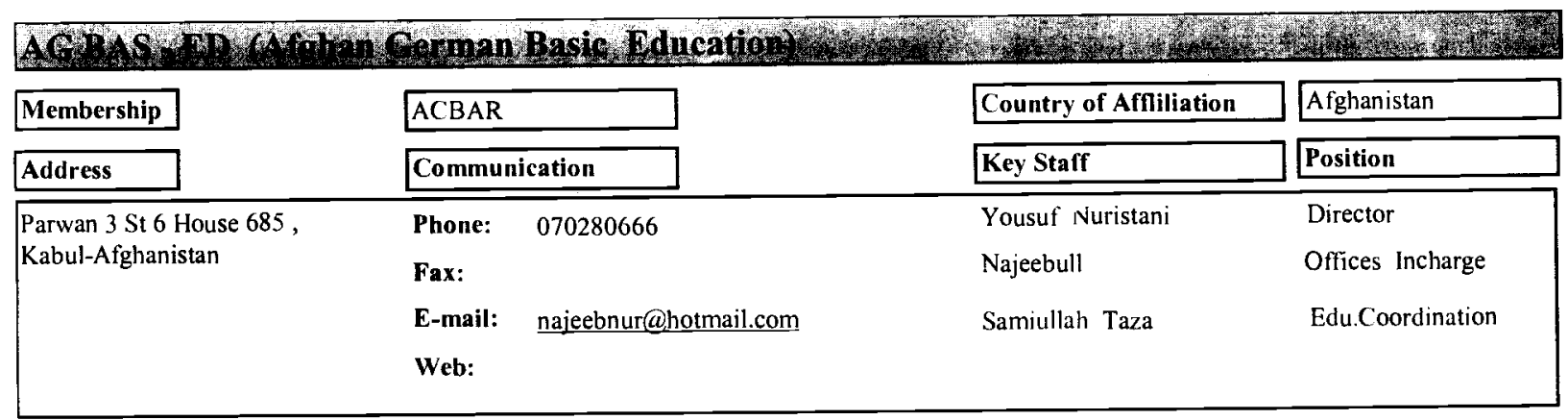

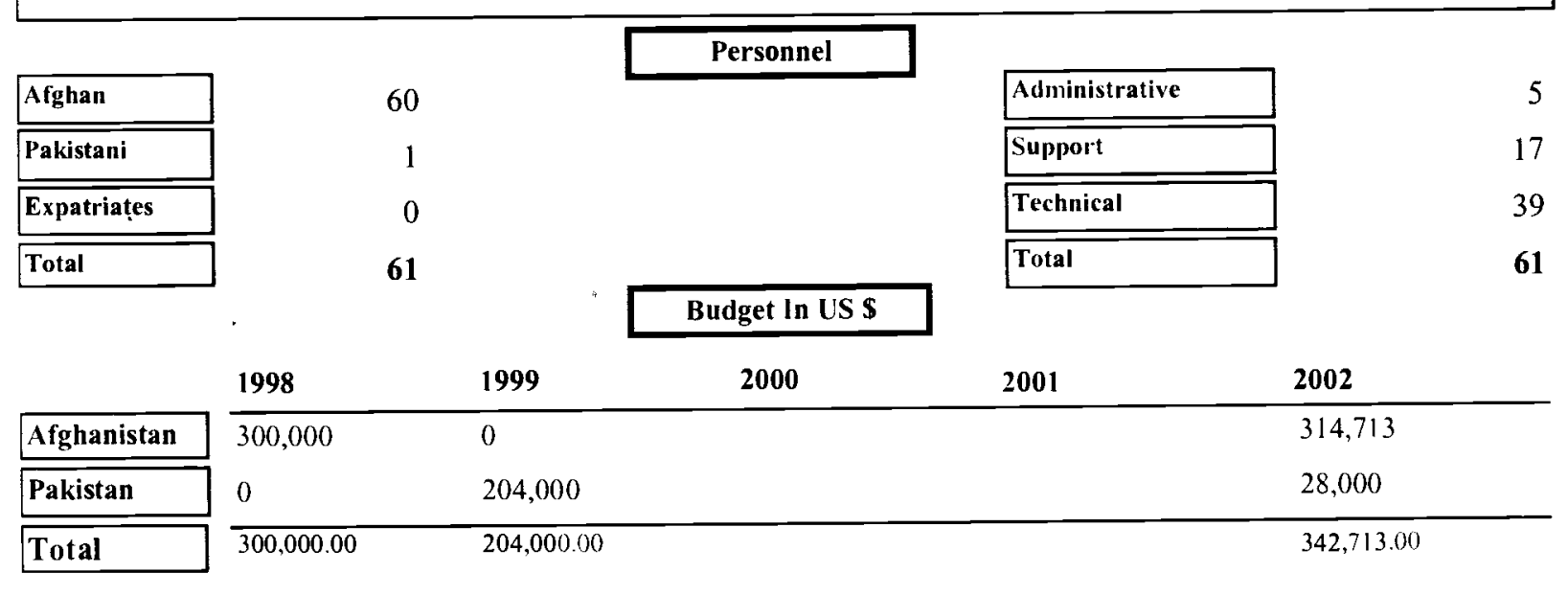

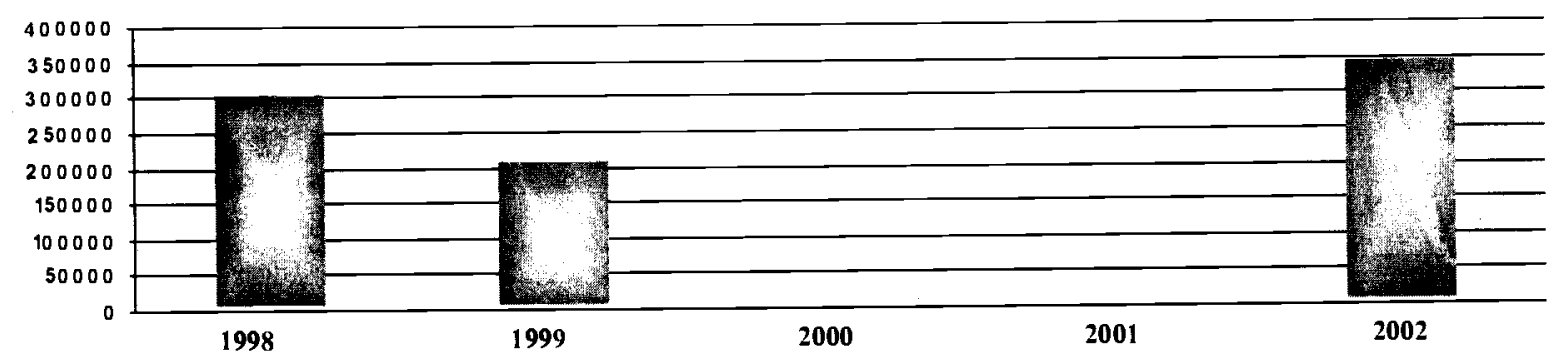

\begin{tabular}{|c|c|c|c|c|c|c|}
\hline \multicolumn{2}{|c|}{ Donors } & & llocation & \multirow[b]{2}{*}{ Province } & \multicolumn{2}{|c|}{ Targeted Provinces } \\
\hline Donors & $\%$ Funded & Allocation & $1 \%$ Funded & & Sector & $\%$ Targeted \\
\hline \multirow{7}{*}{$\begin{array}{l}\text { DED } \\
\text { GI'L } \\
\text { SV Netherland } \\
\text { UNCIEF }\end{array}$} & & Education & 100 & Kabul & Education & 3 \\
\hline & & & & Khost & E:ducation & 18 \\
\hline & & & & Kunar & Fducation & 20 \\
\hline & & & & Laghman & Education & 4 \\
\hline & & & & Logar & Education & 8 \\
\hline & & & & Nuristan & Foducation & 15 \\
\hline & & & & Paktia & Education & 5 \\
\hline
\end{tabular}

Sub Offices

\begin{tabular}{|c|c|c|c|c|c|}
\hline Sub Office & City / Town & Phone & Fax & E-mail & In Charge \\
\hline $\begin{array}{l}\text { NWFP.Shaeen Town St.l Esmat } \\
\text { School Buliding }\end{array}$ & Peshawar & 843470.850725 & 842693 & nuristan (abrain nel.pk & Najechullah \\
\hline Khost City.Proja & Khost & 843470.850725 & 842693 & nuristan abrain.nel.pis & Voorthlali \\
\hline Nuristan. Wan Bazar & Nuristan & 843470.850725 & 842693 & nuristan(abrain net.pk & Abdullah \\
\hline 40 Metra line. Said Kayan St & Jalalabad & 843470.850725 & $8+2693$ & nuristancabrain netpk & Saddullah Qari \\
\hline $\begin{array}{l}\text { Kunar. Asadabad City Kalamiv } \\
\text { velley }\end{array}$ & Asadabad & 843470.850725 & 842698 & nuristan@brain.net.pk & Ghullamullah \\
\hline
\end{tabular}




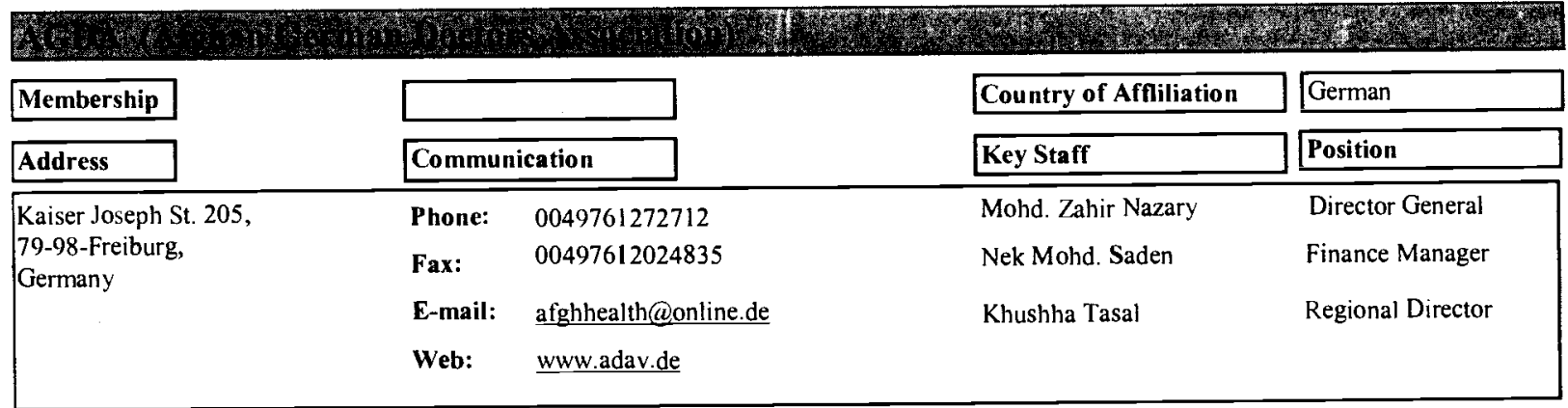

\begin{tabular}{|c|c|c|c|c|}
\hline & & Personnel & & \\
\hline Afghan & 26 & & Administrative & 3 \\
\hline Pakistani & 0 & & Support & 5 \\
\hline Expatriates & 10 & & Technical & 28 \\
\hline Total & 36 & & Total & 36 \\
\hline
\end{tabular}

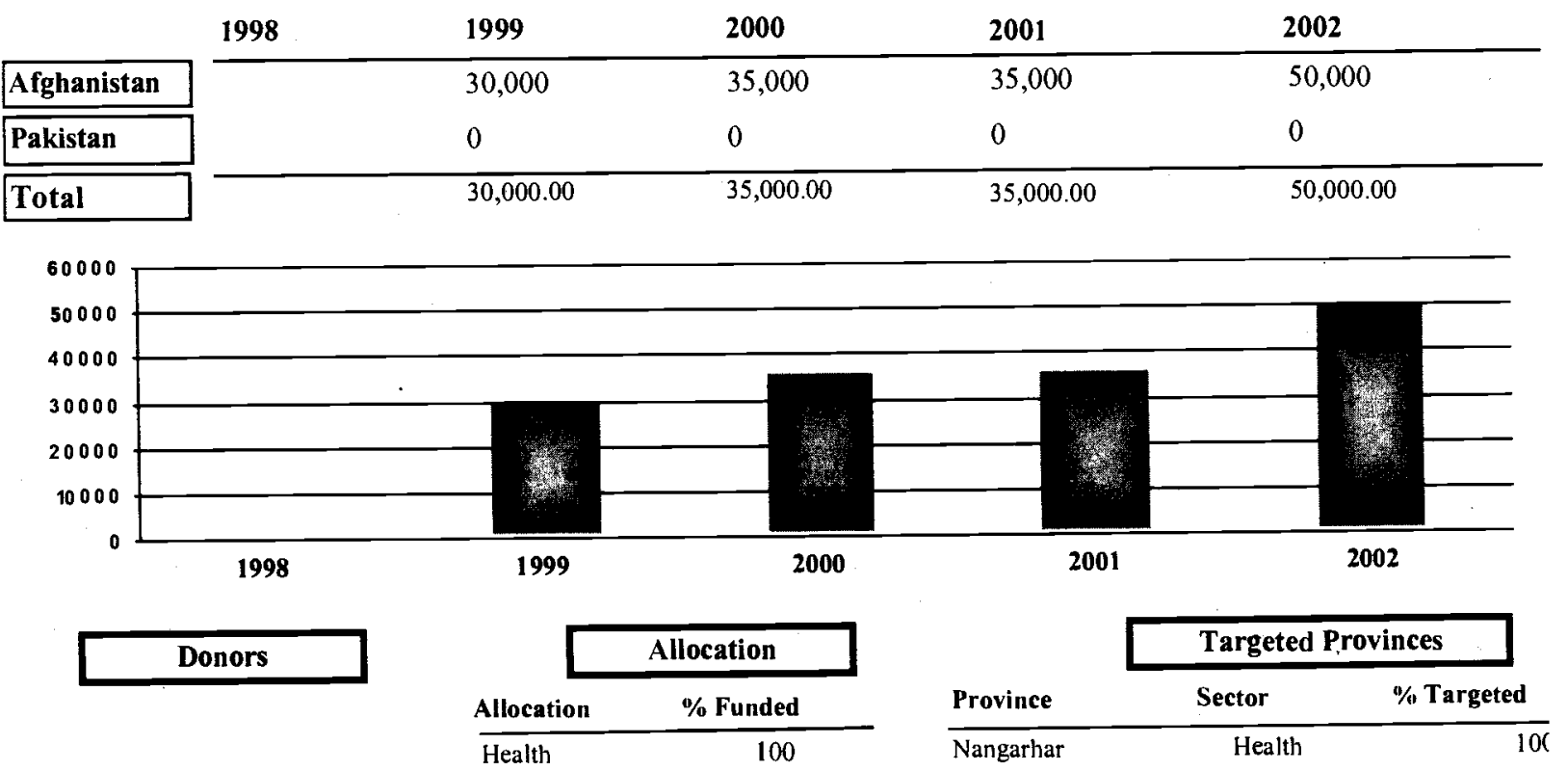

\section{Sub Offices}

\begin{tabular}{l|l|l|l|l|l|l|l|l|l|l|l|l|}
\hline Sub Office & City / Town & Phone & Eargail \\
$\begin{array}{l}\text { Nangarhar. Mushku st. Reg-i-Shah } \\
\text { Mard Khan }\end{array}$ & Jalalabad & Dr. Khushhal \\
\hline
\end{tabular}




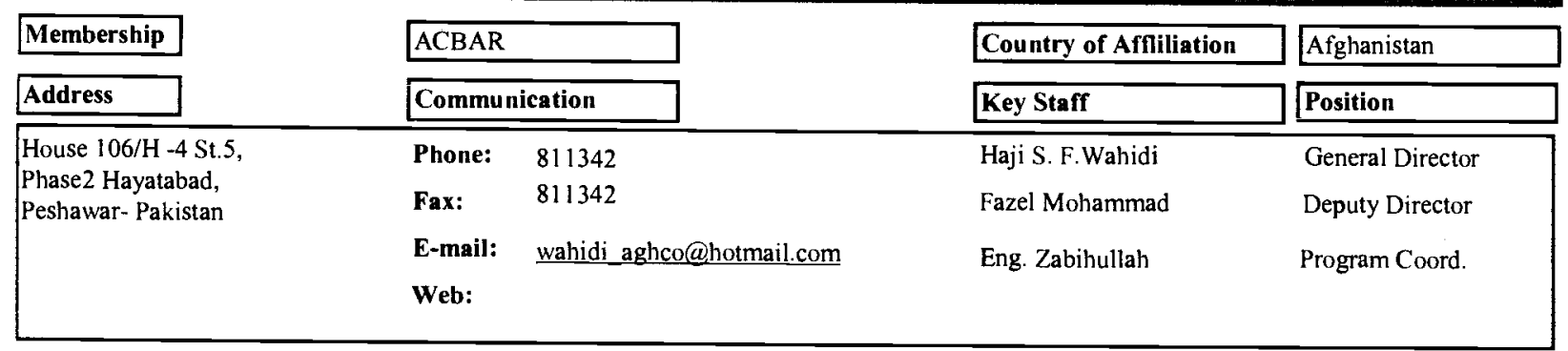

\begin{tabular}{|l|}
\hline Afghan \\
\hline Pakistani \\
\hline \hline Expatriates \\
\hline Total \\
\hline
\end{tabular}

32

Personnel

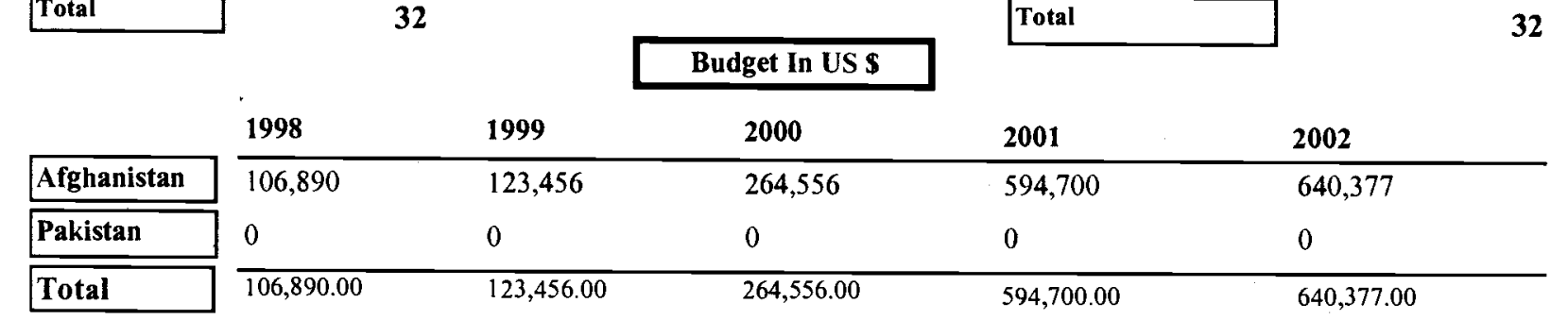

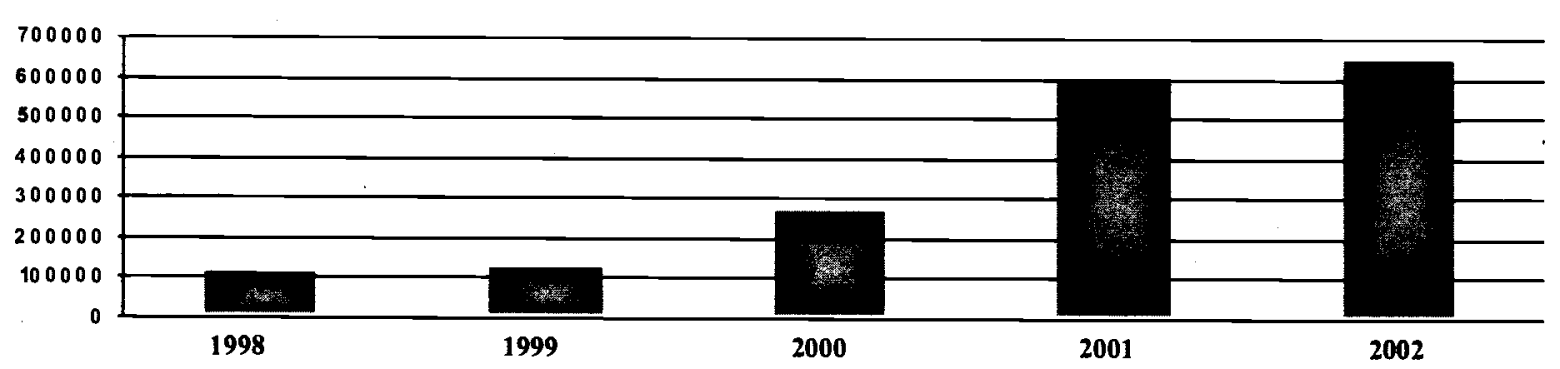

\begin{tabular}{lr}
\hline \multicolumn{1}{|c|}{ Donors } \\
Donors & \% Funded \\
\hline UNHCR & \\
UNICEF & \\
WFP & \\
WHO &
\end{tabular}

\begin{tabular}{lc|}
\hline & Allocation \\
\hline Allocation & \% Funded \\
\hline Emergency & 10 \\
Health & 18 \\
Income Generatio & 2 \\
Infrastructure & 70
\end{tabular}

\begin{tabular}{lll}
\cline { 2 - 3 } Province & \multicolumn{2}{c|}{ Targeted Provinces } \\
\cline { 2 - 3 } Khost & Sector & \% Targeted \\
Kunar & Infrastructure & 20 \\
Laghman & Relief \& Repatriatioin & 3 \\
Nangarhar & Relief \& Repatriatioin & 5 \\
Nuristan & Water Supply & t0 \\
Paktika & Infrastructure & 1 \\
& Income Generation & 20
\end{tabular}

Sub Offices

\begin{tabular}{|c|c|c|c|c|}
\hline Sub Office & City / Town & Phone & E-mail & In Charge \\
\hline $\begin{array}{l}\text { Nangarhar. Opp of University } \\
\text { Hospital }\end{array}$ & Jalalabad & & & Eng.Fazel M. \\
\hline Kabul. Wazir Akbar:Khan 15 street & Kabul & & & Eng. S. Mirwise \\
\hline Kandahar.Chawk-e-Shaheedan & Kandahar & & & Sayed Maruf \\
\hline $\begin{array}{l}\text { Paktia.Near to Qole Urdo Gardiz } \\
\text { City }\end{array}$ & Gardiz & & & Eng. S. Shah \\
\hline
\end{tabular}




\begin{tabular}{|c|c|c|c|}
\hline Membership & ANCB & Country of Affliliation & Afghanistan \\
\hline Address & Communication & Key Staff & Position \\
\hline \multirow{4}{*}{$\begin{array}{l}\text { Jadeh Mokhaberat, } \\
\text { Bbeside Rafa Saloon, } \\
\text { Hirat- Afghanistan }\end{array}$} & Phone: & Abdul Aziz Sarwary & Director \\
\hline & & Mh.Yousuf Etammad & Program Manager \\
\hline & E-mail: & Ab.Jalil Aha \madi & Agriculture Manager \\
\hline & Web: & & \\
\hline
\end{tabular}

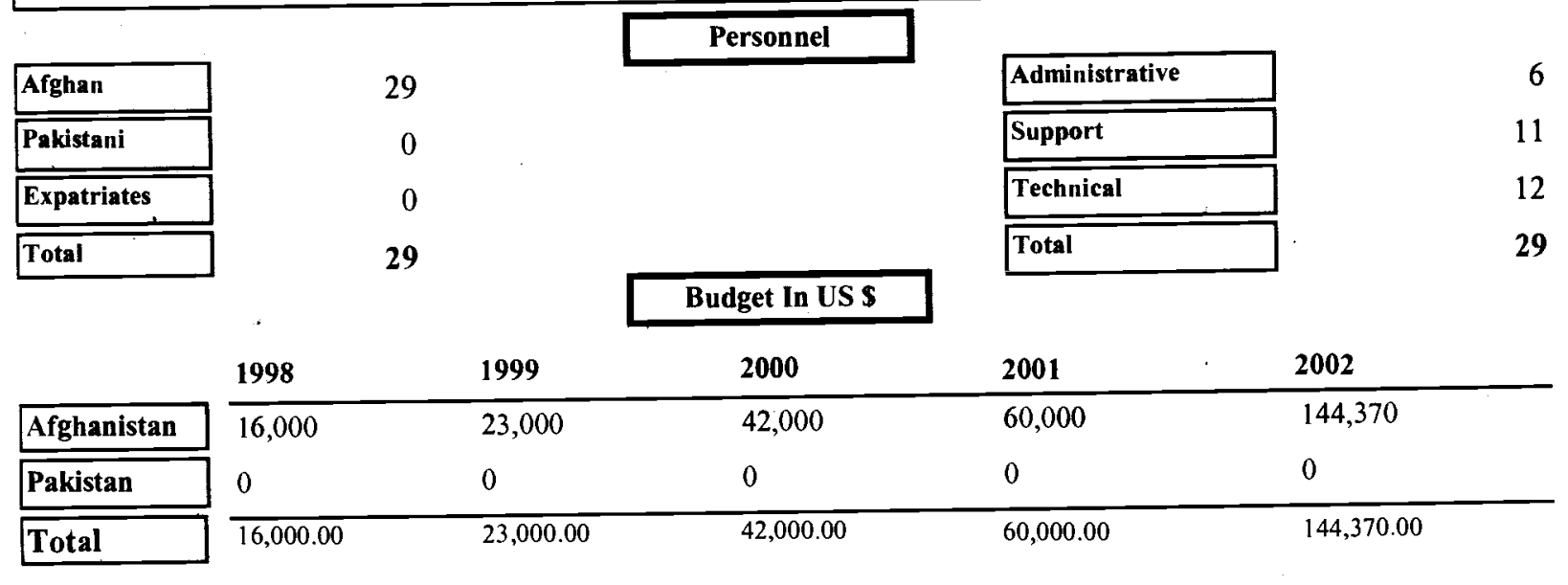

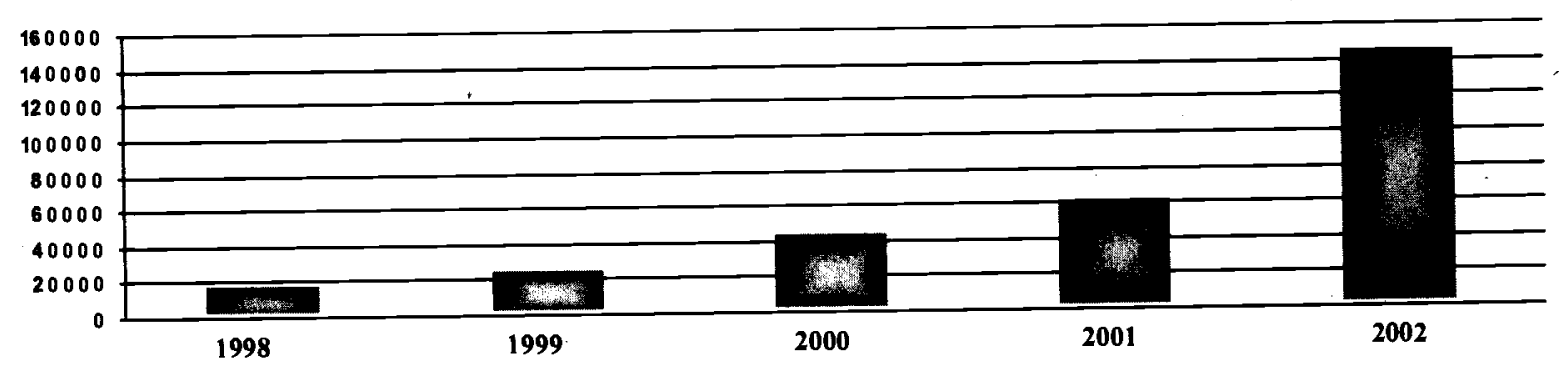

\begin{tabular}{|c|c|c|c|c|c|c|}
\hline \multicolumn{2}{|c|}{ Donors } & \multicolumn{2}{|c|}{ Allocation } & \multirow[b]{2}{*}{ Province } & \multicolumn{2}{|l|}{ Targeted Provinces } \\
\hline Donors & $\%$ Funded & Allocation & \% Funded & & Sector & $\%$ Targeted \\
\hline DACAAR & & Agriculture & 30 & Hirat & Agriculture & 30 \\
\hline EO.CA & & Education & 5 & Hirat & Water Resources & 15 \\
\hline FAO & & Emergency & 40 & Hirat & Health & 5 \\
\hline $\begin{array}{l}\text { IRC } \\
\text { NNHCR }\end{array}$ & & Health & 5 & Hirat & Emergency & $4 c$ \\
\hline $\begin{array}{l}\text { UNHCR } \\
\text { UNICEF }\end{array}$ & & Infrastructure & 10 & Hirat & Infrastructure & $1 c$ \\
\hline WFP & & Water Resource & 10 & & & \\
\hline
\end{tabular}

\section{Sub Offices}

\begin{tabular}{|c|c|c|c|c|c|}
\hline Suh Office & City / Town & Phone & Fax & E-mail & In Charge \\
\hline $\begin{array}{l}\text { Hirat.Qarabagh - Near Qambagh } \\
\text { School }\end{array}$ & Ghoryan & & & & Mohd.Shafiq \\
\hline
\end{tabular}




\begin{tabular}{|c|c|c|c|}
\hline Membership & ACBAR & Country of Affliliation & Afghanistan \\
\hline Address & Communication & Key Staff & Position \\
\hline \multirow{4}{*}{$\begin{array}{l}\text { House } 38 \text { St. } 4 \text { Zarghoona Maidan, } \\
\text { Close to Filling Station Shahr-e- } \\
\text { Now, } \\
\text { Kabul- Afghanistan }\end{array}$} & Phone: & Aziz R. Qarghah & Director \\
\hline & Fax: & Dr.Mohammad & Deputy Director \\
\hline & E-mail: $\quad$ info@ahds.org & M.Karim Farighi & Medical Coordinator \\
\hline & www.ahds.org & & \\
\hline
\end{tabular}

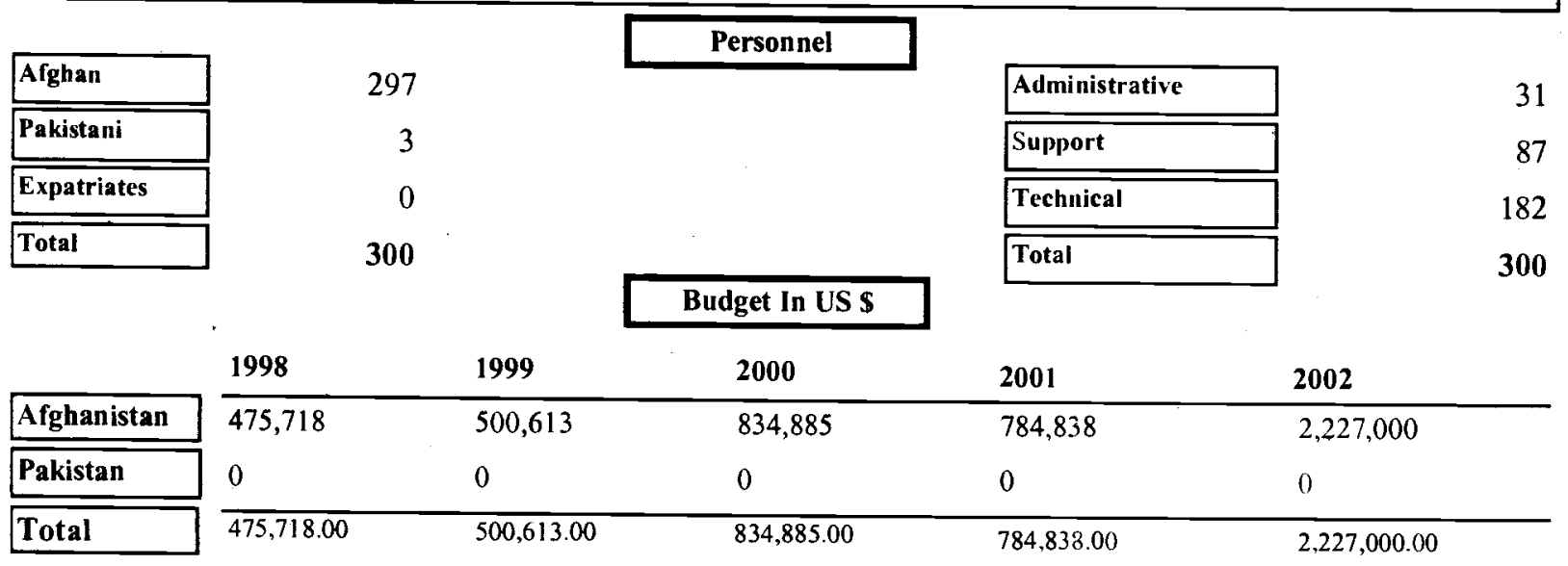

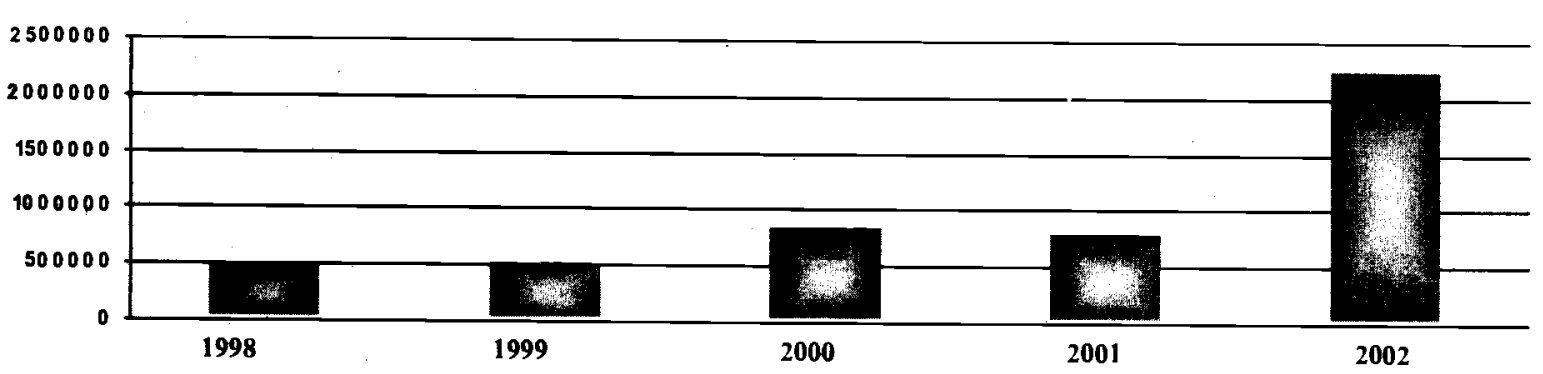

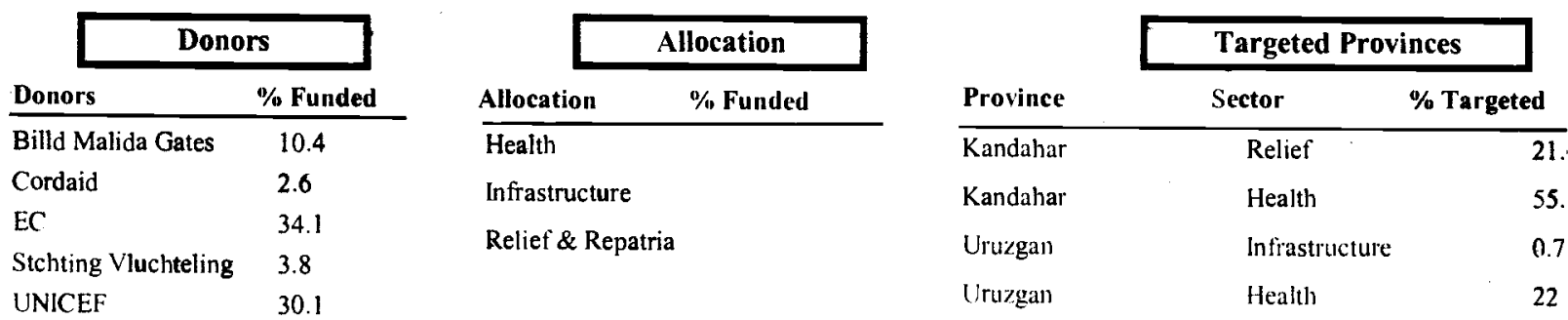

Sub Offices

\begin{tabular}{|c|c|c|c|c|c|}
\hline Sub Office & City / Town & Phone & Fax & E-mail & In Charge \\
\hline $\begin{array}{l}\text { Opposite Sarwar-e-Kayenat Mosque, } \\
\text { Kandahar City }\end{array}$ & Kandahar & +933210422 & & & Dr. Naiem Rahimi \\
\hline Urozgan.Trinkot City, & Trinkot & & & & Dr. Rasool \\
\hline $\begin{array}{l}\text { NWFP.178 - D2 3rd Ghazali Road } \\
\text { Hayatabad }\end{array}$ & Peshawar & 817342 & 825921 & info(wahds.org & Dr. M.K.Farighi \\
\hline
\end{tabular}




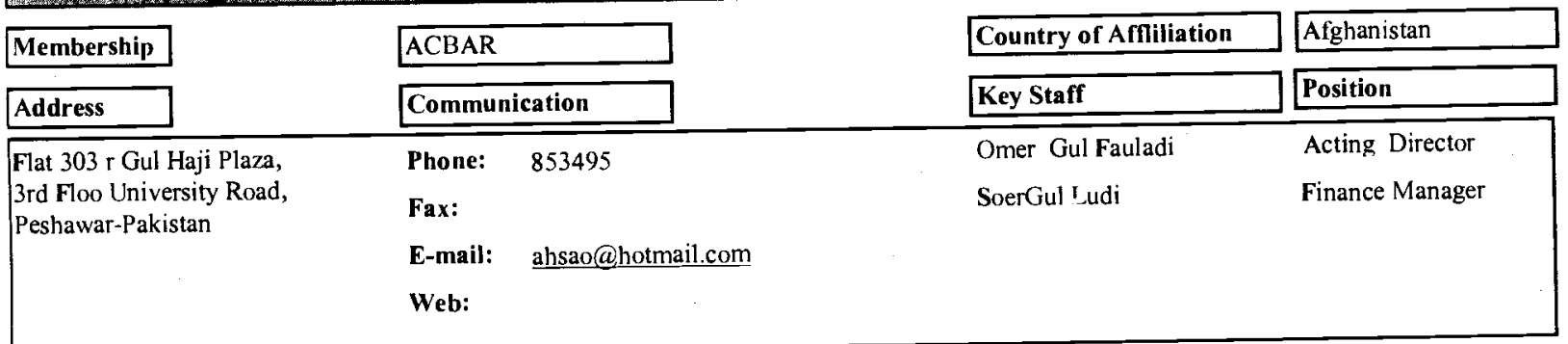

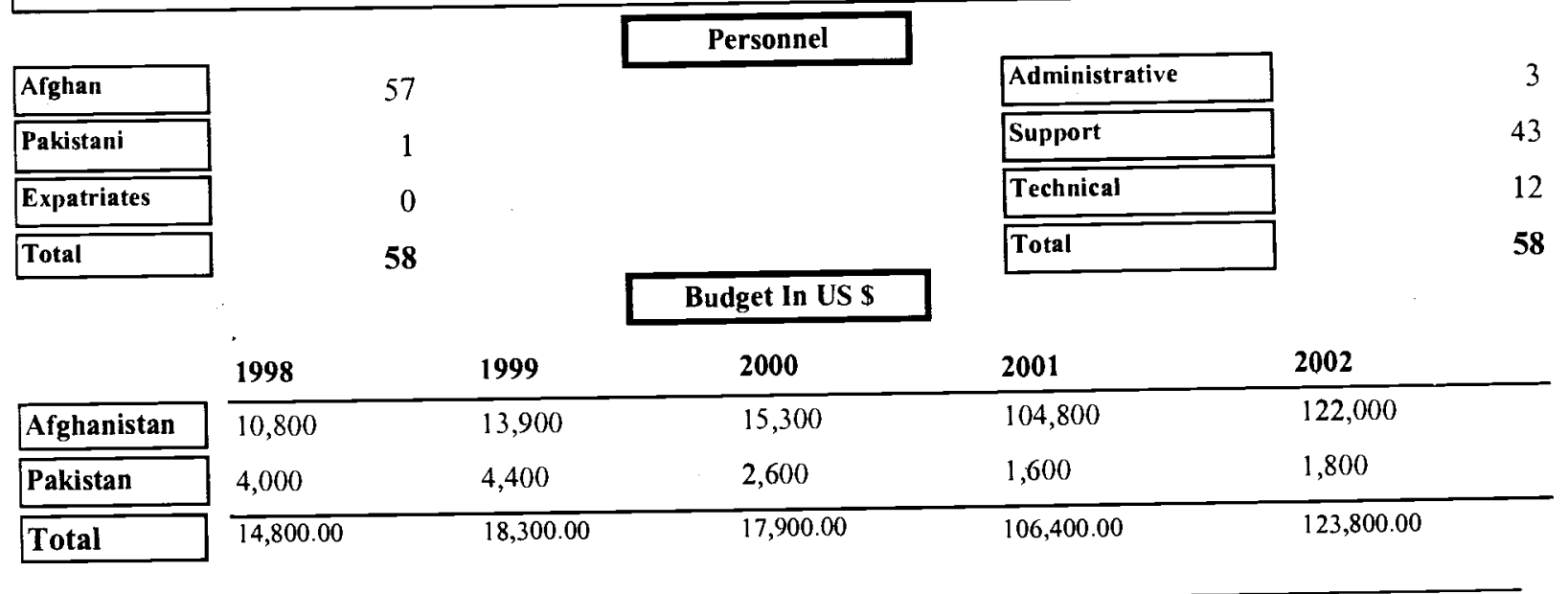

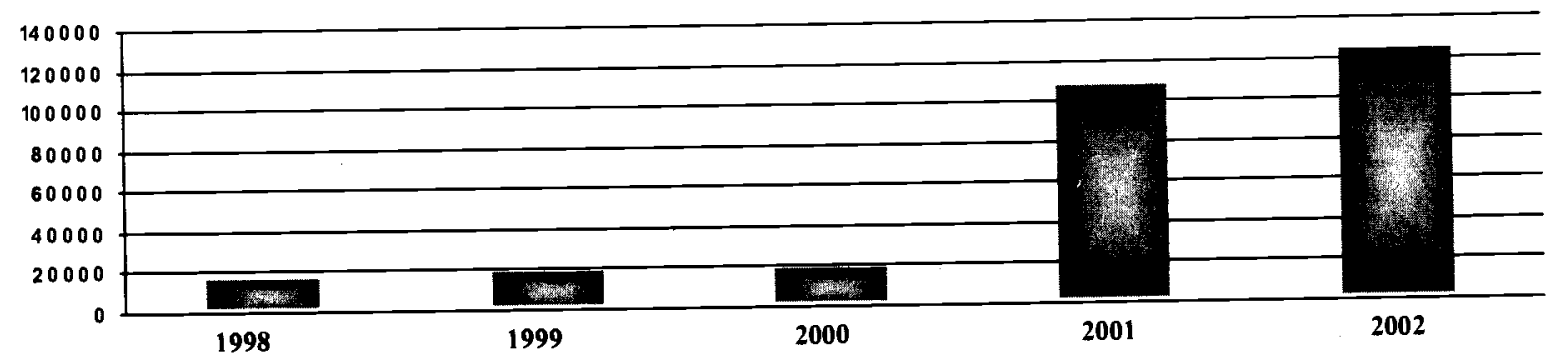

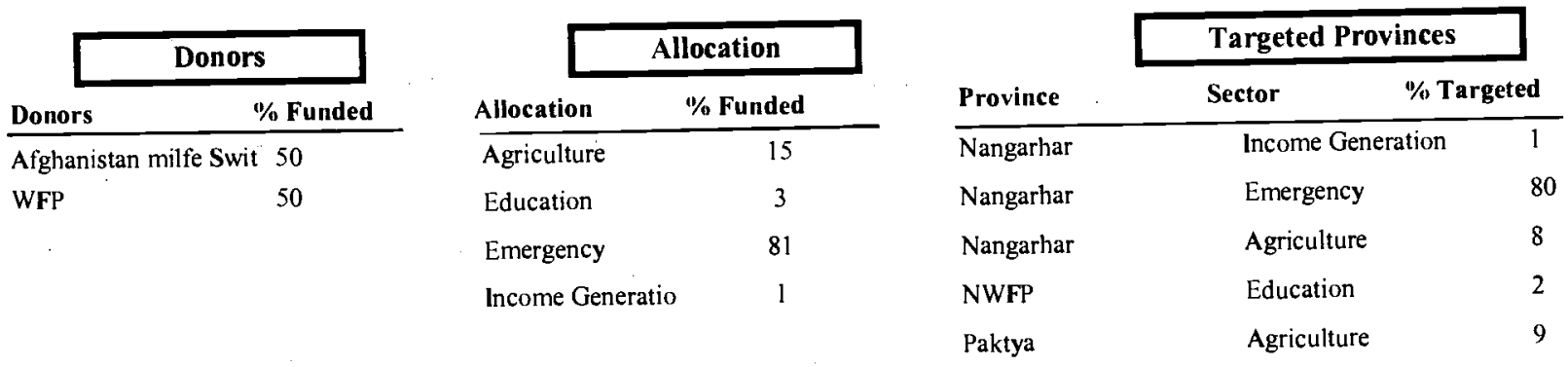

Sub Offices

\begin{tabular}{l|l|l|l|l|l|l|l|l|l|l|l|l|l|l|}
\hline Sub Office & City / Town & Phone & E-mail \\
\hline Nangarhar.Serajul Emarat Garden & Jalalabad & Wasi \\
\hline
\end{tabular}




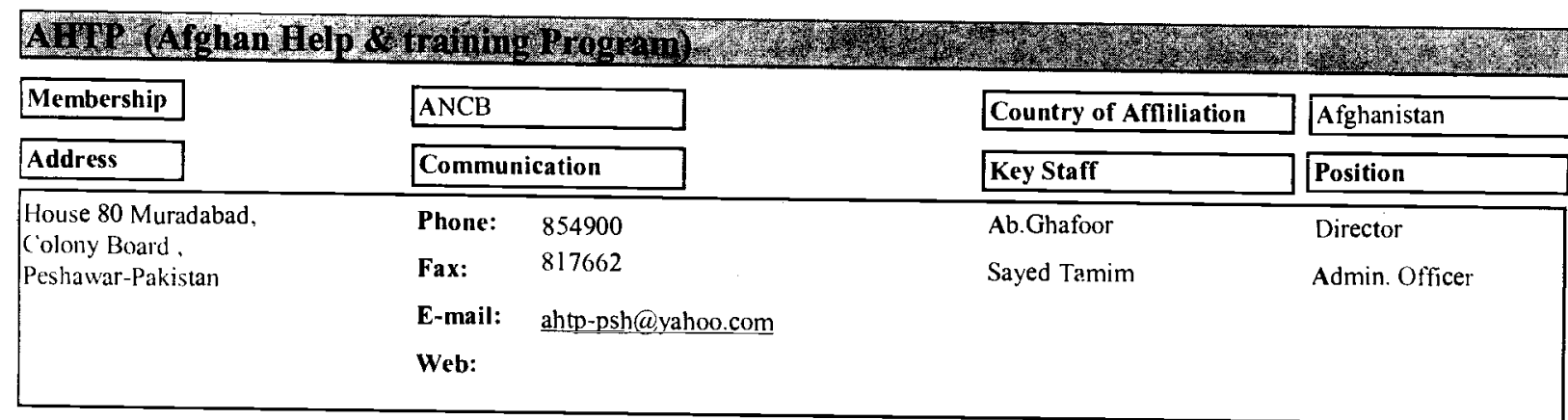

\begin{tabular}{|c|c|c|c|c|c|c|}
\hline & & & Personnel & & & \\
\hline Afghan & \multicolumn{2}{|c|}{63} & & Administrative & & 17 \\
\hline Pakistani & \multicolumn{2}{|c|}{3} & & Support & & 21 \\
\hline Expatriates & \multicolumn{2}{|c|}{0} & & Techrical & & 28 \\
\hline \multirow[t]{3}{*}{ Total } & \multirow{2}{*}{\multicolumn{2}{|c|}{66}} & & Total & & 66 \\
\hline & & & Budget In US \$ & & & \\
\hline & 1998 & 1999 & 2000 & 2001 & \multicolumn{2}{|l|}{2002} \\
\hline Afghanistan & 10,856 & 11,461 & 0 & 0 & \multicolumn{2}{|l|}{129,298} \\
\hline Pakistan & 0 & 3,757 & 37,680 & 39,600 & \multicolumn{2}{|l|}{65,092} \\
\hline Total & $10,856.00$ & $15,218.00$ & $37,680.00$ & $39,600.00$ & \multicolumn{2}{|l|}{$194,390.00$} \\
\hline
\end{tabular}

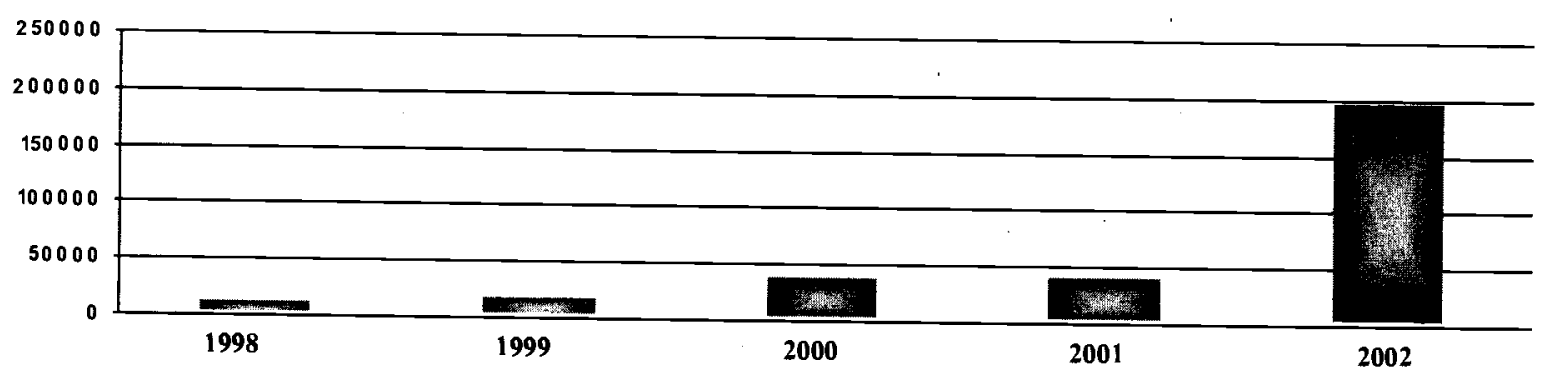

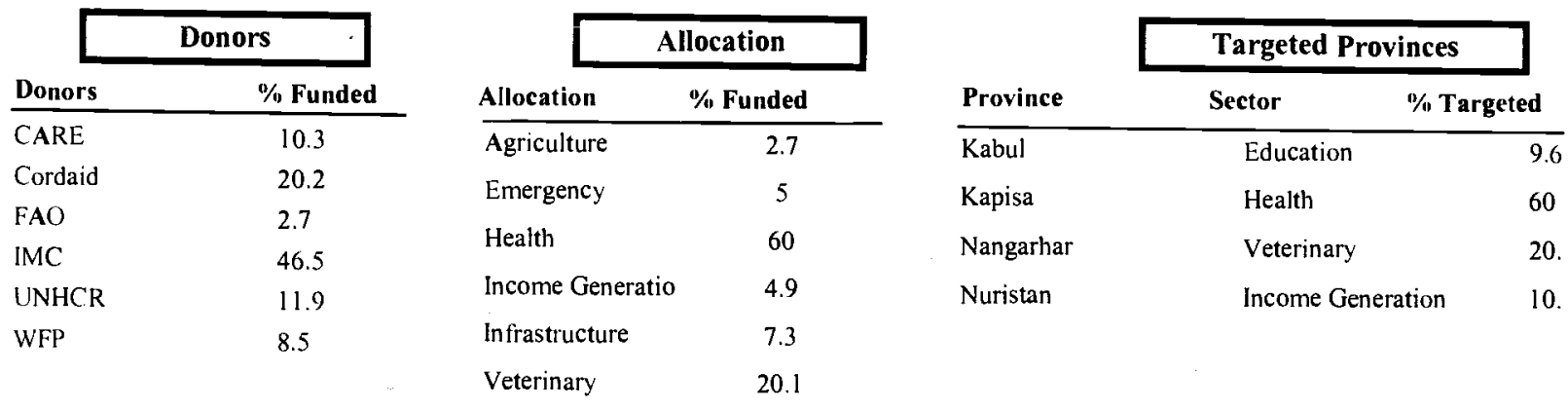

Sub Offices

\begin{tabular}{|c|c|c|c|c|}
\hline Sub Office & City / Town & Phone & E-mail & In Charge \\
\hline Gola-I-e Kloop,Shashdarak & Kabul & 21694 & & S.Tamim \\
\hline $\begin{array}{l}\text { Nangrahar:Zara Sarandwali, Near } \\
\text { UNICEF office }\end{array}$ & Jalalabad & 21694 & & Safiullah \\
\hline
\end{tabular}




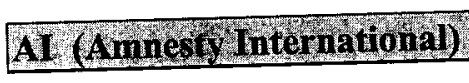

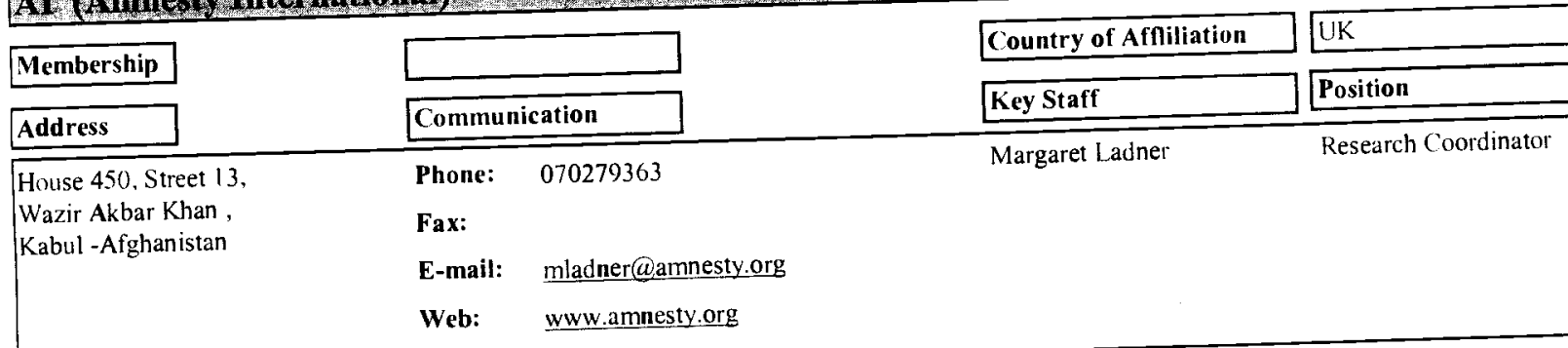

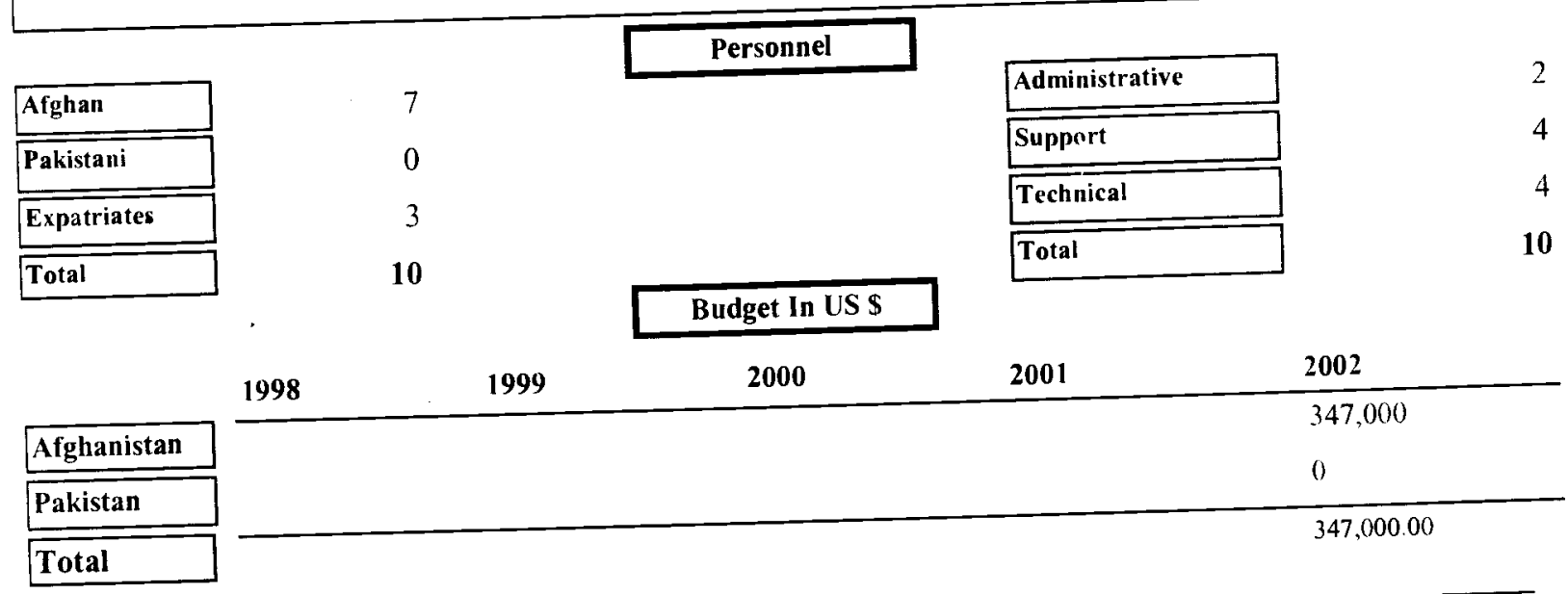

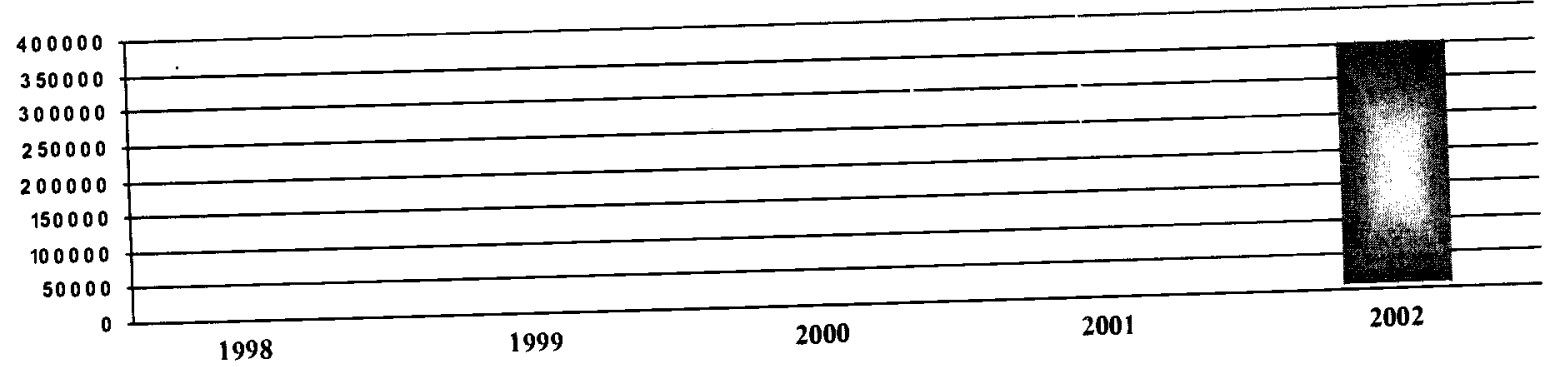

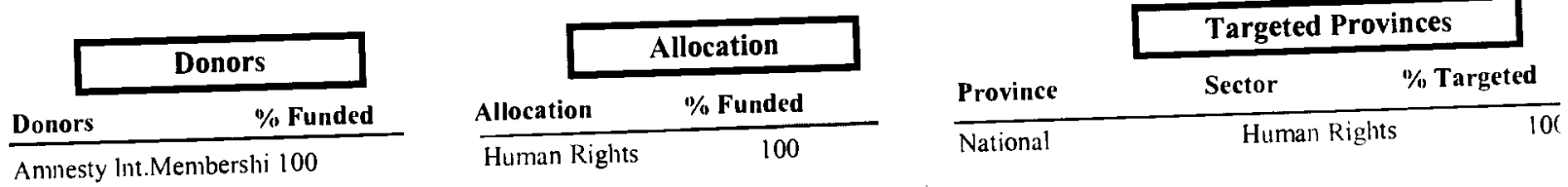

Sub Offices 
Adi (Afghan Institute of Leaning)

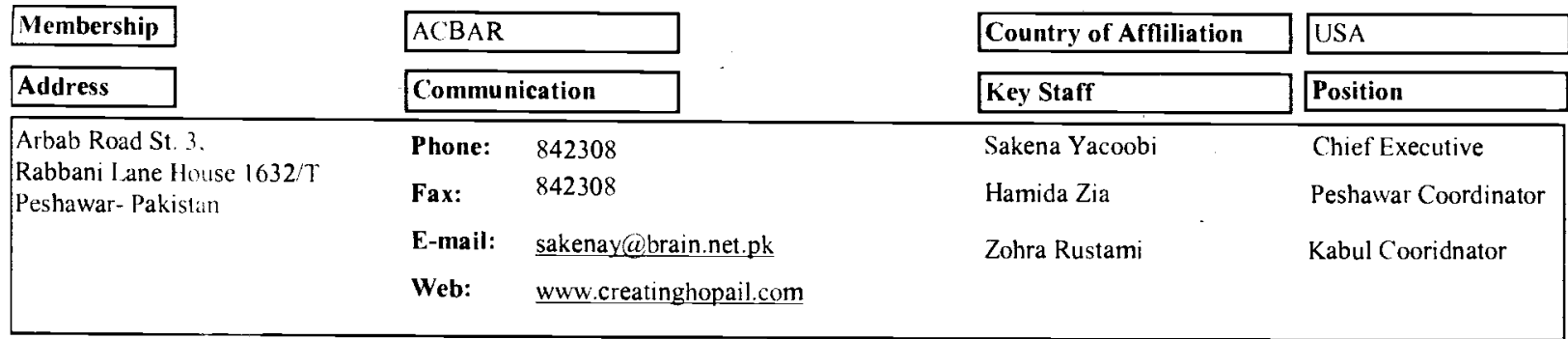

\begin{tabular}{|l|}
\hline Afghan \\
\hline Pakistani \\
\hline Expatriates \\
\hline Total \\
\hline
\end{tabular}

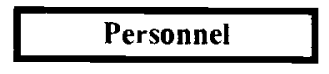

336
1
1
338

\begin{tabular}{|l|}
\hline Administrative \\
\hline Support \\
\hline Technical \\
\hline Total \\
\hline
\end{tabular}

Budget In US \$

\begin{tabular}{|c|c|c|c|c|c|}
\hline & 1998 & 1999 & 2000 & 2001 & 2002 \\
\hline Afghanistan & 12,000 & 12,000 & 60,000 & 70,000 & 350,000 \\
\hline Pakistan & 108,000 & 108,000 & 204,000 & 230,000 & 250,000 \\
\hline Total & $120,000.00$ & $120,000.00$ & $264,000.00$ & $300,000.00$ & $600,000.00$ \\
\hline
\end{tabular}

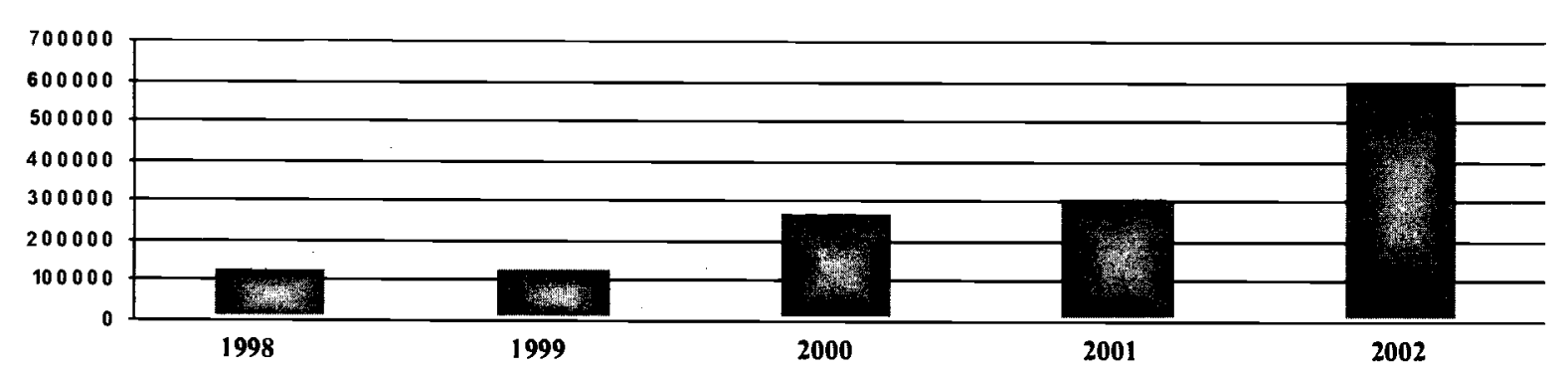

\begin{tabular}{lc}
\multicolumn{1}{c|}{ Donors } \\
Donors & \% Funded \\
\hline Canada Fund & 3 \\
CH & 45 \\
Globel Fund & 8 \\
Private & 5 \\
UNFPA & 33 \\
UNHCR & 5 \\
WLP & 1
\end{tabular}

\begin{tabular}{lc}
\cline { 2 - 2 } & \multicolumn{2}{c|}{ Allocation } \\
Allocation & \% Funded \\
\hline Education & 50 \\
Health & 25 \\
Human Rights & 15 \\
Income Generatio & 10
\end{tabular}

\begin{tabular}{lcc} 
& \multicolumn{2}{c|}{ Targeted Provinces } \\
\cline { 2 - 3 } Province & Sector & \% Targeted \\
\hline Hirat & 18 \\
Kabul & 25 \\
Logar & 5 \\
Nangarhar & 5 \\
NWFP & 10
\end{tabular}

\section{Sub Offices}

\begin{tabular}{|c|c|c|c|c|c|}
\hline Sub Office & City / Town & Phone & Fax & E-mail & In Charge \\
\hline $\begin{array}{l}\text { Kabul.Karte Parwan Street } 3 \\
\text { House } 387\end{array}$ & Kabul & 30582 & & & Zohra Rustami \\
\hline
\end{tabular}




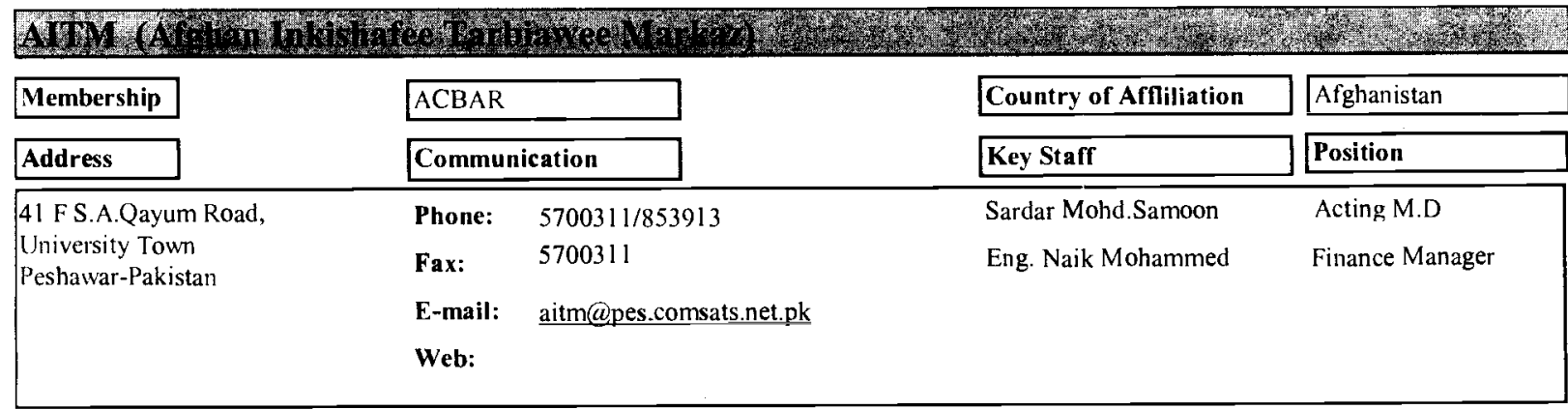

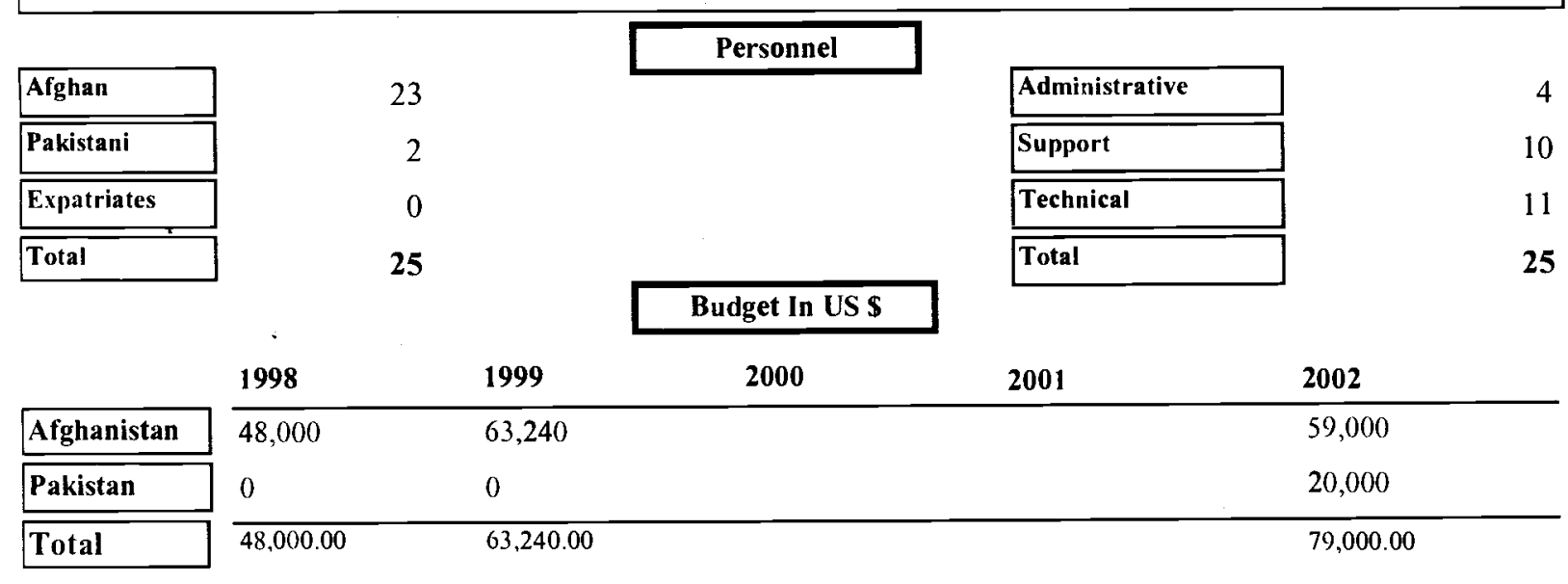

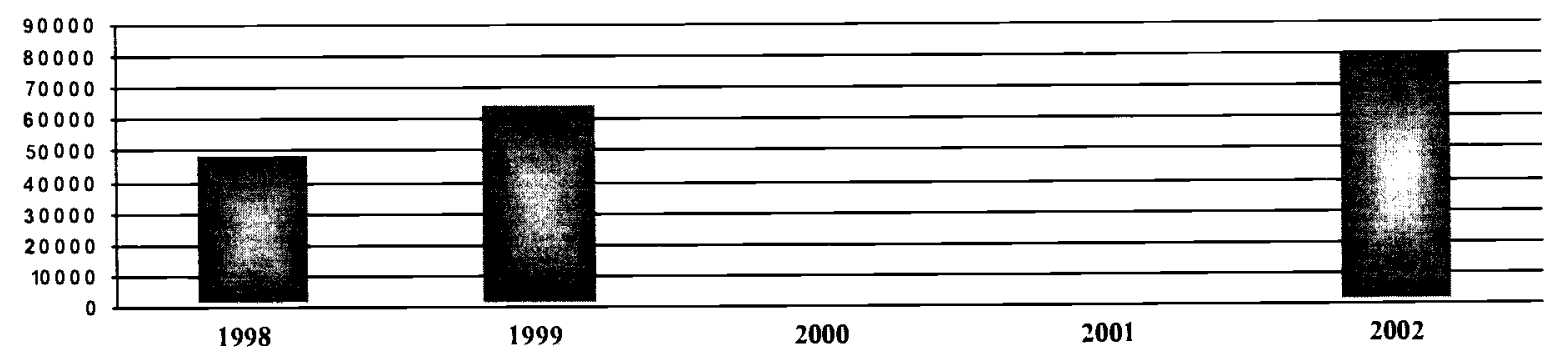

\begin{tabular}{|c|c|c|c|c|c|c|}
\hline \multicolumn{2}{|c|}{ Donors } & & location & \multirow[b]{2}{*}{ Province } & \multicolumn{2}{|c|}{ Targeted Provinces } \\
\hline Donors & "\% Funded & Allocation & $\%$ Funded & & Sector & $1 \%$ Targeted \\
\hline$\overline{\text { IRC' }}$ & 3 & Education & 90 & $\overline{\text { Hirat }}$ & Health & 1 \\
\hline Other & 10 & Gender Issues & 6 & Kabul & Education & 60 \\
\hline UNAMA & 22 & Health & 4 & Nangarhar & Education & 9 \\
\hline UNICEF & 4 & & & NWFP & Education & 30 \\
\hline World Bank & 61 & & & & & \\
\hline
\end{tabular}

Sub Offices

\begin{tabular}{l|l|l|l|l|l|l|l|l|l|l|l|}
\hline Sub Office & City / Town & Phone & Farge \\
\hline $\begin{array}{l}\text { House 239 Lane 4 St.15 Wazir } \\
\text { Akbar Khan }\end{array}$ & Kabul & 2300505 & Sardar Mohd. \\
\hline
\end{tabular}




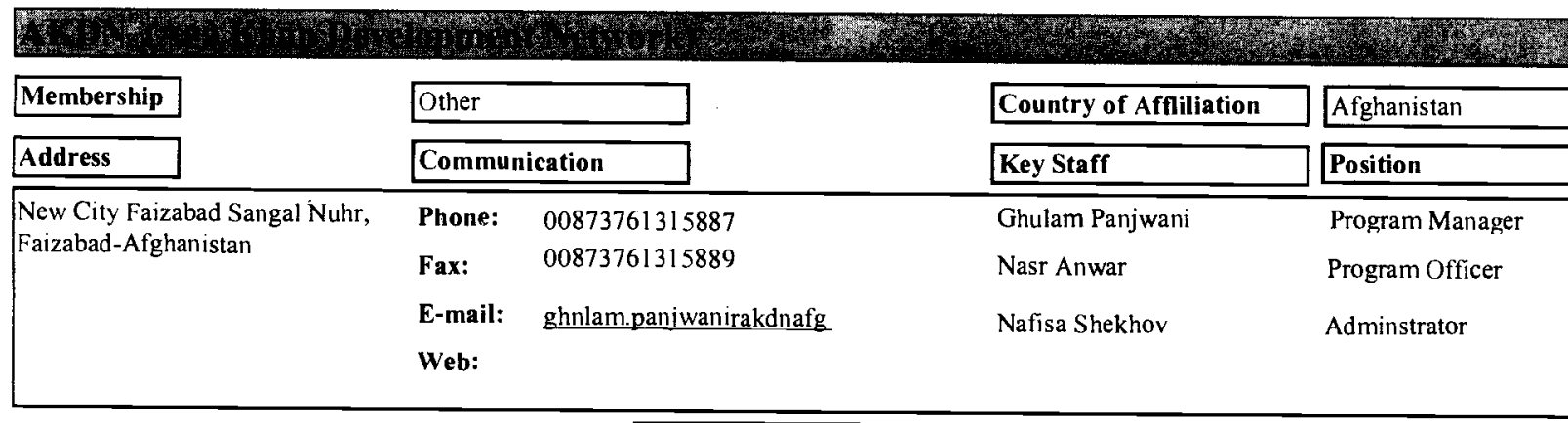

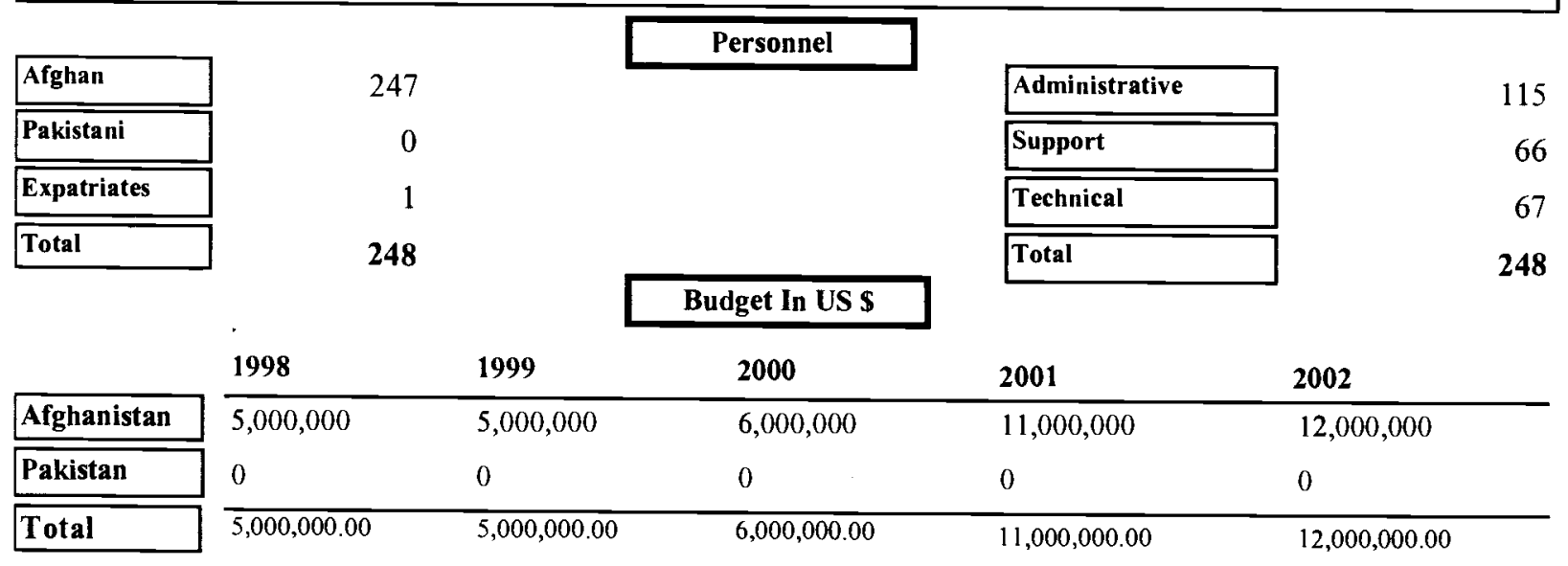

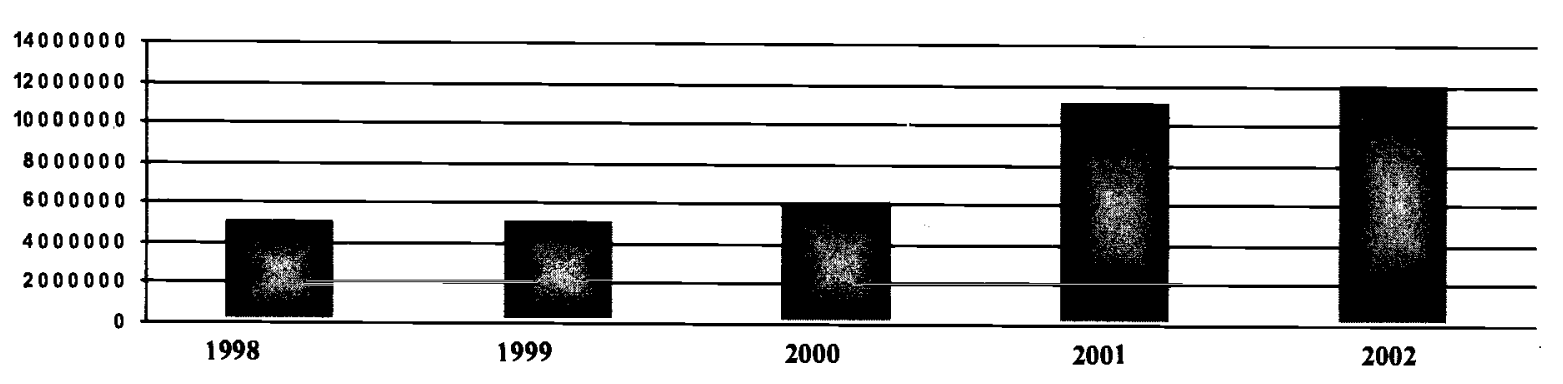

\begin{tabular}{|c|c|c|c|c|c|}
\hline \multicolumn{2}{|c|}{ Donors } & \multicolumn{2}{|c|}{ Allocation } & \multirow[b]{2}{*}{ Province } & Targeted Provinces \\
\hline Donors & \% Funded & Allocation & $\%$ Funded & & $\%$ Targeted \\
\hline DFID & 20 & Agriculture & 100 & Badakhshan & Other \\
\hline EURONAID & 40 & & & Badakhshan & Social Programs \\
\hline FAO & 10 & & & Badakhshan & Infrastructure \\
\hline GTZ & 10 & & & Badakhshan & inirastructure \\
\hline \multirow[t]{4}{*}{ ICARDA } & 20 & & & Badakhshan & Education \\
\hline & & & & Badakhshan & Health \\
\hline & & & & Badakhshan & Agriculture \\
\hline & & & & Badakhshan & Human Rights \\
\hline
\end{tabular}

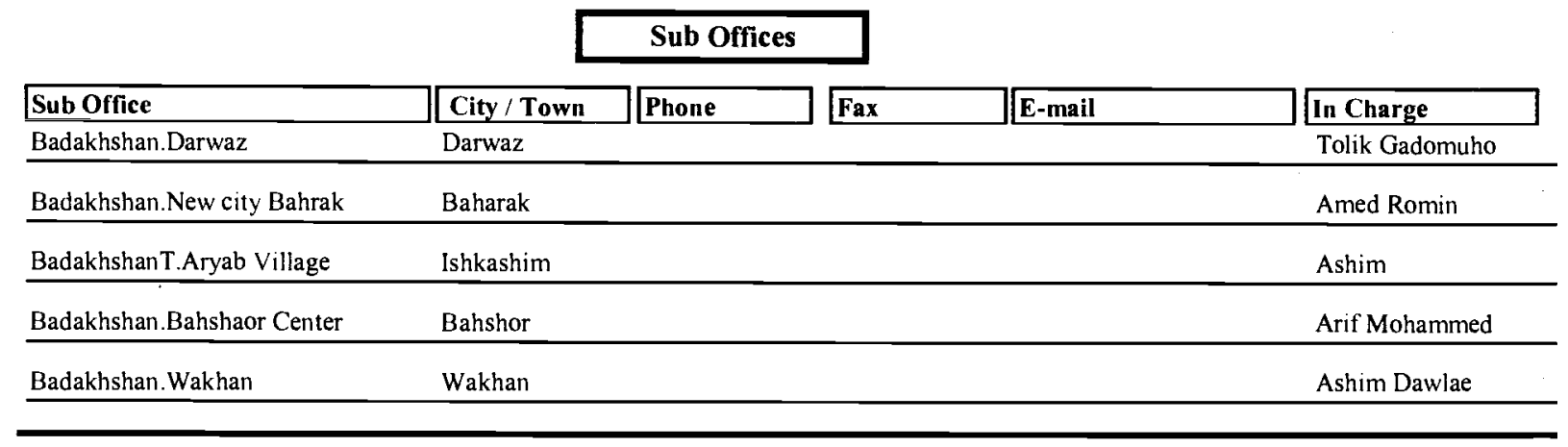




\begin{tabular}{|c|c|c|c|}
\hline Membership & Other & Country of Affiliation & Lialy \\
\hline Address & Communication & Key Staff & Position \\
\hline \multirow{4}{*}{$\begin{array}{l}\text { Bezard Avenue, } \\
\text { Hirat-Afghanistan }\end{array}$} & +873702001675 & Rocco Angeue & Head of Mission \\
\hline & Fax: & Micale Pctoctli & Program Officer \\
\hline & herat@alisei.org & & \\
\hline & www.alise.org & & \\
\hline
\end{tabular}

\begin{tabular}{|l|}
\hline Afghan \\
\hline Pakistani \\
\hline \hline Expatriates \\
\hline Total \\
\hline
\end{tabular}

Personnel

10

80

\begin{tabular}{|l|}
\hline Administrative \\
\hline Support \\
\hline Technical \\
\hline Total \\
\hline
\end{tabular}

Budget In US S

\begin{tabular}{|c|c|c|c|c|c|}
\hline & 1998 & 1999 & 2000 & 2001 & 2002 \\
\hline Afghanistan & & & & & 18,055 \\
\hline Pakistan & & & & & 0 \\
\hline Total & & & & & $18,055.00$ \\
\hline \multicolumn{6}{|l|}{20000} \\
\hline \multicolumn{6}{|l|}{10000} \\
\hline & 1998 & 1999 & 2000 & 2001 & 2002 \\
\hline . & nors & & Allocation & & Targeted Provinces \\
\hline Donors & $\%$ Funded & Allocation & $\%$ Funded & Province & $\%$ Targeted \\
\hline$\overline{D F I D}$ & 25 & Agriculture & 15 & Badghis & 10 \\
\hline ECHO & 25 & Emergency & 2 & & \\
\hline IOM & 25 & Infrastructure & 18 & & \\
\hline UNHCR & 25 & Other & 65 & & \\
\hline
\end{tabular}

\begin{tabular}{|c|c|c|c|c|}
\hline & & Sub Offices & & \\
\hline Sub Office & City / Town & Phone & E-mail & In Charge \\
\hline Badghis.Qala Enaw & Qala Enaw & 0087376290085 & badghis@alise.org & Juan Jose Tejada \\
\hline Badghis.Bala Morghab & Bala Morghab & 0088216502662 & morgab@alise.org & Alberto Bilenctel \\
\hline Badghis.Ghormaer & Ghormaer & 0088216502662 & morgab@alise.org & Alborto Bilenctel \\
\hline
\end{tabular}




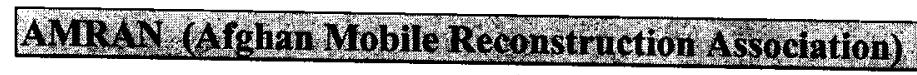

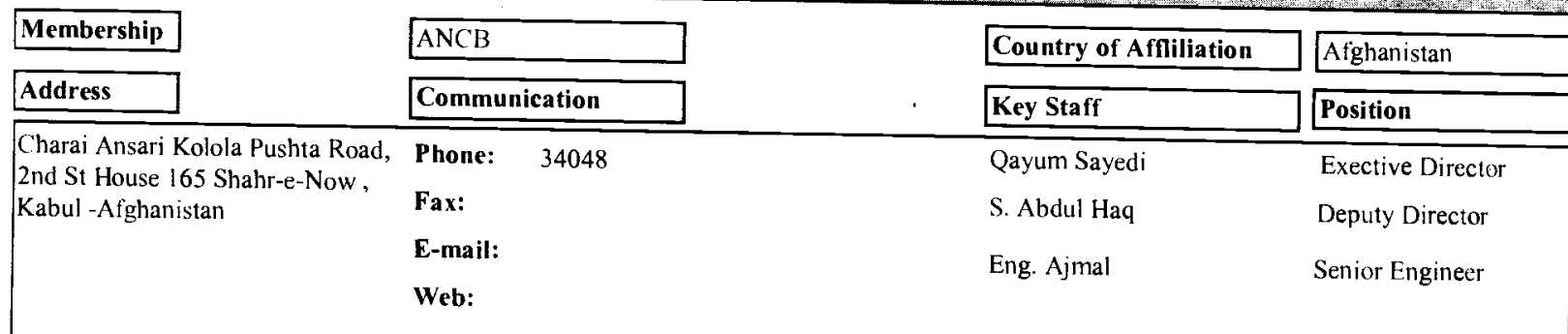

\begin{tabular}{|l|rc|}
\hline Afghan & & Personnel \\
\hline Pakistani & 37 & \\
\hline \hline Expatriates & 3 & \\
\hline Total & 0 & \\
\hline & 40 & Budget In US S \\
\hline
\end{tabular}

\begin{tabular}{|l|r|}
\hline Administrative \\
\hline Support \\
\hline Technical \\
\hline Total \\
\hline
\end{tabular}

\begin{tabular}{|c|c|c|c|c|c|}
\hline & 1998 & 1999 & 2000 & 2001 & 2002 \\
\hline Afghanistan & 63,637 & 88,545 & 96,925 & 136,301 & 216,892 \\
\hline Pakistan & 0 & 0 & 0 & 0 & 0 \\
\hline Total & $63,637.00$ & $88,545.00$ & $96,925.00$ & $136,301.00$ & $216,892.00$ \\
\hline
\end{tabular}

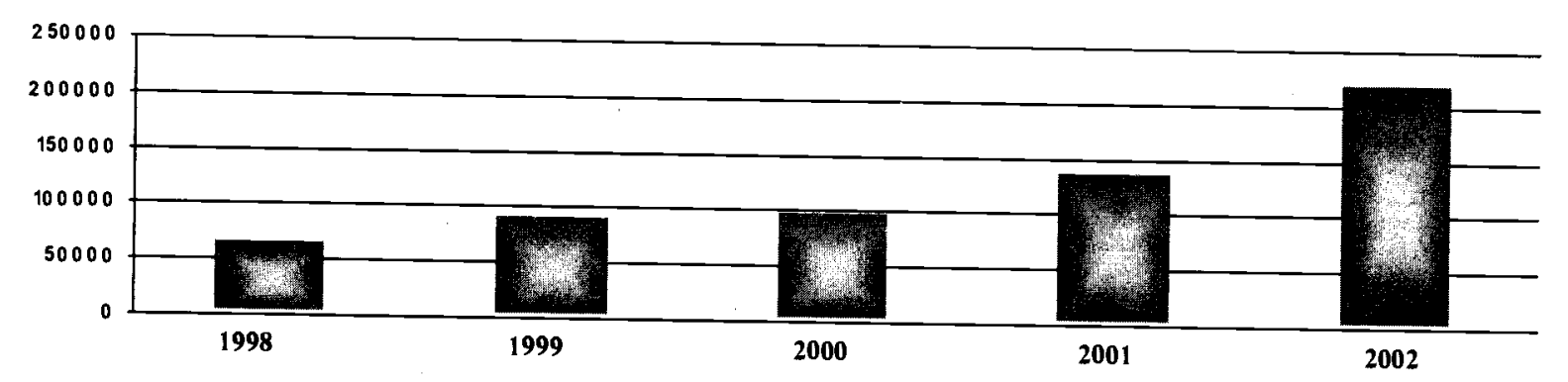

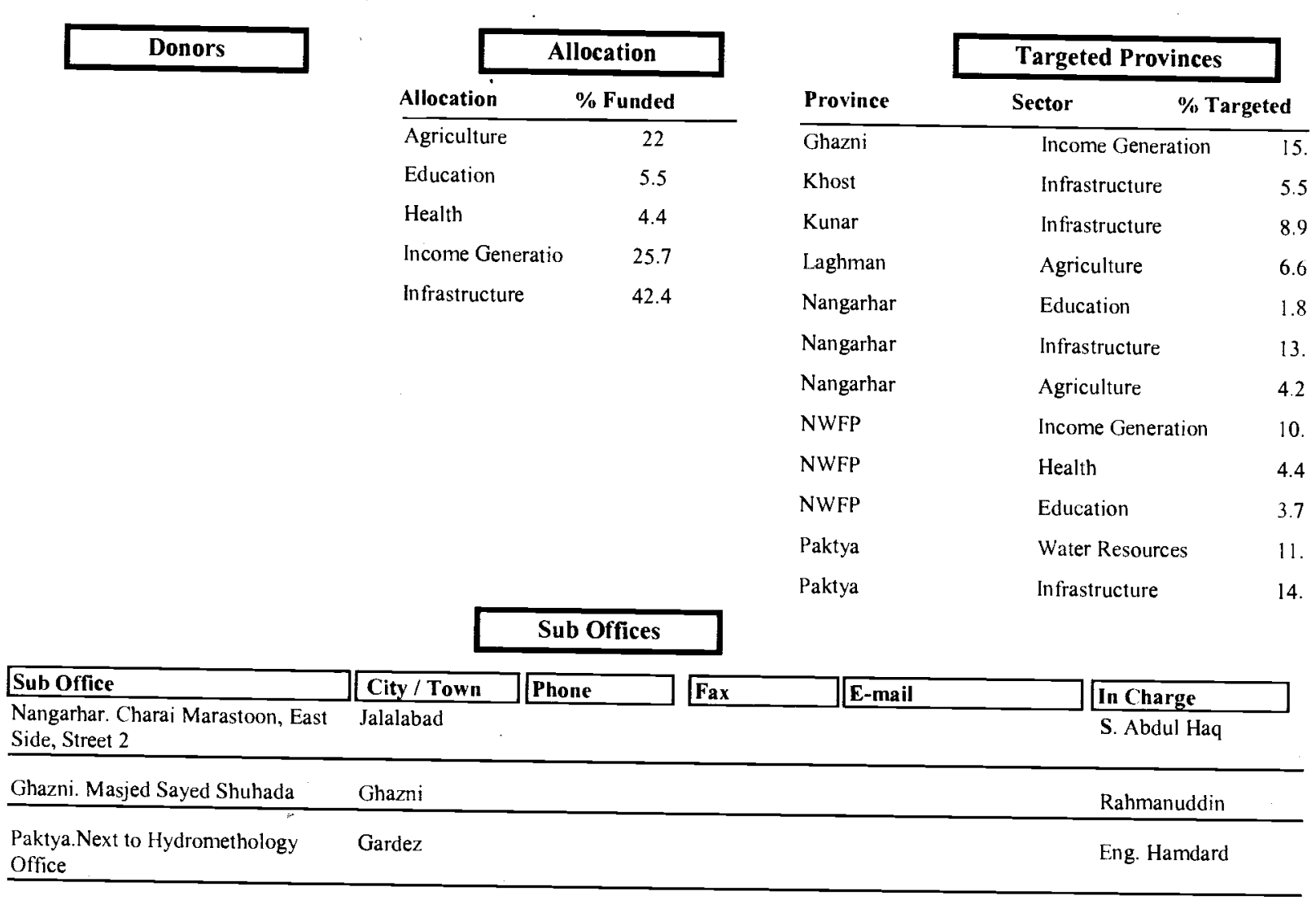


Gull Haji Plaza, 3rd Floor, Flat 311 Peshawar Main Jamrud Road

$091-85446$

\begin{tabular}{|c|c|c|c|c|}
\hline Membership & ANCB & & Country of Affliliation & Afghanistan \\
\hline Address & Commu & cation & Key Staff & Position \\
\hline \multirow{3}{*}{$\begin{array}{l}\text { 1433-2 Canal Road, } \\
\text { University Town, } \\
\text { Peshawar-Pakistan }\end{array}$} & & 5702888 & Mohd.Nasir Sherzad & Director \\
\hline & Fax: & 5700784 & Abdul Baseer & Manager \\
\hline & $\begin{array}{l}\text { E-mail: } \\
\text { Web: }\end{array}$ & amwal@psh.paknet.com.pk & Mohammad Amin & Office Manager \\
\hline
\end{tabular}

\begin{tabular}{|l|}
\hline Afghan \\
\hline Pakistani \\
\hline Expatriates \\
\hline Total \\
\hline
\end{tabular}

\section{Personnel}

\begin{tabular}{|l|r|}
\hline Administrative \\
\hline Support \\
\hline Technical \\
\hline Total \\
\hline
\end{tabular}

Budget In US \$

\begin{tabular}{|c|c|c|c|c|c|}
\hline & 1998 & 1999 & 2000 & 2001 & 2002 \\
\hline Afghanistan & 0 & 0 & 0 & 0 & 0 \\
\hline Pakistan & 18,750 & 12,366 & 25,771 & 23,906 & 27,800 \\
\hline Total & $18,750.00$ & $12,366.00$ & $25,771.00$ & $23,906.00$ & $27,800.00$ \\
\hline
\end{tabular}

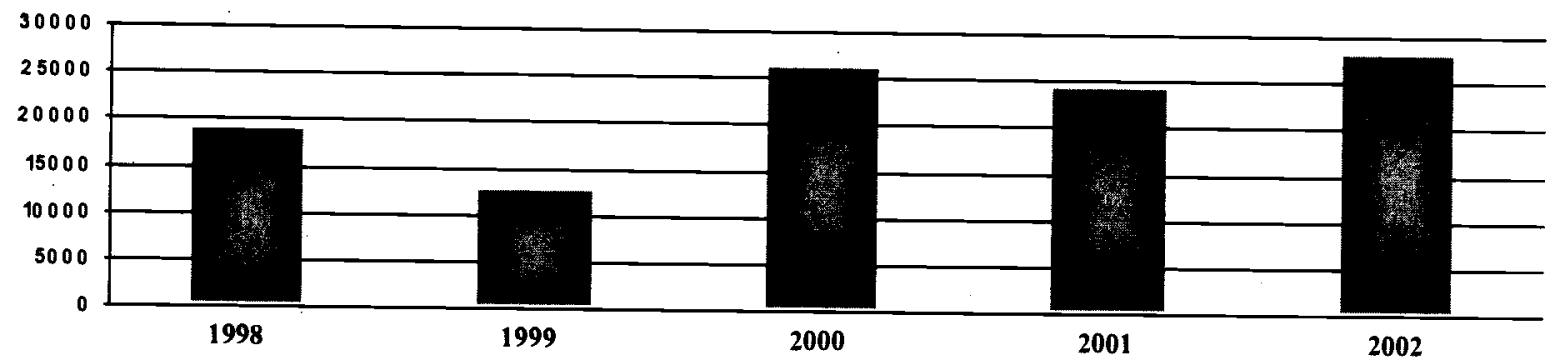

\begin{tabular}{|c|c|c|c|c|c|c|}
\hline \multicolumn{2}{|c|}{ Donors } & \multicolumn{2}{|c|}{ Allocation } & \multirow[b]{2}{*}{ Province } & \multicolumn{2}{|c|}{ Targeted Provinces } \\
\hline Donors & $\%$ Funded & Allocation & $\%$ Funded & & Sector & $\%$ Targeted \\
\hline Private & 10 & Health & 100 & NWFP & Healt & 10 \\
\hline
\end{tabular}




\section{ANAR (Afghanistan National Assoclation for Rehabt)}

\begin{tabular}{|c|c|c|c|}
\hline \begin{tabular}{|l|} 
Membership \\
\end{tabular} & $\mathrm{ANCB}$ & Country of Affliliation & Afghanistan \\
\hline Address & Communication & Key Staff & Position \\
\hline \multirow{3}{*}{$\begin{array}{l}\text { House } 3337 \text { th St. Taimani, } \\
\text { Kabul - Afghanistan }\end{array}$} & Phone: $\quad 2200228$ & M.Sediq Patnian & Director \\
\hline & Fax: & M.Hassan & Deputy Director \\
\hline & $\begin{array}{l}\text { E-mail: } \\
\text { Web: }\end{array}$ & M.Zabiullah & Admin Officer \\
\hline
\end{tabular}

\begin{tabular}{|c|c|c|c|c|}
\hline & & Personnel & & \\
\hline Afghan & 15 & & Administrative & 9 \\
\hline Pakistani & 0 & & Support & 0 \\
\hline Expatriates & 0 & & Technical & 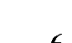 \\
\hline Total & 15 & & Total & 15 \\
\hline
\end{tabular}

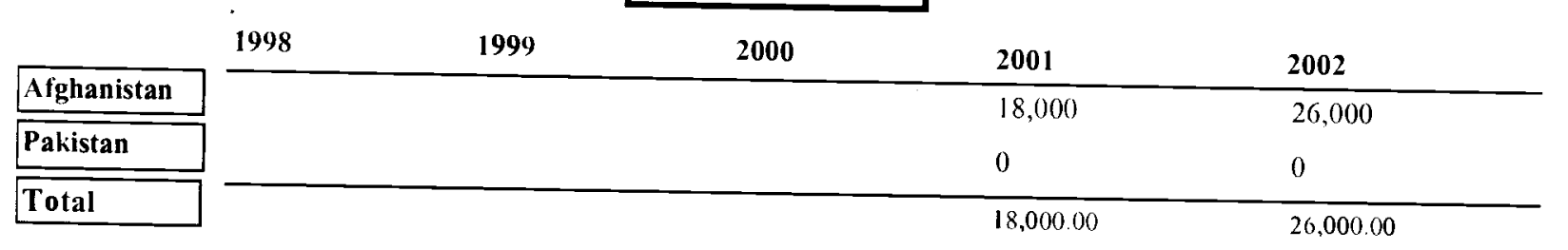

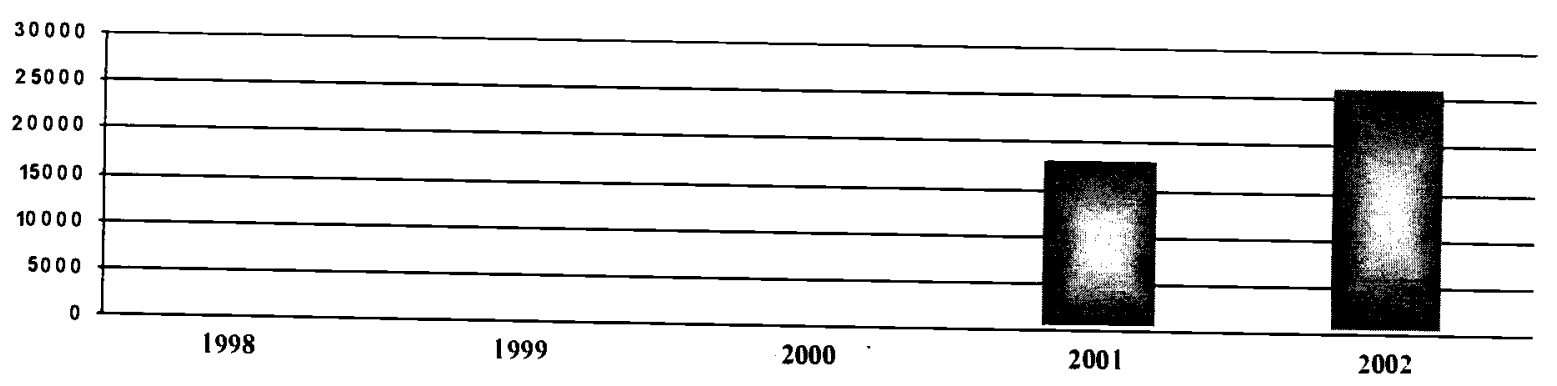

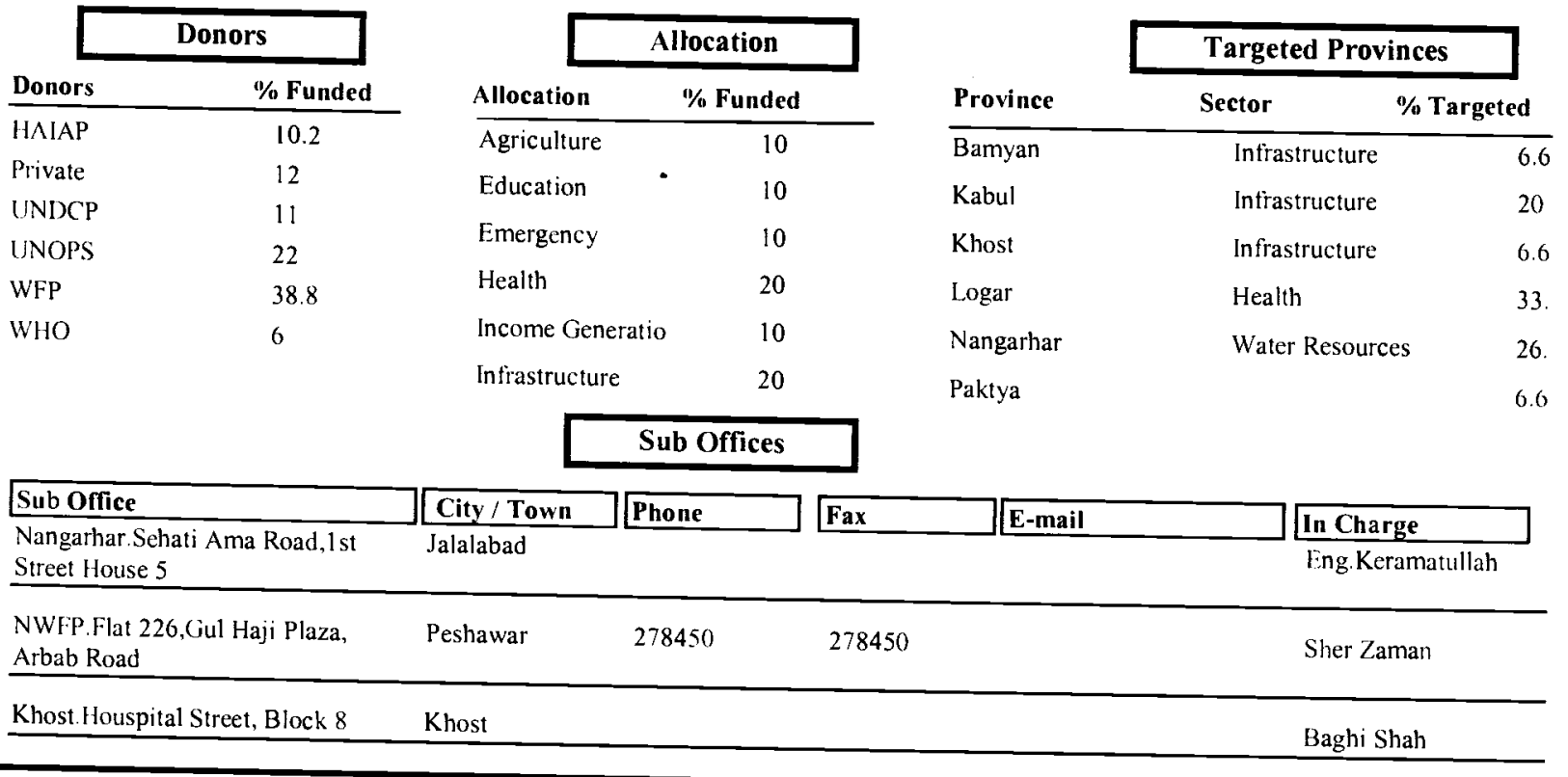




\begin{tabular}{|c|c|c|c|}
\hline Membership & ICVA & Country of Affliliation & Afghanistan \\
\hline Address & Communication & Key Staff & Position \\
\hline \multirow{4}{*}{$\begin{array}{l}\text { House I Street } 3 \text { Qalai Fatullah, } \\
\text { Shaher-e-now } \\
\text { Kabul - Afghanistan }\end{array}$} & 070278221 & S. Fazlullah Wahidi & Chairman \\
\hline & Fax: & S. Amir Tahseen & Vice Chairman \\
\hline & E-mail: $\quad$ ancb@pes.comsats.net.pk & Eng. Rahmatullah & Executive Director \\
\hline & Web: & & \\
\hline
\end{tabular}

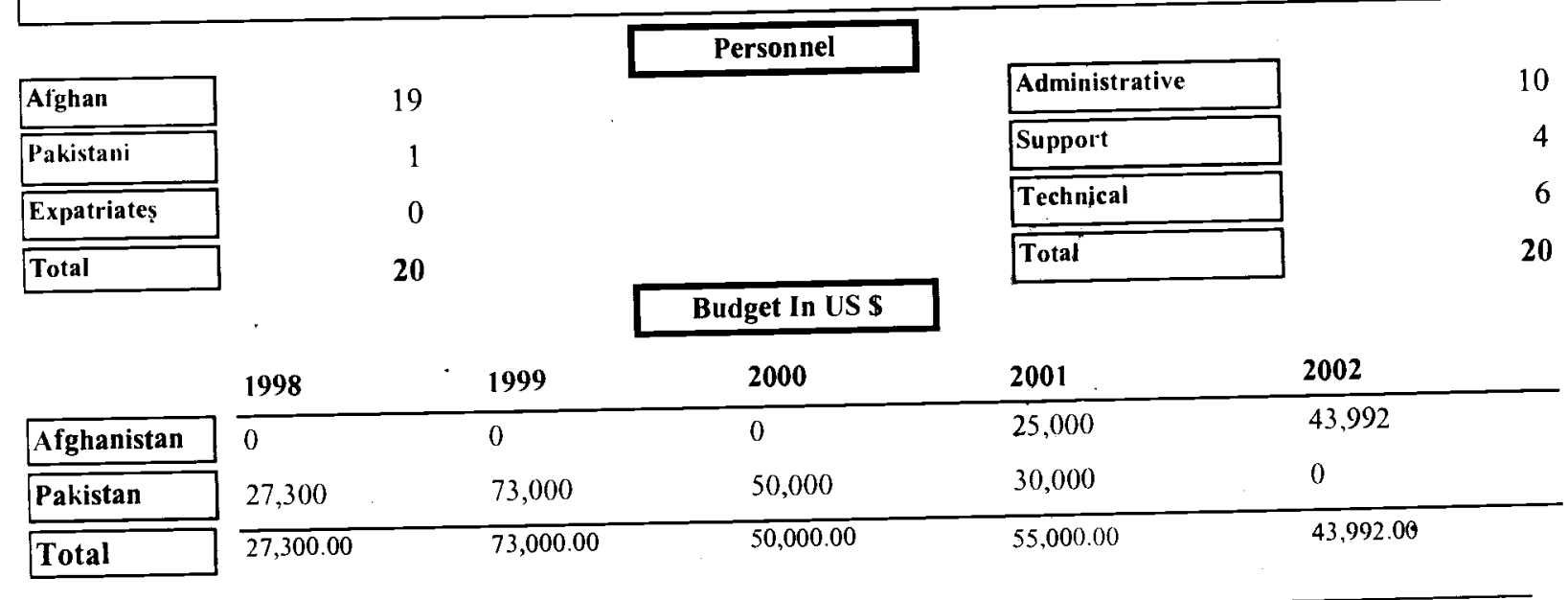
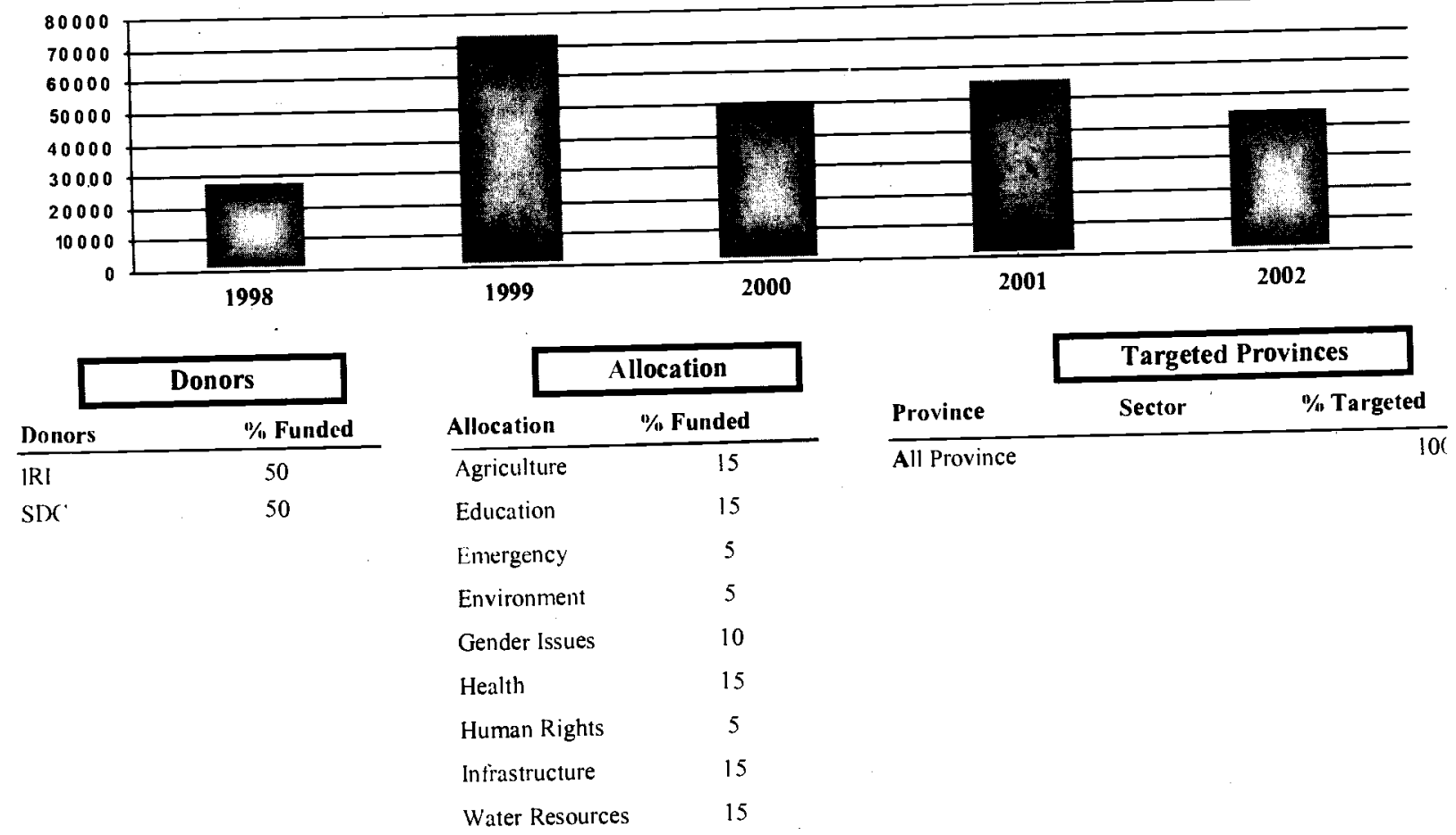

Sub Offices

\begin{tabular}{|c|c|c|c|c|c|}
\hline Sub Office & City/Town & Phone & Fax & E-mail & In Charge \\
\hline $\begin{array}{l}\text { NWFP. } 25 \text { Chinar Road, University } \\
\text { Town, }\end{array}$ & Peshawar & 853849 & 853804 & $\begin{array}{l}\text { ancb@pes.comsats.net.p } \\
\underline{\mathbf{k}}\end{array}$ & Ahmad Mirzad \\
\hline $\begin{array}{l}\text { Nangarhar. 1st Road, 1st House. } \\
\text { Opp. Univ. Hospotal }\end{array}$ & Jalalabad & & & & \\
\hline
\end{tabular}




\begin{tabular}{|c|c|c|c|}
\hline Membership & SWABAC & Country of Affliliation & Afghanistan \\
\hline Address & Communication & Key Staff & Position \\
\hline \multirow{4}{*}{$\begin{array}{l}\text { Haji Omar House Dond Road, } \\
\text { Behind Mechanic School, } \\
\text { Shahr-i-Naw, } \\
\text { Kandahar-Afghanistan }\end{array}$} & Phone: $\quad+8821689850355$ & Ab.Qadeer Abid & Director \\
\hline & Fax: & Mohd.Hanif Faiz & Deputy Director \\
\hline & E-mail: & Eng.Agha Mohd. & Program Officer \\
\hline & Web: & & \\
\hline
\end{tabular}

\begin{tabular}{|c|c|c|}
\hline & & Personnel \\
\hline Afghan & 18 & \\
\hline Pa kistani & 0 & \\
\hline Expatriates & 0 & \\
\hline Total & 18 & \\
\hline
\end{tabular}

Budget In US \$

\begin{tabular}{l|r}
\hline Administrative & \multicolumn{1}{|c}{5} \\
\hline Support & 9 \\
\hline Technical & 4 \\
\hline Total & $\mathbf{1 8}$ \\
$\mathbf{2 0 0 1}$ & $\mathbf{2 0 0 2}$ \\
\hline 130,000 & 291,000 \\
0 & 0 \\
\hline $130,000.00$ & $291,000.00$
\end{tabular}

\begin{tabular}{|c|c|c|c|c|c|}
\hline & 1998 & 1999 & 2000 & 2001 & 2002 \\
\hline Afghanistan & 55,000 & 66,000 & 120,000 & 130,000 & 291,000 \\
\hline Pakistan & 0 & 0 & 0 & 0 & 0 \\
\hline Total & $55,000.00$ & $66,000.00$ & $120,000.00$ & $130,000.00$ & $291,000.00$ \\
\hline
\end{tabular}

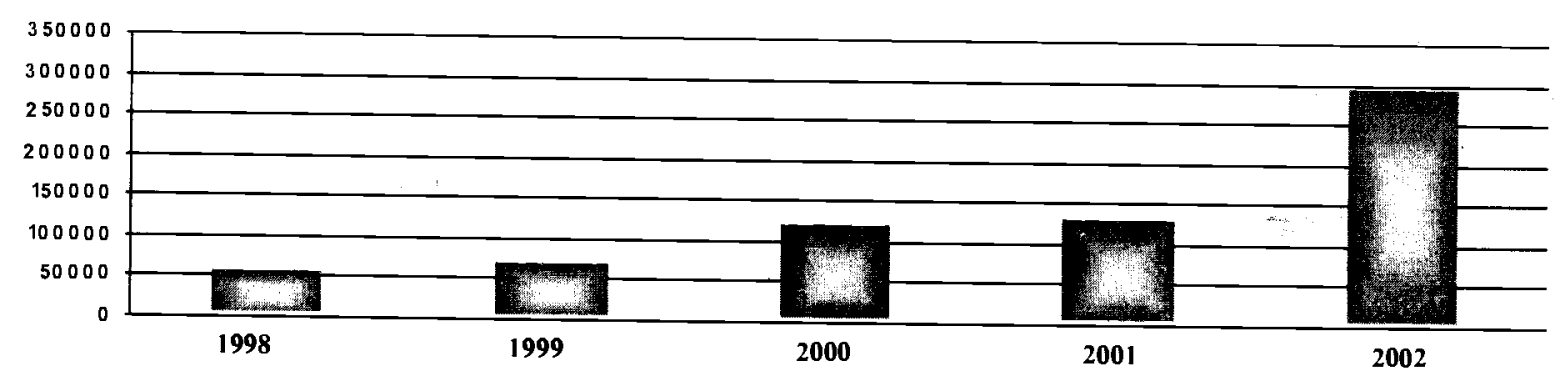

\begin{tabular}{lc}
\multicolumn{2}{c|}{ Donors } \\
Donors & $\%$ Funded \\
\hline OXFAM GB & 10 \\
UNHCR & 20 \\
UNICEF & 20 \\
UNOPS & 20 \\
WFP & 30
\end{tabular}

\begin{tabular}{lc|}
\multicolumn{1}{c|}{ Allocation } \\
Allocation & $\%$ Funded \\
\hline & 0 \\
Emergency & 5 \\
Infrastructure & 20 \\
Relief \& Repatria & 45 \\
Water Resources & 30
\end{tabular}

\begin{tabular}{|c|c|c|c|}
\hline \multirow[b]{2}{*}{ Province } & \multicolumn{2}{|c|}{ Targeted Provinces } & \\
\hline & Scetor & $\%$ Targ & \\
\hline Kandahar & Emer & & 10 \\
\hline Kandahar & Wate & rces & 10 \\
\hline Kandahar & Intras & & 30 \\
\hline Zabul & Relie & atriatioin & 20 \\
\hline Zabul & Wate & res & 20 \\
\hline
\end{tabular}

Sub Offices

\begin{tabular}{|c|c|c|c|c|}
\hline Sub Office & City / Town & Phone & E-mail & In Charge \\
\hline Zabu.Shajoy bazar & Shajoy & & & Yar Mohd \\
\hline Zabul.Shari Safa bazar & Jalduk & & & Najibullah \\
\hline Zaloul.Qalat nawrak bazar & Qalat & & & Lutfullah \\
\hline Kandahar:Zhare dasht IDPs camp & Zhare & & & A.Manan \\
\hline Balochistan Pishin bazar & Quetta & & & Naqibullah \\
\hline
\end{tabular}


APWO (Afghan Public Welfare Organization)

\begin{tabular}{|c|c|c|c|}
\hline Membership & $A N C B$ & Country of Affliliation & Afghanistan \\
\hline Address & Communication & Key Staff & Position \\
\hline \multirow{4}{*}{$\begin{array}{l}\text { Apartment } 2 \text { I lanam St, } \\
\text { Behined Ministry of Women } \\
\text { Aftairs, } \\
\text { Shahr-e-Now, } \\
\text { Kabul-Afghanistan }\end{array}$} & Phone: & S. Rahim Sattar & Director \\
\hline & Fax: & Lal Pacha & Head of Jạlalabad \\
\hline & E-mail: & Eng..Juma Gul & Head of Kabul \\
\hline & lleb: & & \\
\hline
\end{tabular}

\begin{tabular}{|c|c|c|c|c|}
\hline & & Personnel & & \\
\hline Afghan & 50 & & Administrative & 16 \\
\hline Pakistani & 0 & & Support & 19 \\
\hline Expatriates & 0 & & Technical & 15 \\
\hline Total & 50 & & Total & 50 \\
\hline
\end{tabular}

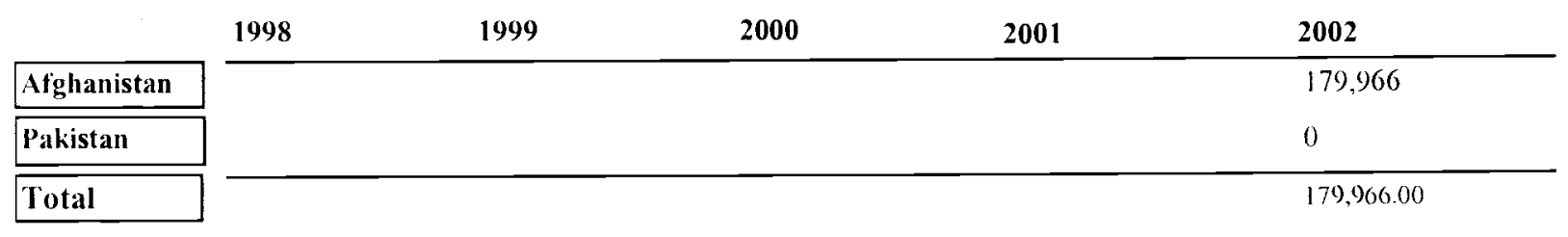

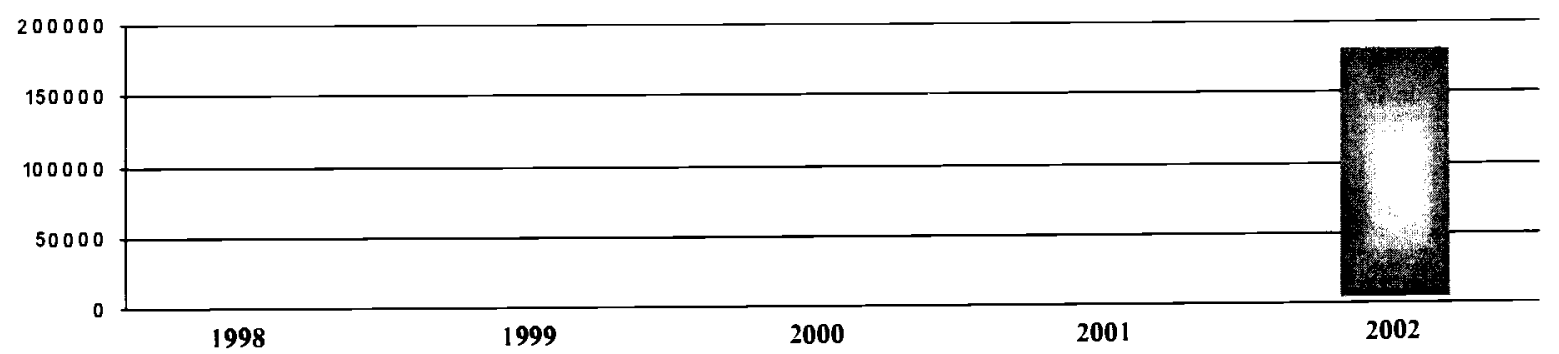

\begin{tabular}{|c|c|c|c|c|c|c|c|}
\hline \multirow[b]{2}{*}{ Donors } & Donors & \multicolumn{2}{|c|}{ Allocation } & \multirow[b]{2}{*}{ Province } & \multicolumn{3}{|c|}{ Targeted Provinces } \\
\hline & $11 / 1$ Funded & Allocation & \% Funded & & Sector & $1 / \%$ Targ & \\
\hline ( $\triangle \mathrm{RE}$ & 8 & Infrastructure & 44 & Ghazni & Relie & triatioin & 5 \\
\hline IRC & 13 & Relief \& Repatria & 33 & Nangarhar & Wate & ces & 10 \\
\hline UNHCR & 32 & Water Resources & 23 & Nangarhar & Relie & Atriatioin & 0 \\
\hline I NNICI:I: & 7 & & & Nangarhar & Infra & & 69 \\
\hline WFP & 40 & & & Paktika & Wate & ces & 10 \\
\hline
\end{tabular}

Sub Offices

\begin{tabular}{|c|c|c|c|c|c|}
\hline Sub Office & City / Town & Phone & Fax & E-mail & In Charge \\
\hline $\begin{array}{l}\text { Nangarhar House } 4 \text { St: } 2 \text {, Region } \\
\text { 4,Godam-e-Sangi Road }\end{array}$ & Jalalabad & & & & Lal Pache \\
\hline $\begin{array}{l}\text { NWFP. House 3,Opposite Secandary } \\
\text { Board, Khail Town }\end{array}$ & Peshawar & 840386 & & apwo@brain.net.pk & \\
\hline
\end{tabular}




\section{ARAO (Afghan Rehabilitation and Agriculture Organization)}

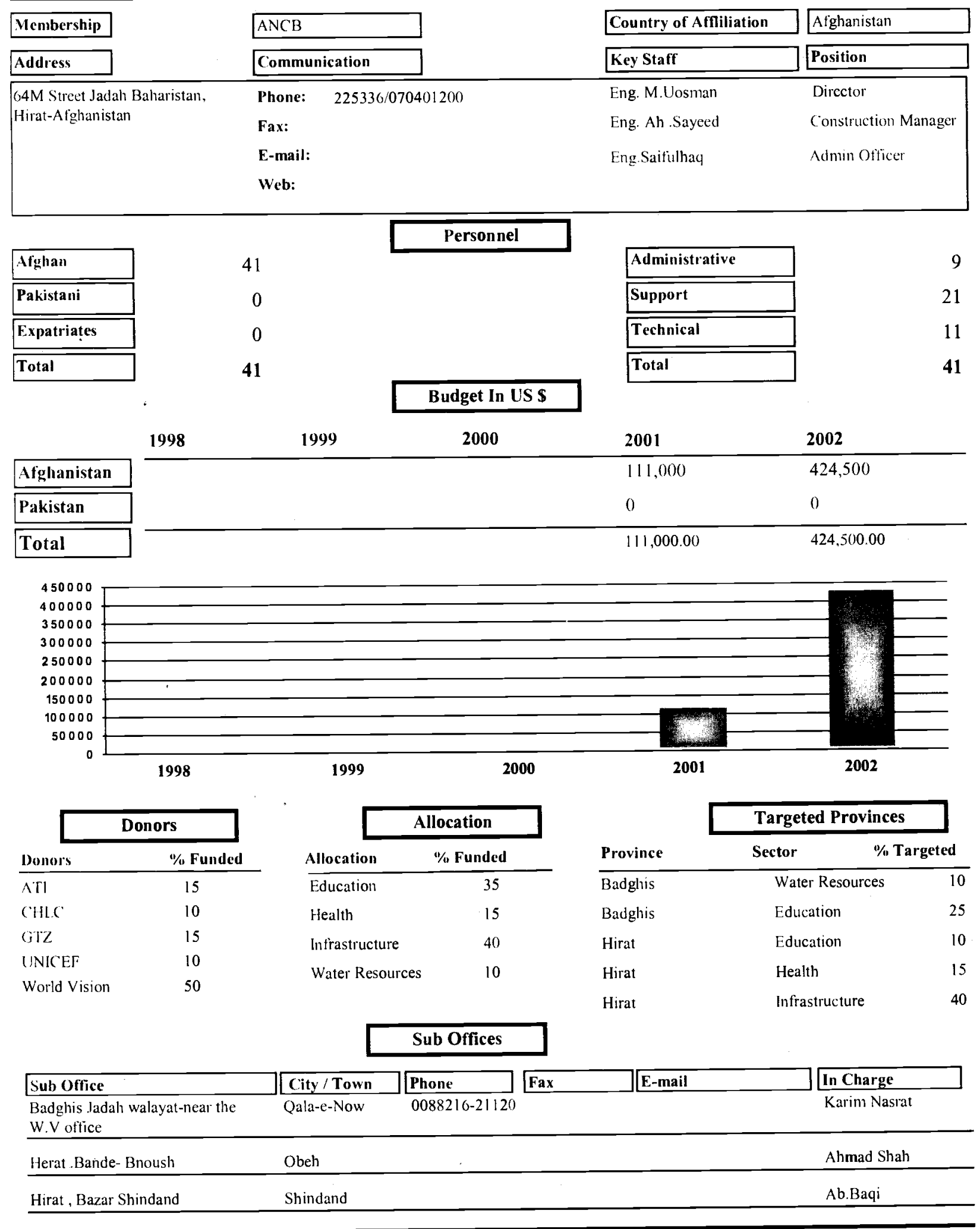




\begin{tabular}{|c|c|c|c|}
\hline Membership & ACBAR & Country of Affiliation & Afghanistan \\
\hline Address & Communication & Key Staff & Position \\
\hline \multirow{4}{*}{$\begin{array}{l}\text { Shahr-e-Now Opp. Butcher Street, } \\
\text { Kabul- Afghanistan. }\end{array}$} & 070282742 & Zalmai Naseeri & Director \\
\hline & Fax: & Eng. Naqibullah & Deputy Director \\
\hline & E-mail: & Gh.Sarwar & Administrator \\
\hline & Web: & & \\
\hline
\end{tabular}

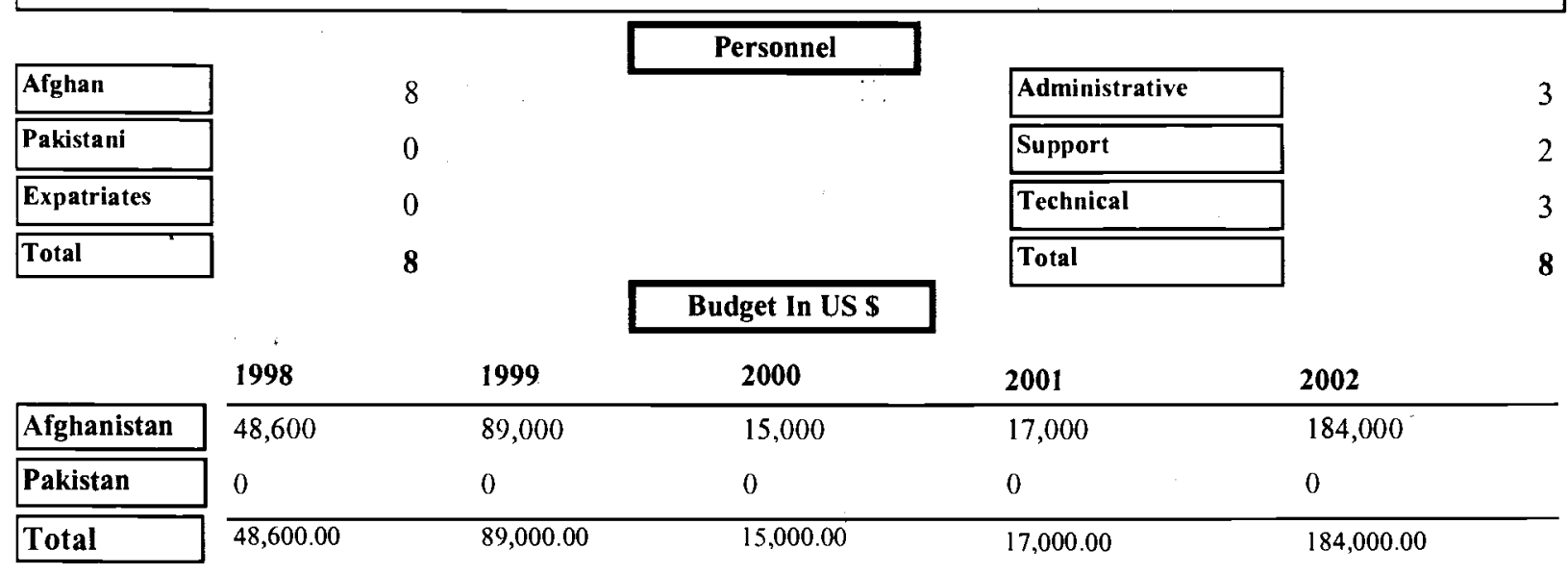

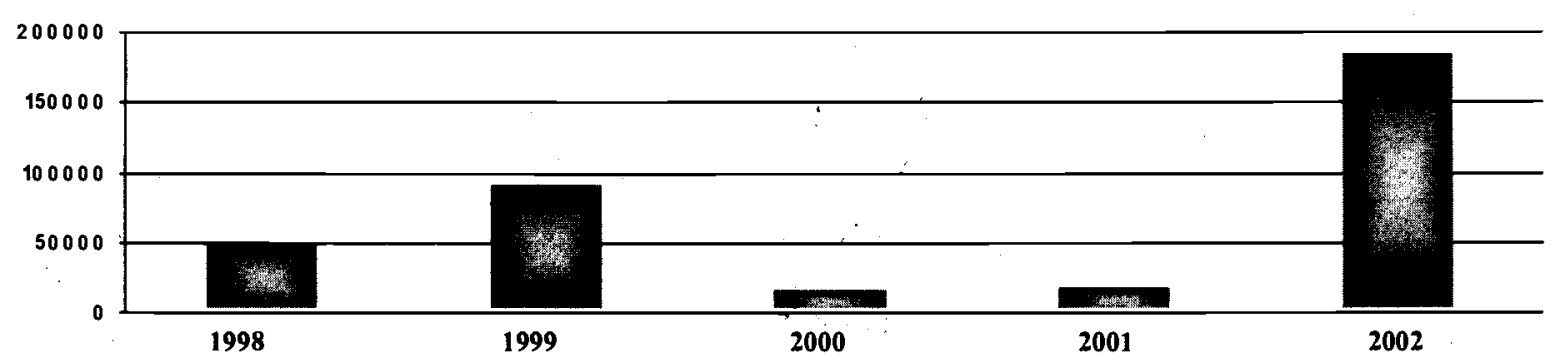

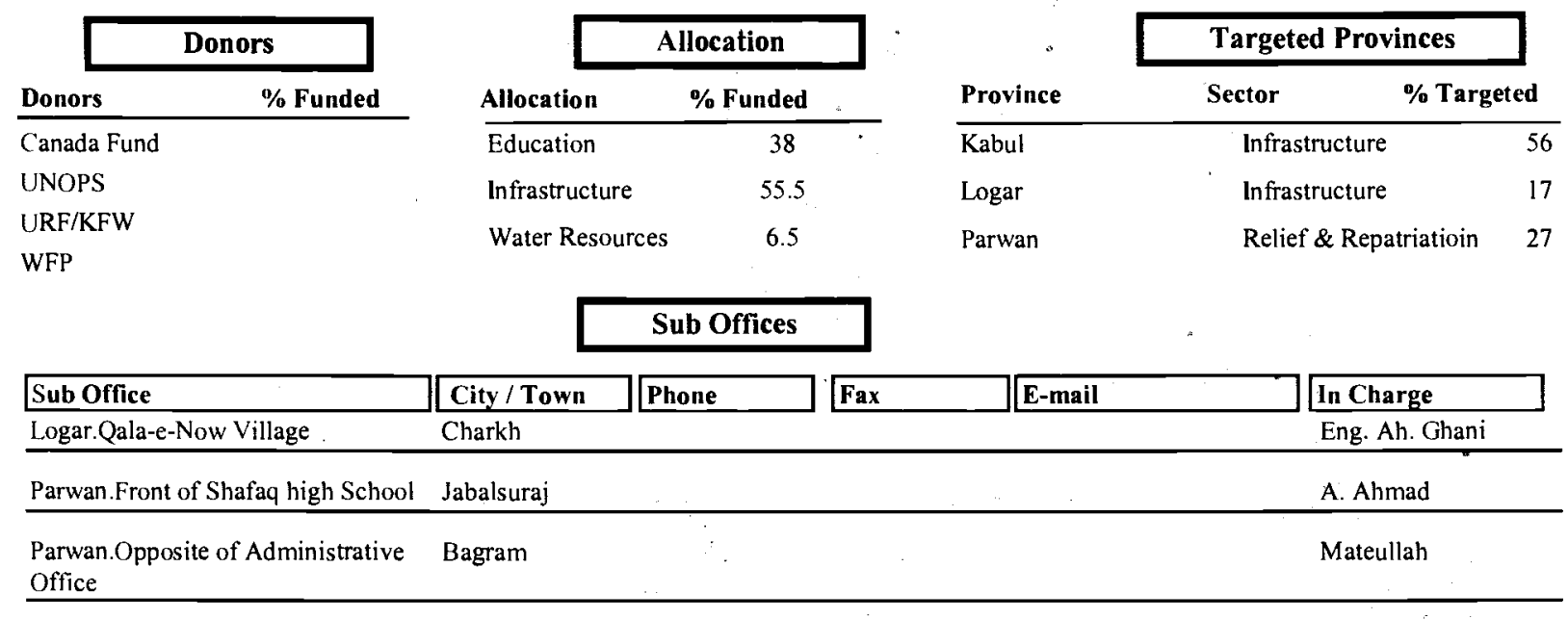




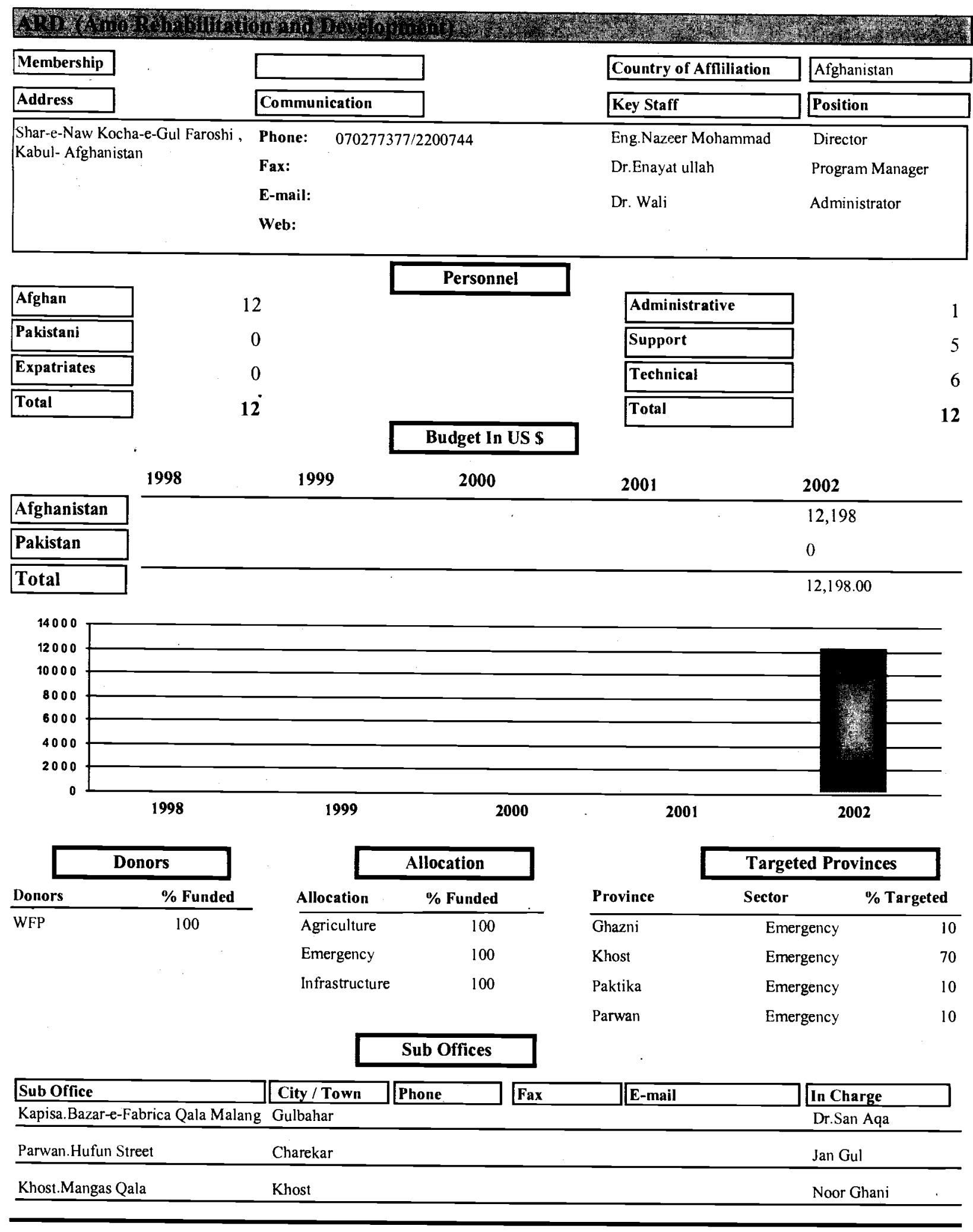




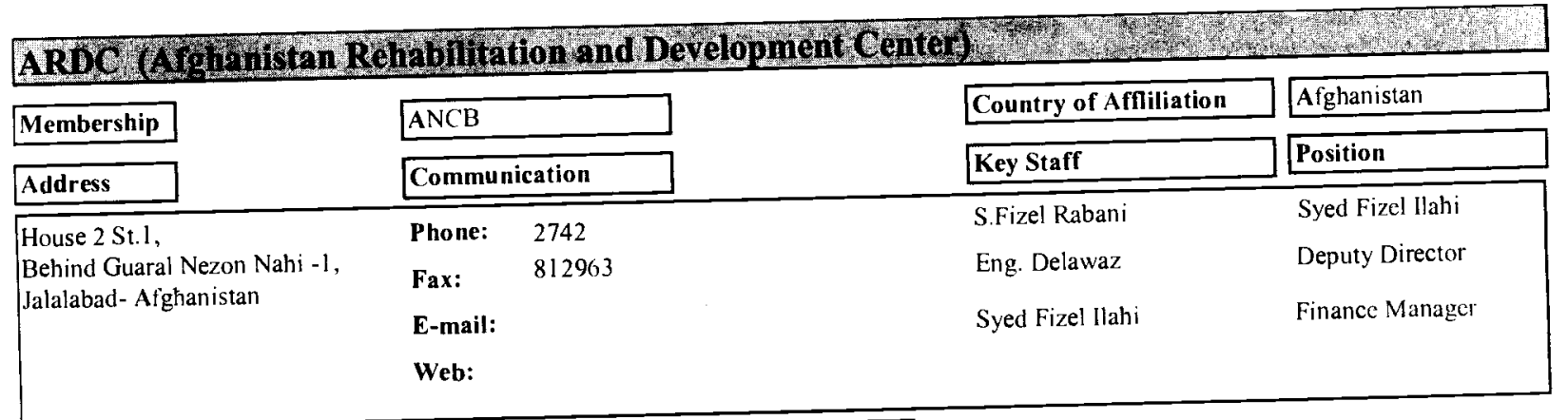

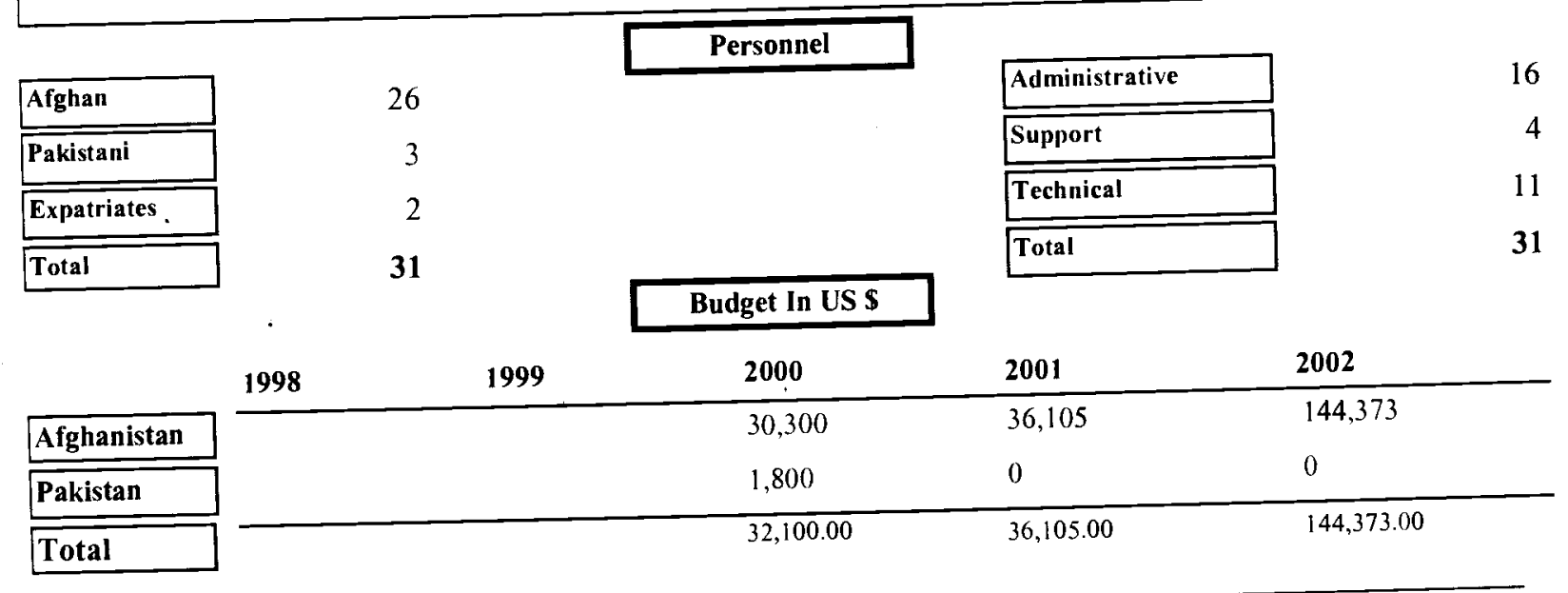

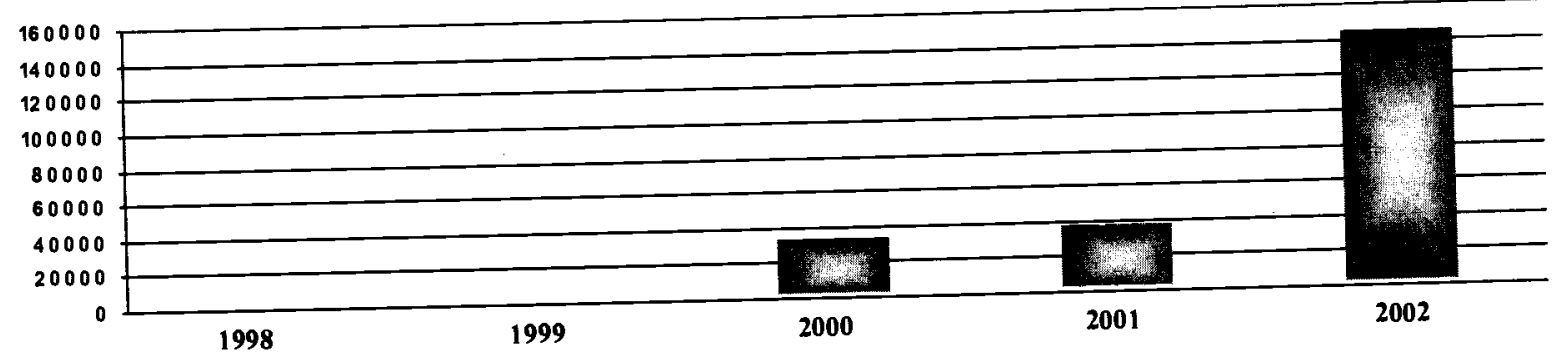

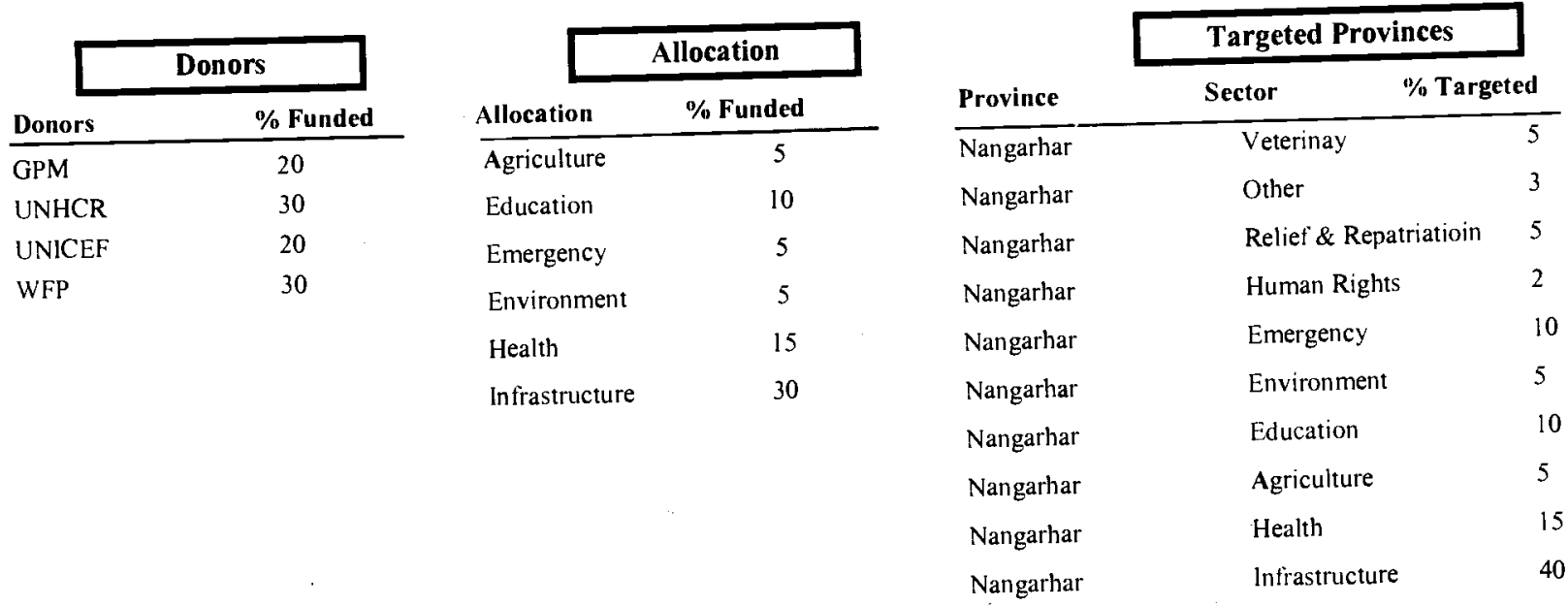

\begin{tabular}{|c|c|c|c|c|c|}
\hline & & Sub Offices & & & \\
\hline Sub Office & City/Town & Phone & Fax & E-mail & In Charge \\
\hline $\begin{array}{l}\text { Charhir Torabazkhan Kocha-I- Gul } \\
\text { Froshi }\end{array}$ & Kabul & $34343 / 0727970$ & & $\begin{array}{l}\text { s_rabbani_2001@yahoo. } \\
\text { com }\end{array}$ & Eng. Delawen \\
\hline $\begin{array}{l}\text { NWFP. } 89 \text {-A Continantal Product. } 9 \\
\text { in dDustrial Area }\end{array}$ & Peshawar & $81296 / 814313$ & 812963 & & \\
\hline
\end{tabular}




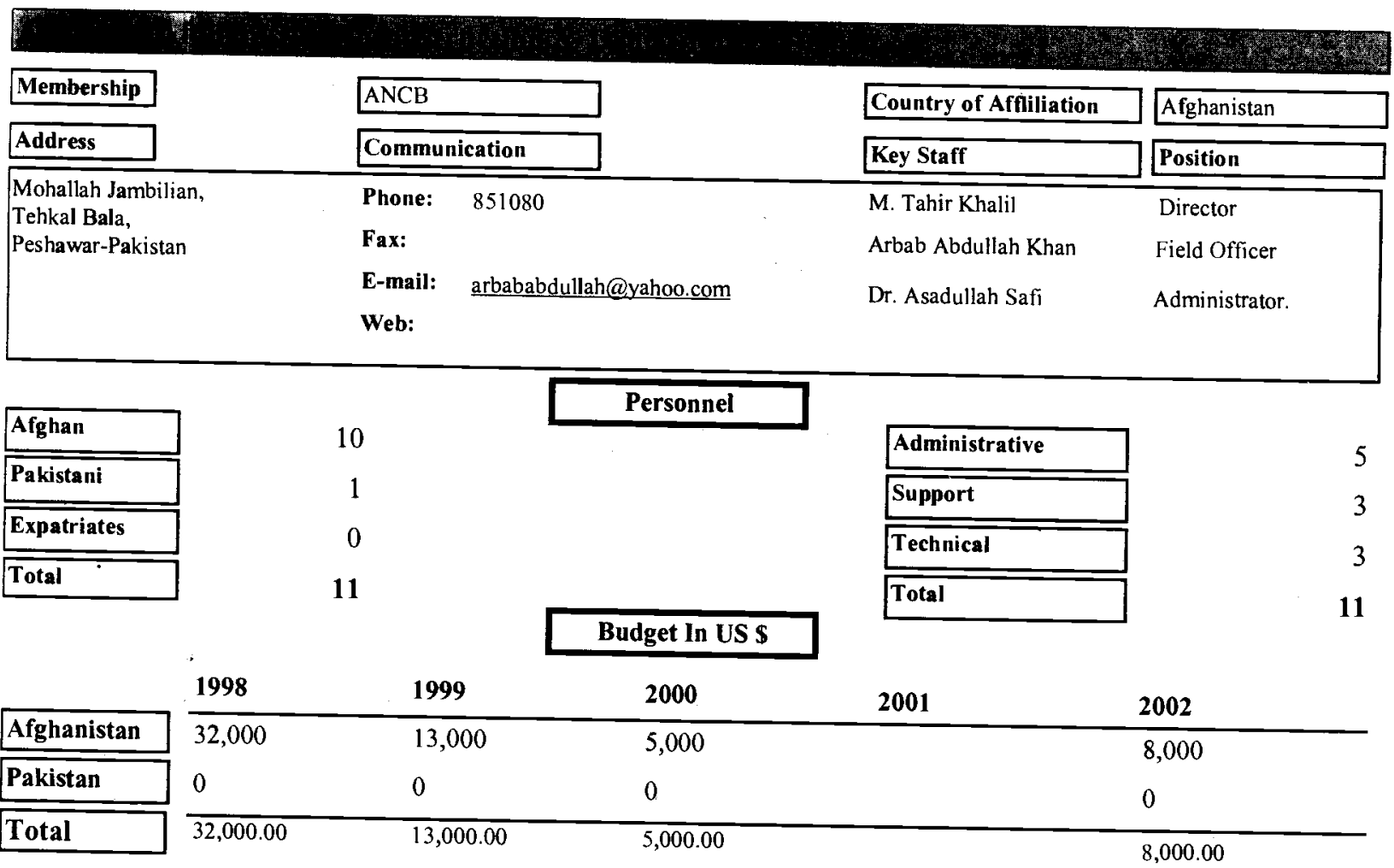
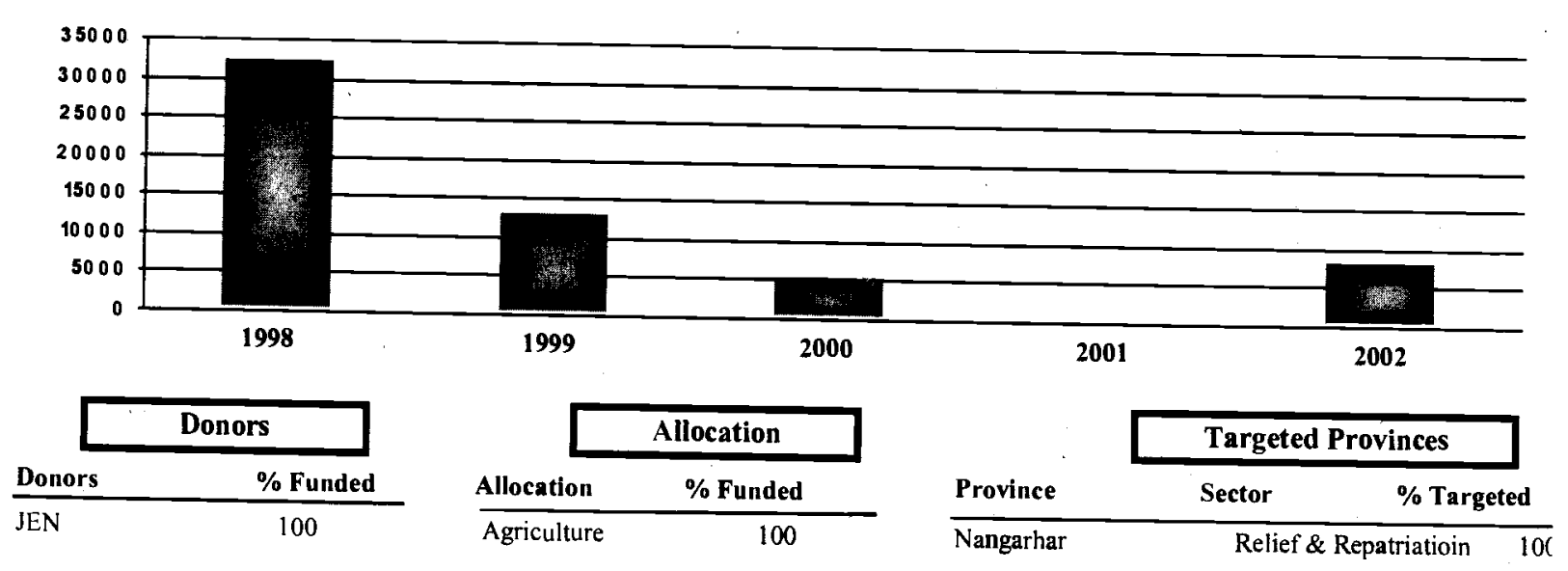

\section{Sub Offices}

\begin{tabular}{l|l|l|l|l|l|l|l|l|l|l|l|l|l|l|}
\hline Sub Office & City $/$ Town & Phone & Eharge \\
$\begin{array}{l}\text { Nangarhar.Toup Chondi, Back } \\
\text { custome Office }\end{array}$ & Jalalabad & Eng. Zarwar \\
\hline
\end{tabular}




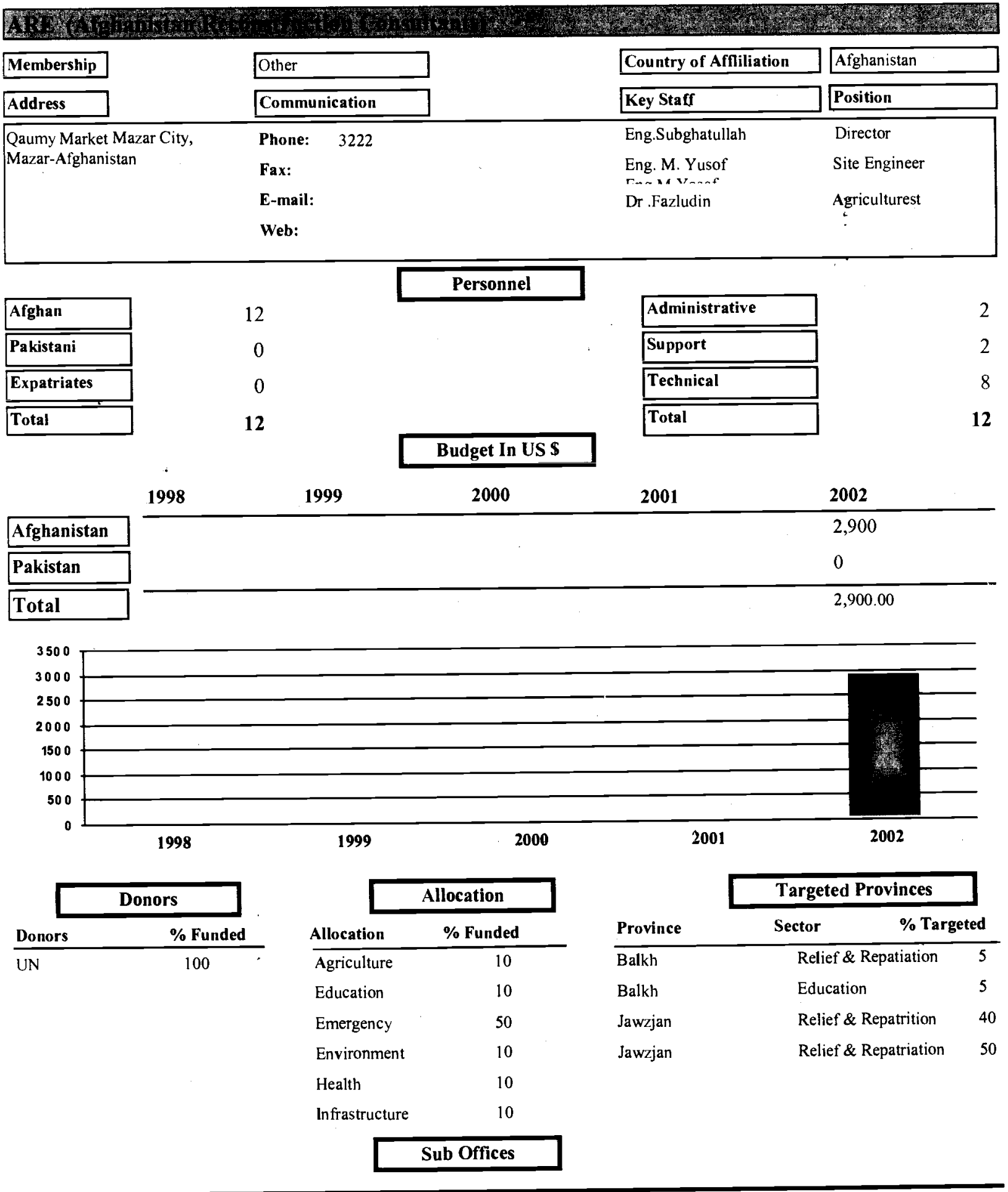




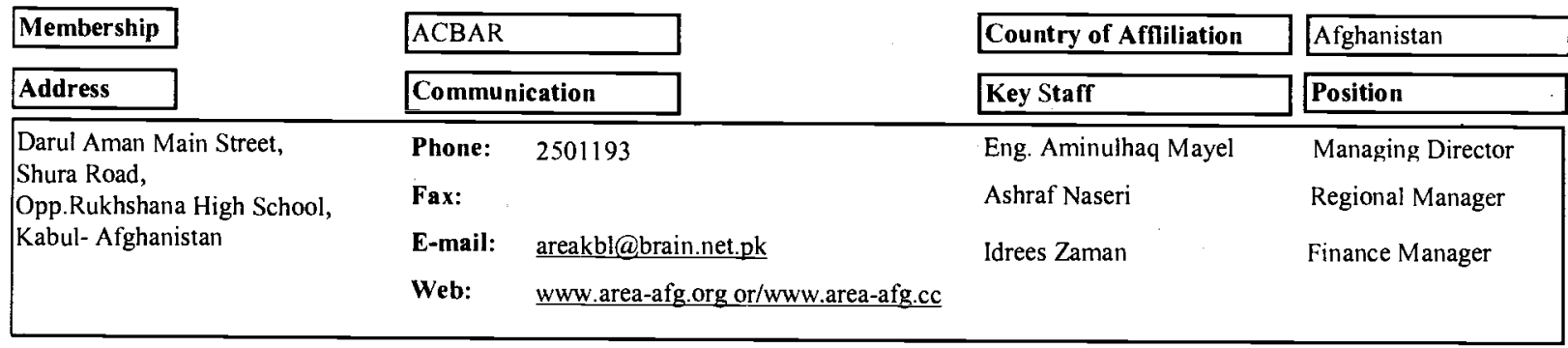

\begin{tabular}{|l|}
\hline Afghan \\
\hline \hline Pakistani \\
\hline \hline Expatriates \\
\hline Total \\
\hline
\end{tabular}

Personnel

\begin{tabular}{|c|c|c|c|c|c|}
\hline & & & & Total & \\
\hline & 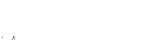 & & Budget In US \$ & & \\
\hline & 1998 & 1999 & 2000 & 2001 & 2002 \\
\hline Afghanistan & 477,566 & 966,536 & $1,735,963$ & $2,153,359$ & $6,992,354$ \\
\hline Pakistan & 0 & 0 & 0 & 0 & 0 \\
\hline Total & $477,566.00$ & $966,536.00$ & $1,735,963.00$ & $2,153,359.00$ & $6,992,354.00$ \\
\hline 8000000 & & & & & \\
\hline $\begin{array}{l}7000000 \\
6000000\end{array}$ & & & & & \\
\hline 5000000 & & & & & \\
\hline 4000000 & & & & & \\
\hline 3000000 & & & & & W \\
\hline $\begin{array}{r}2000000 \\
1000000\end{array}$ & & & & 12 & \\
\hline & 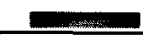 & 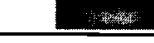 & Nis. & & \\
\hline & 1998 & 1999 & 2000 & 2001 & 2002 \\
\hline
\end{tabular}

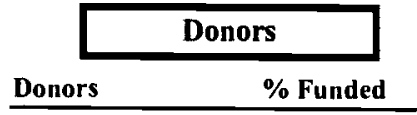

Austrian Government 0

Canada Fund

Christian Aid

DFID

$\mathrm{EC}$

$\mathrm{ECHO}$

EU

Govt: of Japan

IRC

Ministry of Foreign Off

Ministry of Foreign Off

Mulim Aid UK

Musim Helfen-German

NCA

NOVIB

OFDA

Swiss Dev.coop

The Netherlands Gover

TRO CAIR

UNDP

UNHCR

UNOCHA

WFP
Administrative 68

Support 209

Technical 247

524

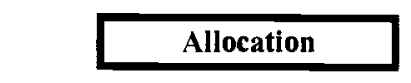

Allocation $\quad \%$ Funded

Agriculture

Education

Emergency

Environment

Income Generatio

Infrastructure

Mines

Other

Relief \& Repatria

Social Programs
Targeted Provinces

Province $\quad$ Sector \% Targeted

Balkh $\quad$ Social Programs 9

Hirat

Kabul

Nangarhar 


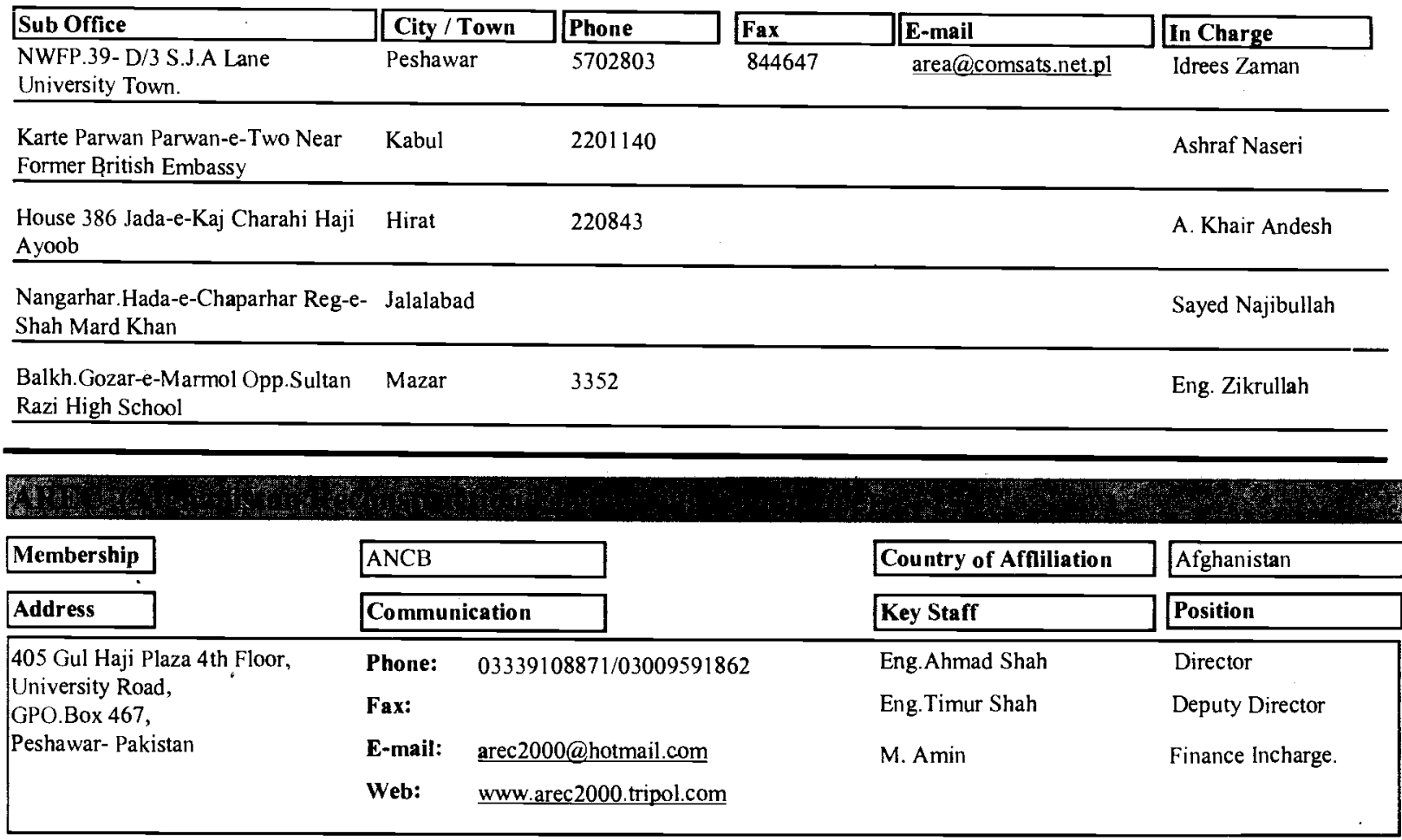

\begin{tabular}{|l|}
\hline Afghan \\
\hline \hline Pakistani \\
\hline Expatriates \\
\hline Total \\
\hline
\end{tabular}

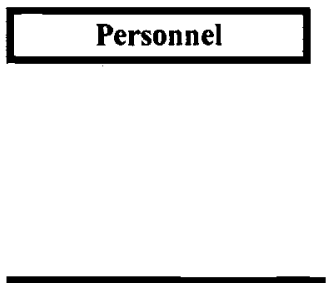

\begin{tabular}{|l|}
\hline Administrative \\
\hline Support \\
\hline Technical \\
\hline Total \\
\hline
\end{tabular}

Budget In US S

\begin{tabular}{|c|c|c|c|c|c|}
\hline & 1998 & 1999 & 2000 & 2001 & 2002 \\
\hline Afghanistan & 80,000 & 95,000 & 100,000 & 110,000 & 200,000 \\
\hline Pakistan & 720,000 & 800,000 & 830,000 & 840,000 & 860,000 \\
\hline Total & $800,000.00$ & $895,000.00$ & $930,000.00$ & $950,000.00$ & $1,060,000.00$ \\
\hline \multicolumn{6}{|l|}{1200000} \\
\hline \multicolumn{6}{|l|}{1000000} \\
\hline 800000 & & & & & \\
\hline \multicolumn{6}{|l|}{600000} \\
\hline \multicolumn{6}{|l|}{400000} \\
\hline \multicolumn{6}{|l|}{200000} \\
\hline & 1998 & 1999 & 2000 & 2001 & 2002 \\
\hline
\end{tabular}

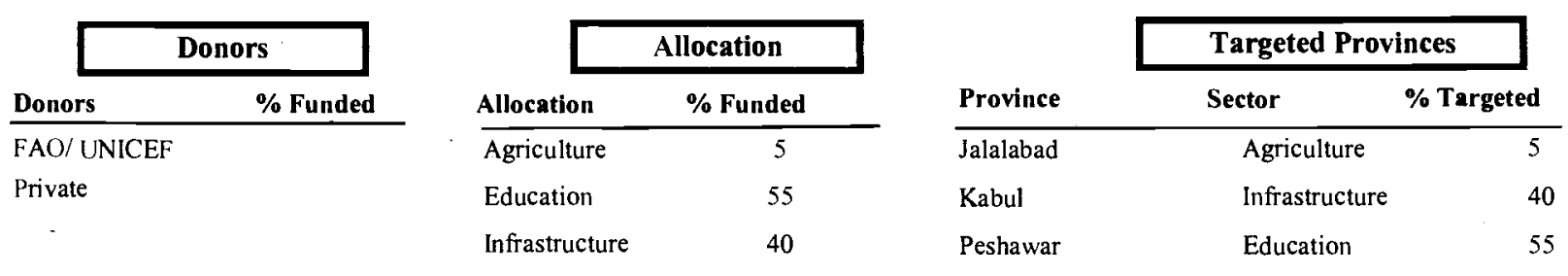

Sub Offices

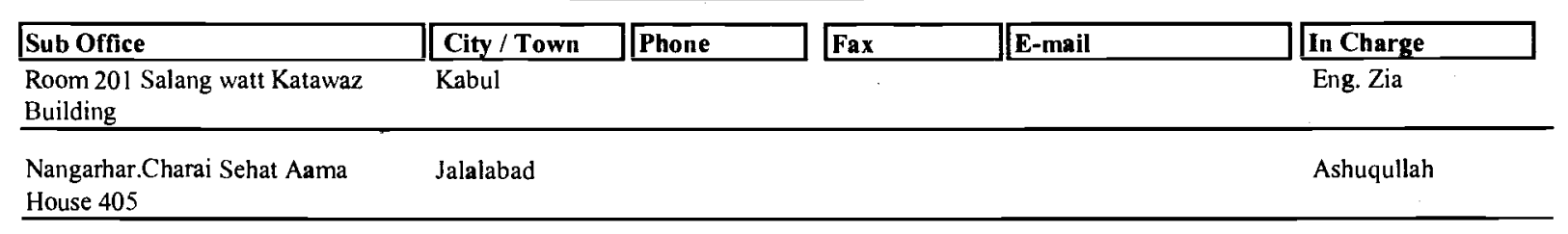




\begin{tabular}{|c|c|c|c|}
\hline Membership & ANCB & Country of Affliliation & Pakistan \\
\hline Address & Communication & Key Staff & Position \\
\hline \multirow{4}{*}{$\begin{array}{l}\text { Borad Opposite Ziarat Stop, } \\
\text { Al-Taqwa High School, } \\
\text { Peshawar-Pakistan }\end{array}$} & Phone: & Eng.Enayatullah & Director \\
\hline & Fax: $\quad 851697$ & Redwant:lllah & Supervisor \\
\hline & E-mail: arep20@hotmail.com & M.Ajmal & Admin /Finance \\
\hline & Web: & & \\
\hline
\end{tabular}

\begin{tabular}{|l|r|}
\hline Afghan & 98 \\
\hline Pakistani & 0 \\
\hline Expatriates & 0 \\
\hline Total & 98 \\
\hline
\end{tabular}

Personnel

\begin{tabular}{|c|c|c|c|c|c|}
\hline \multirow[t]{3}{*}{ Total } & \multirow{2}{*}{\multicolumn{2}{|c|}{98}} & & \multirow[t]{2}{*}{ Total } & \multirow[b]{3}{*}{2002} \\
\hline & & & Budget In US S & & \\
\hline & 1998 & 1999 & 2000 & 2001 & \\
\hline Afghanistan & & & 0 & 0 & 0 \\
\hline Pakistan & & & 20,500 & 9,966 & 79,750 \\
\hline Total & & & $20,500.00$ & $9,966.00$ & $79,750.00$ \\
\hline
\end{tabular}

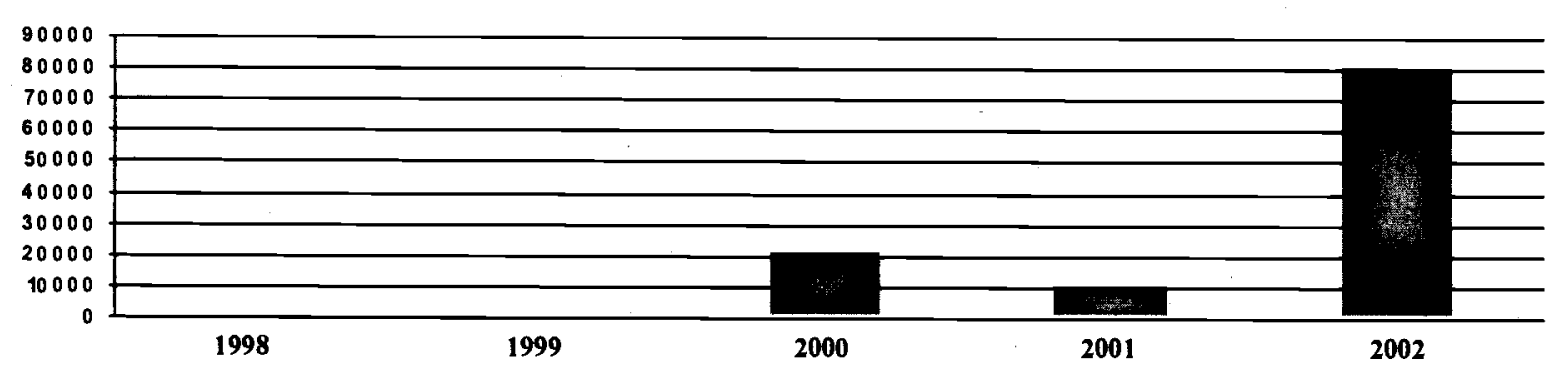

\begin{tabular}{|c|c|c|c|c|c|c|}
\hline \multicolumn{2}{|c|}{ Donors } & & llocation & \multirow[b]{2}{*}{ Province } & \multicolumn{2}{|c|}{ Targeted Provinces } \\
\hline Donors & $\%$ Funded & Allocation & $\%$ Funded & & Sector & $\%$ Targeted \\
\hline Canada Fund/CIDA & 50 & Education & 90 & Islamabad & Education & 20 \\
\hline JRAC & 50 & Emergency & 5 & Peshawar & Education & 70 \\
\hline & & Other & 5 & Peshawar & Education & 10 \\
\hline
\end{tabular}

Sub Offices

\begin{tabular}{|c|c|c|c|c|}
\hline Sub Office & City / Town & \begin{tabular}{|l|} 
Phone \\
\end{tabular} & E-mail & In Charge \\
\hline $\begin{array}{l}\text { Prawan } 3 \text { House } 4 \text { Haji Azmatullah } \\
\text { Apartment }\end{array}$ & Kabul & 070275377 & arep20@hotmail.com & \\
\hline $\begin{array}{l}\text { Nangarhar. Nahya } 3 \text { Joe } 71 \text { st Road } \\
\text { 4th Street }\end{array}$ & Nangarhar & & arep20@hotmail.com & M.Emal \\
\hline
\end{tabular}




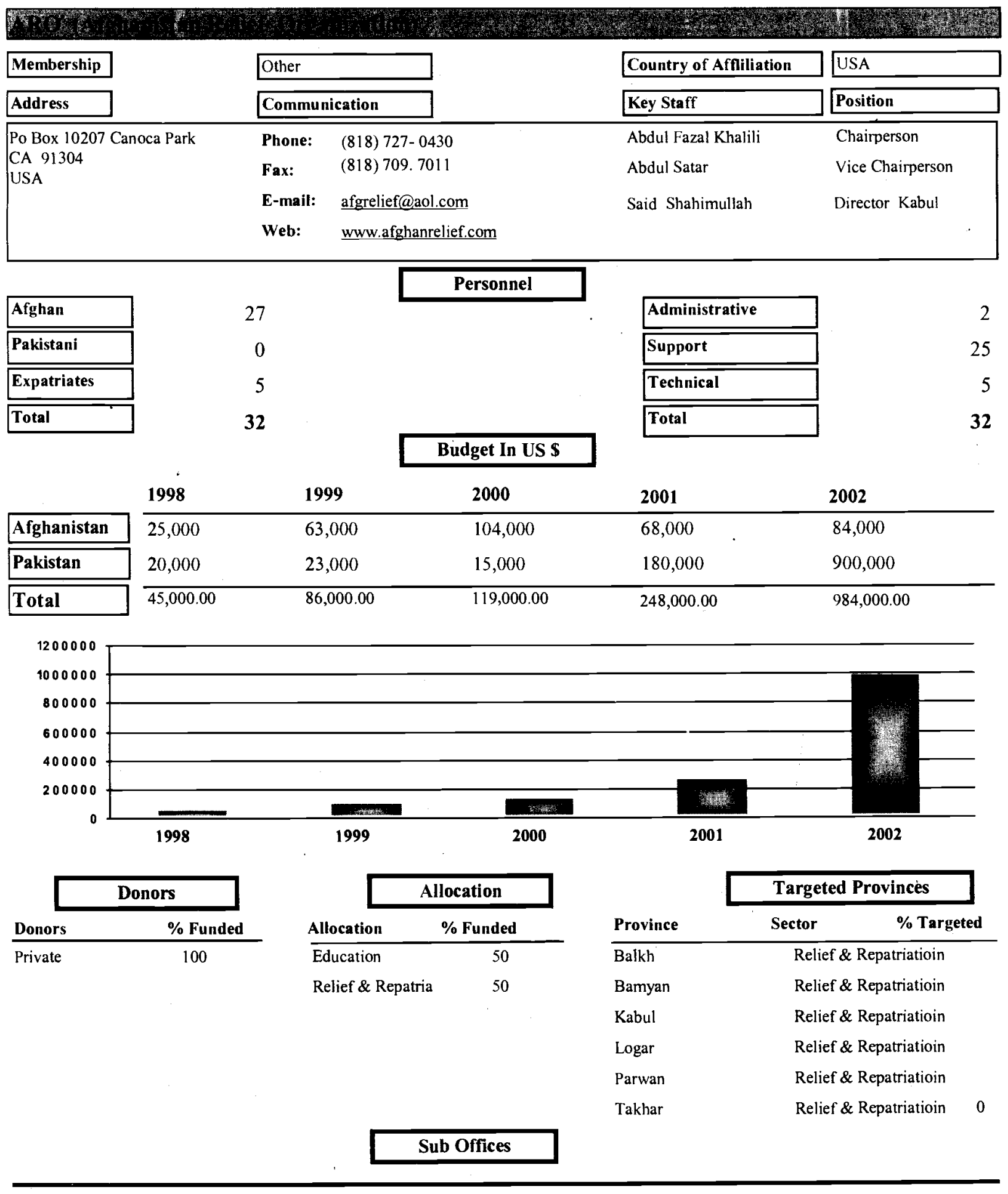




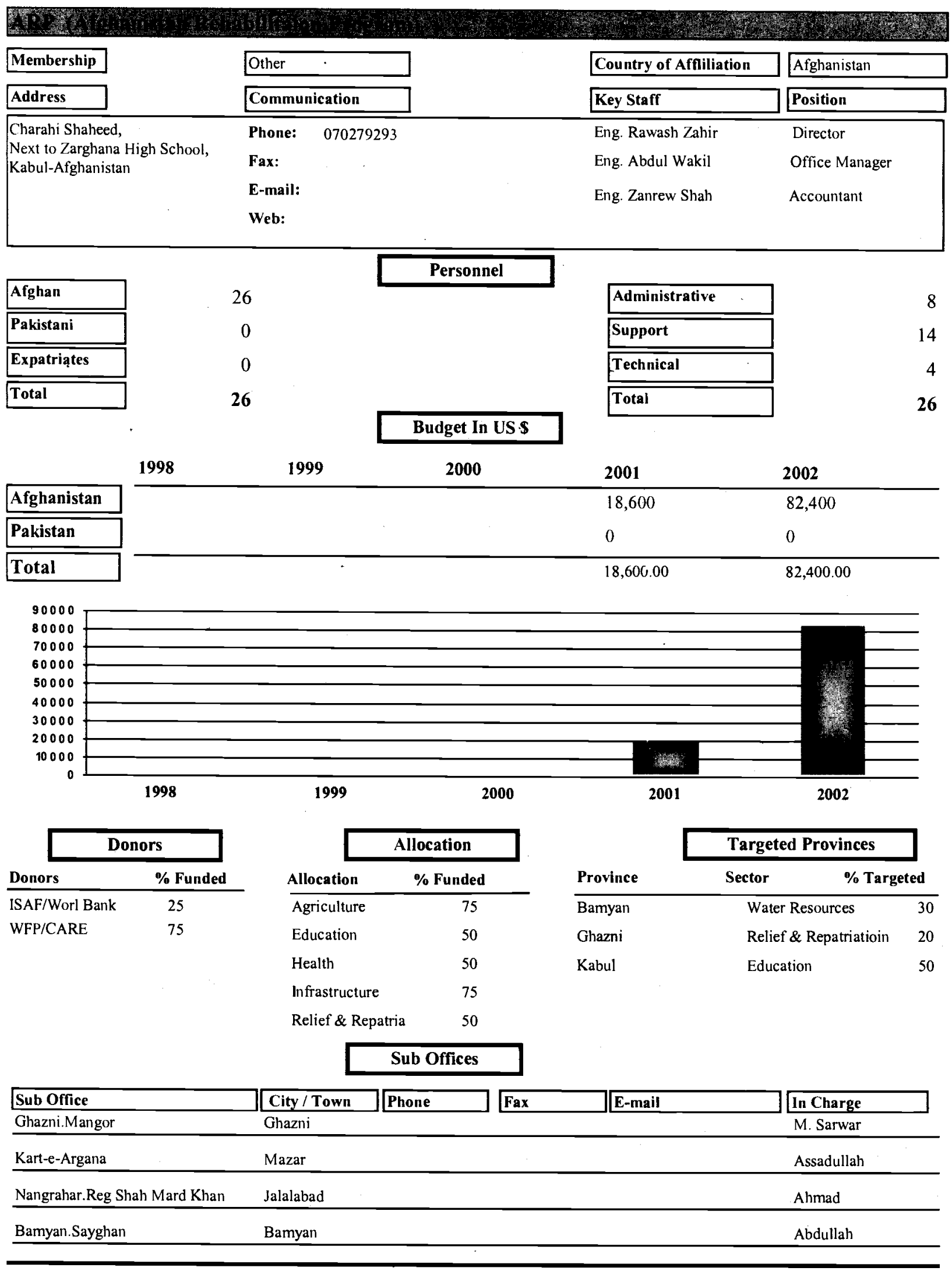




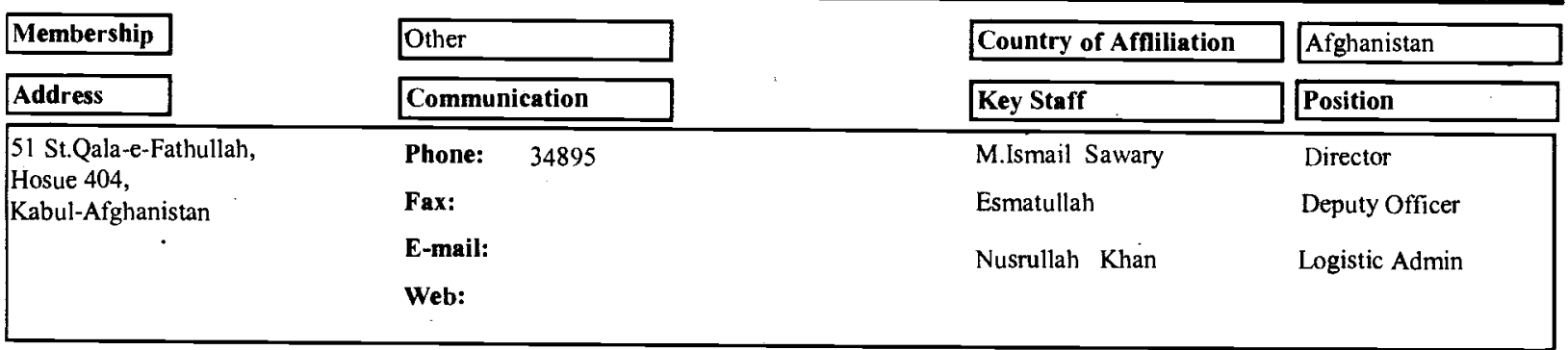

\begin{tabular}{|l|}
\hline Afghan \\
\hline \hline Pakistani \\
\hline Expatriates \\
\hline Total \\
\hline
\end{tabular}

Personnel

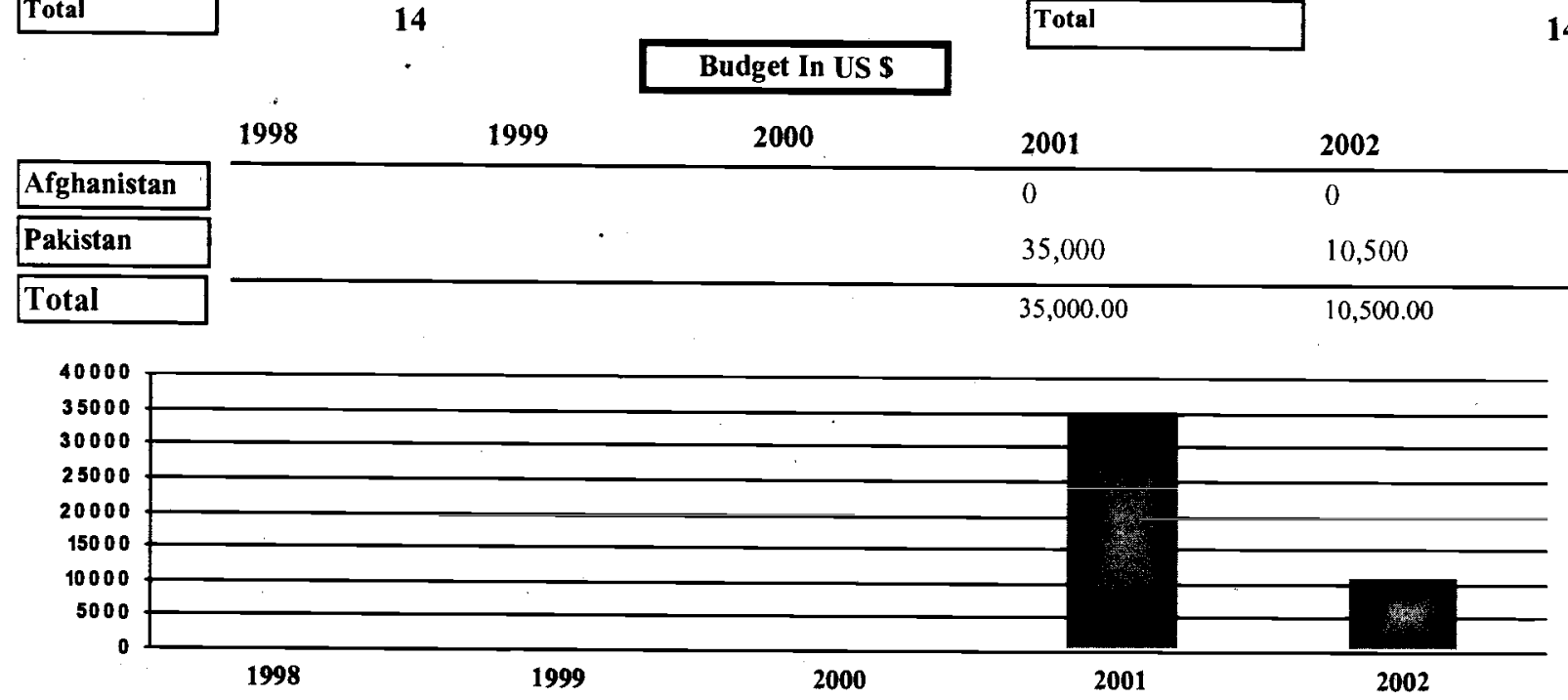

\begin{tabular}{|c|c|c|c|c|c|c|}
\hline \multicolumn{2}{|c|}{ Donors } & \multicolumn{2}{|c|}{ Allocation } & \multirow[b]{2}{*}{ Province } & \multicolumn{2}{|l|}{ Targeted Provinces } \\
\hline Donors & $\%$ Funded & Allocation & $\%$ Funded & & $\%$ Targ & \\
\hline CARE & & Agriculture & 20 & Ghazni & Emergency & 5 \\
\hline CARE & & Education & 20 & Ghazni & Water Resources & 60 \\
\hline JSDF & & Emergency & 20 & Kabul & Relief \& Repatriatioin & 50 \\
\hline UNHCR & & Environment & 10 & Paktia & Agriculture & 10 \\
\hline UNICEF & & Gender Issues & 10 & Parwan & Relief \& Repatriatioin & 100 \\
\hline WFP & & Infrastructure & 20 & & & \\
\hline
\end{tabular}

Sub Offices

\begin{tabular}{|c|c|c|c|c|}
\hline Sub Office & City / Town & Phone & E-mail & In Charge \\
\hline Ghazni.Gero & Ghazni & & & \\
\hline Ghazni.Nawar & Nawar & & & \\
\hline NWFP. Arbab Road Faisal Mosque & Peshawar & 41376 & & 41376 \\
\hline Parwan.Cernen Factory & Jabalsaraj & & & \\
\hline
\end{tabular}




\begin{tabular}{|c|c|c|c|}
\hline Membership & Other & Country of Affiliation & Afghanistan \\
\hline Address & Communication & Key Staff & Position \\
\hline \multirow{4}{*}{$\begin{array}{l}\text { Mazar City Qaumy Market, } \\
\text { Mazar-Afghanistan }\end{array}$} & Phone: 3222 & Khja Abdul Haq & Director of \\
\hline & Fax: & Eng-Shirbaz & Side Enginneer \\
\hline & E-mail: & M. Daud & Officer \\
\hline & Web: & & \\
\hline
\end{tabular}

\begin{tabular}{|l|}
\hline Afghan \\
\hline \hline Pakistani \\
\hline Expatriates \\
\hline Total \\
\hline
\end{tabular}

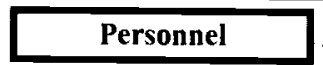

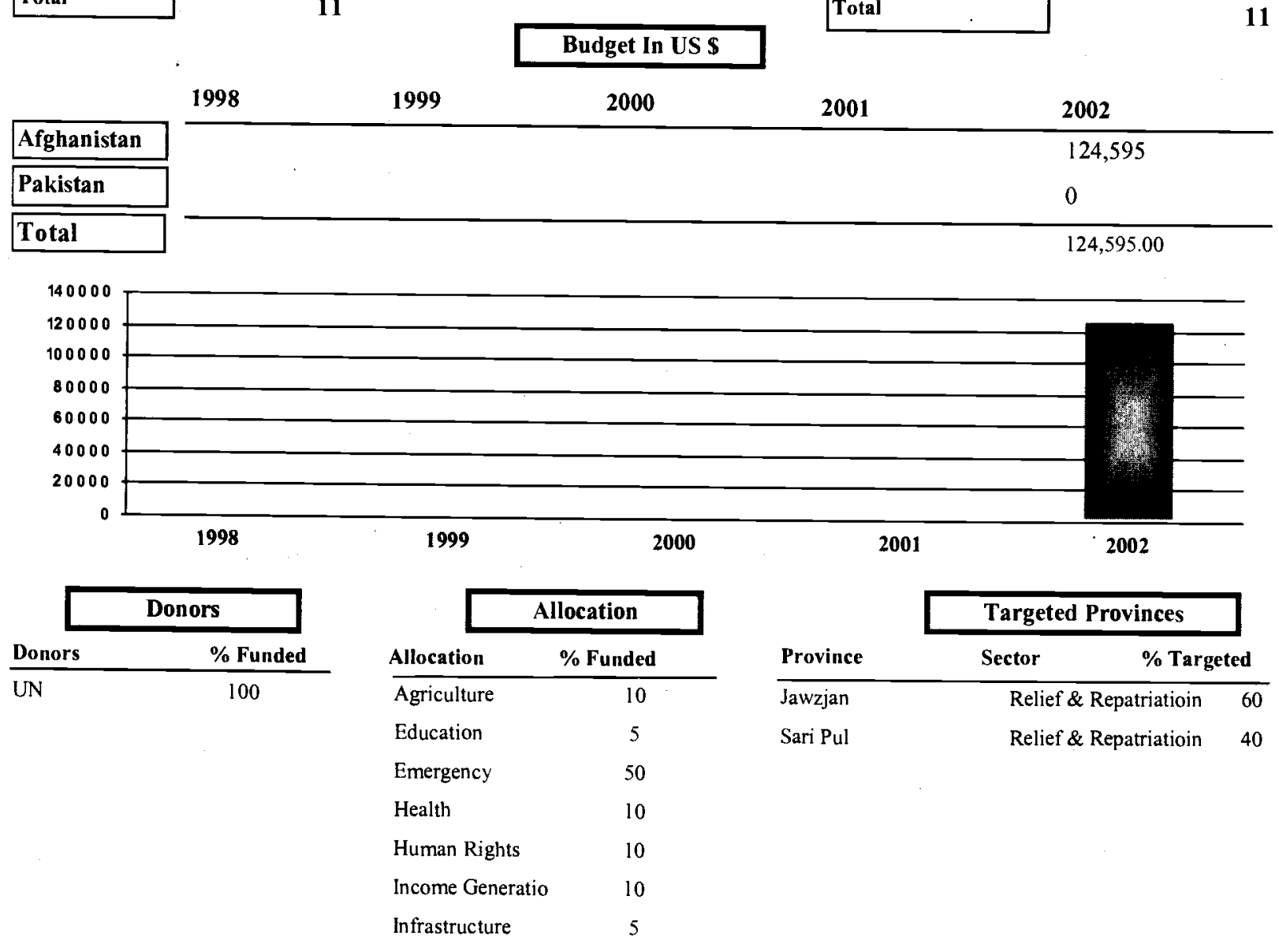

\section{Sub Offices}




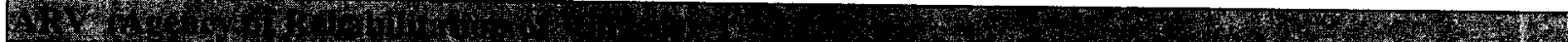

\begin{tabular}{|c|c|c|c|}
\hline Membership & Other & Country of Affliliation & \begin{tabular}{|l|} 
Afghanistan \\
\end{tabular} \\
\hline Address & Communication & Key Staff & Position \\
\hline \multirow{4}{*}{$\begin{array}{l}\text { North of Charh-e-Zamanjan, } \\
\text { Badmarghan District, } \\
\text { Hirat-Afghanistan }\end{array}$} & Phone: & Obaidulllah Seddiqi & Director \\
\hline & Fax: & A. Basir Nawai & Head of Construction \\
\hline & E-mail: & M. A.Timoree & Head of Agriculture \\
\hline & Web: & & \\
\hline
\end{tabular}

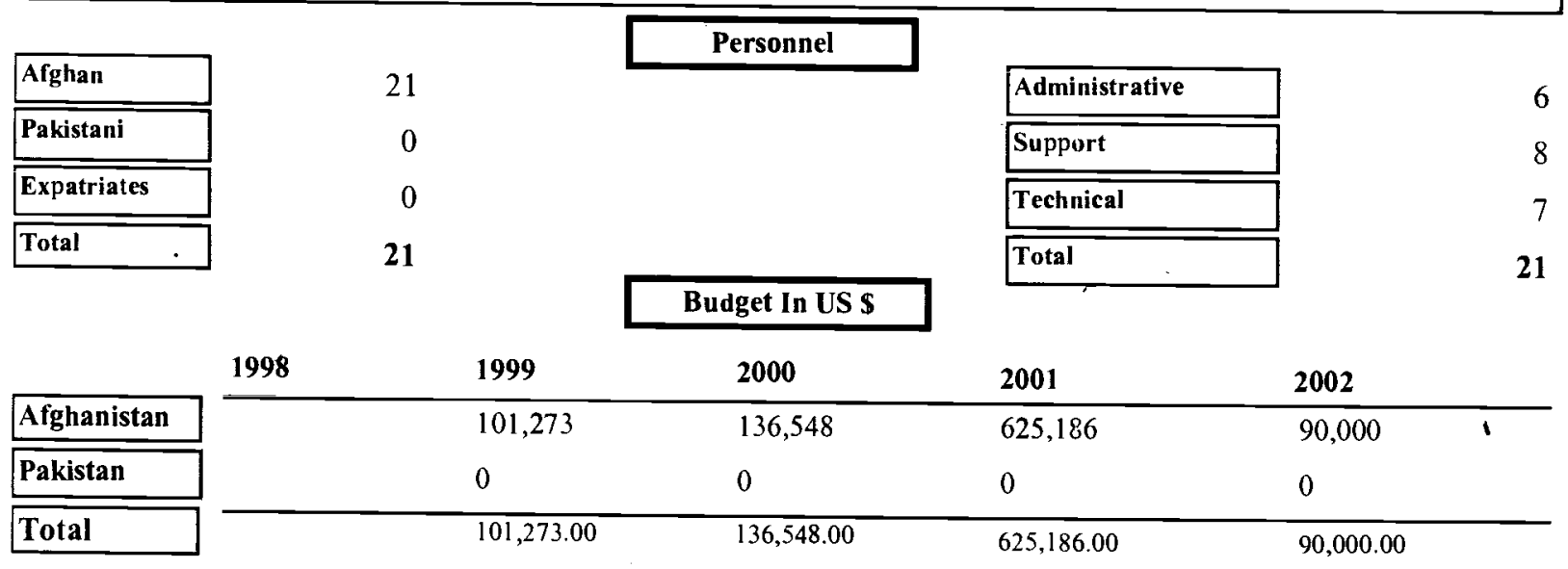

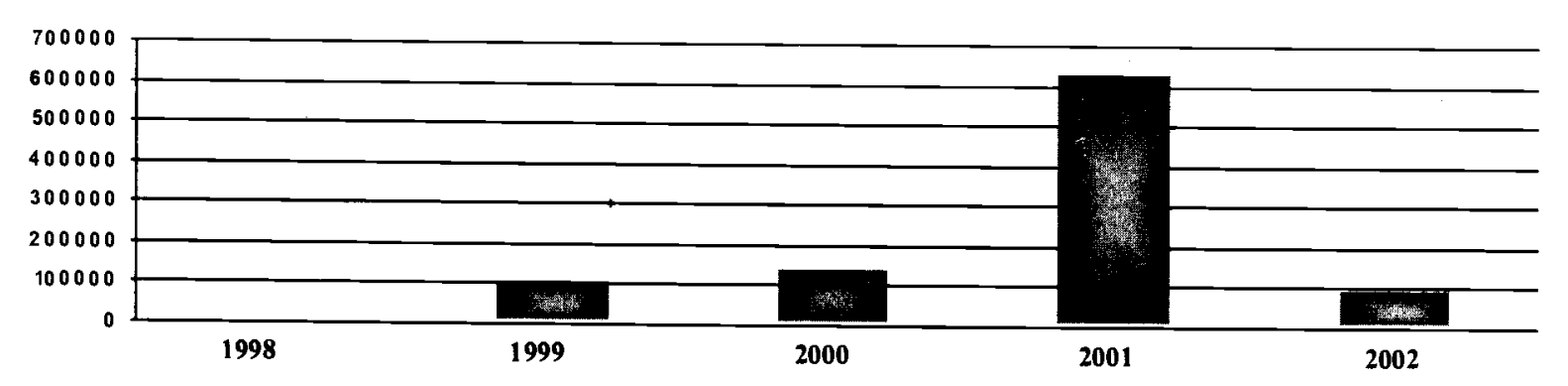

\begin{tabular}{|c|c|c|c|c|c|c|c|}
\hline & & & ocation & & Target & inces & \\
\hline Donors & $\%$ Funded & Allocation & $\%$ Funded & Province & Sector & $\%$ Targ & \\
\hline Other & 52.7 & Emergency & 31.5 & Ghor & Wate & & 12 \\
\hline UN & 47.3 & Infrastructure & 18.5 & Hirat & Relie & atriatioin & 10 \\
\hline & & Other & 40 & Hirat & Emer & & 32 \\
\hline & & Relief \& Repatria & 10 & Hirat & Infras & & 46 \\
\hline & & Sul & Offices & & & & \\
\hline
\end{tabular}




\begin{tabular}{|c|c|c|c|}
\hline Membership & Other & Country of Affiliation & Switzerland \\
\hline Address & Communication & Key Staff & Position \\
\hline \multirow{4}{*}{$\begin{array}{l}\text { Charrahi Malik Asghar, } \\
\text { Opposite PublicLibrary, } \\
\text { Kabul- Afghanistan }\end{array}$} & Phone: & Mohd.Yousuf & Director \\
\hline & Fax: & Lal Mohd. Shamim & Deputy Director \\
\hline & E-mail: & Mir. S.Sadat & Administrator \\
\hline & Web: & & \\
\hline
\end{tabular}

\begin{tabular}{|l|}
\hline Afghan \\
\hline Pakistani \\
\hline \hline Expatriates \\
\hline Total \\
\hline
\end{tabular}

Personnel

Administrative

0

0

65

\begin{tabular}{|c|c|}
\hline Admi & 3 \\
\hline Support & 21 \\
\hline Technical & 4 \\
\hline Total & \\
\hline 2001 & 2002 \\
\hline 163,690 & 114,221 \\
\hline 0 & 0 \\
\hline $163,690.00$ & $114,221.00$ \\
\hline
\end{tabular}

Budget In US S

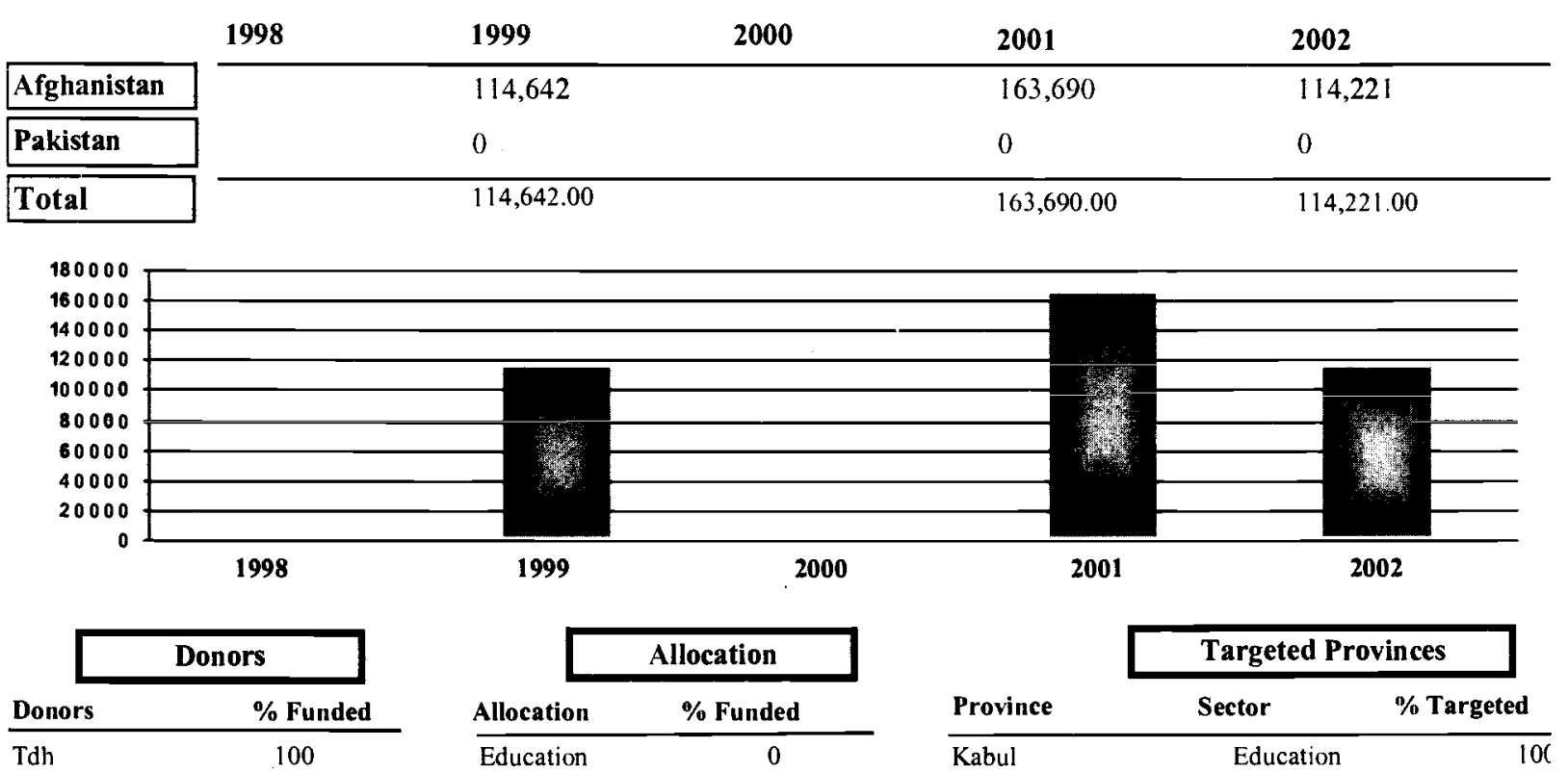




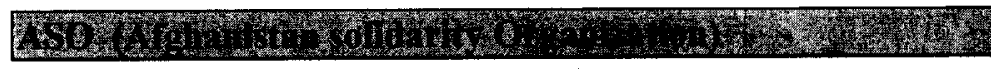

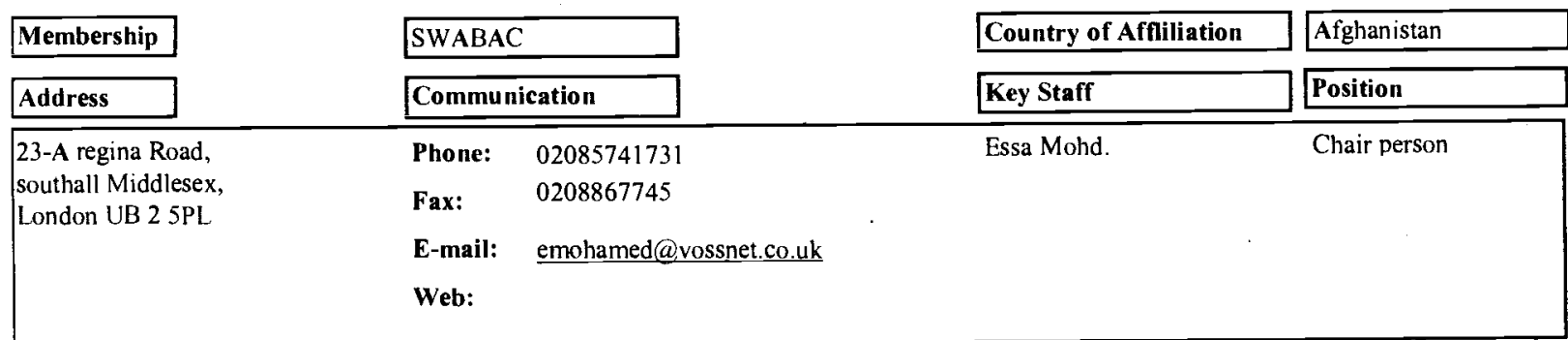

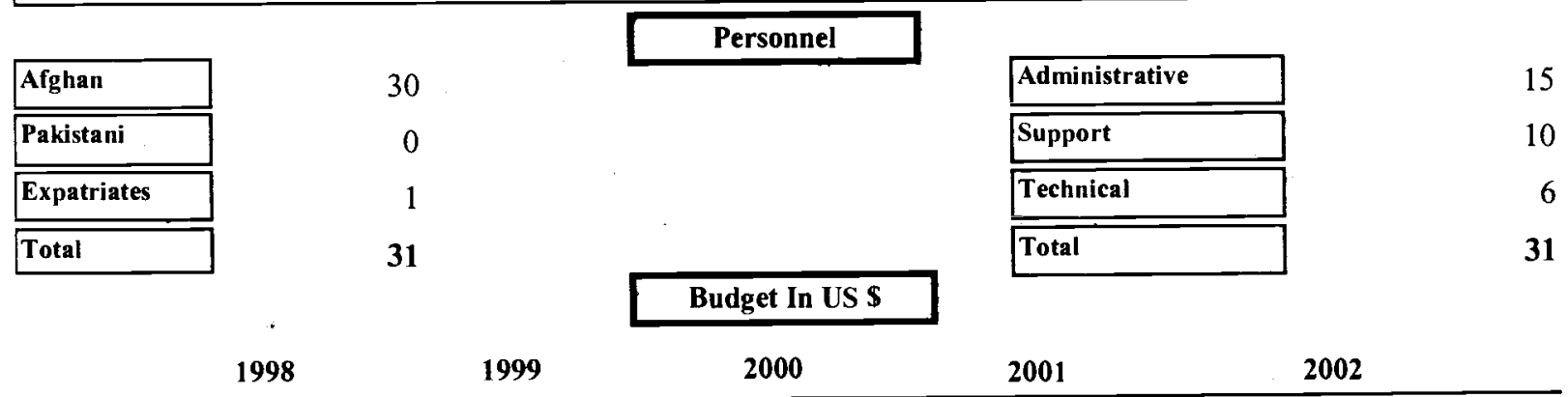

\begin{tabular}{|l|}
\hline Afghanistan \\
\hline Pakistan \\
\hline Total \\
\hline
\end{tabular}

1998

\begin{tabular}{cc|}
\hline & Donors \\
\hline Donors & $\%$ Funded \\
\hline
\end{tabular}

ASO

UNHCR

UNICEF

WFP
19992000

\begin{tabular}{l} 
Allocation \\
Allocation \% Funded \\
\hline Income Generatio \\
Infrastructure \\
Water Resources
\end{tabular}

2001

2002

\begin{tabular}{lll} 
& \multicolumn{2}{c|}{ Targeted Provinces } \\
\cline { 2 - 2 } Province & Sector & $\%$ Targeted \\
\hline Kabul & Infrastructure \\
Kandahar & Infrastructure \\
Kandahar & Water Resources \\
Nimroz & Infrastructure \\
Zabul & Other
\end{tabular}

Sub Offices

\begin{tabular}{|c|c|c|c|c|c|}
\hline Sub Office & City / Town & Phone & Fax & E-mail & In Charge \\
\hline $\begin{array}{l}\text { Quetta. 16-B Chaman housing } \\
\text { scheme }\end{array}$ & Quetta & 828037 & 828025 & $\begin{array}{l}\text { asouk@qta.paknet.com.p } \\
\underline{\mathrm{k}}\end{array}$ & Keith Franklin \\
\hline Kabul.Karti char & Kabul & $070-224420$ & & walidwafi@yahoo.com & Wafi Walim \\
\hline Kandahar.2nd St. 3rd house Grishk & Grishk & +882168885400 & & $\begin{array}{l}\text { asokandahar@hotmail.c } \\
\text { om }\end{array}$ & A.Q.Palwal \\
\hline
\end{tabular}




\begin{tabular}{|c|c|c|c|}
\hline Membership & & Country of Affiliation & Afghanistan \\
\hline Address & Communication & Key Staff & Position \\
\hline \multirow{4}{*}{$\begin{array}{l}\text { Next to noorzai Property, } \\
\text { Akhtary chowk Chawny, } \\
\text { Kandahar-Afghanistan }\end{array}$} & Phone: & Norr Rahman & Director \\
\hline & Fax: & Eng.Shafiq & Senior Engineer \\
\hline & E-mail: $\quad$ assadkh@umher.un & Abdul Rahim & Admin/Finance \\
\hline & Web: & & \\
\hline
\end{tabular}

\begin{tabular}{|l|}
\hline Afghan \\
\hline Pakistani \\
\hline Expatriates \\
\hline Total \\
\hline
\end{tabular}

Personnel

\begin{tabular}{|c|c|c|c|c|c|}
\hline & . & & Budget In US S & & \\
\hline & 1998 & 1999 & 2000 & 2001 & 2002 \\
\hline Afghanistau & 18,000 & 30,000 & 45,000 & 40,000 & 60,000 \\
\hline Pakistan & 6,000 & 14,000 & 0 & 20,000 & 41,000 \\
\hline Total & $\overline{24,000.00}$ & $44,000.00$ & $45,000.00$ & $60,000.00$ & $101,000.00$ \\
\hline
\end{tabular}

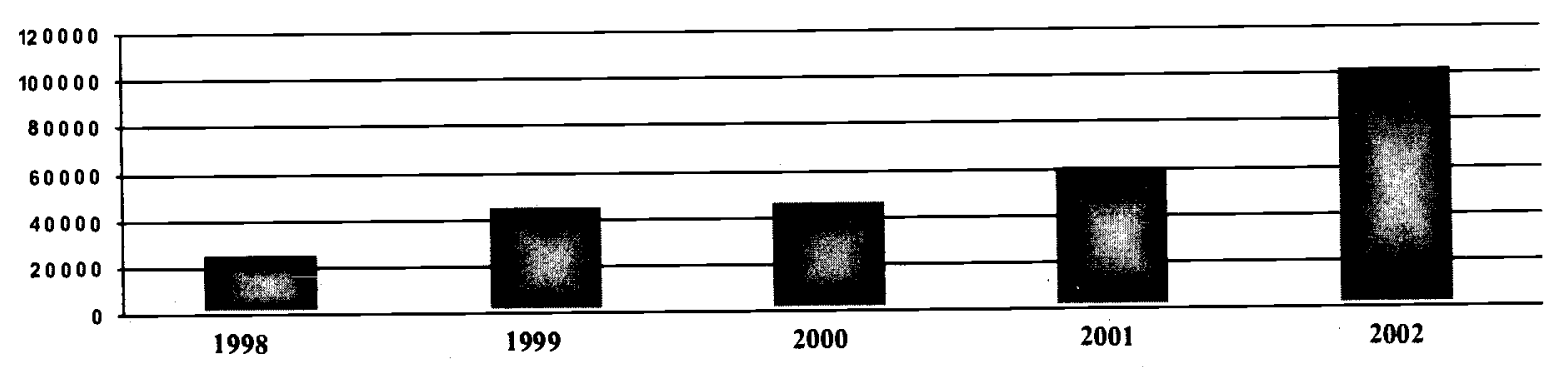

\begin{tabular}{|c|c|c|c|c|c|c|}
\hline \multicolumn{2}{|c|}{ Donors } & & location & \multirow[b]{2}{*}{ Province } & \multicolumn{2}{|c|}{ Targeted Provinces } \\
\hline Donors & $\%$ Funded & Allocation & $\%$ Funded & & Sector & $\%$ Targeted \\
\hline UNHCR & 20 & Agriculture & 20 & & & 0 \\
\hline UNICEF & 40 & Education & 10 & Hilmand & Infrastructure & 7 \\
\hline UNOPS & 20 & Health & 5 & Hilmand & Education & 5 \\
\hline \multirow[t]{4}{*}{ WFP } & 20 & Human Rights & 5 & Kandahar & Health & 10 \\
\hline & & Infrastructure & 60 & Kandahar & Agriculture & 10 \\
\hline & & & & Kandahar & Infrastructure & 8 \\
\hline & & & & Zabul & Infrastructure & 60 \\
\hline
\end{tabular}

Sub Offices

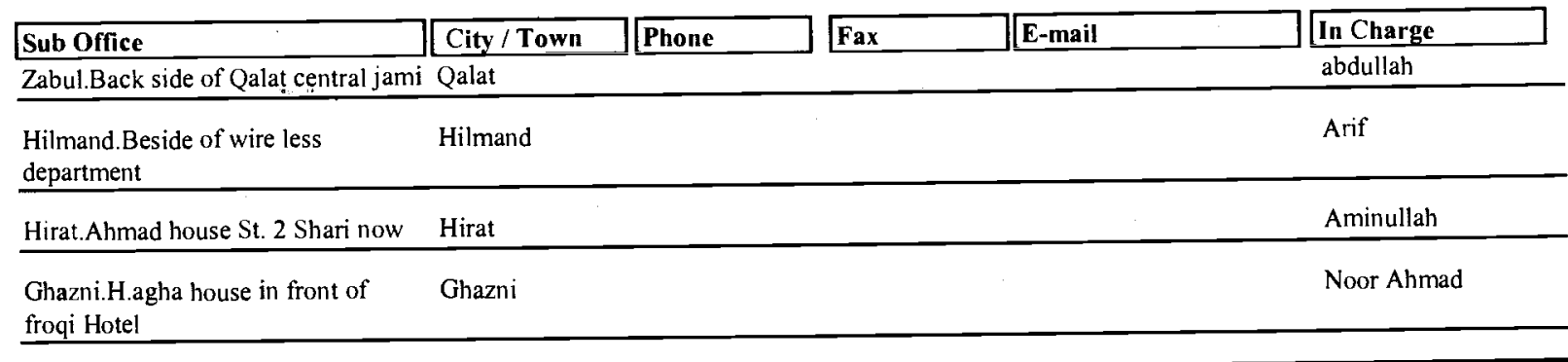




\begin{tabular}{|c|c|c|c|}
\hline Membership & ANCB & Country of Affiliation & Afghanistan \\
\hline Address & Communication & Key Staff & Position \\
\hline \multirow{4}{*}{$\begin{array}{l}\text { Taimani Street 3, } \\
\text { Opposite IOM, } \\
\text { Kabul- Afghanistan }\end{array}$} & $2200679 / 070278048$ & Sher Zaman & Director \\
\hline & Fax: & M.Tahir & Project Managerr \\
\hline & E-mail: & Raj Wali & Accountant \\
\hline & Web: & & \\
\hline
\end{tabular}

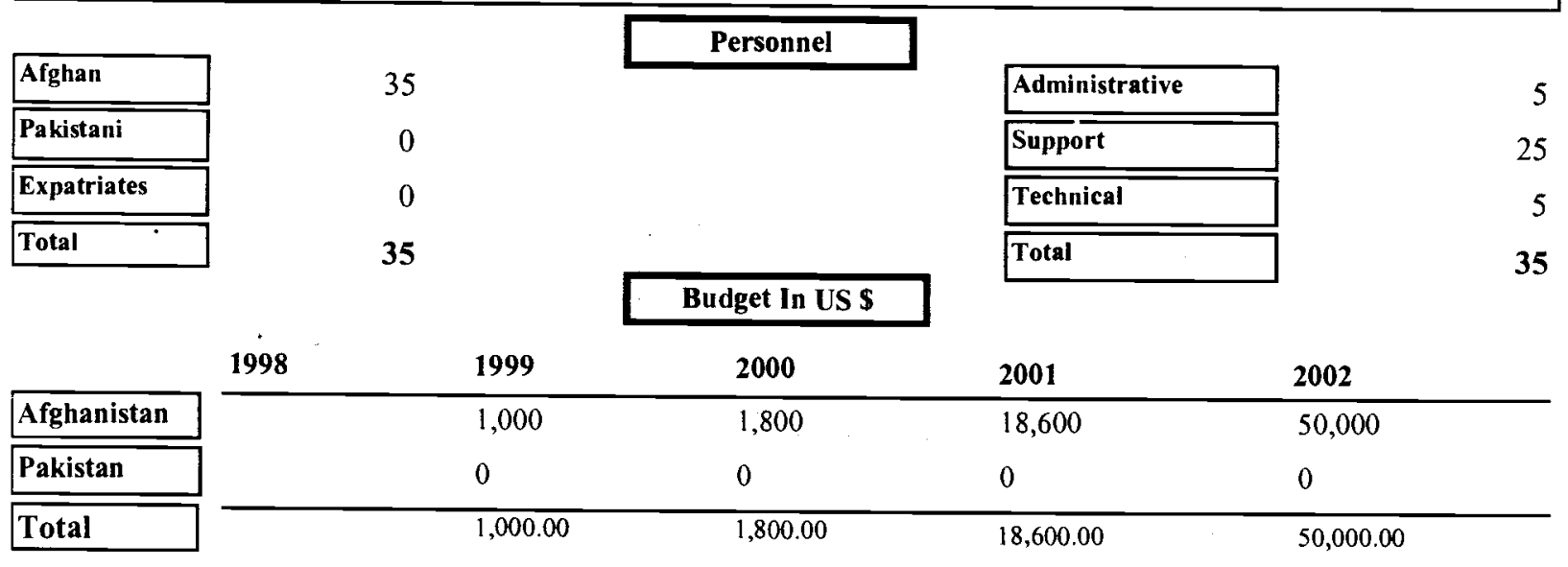
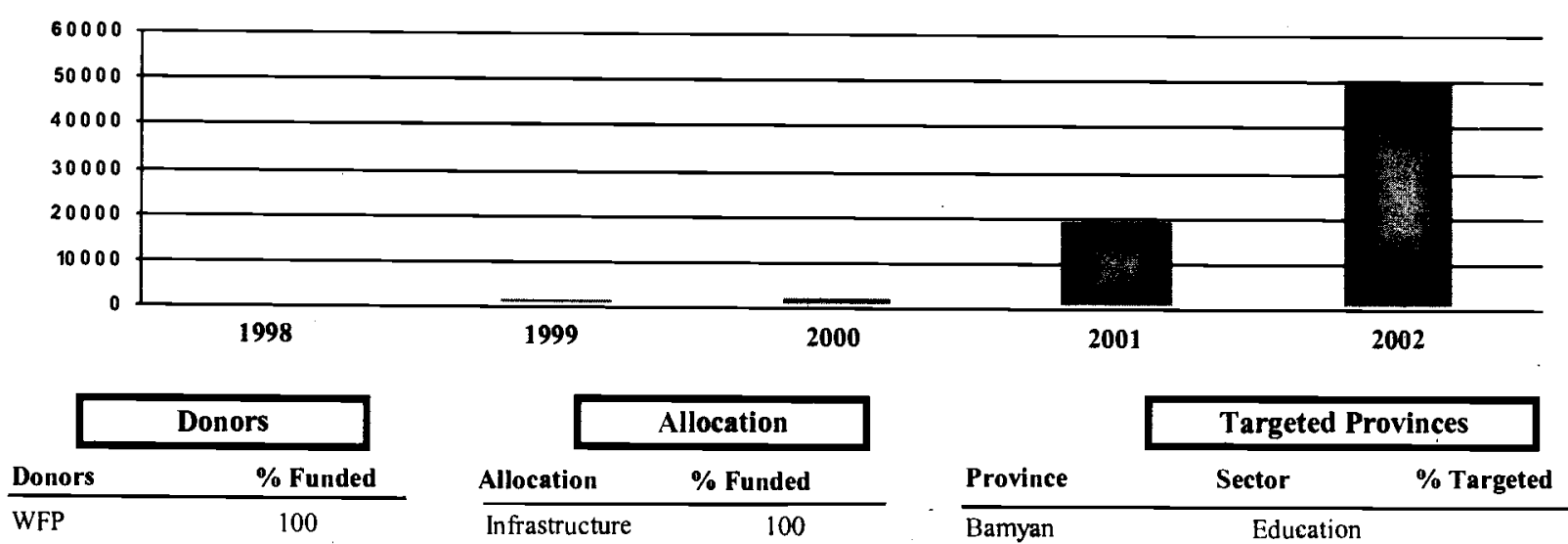

\begin{tabular}{ll} 
& \multicolumn{1}{c|}{ Targeted Provinces } \\
\cline { 2 - 2 } Province & Sector \\
\hline Bamyan & Education \\
Ghazni & Water Resources \\
Ghazni & Water Resources \\
Kabul & Education \\
Logar & Water Resources \\
Logar & Water Resources \\
Paktika & Water Resources \\
Paktika & Water Resources \\
Perwan & Water Resources \\
Perwan & Education \\
Wardak & Infrastructure \\
Wardak & Water Resources \\
Wardak & Water Resources \\
Wardak & Infrastructure
\end{tabular}

Sub Offices

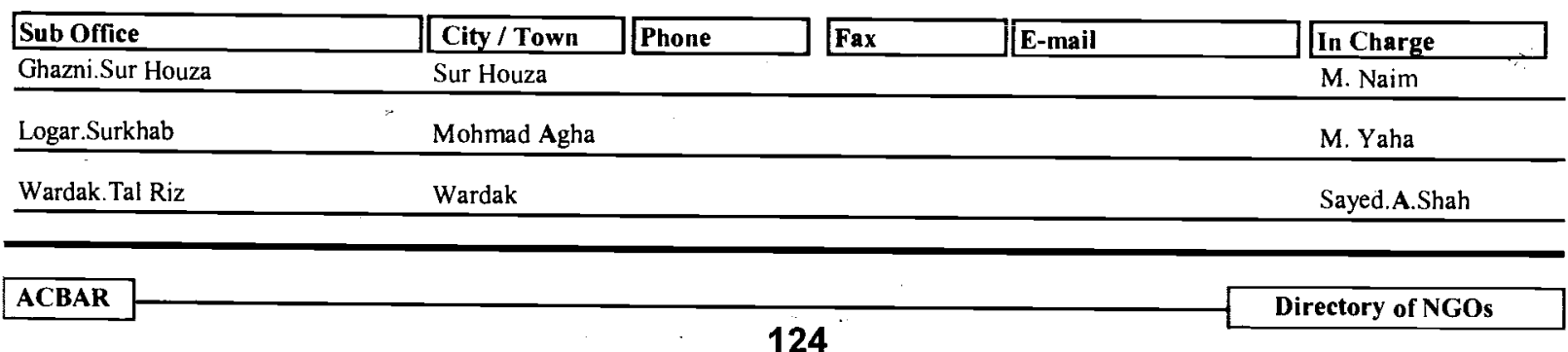




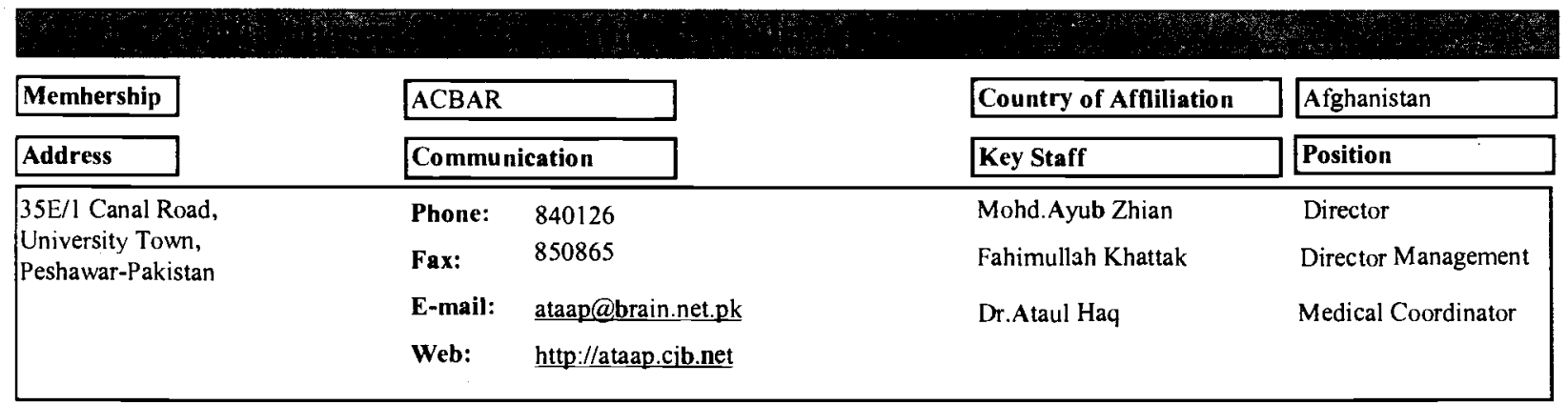

\begin{tabular}{|l|}
\hline Afghan \\
\hline Pakistani \\
\hline Expatriates \\
\hline Total \\
\hline
\end{tabular}

106
2
0
108

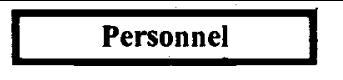

\begin{tabular}{|c|c|c|c|c|c|}
\hline \multirow[t]{3}{*}{ Total } & \multirow{2}{*}{\multicolumn{2}{|c|}{108}} & \multirow[b]{2}{*}{ Budget In US S } & Total & \multirow[b]{3}{*}{2002} \\
\hline & & & & & \\
\hline & 1998 & 1999 & 2000 & 2001 & \\
\hline Afghanistan & 120,000 & 200,000 & 170,000 & 170,000 & 170,000 \\
\hline Pakistan & 0 & 0 & 0 & 0 & 0 \\
\hline Total & $\overline{120,000.00}$ & $200,000.00$ & $170,000.00$ & $170,000.00$ & $170,000.00$ \\
\hline
\end{tabular}
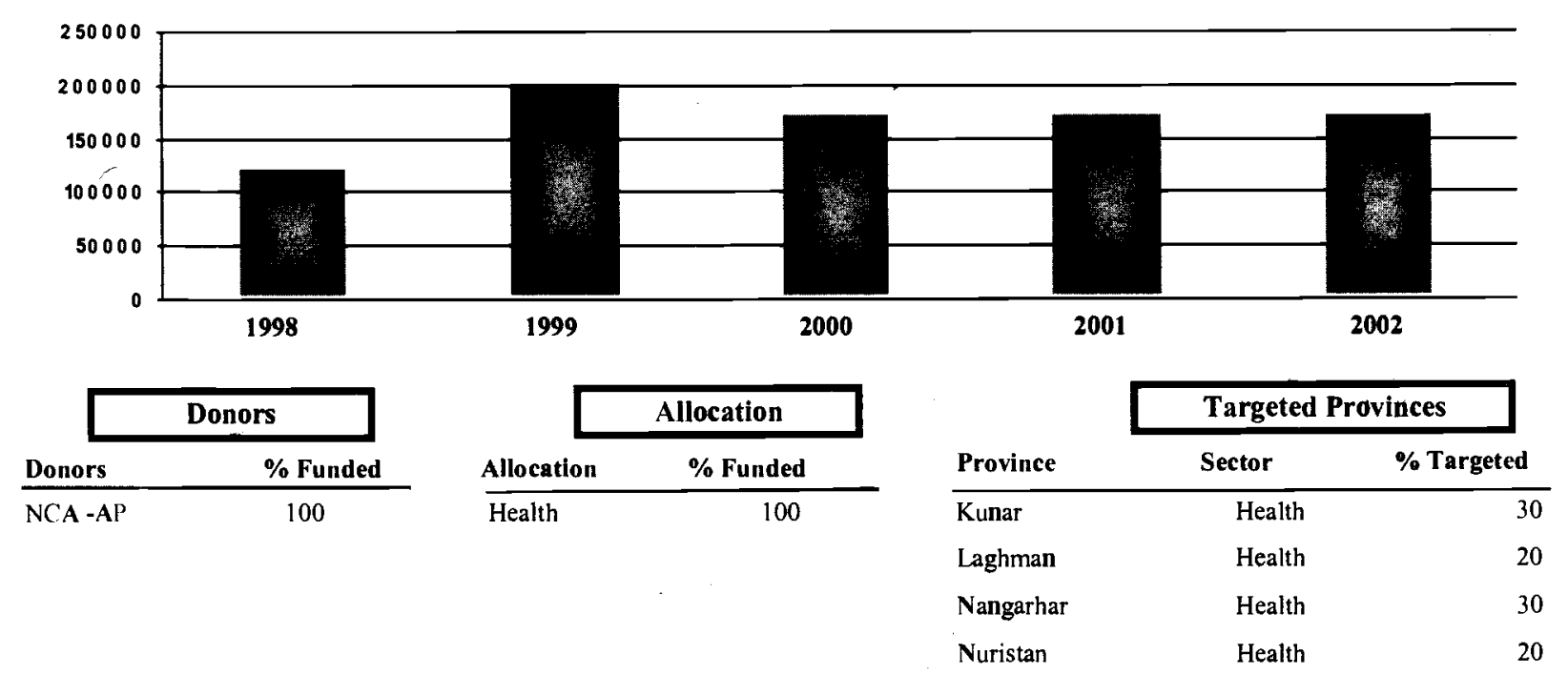

Sub Offices

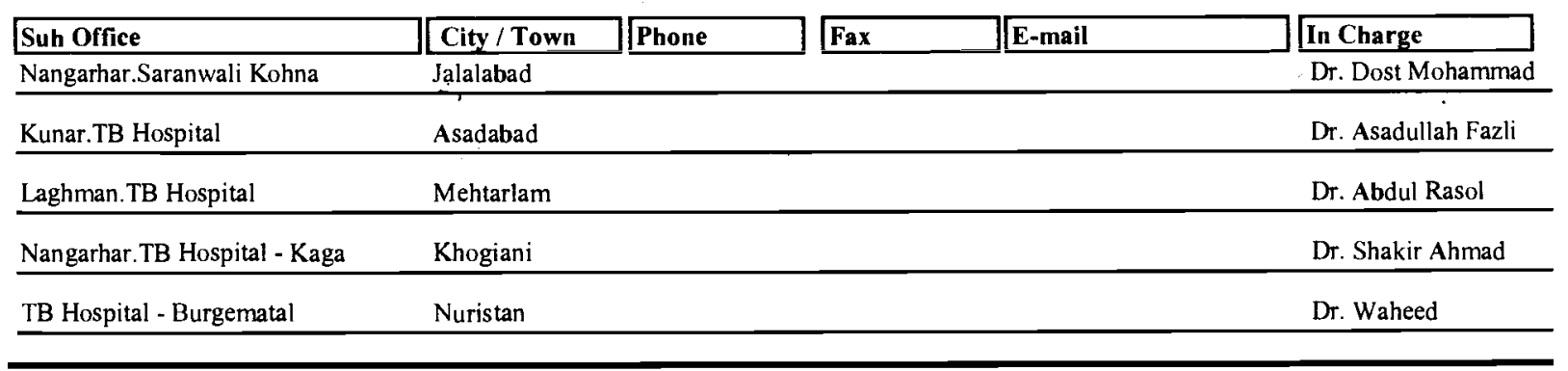




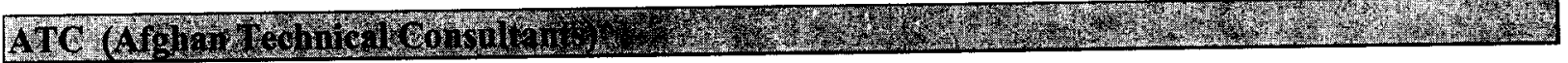

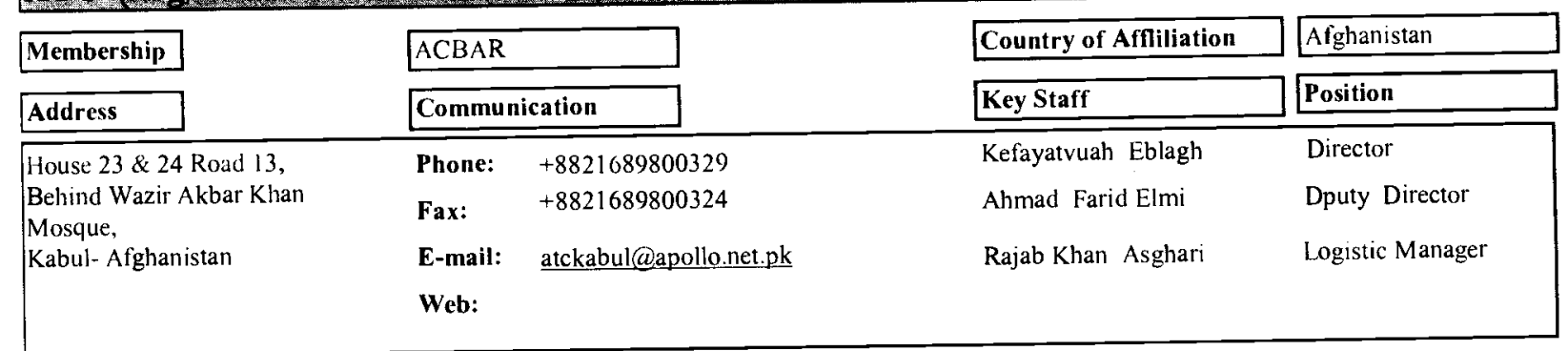

\begin{tabular}{|c|c|c|c|c|c|}
\hline & & & Personnel & & \\
\hline Afghan & \multicolumn{2}{|c|}{1245} & & Administrative & 262 \\
\hline Pakistani & \multicolumn{2}{|c|}{0} & & Support & 983 \\
\hline Expatriates & \multicolumn{2}{|c|}{0} & & Technical & 0 \\
\hline \multirow[t]{3}{*}{ Total } & \multirow{2}{*}{\multicolumn{2}{|c|}{1245}} & & Total & 1245 \\
\hline & & & Budget In US \$ & & \\
\hline & 1998 & 1999 & 2000 & 2001 & 2002 \\
\hline Afghanistan & $3,362,588$ & $4,792,386$ & $2,267,938$ & $4,579,654$ & \\
\hline Pakistan & 0 & 0 & 0 & 0 & \\
\hline Total & $3,362,588.00$ & $4,792,386.00$ & $2,267,938.00$ & $4,579,654.00$ & \\
\hline
\end{tabular}
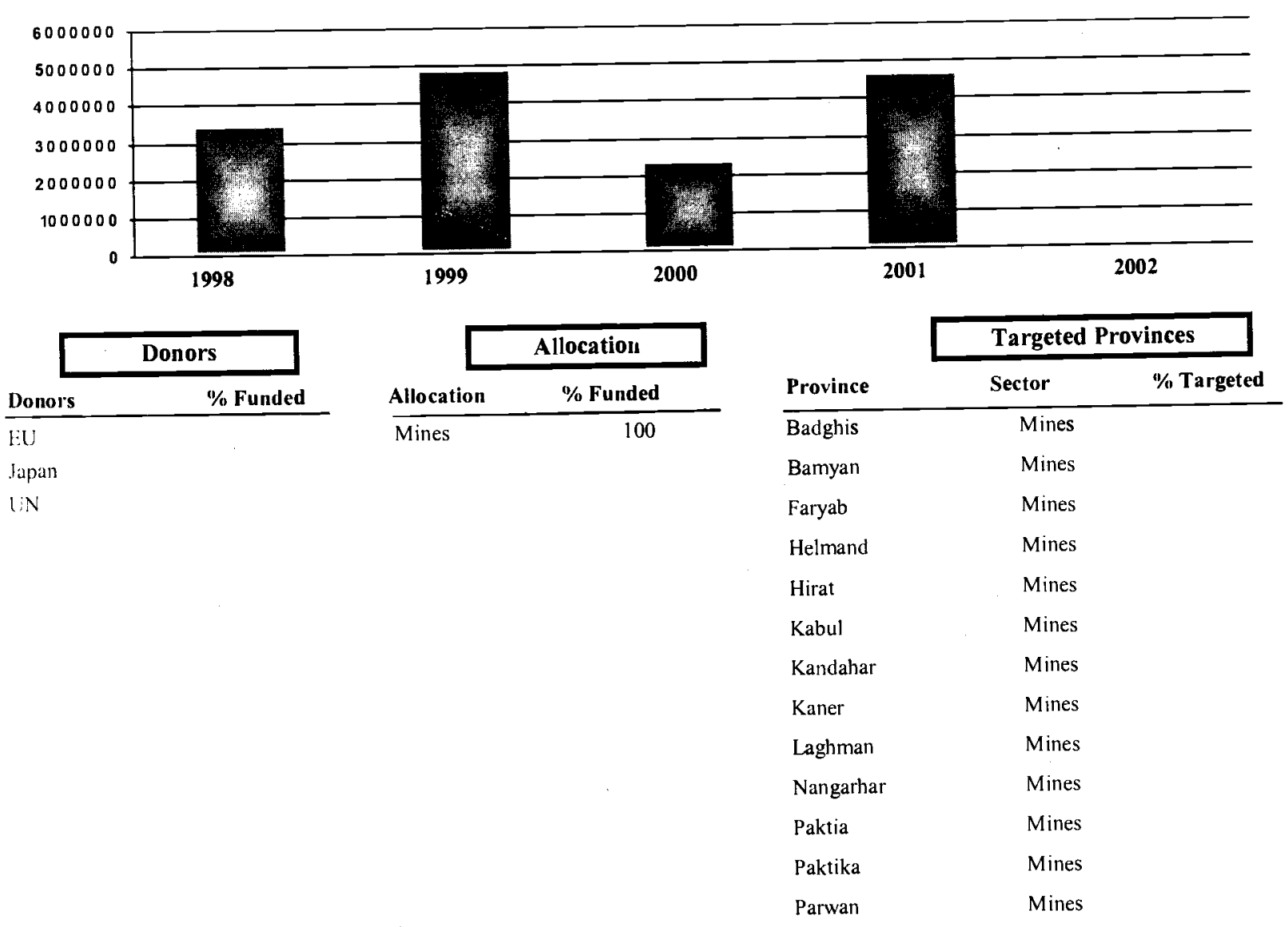

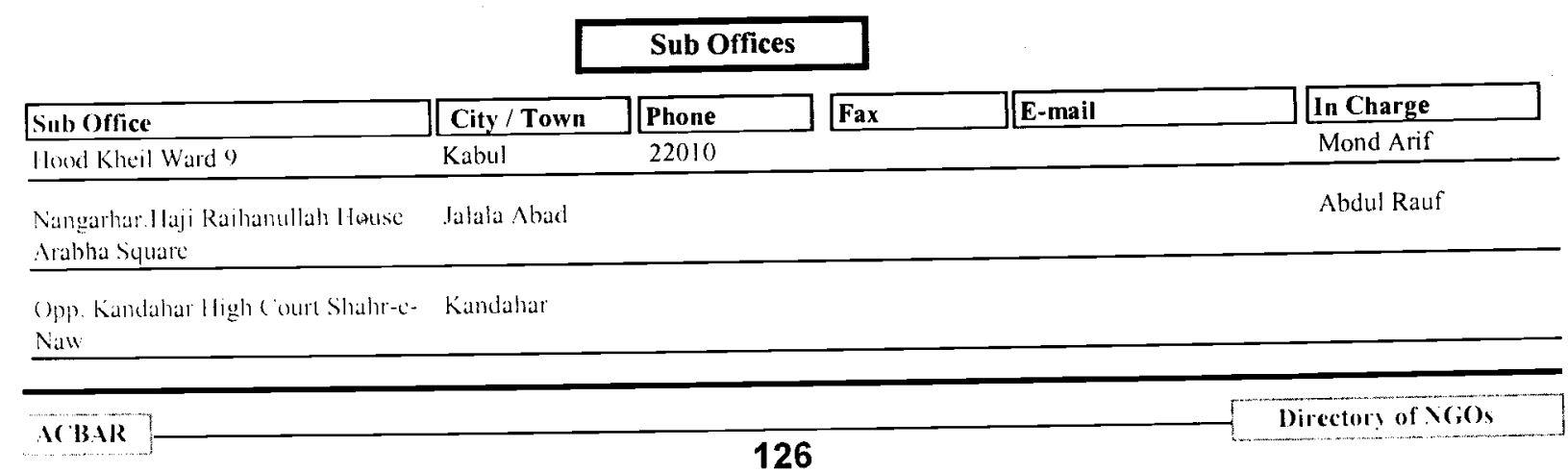




\begin{tabular}{|c|c|c|c|}
\hline Membership & & Country of Affiliation & TURKEY \\
\hline Address & Communication & Key Staff & Position \\
\hline \multirow{4}{*}{$\begin{array}{l}\text { Maiwand Road, } \\
\text { Cinema Pamir 9th Floor, } \\
\text { Kabul-Afghanistan }\end{array}$} & $2100722 / 070283732$ & Feti Karakoc & Advisor \\
\hline & Fax: & Hafiz & Field Officer \\
\hline & fkarakoc@hotmail.com & & \\
\hline & Web: & & \\
\hline
\end{tabular}

\begin{tabular}{|r|r|}
\hline Afghan & 74 \\
\hline Pakistani & 0 \\
\hline Expatriates & 42 \\
\hline Total & 116 \\
\hline
\end{tabular}

Personnel

\begin{tabular}{|c|c|c|c|c|c|}
\hline & - & & Budget In US S & & \\
\hline & 1998 & 1999 & 2000 & 2001 & 2002 \\
\hline Afghanistan & 350,394 & 550,117 & 584,094 & 378,000 & 790,000 \\
\hline Pakistan & 0 & 0 & 0 & 0 & 0 \\
\hline Total & $350,394.00$ & $550,117.00$ & $584,094.00$ & $378,000.00$ & $790,000.0$ \\
\hline
\end{tabular}
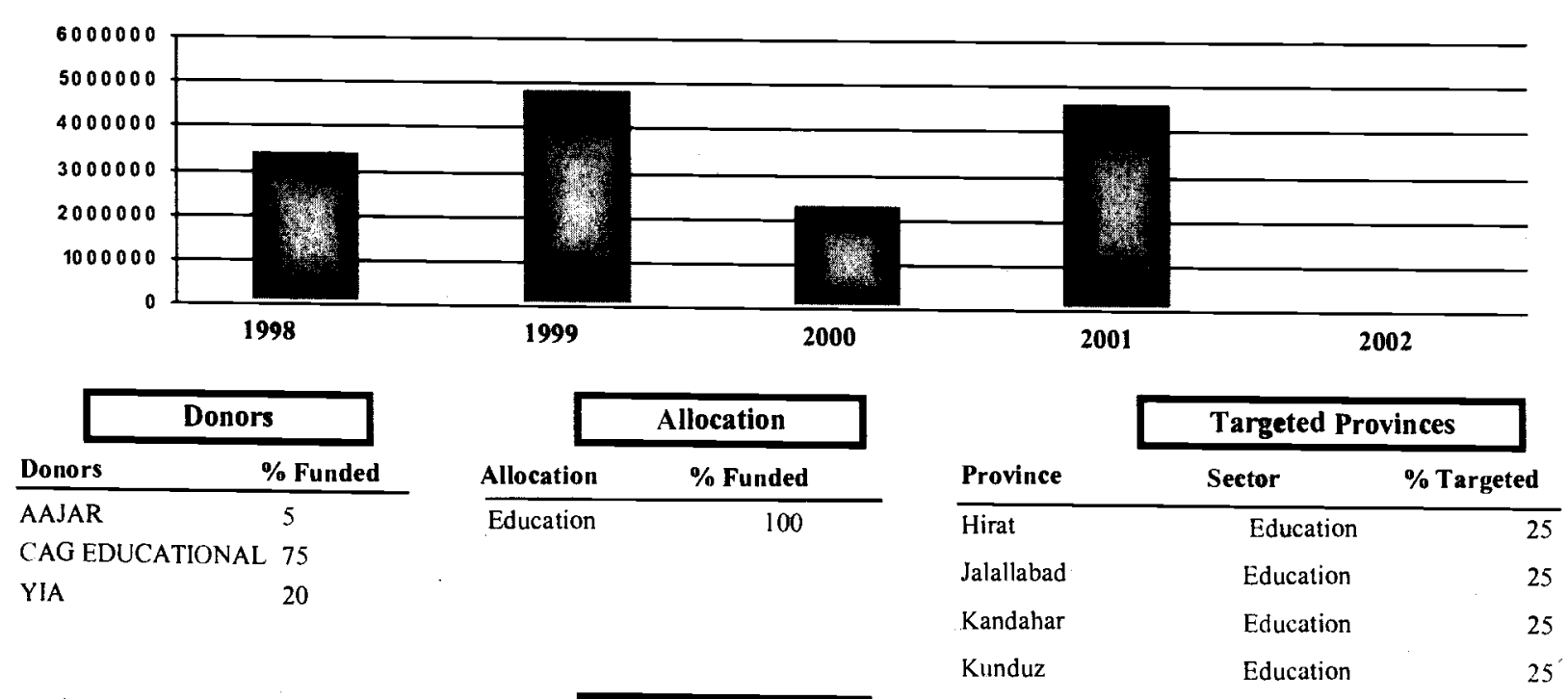

\begin{tabular}{|c|c|c|c|c|c|}
\hline & \multirow{2}{*}{ Sub Offices } & & \multirow{2}{*}{ and } \\
\hline & & & & & \\
\hline Sub Office & City / Town & Phone & Fax & E-mail & In Charge \\
\hline $\begin{array}{l}\text { Balkh.5-Storey Buliding Opposite } \\
\text { of Balkh University }\end{array}$ & Mazar & 0087076318787 & & & Bilal Bey \\
\hline $\begin{array}{l}\text { Jawzjan.Lise -I Afghan Turk } \\
\text { Tasaddi - Gas }\end{array}$ & Shibirghan & 2100724 & & & Orhan Bey \\
\hline Lise -1 Ahmad Shah Baba & Kandahar & 2100613 & & & Ah.Kadir Bey \\
\hline Shah DU Shamsheer Lise - Ariana & Kabul & 0090505568990 & & & Resil Kocman \\
\hline
\end{tabular}




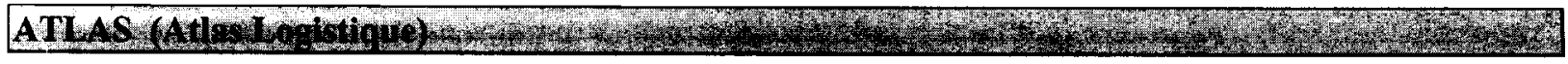

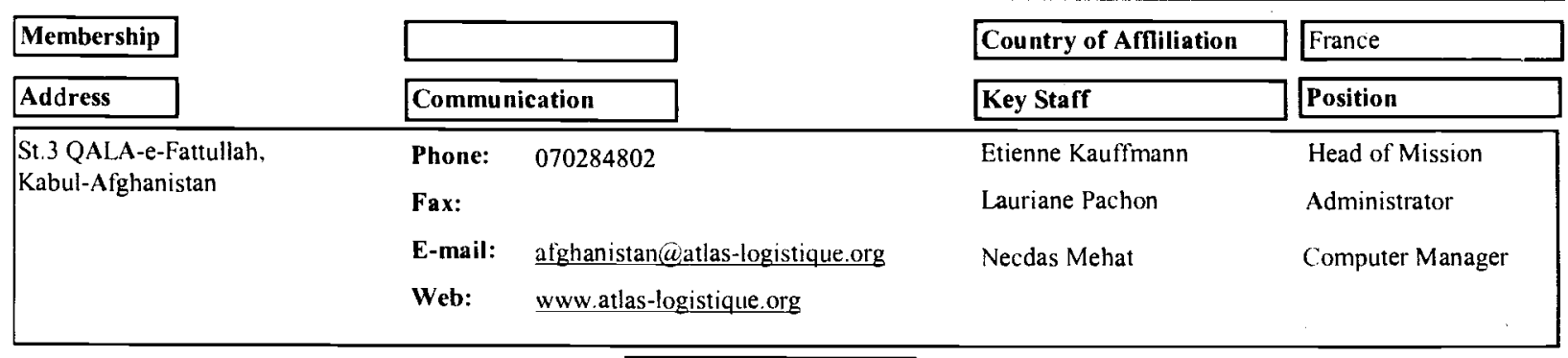

\begin{tabular}{|c|c|c|c|c|c|c|}
\hline & & & Personnel & & & \\
\hline Afghan & & 0 & & Administrative & & 0 \\
\hline Pakistani & & 0 & & Support & & 0 \\
\hline Expatriates & & 4 & & Technical & & 4 \\
\hline Total & & 4 & & Total & & 4 \\
\hline & & & Budget In US \$ & & & \\
\hline & 1998 & 1999 & 2000 & 2001 & 2002 & \\
\hline
\end{tabular}

\begin{tabular}{|l|l|l}
\hline Afghanistan \\
\hline Pakistan \\
\hline Total
\end{tabular}

1998

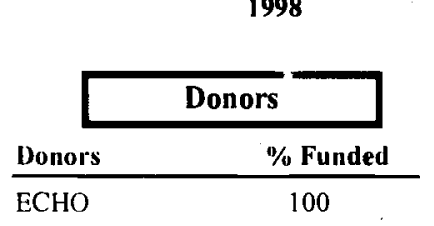

1999

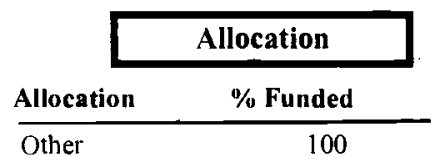

2001

2002

\section{Sub Offices}

\begin{tabular}{|c|c|c|c|c|c|}
\hline$\overline{\text { Sub Offic }}$ & City / Town & Phone & Fax & E-mail & In Charge \\
\hline $\begin{array}{l}\text { NWFP.5313 Park Avenue University } \\
\text { Town }\end{array}$ & Peshawar & $0300-9599975$ & 840389 & $\begin{array}{l}\text { pakistan@atlas- } \\
\text { logistique.org }\end{array}$ & Mr. Proechel \\
\hline
\end{tabular}




\begin{tabular}{|c|c|c|c|c|}
\hline Membership & \multicolumn{2}{|l|}{ Other } & Country of Affiliation & Afghanistan \\
\hline Address & \multicolumn{2}{|c|}{ Communication } & Key Staff & \begin{tabular}{|l} 
Position \\
\end{tabular} \\
\hline \multirow{4}{*}{$\begin{array}{l}\text { Hosue } 53 \text { J-1 St. } 11, \\
\text { Phase ll Hayatabad, } \\
\text { Peshawar - Pakistan }\end{array}$} & Phone: & 812259 & \multirow[t]{4}{*}{ Fatana Gailani } & \multirow[t]{4}{*}{ Director } \\
\hline & Fax: & 812138 & & \\
\hline & E-mail: & awc2@1 & & \\
\hline & Web: & www.af & & \\
\hline
\end{tabular}

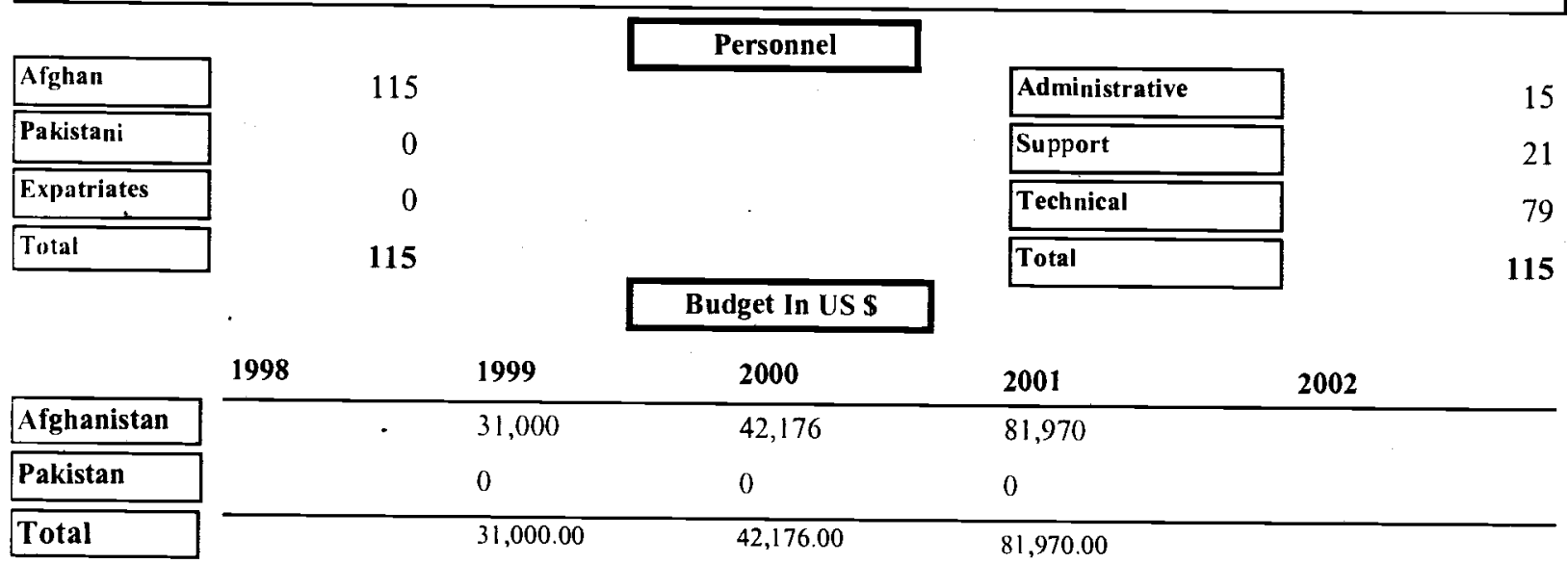
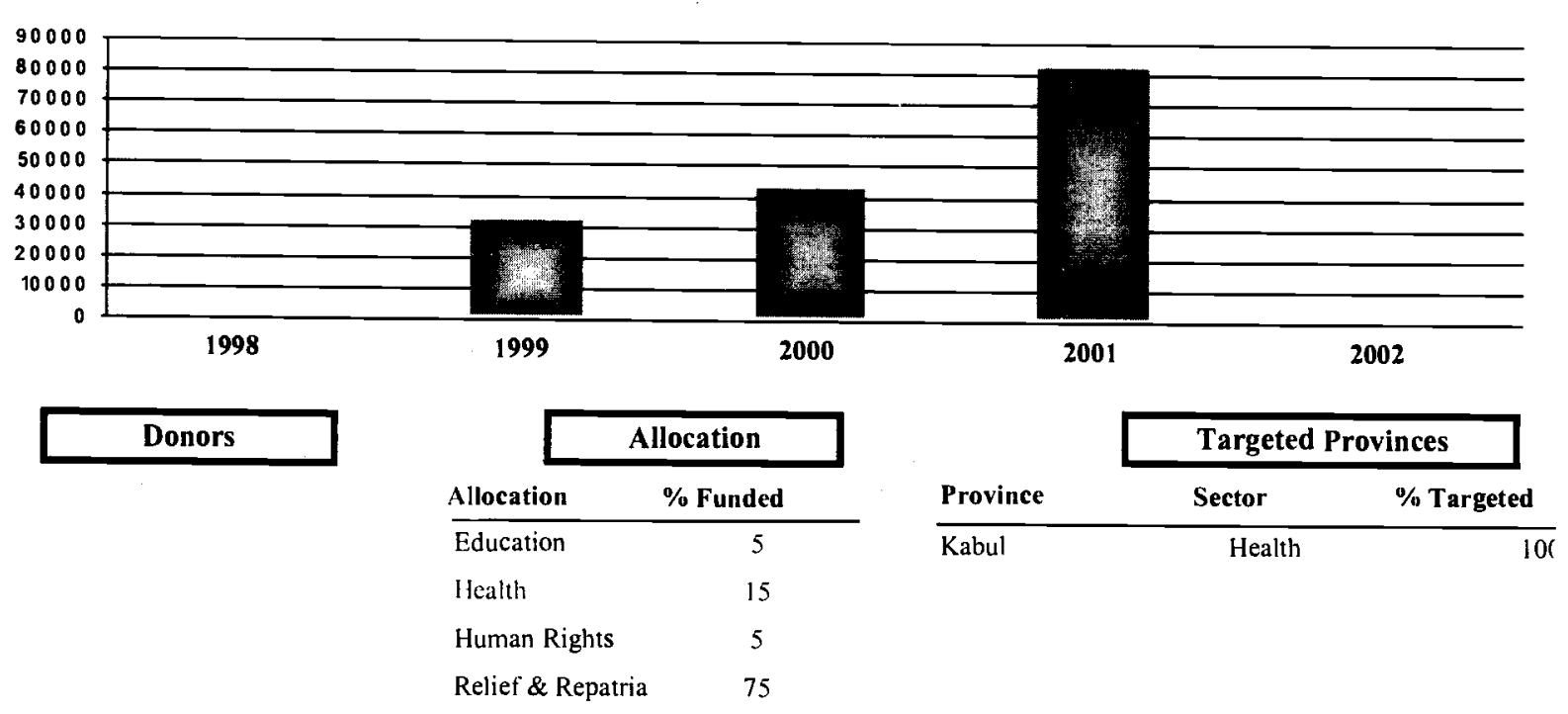

Sub Offices

\begin{tabular}{|c|c|c|c|c|c|}
\hline Sub Office & City / Town & Phone & Fax & E-mail & In Charge \\
\hline Qala-e-Fathullah & Kabul & & & & Muneer \\
\hline
\end{tabular}




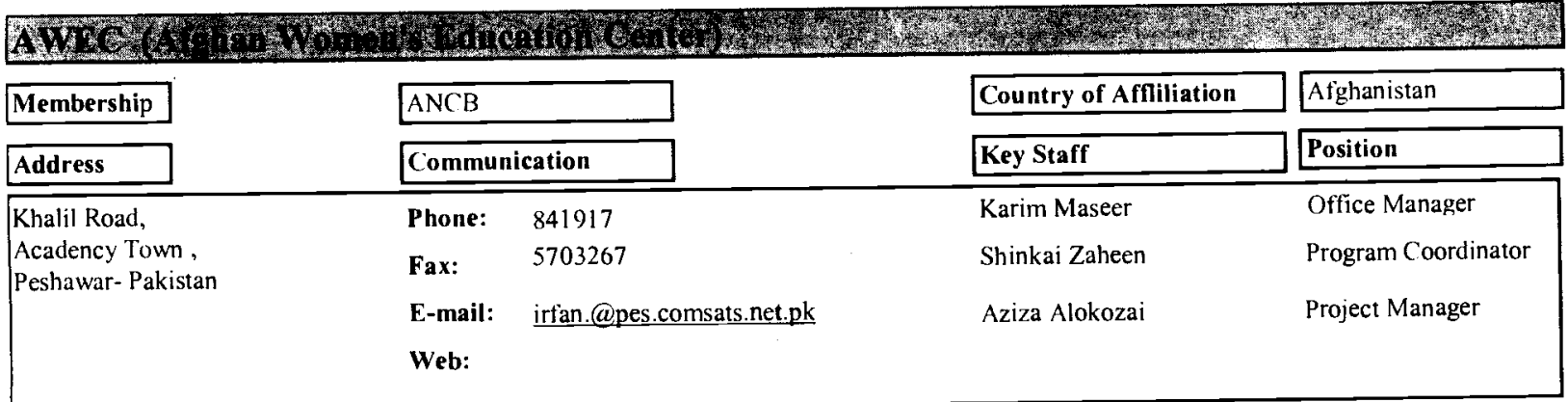

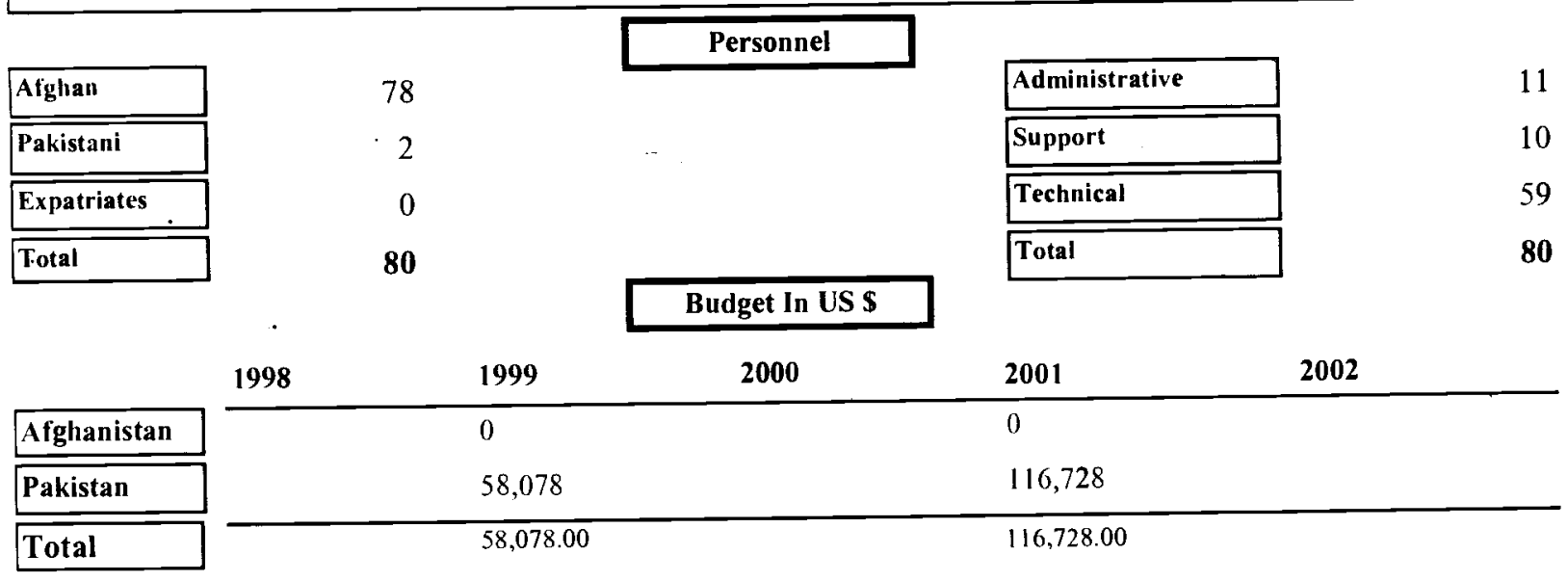

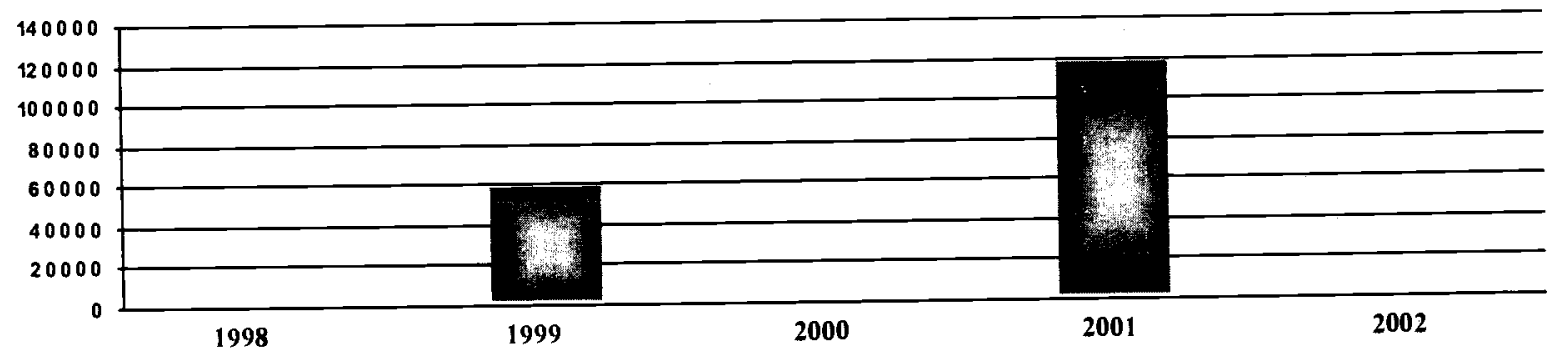

\begin{tabular}{|c|c|c|c|c|c|c|}
\hline \multicolumn{2}{|c|}{ Donors } & & location & \multirow[b]{2}{*}{ Province } & \multicolumn{2}{|l|}{ Targeted Provinces } \\
\hline Donors & $1 \%$ Funded & Allocation & $\%$ Funded & & $\%$ Targe & \\
\hline Canada Fund & 10 & Education & 50 & Kabul & Education & 90 \\
\hline Global Fund & 20 & Health & 10 & Kabul & Relief \& Repatriatioin & 4 \\
\hline Norwegion Govt. & 10 & Human Rights & 5 & Kabul & HRD & 1 \\
\hline Universalist & 20 & Income Generatio & 10 & Kabul & Education & 5 \\
\hline Women commision & 40 & Other & 15 & & & \\
\hline & & Relief \& Repatria & 10 & & & \\
\hline
\end{tabular}

Sub Offices 


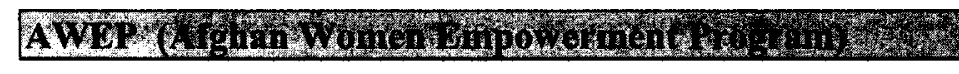

\begin{tabular}{|c|c|c|c|}
\hline Membership & ANCB & Country of Affliliation & Afghanistan \\
\hline Address & Communication & Key Staff & Position \\
\hline \multirow{4}{*}{$\begin{array}{l}\text { Jami Watt, House 288, } \\
\text { Shar-e- Now, } \\
\text { Kabul-Afghanistan }\end{array}$} & 070282056 & Jamila Zameer & Coordinator \\
\hline & Fax: & Nazeer Zameer & Office Manager \\
\hline & E-mail: & & \\
\hline & Web: & & \\
\hline
\end{tabular}

\begin{tabular}{|l|}
\hline Afghan \\
\hline \hline Pakistani \\
\hline Expatriates \\
\hline Total \\
\hline
\end{tabular}

\begin{tabular}{|l|l}
\hline Administrative \\
\hline Support \\
\hline Technical \\
\hline Total & 5 \\
\hline
\end{tabular}

Budget In US \$

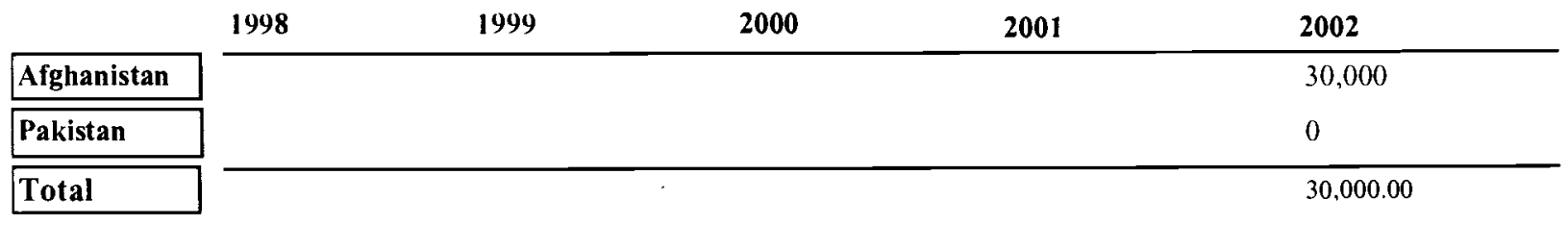

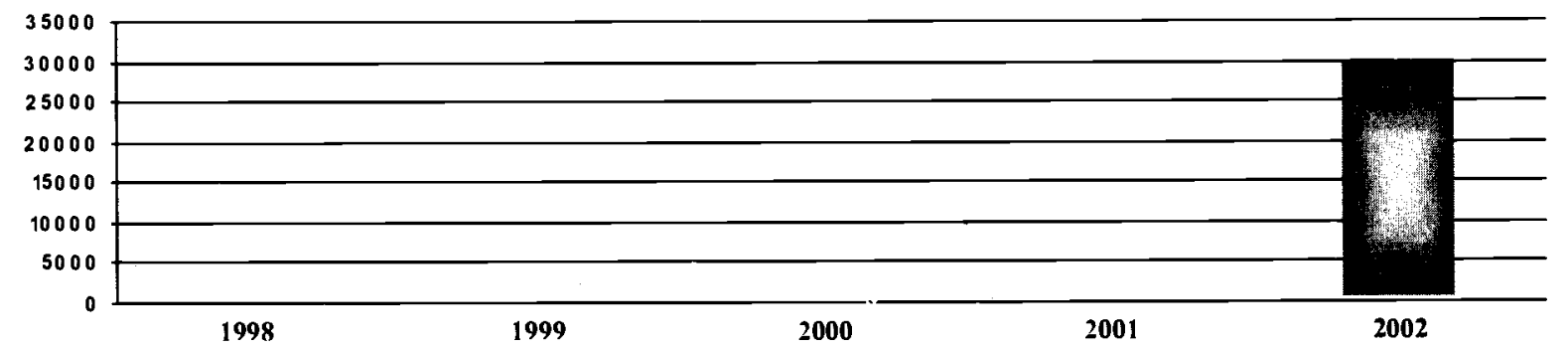

\begin{tabular}{|c|c|c|c|}
\hline \multicolumn{2}{|c|}{ Donors } & & Allocation \\
\hline Donors & $1 \%$ Funded & Allocation & $\%$ Funded \\
\hline GiTh & 100 & Education & 100 \\
\hline
\end{tabular}




\begin{tabular}{|c|c|c|c|c|}
\hline Membership & \multicolumn{2}{|l|}{ Other } & Country of Affiliation & Afghanistan \\
\hline Address & \multicolumn{2}{|c|}{ Communication } & Key Staff & Position \\
\hline \multirow{4}{*}{$\begin{array}{l}80 \text { Abdra Road, } \\
\text { University Town, } \\
\text { Peshawar-Pakistan }\end{array}$} & Phone: & $5704928 / 580670$ & Afifa Azim & Coodinator \\
\hline & & 2200691 & Shuk Haike Kazmi & Office Manager \\
\hline & E-mail: & awn $\omega$ brain.net.pk & Naeem Asghari & Master Trainer \\
\hline & Web: & & & \\
\hline
\end{tabular}

\begin{tabular}{|c|c|c|}
\hline & Personnel & \\
\hline Afghan & & Administrative \\
\hline Pakistani & & Support \\
\hline Expatriates & & Technical \\
\hline Total & & Total \\
\hline
\end{tabular}

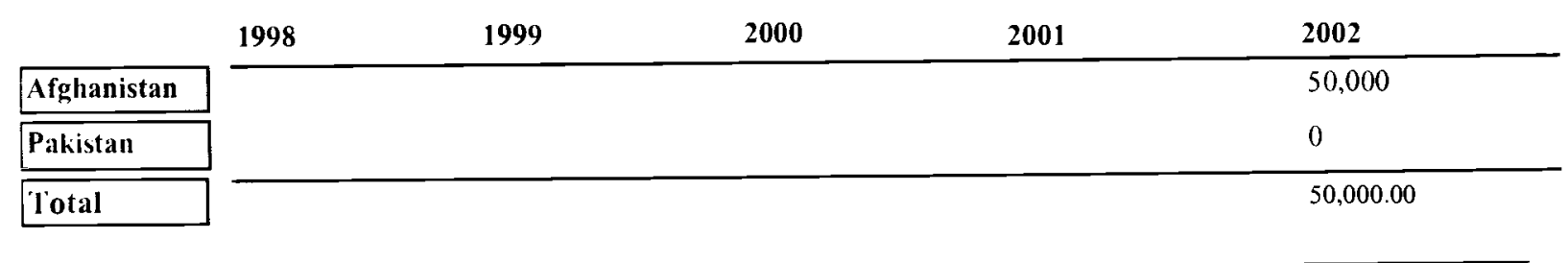

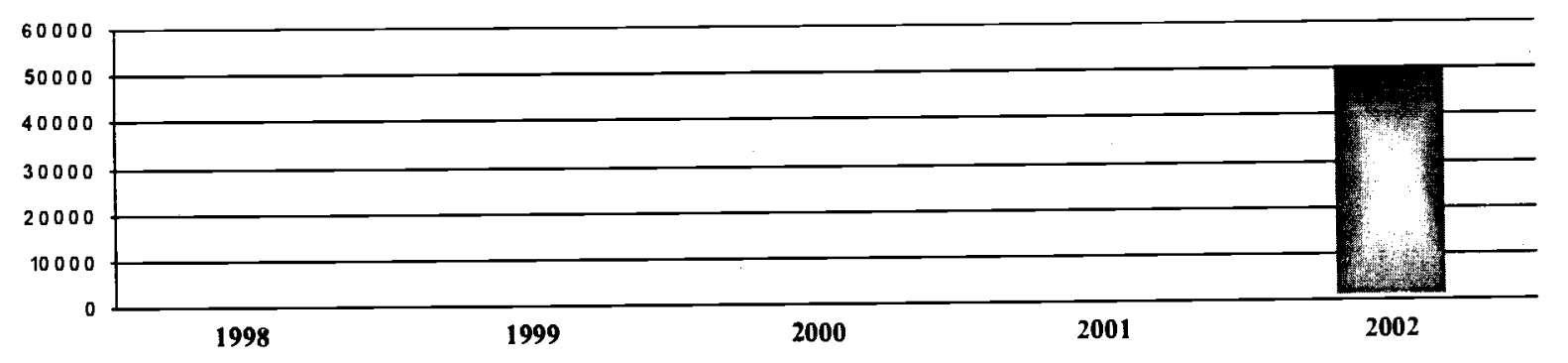

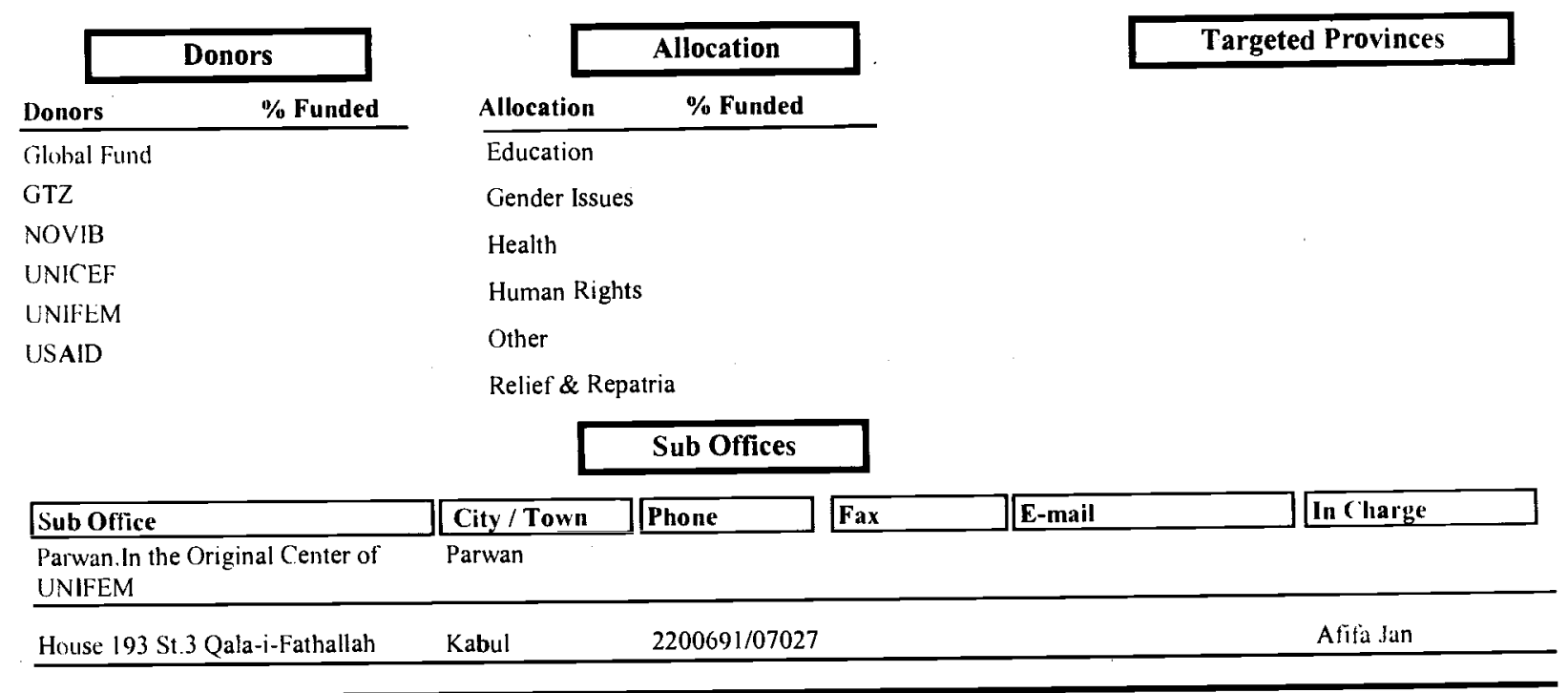




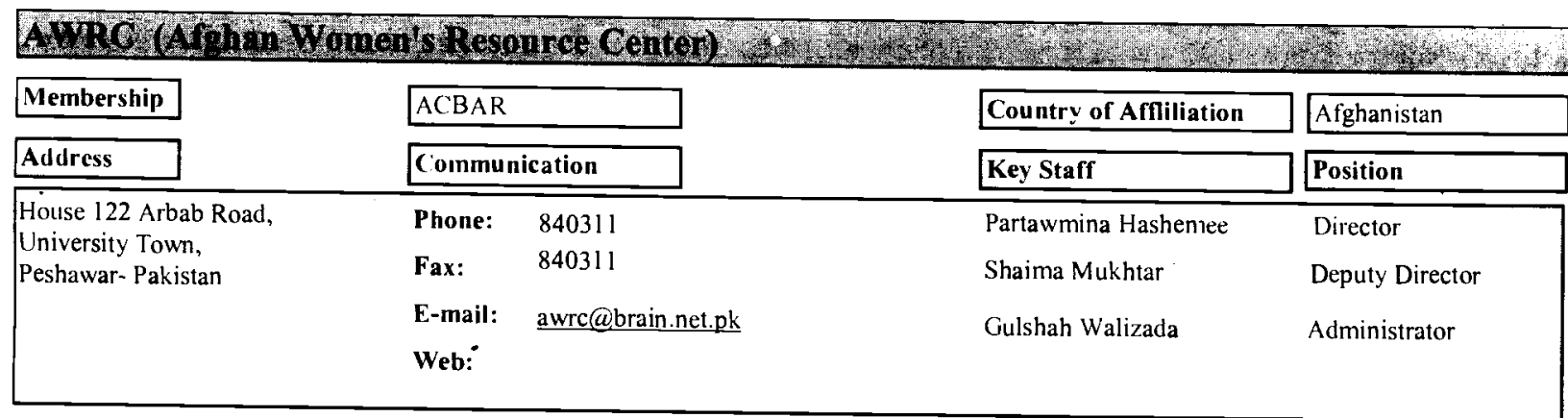

\begin{tabular}{|l|}
\hline Afghan \\
\hline Pakistani \\
\hline Expatriates \\
\hline Total \\
\hline
\end{tabular}

Personnel

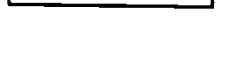

Budget In US \$

\begin{tabular}{|l|}
\hline Administrative \\
\hline Support \\
\hline Technical \\
\hline Total \\
\hline
\end{tabular}

\begin{tabular}{|c|c|c|c|c|c|}
\hline & 1998 & 1999 & 2000 & 2001 & 2002 \\
\hline Afghanistan & 0 & 0 & 0 & 0 & 26,300 \\
\hline Pakistan & 62,069 & 88,232 & 71,105 & 66,108 & 0 \\
\hline Total & $62,069.00$ & $88,232.00$ & $71,105.00$ & $66,108.00$ & $26,300.0$ \\
\hline
\end{tabular}
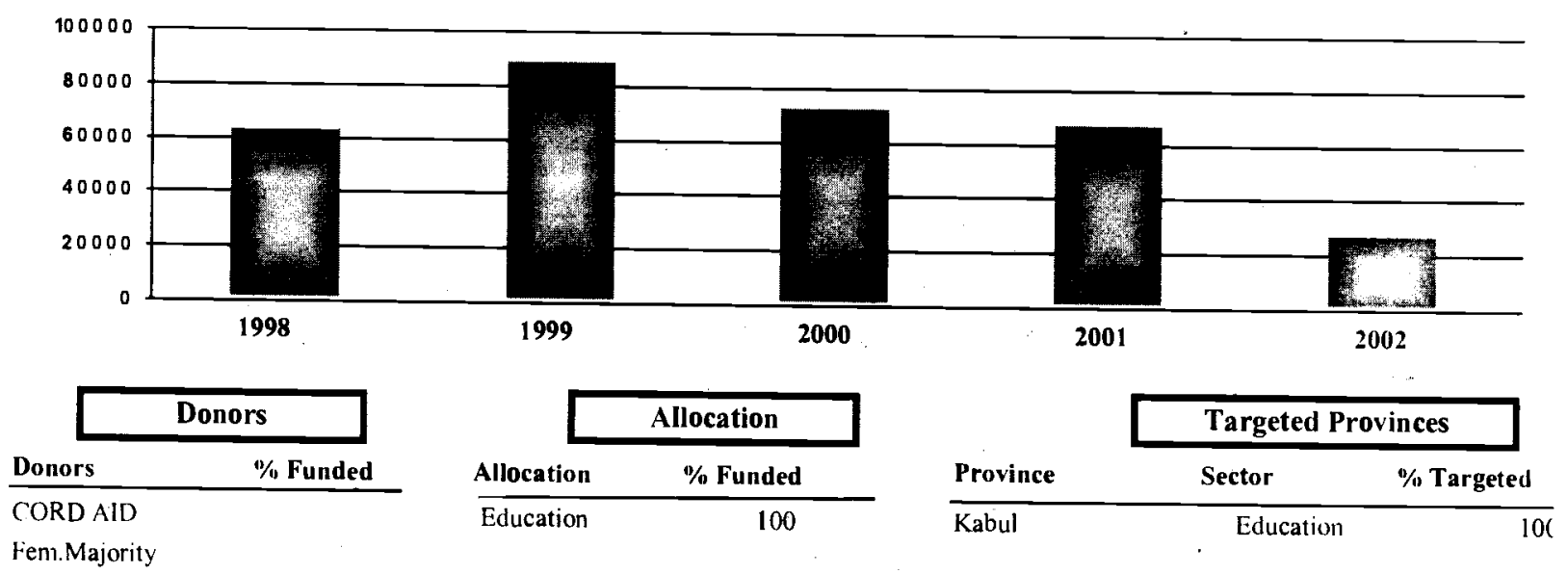

Globad Fund

H.BollFound.

IMC

Japan

W.for W.

\section{Snb Offices}

\begin{tabular}{|c|c|c|c|c|c|}
\hline Sub Office & City / Town & Phone & Fax & E-mail & In Charge' \\
\hline House 221 Street 2 Qalahefatallah & Kabul & & & 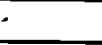 & Aziza Ahmadyar \\
\hline
\end{tabular}




\begin{tabular}{|c|c|c|c|}
\hline Membership & Other & Country of Affiliation & Afghanistan \\
\hline Address & Communication & Key Staff & Position \\
\hline \multirow{4}{*}{$\begin{array}{l}\text { Mazar-e-Sharif City, } \\
\text { Mazar-Afghanistan }\end{array}$} & Phone: & Akhtar Mohd. & Director \\
\hline & Fax: & Eng. Ali Mohd. & Technical Deputy \\
\hline & E-mail: & Samir & Adminstrator \\
\hline & Web: & & \\
\hline
\end{tabular}

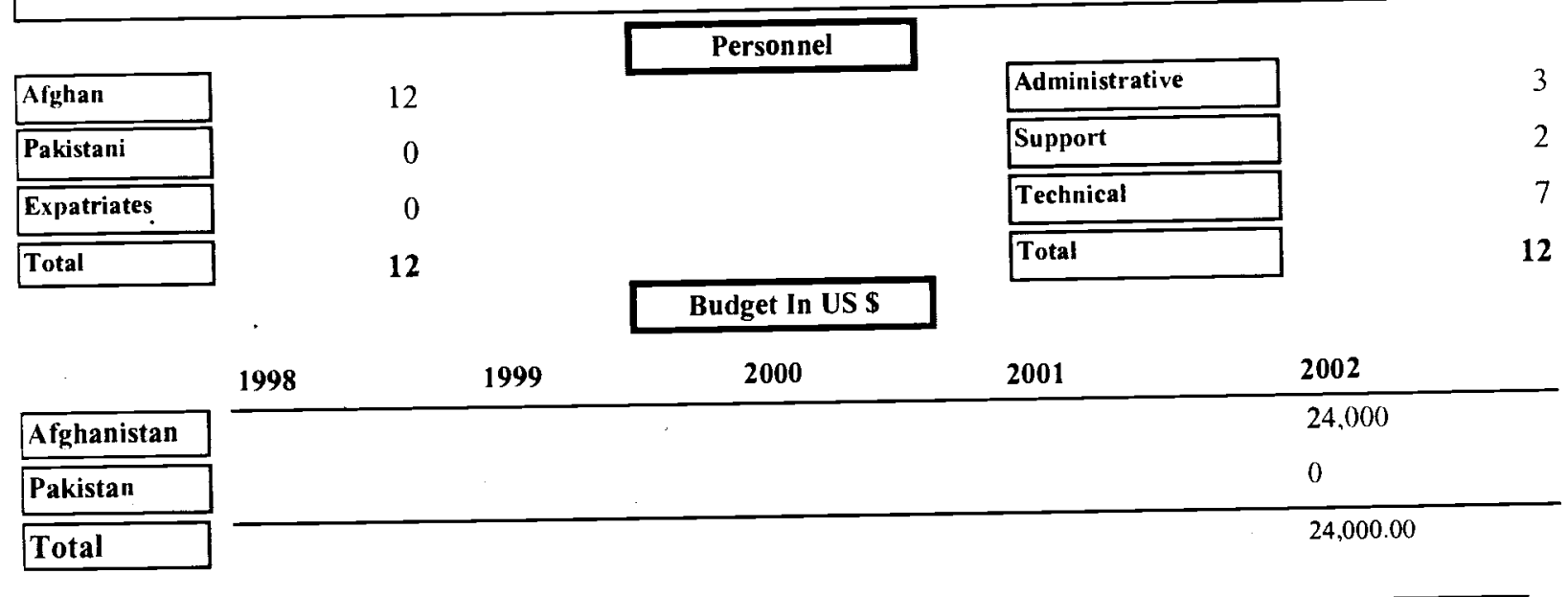
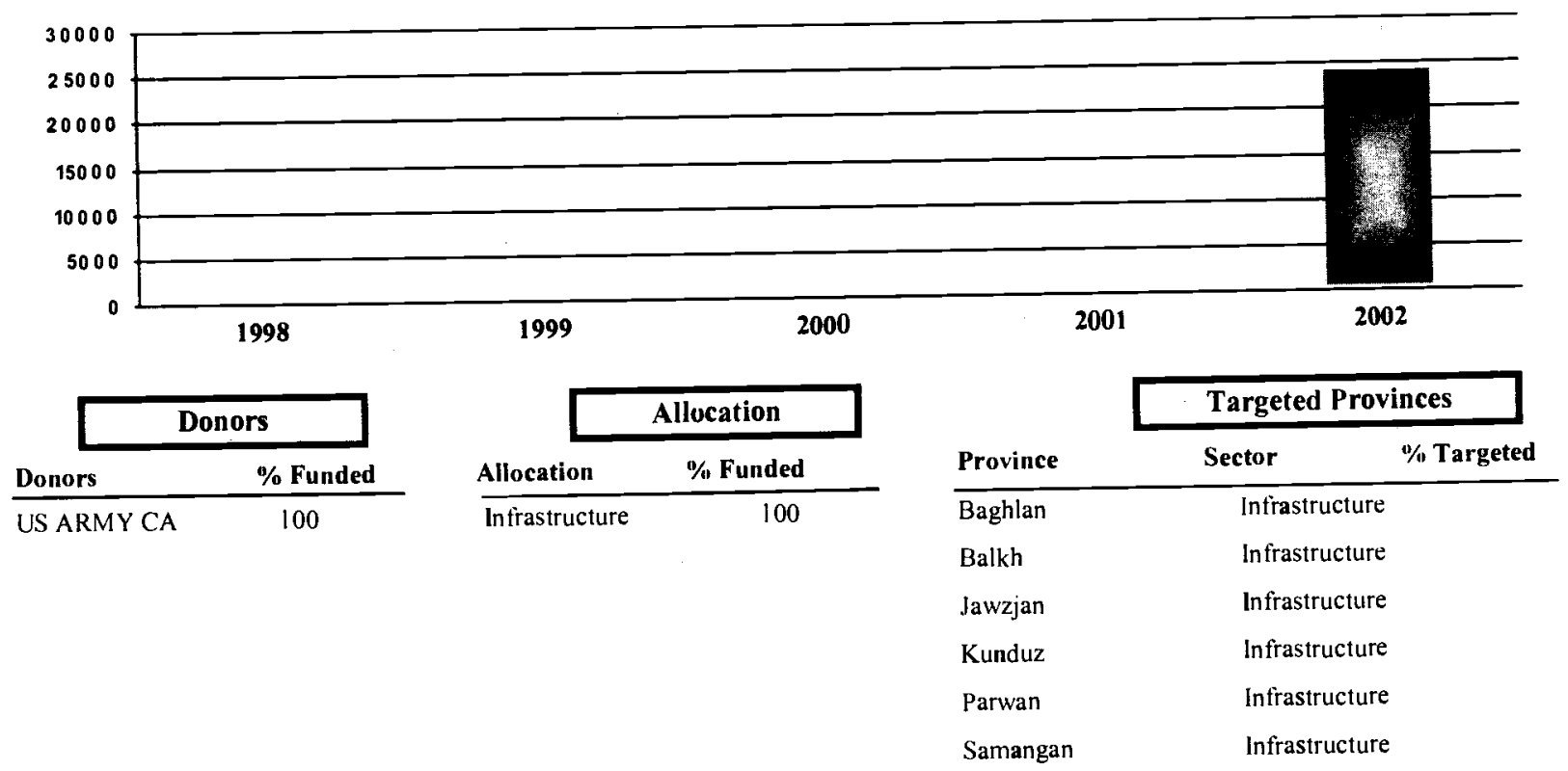

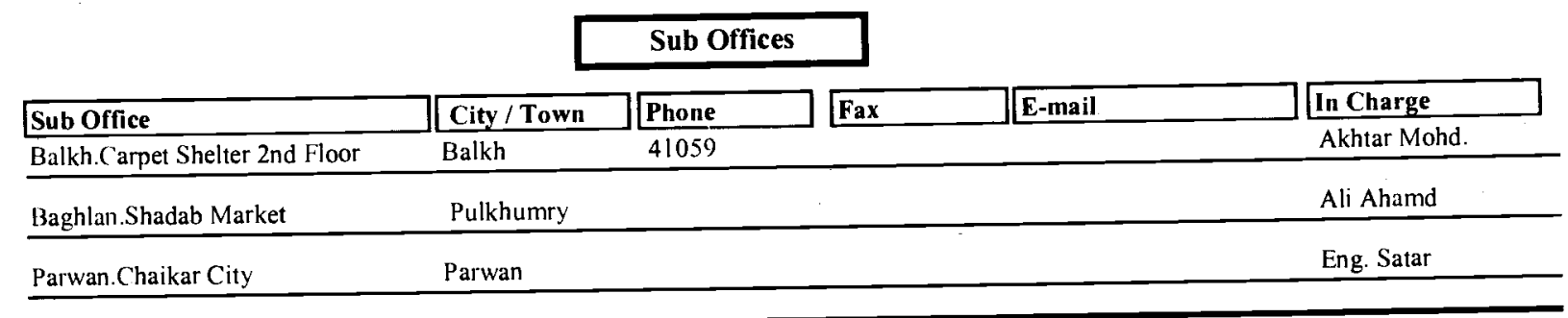




\begin{tabular}{|c|c|c|c|}
\hline Membership & $\mathrm{ANCB}$ & Country of Affliliation & Afghanistan \\
\hline Address & Communication & Key Staff & Position \\
\hline \multirow{3}{*}{$\begin{array}{l}\text { Shahr-e- Now, } \\
\text { Flowers Street 2nd Floor, } \\
\text { Kabul-Afghanistan }\end{array}$} & $33308 / 070280337$ & Abdullah Arghandiwal & Director \\
\hline & Fax: & Fatah Roshangar & Writer \& Journalist \\
\hline & $\begin{array}{l}\text { E-mail: brr@pes.comsats.net.pk } \\
\text { Web: }\end{array}$ & M. Zatar & Engineer \\
\hline
\end{tabular}

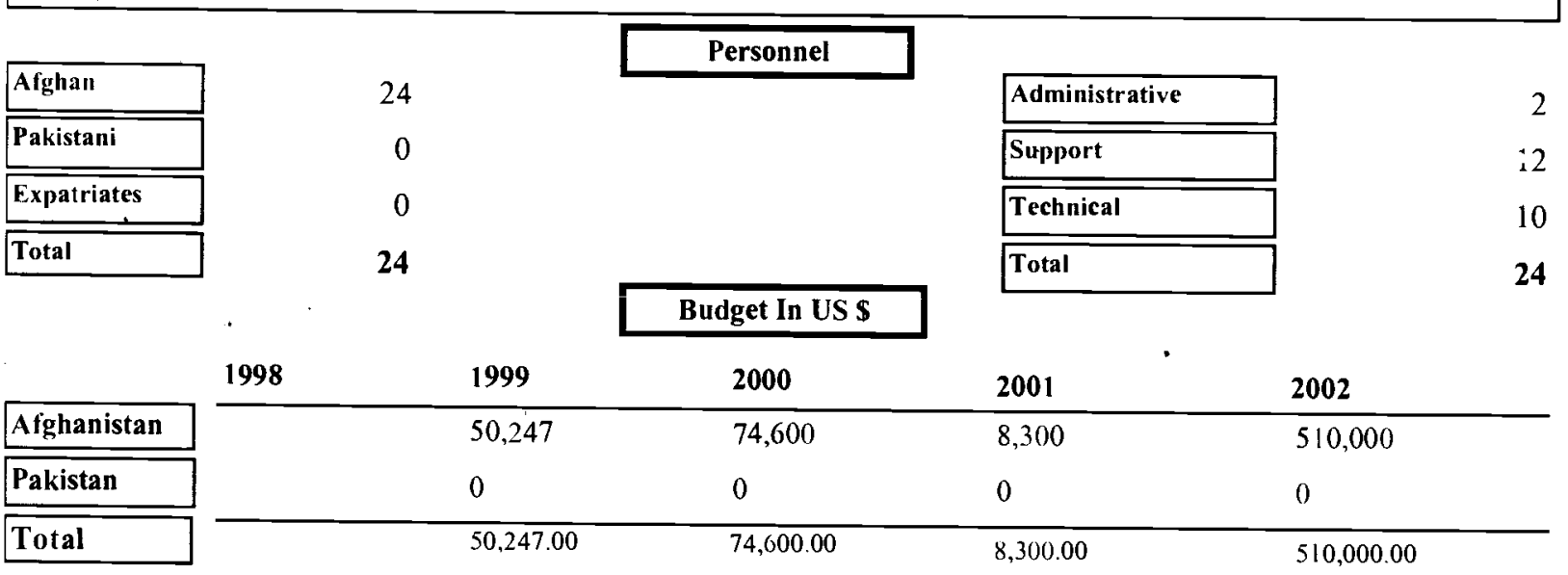

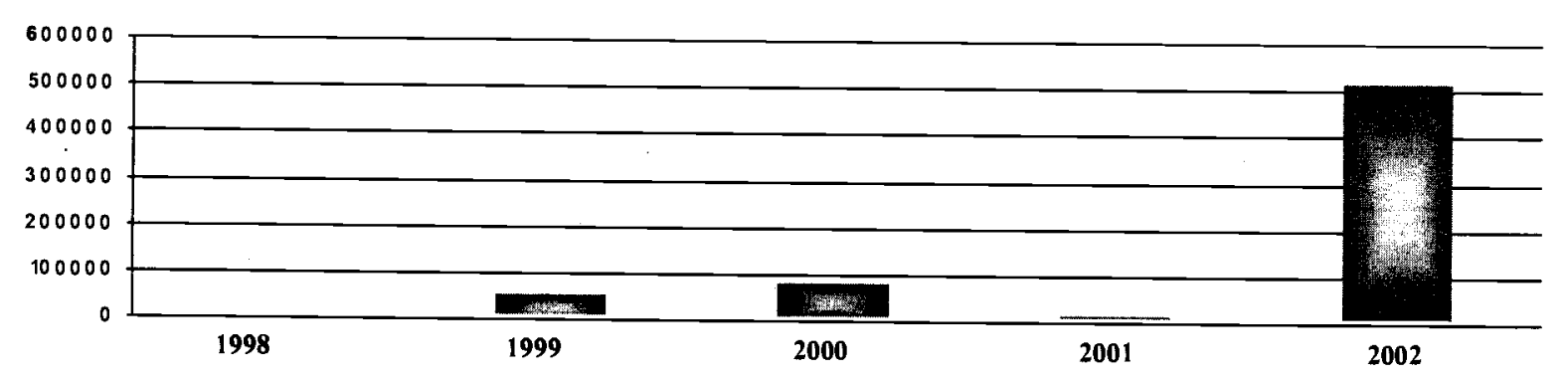

\begin{tabular}{|c|c|c|c|c|c|c|c|}
\hline \multicolumn{2}{|c|}{ Donors } & & location & \multirow[b]{2}{*}{ Province } & \multicolumn{3}{|c|}{ Targeted Provinces } \\
\hline Donors & $\%$ Funded & Allocation & \% Funded & & Sector & $\%$ Target & \\
\hline SDC & 10 & Infrastructure & 100 & Kabul & Infra & & 60 \\
\hline UNHCR & 90 & Other & 100 & Parwan & Relie & triatioin & 40 \\
\hline
\end{tabular}

\section{Sub Offices}

\begin{tabular}{|c|c|c|c|c|c|}
\hline Sub Office & City / Town & \begin{tabular}{|l} 
Phone \\
\end{tabular} & Fax & E-mail & In Charge \\
\hline $\begin{array}{l}\text { NWFP.2nd Floor Room } 219 \text { Gul- } \\
\text { Haji Plaza }\end{array}$ & Peshawar & 5703861 & & BRR@Pes.net.pk & $\mathrm{Ab}$.Ghafor Mirwais \\
\hline
\end{tabular}




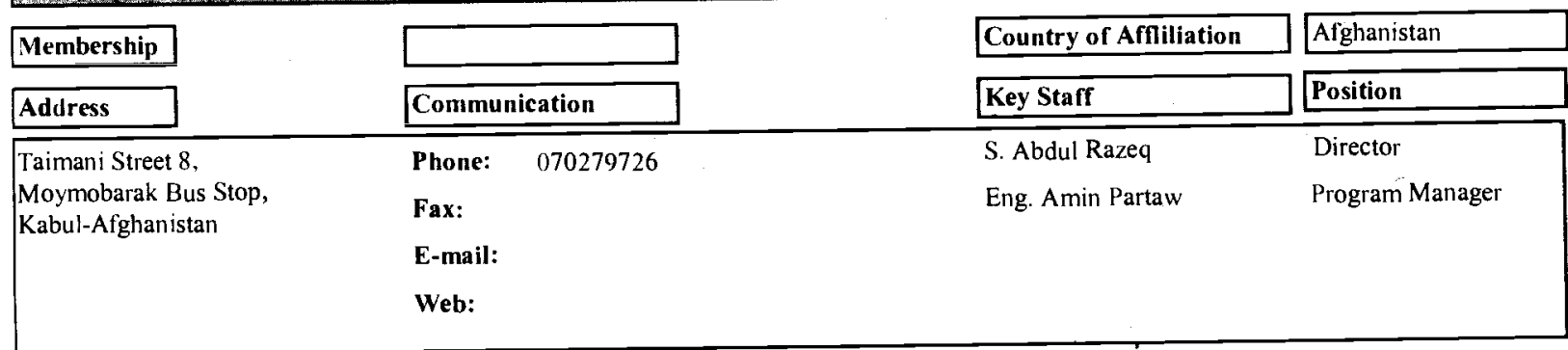

\begin{tabular}{|c|c|c|c|c|c|c|}
\hline & & & Personnel & & & \\
\hline Afghan & & & & Administrative & & 8 \\
\hline Pakistani & & & & Support & & 15 \\
\hline Expatriates & & & & Technical & & 6 \\
\hline \multirow[t]{3}{*}{ Total } & & & & Total & & 29 \\
\hline & . & & Budget In US S & & & \\
\hline & 1998 & 1999 & 2000 & 2001 & \multicolumn{2}{|l|}{2002} \\
\hline Afghanistan & & & & 10,000 & 19,986 & \\
\hline Pakistan & & & & 0 & 0 & \\
\hline Total & & & & $10,000.00$ & $19,980.00$ & \\
\hline
\end{tabular}

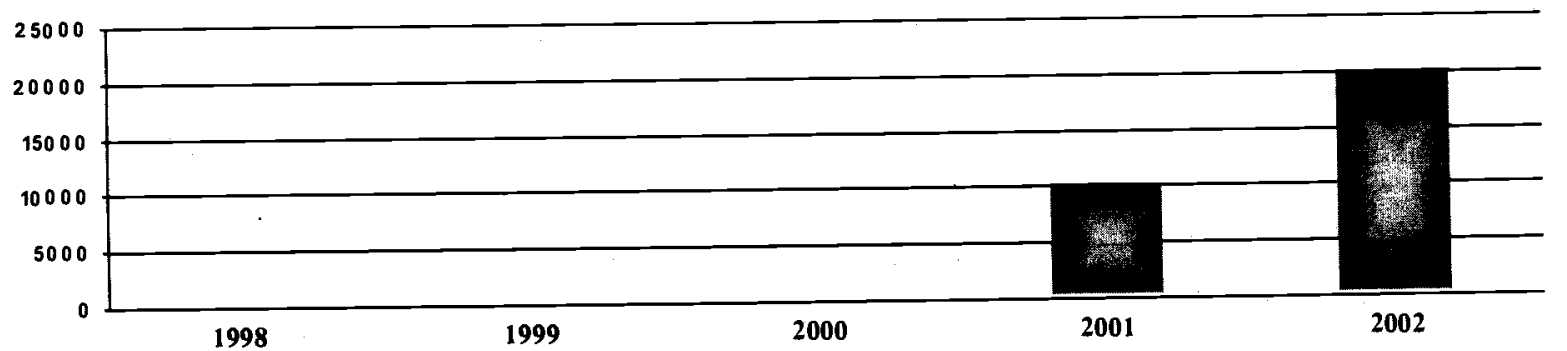

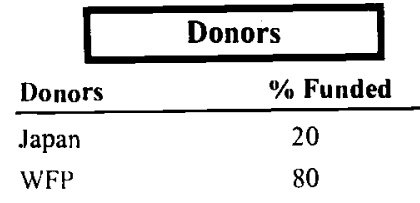

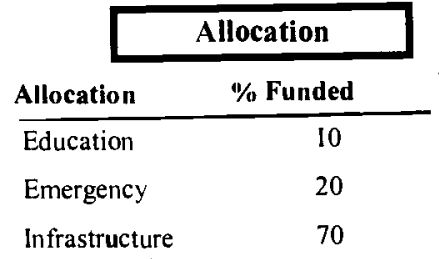

Sub Offices

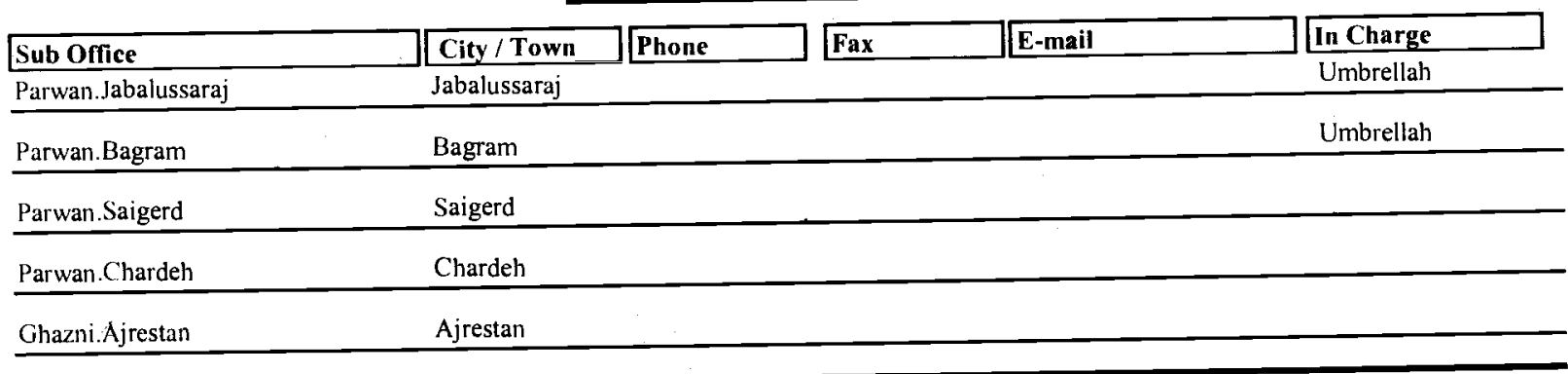




\begin{tabular}{|c|c|c|c|}
\hline Membership & Other & Country of Affiliation & USA \\
\hline Address & Communication & Key Staff & Position \\
\hline \multirow{4}{*}{$\begin{array}{l}\text { Karta-e-Bukhdi, } \\
\text { lst Street, } \\
\text { Mazar-Afghanistan }\end{array}$} & Phone: & Rob Graves & Regional Director \\
\hline & Fax: & John Montanuti & Office Manager \\
\hline & E-mail: robgraves@mail .com & Rasool Yazdangul & Program Manager \\
\hline & Web: & & \\
\hline
\end{tabular}

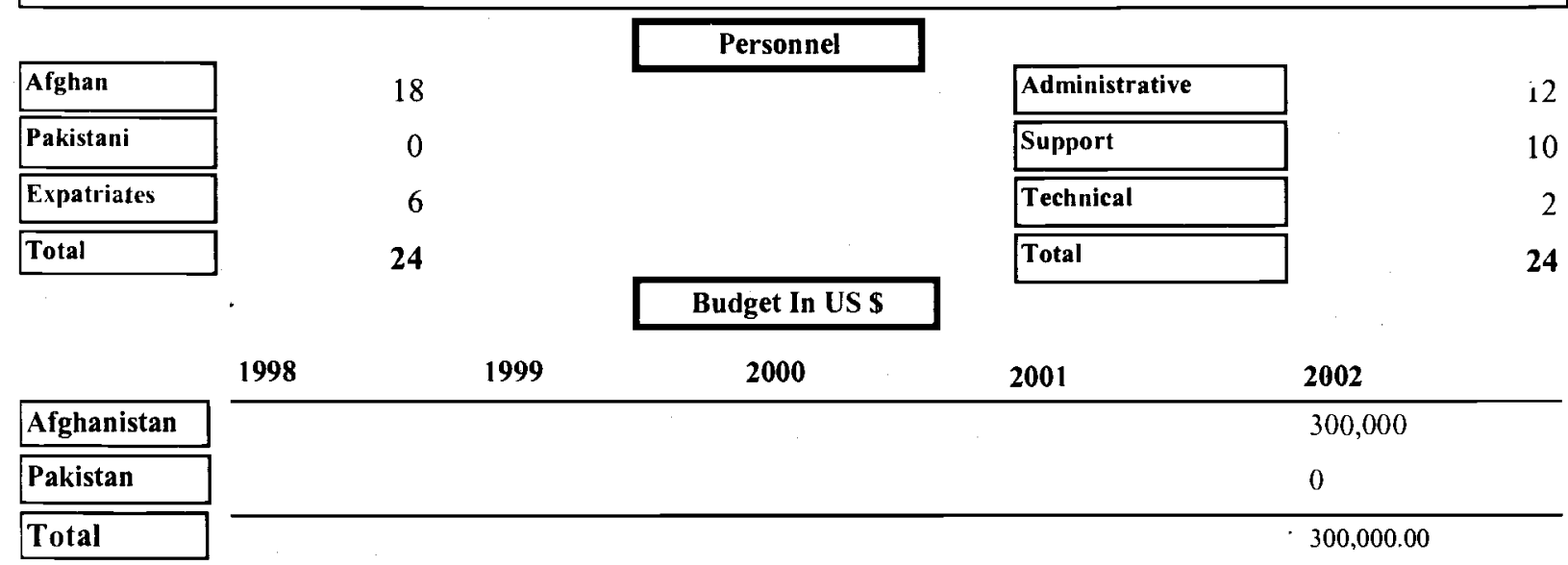

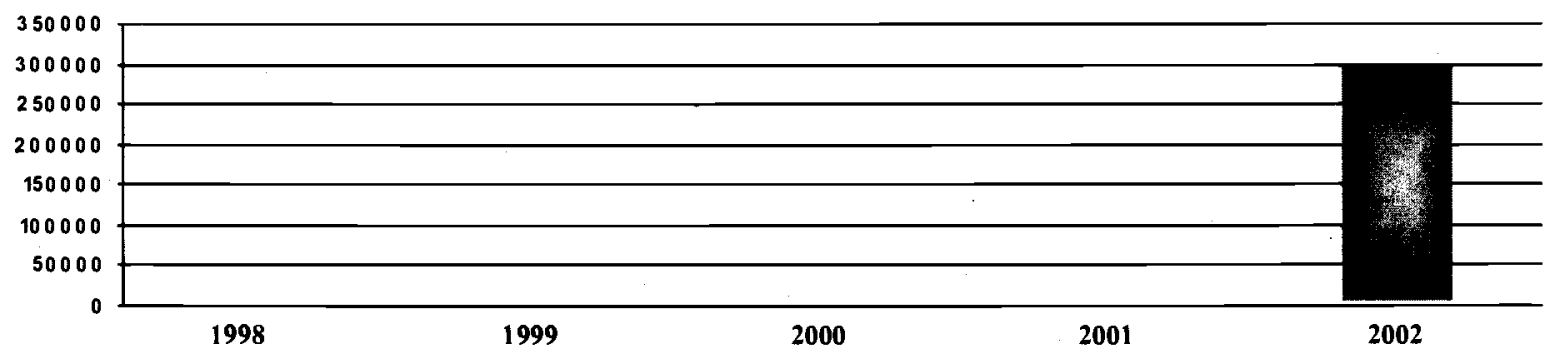

\begin{tabular}{|c|c|c|c|c|c|c|c|}
\hline \multicolumn{2}{|c|}{ Donors } & & llocation & \multirow[b]{2}{*}{ Province } & \multicolumn{3}{|c|}{ Targeted Provinces } \\
\hline Donors & $\%$ Funded & Allocation & $\%$ Funded & & Sector & $\%$ Tar & \\
\hline DFID & & Agriculture & 38 & Balkh & Reli & atriatioin & 26 \\
\hline $10 \mathrm{M}$ & & Education & 11 & Balkh & Edu & & 11 \\
\hline Private & & Infrastructure & 25 & Balkh & Infra & & 25 \\
\hline San's Purse & & Relief \& Repatria & 26 & Balkh & Agri & & 38 \\
\hline
\end{tabular}

World Concern

Sub Offices

\begin{tabular}{|c|c|c|c|c|c|}
\hline Sub Office & City / Town & Phone & Fax & E-mail & In Charge \\
\hline $\begin{array}{l}10 \text { Minglar koohosi Tashkand } \\
700015\end{array}$ & Uzbekistan & $120-6757$ & & cafe@cafengo.org & Jeff Livermsr \\
\hline
\end{tabular}




\begin{tabular}{|c|c|c|c|}
\hline Membership & ACBAR & Country of Affiliation & USA \\
\hline Address & Communication & Key Staff & Position \\
\hline \multirow{4}{*}{$\begin{array}{l}\text { Haji Yaqoob Square Park Road } \\
\text { Shar-e-Now, } \\
\text { Kabul- Afghanistan }\end{array}$} & Phone: & Paul Barker & Country Director \\
\hline & 00873 & Sally Austin & Asist. Director \\
\hline & E-mail: & Michelle Kendall & Asist.Director \\
\hline & Web: & . & \\
\hline
\end{tabular}

\begin{tabular}{|c|c|c|c|c|c|c|}
\hline & & & Personnel & & & \\
\hline Afghan & \multicolumn{2}{|c|}{637} & & Administrative & & 420 \\
\hline Pakistani & \multicolumn{2}{|c|}{8} & & Support & & 219 \\
\hline Expatriates & \multicolumn{2}{|c|}{7} & & Technical & & 13 \\
\hline \multirow[t]{3}{*}{ Total } & \multicolumn{2}{|c|}{652} & & Total & & 652 \\
\hline & & & Bndget In US S & & & \\
\hline & 1998 & 1999 & 2000 & 2001 & \multicolumn{2}{|l|}{2002} \\
\hline Afghanistan & $5,068,262$ & $4,124,043$ & $5,350,007$ & $5,953,702$ & $11,168,267$ & \\
\hline Pakistan & 0 & 0 & 0 & 0 & 0 & \\
\hline Total & $5,068,262.00$ & $4,124,043.0$ & $5,350,007.00$ & $5,953,702.00$ & II,168,207.00 & \\
\hline
\end{tabular}

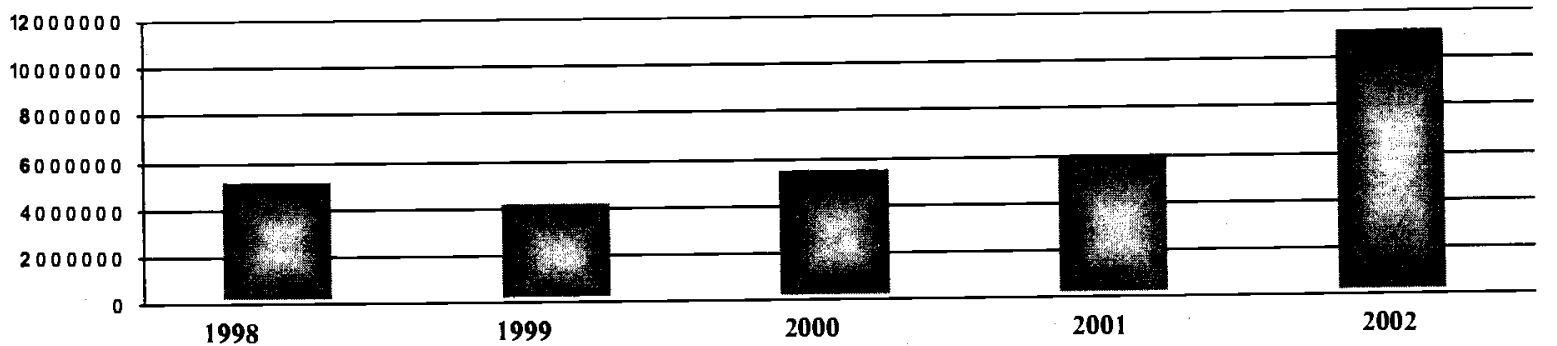

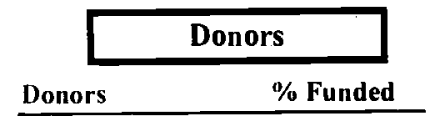

Australian Aid

Canada Govt.

CARE

CIDA

DIID

ECHO

I:U

EURONAID

(iT\%

Sean Coutu

Norwegian Govt

OFDA

Private

UNHIC R

WFP

\begin{tabular}{lc|}
\cline { 2 - 2 } & \multicolumn{2}{c|}{ Allocation } \\
\hline Allocation & \% Funded \\
\hline Agriculture & 1.1 \\
Education & 9.32 \\
Emergency & 35.6 \\
Heaith & 0.34 \\
Income Generatio & 1.86 \\
lnfrastructure & 27.05 \\
Relief \& Repatria & 14.3 \\
Water Resources & 9.83 \\
&
\end{tabular}

Snb Offices

\begin{tabular}{lll} 
& \multicolumn{2}{c|}{ Targeted Provinces } \\
\cline { 2 - 3 } Province & Sector & \multicolumn{2}{c}{ \% Targeted } \\
\hline Badghis & Infrastructure. Emergen & 2.3 \\
Bamyan & Infrastructure.Environm & 1.3 \\
Farah & Infrastructure. Emergen & 0.9 \\
Ghazni & Infrastructure, Edu. HR. & 13. \\
Hirat & Infrastructure. Emergen & 1.3 \\
Kabul & Infrastructure, Edu.Eme & 52. \\
Kandahar & Infrastructure. Emergen & 0.9 \\
Kapisa & Emergency & 4.4 \\
Khost & Infrastructure, Edu. HR. & 2.0 \\
Logar & Infrastructure,Edu.Inco & 3.5 \\
Paktia & Infrastructure, Edu. HR. & 3.5 \\
Paktika & Infrastructure,Edu.Inco & 0.4 \\
Parwan & Infrastructure.Environm & $\therefore .8$ \\
Wardak & Infrastructure,Edu.Relie & 0.1 \\
Zabul & Infrastructure. Emergen & 0.9
\end{tabular}




\begin{tabular}{|c|c|c|c|c|c|}
\hline Sub Office & City / Town & Phone & Fax & E-mail & In Charge \\
\hline $\begin{array}{l}\text { NWFP.6-Park lane, Park Road, } \\
\text { University Town }\end{array}$ & Peshawar & 850614 & 8418226 & afghan@care.org & Istifta Nosh \\
\hline L.ogar.Mohammad Agha District & Mohd.Agha & & & & Eng. Seddiq \\
\hline Khake Ghariban & Ghazni & & & & Feda Mohd \\
\hline Zurmat Road, Gardez City & Gardez & $90873761-8401$ & & $\begin{array}{l}\text { gardez@care.automail.c } \\
\underline{\mathrm{om}}\end{array}$ & Hassan Ahmadzia \\
\hline Khost City & Khost & & & & Mohd. Rahim \\
\hline Paktika.Sharana City & Sharana & & & & Wali Orya \\
\hline Kabul.Qarabagh & Qarabagh & & & & Roohullah \\
\hline Chak-e-Wardak & Wardak & & & & Khuja Jamil \\
\hline Wardak.Jalrez Hospital & Jalrez & & & & Khuja Jamil \\
\hline Wardak. Maidan Shahr & Wardak & & & & Khuja Jamil \\
\hline
\end{tabular}

Caritas (Caritas Germany)

\begin{tabular}{|c|c|c|c|}
\hline Membership & & Country of Affiliation & Germany \\
\hline Address & Communication & Key Staff & Position \\
\hline \multirow{4}{*}{$\begin{array}{l}\text { House } 649, \text { Shahr-e-Now, } \\
\text { Charye Shaid District 10, } \\
\text { Kabul- Afghanistan }\end{array}$} & 070280291 & Jersey Seipel & Head of Mission \\
\hline & & Francois Targe & Deputy Office Rep. \\
\hline & E-mail: $\quad$ oftice.kabul@caritas.de & Abdul Manati & Admin Manager \\
\hline & Web: & & \\
\hline
\end{tabular}

\begin{tabular}{|l|}
\hline Afghan \\
\hline \hline Pakistani \\
\hline \hline Expatriates \\
\hline Total \\
\hline
\end{tabular}

Personnel

\begin{tabular}{|c|c|c|c|c|c|}
\hline & 1998 & 1999 & 2000 & 2001 & 2002 \\
\hline Afghanistan & $1,500,000$ & $1,500,000$ & $1,500,000$ & $2,500,000$ & $2,500,000$ \\
\hline Pakistan & 500,000 & $1,000,000$ & $1,500,000$ & $1,500,000$ & $2,000,000$ \\
\hline Total & $2,000,000.00$ & $2,500,000.00$ & $3,000,000.00$ & $4,000,000.00$ & $4,500,000.00$ \\
\hline
\end{tabular}

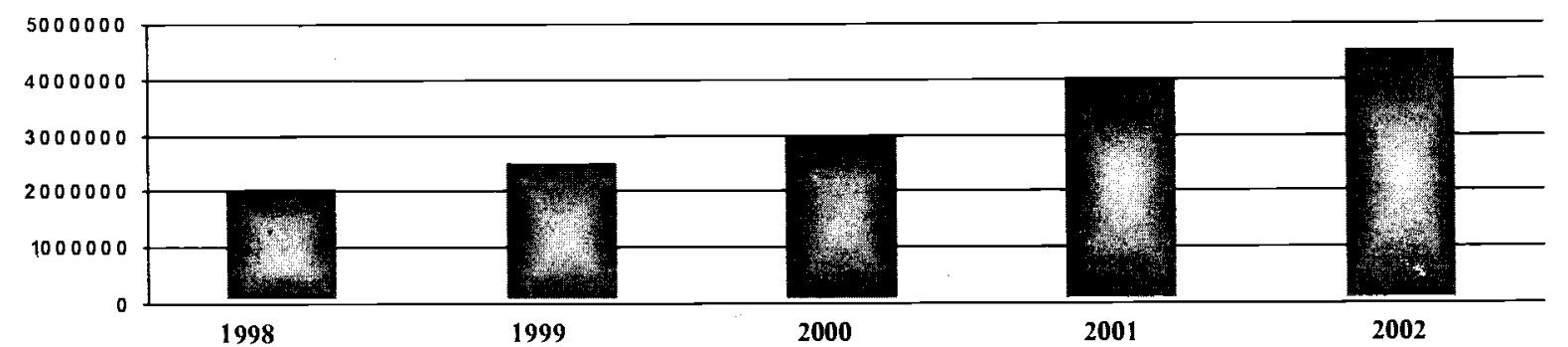

\begin{tabular}{|c|c|c|c|c|c|c|c|}
\hline \multicolumn{2}{|c|}{ Donors } & \multicolumn{2}{|c|}{ Allocation } & \multirow[b]{2}{*}{ Province } & \multicolumn{3}{|c|}{ Targeted Provinces } \\
\hline Donors & $\%$ Funded & Allocation & $\%$ Funded & & Sector & $\% \mathrm{~T}$ & \\
\hline German Govt. & 60 & Education & 30 & Kabul & Min & & 10 \\
\hline \multirow[t]{4}{*}{ Private /Self } & 40 & Health & 20 & Kabul & Heal & & 20 \\
\hline & \multirow{3}{*}{$\ldots$} & Income Gcneratio & 10 & Kabul & Educ & & 30 \\
\hline & & Infrastructure & 30 & Wardak & Inco & ration & 10 \\
\hline & & Mines & 10 & Wardak & Infre & & 30 \\
\hline
\end{tabular}

Sub Offices 


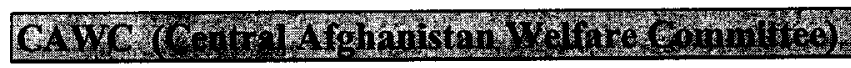

\begin{tabular}{|c|c|c|c|}
\hline Membership & Other & Country of Affliliation & Afghanistan \\
\hline Address & Communication & Key Staff & Position \\
\hline \multirow{4}{*}{$\begin{array}{l}\text { Borge Barq Stop St. Gulam Haider, } \\
\text { Klola Poshta, } \\
\text { Kabul -Afghanistan }\end{array}$} & 070279306 & Nik M. Ahmadi & Director \\
\hline & Fax: & M. Naeem Wahidi & Deputy Director \\
\hline & cawc@psh.paknet.com.pk & Hayatullah Hayat & Admin Officer \\
\hline & Web: & & \\
\hline
\end{tabular}

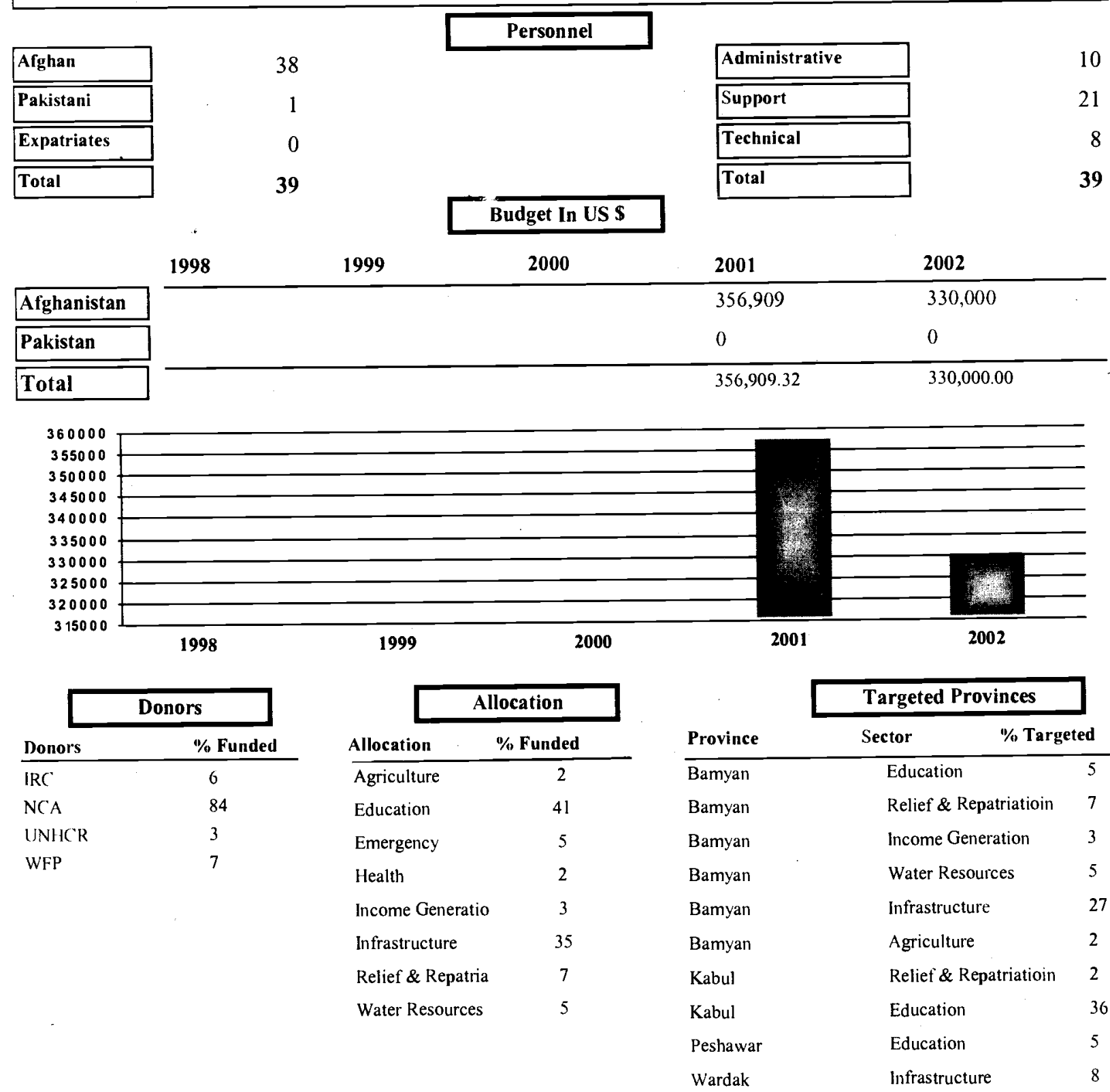

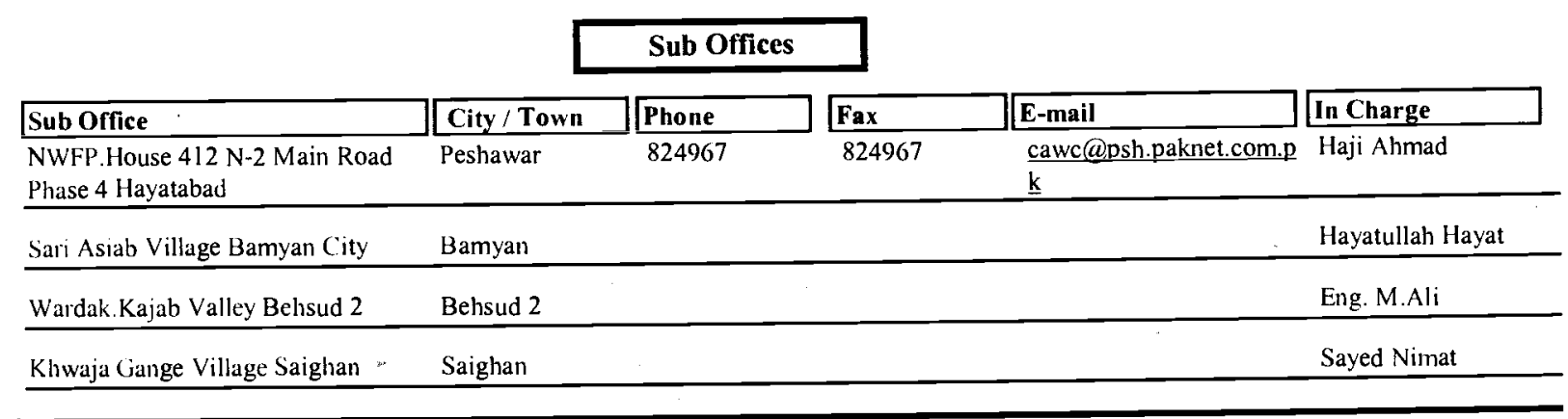




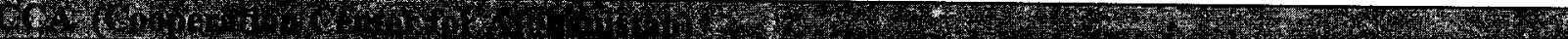

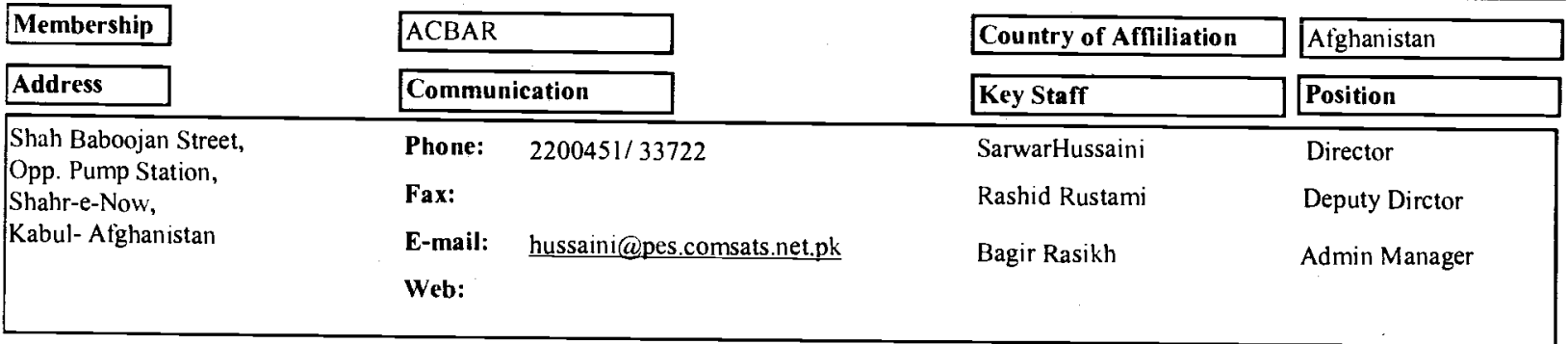

\begin{tabular}{|l|r|}
\hline Afghan & 85 \\
\hline \hline Pakistani & 1 \\
\hline \hline Expatriates & 0 \\
\hline Total & 86
\end{tabular}

Personnel

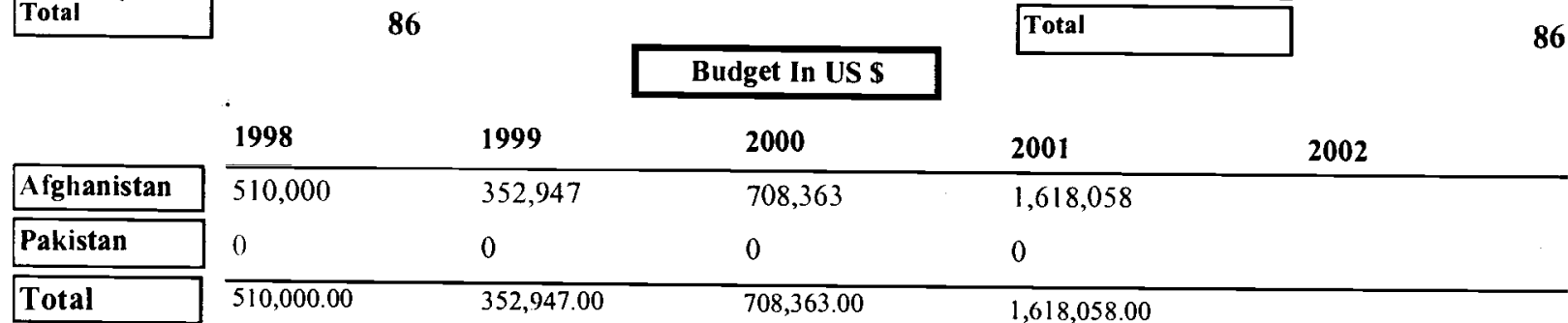

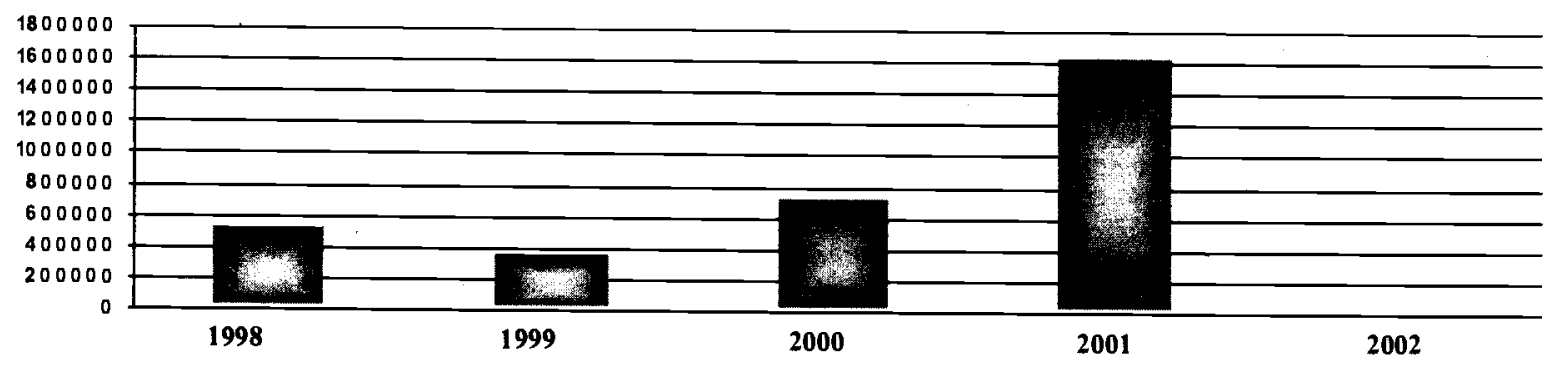

\begin{tabular}{lc}
\multicolumn{2}{c|}{ Donors } \\
\hline Donors & $\%$ Funded \\
\hline ASF & 10 \\
CWS & 10 \\
NCA & 10 \\
NOVIB & 30 \\
WFP & 40
\end{tabular}

\begin{tabular}{lc|}
\multicolumn{1}{c|}{ Allocation } \\
\hline Allocation & $\%$ Funded \\
\hline Education & 10 \\
Emergency & 10 \\
Health & 10 \\
Human Rights & 60 \\
Water Resources & 10
\end{tabular}

\begin{tabular}{llr} 
& \multicolumn{2}{c|}{ Targeted Provinces } \\
\cline { 2 - 3 } Province & Sector & \% Targeted \\
\hline Balkh & Human Rights & 20 \\
Bamyan & Education & 10 \\
Kabul & Human Rights & 40 \\
Sari Pul & Water Resources & 10 \\
Sari Pul & Emergency & 10 \\
Wardak & Health & 10
\end{tabular}

\section{Sub Offices}

\begin{tabular}{|c|c|c|c|c|}
\hline Sub Office & City / Town & Phone & E-mail & In Charge \\
\hline Sar Asia Village, Center of Bamyan & Bamyan & & & Eng. Anwar \\
\hline Mazar.Sarak Hamamm Sarak Bukhdi & Balkh & & & Musa Kashifi \\
\hline Wardak.Ab-e-Shurum & Wardak & & & Eng.Shahabuddin. \\
\hline
\end{tabular}

\begin{tabular}{|l|}
\hline Administrative \\
\hline Support \\
\hline Technical \\
\hline Total
\end{tabular}




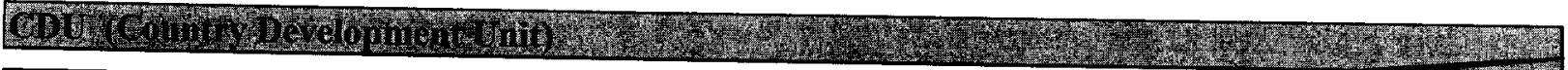

\begin{tabular}{|c|c|c|c|}
\hline Membership & $\widehat{\mathrm{ANCB}}$ & Country of Affliliation & Afghanistan \\
\hline Address & Communication & Key Staff & Positiou \\
\hline \multirow{4}{*}{$\begin{array}{l}\text { KataWaz Buliding, } \\
\text { Oppt. Mili Cenema, } \\
\text { Salang Watt, } \\
\text { Kabul-Afghanistan }\end{array}$} & Phone: $\quad 070276411$ & Ahmad Qadir & Director \\
\hline & Fax: & M. Shaifq & Deputy Director \\
\hline & E-mail: & Ahmad Samad & Chief Accountant \\
\hline & Web: & & \\
\hline
\end{tabular}

\begin{tabular}{|l|r|}
\hline Afghan & 61 \\
\hline \hline Pakistani & 0 \\
\hline \hline Expatriates & 0 \\
\hline Total & 61 \\
\hline
\end{tabular}

Personnel

18

10

Technical 33

Budget In US \$

61

\begin{tabular}{|c|c|c|c|c|c|}
\hline & 1998 & 1999 & 2000 & 2001 & 2002 \\
\hline Afghanistan & & 26,940 & 25,000 & 38,695 & 293,854 \\
\hline Pakistan & & 0 & 0 & 0 & 0 \\
\hline Total & & $26,940.00$ & $25,000.00$ & $38,695.00$ & $293,854.00$ \\
\hline
\end{tabular}

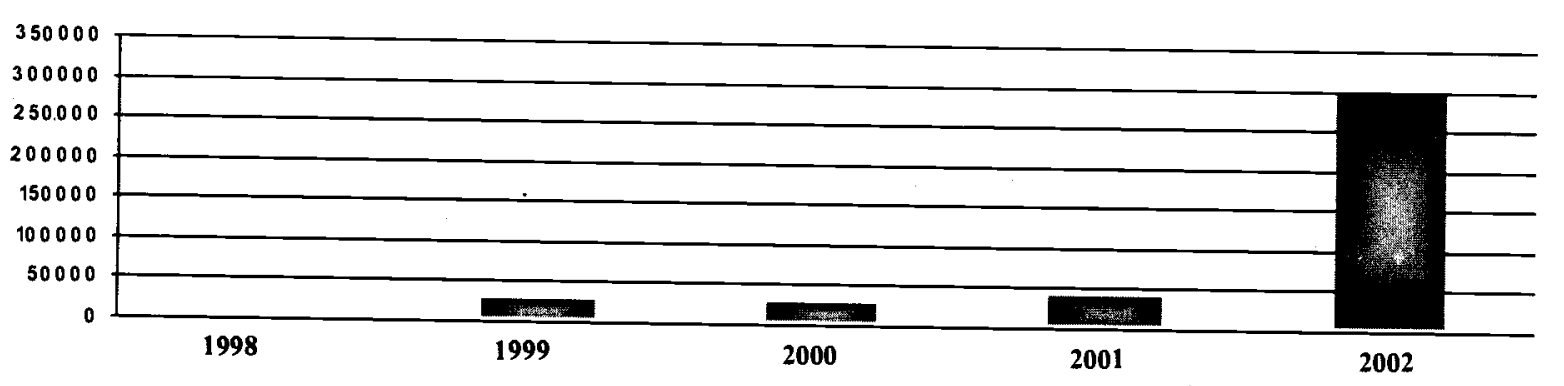

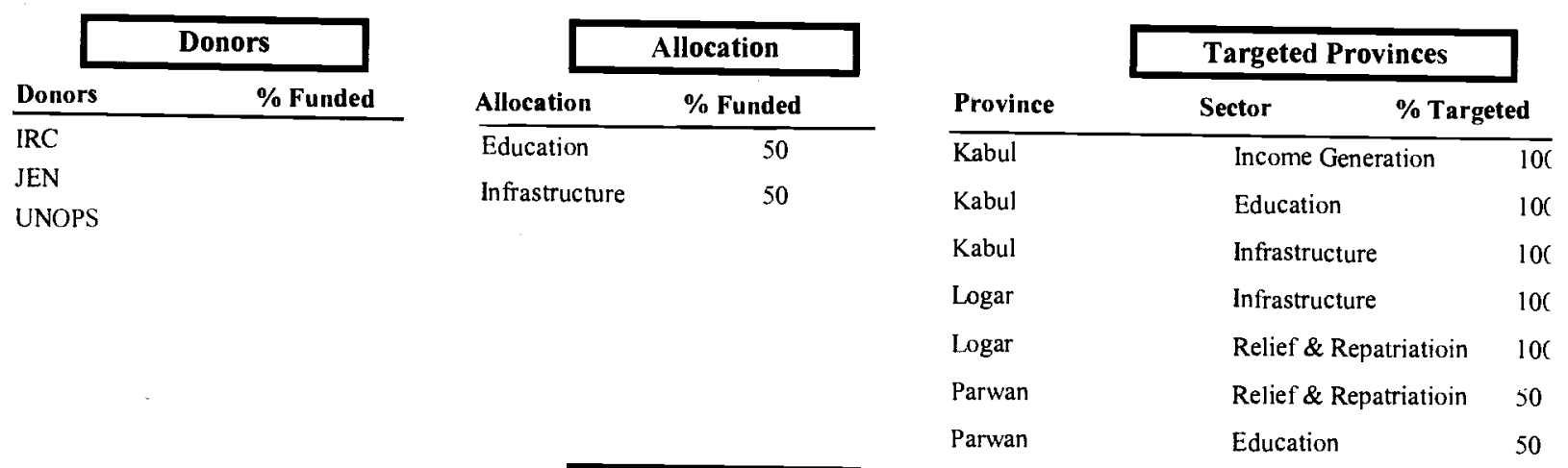

Sub Offices

\begin{tabular}{|c|c|c|c|c|}
\hline Sub Office & City / Town & Phone & E-mail & In Charge \\
\hline Parwan.Old Road .Near Burj Berq & Jabalussaraj & & & Sharif Shah \\
\hline Logar.Kochi School & Logar & & & Ahmadullah \\
\hline Logar.Qalai Kuhna Near Puli Jugi & Baraki & & & M. Jamil \\
\hline
\end{tabular}




\section{CiC (Children in Crisis)}

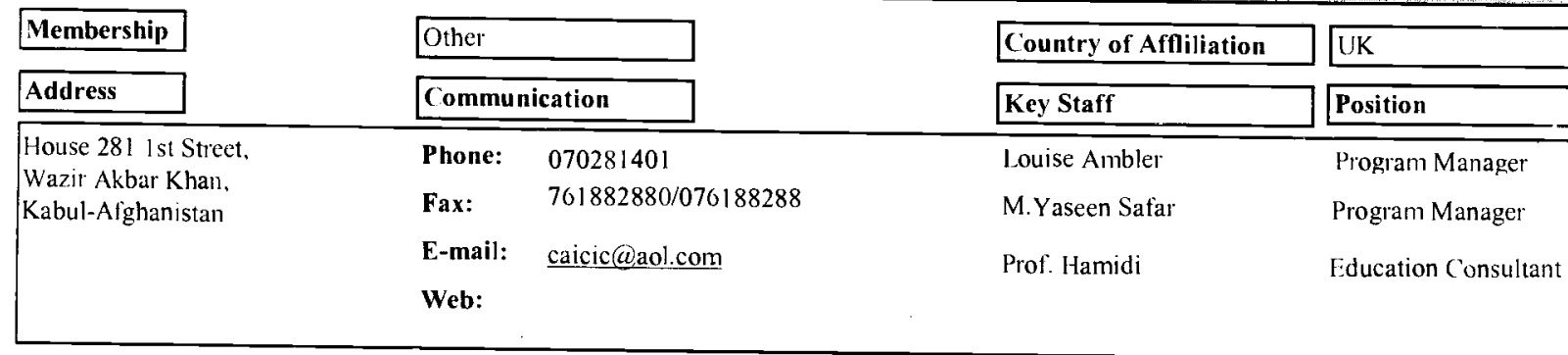

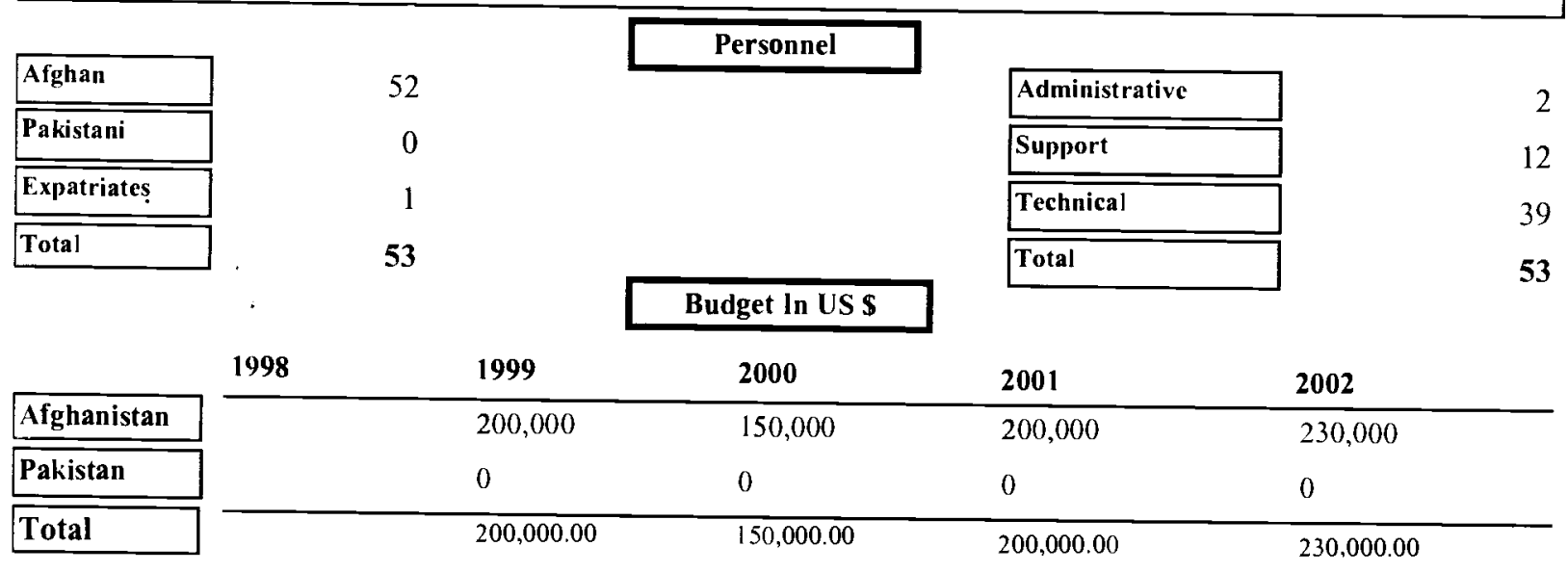
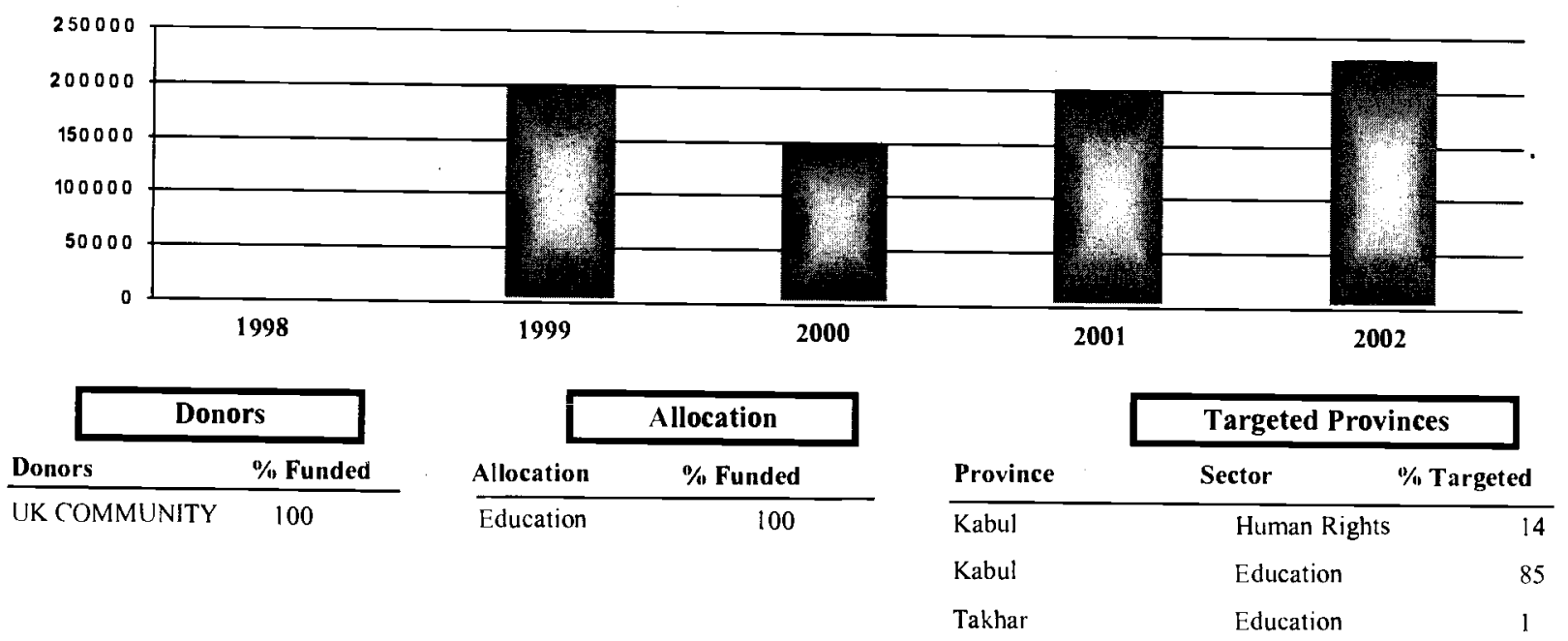

Sub Offices

\begin{tabular}{|c|c|c|c|c|c|}
\hline Sub Office & City / Town & Phone & Fax & E-mail & In Charge \\
\hline $\begin{array}{l}\text { Taloqan City (Former CAD office) } \\
\text { Koch-e-Gudam }\end{array}$ & Takhar & 00873 & & & Amin Aniv \\
\hline
\end{tabular}




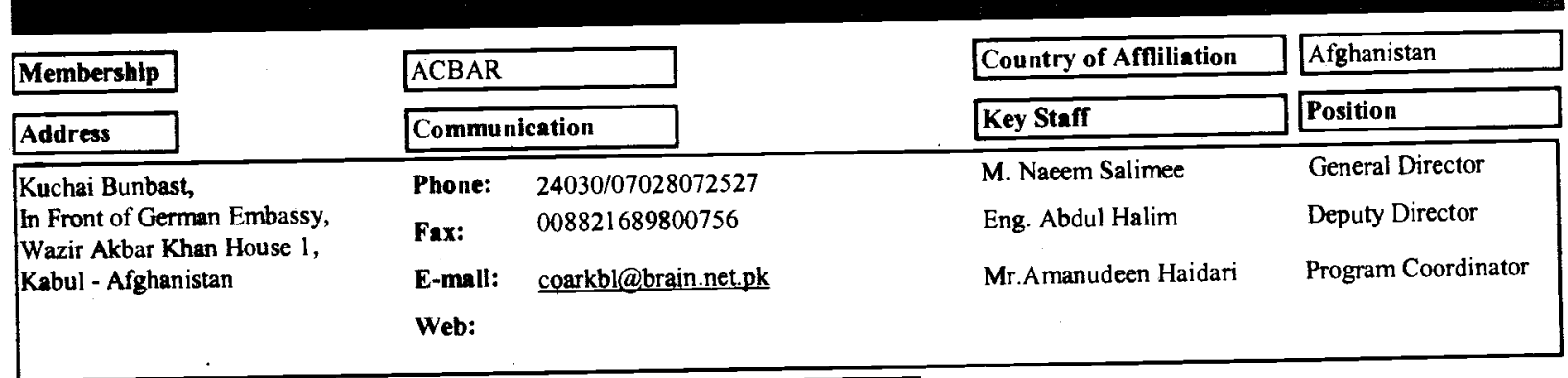

\begin{tabular}{|l|rc|}
\hline & & Personnel \\
\hline Afghan & 220 & \\
\hline Pakistani & 2 & \\
\hline Expatriatios & 2 & \\
\hline \hline Total & 224 & Budget In US S \\
\hline
\end{tabular}

\begin{tabular}{|l|r|}
\hline Administrative & 34 \\
\hline Support & 80 \\
\hline Technical & 110 \\
\hline Total & $\mathbf{2 2 4}$ \\
\hline
\end{tabular}

\begin{tabular}{|c|c|c|c|c|}
\hline & 1998 & 1999 & 2000 & 2002 \\
\hline Afghanistan & 75,550 & $1,248,412$ & & $2,737,813$ \\
\hline Pakistan & 0 & 0 & & 39,348 \\
\hline Total & $\overline{75,550.00}$ & $1,248,412.00$ & & $2,777,161.27$ \\
\hline
\end{tabular}

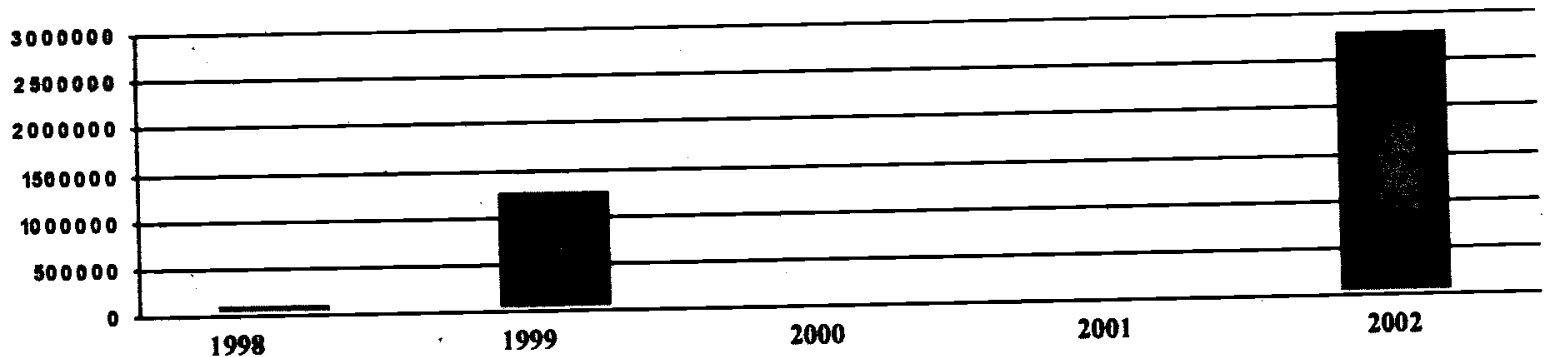

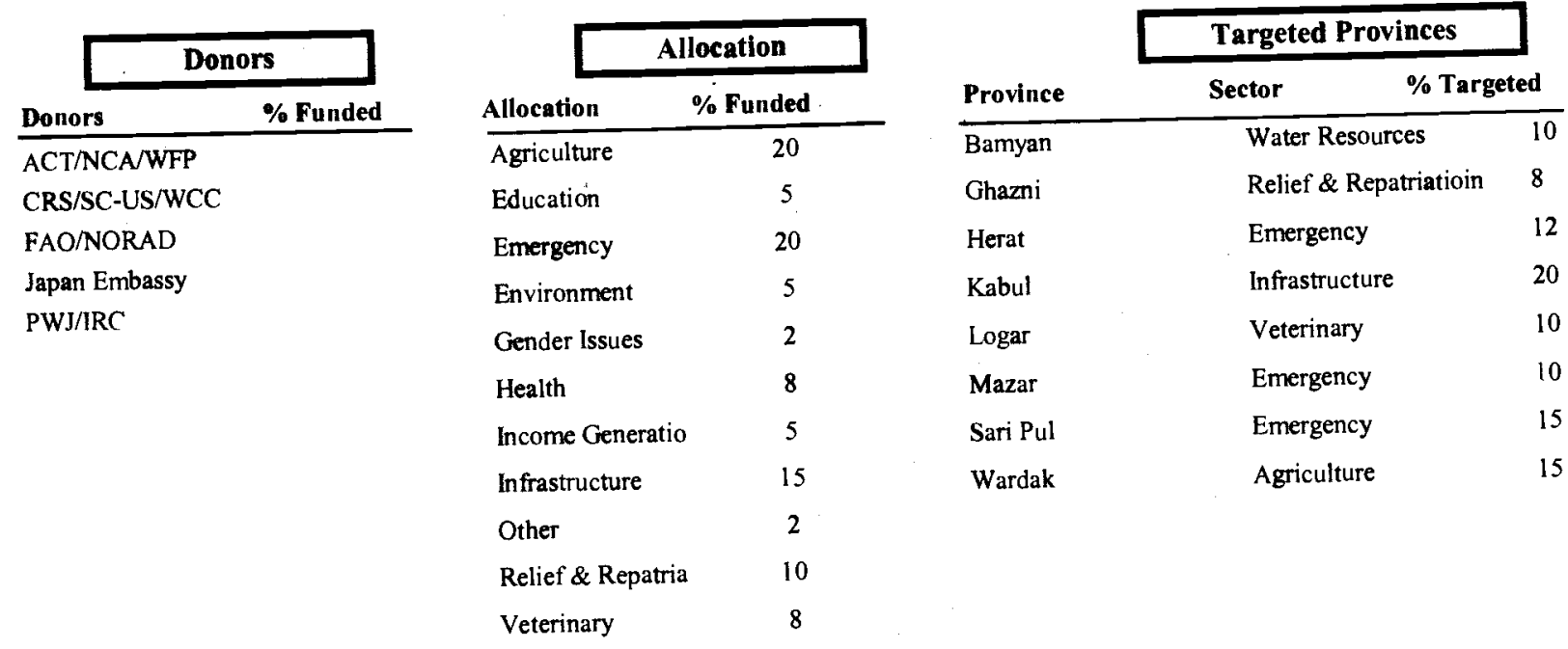

\begin{tabular}{|c|c|c|c|c|}
\hline & & Sub Offices & & \\
\hline Sub Office & City / Town & Phone & E-mail & In Charge \\
\hline Logar.Baraki Rajan Qalai Qazi & Baraki & & & Janatgul Khan \\
\hline Wardak.Sayed Abad Center & Sayedabad & & & Mukhter Kazemi \\
\hline $\begin{array}{l}\text { Ghazni. Bazar Next to Moqur } \\
\text { Hospital }\end{array}$ & Moqur & & & Eng.Gulzada \\
\hline $\begin{array}{l}\text { Public Park Charahi Mustufiat Near } \\
\text { to UNAMA }\end{array}$ & Hirat & 223141 & . & M. Rahim \\
\hline Saighan Dist, Center & Bamyan & & & Jailani \\
\hline ACBAR & & & & Directory of NGOs \\
\hline
\end{tabular}




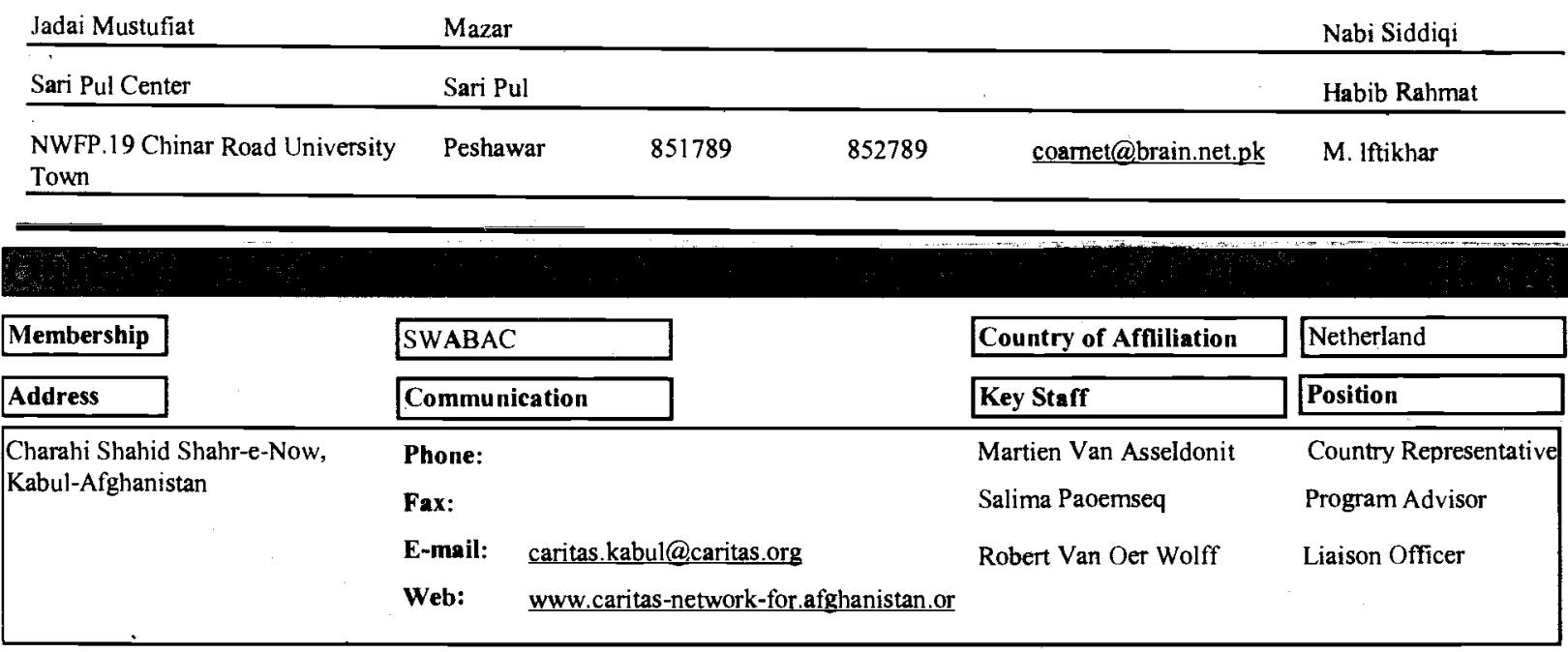

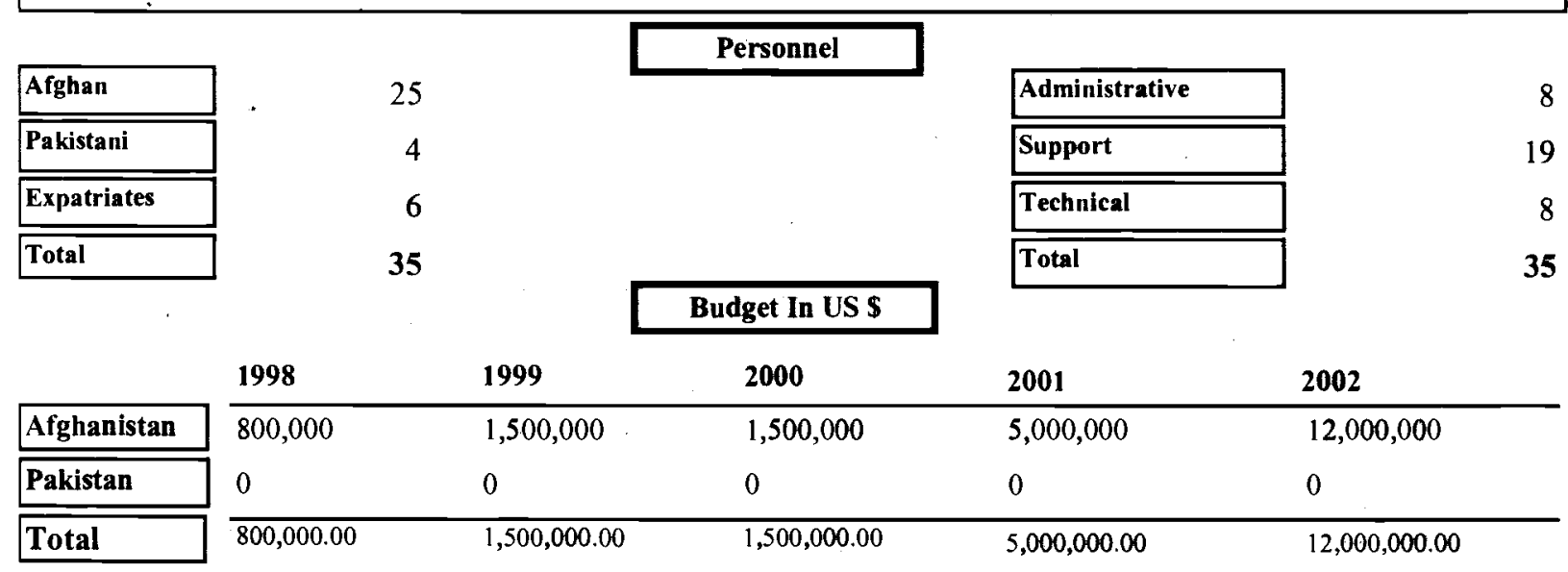

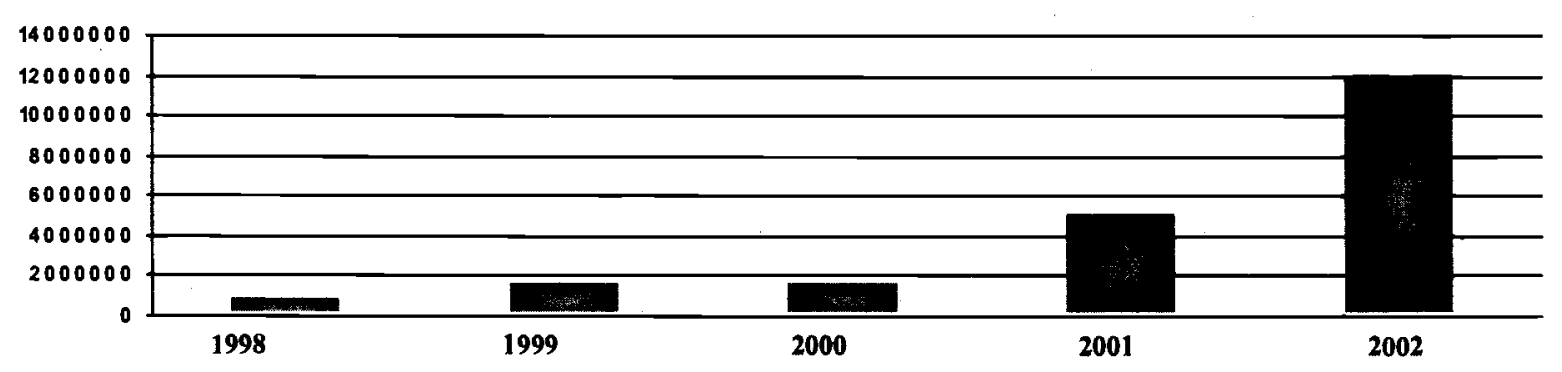

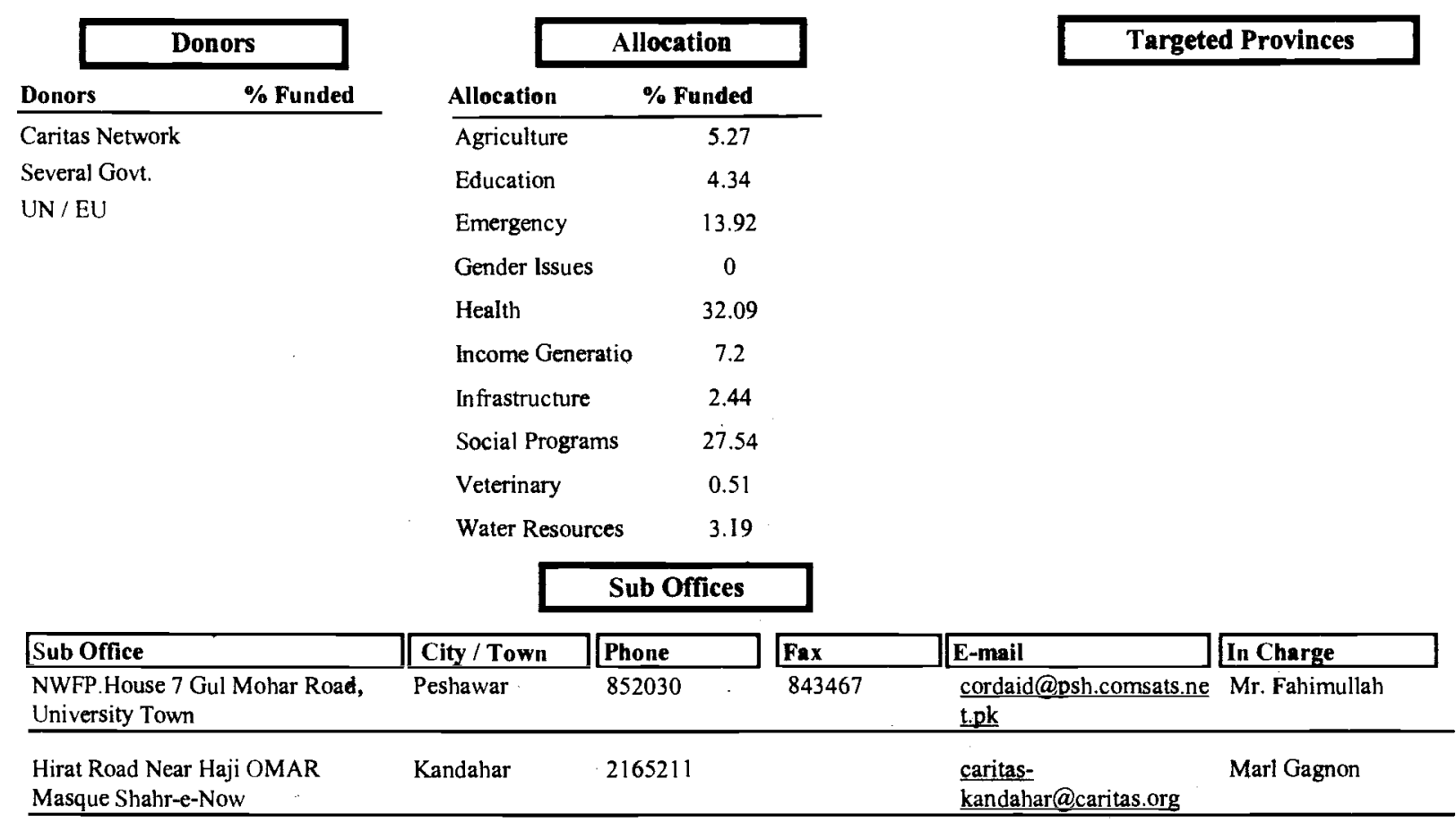

\begin{tabular}{|lll|}
\hline ACBAR & Directory of NGOs \\
\hline
\end{tabular}




\section{CPAU (Cooparation for Peace And Unity)}

\begin{tabular}{|c|c|c|c|}
\hline Membership & Other & Country of Affliliation & Atghanistan \\
\hline Address & Communication & Key Staff & Position \\
\hline \multirow{4}{*}{$\begin{array}{l}\text { Ist Street Qala-c-Fatullah, } \\
\text { Near Zarghuna High School. } \\
\text { Kahul -Afghanistan }\end{array}$} & $070274754 / 070278891$ & Fahim Hakeem & Director \\
\hline & Fax: & Mohd. Suleman & Program Manager \\
\hline & E-mail: afahim@brain.net.pk & Hamidaullah Natiq & Technical Consultant \\
\hline & Web: & & \\
\hline
\end{tabular}

\begin{tabular}{|l|rrr|}
\hline Afghan & 12 & Personnel & \\
\hline Pakistani & 12 & Administrative \\
\hline Expatriates & 1 & Support \\
\hline Total & 13 & Technical & 3 \\
\hline
\end{tabular}

Budget In US \$

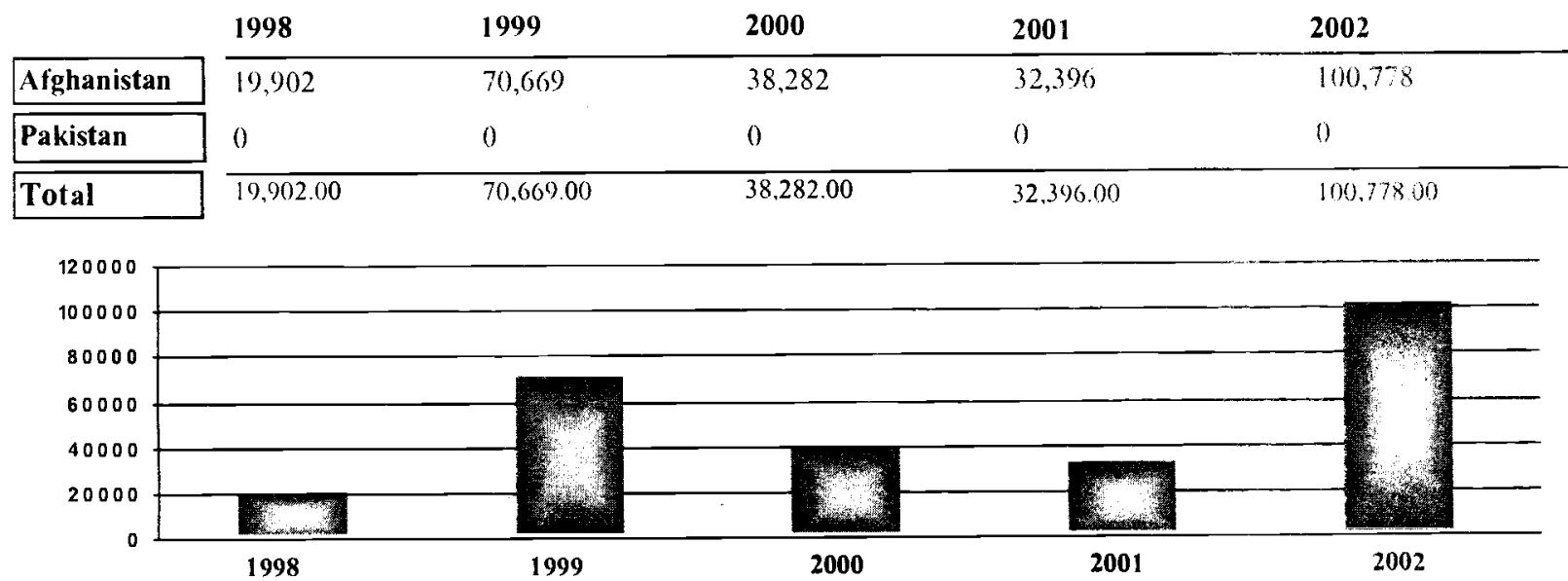

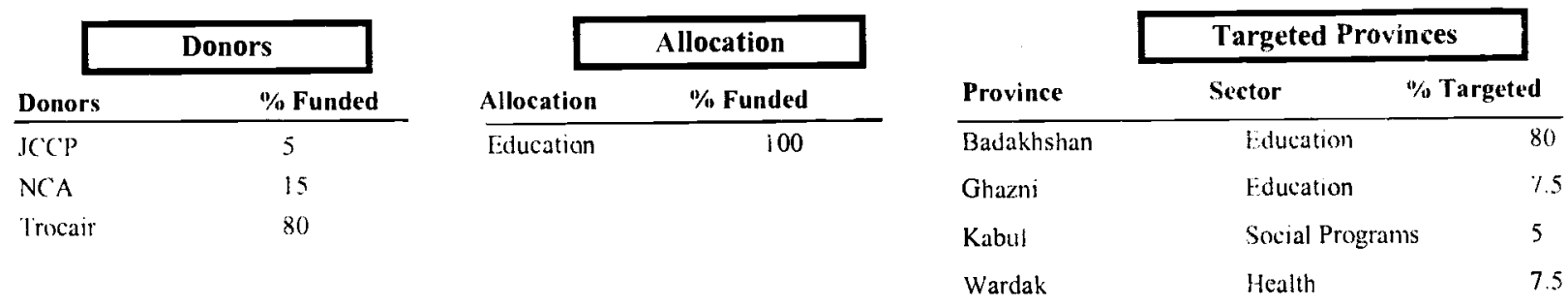

Sub Offices

\begin{tabular}{|c|c|c|c|c|c|}
\hline Sub Office & City / Town & Phone & Fax & E-mail & In Charge \\
\hline $\begin{array}{l}\text { NWFP.23A Rahaman Baba Road, } \\
\text { lniversityTown }\end{array}$ & Pakistan & 5701763 & 840471 & afahim@brain.net.pk & Marzia \\
\hline
\end{tabular}


CPHA (Committee for Promotion of Medical and Humanitarian Aid To Afghanistan)

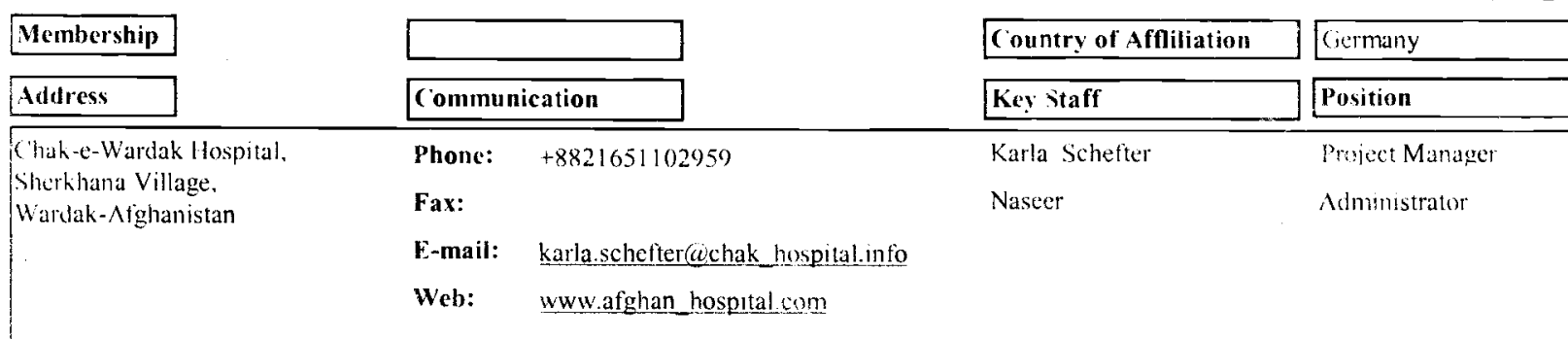

\begin{tabular}{|c|c|c|c|c|c|}
\hline & & & Personnel & & \\
\hline Afghan & & & & Administrative & 4 \\
\hline Pakistani & & & & Support & 50 \\
\hline Expatriates & & & & Technical & 0 \\
\hline \multirow[t]{3}{*}{ Total } & & & & Total & 54 \\
\hline & & & Budget in US S & & \\
\hline & 1998 & 1999 & 2000 & 2001 & 2002 \\
\hline Afghanistan & 320,000 & 350.000 & 360,000 & 360,000 & 450,000 \\
\hline Pakistan & 0 & 0 & 0 & 0 & () \\
\hline Total & 320.000 .00 & $350,000.00$ & $360,000.00$ & $360,000.00$ & $+50,000.00$ \\
\hline
\end{tabular}

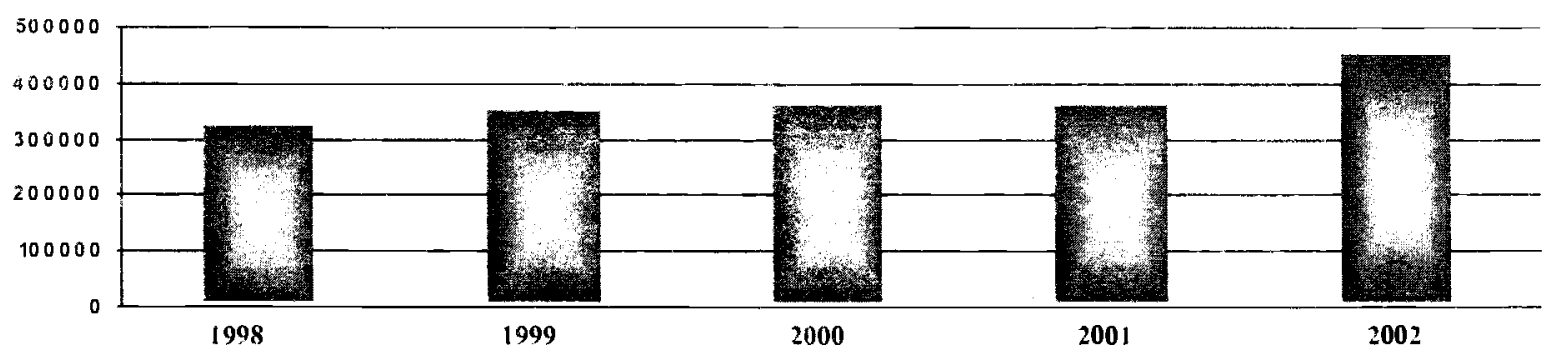

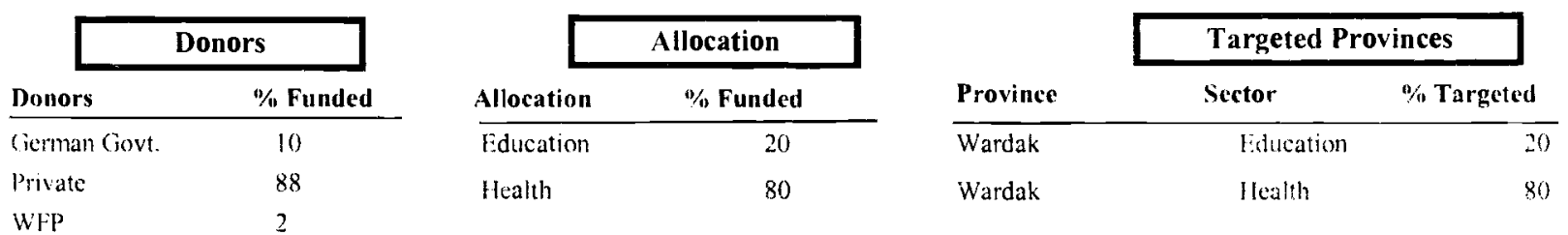

Sub Offices

\begin{tabular}{|c|c|c|c|c|c|}
\hline Sub Office & City/Town & Phone & Fax & E-mail & In Charge \\
\hline $\begin{array}{l}\text { NWFP. RailWay Road P.O.Box } \\
012 \text {, !niversity Town }\end{array}$ & Peshawar & 840776 & 840776 & chic@pes.comsats.net.pk & A.latif \\
\hline
\end{tabular}




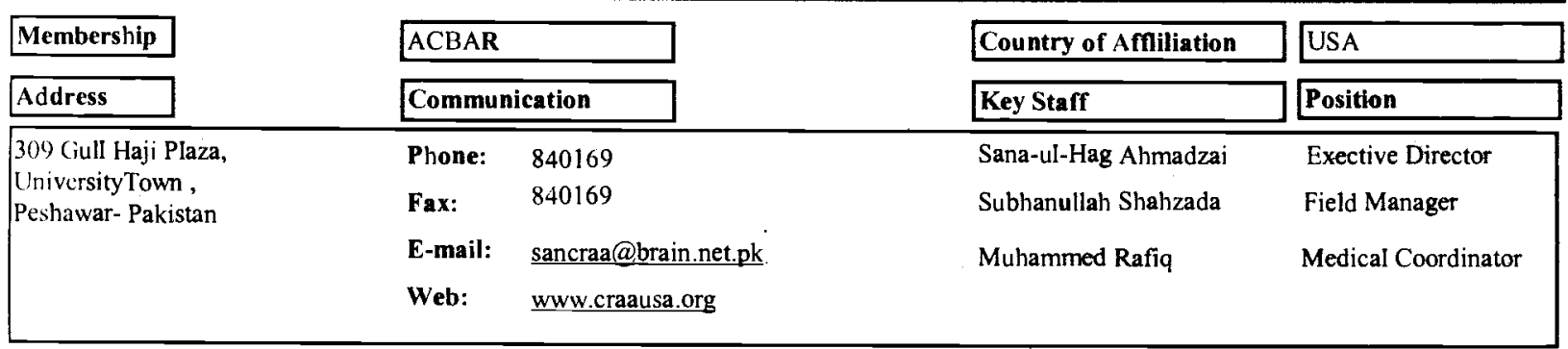

\begin{tabular}{|l|r|}
\hline Afghan & 100 \\
\hline Pakistaoi & 6 \\
\hline Expatriates & 3 \\
\hline Total & 109 \\
\hline
\end{tabular}

Personnel

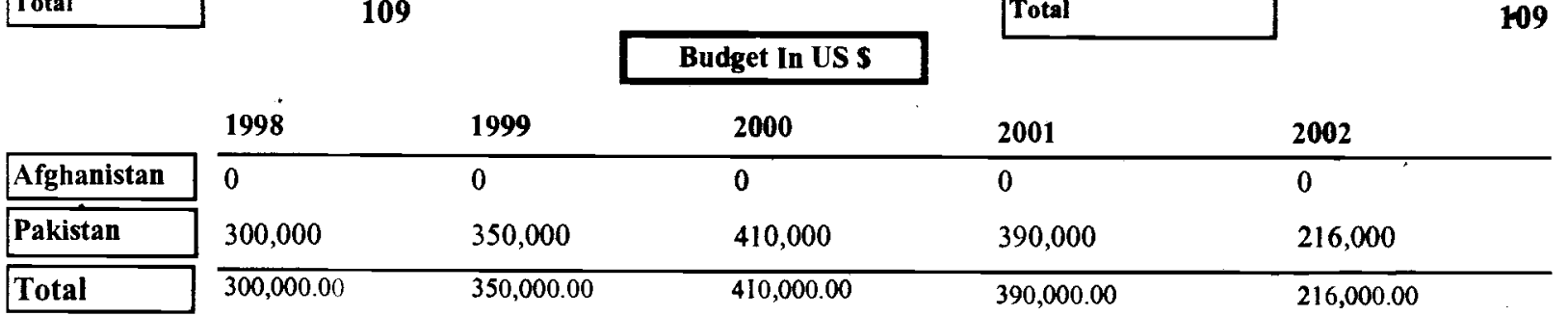

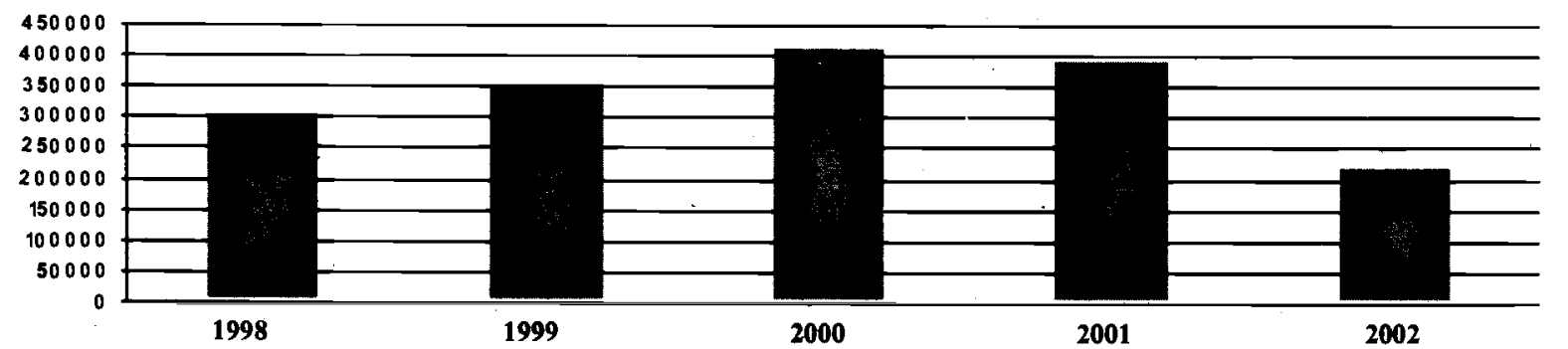

\begin{tabular}{|c|c|c|c|c|c|c|}
\hline \multicolumn{2}{|c|}{ Donors } & \multicolumn{2}{|c|}{ Allocation } & \multirow[b]{2}{*}{ Province } & \multicolumn{2}{|c|}{ Targeted Provinces } \\
\hline Donors & $\%$ Funded & Allocation & $\%$ Funded & & Sector & $\%$ Targeted \\
\hline Caritas & 8 & Agriculture & 70 & Kabul & Agriculture & 40 \\
\hline HPI & 70 & Education & 5 & Kunar & Agriculture & 4 \\
\hline \multirow[t]{4}{*}{ Private } & 22 & Health & 15 & Laghman & Agriculture & 4 \\
\hline & & Income Generatio & 5 & Logar & Agriculture & 8 \\
\hline & & Water Resources & 5 & Nangarhar & Health & 42 \\
\hline & & & & Parwan & Agriculture & 4 \\
\hline
\end{tabular}

\section{Sub Offices}

\begin{tabular}{|c|c|c|c|c|c|}
\hline Sub Office & City / Town & Phone & Fax & E-mail & In Charge \\
\hline $\begin{array}{l}\text { Nangrahar.Chashma Khandi. Street } \\
2 \text { House } 6\end{array}$ & Jalalabad & & & sacraa@brain.net.pk & Subhanullah \\
\hline Mikroyan 3 Block 123-A, Flat 63 & Kabul & & & & Eng.Saleem \\
\hline $\begin{array}{l}\text { Nangahar.Village Shahzadkla } \\
\text { Charparhar }\end{array}$ & Jalalabad & & & sancraa@brain.net.pk & Azizullah \\
\hline
\end{tabular}




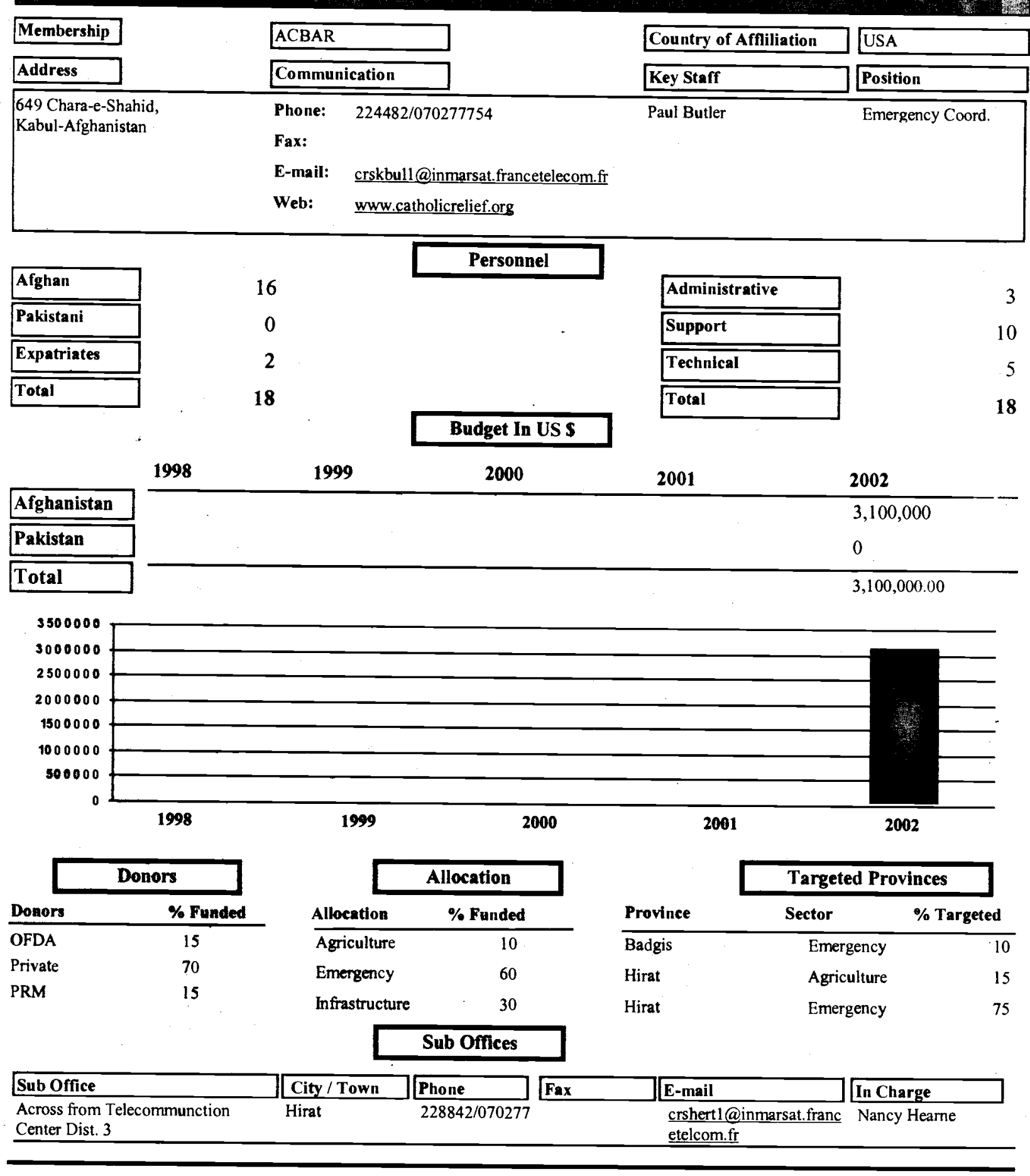




\section{CWS-P/A (Church World Service-Pakistan/Afghanistan)}

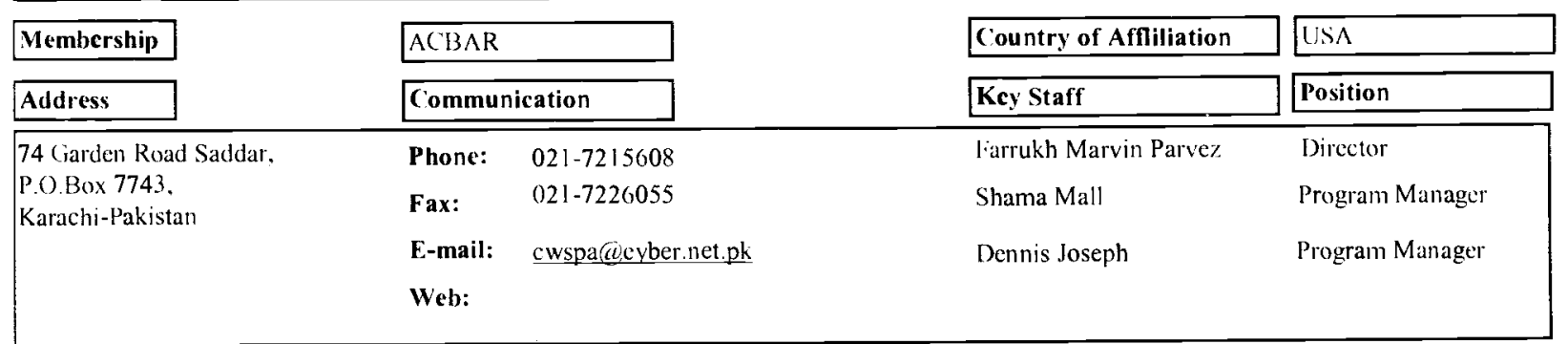

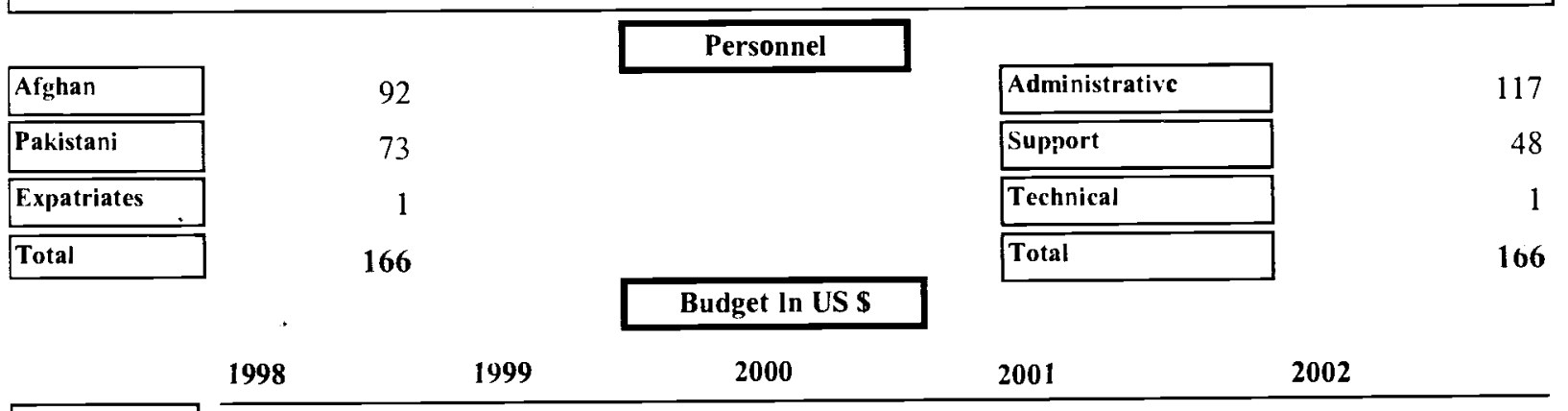

\begin{tabular}{|l|}
\hline Afghanistan \\
\hline Pakistan \\
\hline Total \\
\hline
\end{tabular}

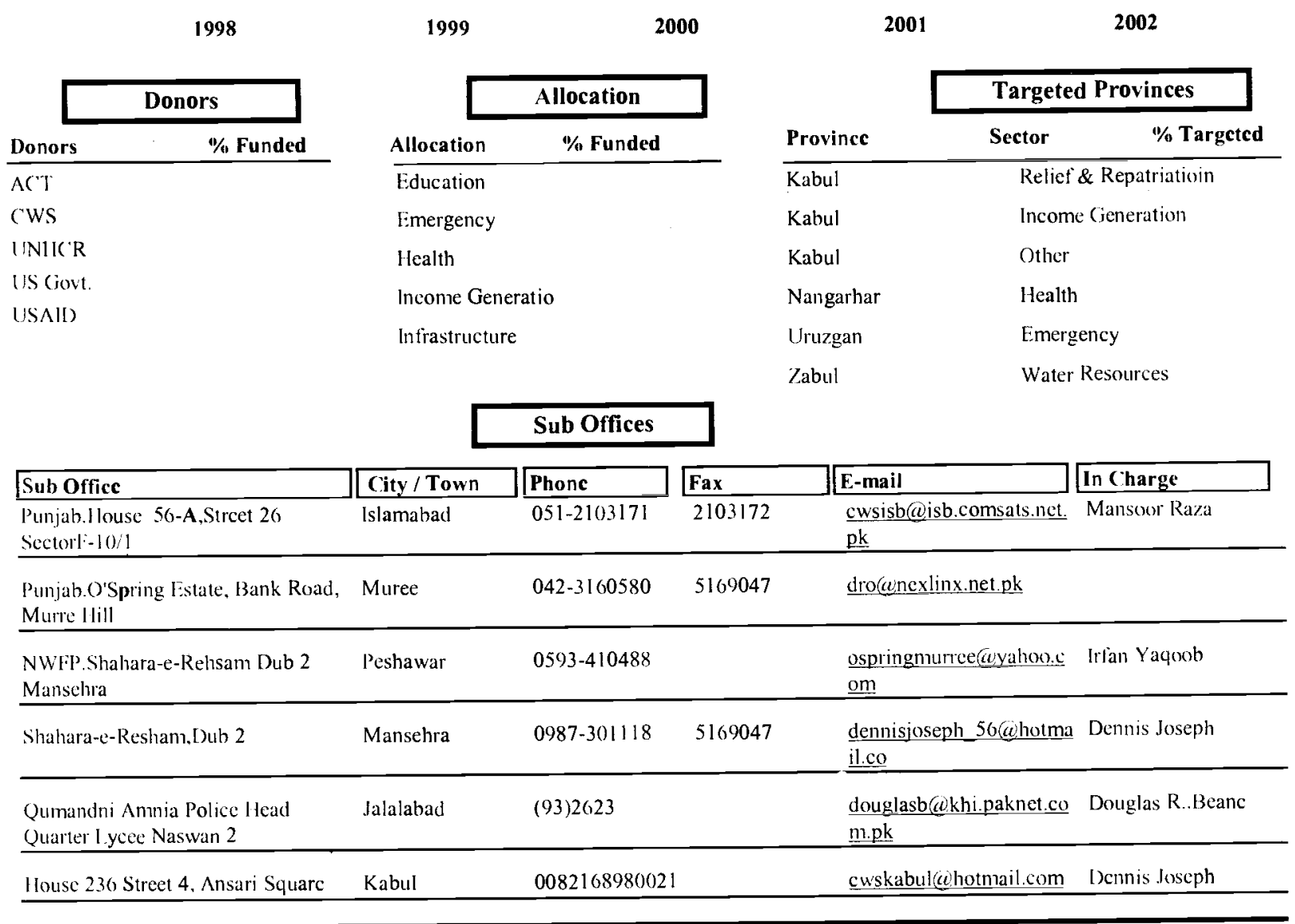




\section{DAC (Danish Afghainstan Communttee)}

\begin{tabular}{|c|c|c|c|}
\hline Membership & Other & Country of Affliliation & Denmark \\
\hline Address & Communication & Key Staff & Position \\
\hline \multirow{4}{*}{$\begin{array}{l}\text { Sadah Mohbas Reg. } 1 \text {, } \\
\text { Hirat-Afghanistan }\end{array}$} & Phone: & Dm Bjamesen & Coordinator \\
\hline & +8737762496626 & Basir Ahmad & Liaison Officer \\
\hline & E-mail: dac.herat@mail.dk & Dr.Auyoub & Health Director \\
\hline & www.afghan.dk & & \\
\hline
\end{tabular}

\begin{tabular}{|l|}
\hline Afghan \\
\hline Pakistani \\
\hline Expatriates \\
\hline Total \\
\hline
\end{tabular}
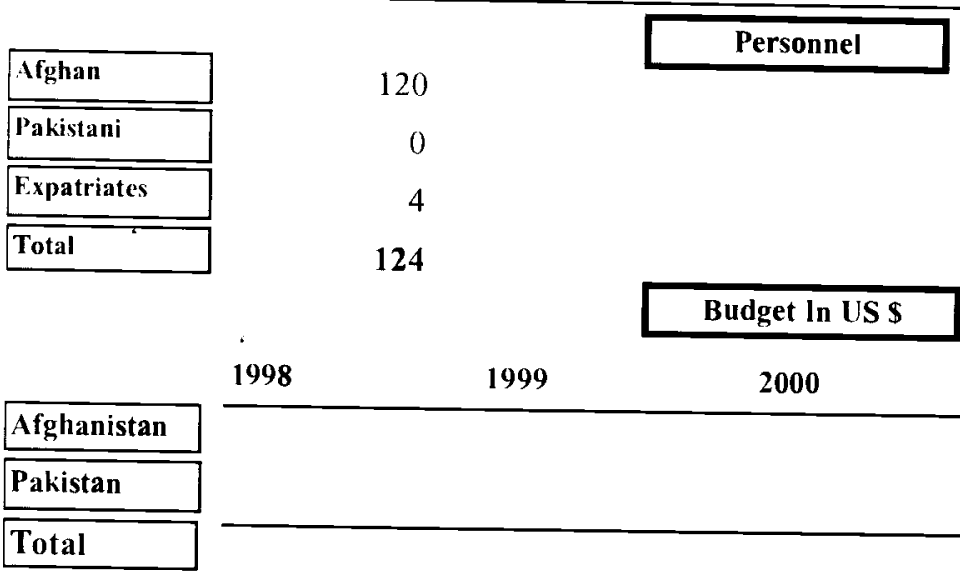

\begin{tabular}{|l|}
\hline Administrative \\
\hline Support \\
\hline Technical \\
\hline Total \\
\hline
\end{tabular}

Budget In US S

124

2000

1998

1999

Us

2001

20,000

$20,000.00$ $1,250,000.00$
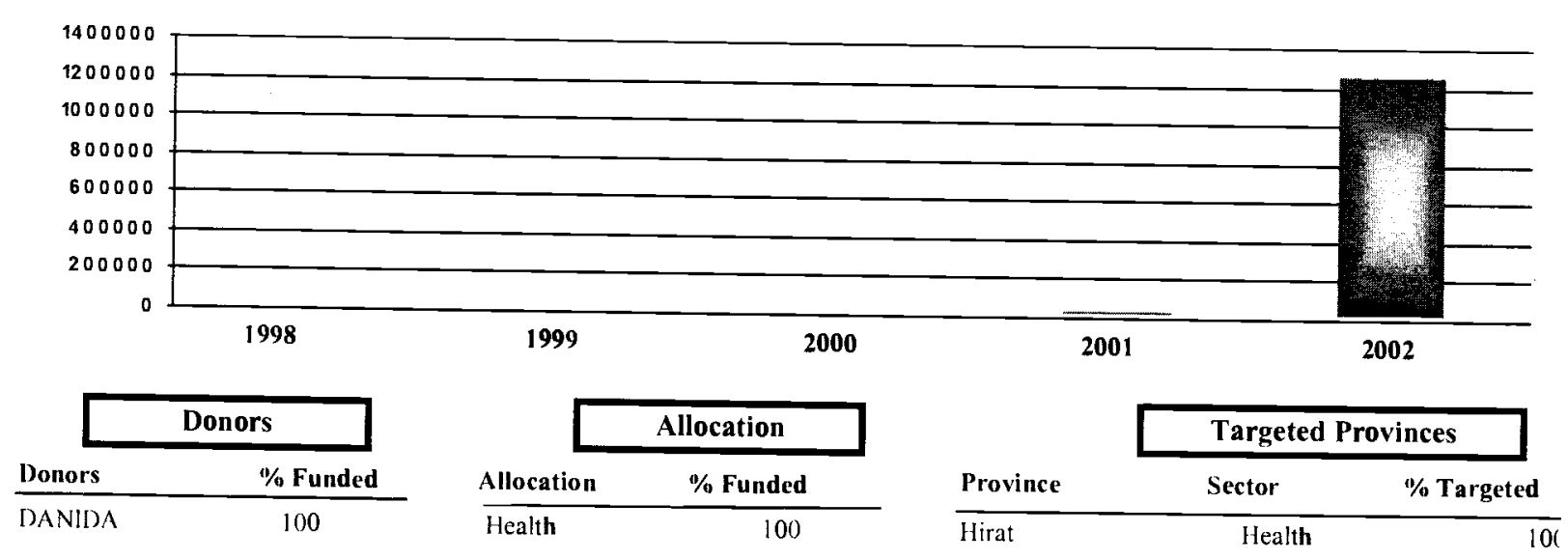

Sub Offices 


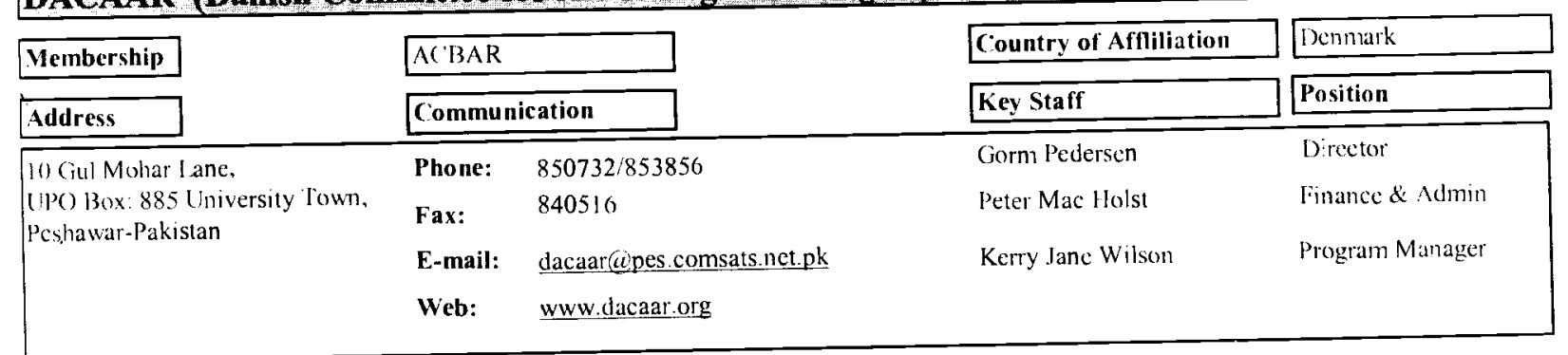

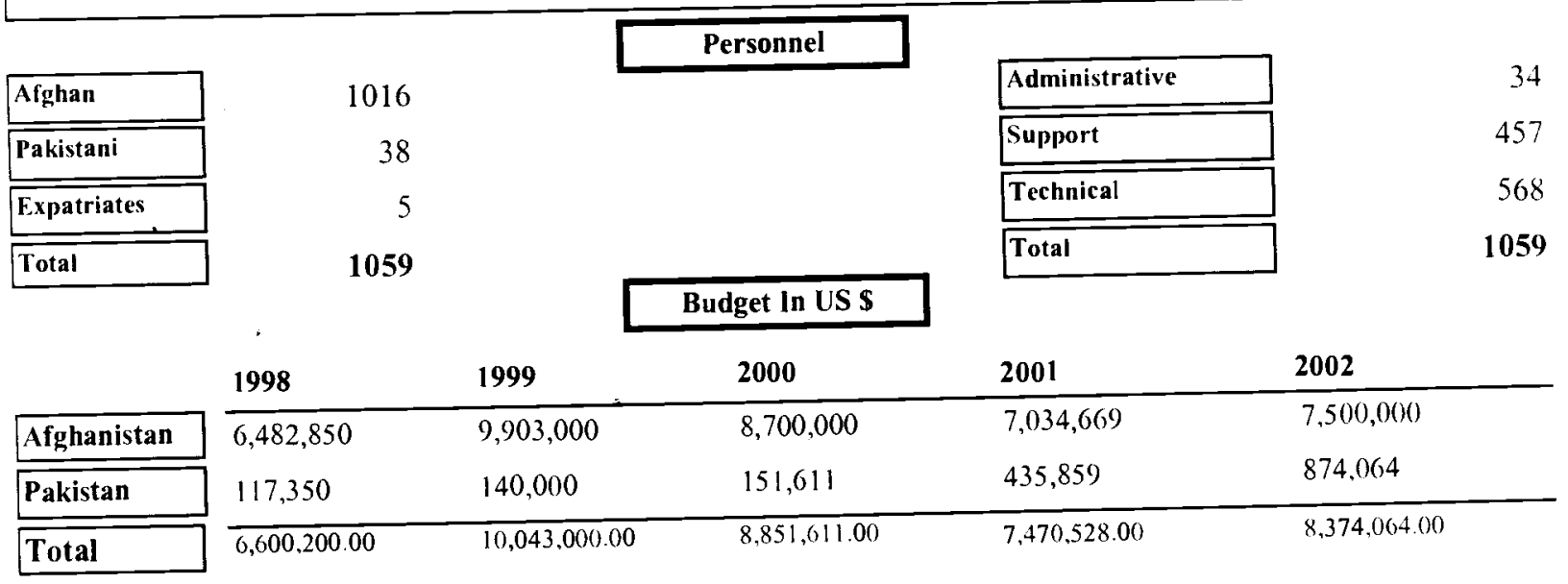

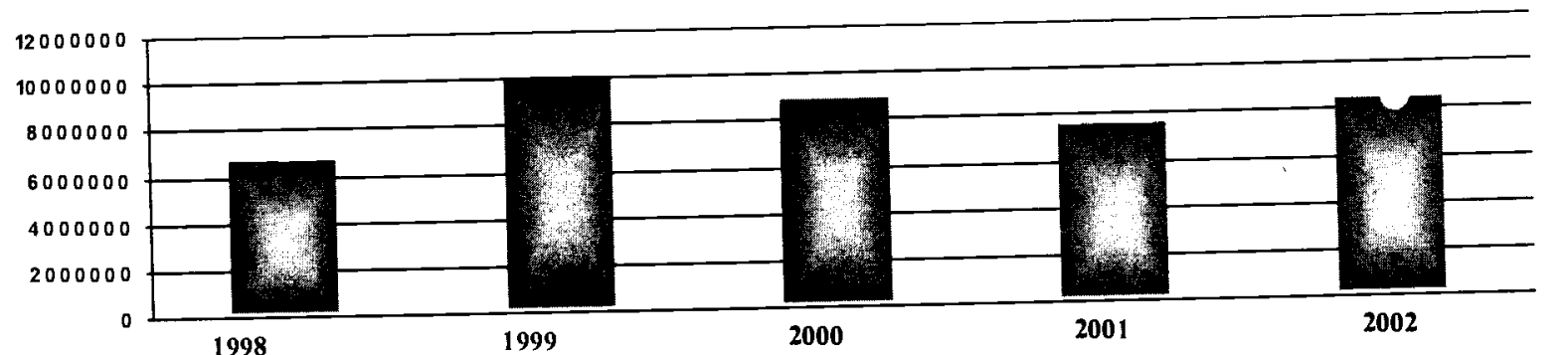

\begin{tabular}{lc}
\multicolumn{2}{c|}{ Donors } \\
Donors & \% Funded \\
\hline AC'T Netherland & 9.95 \\
Danida & 17.64 \\
lC & 41.42 \\
IC 1 HO & 1.63 \\
FAO & 0.02 \\
Others & 2.17 \\
UNHIC R & 4.92 \\
WFP & 21.25
\end{tabular}

\begin{tabular}{lc}
\multicolumn{1}{c|}{} & \multicolumn{2}{c|}{ Allocation } \\
Allocation & \% Funded \\
\hline Agriculture & 29.8 \\
Emergency & 25.38 \\
Health & 2 \\
Infrastructure & 6.44 \\
Water Resources & 36.38 \\
& \\
&
\end{tabular}

\begin{tabular}{ll|} 
& \multicolumn{1}{c|}{ Targeted Provinces } \\
\hline Province & Sector Targeted \\
\hline Badghis & Water Resources \\
Farah & Water Resources \\
Ghazni & Water Resources \\
Ghor & Water Resources \\
Hilmand & Infrastructure \\
Hirat & Water Resources \\
Kabul & Income Generation \\
Kandahar & Water Resources \\
Kapisa & Water Resources \\
Khost & Intrastructure \\
Laghman & Water Resources \\
Nangarhar & Water Resources \\
Ninnroz & Water Resources \\
Paktika & Water Resources \\
Paktya & Water Resources \\
Parwan & Water Resources \\
Uruzgan & Water Resources \\
Wardak & Water Resources \\
Zabul & Water Resources \\
\hline
\end{tabular}

Sub Offices 


\begin{tabular}{|c|c|c|c|c|c|}
\hline Sub Otfice & City / Town & Phone & Fax & E-mail & In Charge \\
\hline I lousc 403 Street 2, Qala-e-Fatullah & Kabul & 070276443 & & dacaar1@get2nel.dk & Ashuqullah $\wedge$ kbari \\
\hline $\begin{array}{l}2 \text { Story l3uilding Shapy I aisa Plan-e- } \\
\text { She }\end{array}$ & Ghazni & +882168980233 & & dacaar2@get2net.dk & Shah Mardan \\
\hline $\begin{array}{l}\text { Next Nangarhar High School, } \\
\text { Infront of (rodant-e-Sangi }\end{array}$ & Jalalabad & +882165420081 & & ¿alalabad $@$ get2net.dk & Eng. Masoom \\
\hline Near (heck Post 1 & Hirat & 070400206 & +87376295203 & herat@post.tele.dk & Mohd. Aqa \\
\hline $\begin{array}{l}\text { Shahr-e-Now, West of Kandahar } \\
\text { Ilotal }\end{array}$ & Kandahar & +882165420081 & & qandahar@get2net.dk & Haji Samandar \\
\hline Iaghman, Alingar & Mehtarlam & +873762951845 & & laghman.kabul@get2net. & Gul Makhan \\
\hline Jaji ( hawani & Paktia & +882168980234 & & jaji.kabul@get2net,dk & Dadullah \\
\hline
\end{tabular}

\section{DAFA (Demining Agency for Afghanistain)}

\begin{tabular}{|c|c|c|c|}
\hline Membership & SWABAC & Country of Affliliation & Afghanistan \\
\hline Address & Communication & Key Staff & Position \\
\hline \multirow{4}{*}{$\begin{array}{l}\text { Shahr-e-Now Near Dand, } \\
\text { Kandahar-l lirat High Way, } \\
\text { Kandahar- } \text { Aghanistan }\end{array}$} & $081825237 / 834687$ & Abdul Sattar & Director \\
\hline & $081-825247$ & Daud Farahi & OIC Officer \\
\hline & E-mail: dafa@qta.infolink.net.pk & A.S.Monib & Admin Officer \\
\hline & Web: & & \\
\hline
\end{tabular}

\begin{tabular}{|l|r}
\hline Afghan & 638 \\
\hline Pakistani & 1 \\
\hline Expatriates & 0 \\
\hline Total & 639 \\
\hline
\end{tabular}

Personnel

\begin{tabular}{lllll} 
& & & & \\
& & Budget ln US S & & \\
& 1998 & 2000 & 2001 & 2002 \\
\hline Afghanistan & & & & \\
\hline Pakistan & & & & \\
\hline Total & & & & \\
\hline
\end{tabular}

\begin{tabular}{|c|c|c|c|c|c|c|}
\hline & 1998 & 1999 & 2000 & 2001 & & \\
\hline & & & llocation & & Target & inces \\
\hline Donors & $\%$ Funded & Allocation & $\%$ Funded & Province & Sector & $\%$ Targeted \\
\hline UNDP & 100 & Mines & 100 & Kandahar & Mine & \\
\hline & & & & Zabul & Mine & \\
\hline
\end{tabular}

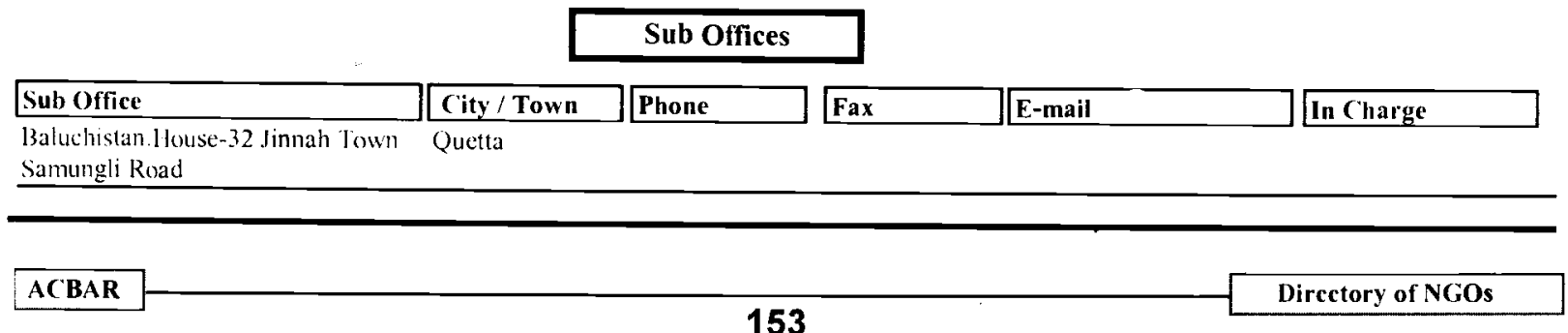


DCA (Butch Committee for Afghanistan)

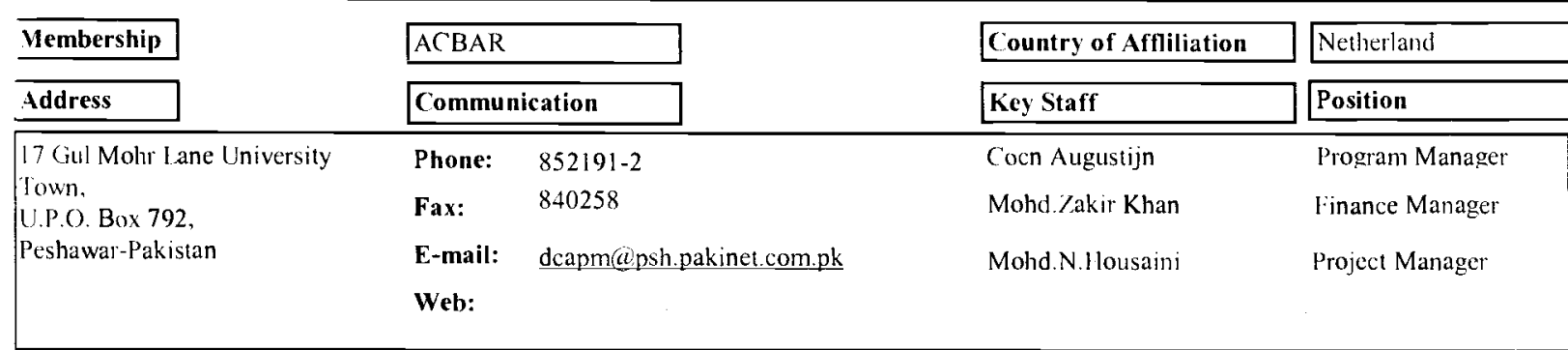

\begin{tabular}{|l|}
\hline Afghan \\
\hline \hline Pakistani \\
\hline Expatriates \\
\hline Total \\
\hline
\end{tabular}

Personnel

\begin{tabular}{|l|}
\hline Administrative \\
\hline Support \\
\hline Technical \\
\hline Total \\
\hline
\end{tabular}

Budget ln US \$

\begin{tabular}{|c|c|c|c|c|}
\hline & 1998 & 1999 & 2001 & 2002 \\
\hline Afghanistan & 579,900 & 613,380 & 647,676 & 863,568 \\
\hline Pakistan & 0 & 56,620 & 0 & 0 \\
\hline Total & $579,900.00$ & $670,000.00$ & $047,676.00$ & $863,568.00$ \\
\hline
\end{tabular}

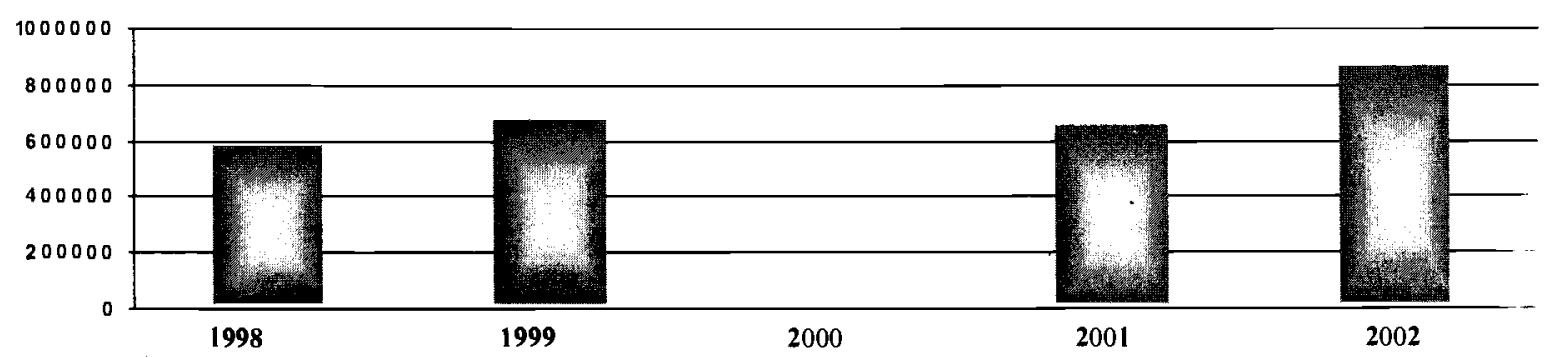

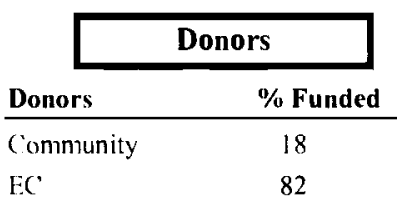

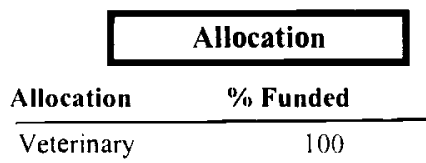

Veterinary

100

\begin{tabular}{lcr} 
& \multicolumn{2}{c|}{ Targeted Provinces } \\
\cline { 2 - 3 } Province & \multicolumn{1}{c|}{ Sector } & \% Targeted \\
\hline Badghis & Veterinary & 25 \\
Farah & Veterinary & 25 \\
Ghor & Veterinary & 25 \\
Hirat & Veterinary & 25
\end{tabular}

Sub Offices

\begin{tabular}{|c|c|c|c|c|c|}
\hline Sub Office & City / Town & Phone & Fax & E-mail & In Charge \\
\hline Kabul.Parwan 2 Street 2 & Kabul & 2200643 & & dcakabul@uwnct.n] & Dr.Tanin \\
\hline Hirat Jade Majidi & Hirat & 223567 & & deaherat cuwnet.ni & Dr.Housaini \\
\hline
\end{tabular}




\begin{tabular}{|c|c|c|c|}
\hline Membership & $\mathrm{ANCB}$ & Country of Affliliation & Afghanistan \\
\hline Address & Communication & Key Staff & Position \\
\hline \multirow{4}{*}{$\begin{array}{l}\text { louse } 131 \text { Succt } 15, \\
\text { Wayir Akbar Khan, } \\
\text { Kabl-Afghanistan }\end{array}$} & 070278108 & Iing. A.Cihani & Director \\
\hline & Fax: & M.llamayoon & Deputy Director \\
\hline & E-mail: $\quad$ deg-af@yahoocom & Eng. Ataullah & Admin \\
\hline & Wab: & & \\
\hline
\end{tabular}

\begin{tabular}{|l|}
\hline Afghan \\
\hline Pakistani \\
\hline Expatriates \\
\hline Total \\
\hline
\end{tabular}

11

3

0

14

\begin{tabular}{|l|}
\hline Administrative \\
\hline Support \\
\hline Technical \\
\hline Total \\
\hline
\end{tabular}

\begin{tabular}{|l|}
\hline Afghanistan \\
\hline Pakistan \\
\hline Total \\
\hline
\end{tabular}

$\frac{1998}{36,172}$
0
$30,172.00$

1999
79,605
0
79.605 .00

Budget In US \$

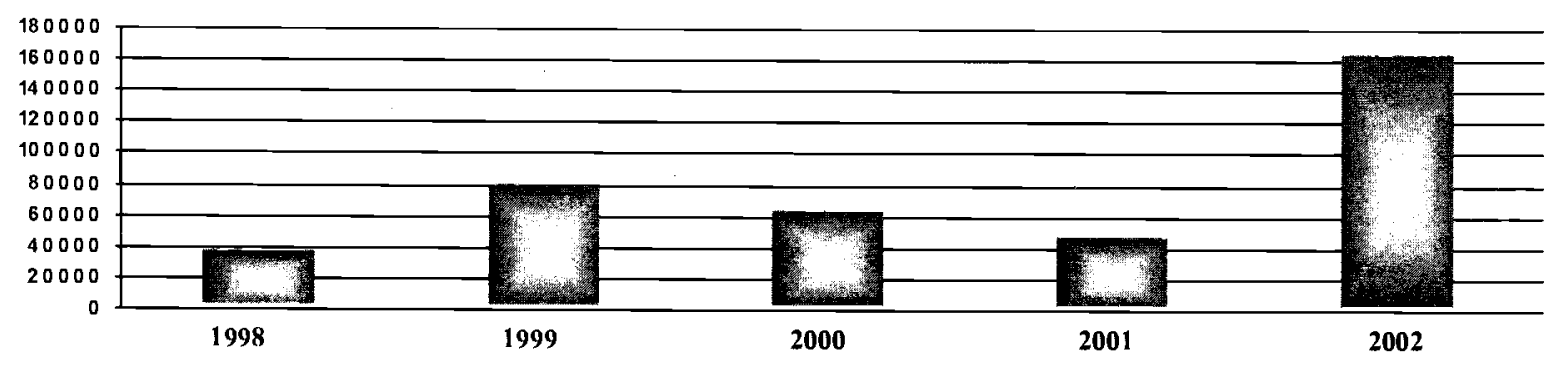

\begin{tabular}{lc}
\multicolumn{2}{c|}{ Donors } \\
Donors & \% Funded \\
\hline AACA & 8 \\
Japan limbassy & 10 \\
UNAMA & 10 \\
UNIICR & 12 \\
UNICII: & 10 \\
UNOPS & 30 \\
WIP & 20
\end{tabular}

\begin{tabular}{lc|}
\hline \multicolumn{1}{c|}{ Allocation } \\
Allocation & $\%$ Funded \\
\hline Education & 10 \\
Energency & 5 \\
Gender lssues & 10 \\
Ilealth & 15 \\
Inconc (ieneratio & 10 \\
Infrastructurc & 50
\end{tabular}

\begin{tabular}{|c|c|c|c|}
\hline \multirow{3}{*}{$\frac{\text { Province }}{\text { Kabul }}$} & \multicolumn{3}{|c|}{ Targeted Provinces } \\
\hline & Sector & \multicolumn{2}{|c|}{$\%$ Targeted } \\
\hline & \multicolumn{2}{|c|}{ Water Resources } & 10 \\
\hline Kabul & \multicolumn{2}{|c|}{ Infrastructure } & 10 \\
\hline Khost & \multicolumn{2}{|c|}{ Fducation } & 5 \\
\hline Kunar & \multicolumn{2}{|c|}{ Fducation } & 5 \\
\hline Laghman & \multicolumn{2}{|c|}{ Water Resources } & 10 \\
\hline Ningarhar & \multicolumn{2}{|c|}{ Infrastructure } & 10 \\
\hline Paktika & \multicolumn{2}{|c|}{ Relicf \& Repatriation } & 10 \\
\hline P'arwan & \multicolumn{2}{|c|}{ limergency } & 10 \\
\hline Wardak & \multicolumn{2}{|c|}{ Fmergency } & 30 \\
\hline
\end{tabular}

Sub Offices

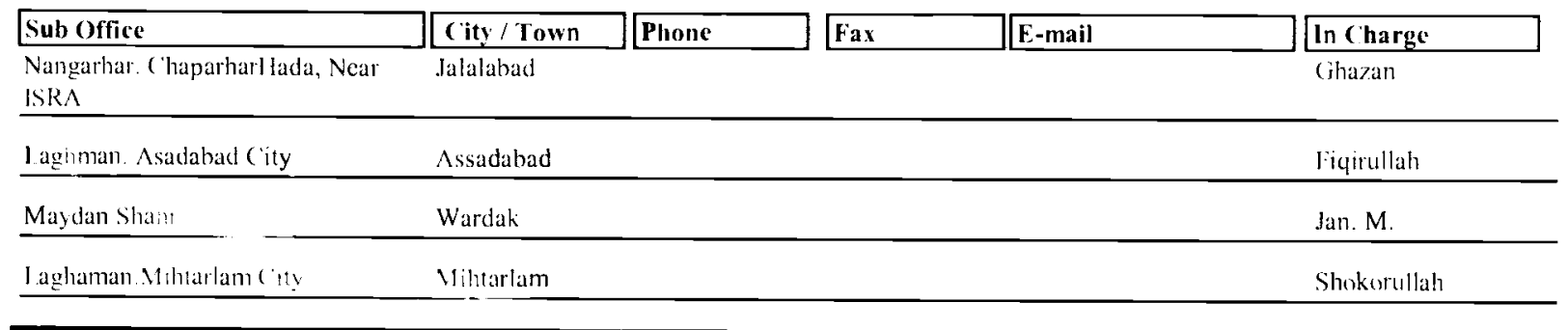




\section{DHSA (Development and Humanitarian Services for Afghanistan)}

\begin{tabular}{|c|c|c|c|}
\hline Membership & & Country of Affiliation & Afghanistan \\
\hline Address & Communication & Key Staff & Position \\
\hline \multirow{4}{*}{$\begin{array}{l}223 \text { Ist Bus Stop Kolola Pashata, } \\
\text { Near to Abuhanif Mosque. } \\
\text { Kabul- } \Lambda \text { fghanistan }\end{array}$} & 2200573 & Shahit Alt. Zahine & Genral Director \\
\hline & Fax: & Rahim Khurram & Prog Coordinator \\
\hline & saphir@brain.nel.pk & Mirajan Jahid & Adnin. Finance \\
\hline & Web: & & \\
\hline
\end{tabular}

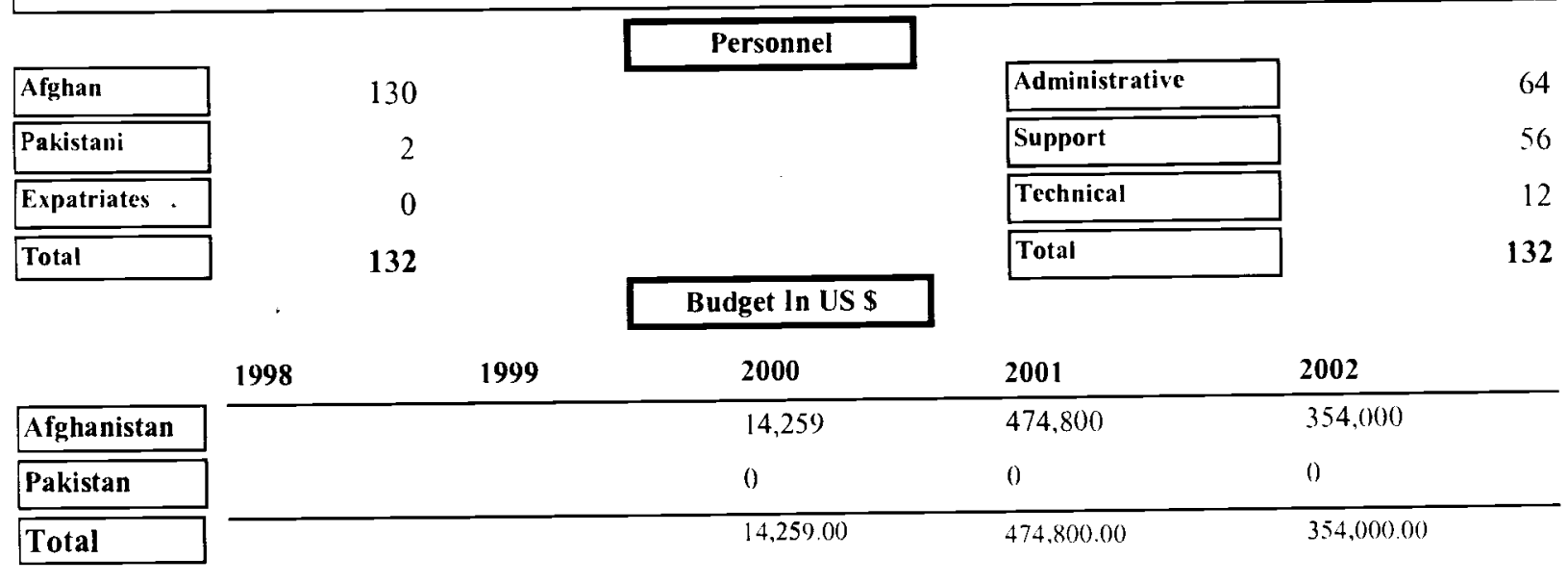

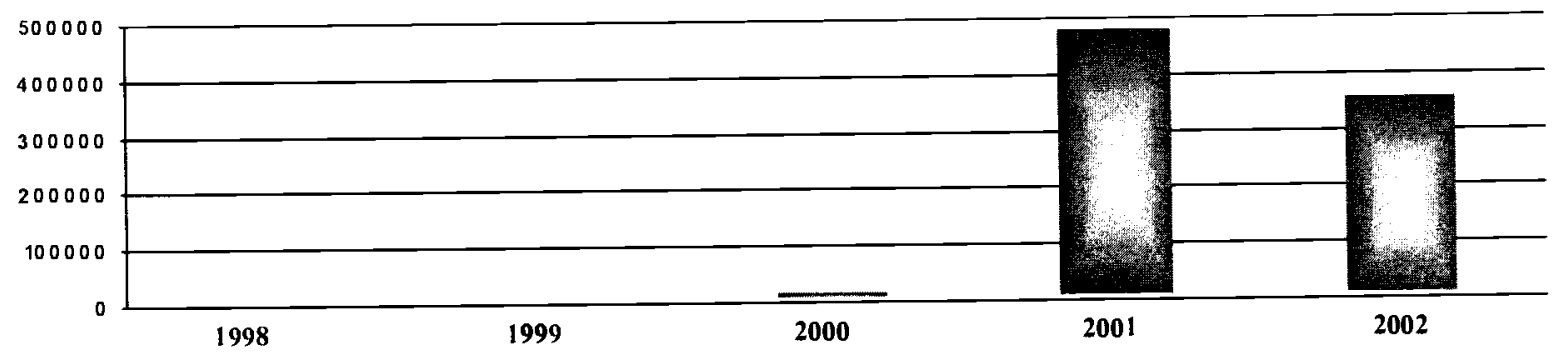

\begin{tabular}{|c|c|c|c|c|c|c|}
\hline \multicolumn{2}{|c|}{ Donors } & & location & \multirow[b]{2}{*}{ Province } & \multicolumn{2}{|l|}{ Targeted Provinces } \\
\hline Donors & $\%$ Funded & Allocation & $\%$ Funded & & $\%$ Targe & \\
\hline Canada Fund & & Agriculture & 5 & Baghlan & limergency & 3 \\
\hline ( ARI: & & Education & 5 & Balkh & Relief \& Repatriatioin & 30 \\
\hline Caritas Ciermany & & limergency & 10 & Bamyan & Infrastructure & 3 \\
\hline til & & Health & 5 & Ghazni & Relief \& Repatriatioin & 10 \\
\hline $\begin{array}{l}\text { G()AI. } \\
\text { IRT }\end{array}$ & & Infrastructure & 20 & Kabul & Intrastructure & 20 \\
\hline Japan & & Other & 25 & Khost & Agriculture & 3 \\
\hline NOVIB & & & & Logar & Water Resources & 3 \\
\hline UNDP & & & & Paktika & Infrastructure & 3 \\
\hline INOCHA & & & & Parwan & Agriculture & 2 \\
\hline $\begin{array}{l}\text { UNOPS } \\
\text { US limbassy }\end{array}$ & & . & & Samangan & Water Resources & 10 \\
\hline WFP & & & & Uruzgan & Education & 10 \\
\hline & & & & H...dak & Relief \& Repatriatioin & 3 \\
\hline
\end{tabular}

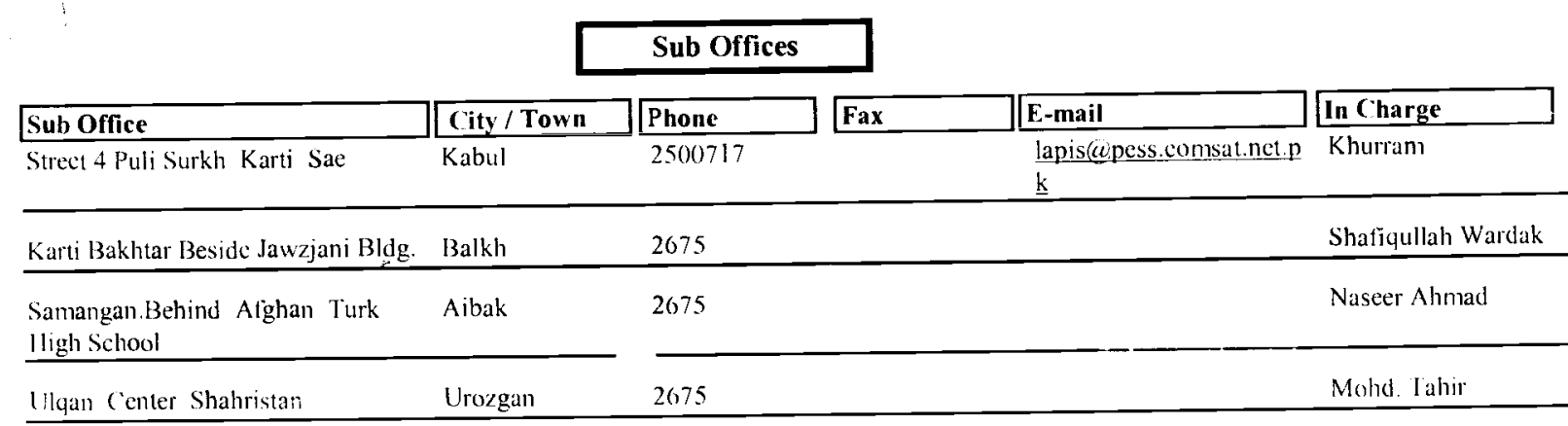




\section{DS (Darul Shefa)}

\begin{tabular}{|c|c|c|c|}
\hline Membership & Other & Country of Affliliation & Afghanistan \\
\hline Address & Communication & Key Staff & Position \\
\hline \multirow{3}{*}{$\begin{array}{l}\text { Street 2. Canal Town, } \\
\text { Nasir Bash Road Board. } \\
\text { Peshawar-Pakistan }\end{array}$} & Phone: & Bakhtar $\Lambda$ minzai & Director \\
\hline & Fax: & Mujahid Cardezi & Coordinator \\
\hline & $\begin{array}{l}\text { E-mail: dshefa@ules.com sats netpk } \\
\text { Web: }\end{array}$ & Saced Gul & C'onsultant \\
\hline
\end{tabular}

\begin{tabular}{|l|}
\hline Afghan \\
\hline Pakistani \\
\hline Expatriates \\
\hline Total \\
\hline
\end{tabular}

Personnel

Budget ln US \$

\begin{tabular}{|l|}
\hline Administrative \\
\hline Support \\
\hline Technical \\
\hline Total \\
\hline
\end{tabular}

\section{4}

36

\begin{tabular}{|c|c|c|c|}
\hline & 1999 & 2001 & 2002 \\
\hline Afghanistan & & 0 & 75,000 \\
\hline Pakistan & & 273,315 & 225,000 \\
\hline Total & & $273,315.00$ & $300,000.00$ \\
\hline
\end{tabular}

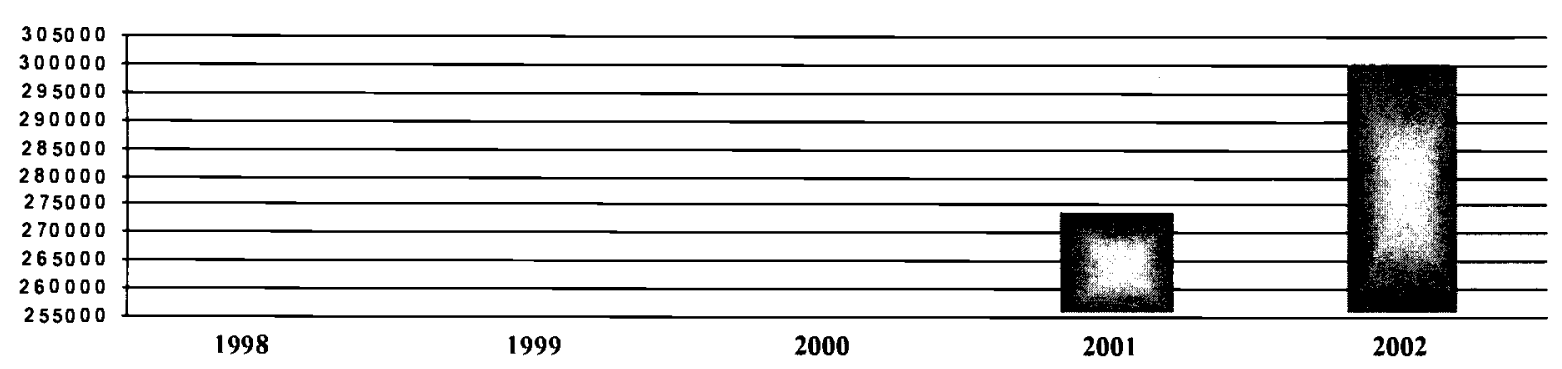

\begin{tabular}{|c|c|c|c|c|c|c|}
\hline \multicolumn{2}{|c|}{ Donors } & & llocation & \multirow[b]{2}{*}{ Province } & \multicolumn{2}{|c|}{ Targeted Provinces } \\
\hline Donors & $\%$ Funded & Allocation & $\%$ Funded & & Sector & $1 \%$ Targeted \\
\hline Al Bukhary Fou. & 20 & Fiducation & 15 & Kabul & Education & 5 \\
\hline I.11.H. Furkey & 10 & Fimergency & 30 & Kabul & Health and Edu. & 5 \\
\hline Muslim Aid UK & 60 & Health & 40 & Paktika & Health & 30 \\
\hline UNICHF & 10 & Reliel \& Re & 15 & Paktika & Education & 60 \\
\hline
\end{tabular}

\section{Sub Offices}

\begin{tabular}{|c|c|c|c|c|c|}
\hline Sub Office & City / Town & Phone & Fax & E-mail & In Charge \\
\hline Stree I4 Wazil Akbar Khan & Kabul & & & & Mujahid \\
\hline
\end{tabular}


Edhi (Edhi Welfare center)

\begin{tabular}{|c|c|c|c|}
\hline Membership & & Country of Affliliation & Pakistan \\
\hline Address & Communication & Key Staff & Position \\
\hline \multirow{4}{*}{$\begin{array}{l}\text { Kabul Road Arzaq Street, } \\
\text { lalalabad -Afghanistan }\end{array}$} & Phone: & M. Khalil & Incharge \\
\hline & Fax: & ling. Kaber & Incharge Ssubotfice \\
\hline & E-mail: & Reragul & Security \\
\hline & Web: & & \\
\hline
\end{tabular}

\begin{tabular}{|l|}
\hline Afghan \\
\hline Pakistani \\
\hline Expatriates \\
\hline Total \\
\hline
\end{tabular}

Personnel

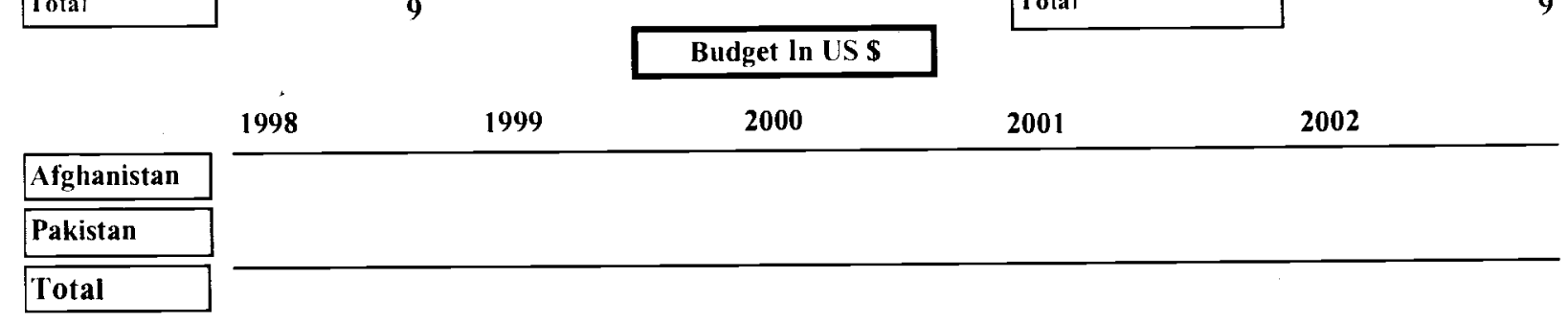

1998

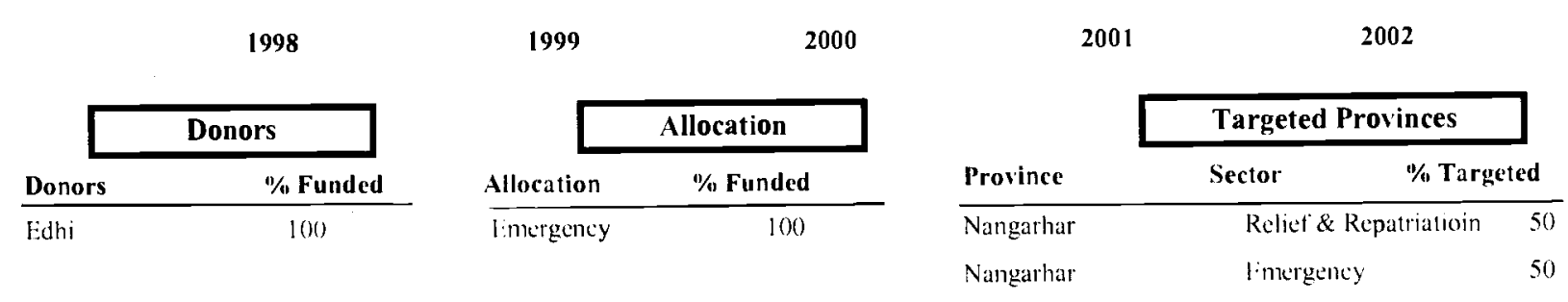

1999

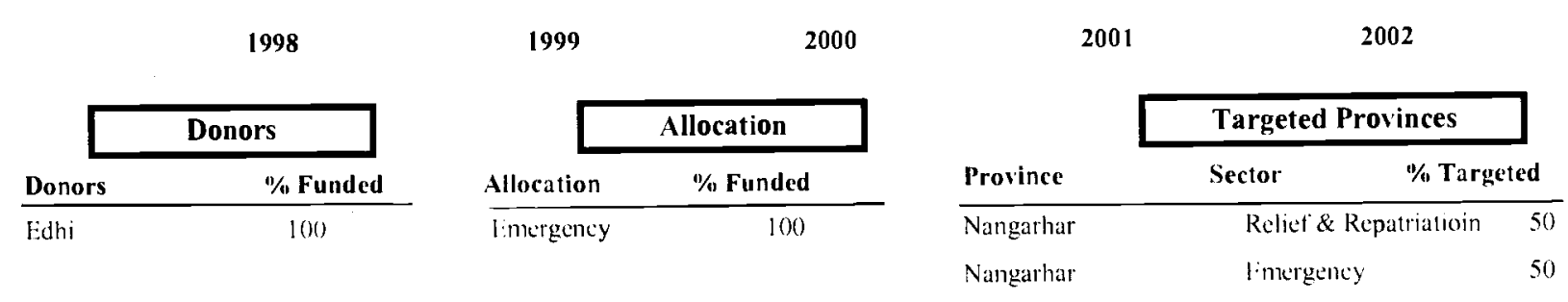

\begin{tabular}{|l|}
\hline Administrative \\
\hline Support \\
\hline Technical \\
\hline Total \\
\hline
\end{tabular}

\section{Sub Offices}

\begin{tabular}{|c|c|c|c|c|}
\hline Sub Office & City / Town & Phone & \begin{tabular}{|l|l|} 
Fax & E-mail \\
\end{tabular} & In Charge \\
\hline Kabul, Klola Pushta & Kabul & & & ling Kaber \\
\hline Sind. Metader Bulding Market & Karchi & & & Belgis lidhi \\
\hline
\end{tabular}




\section{EMDAD (Engineering and Medical Department for Afghanistan Development)}

\begin{tabular}{|c|c|c|c|}
\hline Membership & ANC B & Country of Affliliation & \begin{tabular}{|l} 
fighanistan \\
\end{tabular} \\
\hline Address & Communication & Key Staff & Position \\
\hline \multirow{3}{*}{$\begin{array}{l}\text { I louse } 428 \text { Strect } 8 \text { Tamani, } \\
\text { Kabul - Afghammian }\end{array}$} & Phone: 34490 & Ab. Nhmad & Director \\
\hline & Fax: & Eing. Ashequlliah & Deputy Director \\
\hline & $\begin{array}{l}\text { E-mail: } \\
\text { Web: }\end{array}$ & Abdullah & Chicf tingineer \\
\hline
\end{tabular}

\begin{tabular}{|l|}
\hline Afghan \\
\hline Pakistani \\
\hline Expatriates \\
\hline Total \\
\hline
\end{tabular}

14

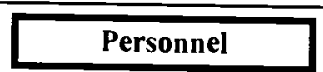

0

0

14

Budget In US \$

\begin{tabular}{|r|r}
\hline Administrative \\
\hline Support \\
\hline Technical \\
\hline Total \\
\hline
\end{tabular}

\begin{tabular}{|llllll}
\multicolumn{1}{l}{} & $\mathbf{1 9 9 8}$ & $\mathbf{2 0 0 0}$ & $\mathbf{2 0 0 1}$ & $\mathbf{2 0 0 2}$ \\
\cline { 3 - 6 } Afghanistan & 56,250 & 51,272 & 140,282 & 61,710 \\
\hline Pakistan & 0 & 0 & 0 & 0 \\
\hline Total & $56,250.00$ & $51,272.00$ & $140,282.00$ & 01.710 .00 \\
\hline
\end{tabular}
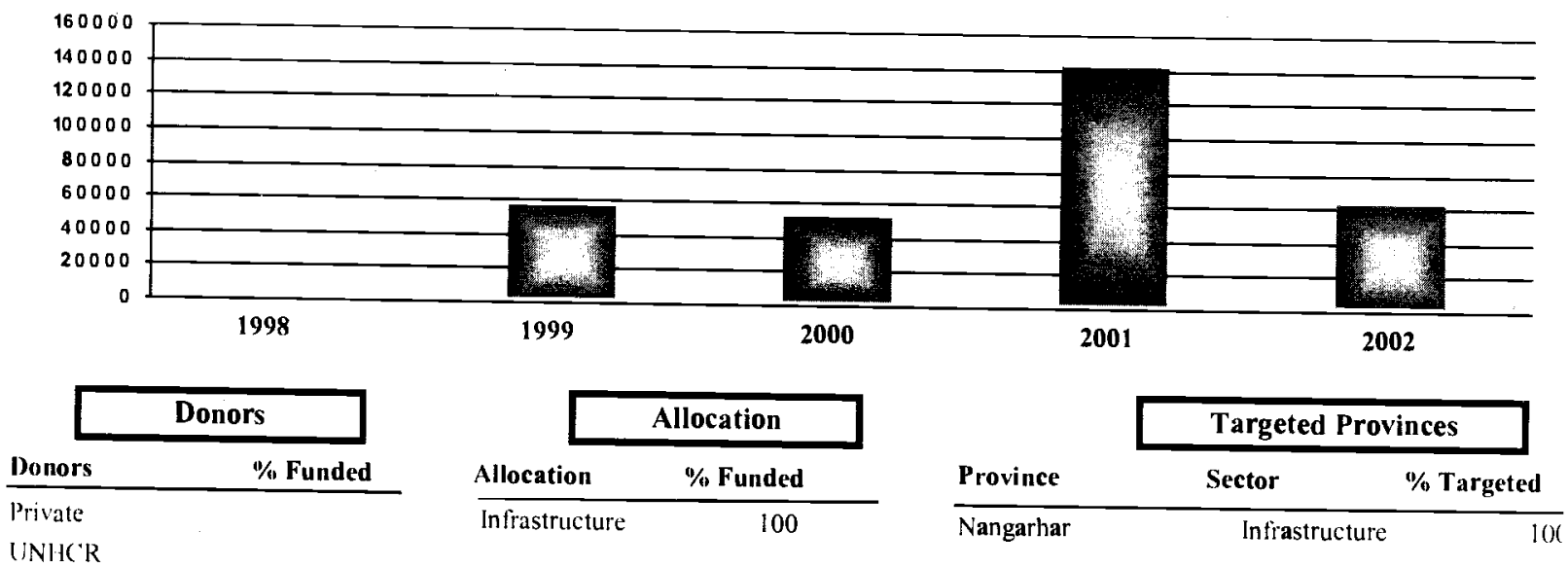

INOCHA

WFP

Sub Offices

\begin{tabular}{|c|c|c|c|c|}
\hline Sub Office & City / Town & Phone & E-mail & In Charge \\
\hline $\begin{array}{l}\text { Charahi Marasston Infront of } \\
\text { (hecknowry l tigh School }\end{array}$ & Jalalabad & & & Nasir Ahma \\
\hline
\end{tabular}




\begin{tabular}{|c|c|c|c|}
\hline Membership & & Country of Affiliation & $\Lambda$ tghanistan \\
\hline Address & Communication & Key Staff & Position \\
\hline \multirow{4}{*}{$\begin{array}{l}\text { Apt.I Block } 2 \text { ('harai Haji } \\
\text { Yaqoob. } \\
\text { Shahr-e-Naw, } \\
\text { Kabul-Afghanistan }\end{array}$} & 070289118 & Mohd. Shati & Eng.Manager \\
\hline & Fax: & Mohd.Hafiz & Program Coord. \\
\hline & E-mail: & Wahedullah & Finance Officer \\
\hline & Web: & & \\
\hline
\end{tabular}

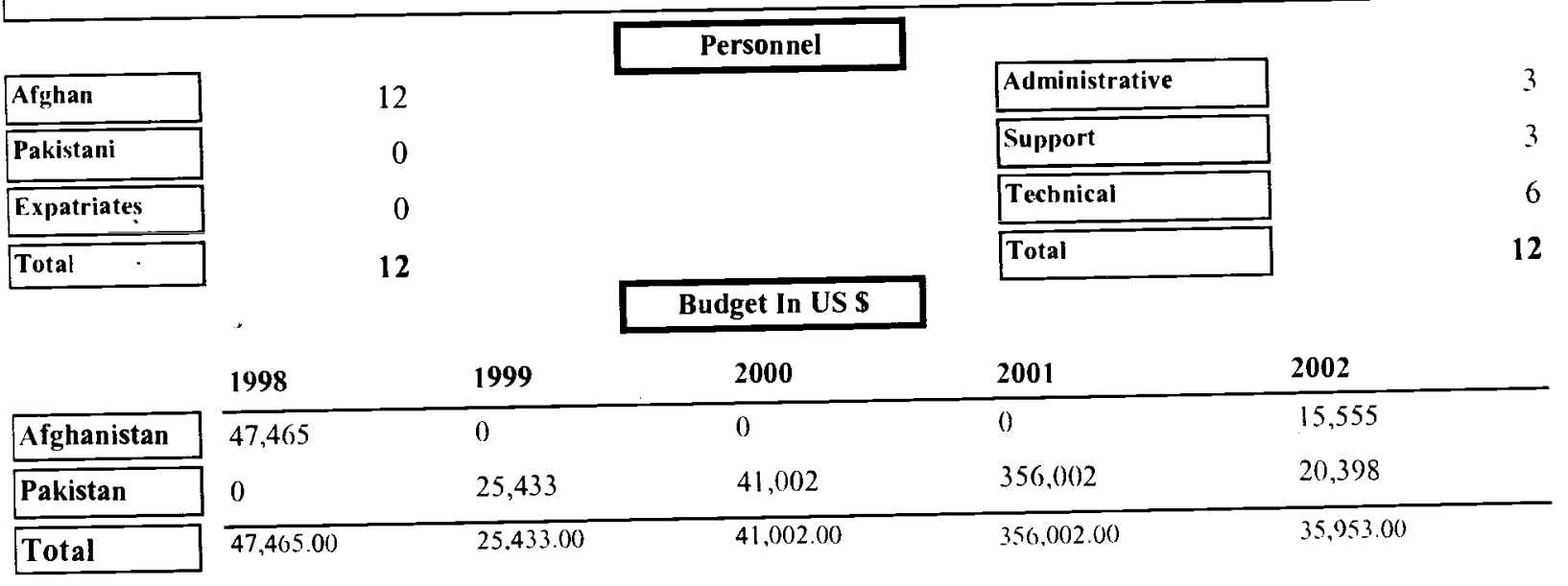

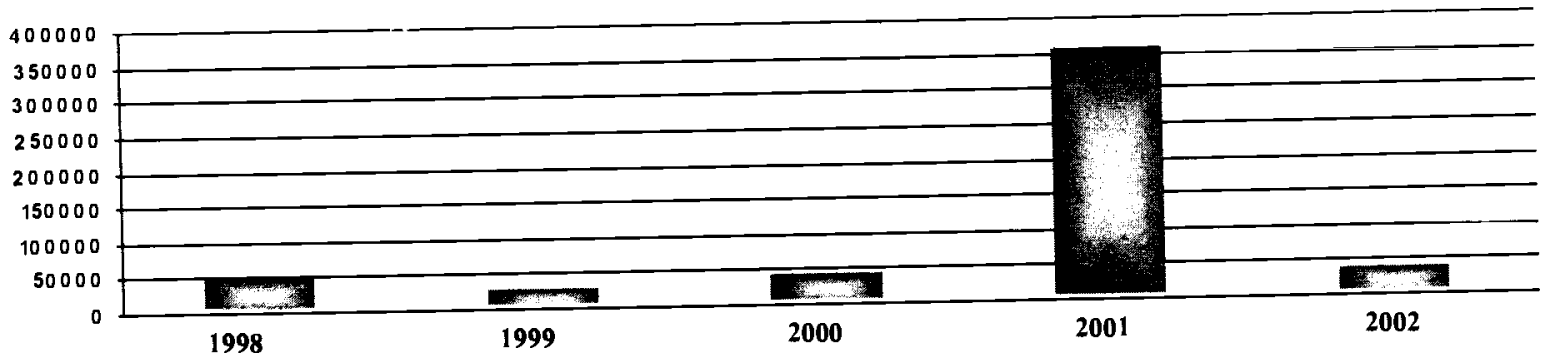

\begin{tabular}{lc}
\hline \multicolumn{2}{c|}{ Donors } \\
Donors & \% Funded \\
\hline (ORD AlD & 15 \\
IRC & 60 \\
Other & 5 \\
UNHC R & 20
\end{tabular}

\begin{tabular}{lc|}
\hline & Allocation \\
\hline Allocation & $\%$ Funded \\
\hline Emergency & 10 \\
Environment & 10 \\
Income Generatio & 10 \\
Infrastructure & 70
\end{tabular}

\begin{tabular}{llc} 
& \multicolumn{2}{c|}{ Targeted Provinces } \\
\cline { 2 - 3 } Province & Sector & "1/ Targeted \\
\hline Ghazni & Infrastructure & 20 \\
Kabul & Income (ieneration & 5 \\
Kabul & Environment & 5 \\
Kabul & Infrastructure & 50 \\
Logar & Income (jeneration & 5 \\
Logar & Environment & 5 \\
L.ogar & Infrastructure & 20
\end{tabular}

Sub Offices

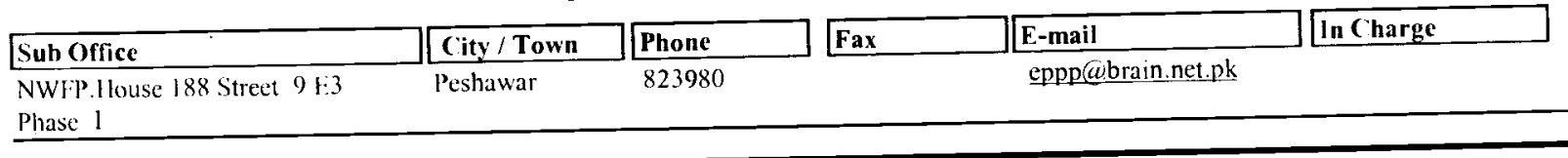


ERO (Ehsan Rehabilitation Organization)

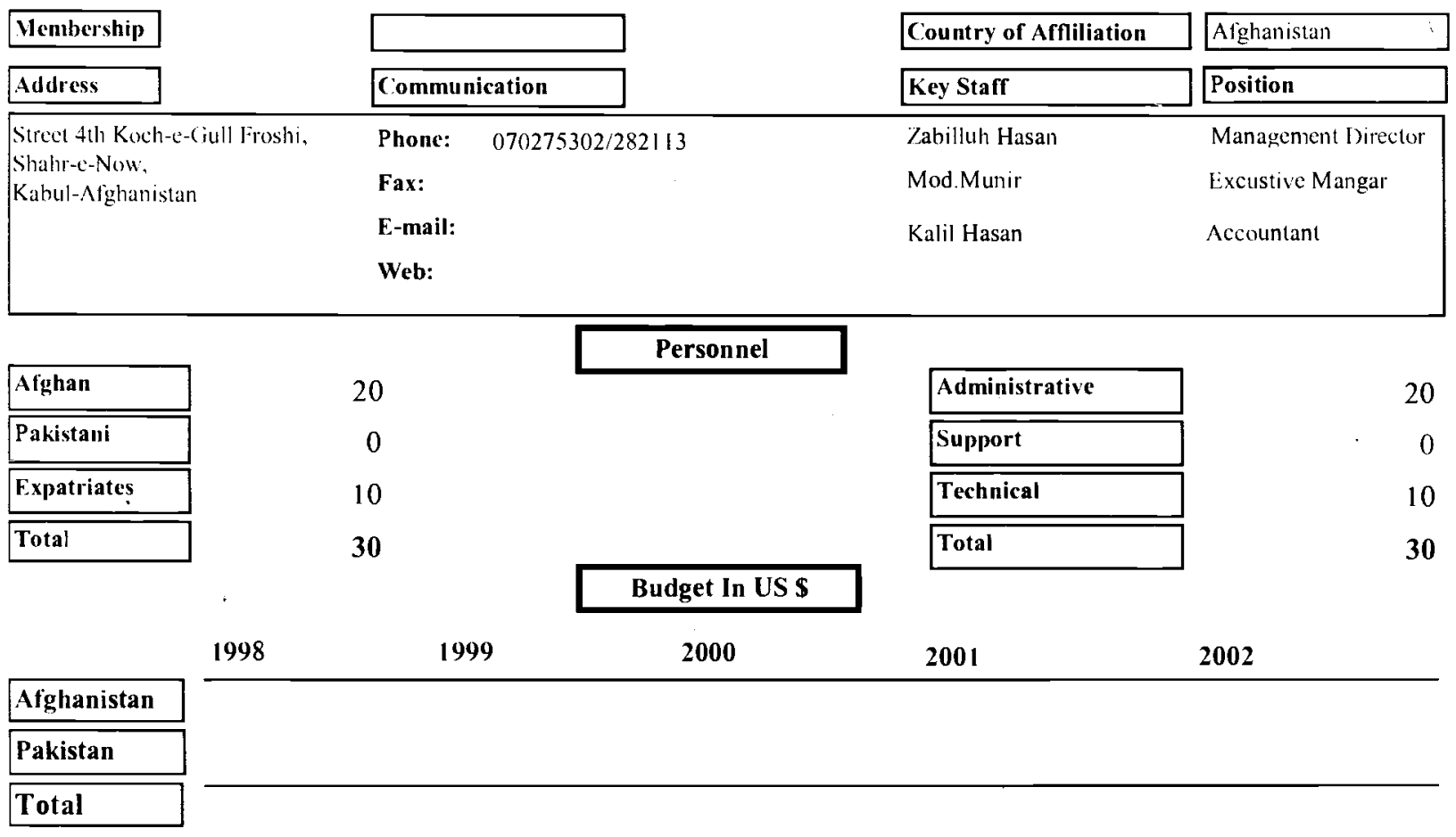

1998

\begin{tabular}{lc}
\multicolumn{2}{c|}{ Donors } \\
\cline { 2 - 2 } Donors & \% Funded \\
\hline (iBS & 33.4 \\
KLW & 33.3 \\
IINDP & 33.3
\end{tabular}

1999

\begin{tabular}{lc} 
& \multicolumn{2}{c|}{ Allocation } \\
\hline Allocation & \% Funded \\
\hline Agriculture & 50 \\
Infrastructure & 25 \\
& 25
\end{tabular}

2001

2002

\begin{tabular}{lcr}
\cline { 2 - 3 } & \multicolumn{2}{c|}{ Targeted Provinces } \\
\cline { 2 - 3 } Province & Sector & $\%$ Targeted \\
\hline Kabul & Education & 40 \\
Logar & Health & 60
\end{tabular}

Sub Offices

\begin{tabular}{|c|c|c|c|c|c|}
\hline Sub Oftice & City / Town & Phone & Fax & E-mai & In Charge \\
\hline Kart-e- 4 infront ol M.II.I:du. & Kabul & 2501128 & & & Menajaluraman \\
\hline
\end{tabular}


FECO (Fayez Eng. And construction Organization)

\begin{tabular}{|c|c|c|c|}
\hline Nembership & & Country of Affliliation & Atghanistan \\
\hline Address & Cnmmunication & Key Staff & Position \\
\hline \multirow{4}{*}{$\begin{array}{l}\text { 3rd Part of Khair Khana, } \\
\text { Ianish Bus Stop, } \\
\text { Kabul-Afghanistan. }\end{array}$} & 070279313 & Mohd Sharif & Director \\
\hline & Fax: & Eng.Aziz & Deputy Dirctor \\
\hline & E-mail: & Ahmad Parwiz. & Finance $\wedge$ ssistant \\
\hline & Web: & & \\
\hline
\end{tabular}

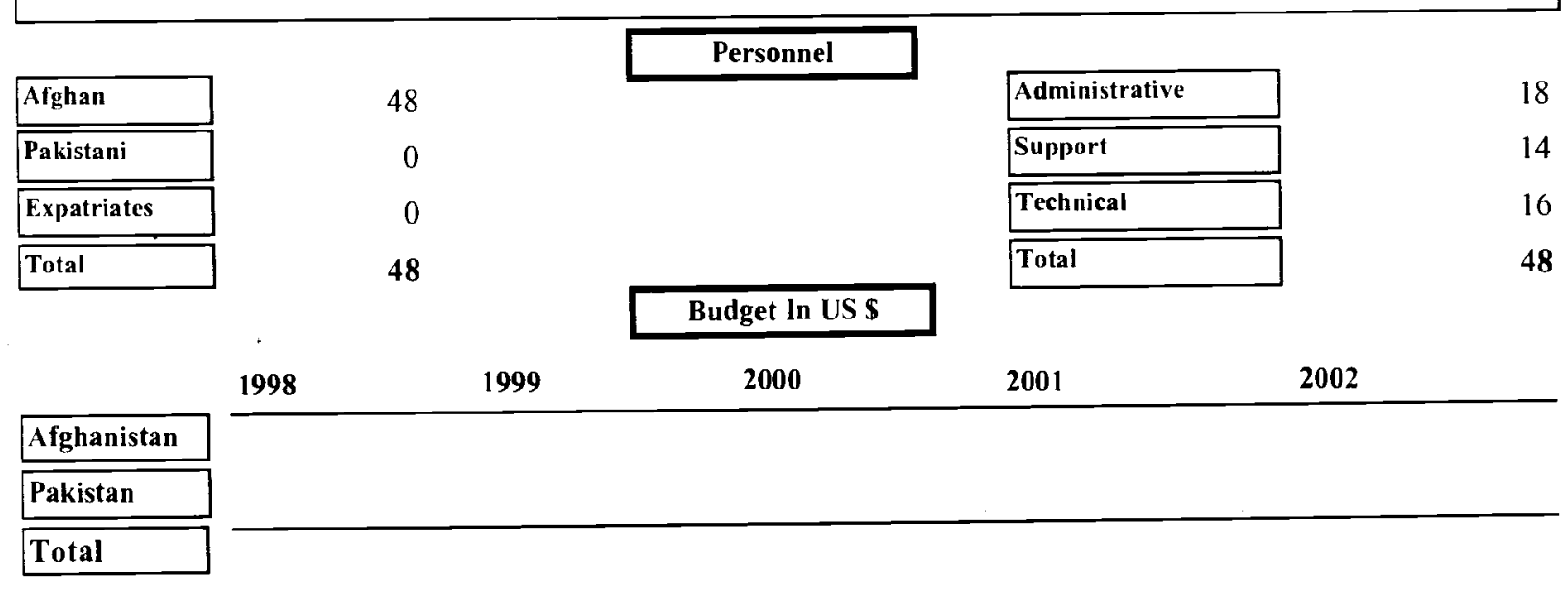

1998

\begin{tabular}{lc}
\hline \multicolumn{2}{c|}{ Donors } \\
Donors & $\%$ Funded \\
\hline SC-US & 10 \\
UNHCR & 23 \\
UNICEF & 5 \\
UNOCHA & 2 \\
WFP & 60
\end{tabular}

1999

\begin{tabular}{lc|}
\cline { 2 - 2 } & \multicolumn{2}{c|}{ Allocation } \\
\hline Allocation & \% Funded \\
\hline Agriculture & 7 \\
Infrastructure & 26 \\
Other & 12 \\
Relief \& Repatria & 25 \\
Water Resources & 30
\end{tabular}

2001

2002

\begin{tabular}{lll} 
& \multicolumn{2}{c|}{ Targeted Provinces } \\
\cline { 2 - 3 } Province & Sector & \% Targeted \\
\hline Balkh & Relief \& Repatriatioin & 5 \\
Faryab & Other & 9 \\
Faryab & Water Resources & 23 \\
Faryab & Relicf \& Repatriatioin & 20 \\
Faryab & Infrastructure & 22 \\
Faryab & Agriculture & 7 \\
Jawzjan & Other & 3 \\
Jawzjan & Water Resources & 7 \\
Jawzjan & Infrastructurc & 4
\end{tabular}

Sub Offices

\begin{tabular}{|c|c|c|c|c|}
\hline Sub Office & City / Town & Phone & E-mail & In Charge \\
\hline Karta Zahruddin Fayabi & Balkh & 2386 & & M. Sharif \\
\hline Karta 1)ostum & Jawazjan & & & Eng Wahid \\
\hline Nawabad Maymana & Faryab & & & Eng. $\triangle$ man \\
\hline
\end{tabular}


FFO (Farhad Fecdows Organization)

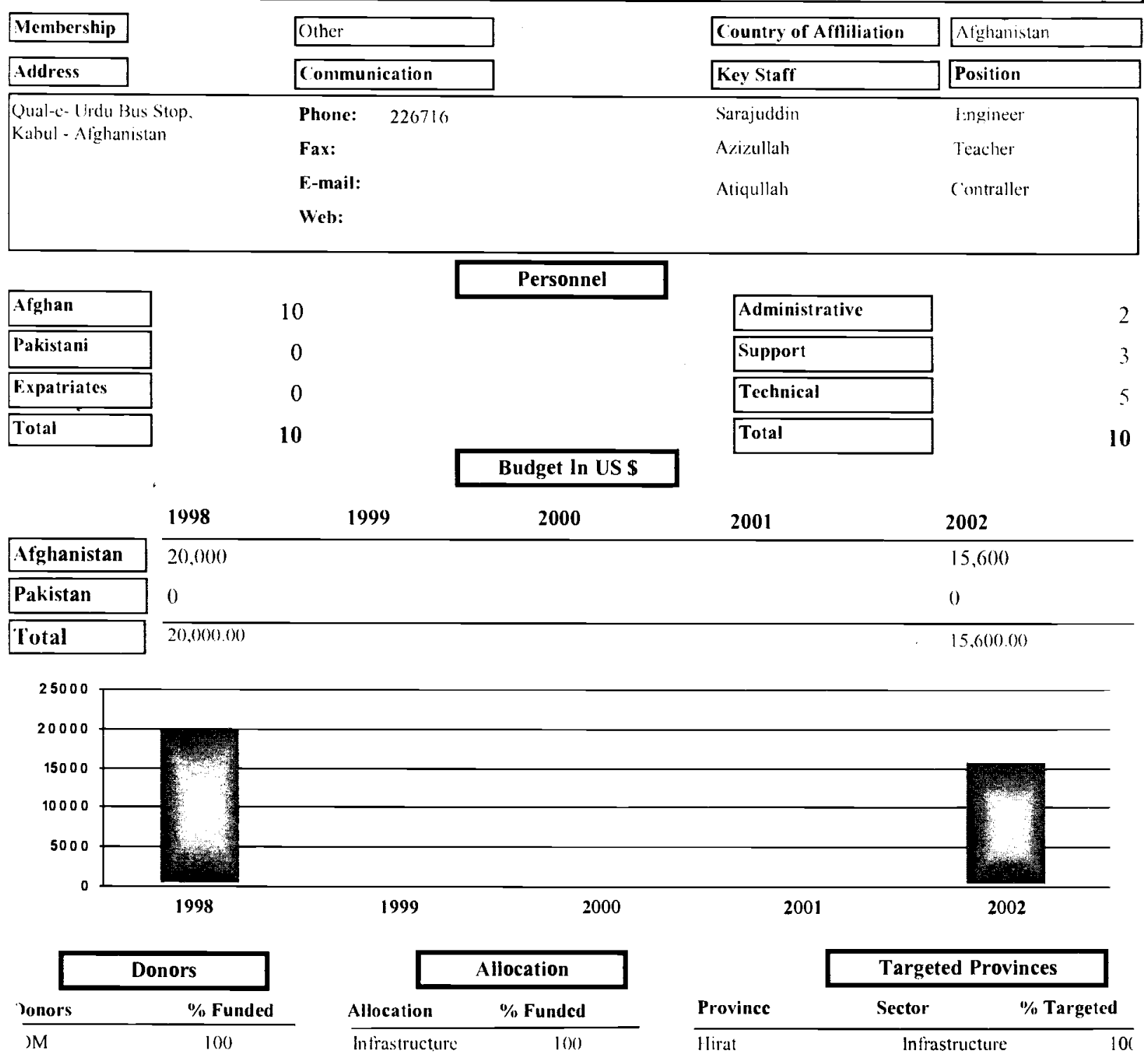

\section{Sub Offices}

\begin{tabular}{|c|c|c|c|c|c|}
\hline$[$ b Office & City / Town & Phone & Fax & E-mail & In Charge \\
\hline is dghis (lose to Nirport & Badghis & & & & A.Yhari \\
\hline
\end{tabular}




\begin{tabular}{|c|c|c|c|}
\hline Membership & $\triangle N\left({ }^{\circ} B\right.$ & Country of Affliliation & Alghanistan \\
\hline Address & Communication & Key Staff & Position \\
\hline \multirow{4}{*}{$\begin{array}{l}\text { I louse 1Streel o } \\
\text { Nasir Bagh Road Baord. } \\
\text { Peshawar-Pakistan }\end{array}$} & Phonc: & ling.Sharifa & I:xeulive Director \\
\hline & Fax: & Amin laqir Zada & Asst Director \\
\hline & fido(apsh.pakncl.com.pk & ljazulhaq Sahibrada & Administrator \\
\hline & Web: & & \\
\hline
\end{tabular}

\begin{tabular}{|l|}
\hline Afghan \\
\hline Pakistani \\
\hline Expatriates \\
\hline Total
\end{tabular}

\section{Personnel}

\begin{tabular}{|c|c|c|c|c|c|}
\hline & & & Budget ln US \$ & & \\
\hline & 1998 & 1999 & 2000 & 2001 & 2002 \\
\hline Afghanistan & 27,000 & 12,000 & 51,000 & 47,000 & 45,000 \\
\hline Pakistan & () & () & 0 & () & 38,000 \\
\hline Total & $27,000.00$ & $12,000.00$ & $51,000.00$ & $47,000.00$ & $83,000.00$ \\
\hline
\end{tabular}

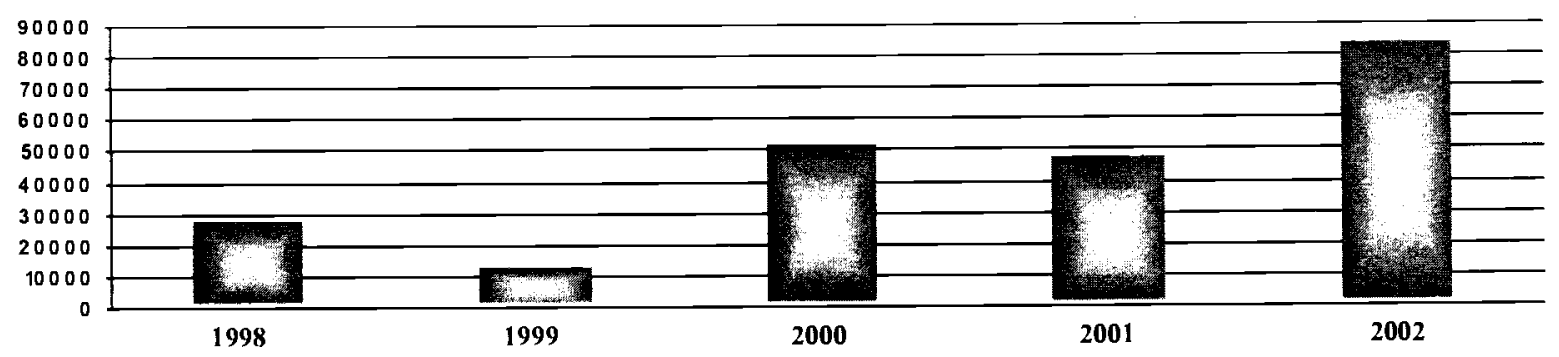

\begin{tabular}{|c|c|c|c|c|c|c|c|}
\hline \multicolumn{2}{|c|}{ Donors } & & location & \multirow[b]{2}{*}{ Province } & \multicolumn{3}{|c|}{ Targeted Provinces } \\
\hline Donors & $1 \%$ Funded & Allocation & $\%$ Funded & & Sector & $1 / \% \mathrm{Ta}$ & \\
\hline CIDA - Canada & 60 & Education & 15 & $\overline{\text { Kabul }}$ & Intrastructure & & 5 \\
\hline DHD & 2 & Health & 4 & Kabul & I:ducationn & & 45 \\
\hline (GRA - Japan & 30 & Income (ieneratio & 75 & NW & lealth & & 2 \\
\hline UNIICR & 3 & Infrastructure & 0 & NWIP & Fducation & & 3 \\
\hline $\begin{array}{l}\text { UWT } \\
\text { WIPP }\end{array}$ & 3 & & & NWFP & Fducation & & 5 \\
\hline & & & & NWIP' & Inconce (iencr & ation & 40 \\
\hline
\end{tabular}

Sub Offices

\begin{tabular}{|c|c|c|c|c|}
\hline Sub Officc & City / Town & Phone & Fax & In Charge \\
\hline Housc 233 Opp. Robbia School & Kabul & 070281127 & & frdo@psh.paknel.compk ling.Nacem \\
\hline
\end{tabular}




\section{FTC (Feed the Childern International)}

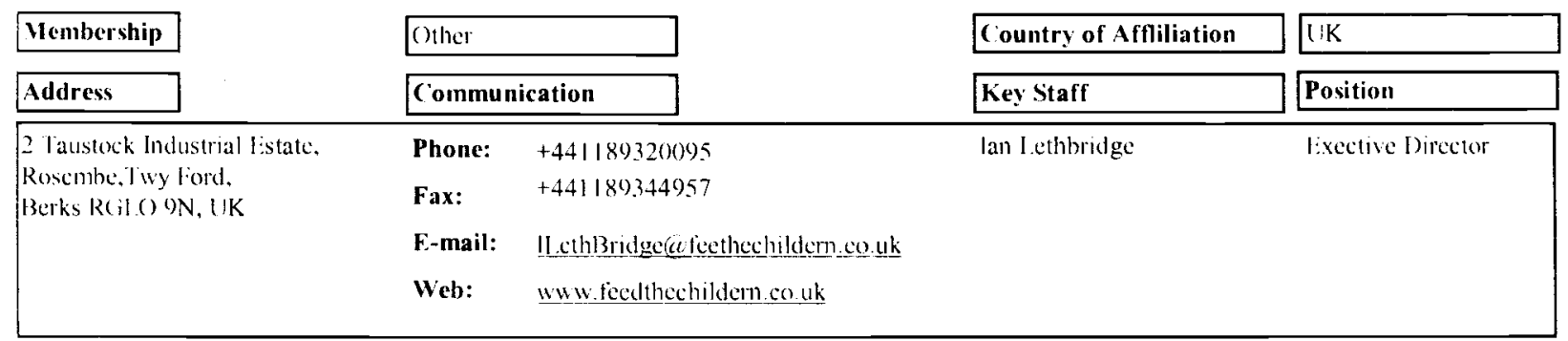

\begin{tabular}{|l|}
\hline Afghan \\
\hline Pakistani \\
\hline Expatriates \\
\hline Total \\
\hline
\end{tabular}

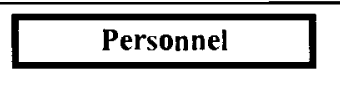

\begin{tabular}{|l|}
\hline Administrative \\
\hline Support \\
\hline Technical \\
\hline Total \\
\hline
\end{tabular}

Budget In US \$

\begin{tabular}{|c|c|c|c|c|}
\hline & 1998 & 1999 & 2001 & 2002 \\
\hline Afghanistan & & & $243,0(0)$ & 45,000 \\
\hline Pakistan & & & 0 & 0 \\
\hline Total & & & $243,000.00$ & $45,000.00$ \\
\hline
\end{tabular}

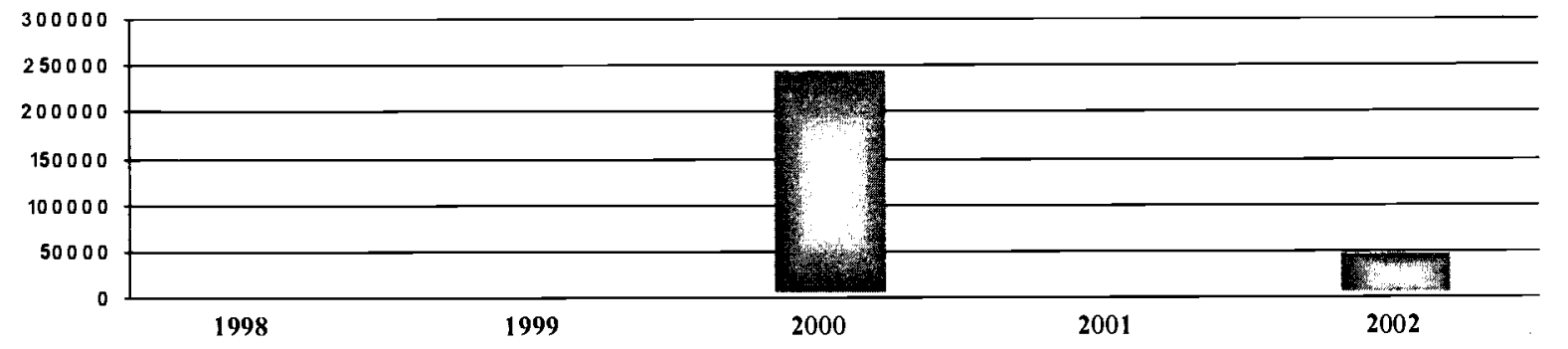

\begin{tabular}{|c|c|c|c|c|c|c|}
\hline \multicolumn{2}{|c|}{ Donors } & & llocation & \multirow[b]{2}{*}{ Province } & \multicolumn{2}{|c|}{ Targeted Provinces } \\
\hline Donors & $\%$ Funded & Allocation & $\%$ Funded & & Sector & $1 \%$ Targeted \\
\hline \multirow[t]{2}{*}{ UN-WFP } & 100 & Emergency & 85 & l. Lirat & Emergency & 85 \\
\hline & & Infrastructure & 15 & Hirat & Infrastructure & 15 \\
\hline
\end{tabular}

Sub Offices

\begin{tabular}{|c|c|c|c|c|c|}
\hline Sub Office & City / Town & Phone & Fax & E-mail & In Charge \\
\hline Ilirat Jade Majcedy & I Iirat & 220612 & & $\begin{array}{l}\text { ftcisatcoml@omail.statio } \\
\text { n } 12 . \mathrm{com}\end{array}$ & Chris Boceill \\
\hline
\end{tabular}


FTH (Fotdh Construction and Reconstruction Committee)

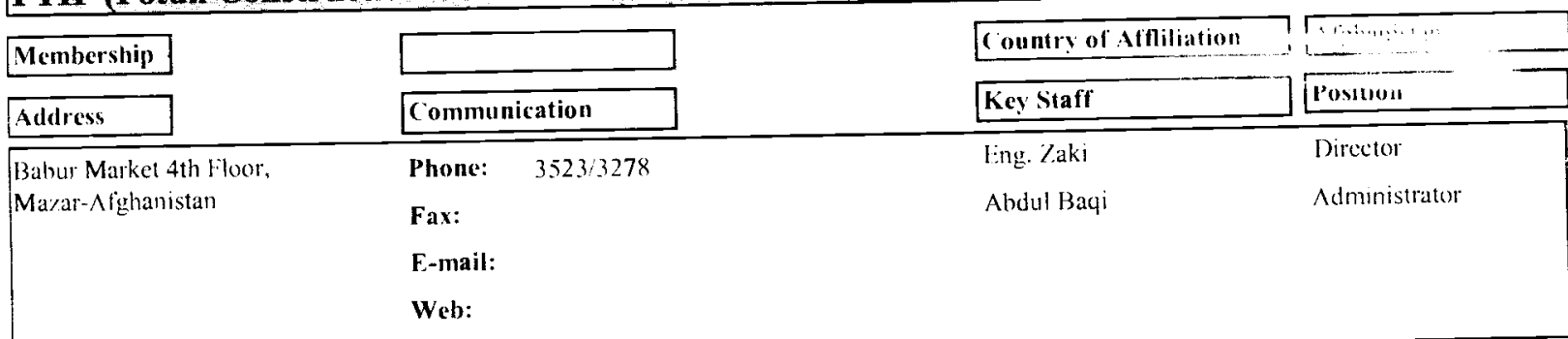

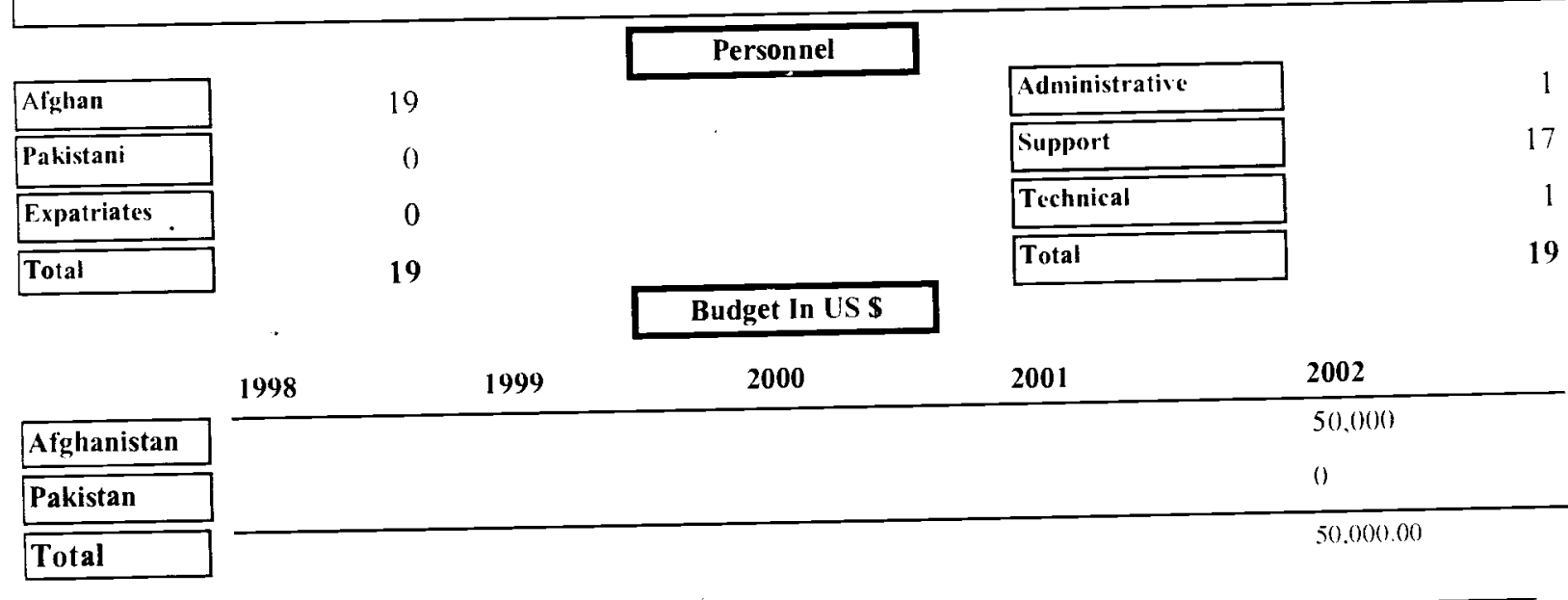

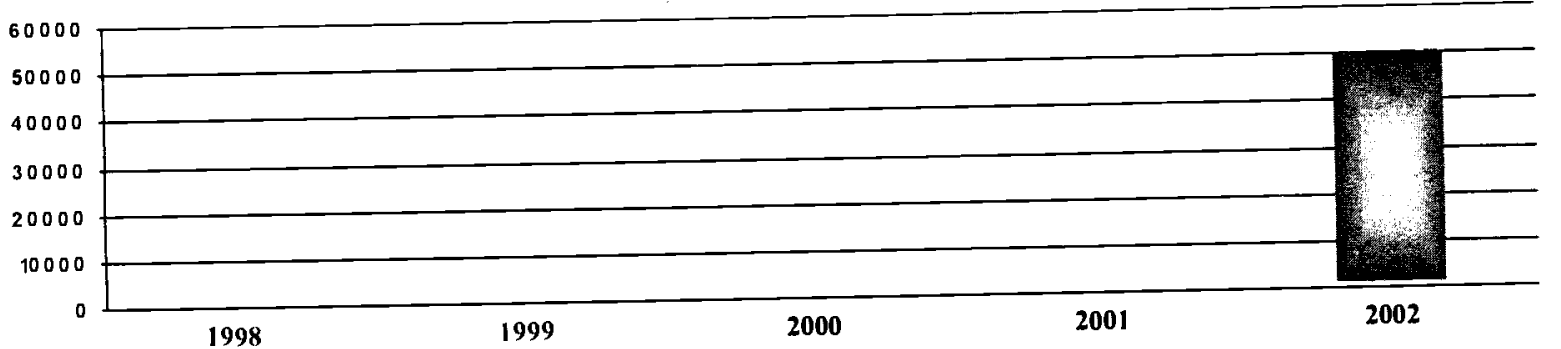

\begin{tabular}{lcllc}
\hline \multicolumn{2}{c|}{ Donors } & & \multicolumn{2}{c|}{ Allocation } \\
Donors & "\% Funded & & Allocation & \% Funded \\
UNHCR & 40 & & Agriculture & 20 \\
UNICEF & 40 & & Education & 40 \\
WIPP & 20 & & Intiastructure & 40
\end{tabular}

Targeted Provinces

Sub Offices 


\section{FWF (Family Welfare Foundation)}

\begin{tabular}{|c|c|c|c|}
\hline Membership & Other & Country of Affiliation & Afghansitan \\
\hline Address & Communication & Key Staff & Position \\
\hline \multirow{3}{*}{$\begin{array}{l}\text { House } 4 \text { Street } 14, \\
\text { Gulai Paikub-e-Naswar, } \\
\text { Qalai lathullah, } \\
\text { Kabul - Nighanistan }\end{array}$} & Phonc: $\quad 070276071$ & S.A.Haidari & Director \\
\hline & Fax: & Nasrullah Kabir & Deputy Director \\
\hline & $\begin{array}{l}\text { E-mail: } \\
\text { Web: }\end{array}$ & Ebadullah Amid & Admin Officer \\
\hline
\end{tabular}

\begin{tabular}{|l|c|l|l|}
\hline Afghan & 24 & Personnel & \\
\hline Pakistani & & & \\
\hline Expatriates & 0 & & \\
\hline Total & 0 & & \\
\hline
\end{tabular}

\begin{tabular}{|c|c|c|c|c|c|}
\hline & 1998 & 1999 & 2000 & 2001 & 2002 \\
\hline Afghanistan & 28,427 & 48,843 & 54,756 & 35,668 & 61,198 \\
\hline Pakistan & 0 & 0 & 0 & 0 & 0 \\
\hline Total & 28.427 .00 & $48,843,00$ & $54,755.60$ & $35,608.40$ & $61,198.00$ \\
\hline
\end{tabular}

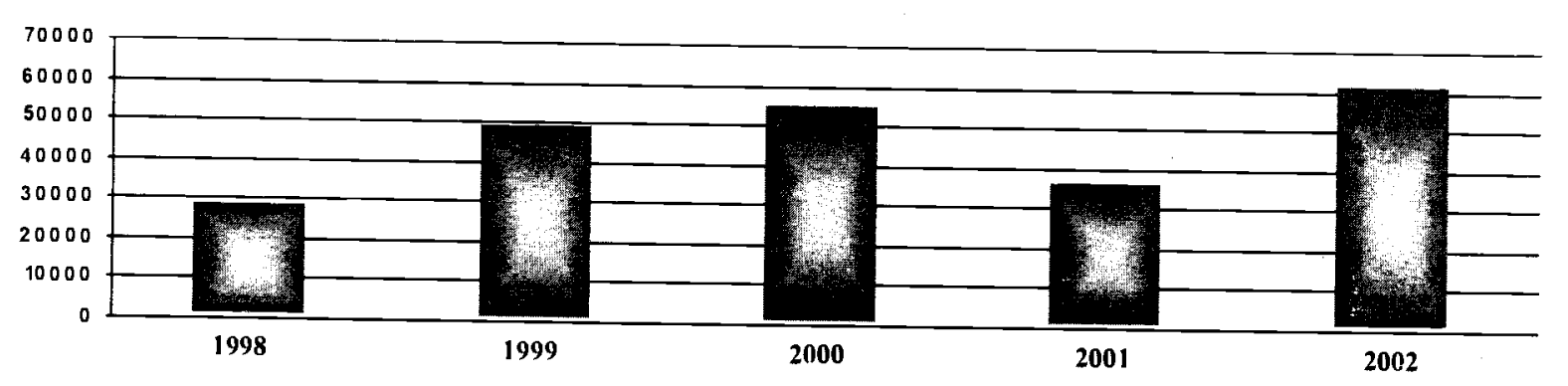

\begin{tabular}{lcllc}
\hline \multicolumn{2}{c|}{ Donors } & & \multicolumn{2}{c|}{ Allocation } \\
Donors & \% Funded & & Allocation & \% Funded \\
\cline { 1 - 1 } Canada Fund/S( '-S & 33.8 & & Education & 76.3 \\
IINICEF/CDAP & 60.2 & & lncome Generatio & 16.6 \\
& & & Relief \& Repatria & 7.1
\end{tabular}

Sub Offices

\begin{tabular}{l} 
Sub Office \\
llouse 2 Street 2 Said Noor M.Shah Kabul \\
Mina Kart-e-Now \\
\hline Ilouse 223 Shoura Strect. Kart-e-Sia Kabul \\
\hline
\end{tabular}




\begin{tabular}{|c|c|c|c|}
\hline Membership & Other & Country of Affliliation & Afghanistan \\
\hline Address & Communication & Key Staff & Position \\
\hline \multirow{4}{*}{$\begin{array}{l}\text { Qala-e-Fatehulla Road, } \\
\text { Across from M. Mostafa Mosque, } \\
\text { Kabul-Afghanistan }\end{array}$} & Phone: & Wahid Jabarkhil & Director \\
\hline & Fax: & M. Hoomayoon & Deputy \\
\hline & E-mail: falahat-w-o@hotmail.com & Abdul Qaher & Admin \& Finance \\
\hline & Web: & & \\
\hline
\end{tabular}

\begin{tabular}{|c|c|c|c|}
\hline & & Personnel & \\
\hline Afghan & 25 & & Administrative \\
\hline Pakistani & 0 & & Support \\
\hline Expatriates & 0 & & Technical \\
\hline Total & 25 & & Total \\
\hline & & Jdget In US \$ & \\
\hline
\end{tabular}

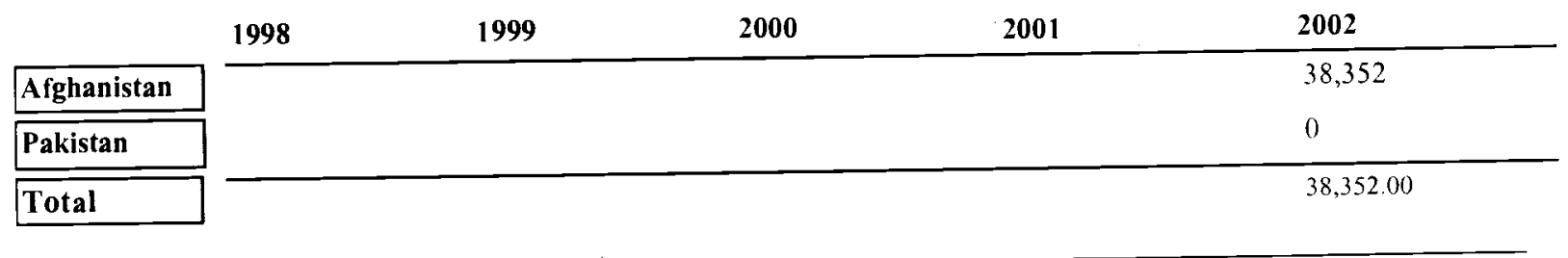

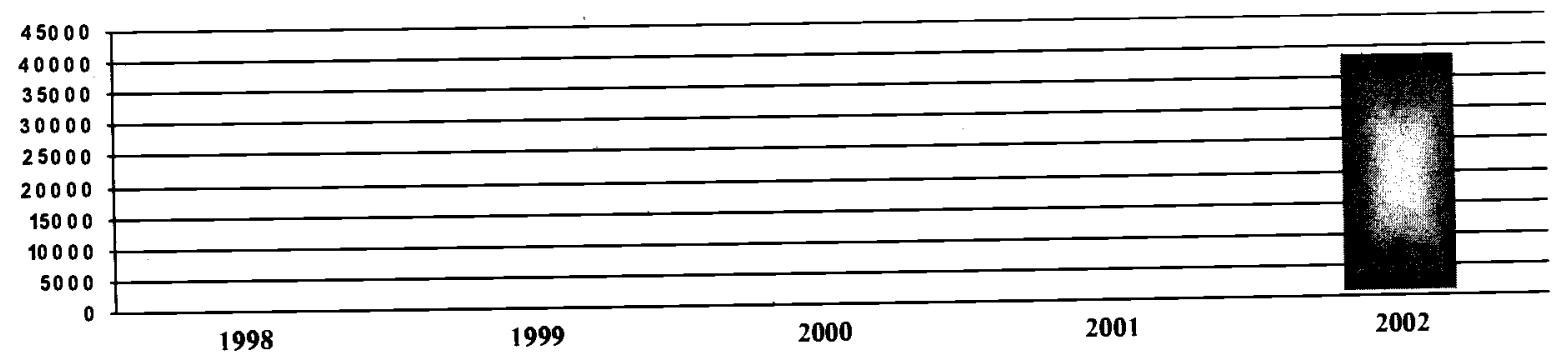

\begin{tabular}{|c|c|c|c|c|c|c|c|}
\hline \multicolumn{2}{|c|}{ Donors } & & llocation & \multirow[b]{2}{*}{ Province } & \multicolumn{3}{|c|}{ Targeted Provinces } \\
\hline Donors & $\%$ Funded & Allocation & $\%$ Funded & & Sector & $\%$ Targe & \\
\hline CARE & 50 & Infrastructure & 50 & Bamyan & Education & & 25 \\
\hline UNHCR & 50 & Other & 50 & Logar & Infrastructure & & 35 \\
\hline & & & & Nangarhar & Relief \& Rep & triatioin & 40 \\
\hline
\end{tabular}

Sub Offices

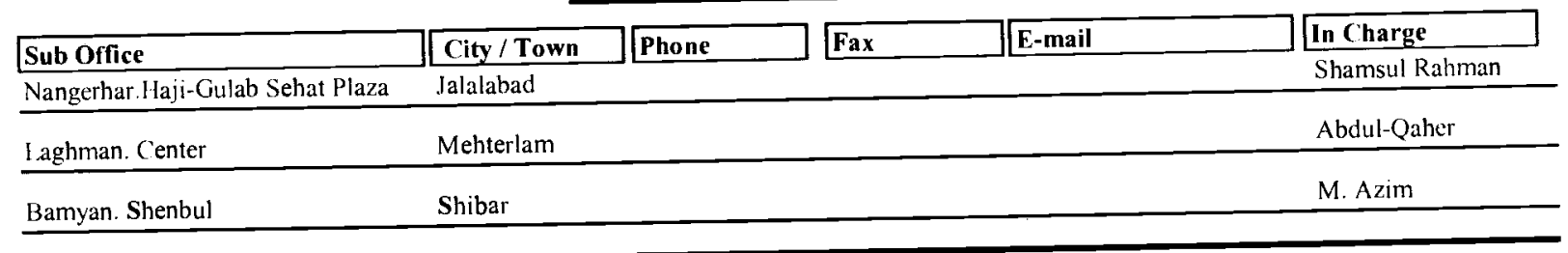




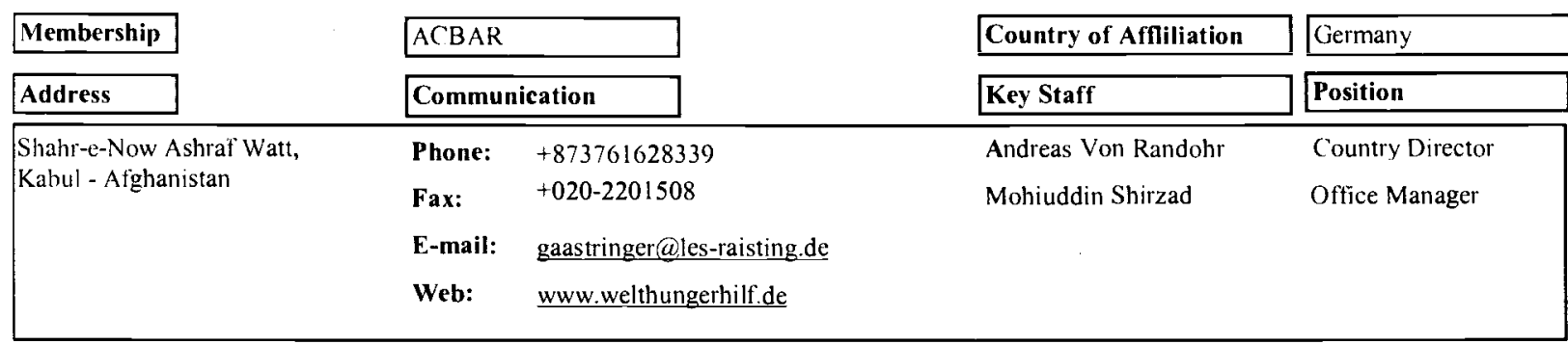

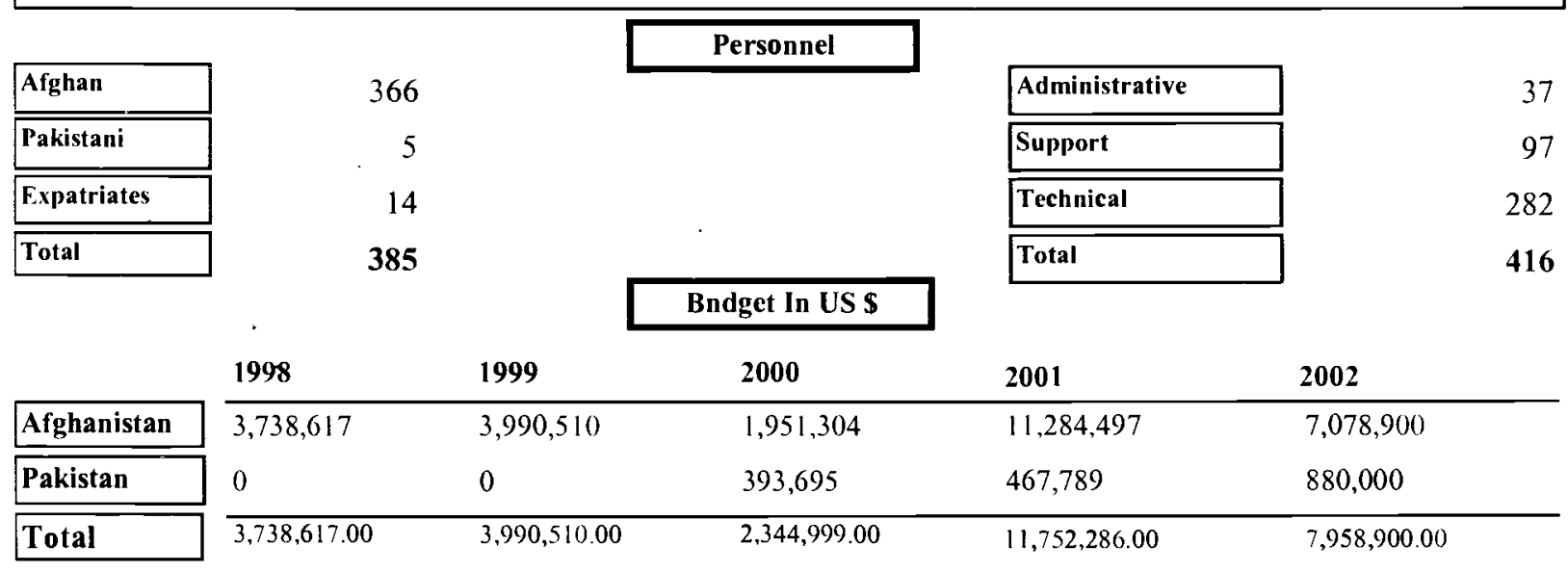

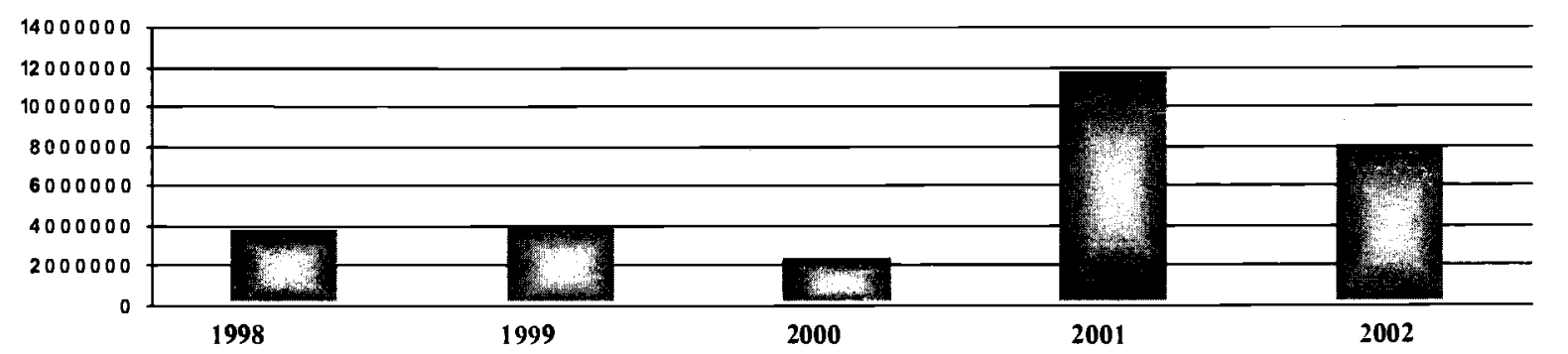

\begin{tabular}{|c|c|c|c|c|c|}
\hline \multicolumn{2}{|c|}{ Donors } & Allocation & \multirow[b]{2}{*}{ Province } & \multicolumn{2}{|c|}{ Targeted Provinces } \\
\hline Donors & $\%$ Funded & & & Sector & $\%$ Targeted \\
\hline \multicolumn{3}{|l|}{$\mathrm{BMZ}$} & Badghis & \multicolumn{2}{|c|}{ Relief \& Repatriatioin } \\
\hline \multicolumn{2}{|l|}{$\mathrm{HC}$} & & Balkh & \multicolumn{2}{|c|}{ Water Resources } \\
\hline \multicolumn{2}{|l|}{ Е('HO } & & Balkh & \multicolumn{2}{|c|}{ Relief \& Repatriatioin } \\
\hline \multicolumn{2}{|c|}{ (jerman Foreign Off. } & & Balkh & \multicolumn{2}{|c|}{ Agriculture } \\
\hline \multicolumn{2}{|c|}{ German Ministry of Ec } & & Jawzjan & \multicolumn{2}{|c|}{ Agriculture } \\
\hline \multirow{4}{*}{\multicolumn{2}{|c|}{ Private }} & & Kabul & \multicolumn{2}{|c|}{ Relief \& Repatriatioin } \\
\hline & & & Sari Pul & \multicolumn{2}{|c|}{ Water Resources } \\
\hline & & & Sari Pul & \multicolumn{2}{|c|}{ Education } \\
\hline & & & Takhar & \multicolumn{2}{|c|}{ Agriculture } \\
\hline
\end{tabular}

\section{Snb Offices}

\begin{tabular}{|c|c|c|c|c|c|}
\hline Sub Office & City / Town & Phone & Fax & E-mail & In Charge \\
\hline $\begin{array}{l}\text { ('harahi Haji Yaqoob Near to HT } \\
\text { Office Shahr-e-Naw }\end{array}$ & Kabul & 070281385 & & $\begin{array}{l}\text { dwhhbrueggemam }(\underline{\text { les- }} \\
\text { raisting.de }\end{array}$ & Clemens Bruggemann \\
\hline $\begin{array}{l}\text { Nangarhar Next to Agabe Sahata- } \\
\text { Awa Hospital }\end{array}$ & Jalalabad & +873761638334 & & fsgaaafg@les-raisting.de & Frieder Nothdurft \\
\hline $\begin{array}{l}\text { Charaim Marastoon Close to PK. } \\
\text { ('onsulate }\end{array}$ & Jalalabad & +873761621170 & & alinkgaa@skylink.com & Babs Alink \\
\hline Kunduz..Sarak Maulawr Sarajuddin & Kunduz & +870761637060 & +87076163706 & $\begin{array}{l}114770.2346 @ \text { compu- } \\
\text { serve.com }\end{array}$ & Stefau recker \\
\hline Badghis.Sagah Nawabad Regi Bazar & Qadis & +873761637220 & & $\begin{array}{l}\text { glueckeot-gaa }(\underline{w}) \text { les- } \\
\text { raisting.de }\end{array}$ & Michael Gluckeit \\
\hline
\end{tabular}




\begin{tabular}{|c|c|c|c|}
\hline NWFP.Circular Road University & Peshawar & 841815 & 843397 \\
\hline
\end{tabular}

\section{GHO (Goharshad Humanitarian Organization)}

\begin{tabular}{|l|}
\hline Membership \\
\hline Address \\
\hline Iade Bank Khone, \\
('harrahi Mahtab Intersection, \\
llirat - Afghanistan \\
\end{tabular}

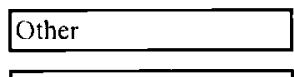

Communication

Phone: $\quad 220475 / 070400098$

Fax:

E-mail:

Web:

\section{i)}

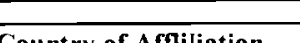

Afghanistan

Country of Affliliation

\begin{tabular}{|c|c|}
\hline Key Staff & Position \\
\hline Abbas Awiry & Manager \\
\hline Ab. Razaq Sattery & Deputy Manager \\
\hline Faiqa Alizada & Iducation Incharge \\
\hline
\end{tabular}

Personnel

\begin{tabular}{|l|}
\hline Administrative \\
\hline Support \\
\hline Technical \\
\hline Total \\
\hline
\end{tabular}

10

10

Budget ln US \$

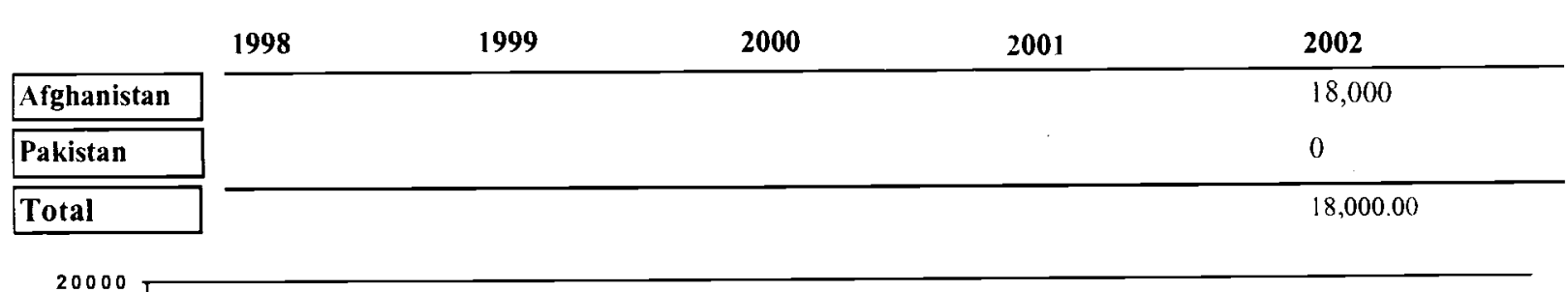
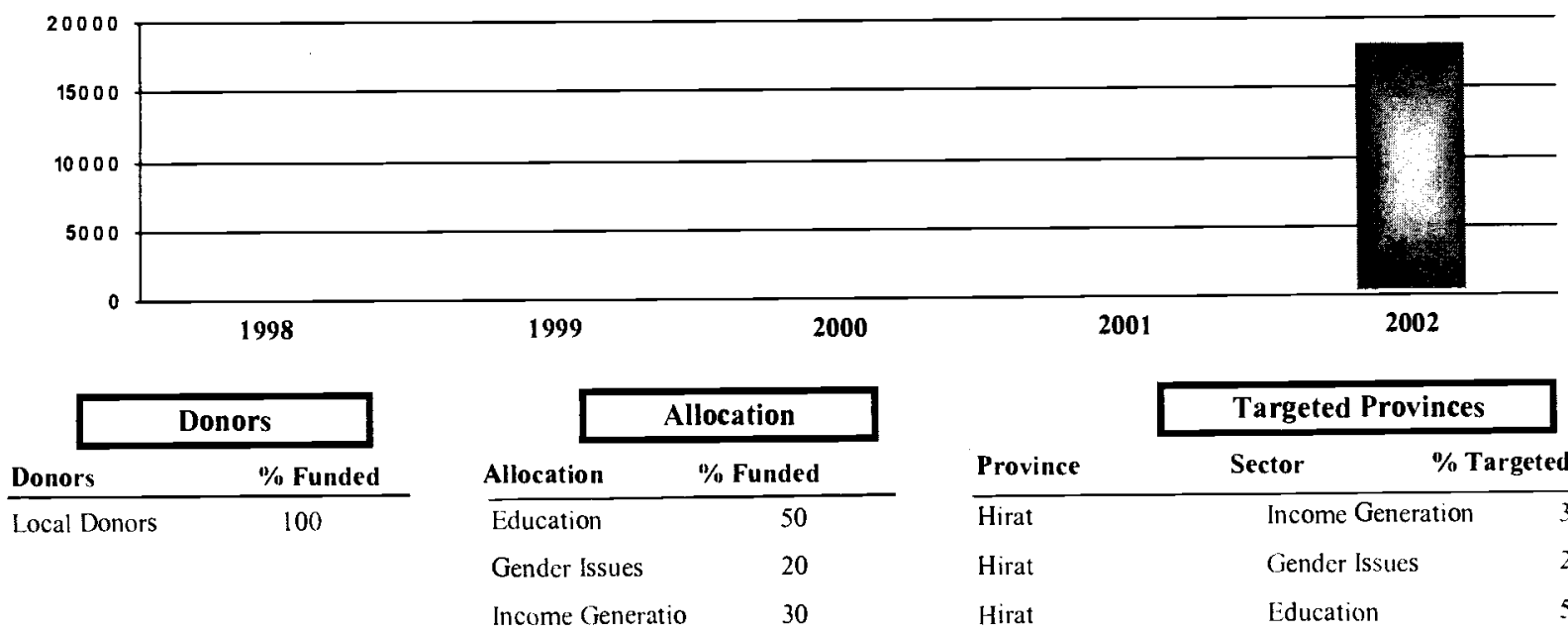

\begin{tabular}{lcr|}
\cline { 2 - 3 } & \multicolumn{2}{c|}{ Targeted Provinces } \\
\cline { 2 - 3 } Province & Sector & \% Targeted \\
\hline Hirat & Income Generation & 30 \\
Hirat & Gender Issues & 20 \\
Hirat & Education & 50
\end{tabular}

Sub Offices 
GOAL (GOAL)

\begin{tabular}{|c|c|c|c|c|}
\hline Membership & & & Country of Affliliation & Ireland \\
\hline Address & \multicolumn{2}{|c|}{ Communication } & Key Staff & Position \\
\hline \multirow{4}{*}{$\begin{array}{l}\text { House } 2172 \text { Strcet } 4, \\
\text { Qala-e-Fatullah, } \\
\text { Kabul - } \text { Ighanistan }\end{array}$} & Phone: & +882165061212 & Fiona Gannon & Country Director \\
\hline & Fax: & & Neil Elliot & Programme Manager \\
\hline & E-mail: & august@inmarsat trancetelecom.f & I isa Leilly & Head Engineering \\
\hline & Web: & Www goalic & & \\
\hline
\end{tabular}

\begin{tabular}{|l|}
\hline Afghan \\
\hline Pakistani \\
\hline Expatriates \\
\hline Total \\
\hline
\end{tabular}

Personnel

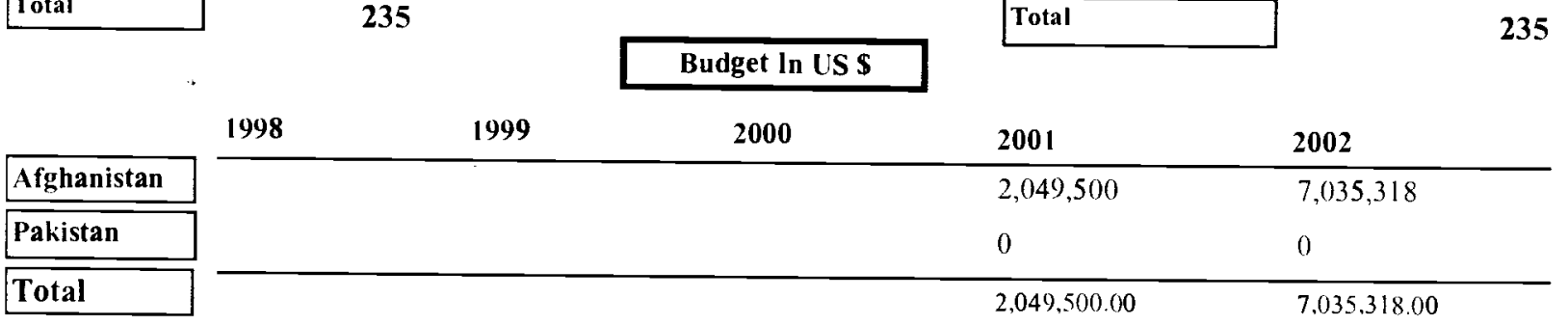

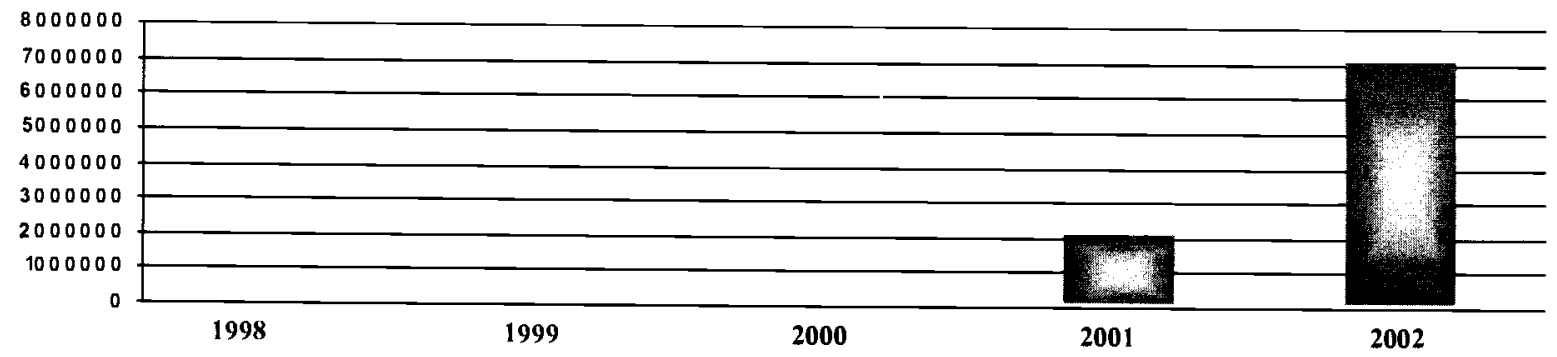

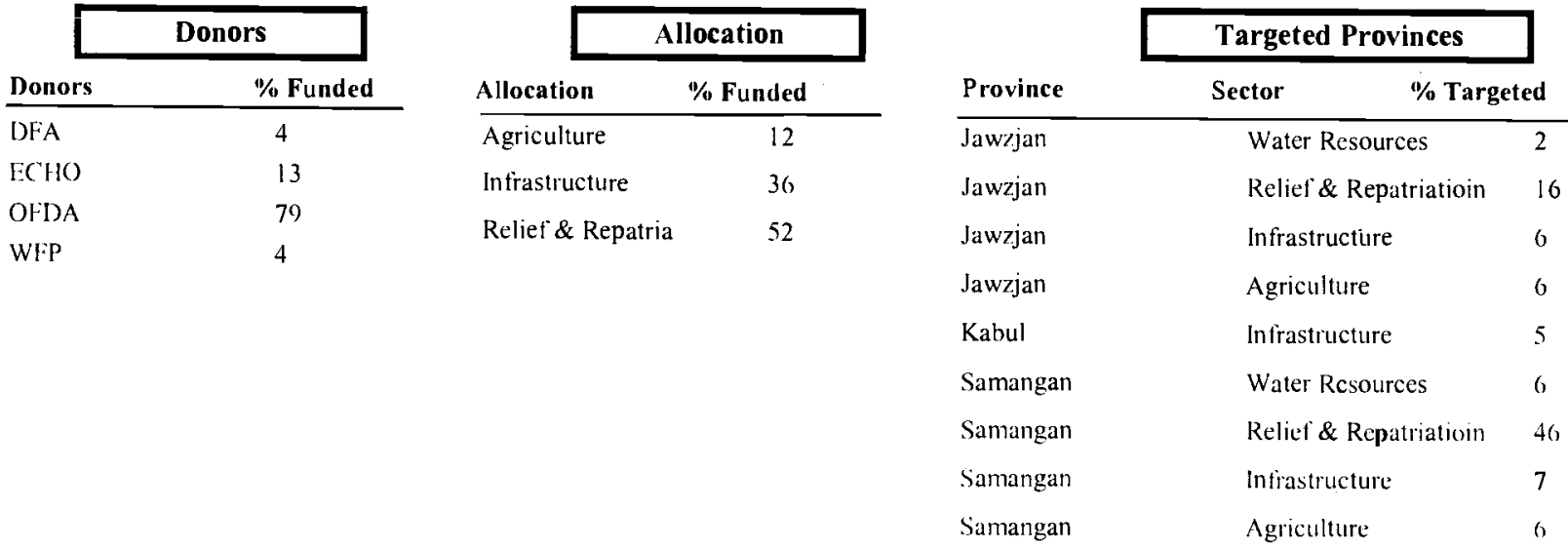

\section{Sub Offices}

\begin{tabular}{|c|c|c|c|c|}
\hline Sub Office & City / Town & Phone & E-mail & In Charge \\
\hline Saleh Housc, Bank Mili Street & Balkh & +873763020678 & $\begin{array}{l}\text { digital@inmarsat.francet } \\
\text { elecom.fr }\end{array}$ & Neil Elliot \\
\hline Samangan.Karte Solh & Aybak & +882165061287 & & Dawien Prillieux \\
\hline Jawzjan. Karte-c-Dustom & Sheberghan & +882165061203 & & Barry Dawies \\
\hline House 12, Strcet $39, \mathrm{Fo} / 1$ & Islamabad & $+02-51-2828442$ & goal (ocomsats.net.pk & Sarah Scott Mitchell \\
\hline
\end{tabular}




\begin{tabular}{|lll|}
\hline Membership & Other & Country of Affiliation \\
\hline Address & Communication & Kcy Staff \\
\hline $\begin{array}{lll}\text { Blond-Ab Intersection, } \\
\text { Pul Rangina Street, }\end{array}$ & Phonc: 223578 & Abdul. Shokur \\
Afghanistan & Fax: & Abbul Ghofoor \\
& E-mail: & Aziz Ahmad \\
& Web: &
\end{tabular}

\begin{tabular}{|c|c|c|c|}
\hline & & Personnel & \\
\hline Afghan & 45 & & Administrative \\
\hline Pakistani & 0 & & Support \\
\hline Expatriates & 0 & & Technical \\
\hline Total & 45 & & Total \\
\hline
\end{tabular}

\begin{tabular}{|c|c|c|c|c|c|}
\hline & 1998 & 1999 & 2000 & 2001 & 2002 \\
\hline Afghanistan & & & 79,800 & 67,030 & 336,581 \\
\hline Pakistan & & & 0 & 0 & 0 \\
\hline Total & & & $79,800.00$ & $67,030.00$ & $336,581.00$ \\
\hline
\end{tabular}

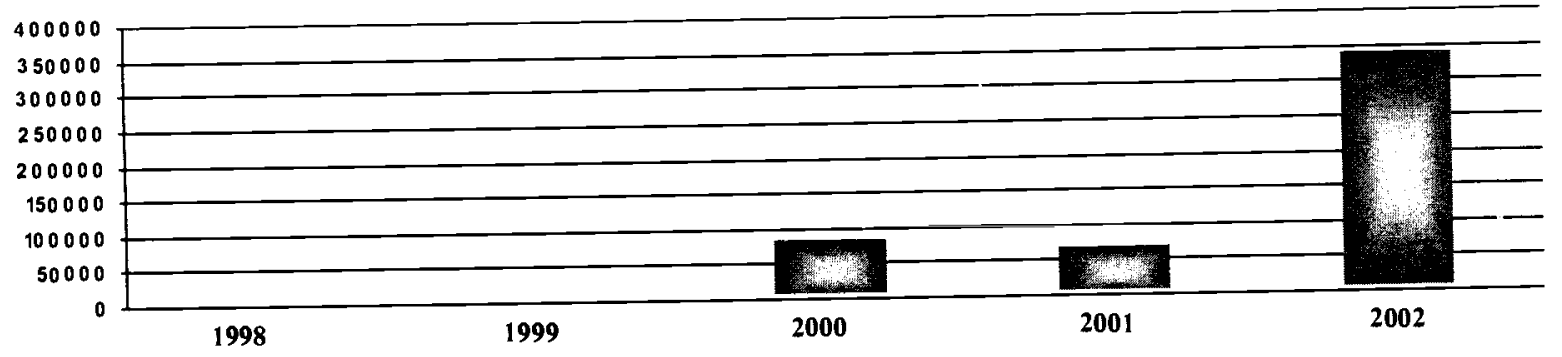

\begin{tabular}{|c|c|c|c|c|c|c|}
\hline \multicolumn{2}{|c|}{ Donors } & & llocation & \multirow[b]{2}{*}{ Province } & \multicolumn{2}{|c|}{ Targeted Provinces } \\
\hline Donors & $\%$ Funded & Allocation & $\%$ Funded & & Sector & $\%$ Targeted \\
\hline FAO & 63 & Agriculture & 59 & Farah & Agriculture & 25 \\
\hline \multirow[t]{4}{*}{ IRC } & 37 & Infrastructure & 41 & Ghor & Agriculture & 7 \\
\hline & & & & Ghor & Agriculture & 18 \\
\hline & & & & Ghor & Other & 25 \\
\hline & & & & Ghor & Infrastructure & 25 \\
\hline
\end{tabular}

\begin{tabular}{l|l|l|l|}
\cline { 3 - 4 } \multicolumn{1}{c|}{ Sub Offices } \\
\hline
\end{tabular}


GRO (Generouse Rehabilition Organazation)

\begin{tabular}{|c|c|c|c|}
\hline Membership & Other & Country of Affliliation & Afghanistan \\
\hline Address & Communication & Key Staff & Position \\
\hline \multirow{4}{*}{$\begin{array}{l}\text { Shahr-e- Naw, } \\
\text { Kocha Gul Feroshi, } \\
\text { Kabul - Afghanistan }\end{array}$} & Phone: $\quad 2200744 / 070276704$ & Sakhi Mohammad & Derictor \\
\hline & Fax: & Mohammad Naser & Assist Derictor \\
\hline & & Mohammad Shakar & Account \\
\hline & Web: & & \\
\hline
\end{tabular}

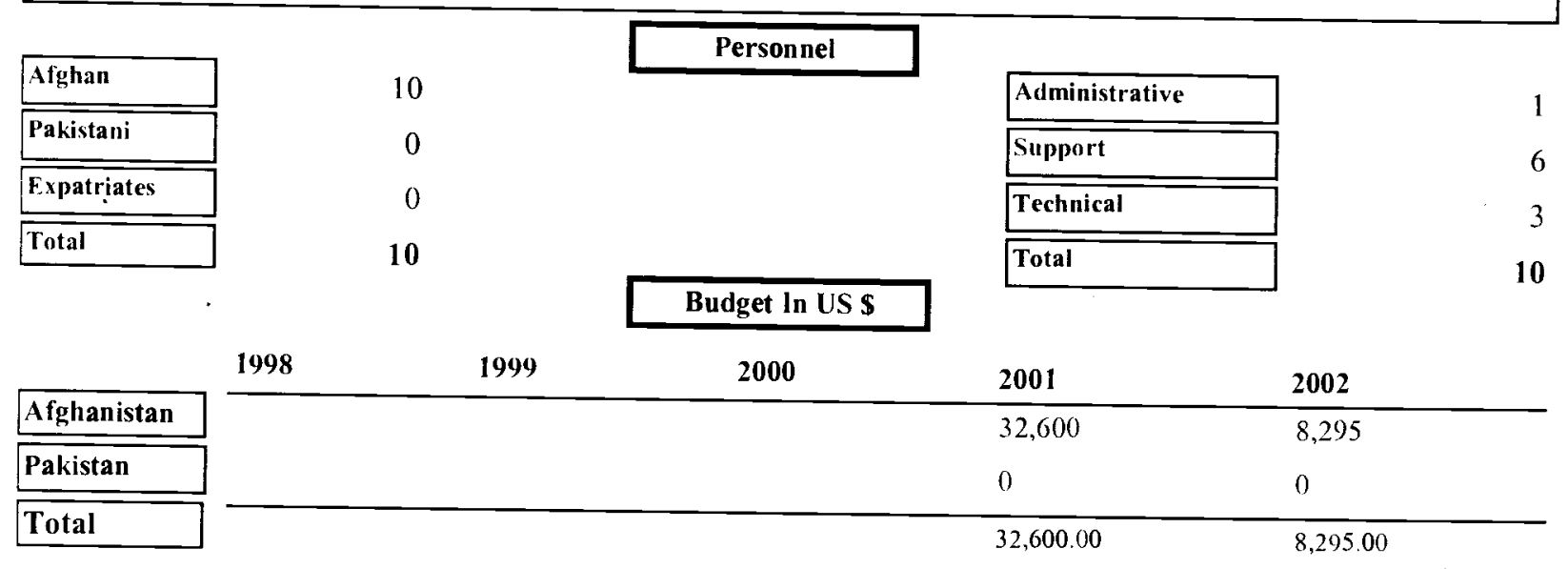

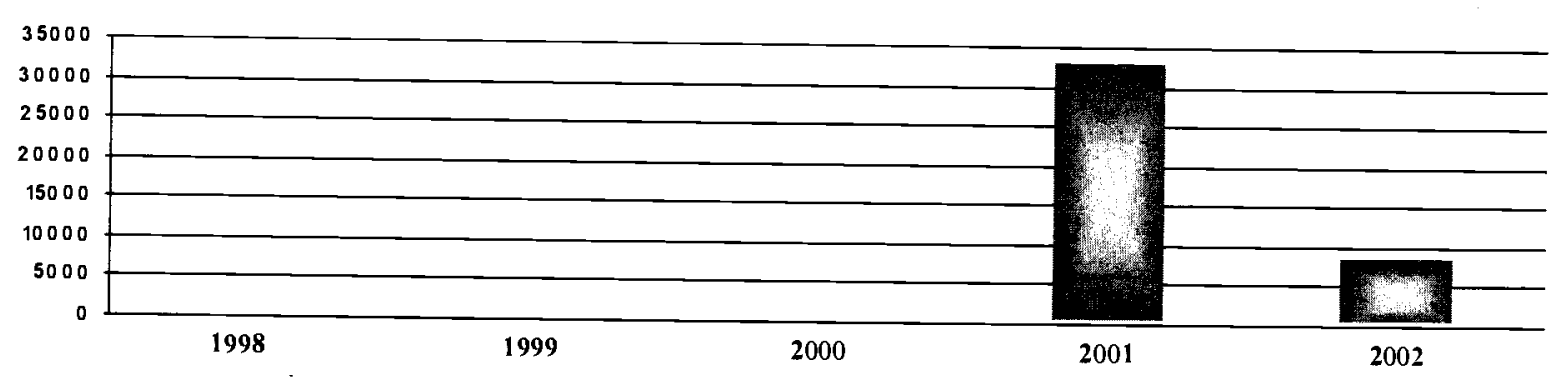

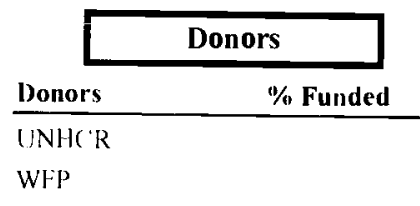

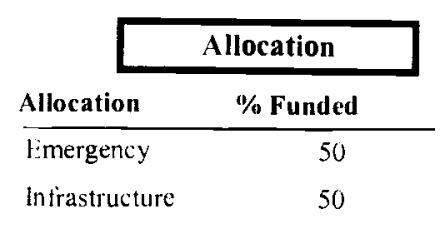

Sub Offices

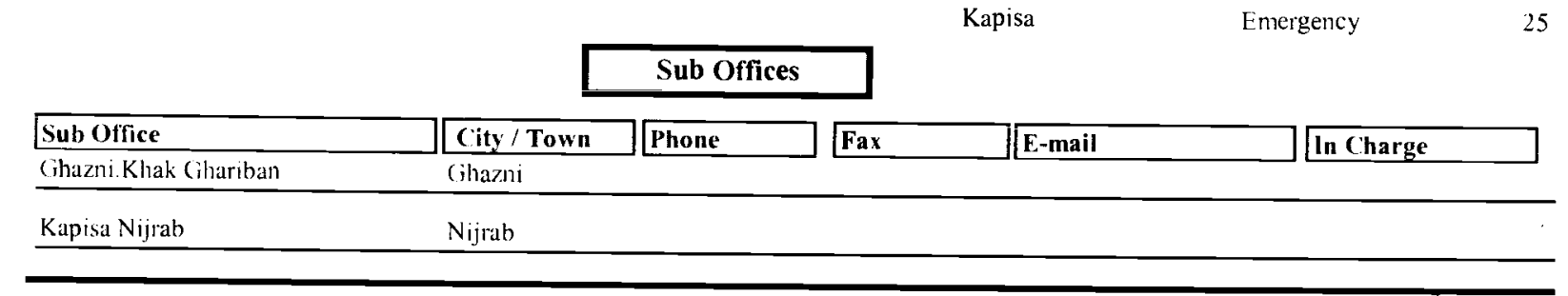




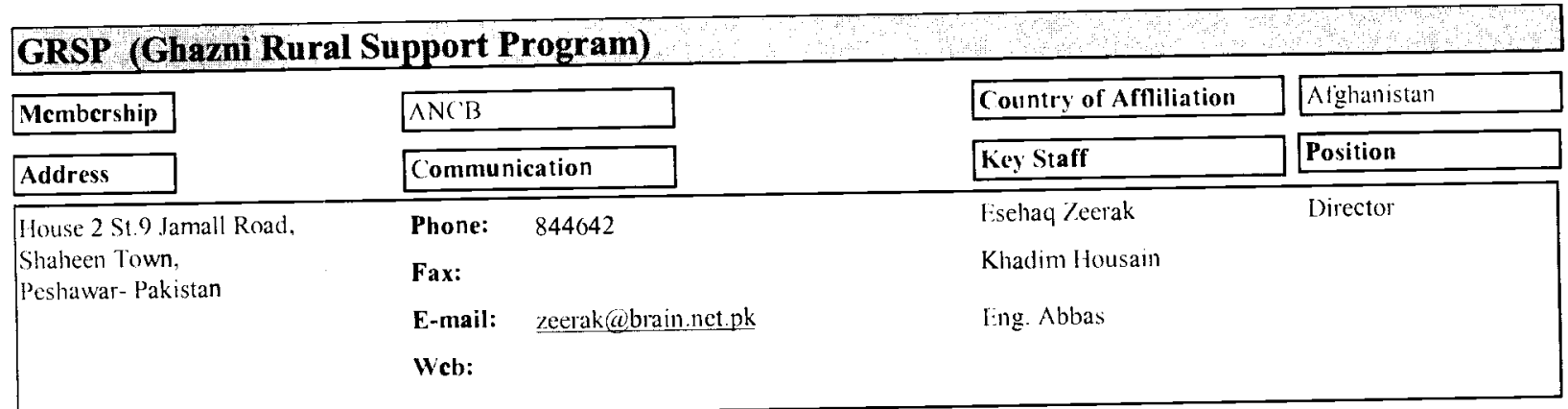

\begin{tabular}{|c|c|c|c|c|c|}
\hline & & & Personnel & & \\
\hline Afghan & \multicolumn{2}{|c|}{103} & & Administrative & 20 \\
\hline Pakistani & \multicolumn{2}{|c|}{0} & & Support & 30 \\
\hline Expatriates & \multicolumn{2}{|c|}{0} & & Technical & 70 \\
\hline \multirow[t]{3}{*}{ Total } & \multirow{2}{*}{\multicolumn{2}{|c|}{103}} & & Total & \multirow[b]{3}{*}{2002} \\
\hline & & & Budget ln US \$ & & \\
\hline & 1998 & 1999 & 2000 & 2001 & \\
\hline Afghanistan & 61,300 & 1,019 & 76,660 & 212,050 & \\
\hline Pakistan & 0 & 0 & 0 & 22,776 & \\
\hline Total & $01,300.00$ & $1,019.00$ & $76,060.00$ & $234,826.00$ & \\
\hline
\end{tabular}

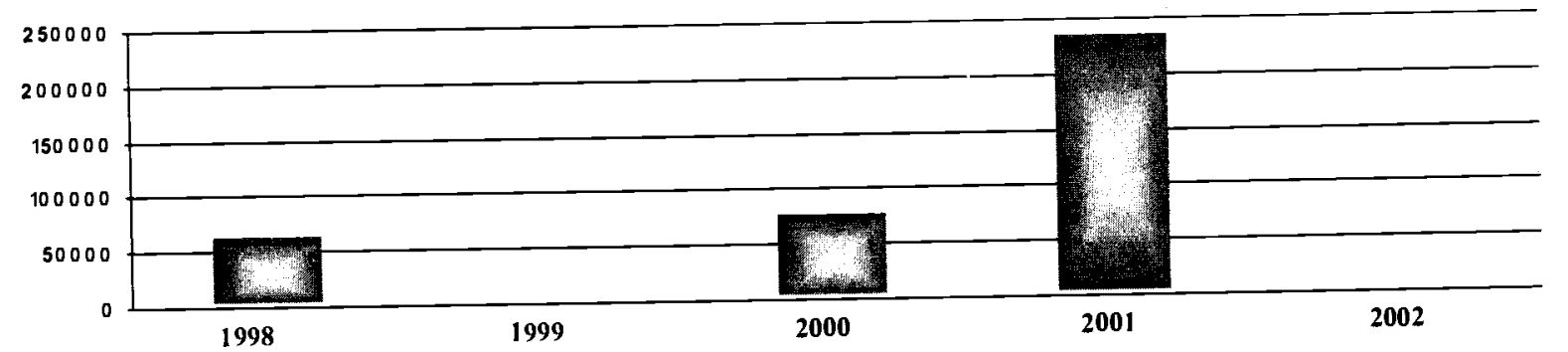

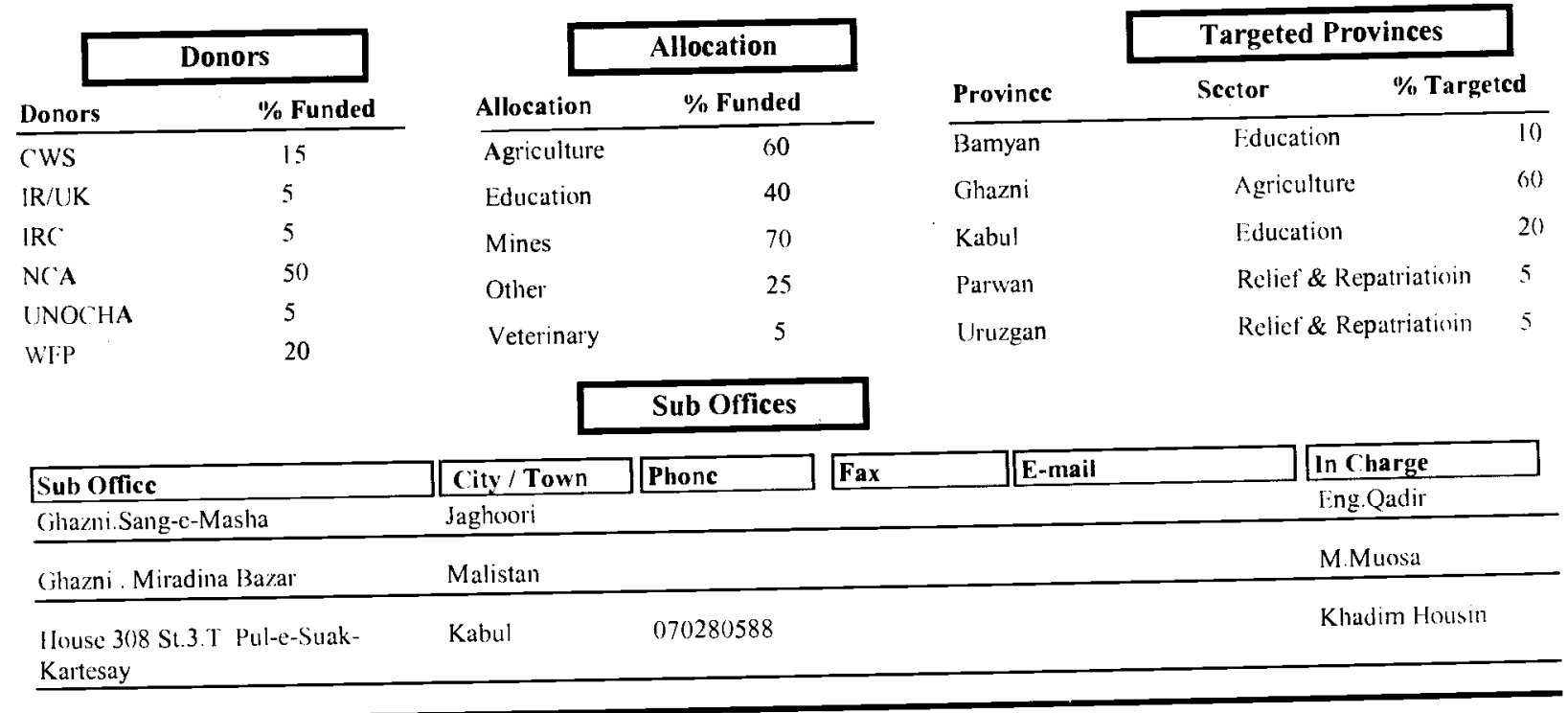


HAFO (Helping Afghan Farmers Organization)

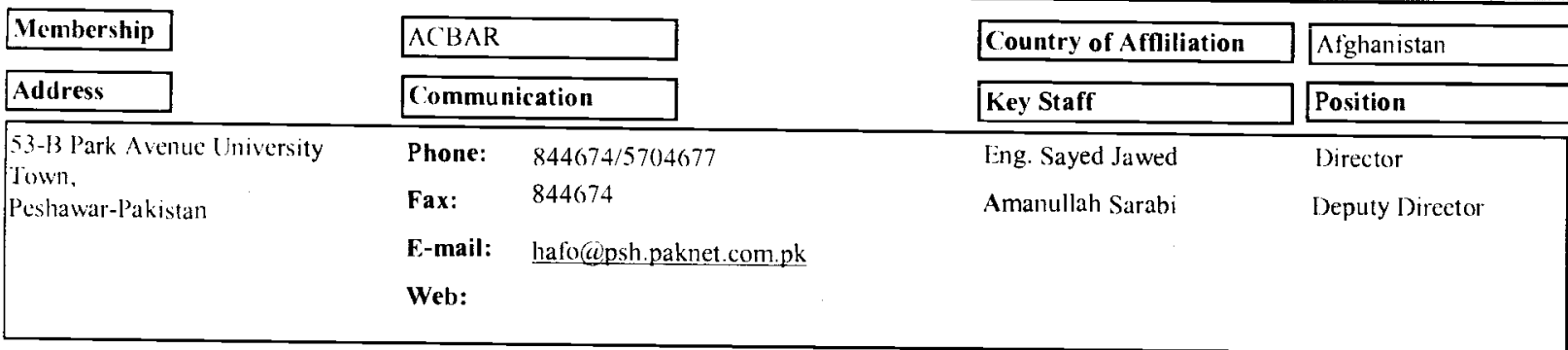

\begin{tabular}{|l|}
\hline Afghan \\
\hline Pakistani \\
\hline Expatriates \\
\hline Total \\
\hline
\end{tabular}

206

5

1

212
Personnel

\begin{tabular}{|l|}
\hline Administrative \\
\hline Support \\
\hline Technical \\
\hline Total \\
\hline
\end{tabular}

60

212

\begin{tabular}{|c|c|c|c|c|c|}
\hline & 1998 & 1999 & 2000 & 2001 & 2002 \\
\hline Afghanistan & 132,250 & 249,000 & 388,000 & 538,000 & $1,080,000$ \\
\hline Pakistan & 0 & 0 & 0 & 0 & 0 \\
\hline Total & $132,250.00$ & $249,000.00$ & $388,000.00$ & $538,000.00$ & $1,080,000.00$ \\
\hline
\end{tabular}

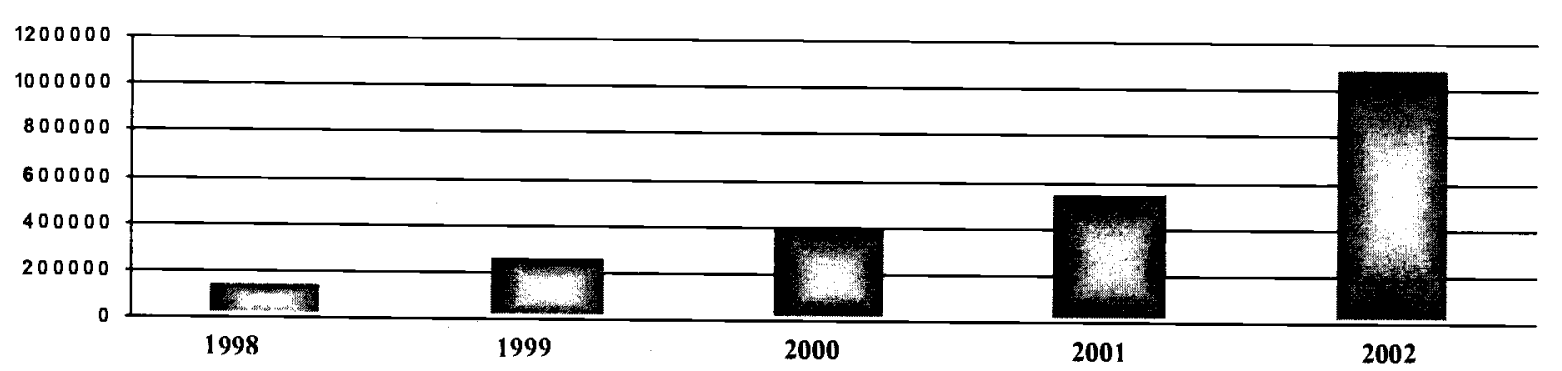

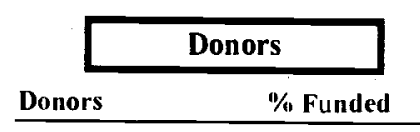

Cord $\mathrm{Aid} /$ Caritas, I:C ' CARE: IC/UNOCHA IRC/UGP/UNICEF NAC/ODW WFP/Other

\begin{tabular}{lc}
\hline & Allocation \\
\hline Allocation & $\%$ Funded \\
\hline Agriculture & 30 \\
Education & 20 \\
Emergency & 10 \\
Income Generatio & 10 \\
Infrastructure & 20 \\
Other & 10
\end{tabular}

Sub Offices

\begin{tabular}{llr} 
& \multicolumn{2}{c|}{ Targeted Provinces } \\
\cline { 2 - 3 } Province & Sector & \% Targeted \\
\hline Ghazni & Education & 20 \\
Hilmand & Infrastructure & 20 \\
Hirat & Relief \& Repatriatioin & 20 \\
Kabul & Infrastructure & 10 \\
Kabul & Water Resources & 10 \\
Kandahar & Education & 20
\end{tabular}

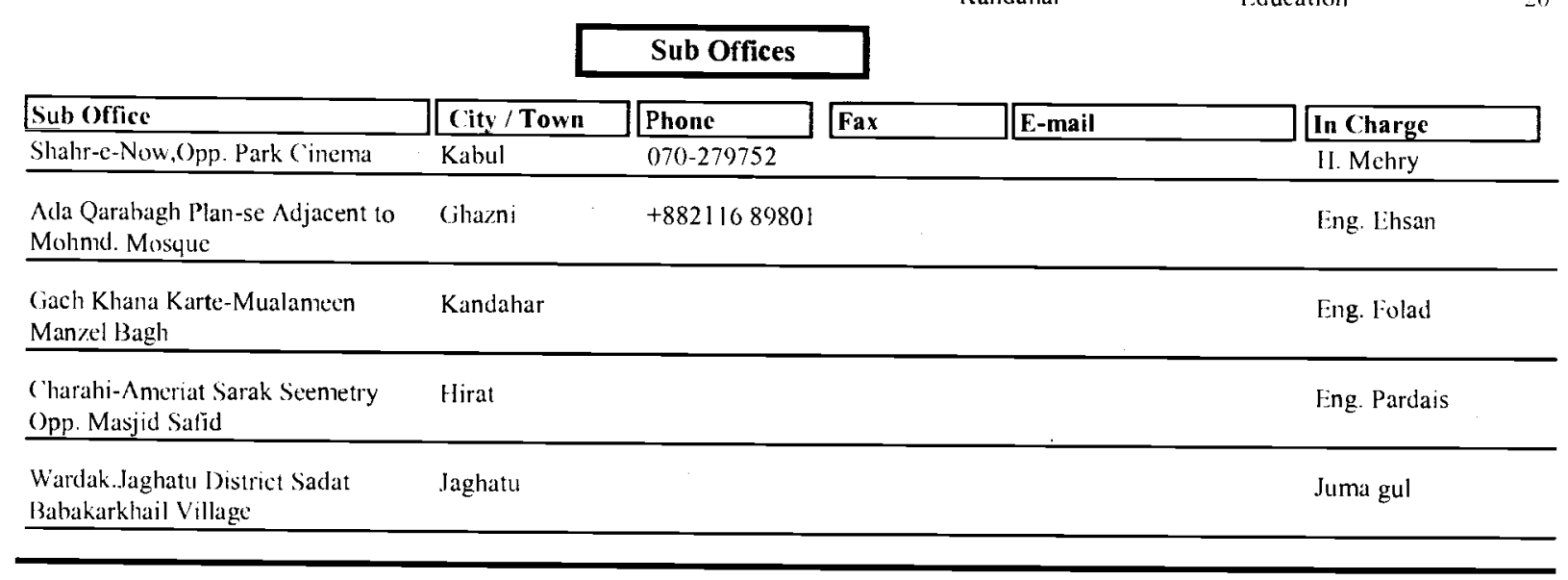


HAND (Humanitarian Assistance Network and Drvrlopment)

\begin{tabular}{|c|c|c|c|}
\hline Membership & Other & Country of Affliliation & Afghanistan \\
\hline Address & Communication & Key Staff & Position \\
\hline \multirow{4}{*}{$\begin{array}{l}\text { Iouse } 255 \text { Opp. Park ( inema, } \\
\text { ( har Rahi Haji Yaqub, } \\
\text { Shahr-e-Now, } \\
\text { Kabul-Afghanistan }\end{array}$} & $32247 / 070275222$ & Sayed Ahrar $\Lambda$ bedi & Director \\
\hline & Fax: & Mirajan & Depuly Director \\
\hline & E-mail: & Ahmad Jamil & Program Ofticer \\
\hline & Web: & & \\
\hline
\end{tabular}

\begin{tabular}{|l|}
\hline Afghan \\
\hline Pakistani \\
\hline Expatriates . \\
\hline Total \\
\hline
\end{tabular}

Personnel

\begin{tabular}{|c|c|c|c|c|c|}
\hline & 1998 & 1999 & 2000 & 2001 & 2002 \\
\hline Afghanistan & 9,000 & 0 & 400 & 6,120 & 13,234 \\
\hline Pakistan & 12,870 & 5,927 & 29,000 & 179,508 & 149,830 \\
\hline Total & $21,870.00$ & $5,927.00$ & $29,400.00$ & $185,628.00$ & $163,064.00$ \\
\hline
\end{tabular}

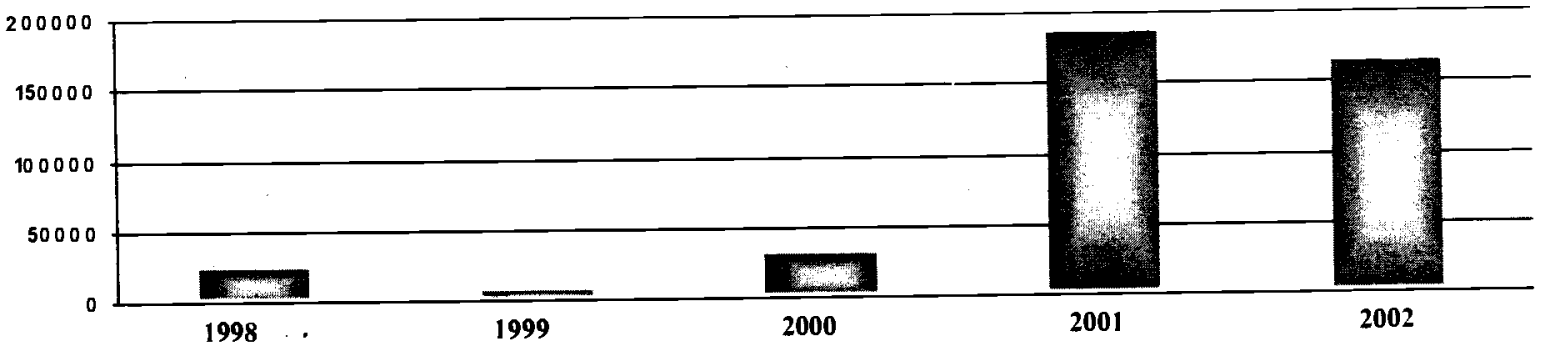

\begin{tabular}{lc}
\hline \multicolumn{2}{c|}{ Donors } \\
Donors & $\%$ Funded \\
\hline CARE & 5 \\
UNHCR & 82 \\
UNOPS & 13
\end{tabular}

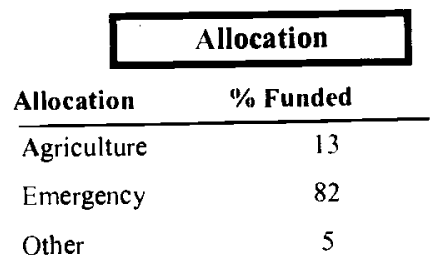

\begin{tabular}{lll} 
& \multicolumn{2}{c|}{ Targeted Provinces } \\
\cline { 2 - 3 } Province & Sector & \% Targeted \\
\hline Ghazni & Relief \& Repatriatioin & 9.8 \\
Kabul & Emergency & 2.0 \\
Kabul & Relief \& Repatriatioin & 5.9 \\
Kabul & Water Resources & 1.5 \\
Logar & Ineome Generation & 1.7 \\
Logar & Relief \& Repatriatioin & 79. \\
Logar & Watcr Resources & 0.3 \\
Wardak & Relief \& Repatriatioin & 7
\end{tabular}

Sub Offices

Sub Office

Plane (3) Opposite IC 'RC Ghazni

(ity

\begin{tabular}{|l|}
\hline Administrative \\
\hline Support \\
\hline Technical \\
\hline Total \\
\hline
\end{tabular}

Budget In US \$ 
HAPA (Humanitarian Action for People of Afghanistan)

\begin{tabular}{|c|c|c|c|}
\hline Membership & SWABAC & Country of Affliliation & Afghanistan \\
\hline Address & Communication & Key Staff & Position \\
\hline \multirow{4}{*}{$\begin{array}{l}\text { Chowk Shari Naw, } \\
\text { Kandahar-Afghanistan }\end{array}$} & Phone: & Mohd.Gul & Director \\
\hline & Fax: & A.Rahmand & Engineer \\
\hline & E-mail: & Azizullah & Engineer \\
\hline & Web: & & \\
\hline
\end{tabular}

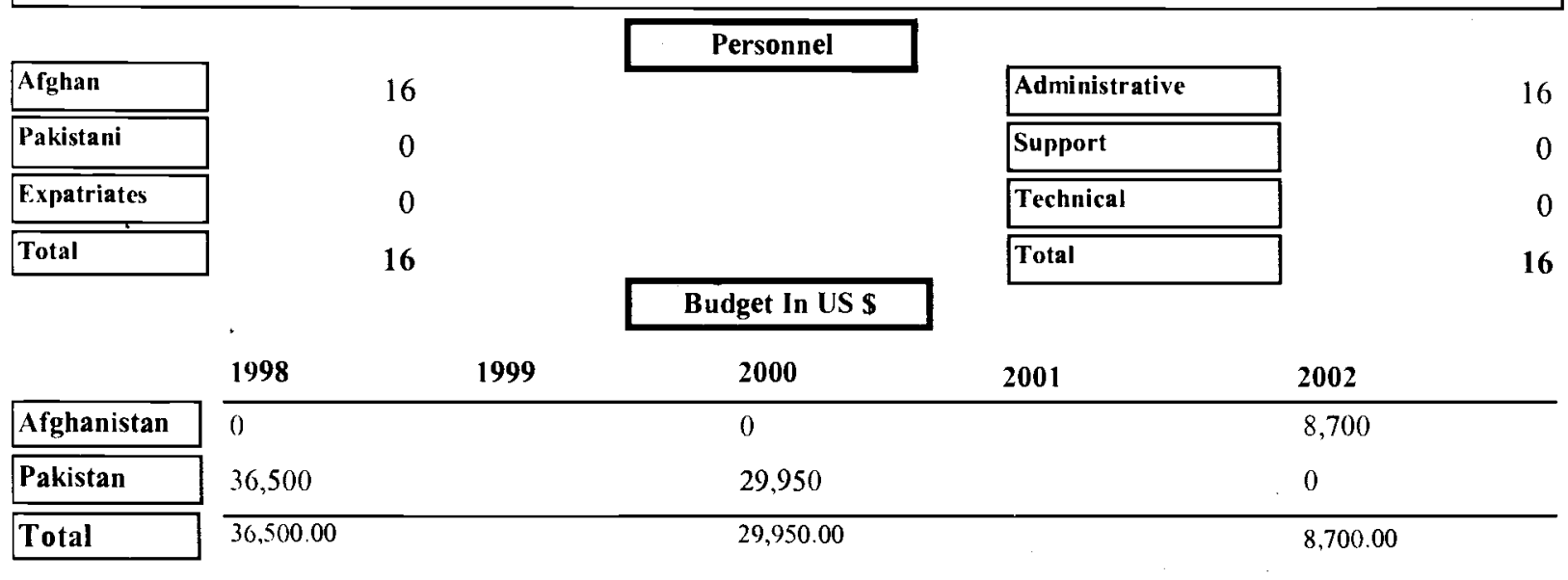

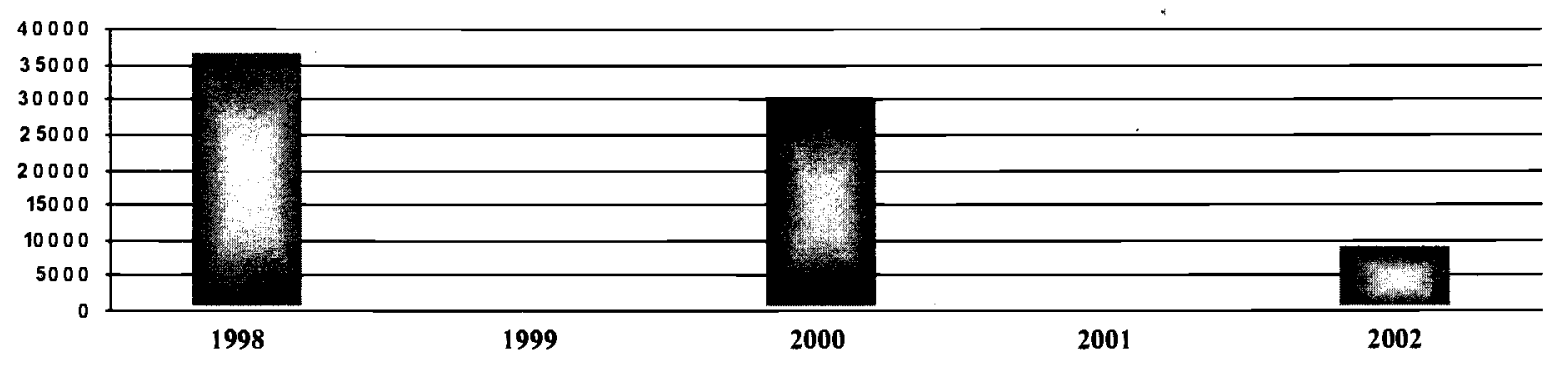

\begin{tabular}{|c|c|c|c|c|c|c|}
\hline \multicolumn{2}{|c|}{ Donors } & & location & \multirow[b]{2}{*}{ Province } & \multicolumn{2}{|c|}{ Targeted Provinces } \\
\hline Donors & \% Funded & Allocation & $\%$ Funded & & Sector & $\%$ Targeted \\
\hline IINI)C'P & 25 & Agriculture & 25 & $\overline{\text { Kandahar }}$ & Agriculture & 100 \\
\hline [INIC'EF & 25 & Intrastructure & 25 & & & \\
\hline UNOPS & 25 & Relief \& Repatria & 25 & & & \\
\hline WFP & 25 & Water Resources & 25 & & & \\
\hline
\end{tabular}


HAS (Humanitarian Assistance Society)

\begin{tabular}{|c|c|c|c|}
\hline Membership & $\triangle N C B$ & Country of Affiliation & Afghanistan \\
\hline Address & Communication & \begin{tabular}{|l|} 
Key Staff \\
\end{tabular} & Position \\
\hline \multirow{4}{*}{$\begin{array}{l}\text { Houise } 248 \text { Street H, } \\
\text { Shahr-i-Now, } \\
\text { Kabul-Aighanistan }\end{array}$} & $2201505 / 070274636$ & M.Bashir Wasil & Dirctor (icneral \\
\hline & Fax: & M. Haroon Katibi & Program Coord. \\
\hline & hasafg@hotmail.com & Haji.M. Nadir & Finance Manager \\
\hline & Web: & & \\
\hline
\end{tabular}

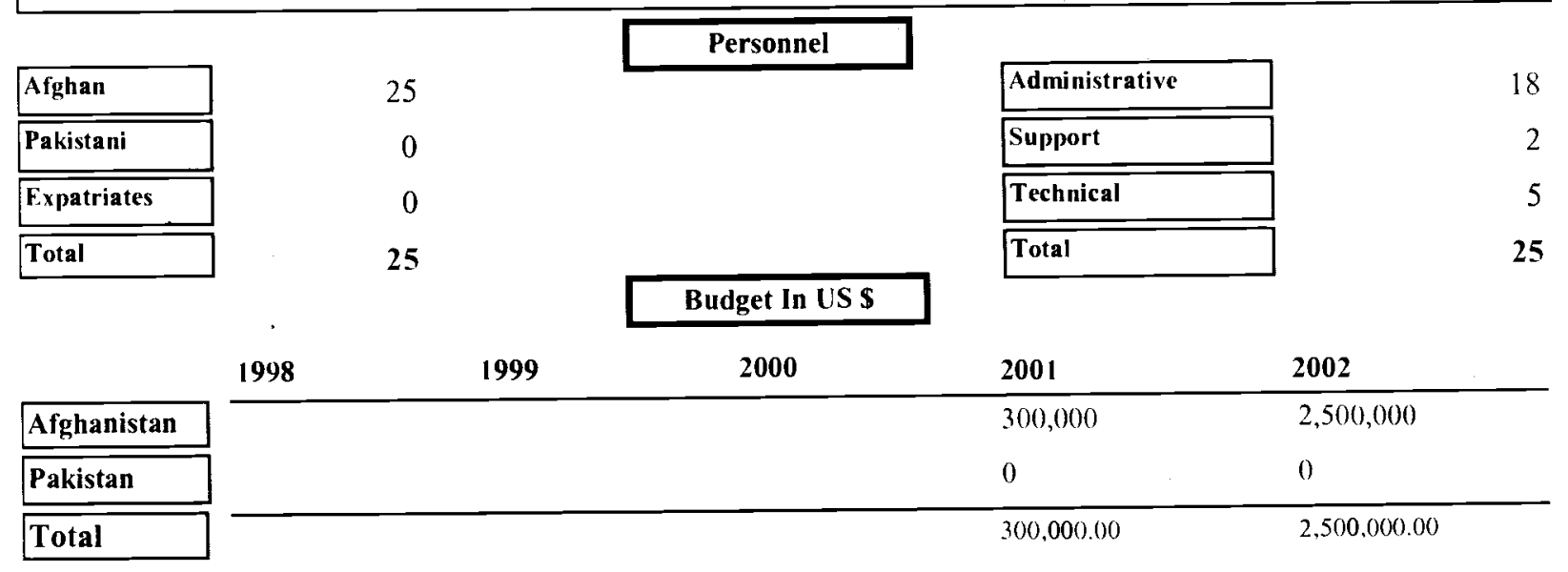

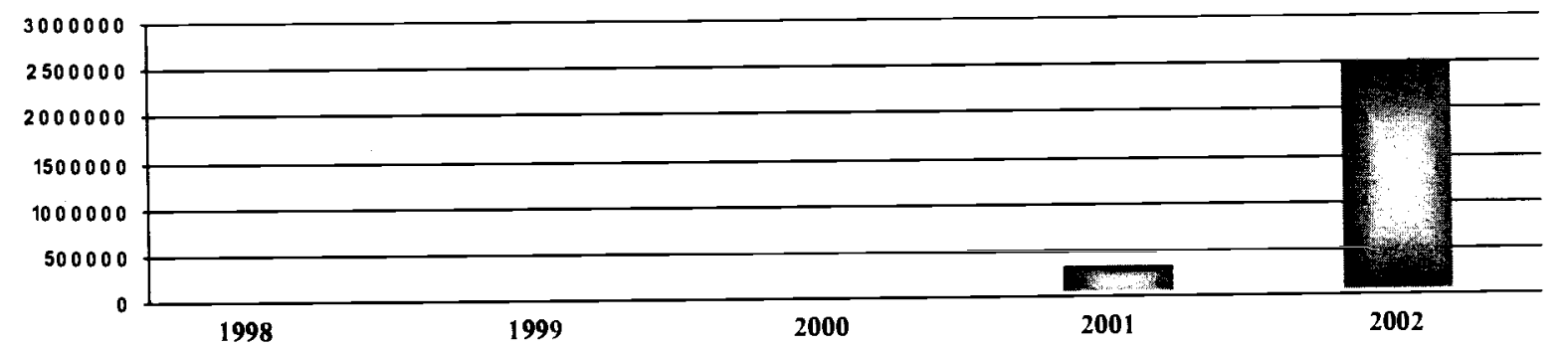

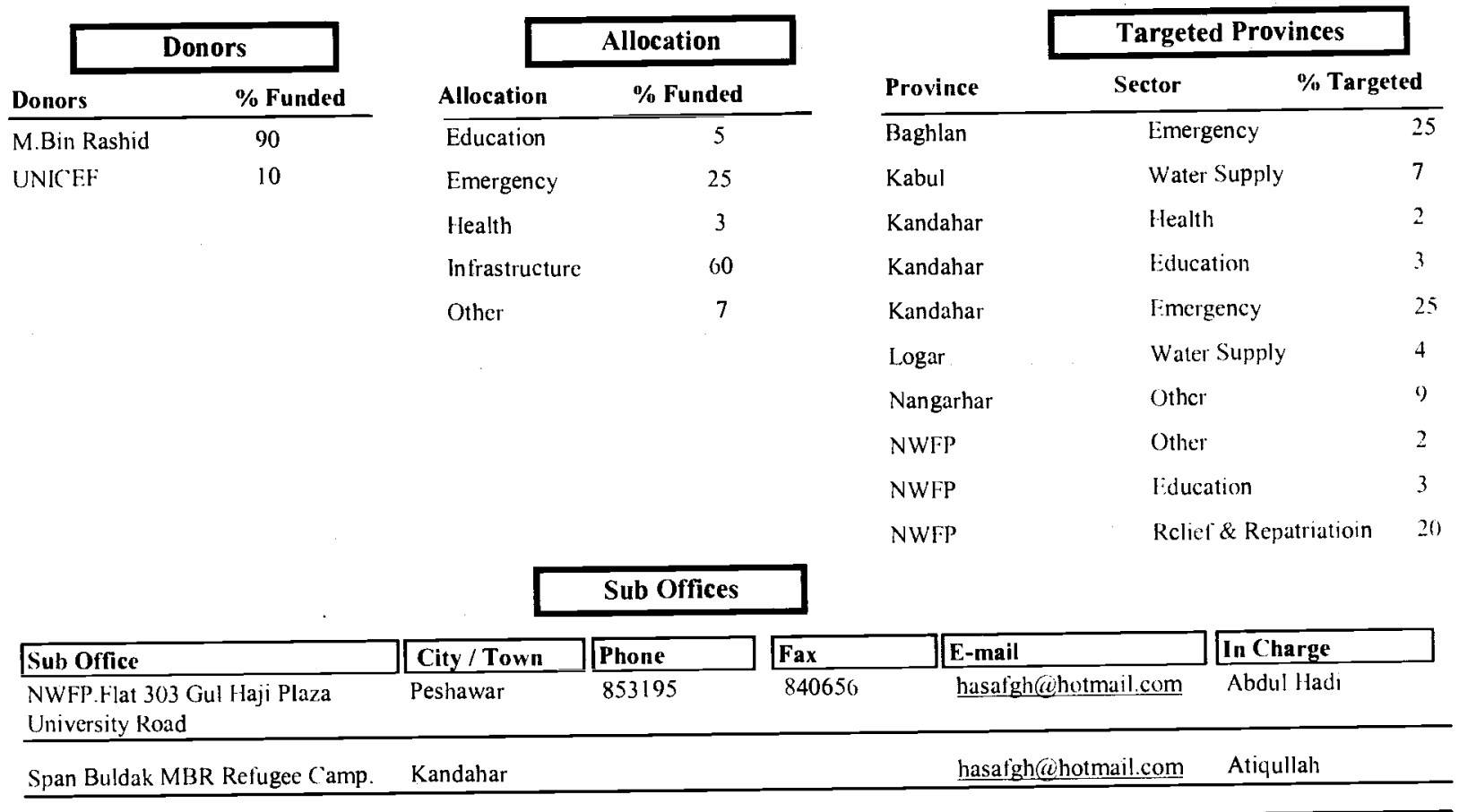




\section{HAWA (Humanitarian Assistance for Welfare of Afghans)}

\begin{tabular}{|c|c|c|c|}
\hline Nembership & $\mathrm{ANClB}$ & Country of Affliliation & Afghanistan \\
\hline Address & Communication & Key Staff & Position \\
\hline \multirow{3}{*}{$\begin{array}{l}\text { Charhi Sdarat Haji Sarder } \\
\text { Aprotment, } \\
\text { Siccond Hloor. } \\
\text { Kabul-Afghanistan }\end{array}$} & Phone: & S.Amerullaha & Director \\
\hline & Fax: & IEng. Moḷd. Afzal & R. Manager \\
\hline & $\begin{array}{l}\text { E-mail: sat.sayadanerullaha(chotmail.con } \\
\text { Web: }\end{array}$ & Koshan & Add Ofticer \\
\hline
\end{tabular}

\begin{tabular}{|l|}
\hline Afghan \\
\hline \hline Pakistani \\
\hline \hline Expatriates \\
\hline Total \\
\hline
\end{tabular}

13

0

0

13

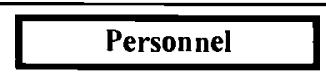

\begin{tabular}{|l|}
\hline Administrative \\
\hline Support \\
\hline Technical \\
\hline Total \\
\hline
\end{tabular}

Budget In US \$

\begin{tabular}{|c|c|c|c|c|c|}
\hline & 1998 & 1999 & 2000 & 2001 & 2002 \\
\hline Afghanistan & 22,000 & 20,000 & 18,000 & 25,000 & 30,000 \\
\hline Pakistan & 0 & 0 & 0 & 0 & 0 \\
\hline Total & $22,000.00$ & 20.000 .00 & $18,000.00$ & $25,000.00$ & $30,000.00$ \\
\hline
\end{tabular}

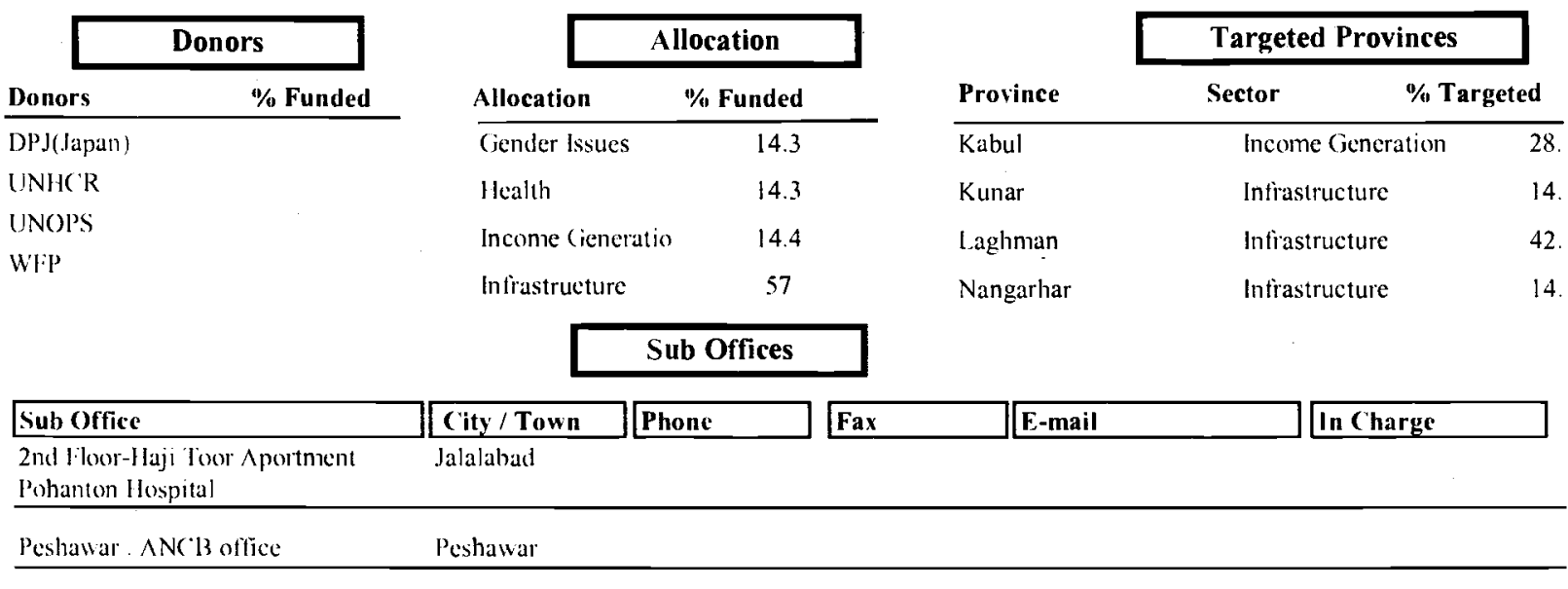




\section{HAWCA (Humanitatian Assistance for Women Children of Afghan)}

\begin{tabular}{|c|c|c|c|}
\hline Membership & & Country of Affliliation & Aighanistan \\
\hline Address & Communication & Key Staff & Position \\
\hline \multirow{4}{*}{$\begin{array}{l}\text { Qala Fatullah } 2 \text { nd St. Shahr-e- } \\
\text { Naw, } \\
\text { Kabul- Aighanistan }\end{array}$} & 070277031 & Orzala Ashraif & Director \\
\hline & 0016014209313 & Dr. Asad Arif & Adinin Officer \\
\hline & hawca (uilhawca.org & & \\
\hline & www hawca.org & & \\
\hline
\end{tabular}

\begin{tabular}{|l|r|}
\hline Afghan & 24 \\
\hline \hline Pakistani & 1 \\
\hline Expatriates & 0 \\
\hline Total & 25 \\
\hline
\end{tabular}

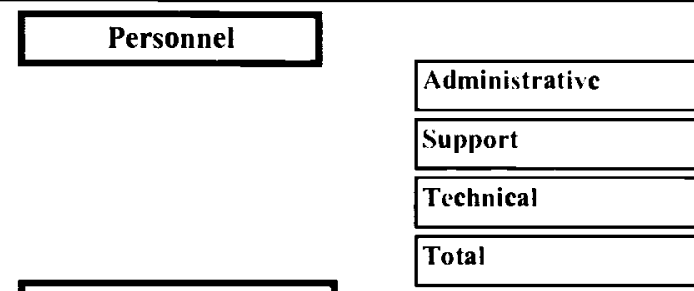

Budget In US S

\begin{tabular}{l|llll}
\multicolumn{1}{l}{} & $\mathbf{1 9 9 9}$ & $\mathbf{2 0 0 0}$ & $\mathbf{2 0 0 1}$ & $\mathbf{2 0 0 2}$ \\
\cline { 3 - 6 } Afghanistan & 0 & 0 & 0 & 0 \\
\hline Pakistan & 18,956 & 25,660 & 207,481 & 272,674 \\
\hline Total & 1.8 .956 .00 & $25,060.00$ & $207,481.00$ & $272,074.00$
\end{tabular}

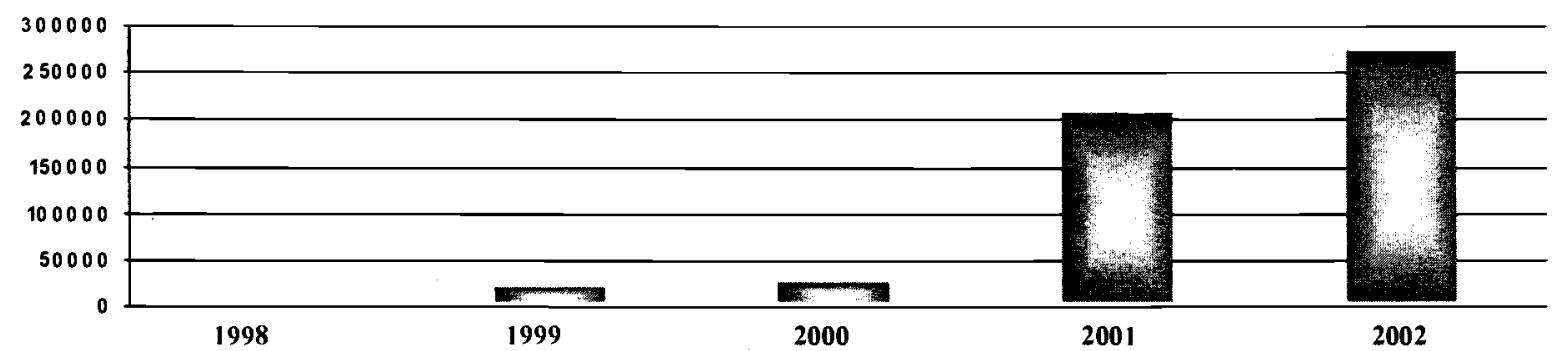

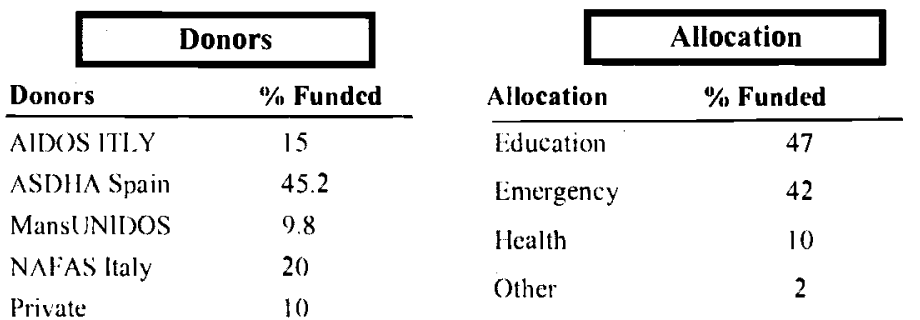

\begin{tabular}{|c|c|c|c|}
\hline \multirow{3}{*}{$\frac{\text { Province }}{\text { Balkh }}$} & \multicolumn{3}{|c|}{ Targeted Provinces } \\
\hline & Scetor & \multicolumn{2}{|c|}{$\%$ Targcted } \\
\hline & Relic & atriatioin & 100 \\
\hline Balkh & I:duc & & 30 \\
\hline Banyan & Relie & atriatioin & 1 \\
\hline Farah & l:duc & & 50 \\
\hline Hirat & l:duc & & 10 \\
\hline Kabul & Fduc & & 30 \\
\hline Kabul & Incor & ration & 2 \\
\hline Kabul & Heal & & 95 \\
\hline Kabul & Relie & atriatioin & \\
\hline Nangarhar & Relic & atriatioin & \\
\hline Nangarhar & Educ & & $3 t$ \\
\hline Nimroz & Relic & atriatioin & 1 \\
\hline Nimroz & liduo & & 50 \\
\hline Nuristan & I:duc & & 5 \\
\hline NWFP & Relic & atriatioin & 10 \\
\hline NWIP & $\operatorname{lncos}$ & ration & $7:$ \\
\hline NWIP & I leal & & in \\
\hline NWIP & Eduo & & $x$ \\
\hline Sannangan & Iduc & & 2 \\
\hline
\end{tabular}

Sub Offices 


\begin{tabular}{|c|c|c|c|c|c|}
\hline Sub Office & City / Town & Phone & Fax & E-mail & In Charge \\
\hline $\begin{array}{l}\text { NWIP' House o4 St. } 7 \text { Sect. L }: 3 \\
\text { Phase 1 Hayalabad }\end{array}$ & Peshawar & 822753 & & hawcalghawca.org & Onar Sayel \\
\hline
\end{tabular}

\section{HCI (Human Concern International)}

\begin{tabular}{|c|c|c|c|}
\hline Membership & $\mathrm{AC} B \mathrm{BAR}$ & Country of Affliliation & Canada \\
\hline Address & Communication & Key Staff & Position \\
\hline $\begin{array}{l}\text { 39) D Syed Jamal-u-Dln Afghani } \\
\text { Road, } \\
\text { University Town, } \\
\text { Peshawar-Pakistan }\end{array}$ & $\begin{array}{ll}\text { Phone: } & 840524 \\
\text { Fax: } & 840544 \\
\text { E-mail: } & \text { hcipak@ } \omega \text { psh.biain.netpk } \\
\text { Web: } & \end{array}$ & Ah. Nawaz & Directror \\
\hline
\end{tabular}

\begin{tabular}{|l|}
\hline Afglian \\
\hline Pakistani \\
\hline Expatriates \\
\hline Total \\
\hline
\end{tabular}

\begin{tabular}{|c|c|c|c|}
\hline \multicolumn{4}{|l|}{ Personnel } \\
\hline & Administrative & & 20 \\
\hline & Support & & 20 \\
\hline & Technical & & 35 \\
\hline & Total & & 75 \\
\hline \multicolumn{4}{|l|}{ Budget ln US $\$$} \\
\hline 2000 & 2001 & 2002 & \\
\hline 54,000 & 27,000 & 87,949 & \\
\hline 270,000 & 302,000 & 121,051 & \\
\hline $324,000.00$ & $329,000.00$ & $209,000.00$ & \\
\hline
\end{tabular}

\begin{tabular}{|c|c|c|c|c|c|}
\hline & 1998 & 1999 & 2000 & 2001 & 2002 \\
\hline Afghanistan & 105,000 & 104,160 & 54,000 & 27,000 & 87,949 \\
\hline Pakistan & 245,000 & 231,840 & 270,000 & 302,000 & 121,051 \\
\hline Total & $350,000.00$ & $336,000.00$ & $324,000.00$ & $329,000.00$ & $209,000.00$ \\
\hline
\end{tabular}
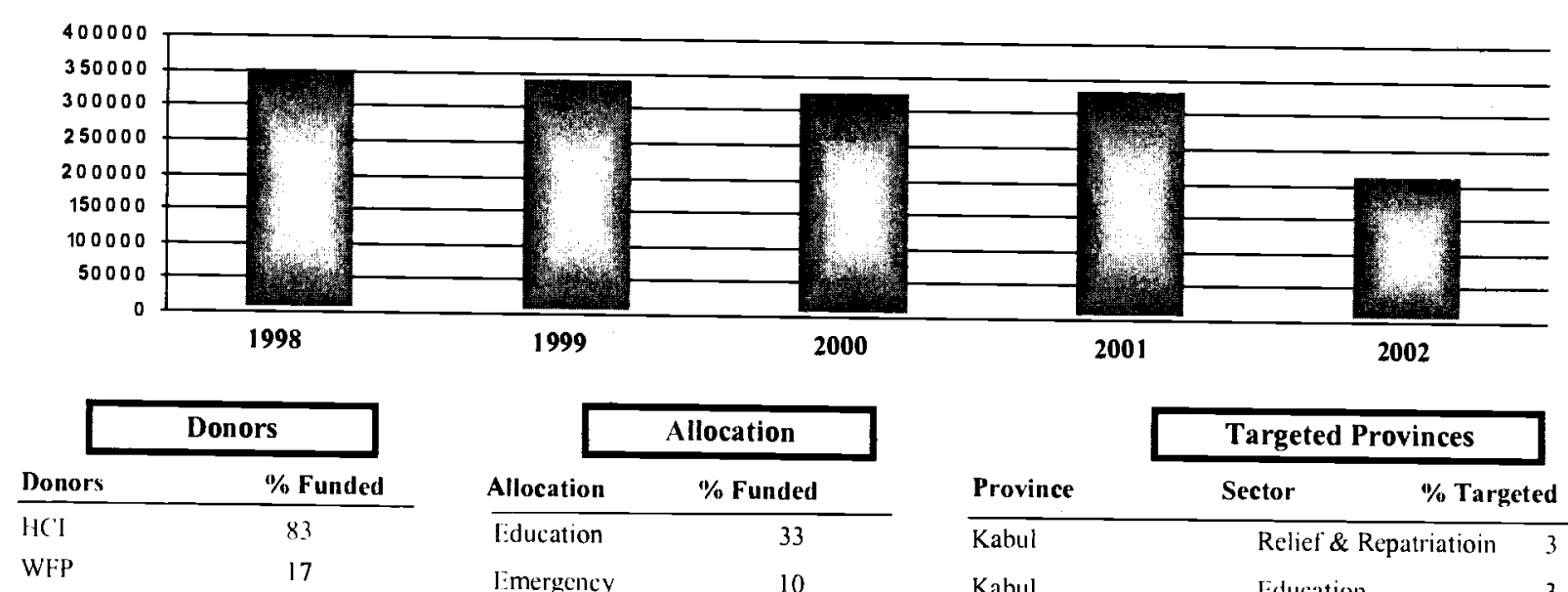

\begin{tabular}{lc|}
\cline { 2 - 2 } & Allocation \\
Allocation & $\%$ Funded \\
\hline Education & 33 \\
Emergency & 10 \\
Health & 7 \\
Income (jeneratio & 3 \\
Infrastructure & 17 \\
Other & 5
\end{tabular}

Sub Offices

\begin{tabular}{lll} 
& \multicolumn{2}{c|}{ Targeted Provinces } \\
\cline { 2 - 3 } Province & \multicolumn{2}{c}{ \%ector Targeted } \\
\hline Kabul & Relief \& Repatriatioin & 3 \\
Kabul & Education & 3 \\
Kunar & Infrastructure & 17 \\
Kunar & Relief \& Repatriatioin & 3 \\
Nangarhar & Health & 2 \\
Nangarhar & Income Generation & 1 \\
Nangarhar & Education & 8 \\
Nangarhar & Relief \& Repatriatioin & 5 \\
NWFP & Other & 5 \\
NWFP & Emergency & 10 \\
NWFP & Income Generation & 2 \\
NWFP & Relief \& Repatriatioin & 14 \\
NWFP & Health & 5 \\
NWFP & Education & 22
\end{tabular}




\begin{tabular}{|c|c|c|c|c|c|}
\hline Sub Office & City / Town & Phone & Fax & E-mail & In Charge \\
\hline $\begin{array}{l}\text { NWIP.Hope Village New Refugee } \\
\text { Camp Akora Khatak. }\end{array}$ & Nawshara & 03205205778 & & & M.Taib \\
\hline $\begin{array}{l}\text { Nangarahar.Opp.Masque Shanzda } \\
\text { Finila }\end{array}$ & Jalalabad & & & . & Shahjehan \\
\hline Kunar.Kurala Asadabad & Asadabad & & & & Ci.Farooq \\
\hline $\begin{array}{l}\text { Kahul.Sarak } 2 \text { Opp. Jamal-e-Din } \\
\text { Mosque Karte Now }\end{array}$ & Kabul & & & & leng. Wali \\
\hline
\end{tabular}

\section{HELP (Hilfe zur Selbsthilfe e.V.)}

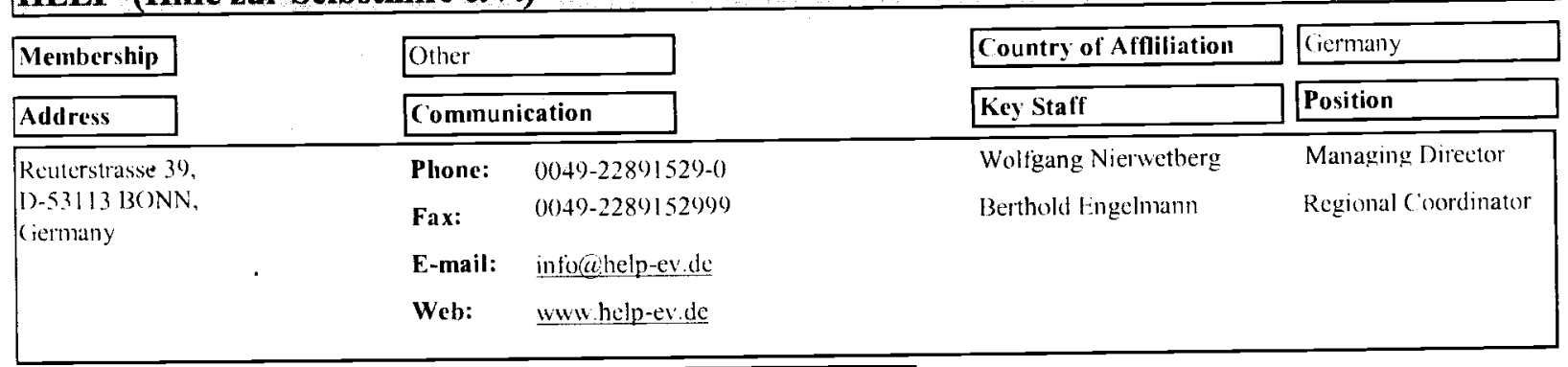

\begin{tabular}{|l|}
\hline Afghan \\
\hline Pakistani \\
\hline Expatriates \\
\hline Total \\
\hline
\end{tabular}

8

0

2

10

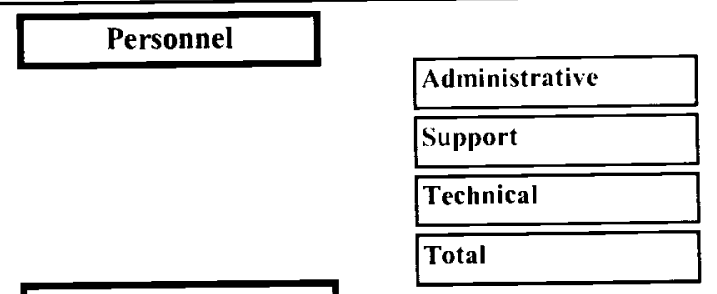

Budget In US \$

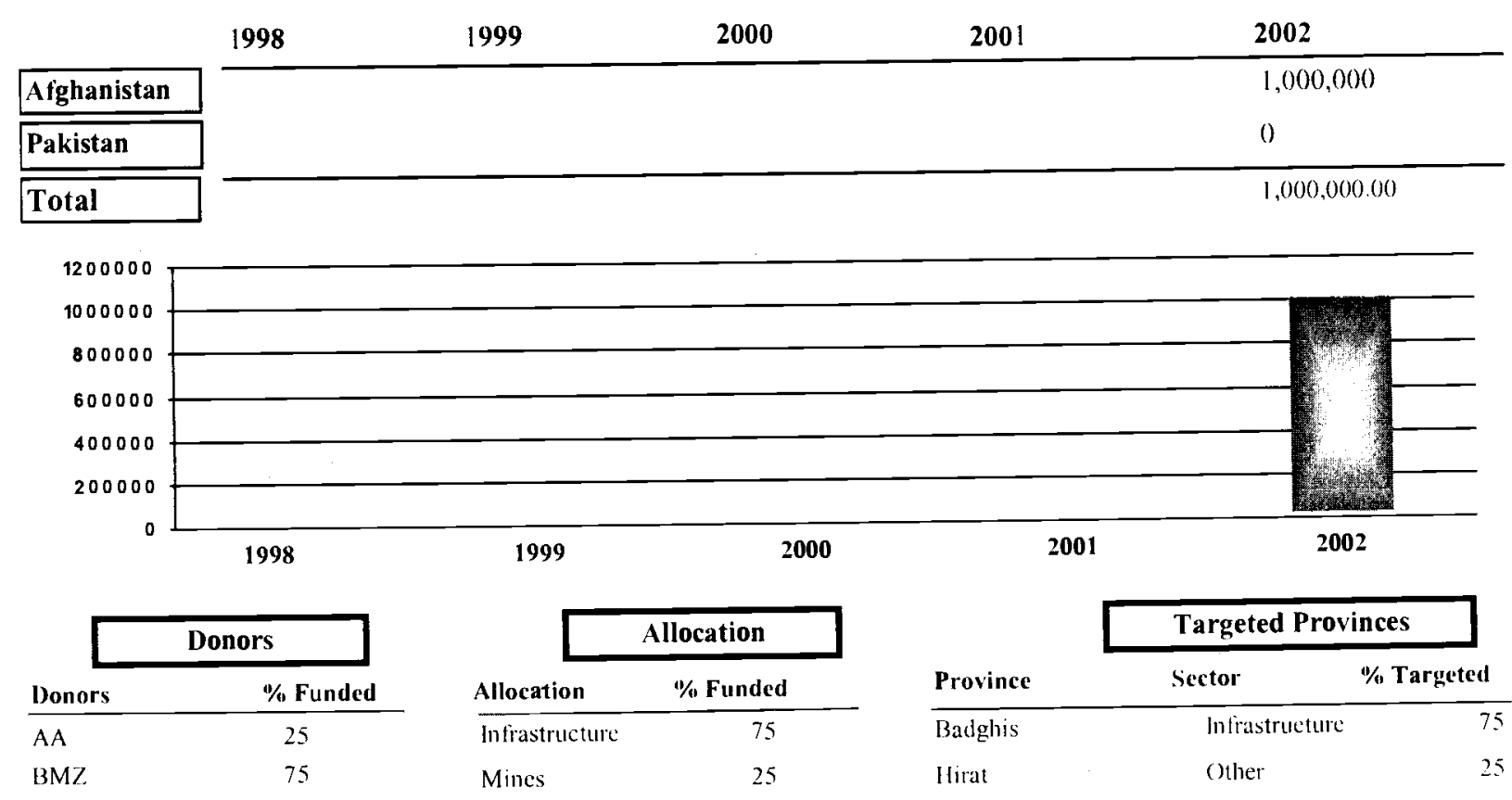

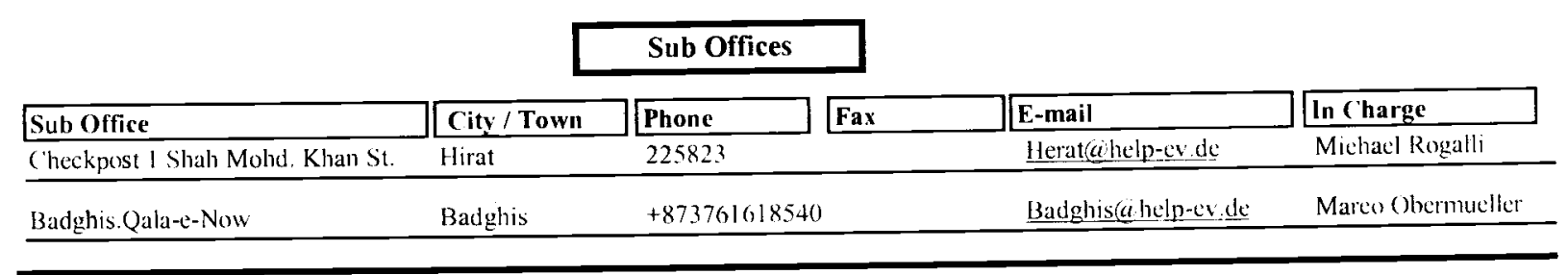




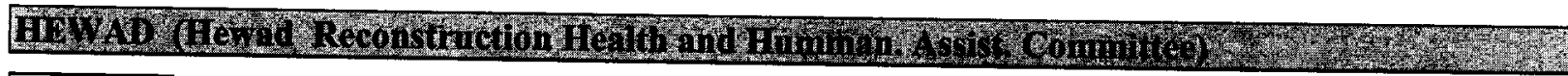

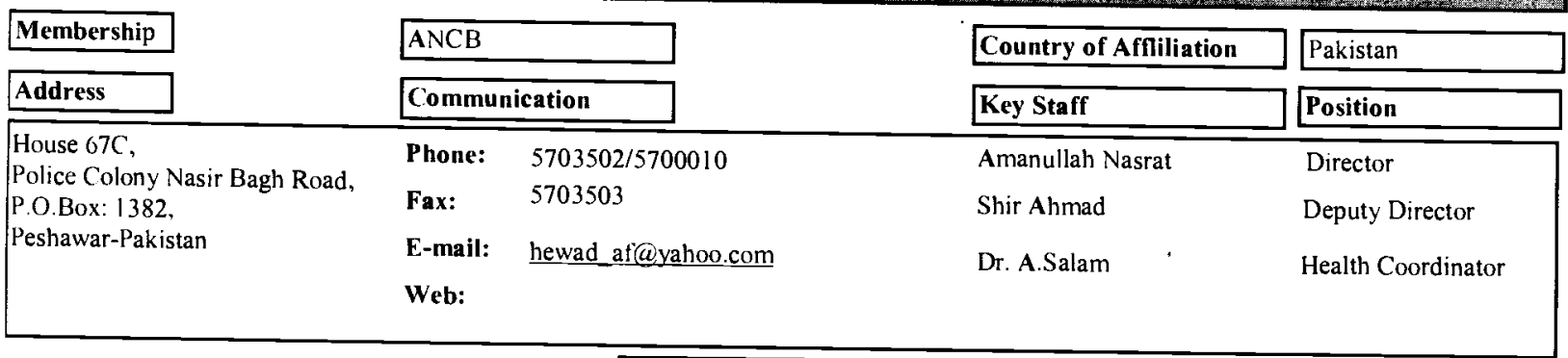

\begin{tabular}{|l|}
\hline Afghan \\
\hline Pakistani \\
\hline Expatriates \\
\hline Total \\
\hline
\end{tabular}

Personnel

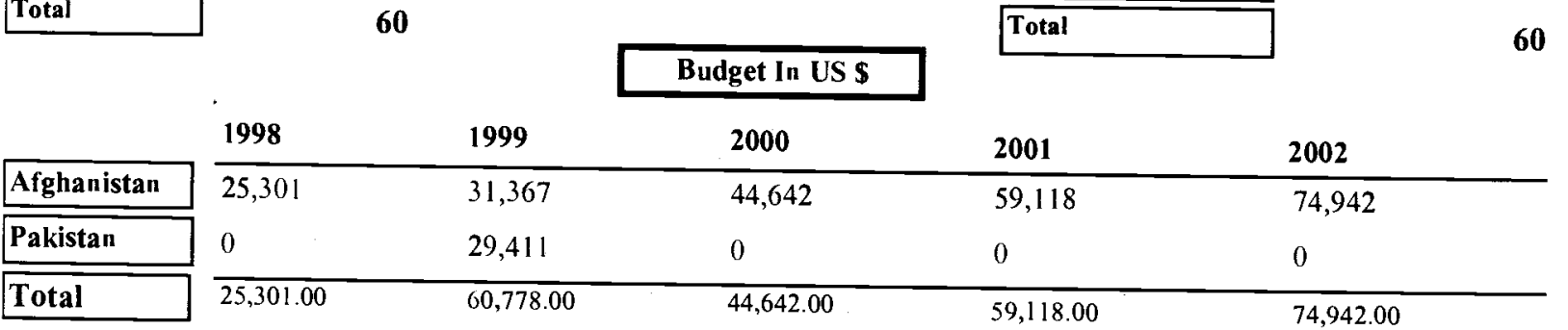

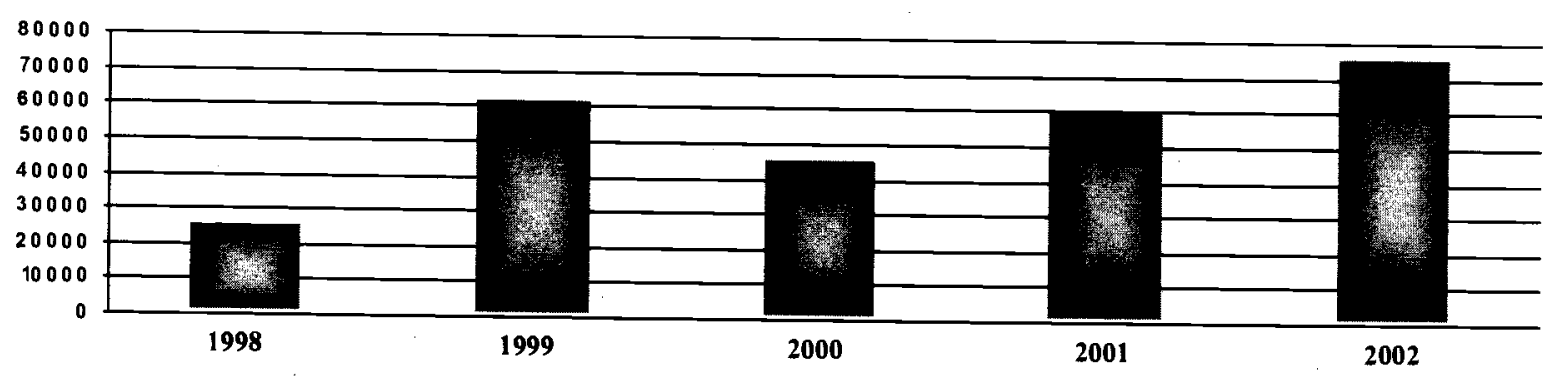

\begin{tabular}{|c|c|c|c|c|c|c|}
\hline & & & location & & Targeted Prov & inces \\
\hline Donors & $\%$ Funded & Allocation & $\%$ Funded & Province & Sector & $\%$ Targeted \\
\hline MEPO & & Education & 20 & Kabul & Education & 20 \\
\hline NAC & & Health & 60 & Laghman & Health & 40 \\
\hline WFP & & Income Ger & 5 & Nangarhar & Infrastructure & 40 \\
\hline & & Infrastructu & 10 & & & \\
\hline & & Relief \& Re & 5 & & & \\
\hline
\end{tabular}

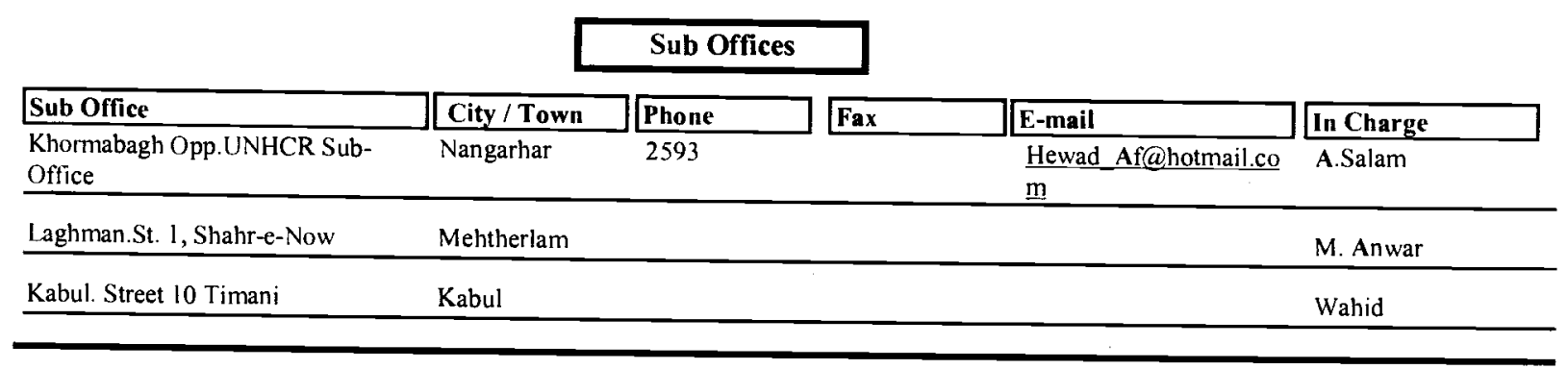




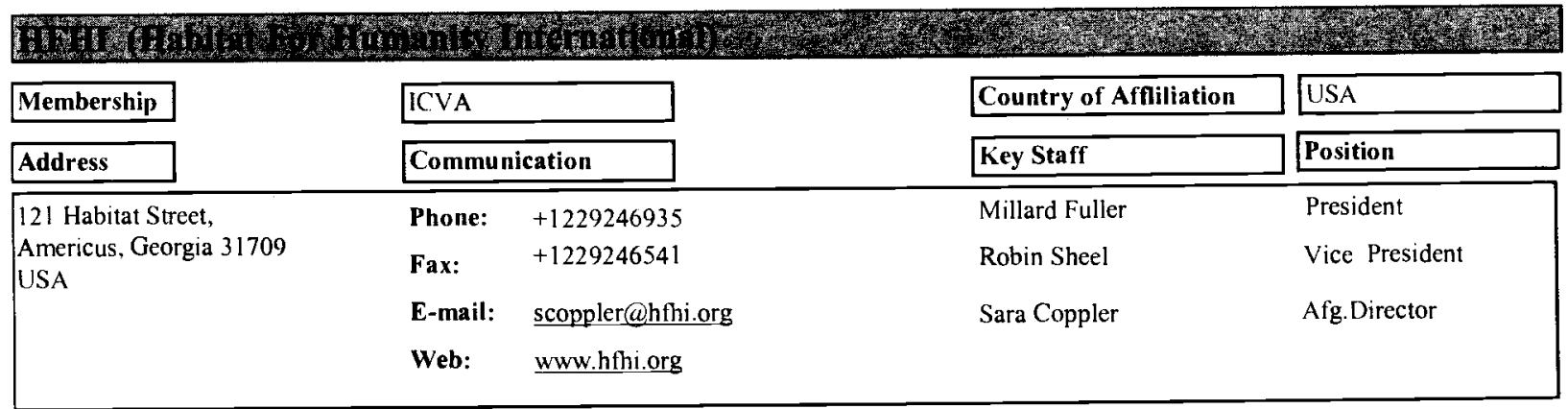

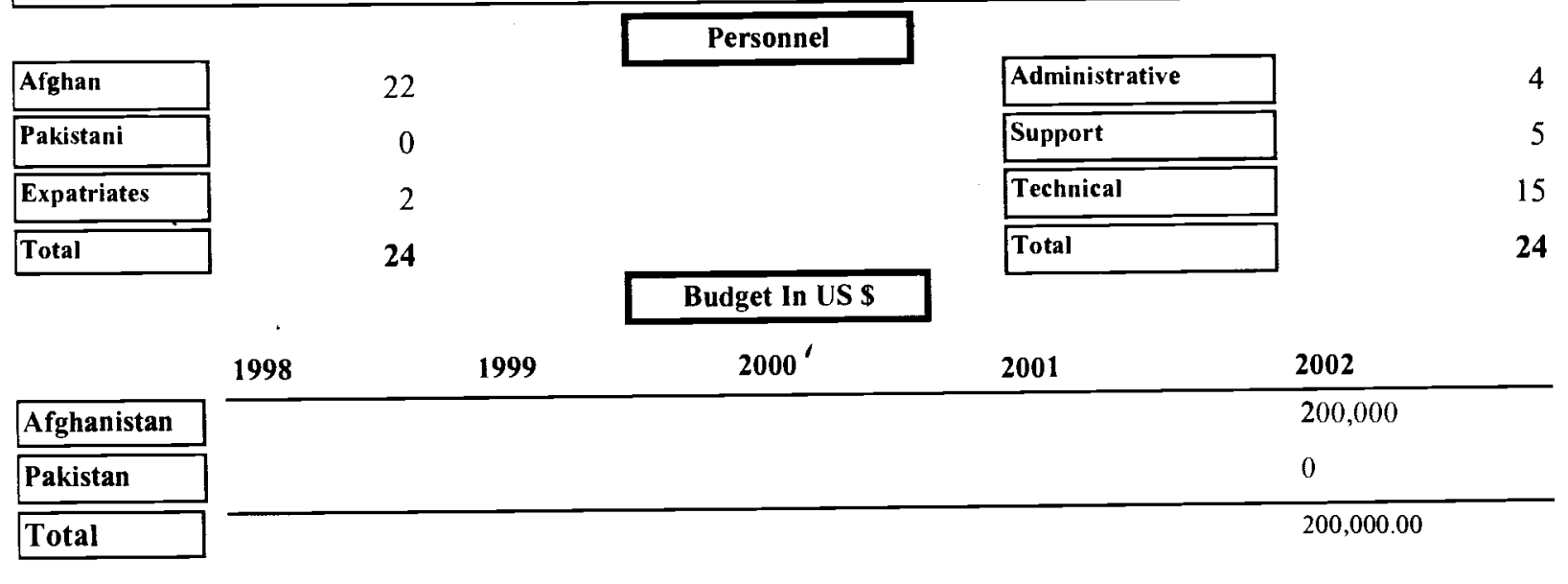

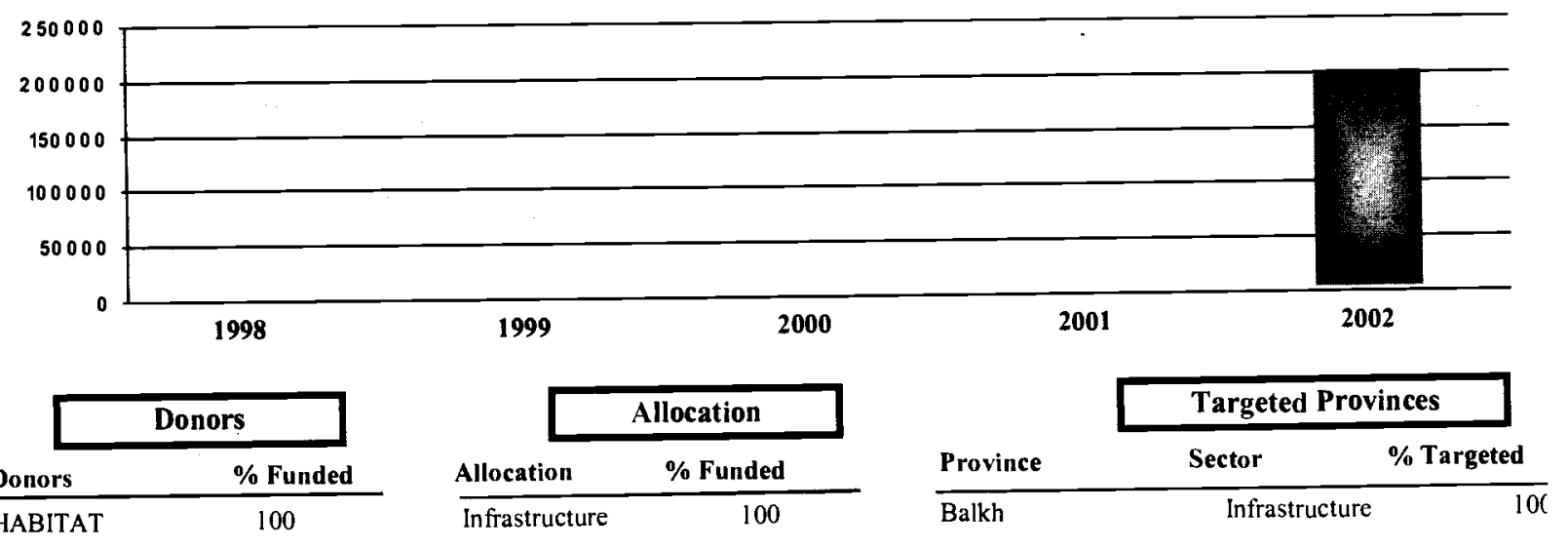

\section{Sub Offices}

\begin{tabular}{|c|c|c|c|c|c|}
\hline Sub Office & City / Town & Phone & Fax & E-mail & In Charge \\
\hline $\begin{array}{l}\text { lst St.Behind Medical Faculty } \\
\text { House }\end{array}$ & Mazar & 40599 & & hthimazar@yahoo.com & S.Coppler \\
\hline
\end{tabular}




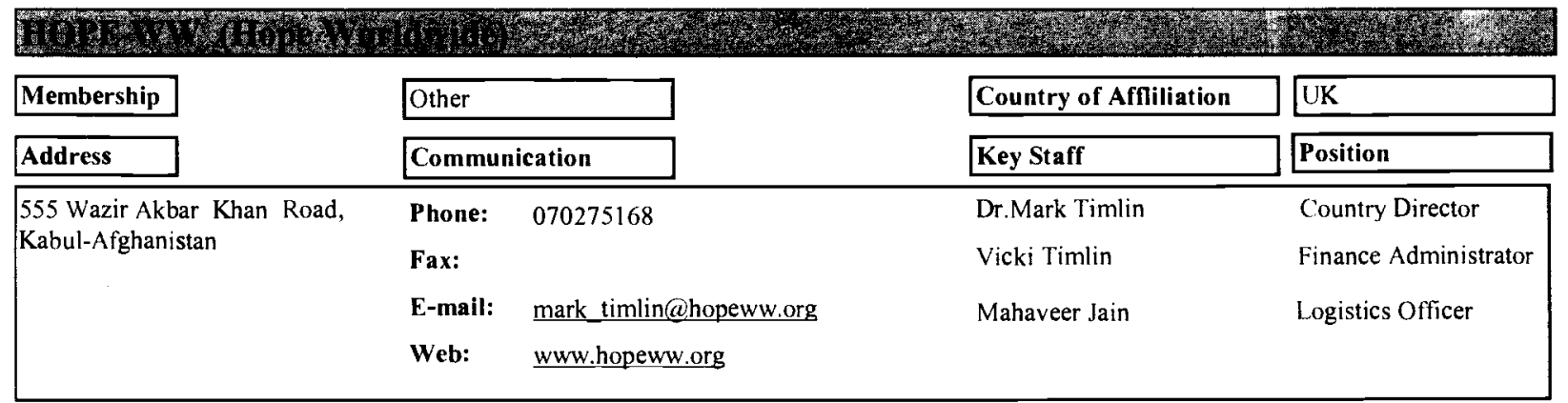

\begin{tabular}{|l|}
\hline Afghan \\
\hline Pakistani \\
\hline Expatriates \\
\hline Total \\
\hline
\end{tabular}

Personnel

\begin{tabular}{|l|}
\hline Administrative \\
\hline Support \\
\hline Technical \\
\hline Total \\
\hline
\end{tabular}

\begin{tabular}{|c|c|c|c|}
\hline & 1998 & 2000 & 2002 \\
\hline Afghanistan & & 100,000 & 270,000 \\
\hline Pakistan & & 20,000 & 10,000 \\
\hline Total & & $120,000.00$ & $280,000.00$ \\
\hline
\end{tabular}

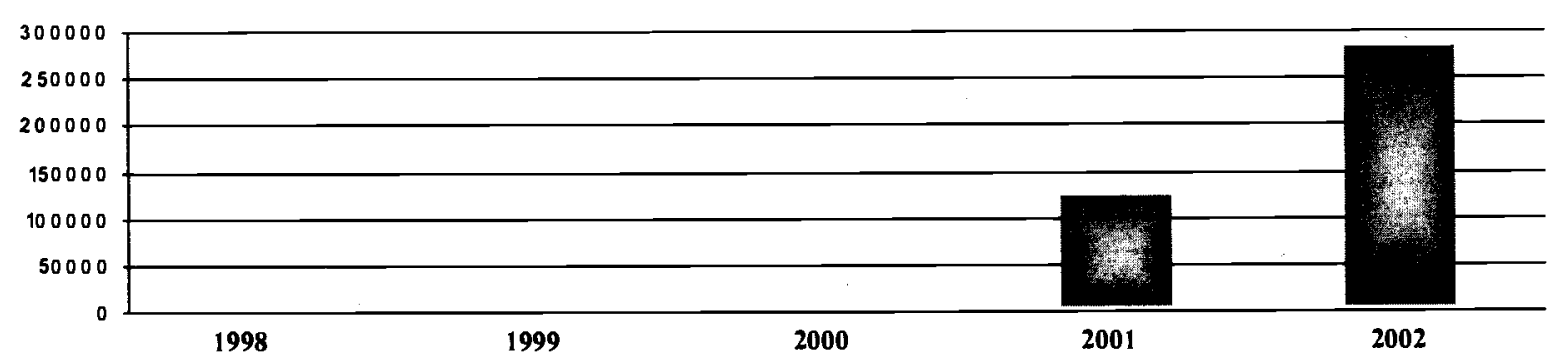

\begin{tabular}{|c|c|c|c|c|c|c|}
\hline \multicolumn{2}{|c|}{ Donors } & & Illocation & \multirow[b]{2}{*}{ Province } & \multicolumn{2}{|c|}{ Targeted Provinces } \\
\hline Donors & $\%$ Funded & Allocation & $\%$ Funded & & Sector & $\%$ Targeted \\
\hline$\overline{D F I D}$ & 28 & $\overline{\text { Education }}$ & 10 & $\overline{\text { Kabul }}$ & Education & 10 \\
\hline GTZ & 26 & Health & 90 & Kabul & Health & 84 \\
\hline Japan Embassy & 9 & & & Wardak & Education & 6 \\
\hline Private & 32 & & & & & \\
\hline
\end{tabular}

Sub Offices

\begin{tabular}{|c|c|c|c|c|c|}
\hline Sub Office & City/Town & Phone & Fax & E-mail & In Charge \\
\hline $\begin{array}{l}\text { NWFP.Aryen Medical St. } 8 \text { Canal } \\
\text { Town Nasir Bagh }\end{array}$ & Peshawar & $0300-9590254$ & & $\begin{array}{l}\text { shakeel_bhath@hotmail. } \\
\text { com }\end{array}$ & Shakeel Bhath \\
\hline
\end{tabular}




\begin{tabular}{|c|c|c|c|}
\hline Membership & $\overline{\mathrm{ANCB}}$ & Country of Affiliation & Afghanistan \\
\hline Address & Communication & Key Staff & Position \\
\hline \multirow{4}{*}{$\begin{array}{l}\text { Jada-e-Qaumandani House 2, } \\
\text { Hirat-Afghanistan }\end{array}$} & Phone: & Saqib Younus & Program Officer \\
\hline & Fax: & Eng. Salahi & Regional Director \\
\hline & E-mail: & A. BasirTookhy & Finance Officer \\
\hline & Web: & & \\
\hline
\end{tabular}

\begin{tabular}{|l|rr|r|}
\hline Afghan & & Personnel & \\
\hline Pakistani & 20 & Administrative \\
\hline Expatriates & 1 & Support \\
\hline Total & 0 & Technical & 6 \\
\hline
\end{tabular}

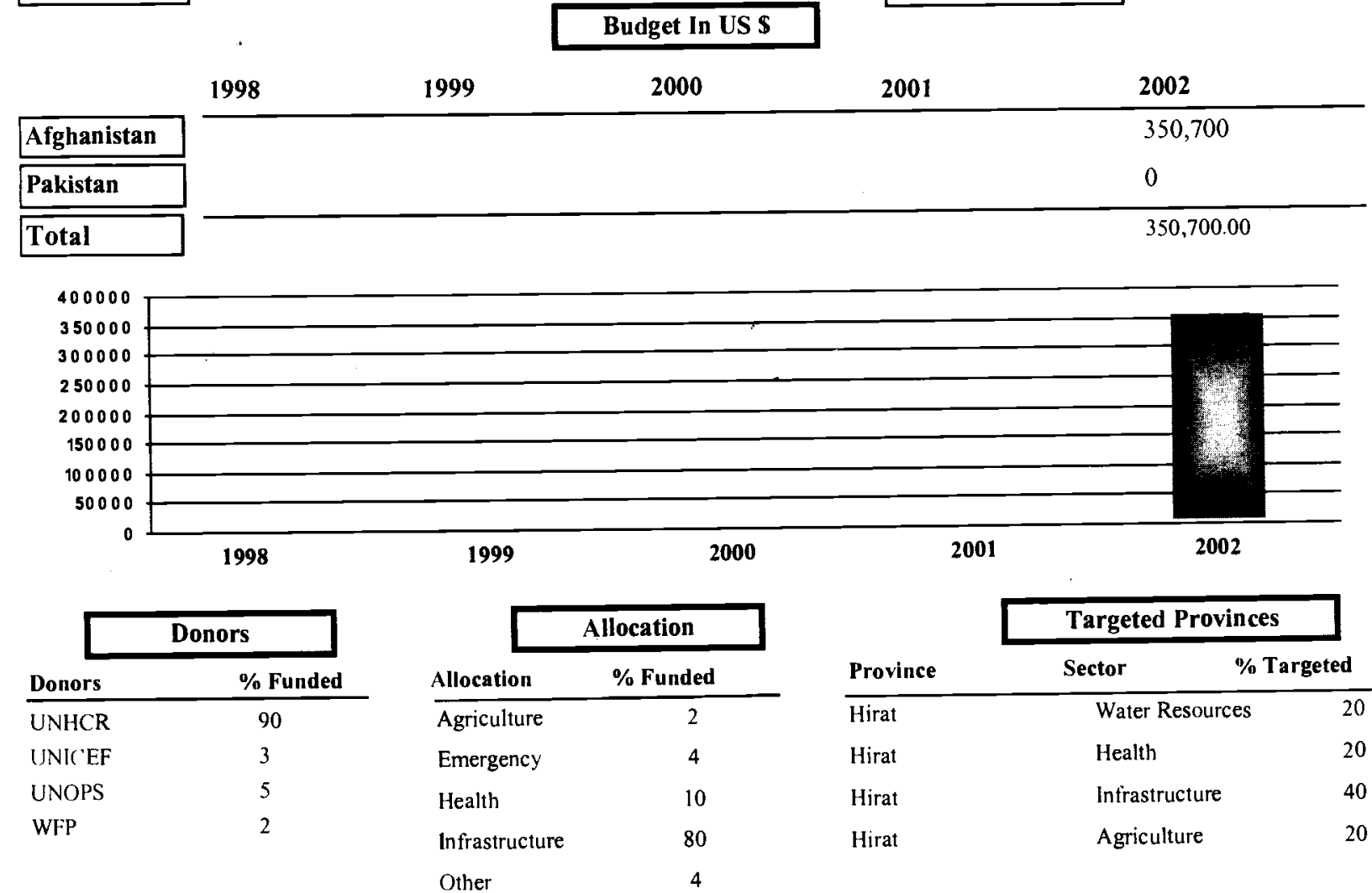

Sub Offices

\begin{tabular}{|c|c|c|c|c|c|}
\hline Sub Office & City / Town & Phone & Fax & E-mail & In Charge \\
\hline Islamabad.House $280 \mathrm{St} .27 \mathrm{~F}-11 / 2$ & Islamabad & 2292232 & & aahmadhrs@yahoo.com & \\
\hline Farah. Nahya-e-Awal Street 6 & Farah & & & & Eng.Hashim \\
\hline
\end{tabular}


HI (H) Trus)

\begin{tabular}{|c|c|c|c|}
\hline Membership & ANCB & Country of Affiliation & UK \\
\hline Address & Communication & Key Staff & Position \\
\hline \multirow{4}{*}{$\begin{array}{l}\text { Charahi Ansari Shahr-e- Naw, } \\
\text { PO Box 3036, } \\
\text { Kabul- Afghanistan }\end{array}$} & Phone: & Farid Homayoun & Country Director \\
\hline & 00873761931818 & Gerhard Zank & OPS Officer \\
\hline & haloafg@yahoo.com & Nasir Ahmad & Asst. Program Man. \\
\hline & www halotrust.org & & \\
\hline
\end{tabular}

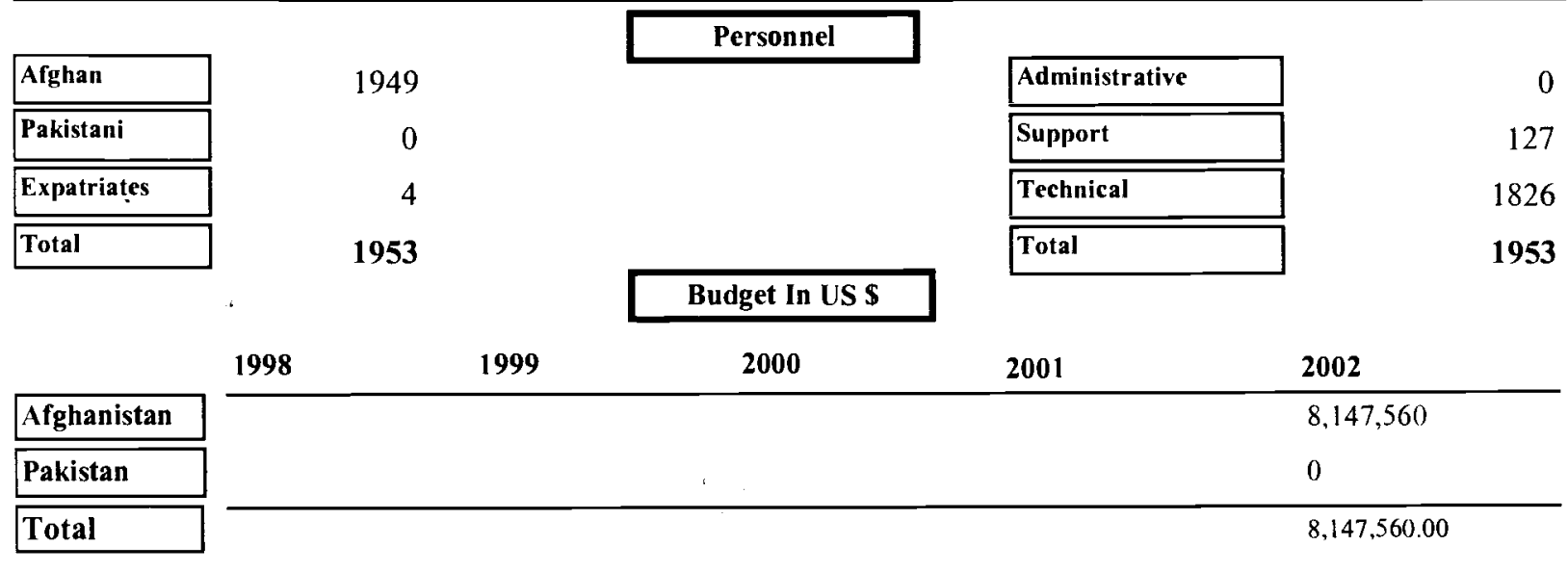

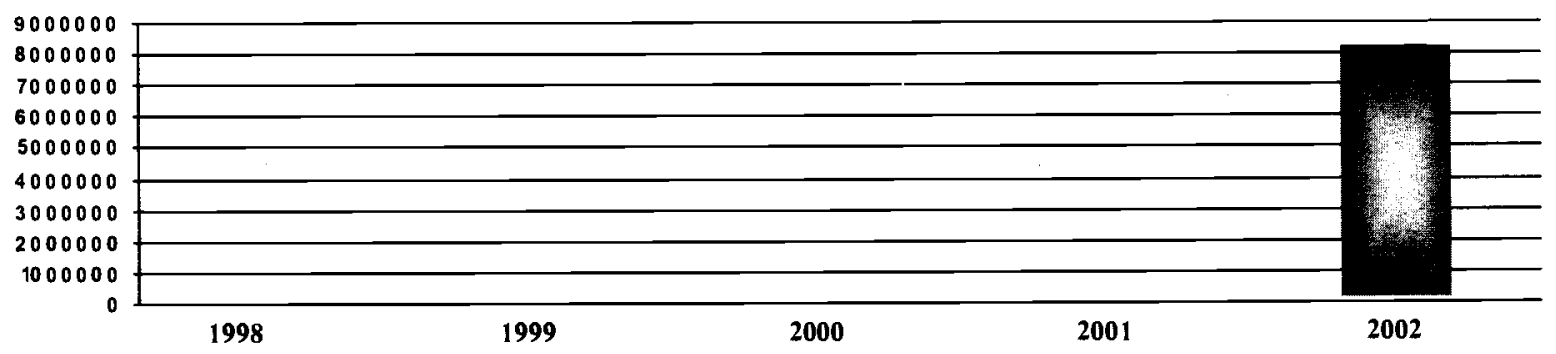

\begin{tabular}{|c|c|c|c|c|c|c|}
\hline \multicolumn{2}{|c|}{ Donors } & & llocation & \multirow[b]{2}{*}{ Province } & \multicolumn{2}{|c|}{ Targeted Provinces } \\
\hline Donors & $\%$ Funded & Allocation & $\%$ Funded & & Sector & $\%$ Targeted \\
\hline \multicolumn{2}{|l|}{ DFID } & Mines & 100 & Badakhshan & Mines & 10 \\
\hline \multicolumn{2}{|l|}{ Dutch Govt. } & & & Baghlan & Mines & 10 \\
\hline \multicolumn{2}{|l|}{$\mathrm{EC}$} & & & Balkh & Mines & 40 \\
\hline \multicolumn{2}{|l|}{ Irish Govt. } & & & Kabul & Mines & 10 \\
\hline \multirow{3}{*}{\multicolumn{2}{|c|}{ US Dept. of State }} & & & Kunduz & Mines & 10 \\
\hline & & & & Parwan & Mines & 10 \\
\hline & & & & Takhar & Mines & 10 \\
\hline
\end{tabular}

Sub Offices

\begin{tabular}{ll|l|l|l|l|l|l|l|l}
\hline Sub Office & City / Town & Phone & Eax \\
\hline Mazar. West of Mazar & Mazar & Akbar \\
\hline Kunduz.Close to Dawra & Kunduz & Dr. Nainat \\
\hline Takhar. Takhar Town & Takhar & Dr. Hamidullah \\
\hline Baghlan. Puli Khumri & Baghlan & $+873761931791+87376193179$ & Eng.Ali \\
\hline
\end{tabular}




\begin{tabular}{|c|c|c|c|}
\hline Membership & Other & Country of Affliliation & Afghanistan \\
\hline Address & Communication & Key Staff & Position \\
\hline \multirow{4}{*}{$\begin{array}{l}\text { Sarak Shura Karte She, } \\
\text { Kabul-Afghanistan }\end{array}$} & 00873762841461 & Harri Lammi & Executive Director \\
\hline & Fax: & Steve Martin & Finance Director \\
\hline & hq@iamafg.org & & \\
\hline & www.iamafg.org & & \\
\hline
\end{tabular}

\begin{tabular}{|l|}
\hline Afghan \\
\hline \hline Pakistani \\
\hline \hline Expatriates \\
\hline Total \\
\hline
\end{tabular}

Personnel

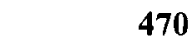

Budget In US \$

\begin{tabular}{|c|c|c|c|c|c|}
\hline & 1998 & 1999 & 2000 & 2001 & 2002 \\
\hline Afghanistan & $1,800,000$ & $1,600,000$ & $1,800,000$ & $1,700,000$ & $2,800,000$ \\
\hline Pakistan & 0 & 0 & 0 & 0 & 0 \\
\hline Total & $1,800,000.00$ & $1,600,000.00$ & $1,800,000.00$ & $1,700,000.00$ & $2,800,000.00$ \\
\hline
\end{tabular}

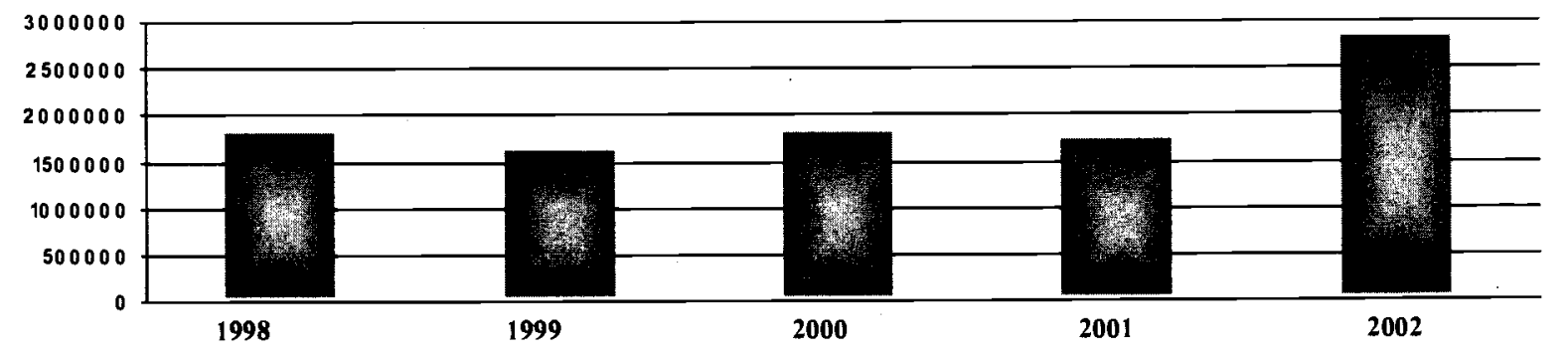

\begin{tabular}{lc}
\multicolumn{2}{c|}{ Donors } \\
Donors & \% Funded \\
\hline IAM Members & 60 \\
Private & 40
\end{tabular}

\begin{tabular}{lc}
\multicolumn{1}{c}{ Allocation } \\
Allocation & $\%$ Funded \\
\hline Agriculture & 1 \\
Education & 7 \\
Health & 65 \\
Income Generatio & 2 \\
Infrastructure & 12 \\
Other & 13
\end{tabular}

\begin{tabular}{lcc} 
& \multicolumn{2}{c|}{ Targeted Provinces } \\
\cline { 2 - 3 } Province & Sector & \% Targeted \\
\hline Balkh & Health & 18 \\
Farah & Other & 1 \\
Ghor & Health & 8 \\
Hirat & Education & 16 \\
Kabul & Health & 56 \\
Wardak & Other & 1
\end{tabular}

Sub Offices

\begin{tabular}{|l|l|l|l|l|l|l|}
\hline Sub Office & City / Town \\
\hline
\end{tabular}

E-mail

In Charge

Bahind Seltan Razia School Marmul Balkh

Streets

NWFP.8D-1 Lane University Town Peshawar

845291

842634

iampwr@pactec.net

Denuk.M 


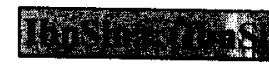

\section{Membership \\ Address :}

No.81 St.6 Sector G2, Phase 2 Hayat Abad, Peshawar-Pakistan
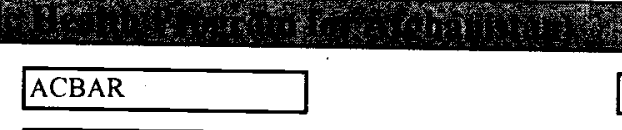

$\begin{array}{ll}\text { E-mail: } & \text { ibph@brain.net.pk } \\ \text { Web: } & \text { www.ibnsina.net }\end{array}$

Country of Affiliation
Key Staff

Anwarul Haq Jabarkhil

Ahmad Jan Naeem

Dr. Mirza Jan
Afghanistan

Position

Chief Advisor

Director General

Program Coordinator

\begin{tabular}{|l|}
\hline Afghan \\
\hline Pakistani \\
\hline Expatriates \\
\hline Total \\
\hline
\end{tabular}

Personnel

6

0

738

Budget In US \$

\begin{tabular}{|l|}
\hline Administrative \\
\hline Support \\
\hline Technical \\
\hline Total \\
\hline
\end{tabular}

\begin{tabular}{|c|c|c|c|c|c|}
\hline & 1998 & 1999 & 2000 & 2001 & 2002 \\
\hline Afghanistan & 790,000 & 721,000 & $8,122,000$ & $1,066,800$ & $2,983,929$ \\
\hline Pakistan & 0 & 0 & 0 & 129,400 & 0 \\
\hline Total & $790,000.00$ & $72 \mathrm{I}, 000.00$ & $8,122,000.00$ & $1,196,200.00$ & $2,983,929.00$ \\
\hline
\end{tabular}

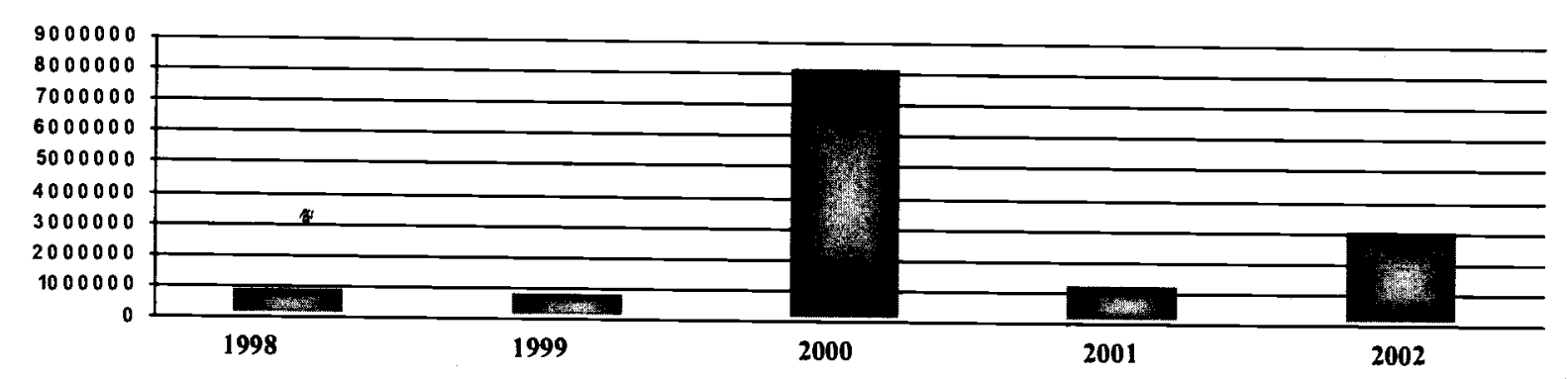

\begin{tabular}{lc|}
\cline { 2 - 2 } & \multicolumn{2}{c|}{ Donors } \\
\hline Donors & \% Funded \\
\hline CORD AID & 43.32 \\
EU & 26.41 \\
IMC & 8.81 \\
NOVIB & 17.4 \\
Rockfeller & 0.96 \\
UNFPA & 0.97 \\
UNICEF & 2.13
\end{tabular}

Sub Offices

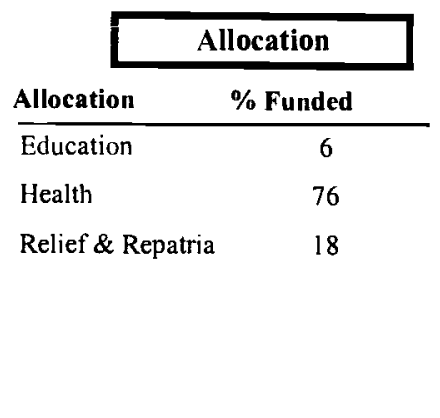

\begin{tabular}{lcc} 
& \multicolumn{2}{c|}{ Targeted Provinces } \\
\cline { 2 - 3 } Province & Sector & \% Targeted \\
\hline Baghlan & Health & 1.5 \\
Balkh & Health & 3 \\
Bamyan & Health & 3.5 \\
Ghazni & Health & 17 \\
Hilmand & Health & 12. \\
Hirat & Health & 8 \\
Kandahar & Health & 1.3 \\
Laghman & Health & 0.7 \\
Nangarhar & Health & 21. \\
NWFP & Health & 14. \\
Paktika & Health & 1.5 \\
Paktya & Health & 2.5 \\
Parwan & Health & 12
\end{tabular}




\begin{tabular}{|c|c|c|c|c|}
\hline Sub Office & City / Town & Phone & E-mail & In Charge \\
\hline $\begin{array}{l}\text { Nangarhar.Near Torkham Adah } \\
\text { Zara Sarenwali }\end{array}$ & JalalAbad & 2017 & & Dr. Ihsanullah \\
\hline $\begin{array}{l}\text { Kabul.House } 7 \text { St. } 10 \text { Wazir Akbar } \\
\text { Khan }\end{array}$ & Kabul & 23458 & & Dr.Noor.M \\
\hline Ziarat Khwaja Ali Sahib Plani 3 & Ghazni & & & Dr.Samaullah \\
\hline $\begin{array}{l}\text { Kandahar.Near Surai Masjid Shahr- } \\
\text { e-Now }\end{array}$ & Kandahar & & & Dr. Daud \\
\hline $\begin{array}{l}\text { Bamyan.Serasiab Village Near } \\
\text { Airport }\end{array}$ & Bamyan & & & Mir.Zaman Shah \\
\hline $\begin{array}{l}\text { Charahee Aameriat Jada-e-See } \\
\text { Kocha-e-bagh-e-Murad }\end{array}$ & Hirat & & & Dr. Wadoodullah \\
\hline $\begin{array}{l}\text { Ashraf Ramazan House Karte Shafa } \\
\text { Khana Kaah Feroshi }\end{array}$ & Mazar & & & Dr.Almmad Jawad \\
\hline
\end{tabular}

\section{ICARDA (Tritenational Center for Agticulture Research in the Diy Areas)}

\begin{tabular}{|c|c|c|c|}
\hline Membership & Other & Country of Affiliation & Syria \\
\hline Address & Communication & Key Staff & Position \\
\hline \multirow{4}{*}{$\begin{array}{l}\text { Anghor Bagh Nasirullah House, } \\
\text { Ialalabad-Afghanistan }\end{array}$} & Phone: & Noorul Haq & Site Manager \\
\hline & Fax: & Lal Mohd. & Eng.Agronom \\
\hline & E-mail: & Mainuddin & Coordinator \\
\hline & Web: & & \\
\hline
\end{tabular}

\begin{tabular}{|c|c|c|c|c|c|c|}
\hline & & & Personnel & & & \\
\hline Afghan & \multicolumn{2}{|c|}{12} & & Administrative & \multirow{4}{*}{. } & 1 \\
\hline Pakistani & \multicolumn{2}{|c|}{0} & & Support & & 6 \\
\hline Expatriates & \multicolumn{2}{|c|}{0} & & Technical & & 5 \\
\hline \multirow[t]{3}{*}{ Total } & & & & Total & & 12 \\
\hline & & & Budget In US \$ & & & \\
\hline & 1998 & 1999 & 2000 & 2001 & 2002 & \\
\hline
\end{tabular}

\begin{tabular}{|l|}
\hline Afghanistan \\
\hline Pakistan \\
\hline Total \\
\hline
\end{tabular}

1998

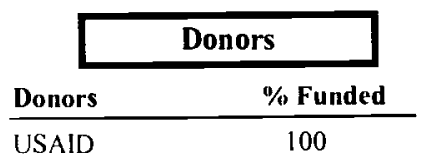

1999

\begin{tabular}{lc|}
\hline & \multicolumn{1}{c|}{ Allocation } \\
\hline Allocation & $\%$ Funded \\
\hline Agriculture & 50 \\
Veterinary & 50
\end{tabular}

2001

2002

\begin{tabular}{lcc} 
& \multicolumn{2}{c|}{ Targeted Provinces } \\
\cline { 2 - 2 } Province & Sector & \% Targeted \\
\hline Kunar & Agriculture \\
Laghman & Agriculture \\
Nangarhar & Agriculture
\end{tabular}


ICMC (International Catholic Migration Commission)

\begin{tabular}{|c|c|c|c|}
\hline Membership & IC'VA & Country of Aftliliation & Swilzerland \\
\hline Iddress & Communication & Key Staff & Position \\
\hline \multirow{3}{*}{$\begin{array}{l}\text { ('inema Square, } \\
\text { Hirat -Afghanistan }\end{array}$} & Phone: & Ken Patterson & Country Repersentive \\
\hline & Fax: & Stephen Maqnard & Program Manager \\
\hline & $\begin{array}{l}\text { E-mail: Kateroner@ohotmail.com } \\
\text { Web: }\end{array}$ & Kate Roner & Program Manager \\
\hline
\end{tabular}

\begin{tabular}{|l|}
\hline Alghan \\
\hline \hline Pakistani \\
\hline Expatriates. \\
\hline Total \\
\hline
\end{tabular}

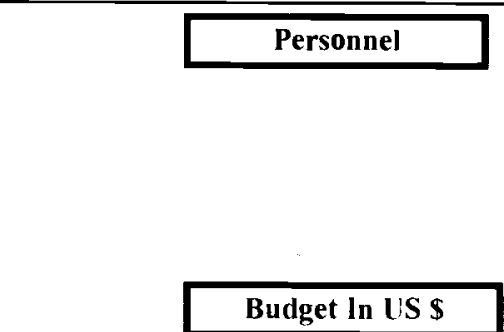

125
5
0
$\mathbf{1 3 0}$

\begin{tabular}{|l|}
\hline Administrative \\
\hline Support \\
\hline Technical \\
\hline Total \\
\hline
\end{tabular}

\begin{tabular}{|l|}
\hline Afghanistan \\
\hline Pakistan \\
\hline Total \\
\hline
\end{tabular}

1998

1999

2000

2001

2002

\begin{tabular}{|c|c|c|c|c|c|c|}
\hline & 1998 & 1999 & 2000 & 2001 & 2002 & \\
\hline & & & llocation & & Targeted Provinces & \\
\hline Donors & $1 / 1$ Funded & Allocation & $\%$ Funded & Province & Sector & \\
\hline PRM(US) & 50 & Other & 100 & Ghor & Income Generation & 30 \\
\hline UNHICR & 50 & & & Ghor & Other & 30 \\
\hline & & & & Hirat & Income Generation & 30 \\
\hline & & & & Hirat & Other & 40 \\
\hline & & & & Kandahar & Income Generation & 30 \\
\hline & & & & Kandahar & Other & 30 \\
\hline
\end{tabular}

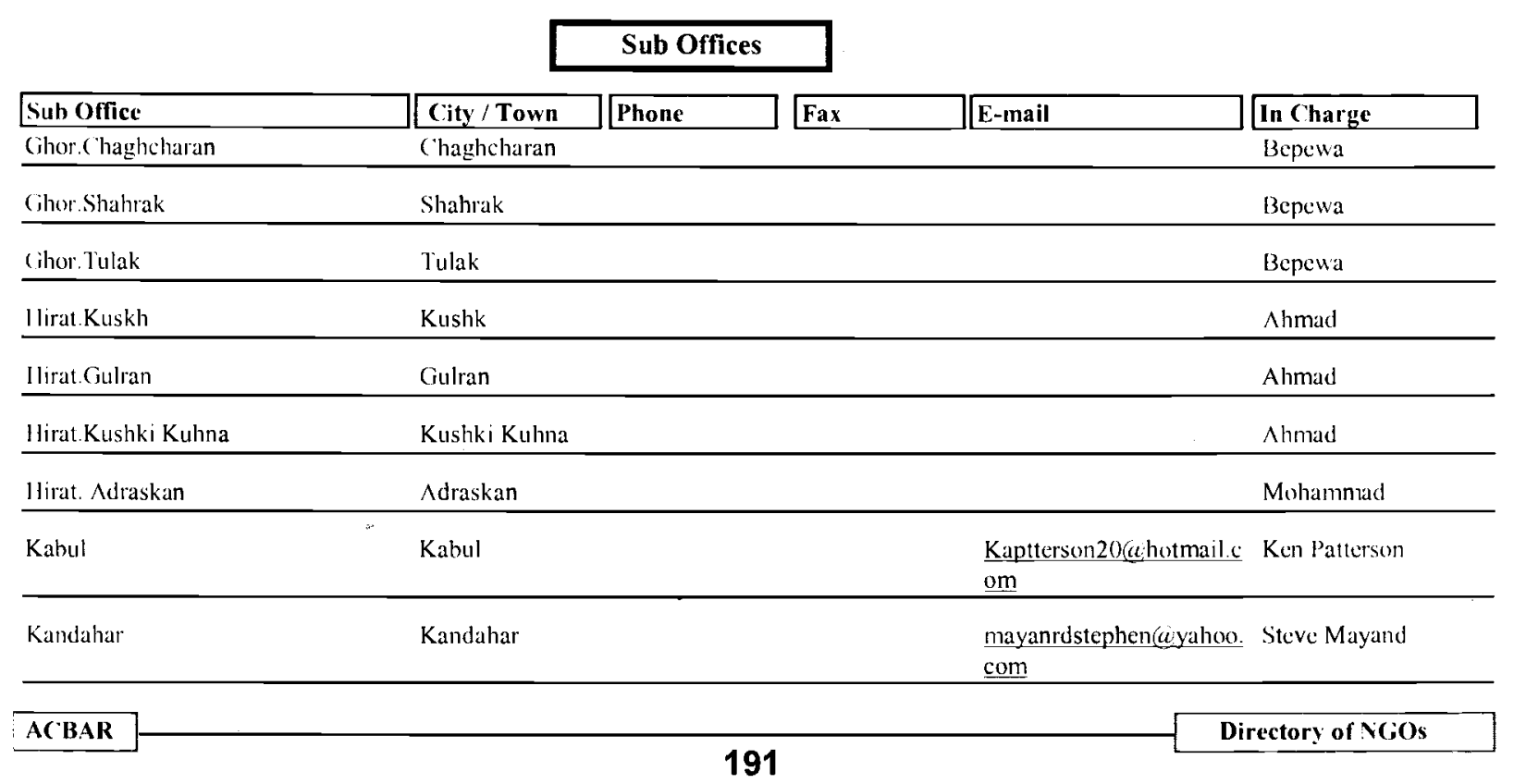




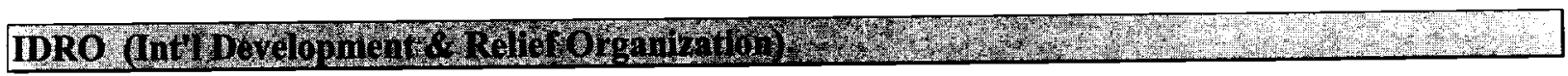

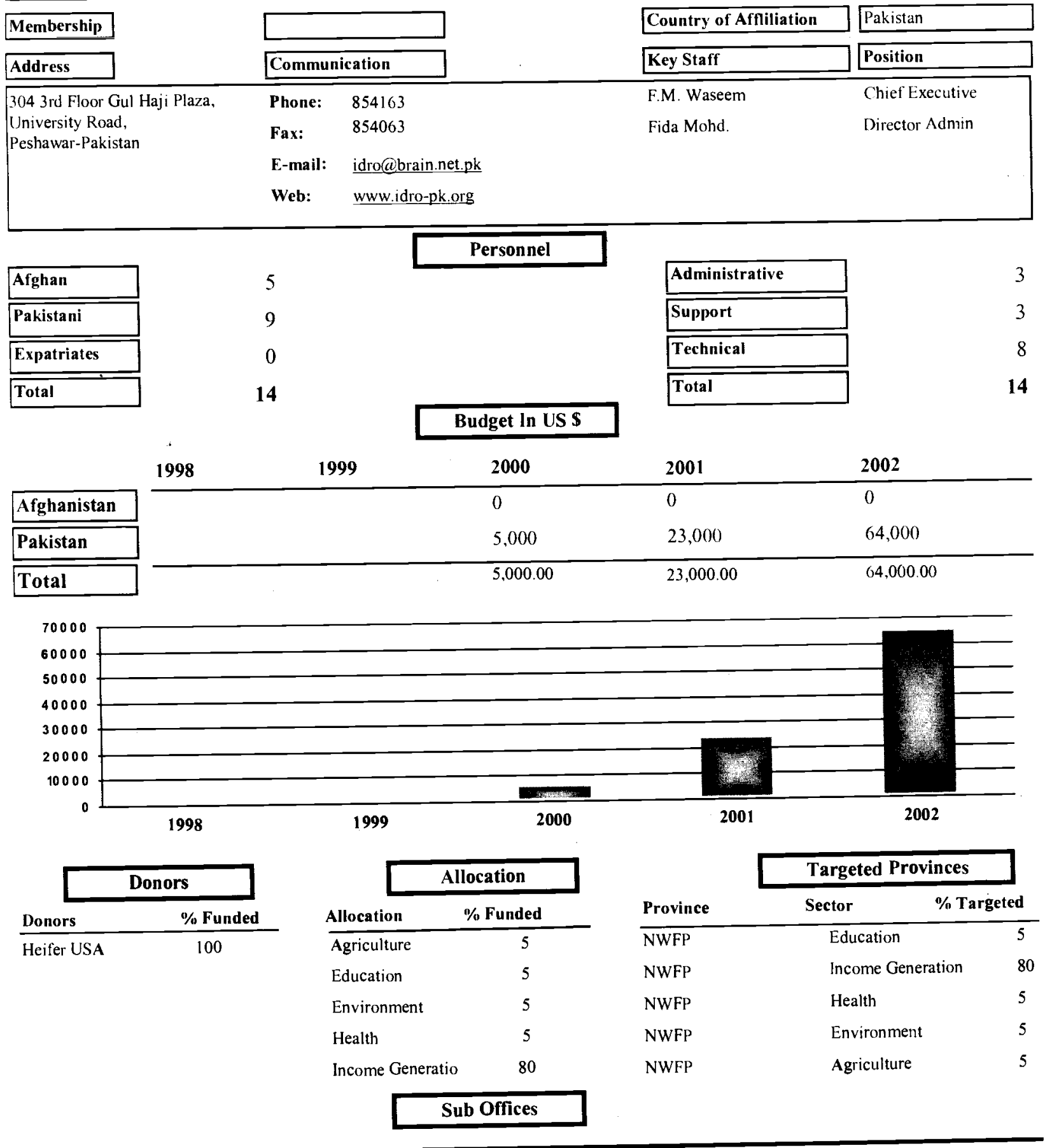


IFHOPE (International Foundation of Ropo)_._.

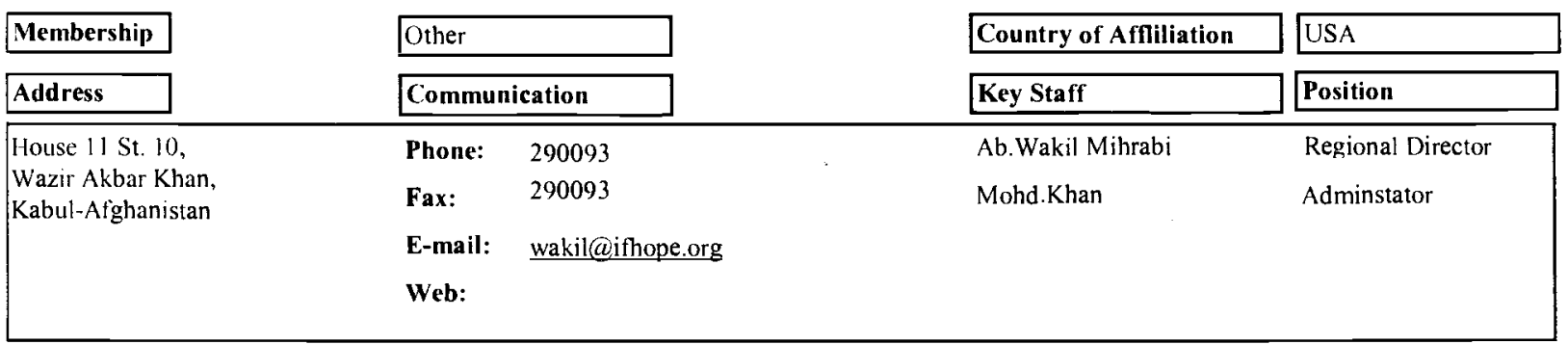

\begin{tabular}{|l|}
\hline Afghan \\
\hline Pakistani \\
\hline Expatriates \\
\hline Total \\
\hline
\end{tabular}

\section{Personnel}

61

61

\begin{tabular}{|l|}
\hline Administrative \\
\hline Support \\
\hline Technical \\
\hline Total \\
\hline
\end{tabular}

Budget In US \$

\begin{tabular}{|l|llll}
\multicolumn{1}{l}{} & $\mathbf{1 9 9 8}$ & $\mathbf{2 0 0 0}$ & $\mathbf{2 0 0 1}$ & $\mathbf{2 0 0 2}$ \\
\cline { 3 - 5 } Afghanistan & & 350,000 & 600,000 & $2,000,000$ \\
\hline Pakistan & & 0 & 200,000 & 300,000 \\
\hline Total & & $350,000.00$ & $800,000.00$ & $2,300,000.00$
\end{tabular}
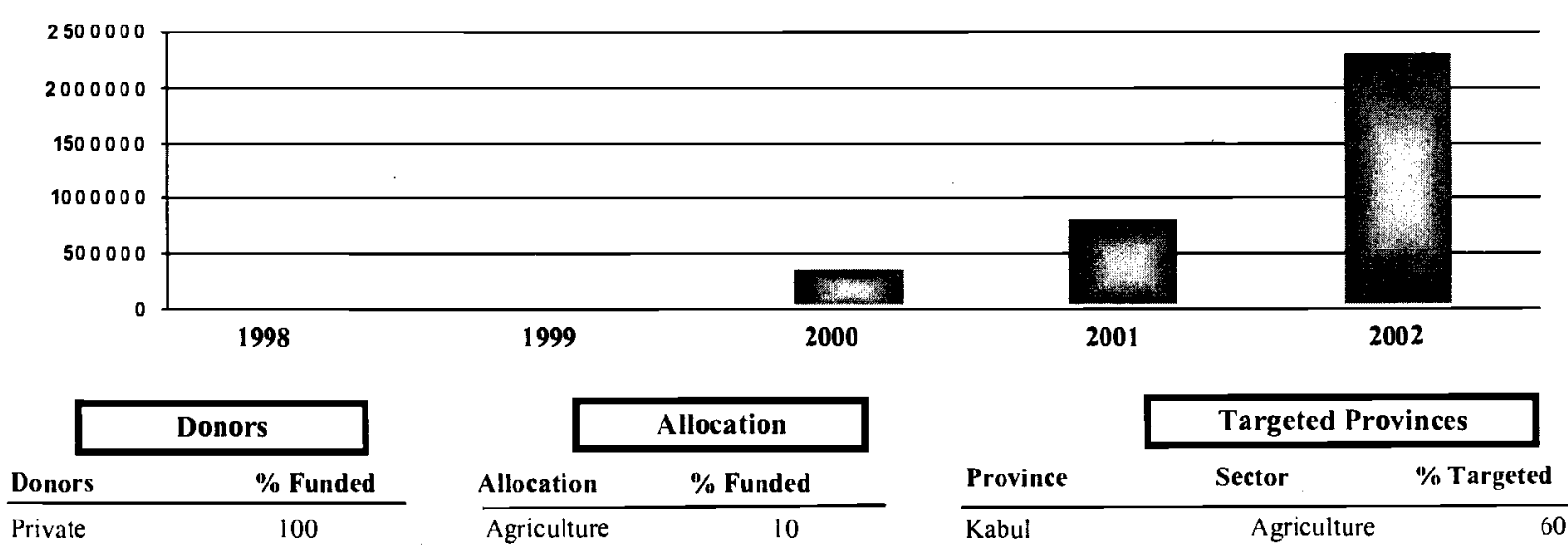

\begin{tabular}{lc|}
\cline { 2 - 2 } & \multicolumn{2}{c|}{ Allocation } \\
Allocation & $\%$ Funded \\
\hline Agriculture & 10 \\
Education & 20 \\
Health & 45 \\
Infrastructure & 15 \\
Relief \& Repatria & 10
\end{tabular}

\begin{tabular}{llr} 
& \multicolumn{2}{c|}{ Targeted Provinces } \\
\cline { 2 - 3 } Province & Sector & $\%$ Targeted \\
\hline Kabul & Agriculture & 60 \\
Nangarhar & Health & 10 \\
Parwan & Infrastructure & 30
\end{tabular}

Sub Offices

\begin{tabular}{|c|c|c|c|c|c|}
\hline Sub Office & \begin{tabular}{|l|} 
City / Town \\
\end{tabular} & Phone & Fax & E-mail & In Charge \\
\hline Hirat..Jadah-e-Gullistan House 119 & Hirat & 225840 & & & Karim \\
\hline $\begin{array}{l}\text { NWFP. House } 186 \text { St. } 9 \text { P1 Phase } 4 \\
\text { Hayatbad }\end{array}$ & Peshawar & 814316 & 824288 & awzada@brain.net.pk & \\
\hline
\end{tabular}


IHRLG (International Human Rights Law Group)

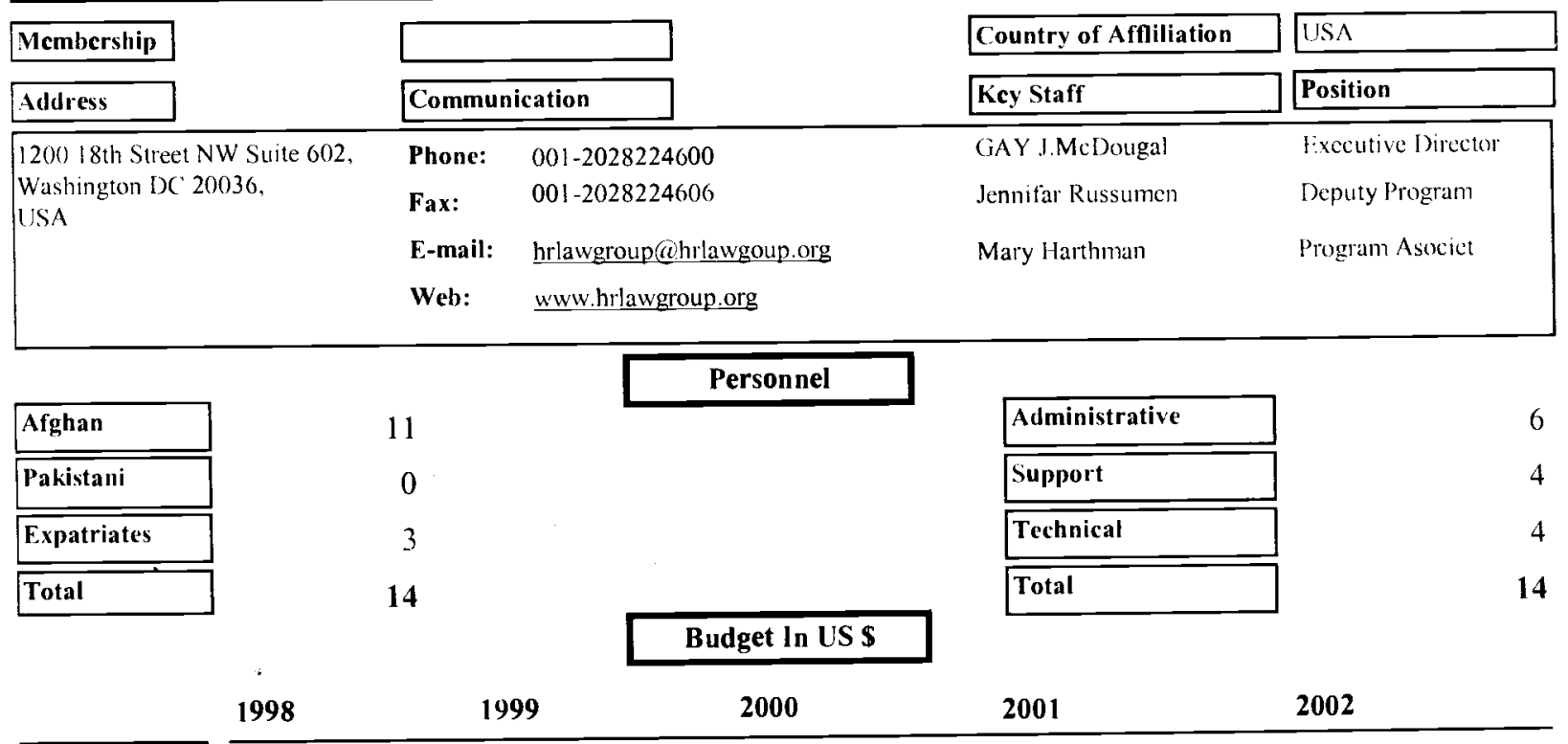

\begin{tabular}{l|l}
\hline Afghanistan \\
\hline Pakistan \\
\hline Total \\
\hline
\end{tabular}

1998

\begin{tabular}{lc|}
\hline \multicolumn{2}{c|}{ Donors } \\
Donors & \% Funded \\
\hline US Govt. & 100
\end{tabular}

1999

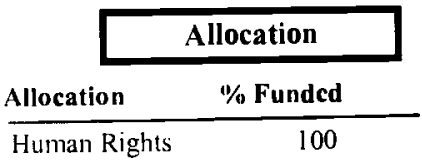

2001

2002

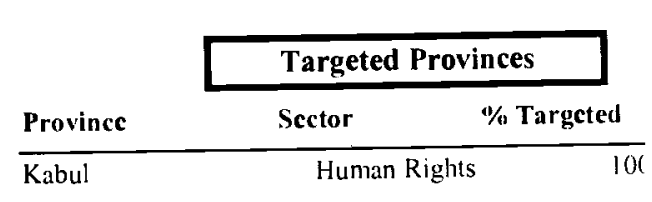

\section{Sub Offices}

\begin{tabular}{|c|c|c|c|c|c|}
\hline Sub Office & City / Town & Phone & Fax & E-mail & In Charge \\
\hline 98 E Abdara Road University Town & Peshawar & & & & \\
\hline $\begin{array}{l}\text { House } 2003 \text { rd Ansari Street Shahr-l- } \\
\text { Nou }\end{array}$ & Kabul & 290225 & 290336 & $\begin{array}{l}\text { humanrights@istiatusnct. } \\
\text { coom }\end{array}$ & Nader Nadery \\
\hline
\end{tabular}




\section{IOC (International Orphan Care)}

\begin{tabular}{|c|c|c|c|}
\hline Membership & & Country of Affiliation & USA \\
\hline Address & Communication & Kcy Staff & Position \\
\hline \multirow{4}{*}{$\begin{array}{l}\text { Shahr-e-Now Infront of Park, } \\
\text { Kabul-Afghanistan }\end{array}$} & 070280162 & S.Abdul Qadeer & ("hairman of Board \\
\hline & $949457-6356$ & Abdullah Osman & ('hairman in $\Lambda \mathrm{fg}$. \\
\hline & E-mail: inforcuorphanproject.org & Hassan Noori & (hairman in US.A \\
\hline & Web: & & \\
\hline
\end{tabular}

\begin{tabular}{|l|}
\hline Afghan \\
\hline \hline Pakistani \\
\hline Expatriates \\
\hline Total \\
\hline
\end{tabular}

Personnel

\begin{tabular}{|c|c|c|c|c|c|}
\hline & \multicolumn{2}{|c|}{-} & & & \\
\hline & 1998 & 1999 & 2000 & 2001 & 2002 \\
\hline Afghanistan & & & & & 20,000 \\
\hline Pakistan & & & & & 0 \\
\hline Total & & & & & 20,000 \\
\hline
\end{tabular}

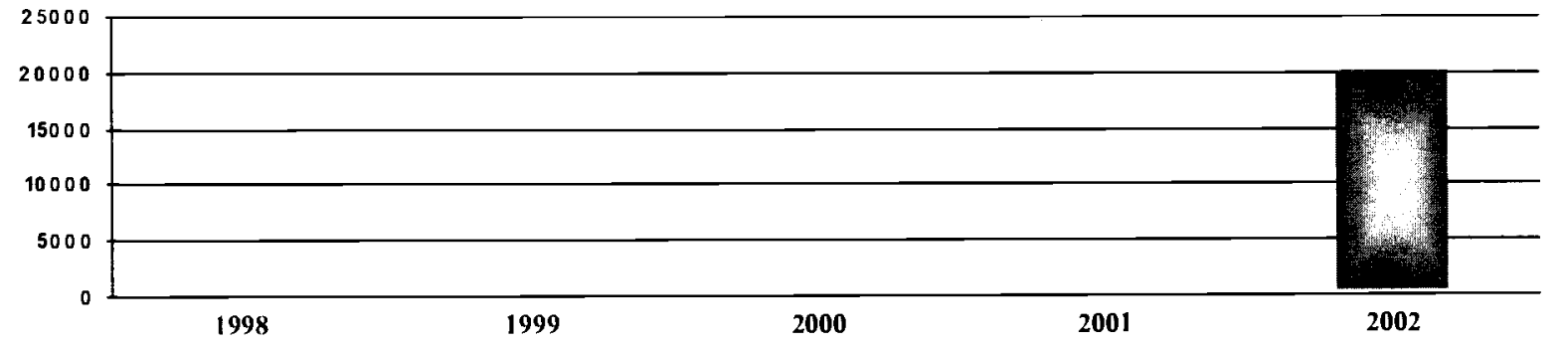

\begin{tabular}{|c|c|c|c|c|c|c|}
\hline \multicolumn{2}{|c|}{ Donors } & & llocation & \multirow[b]{2}{*}{ Province } & \multicolumn{2}{|c|}{ Targeted Provinces } \\
\hline Donors & $\%$ Funded & Allocation & $\%$ Funded & & Sector & $\%$ Targeted \\
\hline \multicolumn{2}{|c|}{ Private (iermany } & liducation & 50 & $\overline{\text { Kabul }}$ & & 10 \\
\hline \multicolumn{2}{|c|}{ Private US $\Lambda$} & Other & 50 & & & \\
\hline
\end{tabular}

\section{Sub Offices}

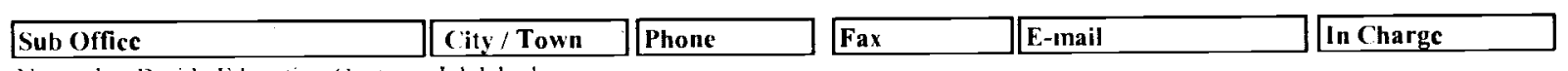




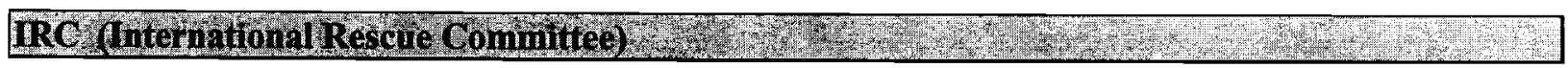

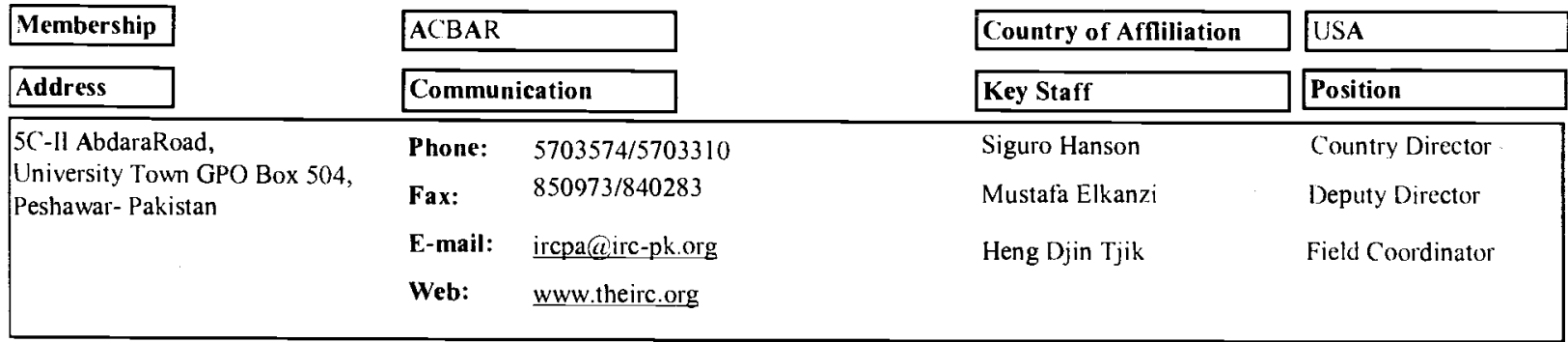

\begin{tabular}{|l|r|}
\hline Afghan & 1196 \\
\hline \hline Pakistani & 130 \\
\hline Expatriates & 9 \\
\hline Total & 1335 \\
\hline
\end{tabular}

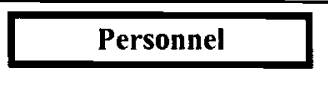

\begin{tabular}{|c|c|c|c|c|c|}
\hline & \multirow{2}{*}{\multicolumn{2}{|c|}{. }} & \multirow{2}{*}{ Budget In US \$ } & & \multirow[b]{3}{*}{2002} \\
\hline & & & & & \\
\hline & 1998 & 1999 & 2000 & 2001 & \\
\hline Afghanistan & $1,499,000$ & 989,975 & & $3,356,530$ & 0 \\
\hline Pakistan & $1,440,000$ & $1,576,381$ & & $3,030,083$ & $12,354,782$ \\
\hline Total & $2,939,000.00$ & $2,566,356.00$ & & $6,386,613.00$ & $12,354,782.00$ \\
\hline
\end{tabular}

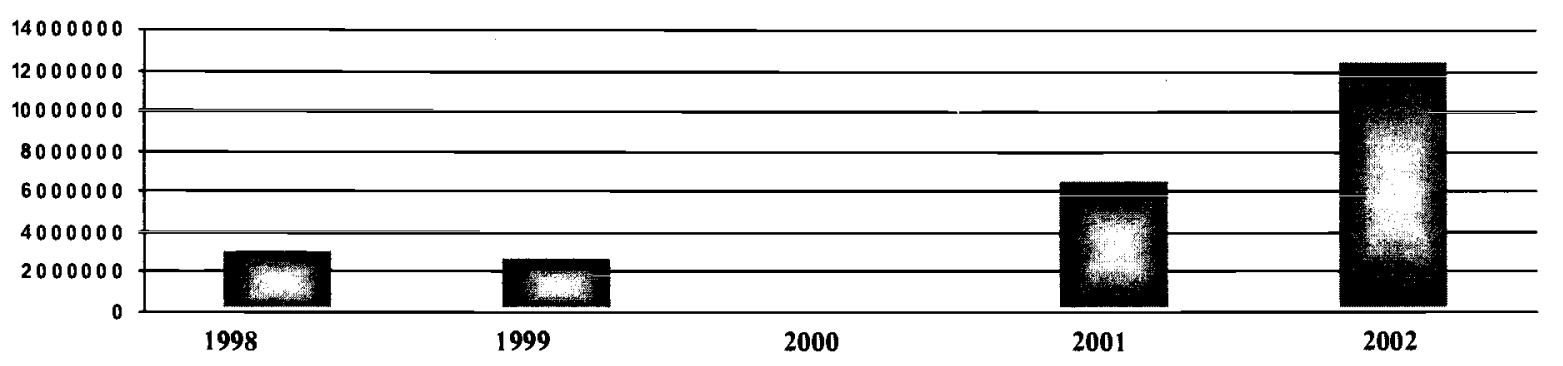

\begin{tabular}{|c|c|c|c|c|c|c|c|}
\hline \multicolumn{2}{|c|}{ Donors } & \multicolumn{2}{|c|}{ Allocation } & \multirow[b]{2}{*}{ Province } & \multicolumn{3}{|c|}{ Targeted Provinces } \\
\hline Donors & $\%$ Funded & Allocation & $\%$ Funded & & Sector & $\%$ Targ & \\
\hline BPRM & 12.5 & $\overline{\text { Education }}$ & 8.6 & $\overline{\text { NWFP }}$ & Othe & & 0 \\
\hline DFID & 9 & Emergency & 03.5 & NWFP & Relie & atriatioin & 17 \\
\hline ЕСHO & 9.3 & Health & 4.6 & NWFP & Heal & & \\
\hline OFDA & 29.2 & Other & 4.5 & NWFP & Educ & & \\
\hline $\begin{array}{l}\text { Other } \\
\text { sv }\end{array}$ & $\begin{array}{l}17.9 \\
9.4\end{array}$ & Relief \& Repatria & 17.2 & NWFP & Eme & & 0. \\
\hline UNHCR & 10.6 & & & & & & \\
\hline WFP & 2.1 & & & & & & \\
\hline
\end{tabular}

Sub Offices

\begin{tabular}{|c|c|c|c|c|c|}
\hline Sub Office & City / Town & Phone & Fax & E-mail & In Charge \\
\hline $\begin{array}{l}\text { DSP Office House } 39 \mathrm{St} .5 \mathrm{~F}-8 / 3 \\
\text { Islamabad }\end{array}$ & Islamabad & 221304 & & $\begin{array}{l}\text { durablesolutionsproject } \\
\text { ohotmail.com }\end{array}$ & Sania Ijj Mazza \\
\hline $\begin{array}{l}\text { NWFP.House } 13 \text { SJ Afghani Road } \\
\text { University Town }\end{array}$ & Peshawar & 851576 & & kazim@pefo.irc-pk.org & Heng Djin Tjik \\
\hline $\begin{array}{l}\text { House } 46 \text { Sector } 10 \text { KDA Housing } \\
\text { Scheme Kohat }\end{array}$ & Kohat & 514886 & & $\begin{array}{l}\text { iremecl@pes.cansats.net. } \\
\text { pk }\end{array}$ & Dr.Tila \\
\hline
\end{tabular}


ISRA (Islamic Relief Agency)

\begin{tabular}{|c|c|c|c|}
\hline Membership & $\widehat{A C B A R}$ & Country of Affliliation & Sudan \\
\hline \begin{tabular}{|l} 
Address \\
\end{tabular} & Communication & Key Staff & Position \\
\hline \multirow{4}{*}{$\begin{array}{l}\text { Housc } 68-\mathrm{D} / 2 \text { S.J.Afghani Raod, } \\
\text { University Town, } \\
\text { Peshawar-Pakistan }\end{array}$} & $840365 / 844961$ & Jaffar Ah.Abdullah & Regional Director \\
\hline & 840429 & Ab.Aziz Abbakar & Country Director \\
\hline & 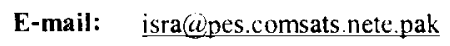 & Arbab Bashir Ahmad & Executive Director \\
\hline & Web: & & \\
\hline
\end{tabular}

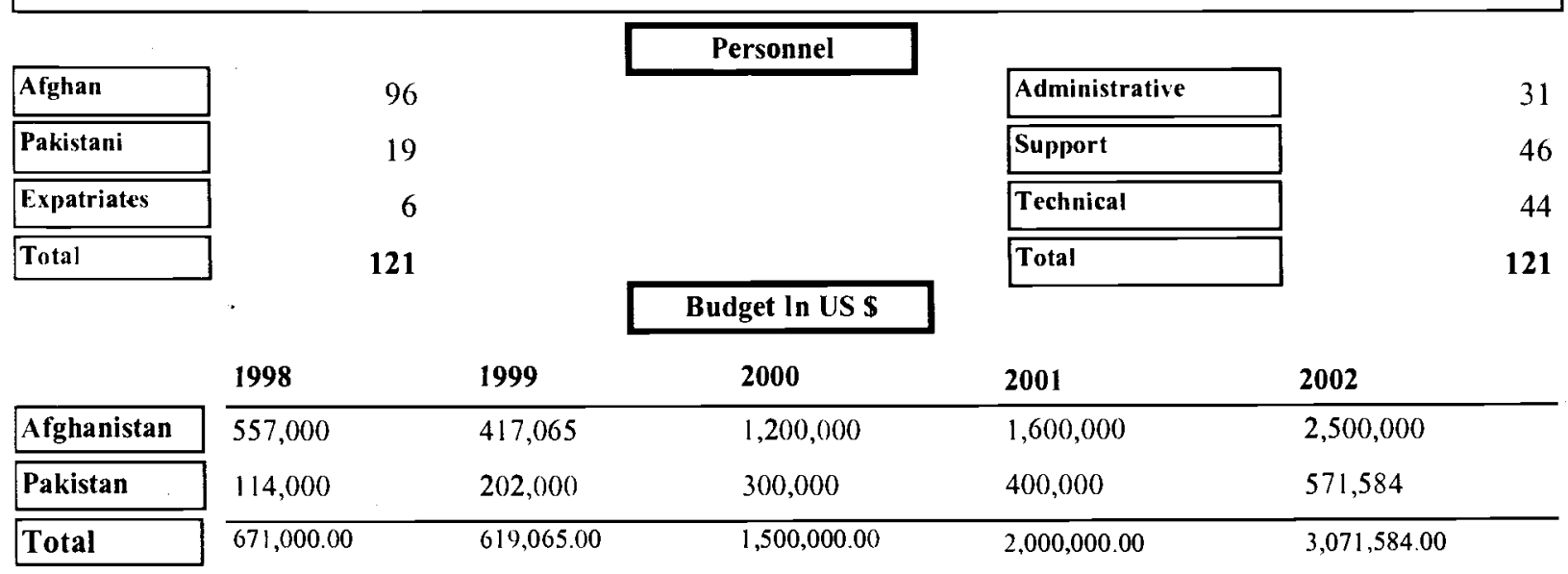

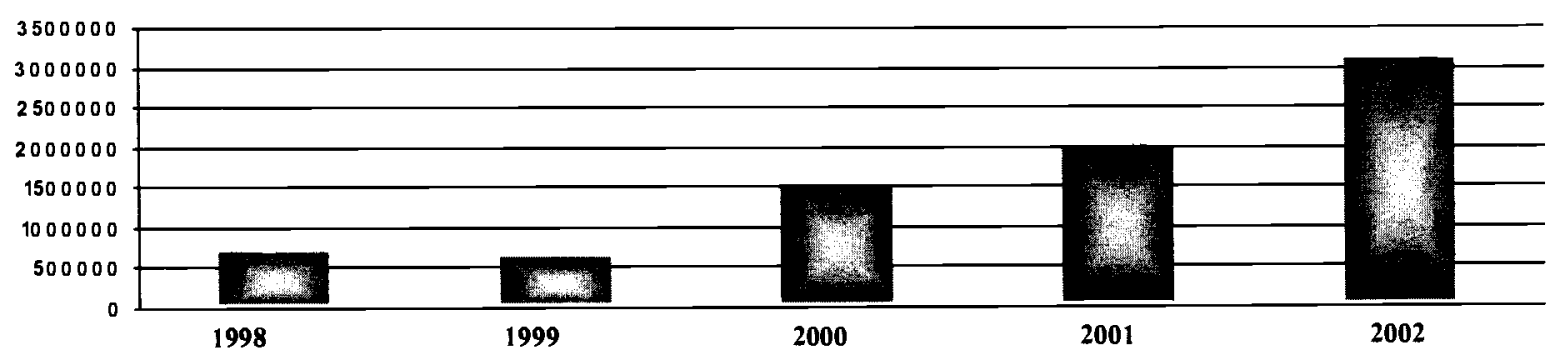

\begin{tabular}{|c|c|c|c|}
\hline \multicolumn{2}{|c|}{ Donors } & \multicolumn{2}{|c|}{ Allocation } \\
\hline Donors & $\%$ Funded & Allocation & $\%$ Funded \\
\hline FAO/UNDP & 20 & Agriculture & 20 \\
\hline GPM & 5 & Education & 15 \\
\hline ISRA Friendship & 10 & Emergency & 2 \\
\hline Office Donation & 40 & Health & 17 \\
\hline UNDCP & 0.5 & Infrastructure & 6 \\
\hline UNHCR & 10 & & \\
\hline UNICEF & 4 & Other & 1 \\
\hline WFP & 10 & Relief \& Repatria & 38 \\
\hline WHO & 0.5 & Water Resources & 1 \\
\hline
\end{tabular}

\begin{tabular}{lll} 
& \multicolumn{2}{c|}{ Targeted Provinces } \\
\cline { 2 - 3 } Province & Sector & \% Targeted \\
\hline Ghazni & Agriculture & 1 \\
Hirat & Relief \& Repatriatioin & 2 \\
Jawzjan & Health & 1 \\
Kabul & Agriculture & 13 \\
Kandahar & Agriculture & 1 \\
Kapisa & Agriculture & 1 \\
Kunar & Education & 10 \\
Kunduz & Other & 1 \\
L.aghman & Agriculture & 4 \\
Logar & Agriculture & 15 \\
Nangarhar & Agriculture & 23 \\
Nimroz & Relief \& Repatriatioin & 1 \\
Pakistan & Health & 14 \\
Paktika & Relief \& Repatriatioin & 1 \\
Paktika & Health & 3 \\
Parwan & Agriculture & 3 \\
Wardak & Agriculture & 6
\end{tabular}

Sub Offices 


\begin{tabular}{|c|c|c|c|c|}
\hline Sub Office & City / Town & Phone & E-mail & In Charge \\
\hline Kululapushta Street 81 louse 207 & Kabul & 070270583 & & A.Mutalib \\
\hline Kandahar Share-Now & Kandahar & 210530 & & ling. Nawaz \\
\hline Kunar $\Lambda$ sad $\wedge$ bad & Asadabad & & & S. Noora Jan \\
\hline $\begin{array}{l}\text { Nangarhar: Tube-well Raod } \\
\text { Chaparhar Adah } \\
\end{array}$ & Jalaiabad & +882108980076 & & Fadlalla Abdelgadir \\
\hline Khost ('ity Near Jama Masjid & Khost & & & Shahpur \\
\hline $\begin{array}{l}\text { I ogar.Baraki District Zaqam Khel } \\
\text { Village }\end{array}$ & Baraki & & & Janna Ancri \\
\hline $\begin{array}{l}\text { Hirat.Bagh Aradi Near to Qul-Urdo } \\
\text { Raod. }\end{array}$ & Hirat & & & Khashal \\
\hline
\end{tabular}

\section{JCCP (The Japan Center for Conflict Prevention)}

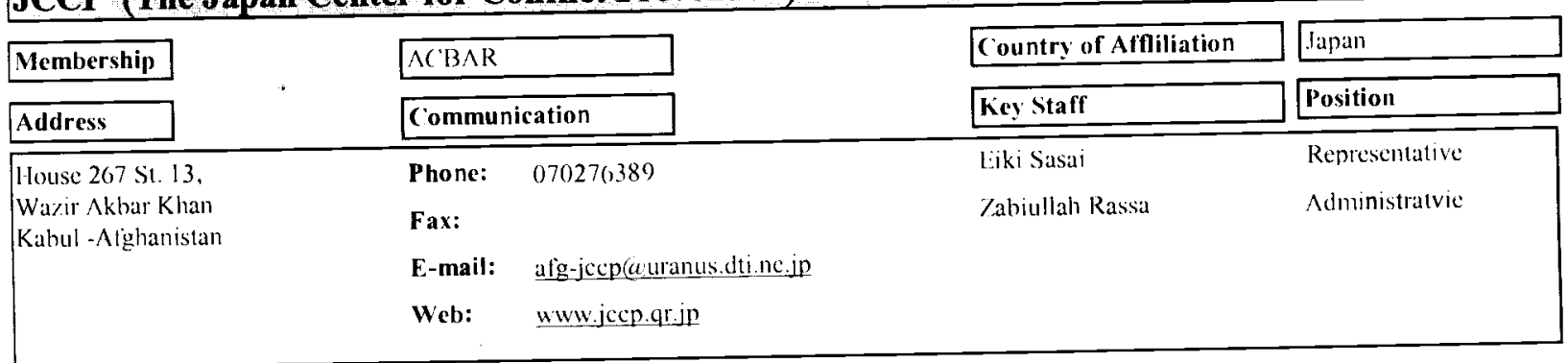

\begin{tabular}{|l|lll|}
\hline Afghan & 7 & Personnel & \\
\hline Pakistani & 0 & & \\
\hline Expatriates & 2 & & Administrative \\
\hline Total & 9 & & \\
\hline
\end{tabular}

Budget In US \$

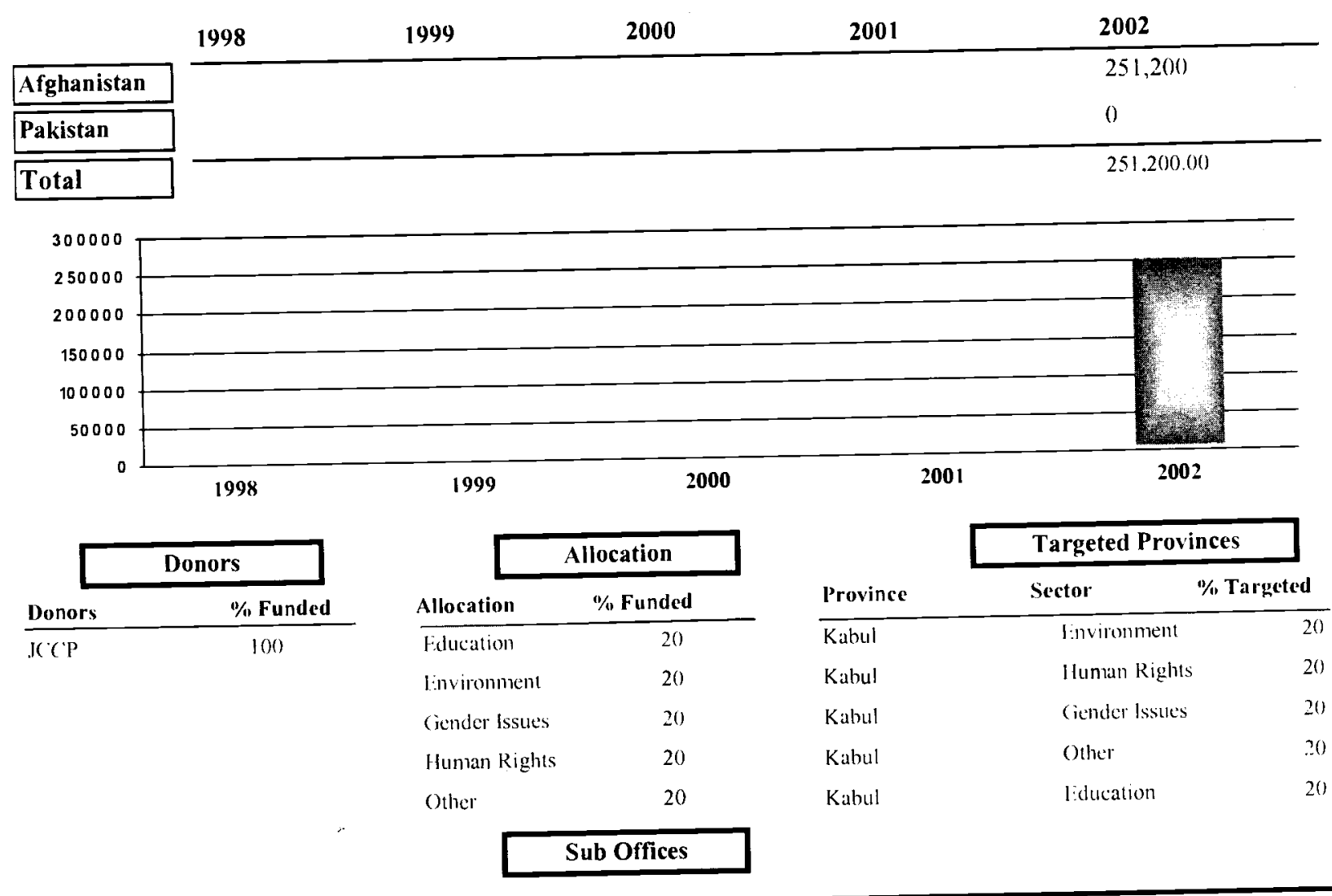


JEN (Japan Emergency NGOs)

\begin{tabular}{|c|c|c|c|}
\hline Membership & Other & Country of Affliliation & Afghanistan \\
\hline Address & Communication & Key Staff & Position \\
\hline \multirow{4}{*}{$\begin{array}{l}\text { Wazir Akbar Khan St.131. } \\
\text { Kabul-Afghanistan. }\end{array}$} & 2301188 & Aska Aoshima & Head ofJEN KBI. \\
\hline & +873762854657 & Nroiyuki Shina & Program Oflicer \\
\hline & Kabul@jen-npo.org & Mohd.Hassan & Senior Progran \\
\hline & www.jen-npo.org & & \\
\hline
\end{tabular}

\begin{tabular}{|l|}
\hline Afghan \\
\hline \hline Pakistani \\
\hline Expatriates \\
\hline Total \\
\hline
\end{tabular}

Personnel

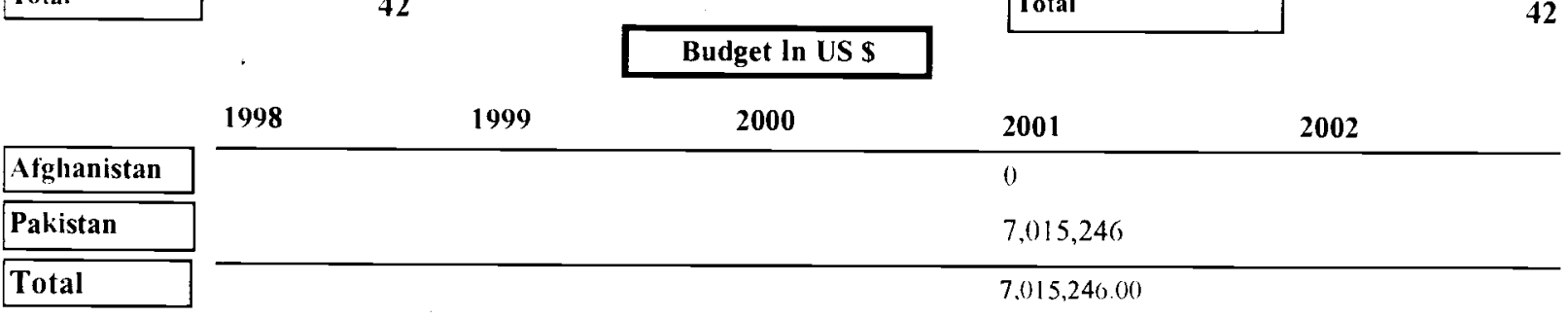

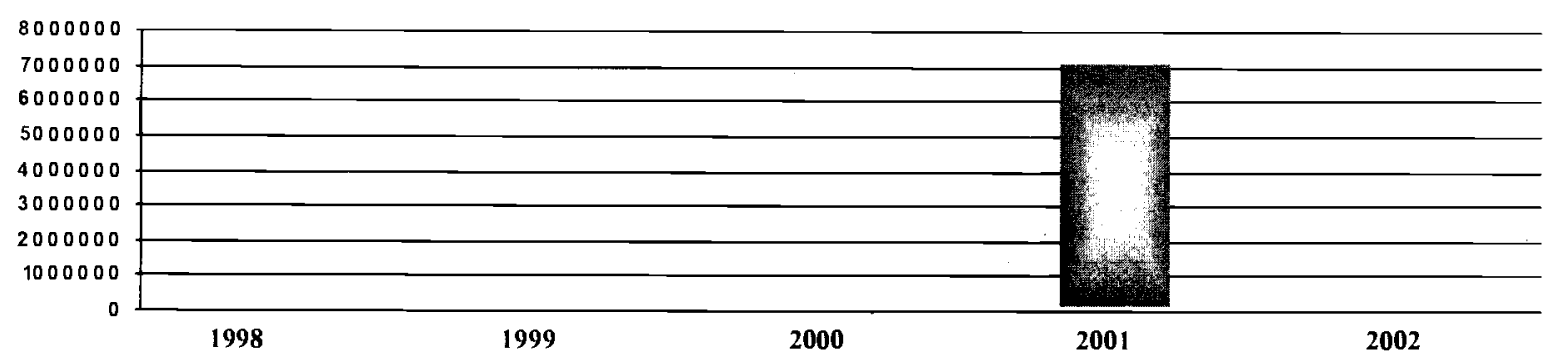

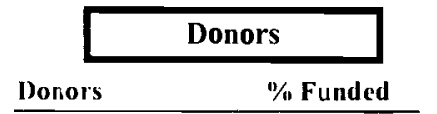

lapan Plat form

$\mathrm{Ml} \wedge \mathrm{A}$ of Japan

(INI)|P

IINIICR

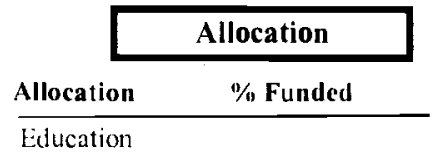

Emergency

Gender Issues

Ineome (ieneratio

\begin{tabular}{|l|}
\hline Administrative \\
\hline Support \\
\hline Technical \\
\hline Total \\
\hline
\end{tabular}

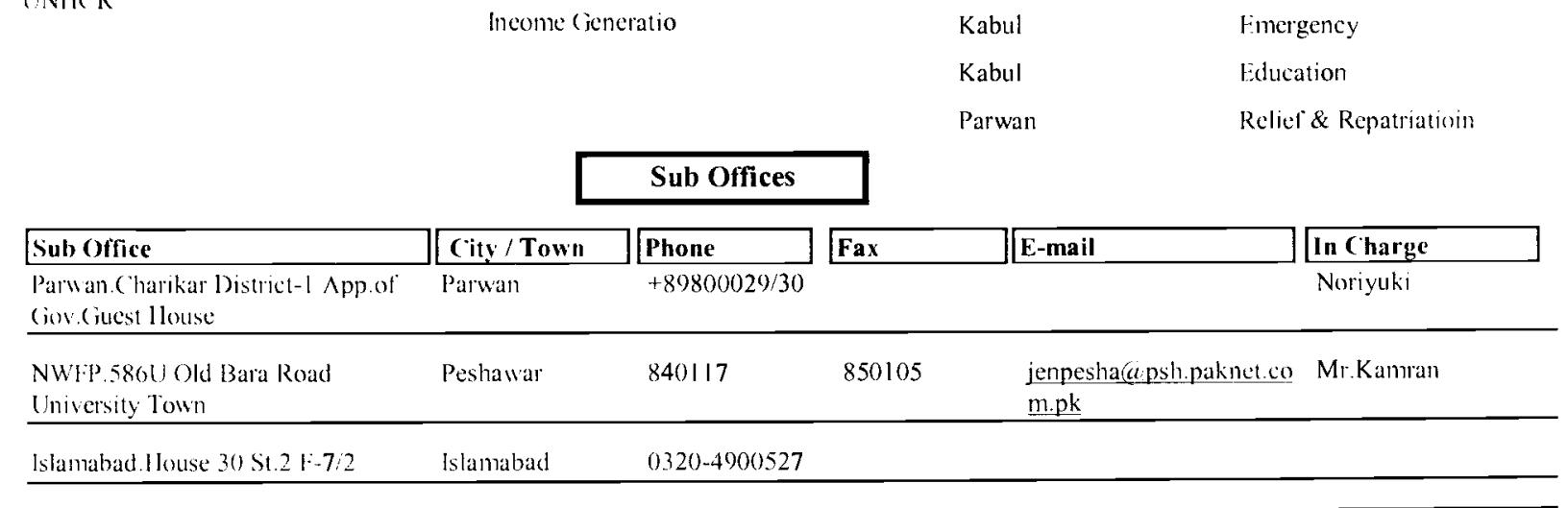

\begin{tabular}{|c|c|}
\hline Province & $\%$ Targeted \\
\hline Kabul & Education \\
\hline Kabul & lneonc Generation \\
\hline Kabul & Gender lssues \\
\hline Kabul & Fimergency \\
\hline Kabul & Education \\
\hline Parwan & Relicf \& Repatriatioin \\
\hline
\end{tabular}




\section{JFF (Japanese International Friendship \& Welfare Foundation)}

\begin{tabular}{|c|c|c|c|}
\hline Membership & & Country of Affliliation & Japan \\
\hline Address & Communication & Key Staff & Position \\
\hline \multirow{4}{*}{$\begin{array}{l}\text { House I Rchaman Baba Rd, } \\
\text { University Town, } \\
\text { Peshawar-Pakistan }\end{array}$} & Phone: & Akbar Ahmadyar & Director \\
\hline & Fax: & Akira Uncda & Coordinator \\
\hline & jiff@brain.net.pk & Mr. Zabiullah & Manager \\
\hline & Web: & & \\
\hline
\end{tabular}

\begin{tabular}{|l|}
\hline Afghan \\
\hline Pakistani \\
\hline \hline Expatriates \\
\hline Total \\
\hline
\end{tabular}

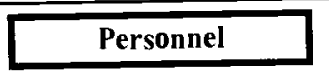

31

2

5

38

\begin{tabular}{|l|}
\hline Administrative \\
\hline Support \\
\hline Technical \\
\hline Total \\
\hline
\end{tabular}

Budget In US \$

\begin{tabular}{|c|c|c|c|c|c|}
\hline & 1998 & 1999 & 2000 & 2001 & 2002 \\
\hline Afghanistan & $\overline{0}$ & $\overline{0}$ & 0 & 0 & 0 \\
\hline Pakistan & 200,000 & 220,000 & 140,000 & 195,000 & 400,000 \\
\hline Total & $\overline{200,000.00}$ & $220,000.00$ & $140,000.00$ & $195,000.00$ & $400,000.00$ \\
\hline
\end{tabular}

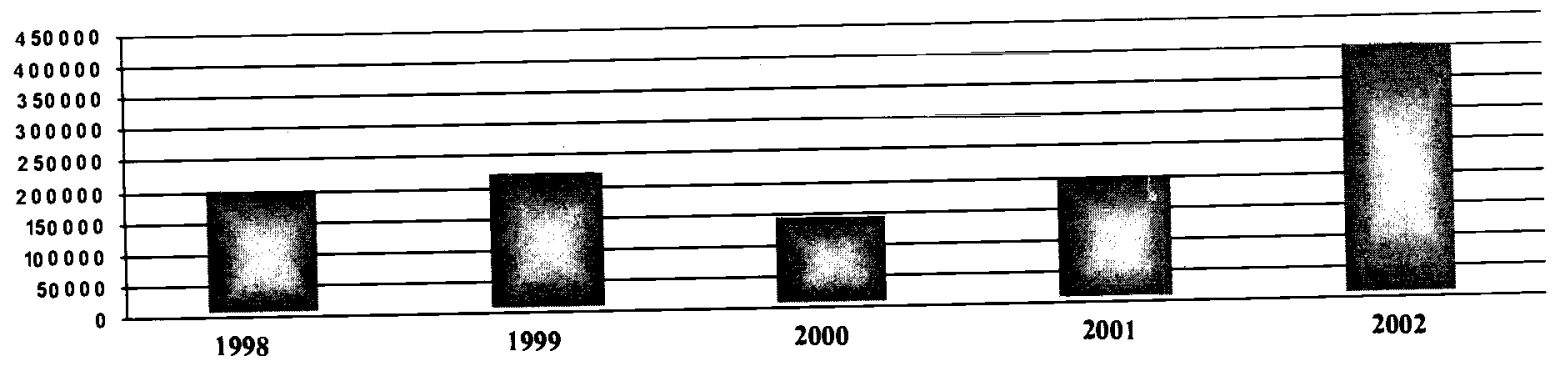

\begin{tabular}{|c|c|c|c|c|c|c|}
\hline \multicolumn{2}{|c|}{ Donors } & \multicolumn{2}{|c|}{ Allocation } & & \multicolumn{2}{|c|}{ Targeted Provinces } \\
\hline Donors & $1 \%$ Funded & Allocation & $\%$ Funded & Province & Sector & $\%$ Targeted \\
\hline Japan Govt. & 50 & Health & 100 & NWFP & Health & 10 \\
\hline JIFF Japan & 50 & & & & & \\
\hline
\end{tabular}

Sub Offices

\begin{tabular}{|c|c|c|c|c|c|}
\hline Sub Office & City / Town & \begin{tabular}{|l|} 
Phone \\
\end{tabular} & Fax & E-mail & In Charge \\
\hline $\begin{array}{l}\text { Kabul.House } 496 \text { Shora Street Kar- } \\
\text { te-Se }\end{array}$ & Kabul & 070276765 & & & Dr. Akbar \\
\hline
\end{tabular}




\section{JVC (Japan International Volunteer Center)}

\section{Membership \\ Address}

Nangarhar ( hashmi Khanji in Ward-1,

Jalalabad - $\Lambda$ fghanistan

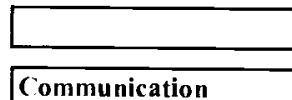

Communication

Phone: 0087376121347

Fax:

E-mail: $\quad$ t-hiro@wta.att.ne.jp

Web: $\quad$ wwwl.jca.apc.orj/juc

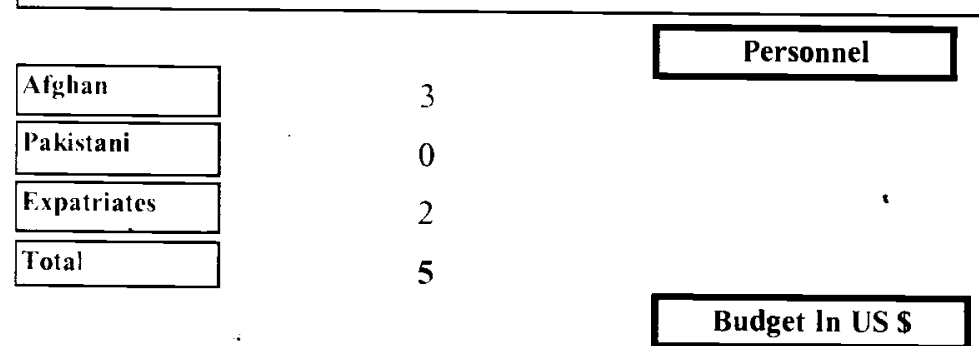

Country of Affliliation

\section{Key Staff}

Hiroshi Taniyama

Junko Uezumi

\begin{tabular}{|l|}
\hline Administrative \\
\hline Support \\
\hline Technical \\
\hline Total \\
\hline
\end{tabular}

Iapan

Position

Repersentotive

Medical Export

Budget In US S

2000

2001

2002

\begin{tabular}{lrr}
\hline Afghanistan & 2001 & 2002 \\
\hline Pakistan & 233,572 \\
\hline Total & 0 \\
\hline
\end{tabular}
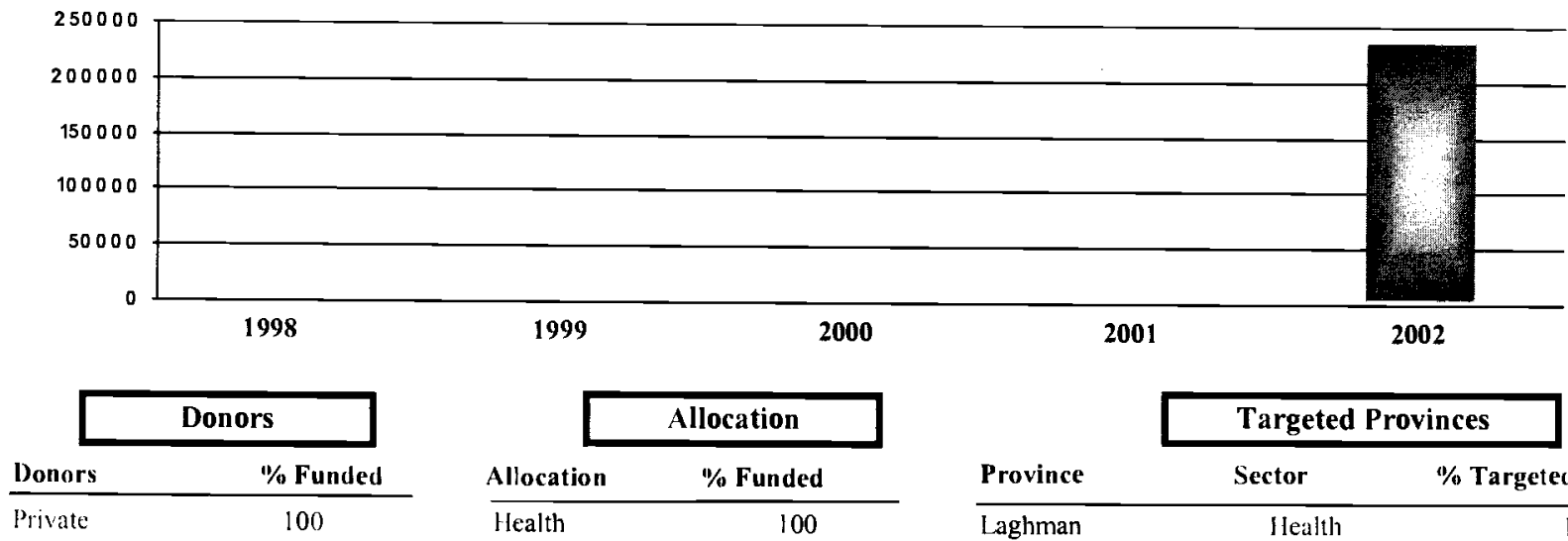
JWA (The Jacob's Well Appeal)

\begin{tabular}{|c|c|c|c|}
\hline Membership & Other & Country of Affliliation & $1: K$ \\
\hline Address & Communication & Key Staft & Position \\
\hline \multirow{4}{*}{$\begin{array}{l}\text { laimani Strect } 8 \text { C'lose to Aria } \\
\text { Clanic. } \\
\text { Kabul-Alghanistan }\end{array}$} & Phone: & Nasrin Ifomayoun & Drecetor \\
\hline & 2290243 & Fardinullah & ()flice Mangen \\
\hline & thejacobswcll(waol.com & Beryl Beyman & 1)mathen \\
\hline & Web: & & \\
\hline
\end{tabular}

\begin{tabular}{|l|}
\hline Ifghan \\
\hline Pakistani \\
\hline Expatriates \\
\hline
\end{tabular}

Personnel

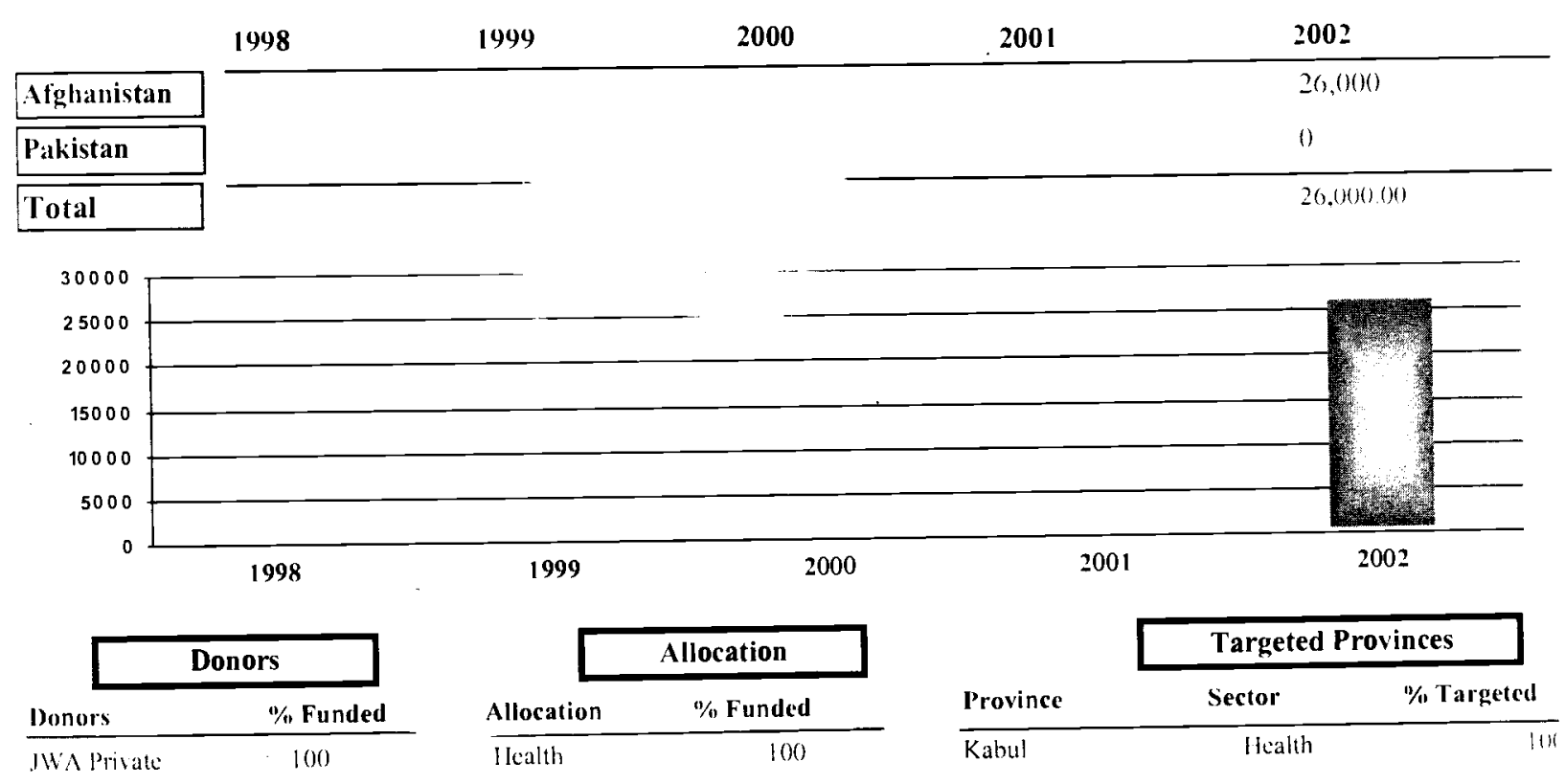


KCF (Khorasan CommunityForum)

\begin{tabular}{|c|c|c|c|}
\hline Nembership & otiner & Country of Affliliation & Afghanistan \\
\hline Address & Communication & Kcy Staff & Position \\
\hline \multirow{4}{*}{\begin{tabular}{|l} 
House 210 Street 11, \\
Tammani Dist 10, \\
Kalbul-Afghanistan
\end{tabular}} & Phone: & Ms.Samia & Manager \\
\hline & Fax: & & \\
\hline & E-mail: & & \\
\hline & Web: & & \\
\hline
\end{tabular}

\begin{tabular}{|l|}
\hline Johan \\
\hline Pakistani \\
\hline Expatriates \\
\hline Total \\
\hline
\end{tabular}

Personnel

\begin{tabular}{|l|}
\hline Adninistrative \\
\hline Support \\
\hline Technical \\
\hline Total \\
\hline
\end{tabular}

18

0)

()

18

Budget In US \$

\begin{tabular}{|c|c|c|c|c|c|}
\hline & 1998 & 1999 & 2000 & 2001 & 2002 \\
\hline Ifghanistan & & 9,900 & 0 & & \\
\hline Pakistan & & () & 9,900 & & \\
\hline Total & & 9.900 .00 & $9,900.00$ & & \\
\hline
\end{tabular}
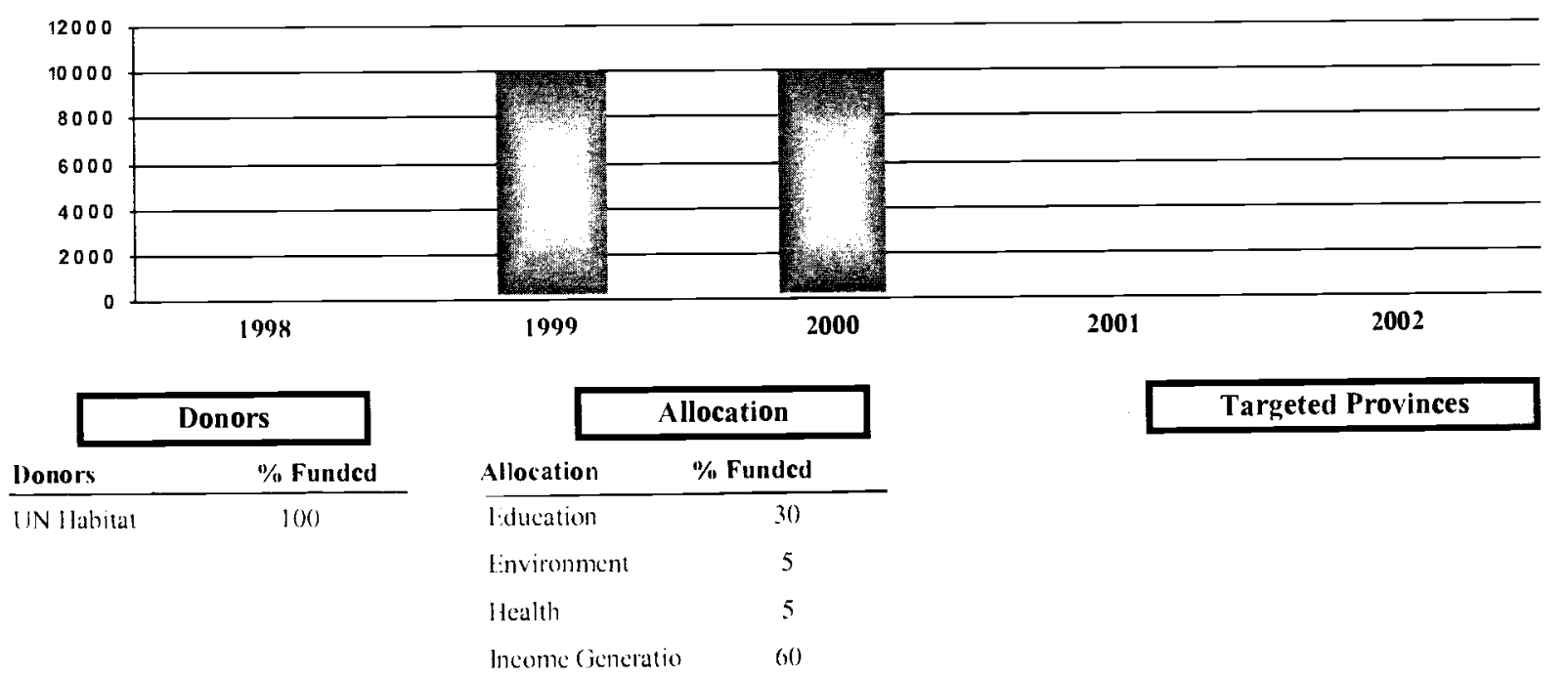

Sub Offices 


\section{KRDO (Khedmat Rehabilitation and Development Organization)}

\begin{tabular}{|c|c|c|c|}
\hline Membership & Other & Country of Affliliation & Afghanistan \\
\hline Address & Communication & Key Staff & Position \\
\hline \multirow{4}{*}{$\begin{array}{l}\text { Housc } 3 \text { Muslim Strect, } \\
\text { Shahr-e-Now, } \\
\text { Kabul-Afghanistan }\end{array}$} & 070275830 & Abdul Mateen & Director \\
\hline & Fax: & Ing. Waheed & Deputy Director \\
\hline & E-mail: & Badriya & Manager \\
\hline & Web: & & \\
\hline
\end{tabular}

\begin{tabular}{|c|c|c|c|c|}
\hline & & Personnel & & \\
\hline Afghan & 20 & & Administrative & 6 \\
\hline Pakistani & 0 & & Support & 4 \\
\hline Expatriates & 0 & & Technical & 10 \\
\hline Total & 20 & & Total & 20 \\
\hline
\end{tabular}

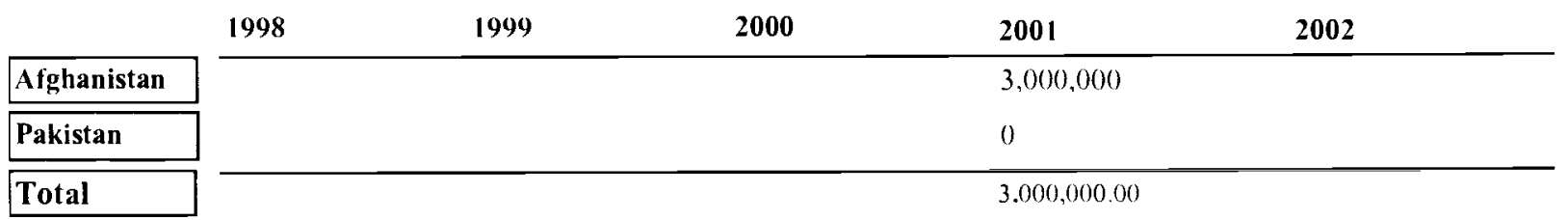

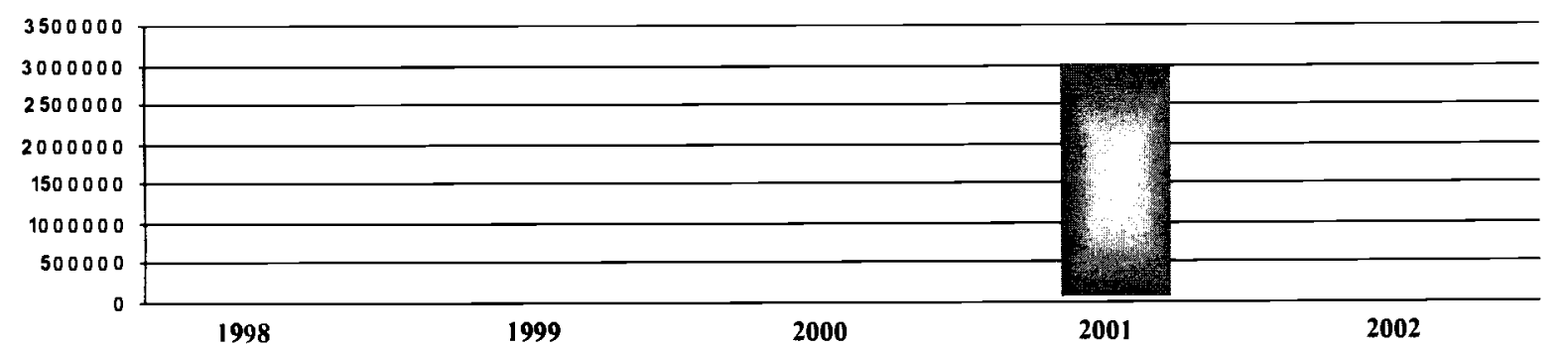

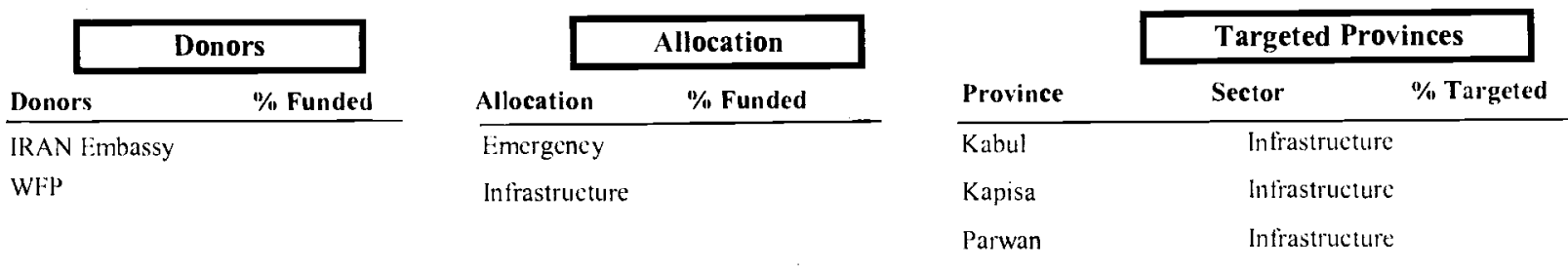

Sub Offices 


\section{LEPCO (Leprosy Control Organization)}

\begin{tabular}{|c|c|c|c|}
\hline Membership & AC BAN & Country of Affliliation & Germany \\
\hline Address & Communication & Key Staff & Position \\
\hline \multirow{4}{*}{$\begin{array}{l}\text { 35 FiB Khushal Khan Khattak Rd, } \\
\text { University Town, } \\
\text { Peshawar-Pakistan }\end{array}$} & 842764 & Thomas Koeing & Director \\
\hline & 842704 & Jawad Ahmadi & Program $\wedge$ dninstant \\
\hline & E-mail: lepeo@brain net.pk & Dr. Azizulla & $\mathrm{TB}+$ +.eprosy Coordmat \\
\hline & Web: & & \\
\hline
\end{tabular}

\begin{tabular}{|l|rr|r|}
\hline \multicolumn{1}{|c|}{} & \multicolumn{1}{|c|}{ Personnel } & \\
\cline { 1 - 1 } Afghan & 100 & Administrative & 7 \\
\hline Pakistani & 3 & Support & 53 \\
\hline Expatriates & 1 & Technical & 44 \\
\hline Total & 104 & Total & 104 \\
\hline
\end{tabular}

Budget In US \$

\begin{tabular}{|c|c|c|c|c|c|}
\hline & 1998 & 1999 & 2000 & 2001 & 2002 \\
\hline Afghanistan & 361,162 & 342,500 & 342.504 & 354,741 & 382,624 \\
\hline Pakistan & 0 & 0 & 0 & 0 & 0 \\
\hline Total & $361,102.00$ & $342,500.00$ & 342.504 .00 & $354,741.00$ & 382.024 .00 \\
\hline
\end{tabular}

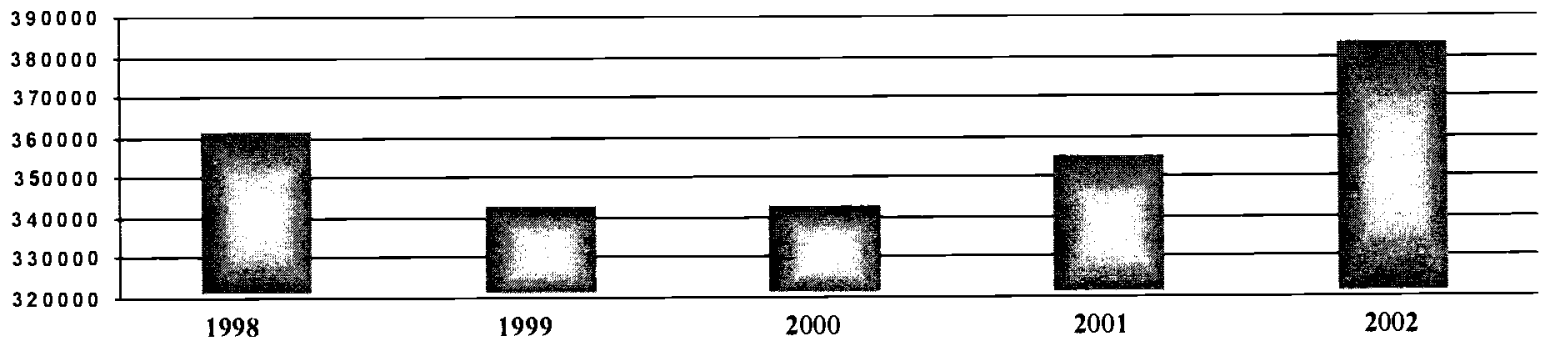

\begin{tabular}{lcccc}
\hline \multicolumn{2}{c|}{ Donors } & & & Allocation \\
Donors & \% Funded & & Allocation & $\%$ Funded \\
CRARITAS & 15 & & Health & 100 \\
(II.RA & 10 & & & \\
MISI:ROI:R & 75 & & &
\end{tabular}

\begin{tabular}{lc|}
\cline { 2 - 2 } & \multicolumn{2}{c|}{ Targeted Provinces } \\
\hline Province & Sector \\
\hline Balkh & Health Targeted \\
Bamyan & Hcalth \\
Ghazni & Itcalth \\
Ghor & I Icalth \\
Uruzgan & Ilealth \\
Wardak & Health
\end{tabular}

Sub Offices

\begin{tabular}{|c|c|c|c|c|c|}
\hline Sub Office & City / Town & Phone & Fax & E-mail & In Charge \\
\hline $\begin{array}{l}\text { Strect } 3 \text { Nowshad Project Dash-1- } \\
\text { Shore }\end{array}$ & Balkh & & & & Habiby \\
\hline
\end{tabular}


LKRO (Loy Kandahar Reconstruction Organization)

\begin{tabular}{|c|c|c|c|}
\hline Mernbership & Other & Country of Affiliation & Afghanistan \\
\hline Address & Communication & Key Staff & Position \\
\hline \multirow{4}{*}{$\begin{array}{l}\text { Kartai Mulimeen Dorahi, } \\
\text { Manzal bagh Strce 2, } \\
\text { Kandahar-Afghanistan }\end{array}$} & Phone: & А.Аziz Balakurzai & 1:xeculive Director \\
\hline & & Abdul Sattar & Deputy 1)irector \\
\hline & F-naail: & Ihsanullah thsan & Administrator \\
\hline & Web: & & \\
\hline
\end{tabular}

\begin{tabular}{|c|c|c|c|c|c|}
\hline & & & Personnel & & \\
\hline Afghan & \multicolumn{2}{|c|}{20} & & Adninistrative & 6 \\
\hline Pakistani & \multicolumn{2}{|c|}{0} & & Support & 9 \\
\hline Expatriates & \multicolumn{2}{|c|}{0} & & Technical & 5 \\
\hline \multirow[t]{3}{*}{ Total } & \multirow{2}{*}{\multicolumn{2}{|c|}{20}} & & Total & 20 \\
\hline & & & Budget In US \$ & & \\
\hline & 1998 & 1999 & 2000 & 2001 & 2002 \\
\hline Afghanistan & 3,937 & 5,300 & & 9,500 & 201,048 \\
\hline Pakistan & () & () & & () & 0 \\
\hline Total & $3,937.00$ & $5,300.00$ & & 9.500 .00 & $201,048.00$ \\
\hline
\end{tabular}

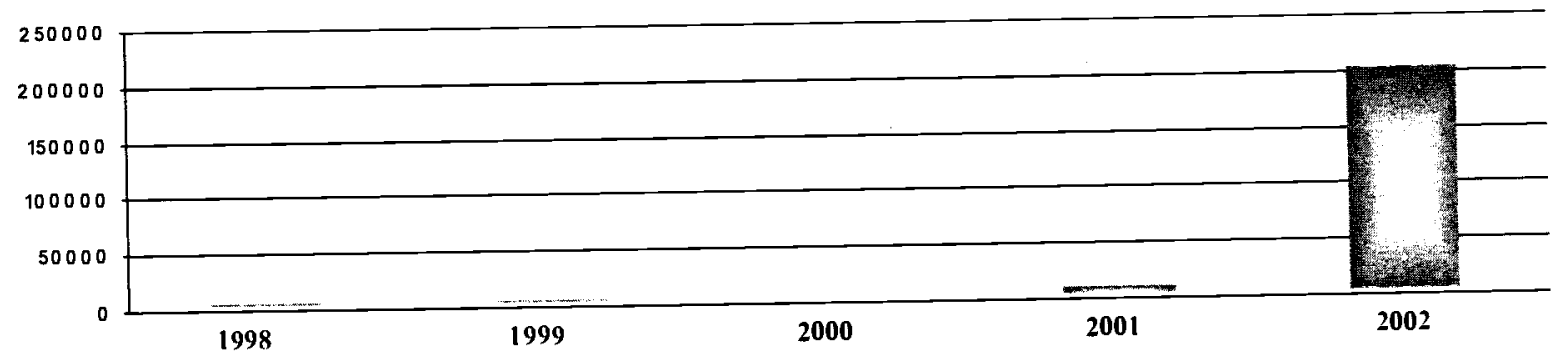

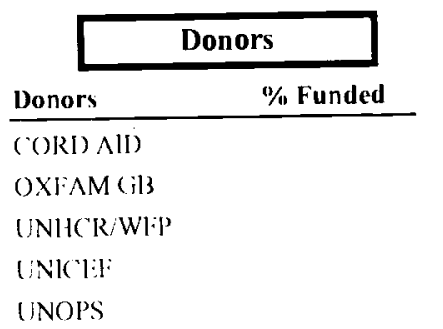

\begin{tabular}{|c|c|}
\hline & Targeted Provinces \\
\hline Province & $\%$ Targeted \\
\hline 1lilmand & Income (icheration \\
\hline flilmand & Water Resiurees \\
\hline Kandahar & (iender lssues \\
\hline Kandahar & Infiastrueture \\
\hline Kandahar & Ineome (iencration \\
\hline Kandahar & Water Resources \\
\hline liruggan & Infrastrueture \\
\hline Zabul & Ineome ciencration \\
\hline Zabul & Gender lssues \\
\hline
\end{tabular}

Sub Offices

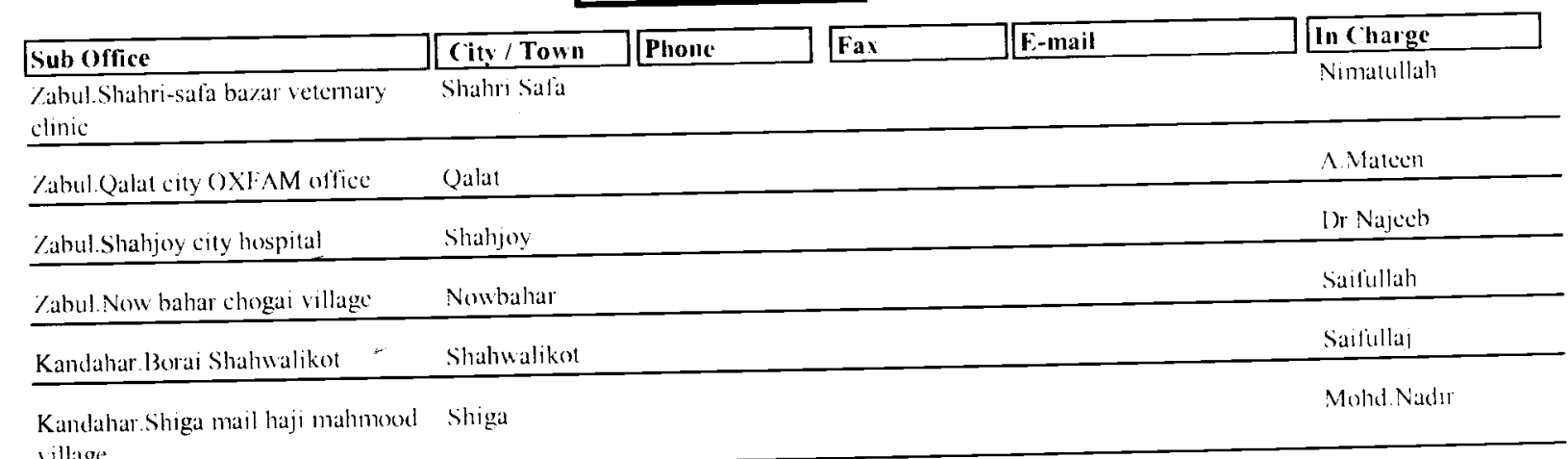

village 


\begin{tabular}{|c|c|c|c|}
\hline Uruzgan. Dehrawad bazar & Dehrawad & & Sattar Khan \\
\hline Hilmand.Lashkar Gah city & L_ashkar Gah & & Sahwali \\
\hline LROA (Lamar Rehal & tation Organ & & \\
\hline Membership & ANCB & Country of Affiliation & Afghanistan \\
\hline Address & Communication & Key Staff & Position \\
\hline \multirow{4}{*}{$\begin{array}{l}\text { Agriculture and Godam Sangai } \\
\text { Road, } \\
\text { Jalalabad - Afghanistan }\end{array}$} & Phone: & Gazi.M.Suffeer & Dirictor \\
\hline & Fax: & Dr. Emal Sherzai & Health \\
\hline & E-mail: & Safiullah & Adminstrator \\
\hline & Web: & & \\
\hline
\end{tabular}

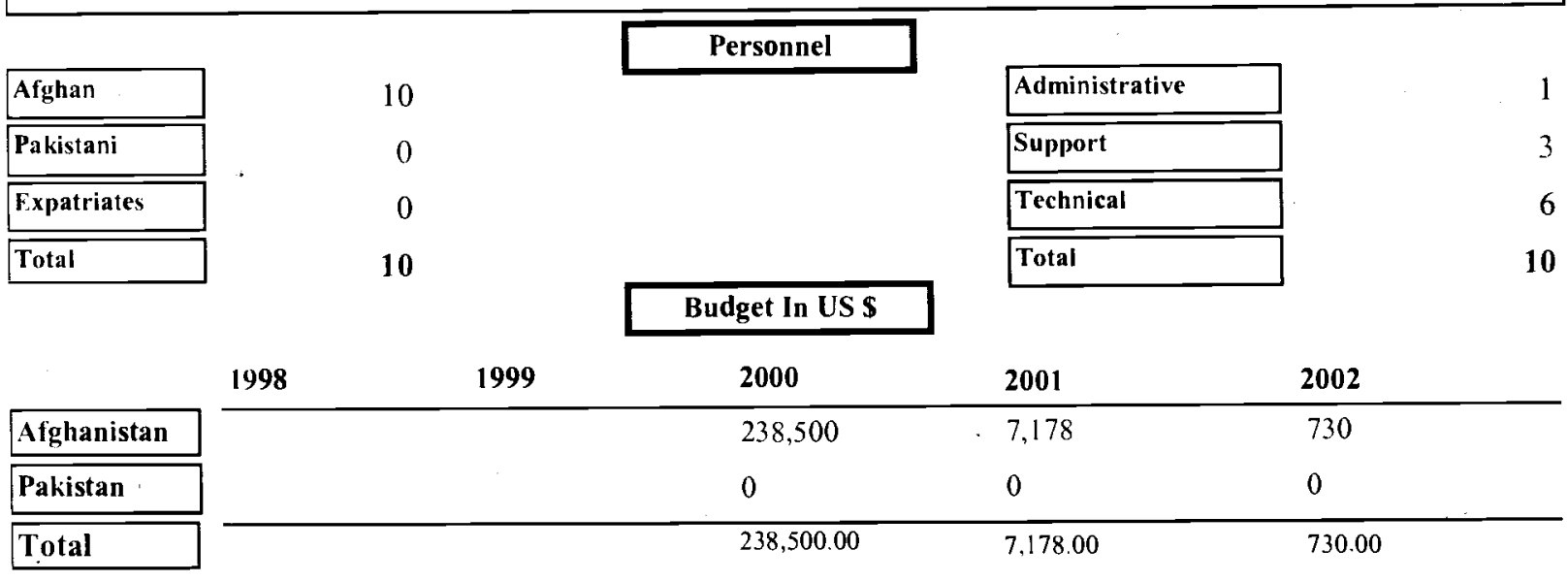

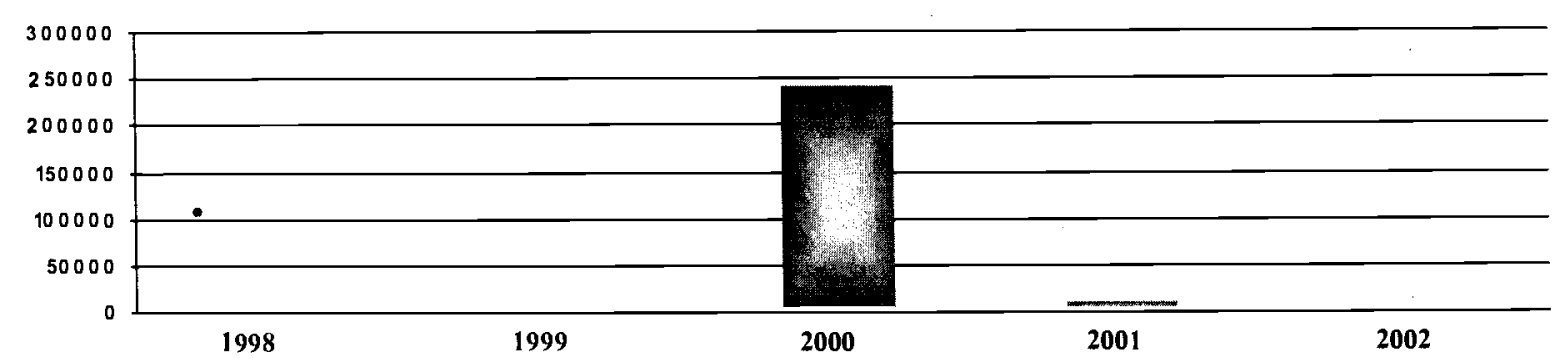

\begin{tabular}{|c|c|c|c|c|c|c|}
\hline \multicolumn{2}{|c|}{ Donors } & & llocation & \multirow[b]{2}{*}{ Province } & \multicolumn{2}{|c|}{ Targeted Provinces } \\
\hline Donors & $\%$ Funded & Allocation & $\%$ Funded & & Sector & $\%$ Targeted \\
\hline UNHC'R & 50 & Education & 20 & Balkh & Education & 10 \\
\hline UNICEF & 20 & Emergency & 30 & Kabul & Intrastructure & 50 \\
\hline \multirow[t]{3}{*}{ WFP } & 30) & Infrastructure & 50 & Kapisa & Education & 10 \\
\hline & & & & Logar & Infrastructure & 20 \\
\hline & & & & Nuristan & Infrastructure & 10 \\
\hline
\end{tabular}

\begin{tabular}{|c|c|c|c|c|c|}
\hline & & Sub Offices & & & \\
\hline Sub Office & City / Town & Phone & Fax & E-mail & In Charge \\
\hline Kabul. Charai Qala-e-Masa 2nd Floor & Kabul & & & & Zikrullah \\
\hline
\end{tabular}


MADERA (Mission d'aide au Developpement Economicies Rurales en Afghanistan)

\begin{tabular}{|c|c|c|c|}
\hline \begin{tabular}{|l|} 
Membership \\
\end{tabular} & ACBAR & Country of Affiliation & France \\
\hline Address & Communication & Key Staff & Position \\
\hline \multirow{4}{*}{$\begin{array}{l}\text { Sahat-e-Ama Crossroad, } \\
\text { Opp.Sahat Ama Hospital, } \\
\text { Jalalabad - Afghanistan }\end{array}$} & +873763011082 & Mecheline Baussard & Directeur Des Prog. \\
\hline & Fax: & Esmatullah Saifi & Directeur adjoint \\
\hline & madjalal@inmarsat.francetelecom.fr & Jamshed Sultani & DirectcurAdjoint \\
\hline & Web: & & \\
\hline
\end{tabular}

\begin{tabular}{|l|}
\hline Afghan \\
\hline Pakistani \\
\hline Expatriates \\
\hline Total \\
\hline
\end{tabular}

\section{Personnel}

\begin{tabular}{|l|}
\hline Administrative \\
\hline Support \\
\hline Technical \\
\hline Total \\
\hline
\end{tabular}
8

242

Budget In US \$

\begin{tabular}{|c|c|c|c|c|c|}
\hline & 1998 & 1999 & 2000 & 2001 & 2002 \\
\hline Afghanistan & $3,303,089$ & $2,208,849$ & $3,443,904$ & $3,653,945$ & $6,067,693$ \\
\hline Pakistan & () & 0 & 0 & 0 & () \\
\hline Total & $3,303,089.00$ & $2,208,849.00$ & $3,443,904.00$ & $3,053,945.00$ & 0.067 .093 .00 \\
\hline
\end{tabular}

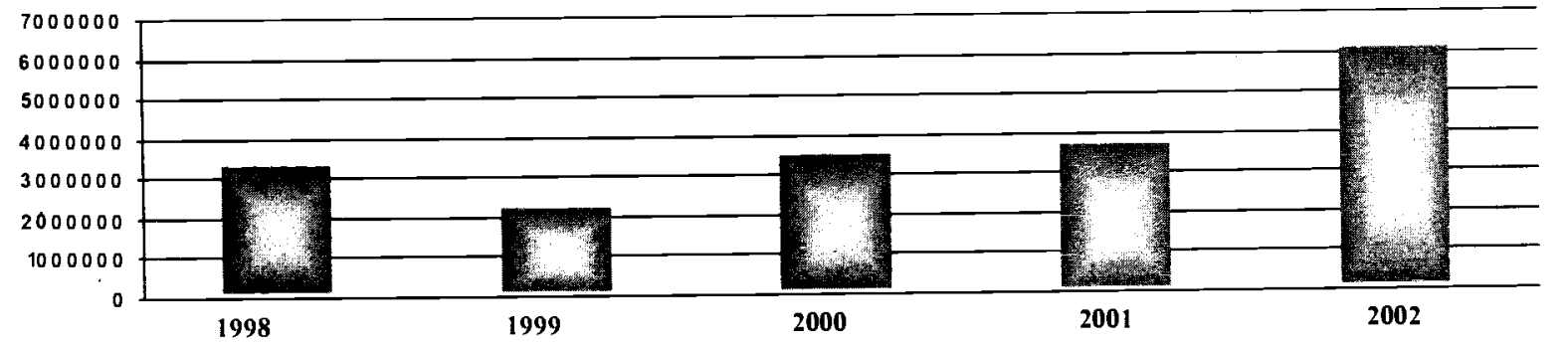

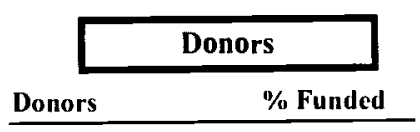

Caritas

$\mathrm{FCHO}$

EU

FAO

French Govt.

UNHCR

UNOGHA

WFP

\begin{tabular}{lc|}
\hline \multicolumn{1}{c|}{ Allocation } \\
Allocation & \% Funded \\
\hline Agriculture & 8 \\
Emergency & 43 \\
Invironment & 2 \\
Income Generatio & 7 \\
Infrastructure & 32 \\
Veterinary & 8
\end{tabular}

\begin{tabular}{lll} 
& \multicolumn{2}{c|}{ Targeted Provinces } \\
\cline { 2 - 3 } Province & Sector & \% Targeted \\
\hline Ghor & Imergency & 10 \\
Ghor & Veterinary & 1.1 \\
Gihor & Other & 1.0 \\
Ghor & Infrastructure & 14 \\
Ghor & Agriculture & 1.2 \\
Kabul & linvironment & 3.3 \\
Kunar & Infrastructure & 12. \\
Kunar & Agriculture & 2.4 \\
Kunar & Invironment & 0.1 \\
Kunar & Other & 2.1 \\
Kunar & Veterinary & 3.1 \\
l.aghman & Other & 1.4 \\
I.aghman & Infrastructure & 1.8 \\
I.aghman & Agriculture & 2.11 \\
I.aghman & Veterinary & 3.5 \\
Nangarhar & Agriculture & 2.4 \\
Nangarhar & Other & 2.4 \\
Nangarhar & Intrastructure & 3.3 \\
Wardak & Emergency & 11. \\
Wardak & Infrastructure & 13. \\
& &
\end{tabular}


Sub Offices

\begin{tabular}{|c|c|c|c|c|c|}
\hline Sub Otfice & City/Town & Phone & Fax & E-mail & In Charge \\
\hline Qala-e-Fateullah Sarak 4 House 471 & Kabul & 070281869 & & $\begin{array}{l}\text { kabul@inmarsat fiancelt } \\
\text { elecom.fr }\end{array}$ & E.Saifi \\
\hline $\begin{array}{l}\text { I3aghe } \Lambda \text { zadi Street Behind } \\
\text { ('aravanserai } \wedge \text { ta }\end{array}$ & Hirat & 220426 & & $\begin{array}{l}\text { madghor@inmarsat.fran } \\
\text { cetelecom.ir }\end{array}$ & Satar Salim \\
\hline $\begin{array}{l}\text { NWIP.4I)-Park Avenue University } \\
\text { Twon }\end{array}$ & Peshawar & 842237 & 840234 & madera@brain.net.pk & Legrande Marie \\
\hline Wardak.Behsud I & Wardak & & & & R. Mehdiyar \\
\hline
\end{tabular}

MALTESER (Malteser Foreign Aid Department)

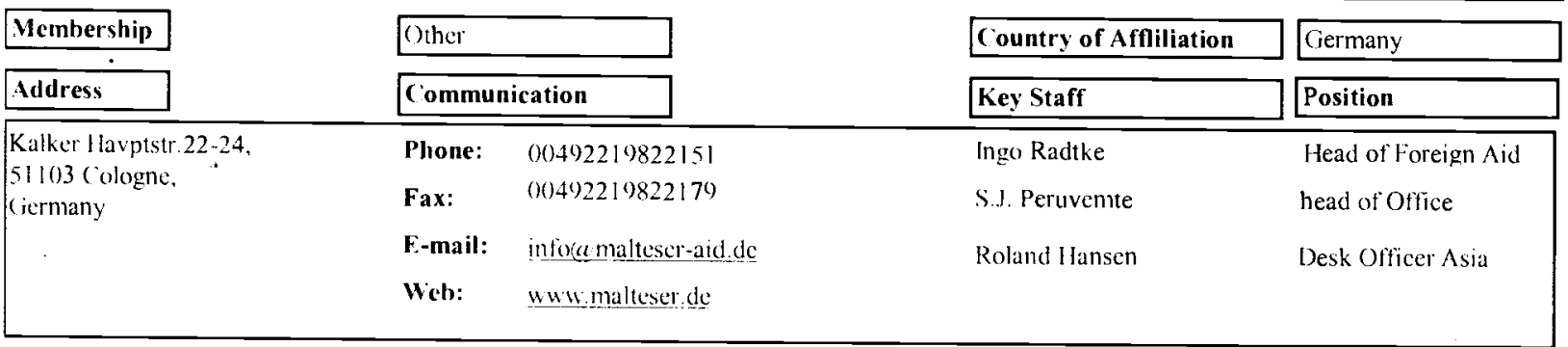

\begin{tabular}{|l|r|}
\hline Afghan & 10 \\
\hline \hline Pakistani & 0 \\
\hline Expatriates & 1 \\
\hline Total & 11 \\
\hline
\end{tabular}

Personnel

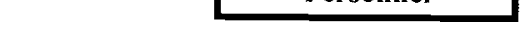

0

11

Budget In US \$

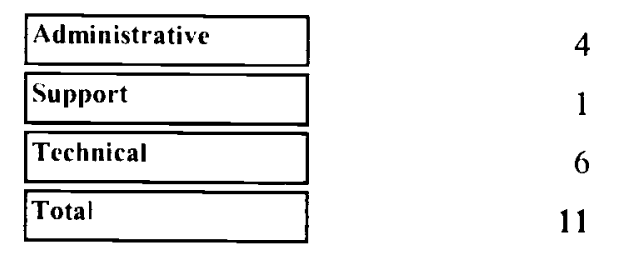

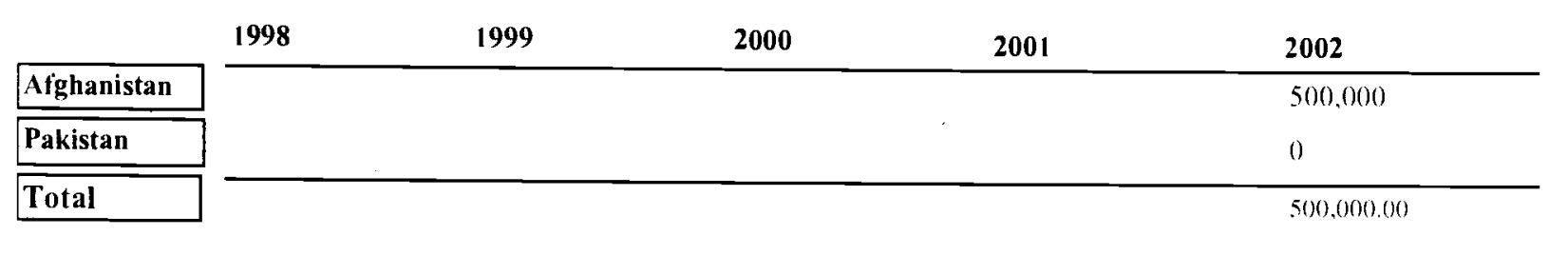

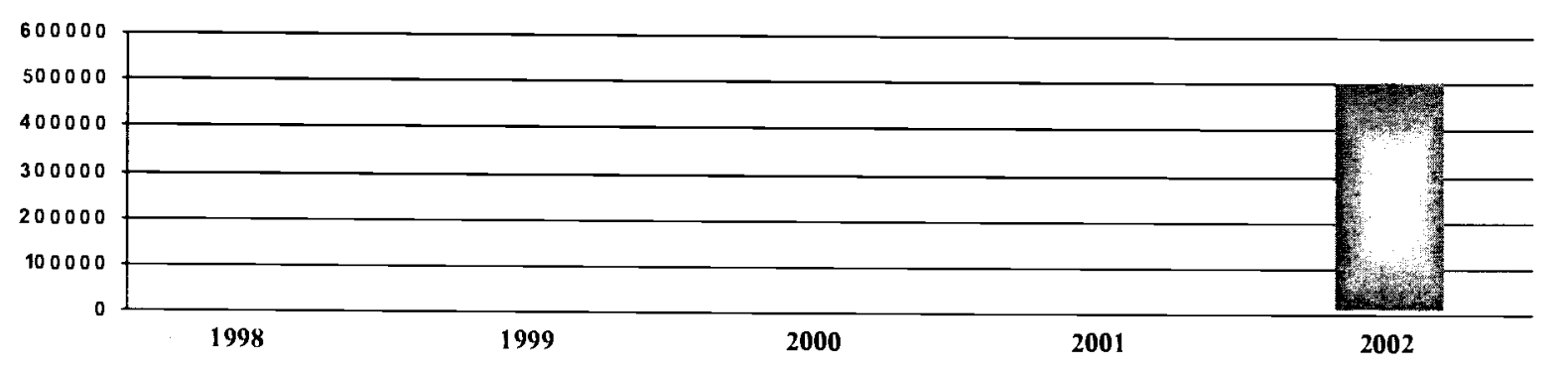

\begin{tabular}{|c|c|c|c|c|c|c|}
\hline \multicolumn{2}{|c|}{ Donors } & \multicolumn{2}{|c|}{ Allocation } & \multirow[b]{2}{*}{ Province } & \multicolumn{2}{|c|}{ Targeted Provinces } \\
\hline Donors & $\%$ Funded & Allocation & $\%$ Funded & & Sector & $\%$ Targeted \\
\hline (jerman $\mathrm{MoF} \wedge$ & 80 & Education & 20 & Badghis & Education & $x$ \\
\hline Own Funds & 20 & Health & 80 & Hirat & Health & in \\
\hline
\end{tabular}

\begin{tabular}{|c|c|c|c|c|}
\hline & & Sub Offices & & \\
\hline Sub Office & City / Town & Phone & E-mail & In Charge \\
\hline Badghis. Hospital Road & Badghis & +873761633270 & $\begin{array}{l}\text { mhd-badghsi@oles- } \\
\text { raisting de }\end{array}$ & Dr.Bcirkle \\
\hline ('heckpost 1 Shah Mohd. Khan St. & Hirat & 225823 & $\begin{array}{l}\text { mhd-herat }(a) \text { les- } \\
\text { rastingde }\end{array}$ & Ute Kirch \\
\hline
\end{tabular}




\section{MAS (Masod Construction Corporation)}

\begin{tabular}{|c|c|c|c|}
\hline Membership & Other & Country of Affliliation & Afghanistan \\
\hline Address & Communication & Key Staff & Position \\
\hline \multirow{4}{*}{$\begin{array}{l}\text { Mazar City Ariana Markate, } \\
\text { Mazar-Afghanistan }\end{array}$} & Phone: & Eng Shar Ali & Incharge \\
\hline & Fax: & Habiburahman & Admin \\
\hline & E-mail: & Dost Mohammad & Supervisor \\
\hline & Web: & & \\
\hline
\end{tabular}

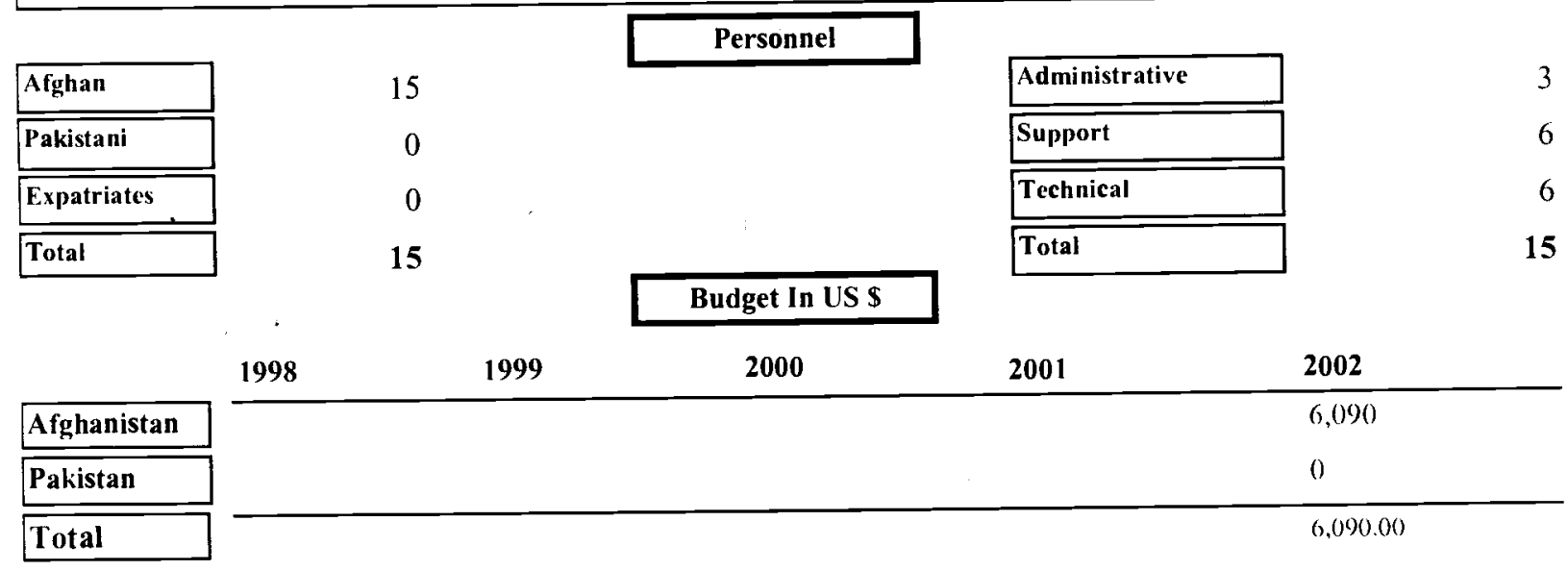

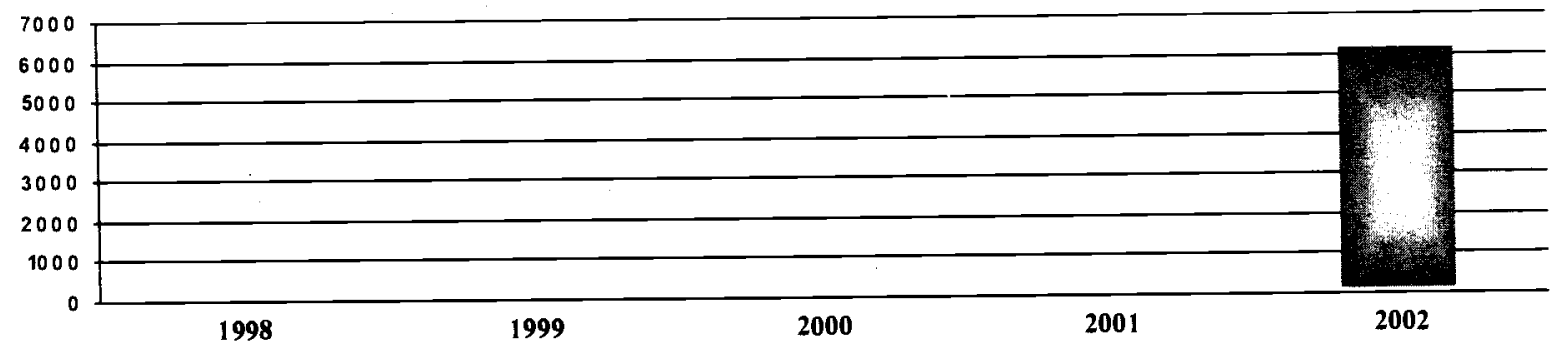

\begin{tabular}{|c|c|c|c|c|c|c|}
\hline \multicolumn{2}{|c|}{ Donors } & . & location & \multirow[b]{2}{*}{ Province } & \multicolumn{2}{|c|}{ Targeted Provinces } \\
\hline Donors & $\%$ Funded & Allocation & $\%$ Funded & & Sector & $\%$ Targeted \\
\hline \multirow[t]{2}{*}{ (jOAL } & 100 & Education & 100 & Balkh & Education & 50 \\
\hline & & & & Samangan & liducation & 50 \\
\hline
\end{tabular}

Sub Offices 


\section{MASHA (Multi-ethnic Afghan School and Humnaitarian Assistance)}

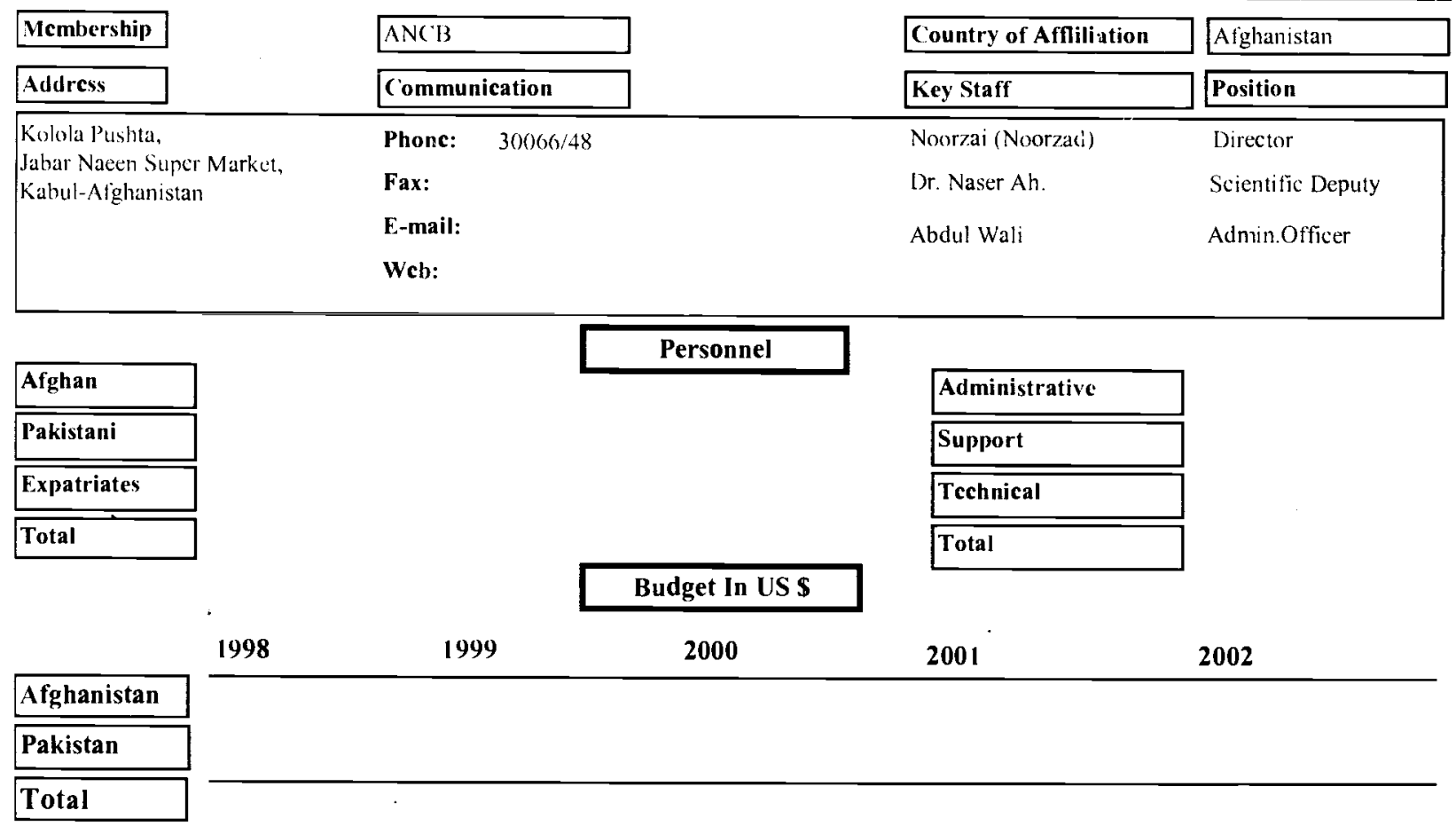

1998

Donors

1999

\begin{tabular}{lc|}
\hline & Allocation \\
\hline Allocation & $\%$ Funded \\
\hline Education & 30 \\
Emergency & 10 \\
Income Generatio & 30 \\
Infrastructure & 30
\end{tabular}

2001

2002

\begin{tabular}{lcr|}
\cline { 2 - 3 } & \multicolumn{2}{c|}{ Targeted Provinces } \\
\hline Province & Sector & $\%$ Targeted \\
\hline Ghazni & Emergency & 10 \\
Ghazni & Intrastructure & 30 \\
Kabul & Education & 30 \\
Kabul & Income Ceneration & 30
\end{tabular}

Sub Offices

\begin{tabular}{|c|c|c|c|c|c|}
\hline Sub Office & City / Town & Phone & Fax & E-mail & In C'harge \\
\hline
\end{tabular}




\section{MBR (Mawlanai Balkd Reliab round)}

\begin{tabular}{|c|c|c|c|}
\hline Membership & & Country of Affliliation & Afghanistan \\
\hline Address & Communication & Key Staff & Position \\
\hline \multirow{4}{*}{$\begin{array}{l}\text { Gozari Darbar, } \\
\text { Maraz-Afghanistan }\end{array}$} & Phone: $\quad 40192$ & M. Sharif & Chief \\
\hline & Fax: & M. Asif & Assistant \\
\hline & E-mail: & M.Asil & Site Engineer \\
\hline & Web: & & \\
\hline
\end{tabular}

\begin{tabular}{|l|}
\hline Afghan \\
\hline Pakistani \\
\hline Expatriates \\
\hline Total \\
\hline
\end{tabular}

Personnel

\begin{tabular}{|l|}
\hline Administrative \\
\hline Support \\
\hline Tgchnical \\
\hline Total \\
\hline
\end{tabular}

Budget In US \$

\begin{tabular}{|c|c|c|c|c|c|}
\hline & 1998 & 1999 & 2000 & 2001 & 2002 \\
\hline Afghanistan & & & & & 727,162 \\
\hline Pakistan & & & & & 0 \\
\hline Total & & & & & $727,162.00$ \\
\hline \multicolumn{6}{|l|}{800000} \\
\hline \multicolumn{6}{|l|}{700000} \\
\hline \multicolumn{6}{|l|}{600000} \\
\hline \multicolumn{6}{|l|}{500000} \\
\hline \multicolumn{6}{|l|}{400000} \\
\hline \multicolumn{6}{|l|}{300000} \\
\hline \multicolumn{6}{|l|}{200000} \\
\hline \multicolumn{6}{|l|}{100000} \\
\hline 0 & 1998 & 1999 & 2000 & 2001 & 2002 \\
\hline \multicolumn{2}{|c|}{ Donors } & & location & & Targeted Provinces \\
\hline Donors & $\%$ Funded & Allocation & $\%$ Funded & Province & $\%$ Targeted \\
\hline \multirow[t]{2}{*}{ WFP } & 100 & Intrastructure & 70 & Balkh & Relief \& Repatriatioin \\
\hline & & Relief \& Repatria & 30 & Balkh & Infrastructure \\
\hline
\end{tabular}

\section{Sub Offices}




\section{MCPA (Mine Clearance Plane Agency)}

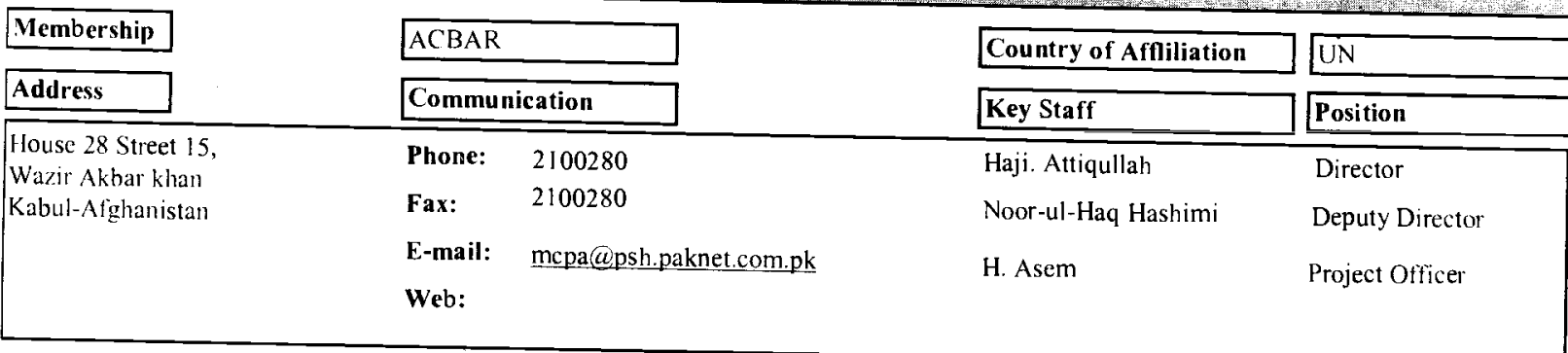

\begin{tabular}{l} 
Afghan \\
\hline Pakistani \\
\hline Expatriates \\
\hline Total \\
\hline
\end{tabular}

Personnel

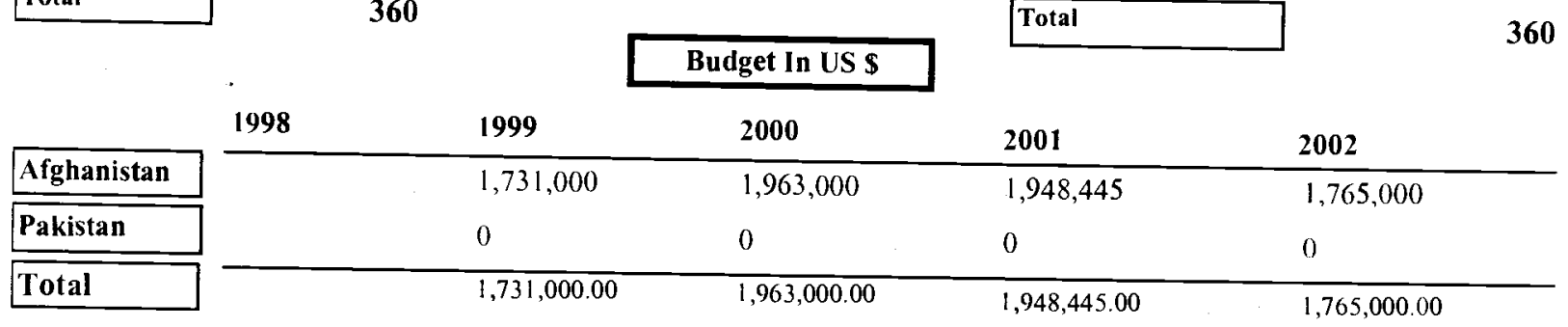

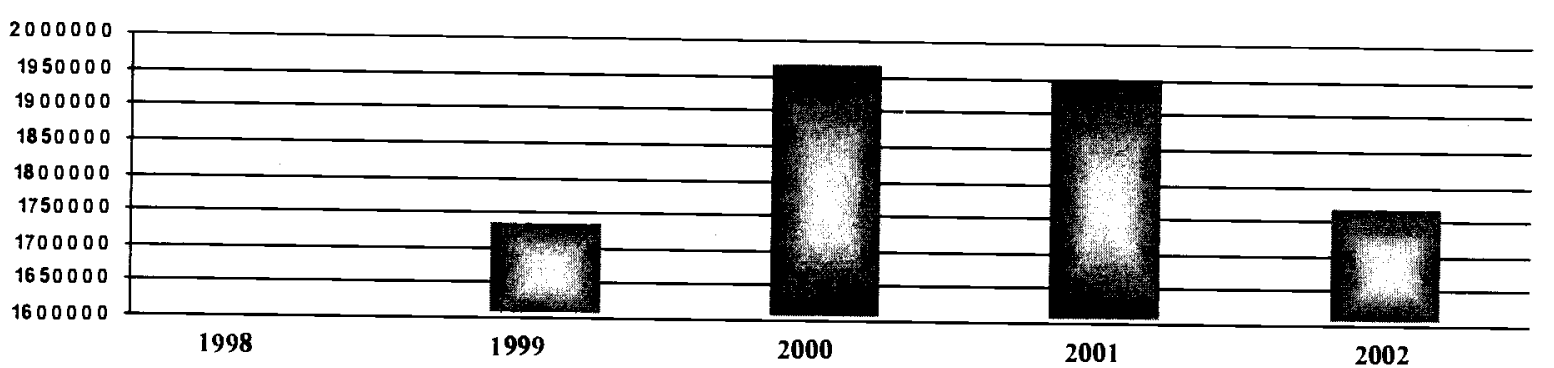

\begin{tabular}{|c|c|c|c|c|c|c|}
\hline \multicolumn{2}{|c|}{ Donors } & & llocation & \multirow[b]{2}{*}{ Province } & \multicolumn{2}{|c|}{ Targeted Provinces } \\
\hline Donors & $1 / \%$ Funded & Allocation & \% Funded & & Sector & $\%$ Targeted \\
\hline UN & 100 & Mines & 100 & All Provinces & Mine & \\
\hline
\end{tabular}

\section{Sub Offices}

\begin{tabular}{|c|c|c|c|c|}
\hline Sub Office & City / Town & Phone & E-mail & In Charge \\
\hline $\begin{array}{l}\text { Kabul.House } 140 \text { St. } 10 \text { Wazir Akbar } \\
\text { Khan }\end{array}$ & Kabul & 21737 & & S.M. Hashimi \\
\hline Jadeh Kaj Baglichai Hirat city & Hirat & & & Mullah John \\
\hline $\begin{array}{l}\text { Hirat Main Road Shar-e-Now Ward } \\
6\end{array}$ & Kandahar & +9340224234 & & Zabiullah \\
\hline $\begin{array}{l}\text { Nangarhar. Pashtonistan ('hawk } \\
\text { Near UNAMA }\end{array}$ & Jalalabad & & & Eng. Hakrim \\
\hline $\begin{array}{l}\text { NWFP.House } 58 / \mathrm{H} 2 \text {, Phase } 2 \text {, } \\
\text { Hayatabad }\end{array}$ & Peshawar & $810194 / 810803$ & 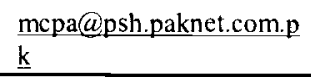 & M. Kabir \\
\hline
\end{tabular}




\section{MOC Mine Detection Dog Center)}

\begin{tabular}{|c|c|c|c|}
\hline Membership & ACBAR & Country of Affliliation & Afghanistan \\
\hline Address & Communication & Key Staff & Position \\
\hline \multirow{4}{*}{$\begin{array}{l}1 \text { louse 27/ Street } 14 . \\
\text { Wazir Akbar Khan, } \\
\text { Kabul-Afghanistan }\end{array}$} & 2301201 & Shohab Hakimi & Director \\
\hline & Fax: & Mohamad Arif & Deputy Director \\
\hline & E-mail: $\quad$ mde@brain.net.pk & Enayatullah & Chicf $\wedge \mathrm{dmin}$ \\
\hline & Web: & & \\
\hline
\end{tabular}

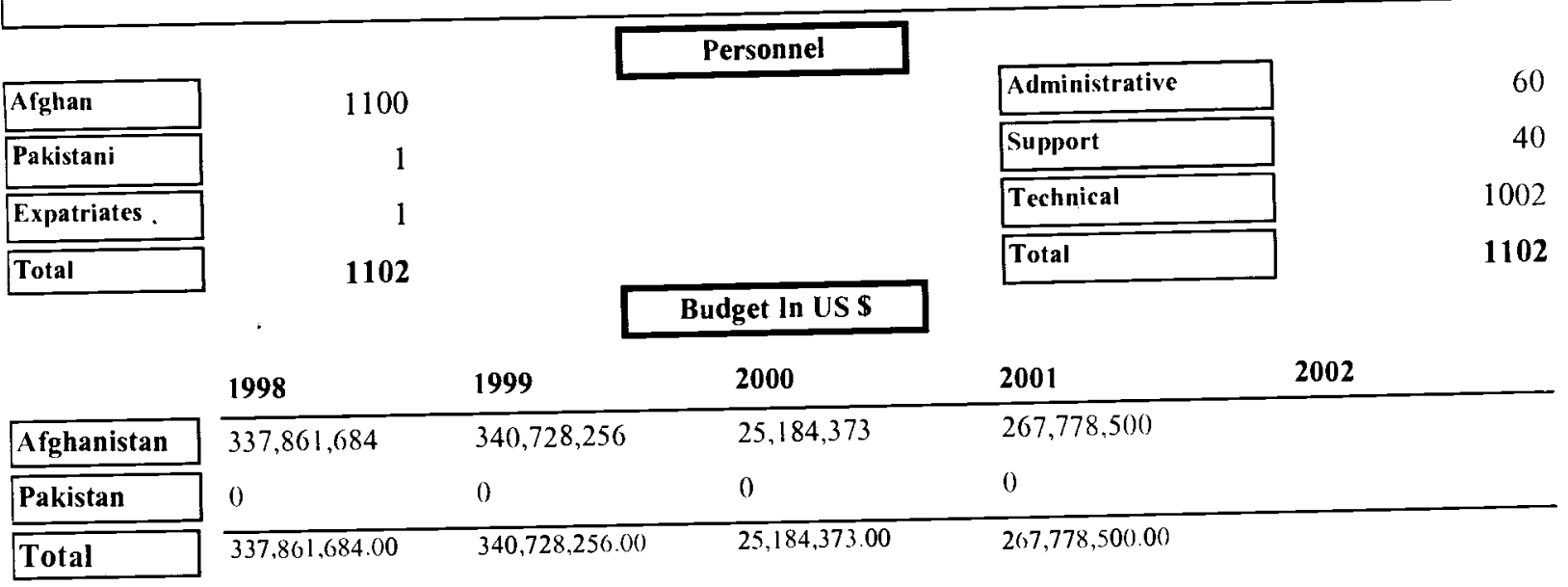

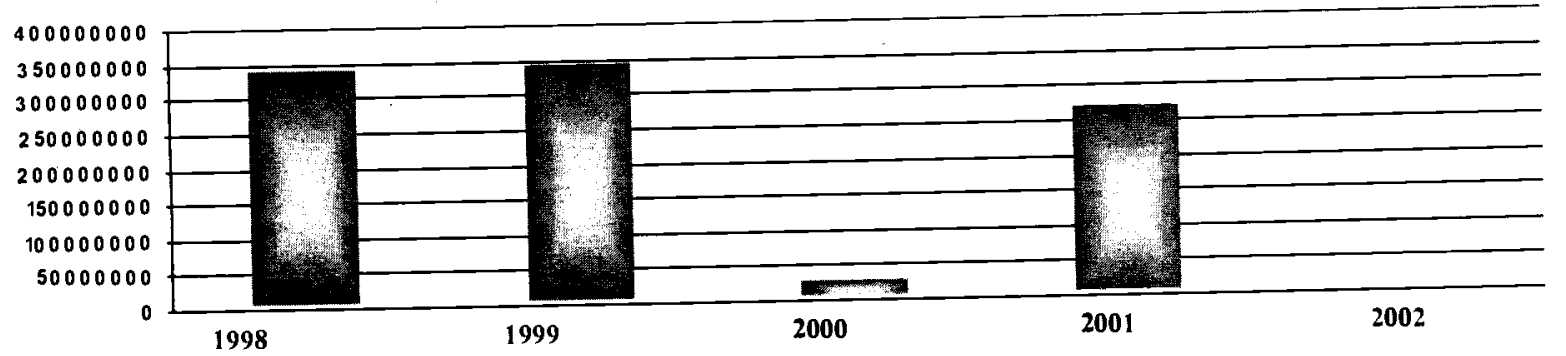

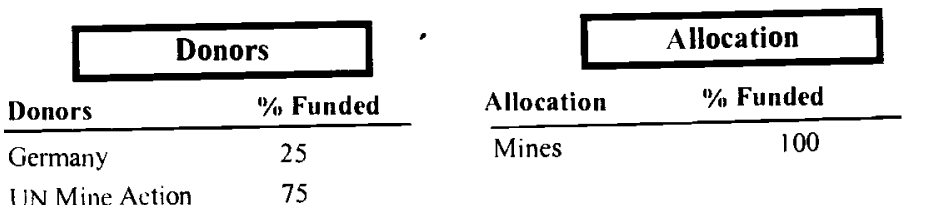

\begin{tabular}{lc|} 
& \multicolumn{2}{c|}{ Targeted Provinces } \\
\cline { 2 - 2 } Province & Sector \\
\hline Badakhshan & Mines \\
Badghis & Mines \\
Baghlan & Mines \\
Balkh & Mines \\
Bamyan & Mines \\
Farah & Mines \\
Faryab & Mines \\
Ghazni & Mines \\
Gihor & Mincs \\
Hilmand & Mines \\
Hirat & Mines \\
Kabul & Mines \\
Kandahar & Mines \\
Kapisa & Mines \\
Khost & Mines \\
Kunar & Mincs \\
Kunduz & Mines \\
l.aghman & Mines \\
E.ogar & Mines \\
Nangarhar & Mincs \\
\hline
\end{tabular}




$\begin{array}{ll}\text { Nimroz } & \text { Mines } \\ \text { Paktika } & \text { Mines } \\ \text { Paktika } & \text { Mines } \\ \text { Parwan } & \text { Mines } \\ \text { Takhar } & \text { Mines } \\ \text { Zabul } & \text { Mines }\end{array}$

Sub Offices

\begin{tabular}{|c|c|c|c|c|c|}
\hline Sub Office & City / Town & Phone & Fax & E-mail & In Charge \\
\hline Kabul. Karti Seeh & Kabul & & & & Ab. Wadord \\
\hline $\begin{array}{l}\text { Bagh Murad lntersection Main Qoul } \\
\text { Ardo Raod }\end{array}$ & Hirat & & & & Heknatullah \\
\hline Mazar Sharif City & Balkh & & & & Mohd Nadir \\
\hline $\begin{array}{l}\text { Kandahar:(jrisshk Bus station, } \\
\text { Kandahar ('ity } \\
\text { I }\end{array}$ & Grisshk & & & & Faqir Mohd. \\
\hline Nangarhar.Kama Bus Station & Jalalabad & & & & Ab.Qayum \\
\hline $\begin{array}{l}\text { NWIP. House 17L: Main Abdra } \\
\text { Road Town }\end{array}$ & Pcshawar & 510007 & 842684 & mdc(abrain.net.pk & Abdul Malik \\
\hline $\begin{array}{l}\text { Kabul.Tape Marang Ian Chaman } \\
\text { Itozori }\end{array}$ & Kabul & 210182 & & & Jawid $A h$. \\
\hline
\end{tabular}




\begin{tabular}{|c|c|c|c|c|}
\hline Membership & & & Country of Affliliation & France \\
\hline Address & \multicolumn{2}{|c|}{ Communication } & Key Staff & Position \\
\hline \multirow{4}{*}{$\begin{array}{l}\text { Kolola Pushta Main Street, } \\
\text { Near Estgah-e- Borj-e-Barq, } \\
\text { Kabul-Atghanistan }\end{array}$} & Phone: & 070282412 & Dr.Sayed & Medical Coordinator \\
\hline & & 00873762094174 & Mr. Hakim & Administrator \\
\hline & E-mail: & mdm59@inmarsat.france.telecon.fr & Eng.labar & C'oordinator \\
\hline & Web: & & & \\
\hline
\end{tabular}

\begin{tabular}{|c|c|c|c|c|c|c|}
\hline & & & Personnel & & & \\
\hline Afghan & \multicolumn{2}{|c|}{304} & & Administrative & & 11 \\
\hline Pakistani & \multicolumn{2}{|c|}{0} & & Support & & 81 \\
\hline Expatriates & \multicolumn{2}{|c|}{14} & & Technical & & 226 \\
\hline \multirow[t]{3}{*}{ Total } & & & & Total & & 318 \\
\hline & & & Budget In US S & & & \\
\hline & 1998 & 1999 & 2000 & 2001 & \multicolumn{2}{|l|}{2002} \\
\hline Afghanistan & & & & $1,000,000$ & \multicolumn{2}{|l|}{$2,000,000$} \\
\hline Pakistan & & & & 0 & \multicolumn{2}{|l|}{0} \\
\hline Total & & & & $1,000.000 .00$ & $2.000,000.00$ & \\
\hline
\end{tabular}

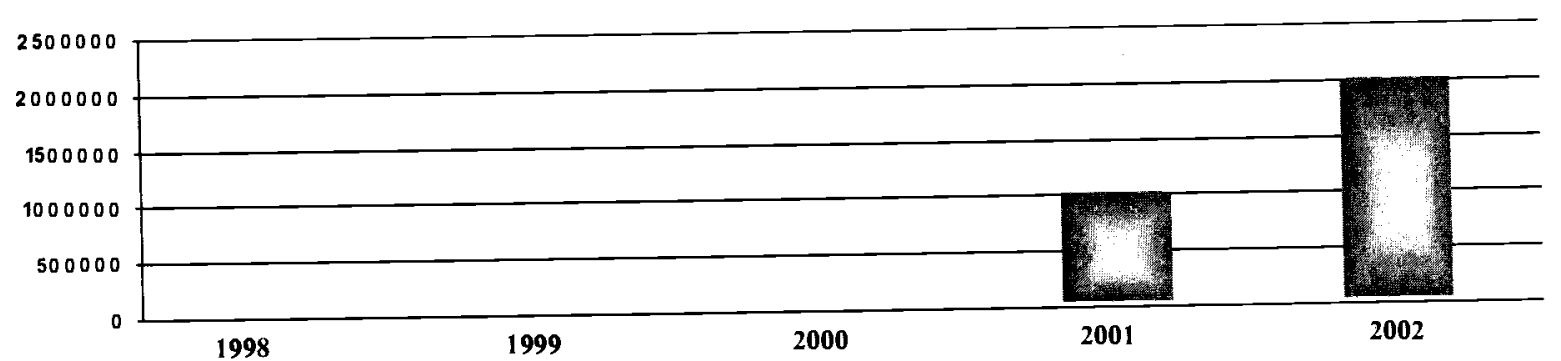

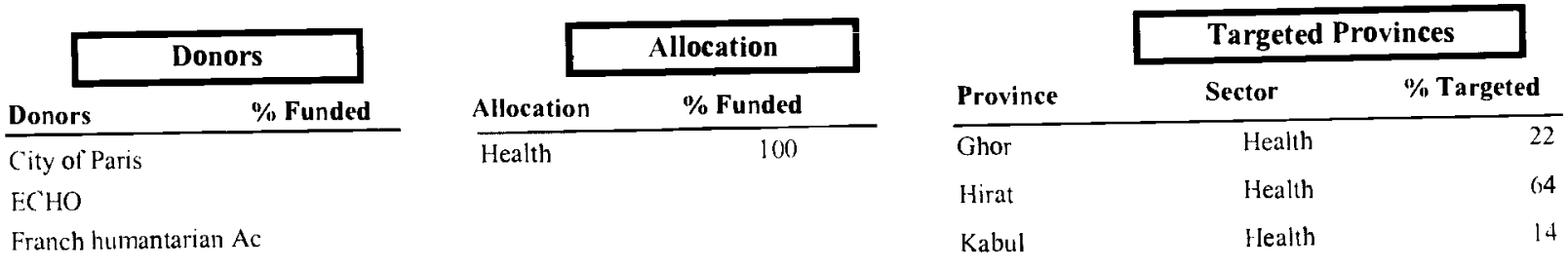

MDM funds

SDC-Swiss Agency for

Sub Offices

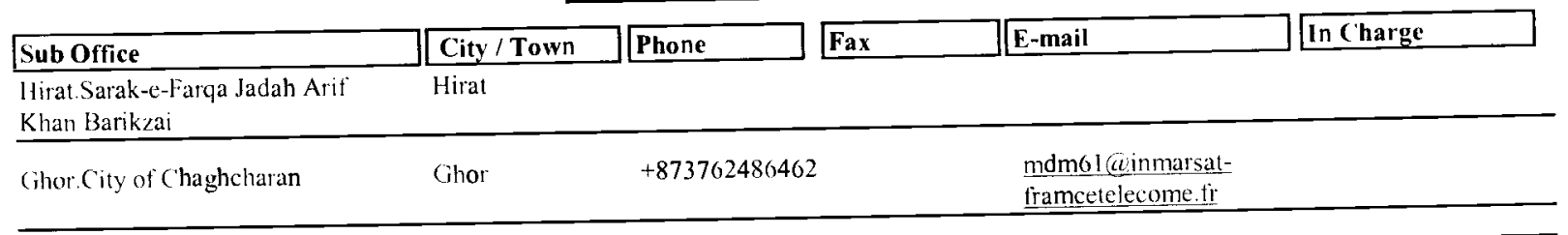




\begin{tabular}{|c|c|c|c|c|}
\hline Membership & $\widehat{A C B A R}$ & & Country of Affiliation & Switzerland \\
\hline Address & Commu & cation & Key Staff & Position \\
\hline \multirow{4}{*}{$\begin{array}{l}\text { Houes } 499 \text { St } 4 \text { Qalai Fatullah, } \\
\text { Kabul-Afghanistan }\end{array}$} & Phone: & 070274501 & Marilynn Jomnston & Country Director \\
\hline & Fax: & 00873762945645 & Jamie Eyre & Relief Coordinator \\
\hline & E-mail: & kabul_atg@medair.automail.com & Clare Rowe & Finance/Admin Manage \\
\hline & Web: & www mediar.org & & \\
\hline
\end{tabular}

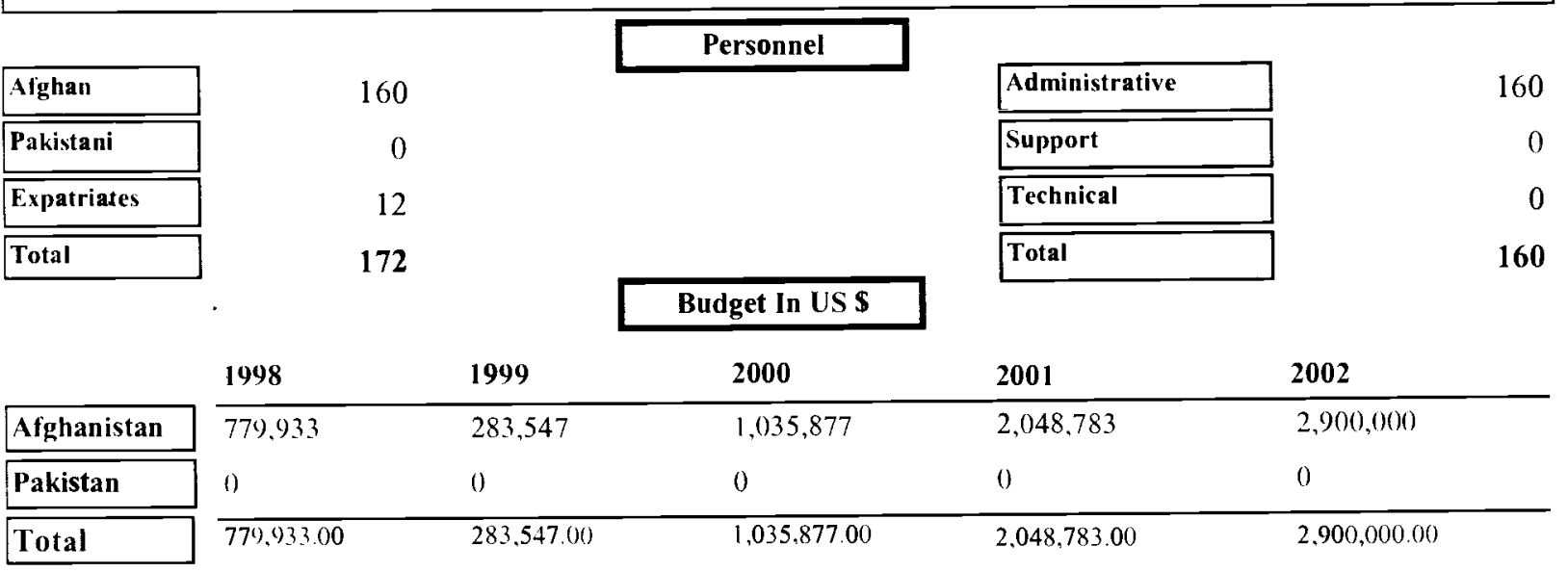

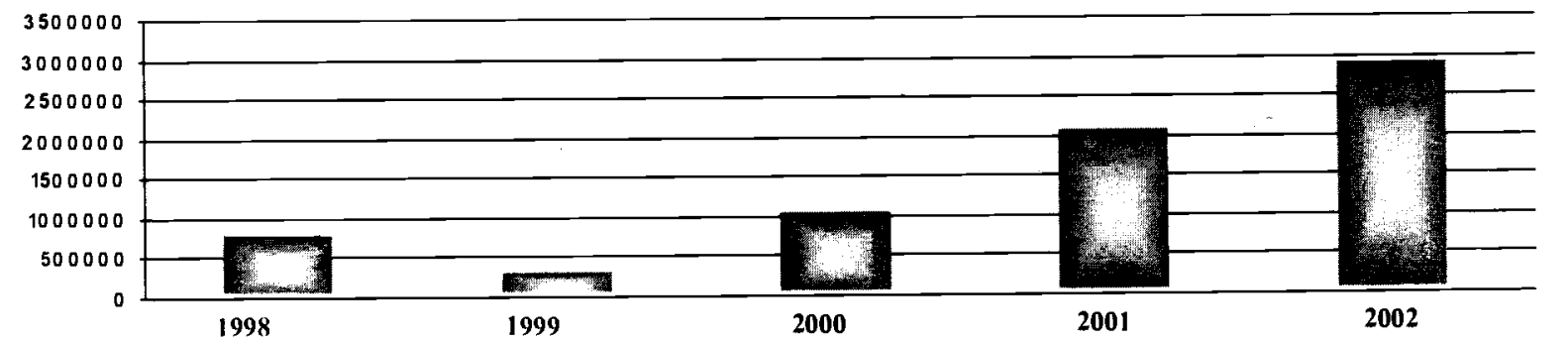

\begin{tabular}{|c|c|c|c|c|c|c|}
\hline \multicolumn{2}{|c|}{ Donors } & & location & \multirow[b]{2}{*}{ Province } & \multicolumn{2}{|c|}{ Targeted Provinces } \\
\hline Donors & \% Funded & Allocation & $\%$ Funded & & Sector & $\%$ Targeted \\
\hline ('II)A & 9.5 & Health & 40 & Badakhshan & Relic & triatioin \\
\hline DFHID & 5.5 & Relicf \& Repatria & 60 & Kabul & Healt & \\
\hline l:(1IO) & 68.1 & & & Logar & Healt & \\
\hline Io)M & 2.5 & & & Paktya & Healt & \\
\hline$\| \mathrm{ICA}$ & 1.1 & & & Wardak & Healt & \\
\hline MCC.CAB & 0.2 & & & & & \\
\hline MSM & 6.3 & & & & & \\
\hline Private & 0.8 & & & & & \\
\hline
\end{tabular}

Sub Offices

\begin{tabular}{|c|c|c|c|c|c|}
\hline Sub Office & City/Town & Phone & Fax & E-mail & In Charge \\
\hline $\begin{array}{l}\text { NWFI'.28 KKK Road University } \\
\text { lown }\end{array}$ & Peshawar & 841336 & & medair@brain.net.pk & \\
\hline Badaklishan. Shar-e-Naw Faizabad & raizabad & & & $\begin{array}{l}\text { badakhshan } e \text { medauraut } \\
\text { omail.com }\end{array}$ & \\
\hline
\end{tabular}




\section{MeRLIN (Merlin)}

\begin{tabular}{|c|c|c|c|}
\hline Membership & & Country of Affliliation & \\
\hline Address & Communication & Key Staff & Position \\
\hline \multirow{4}{*}{$\begin{array}{l}\text { House } 32 \text { Strect } 4 \\
\text { Shahr-e-Now, } \\
\text { Kabul-Afghanistan }\end{array}$} & 070280252 & Nibol Young & Country Manager \\
\hline & Fax: & Peter I afere & Finance officer \\
\hline & kabul@merlin.org.uk & & \\
\hline & www.merlin.org.uk & & \\
\hline
\end{tabular}

\begin{tabular}{|l|r|}
\hline Afghan & 45 \\
\hline Pakistani & 0 \\
\hline Expatriates & 6 \\
\hline Total & 51 \\
\hline
\end{tabular}

\begin{tabular}{|l|r|}
\hline Administrative \\
\hline Support \\
\hline Technical \\
\hline Total \\
\hline
\end{tabular}

Budget In US \$

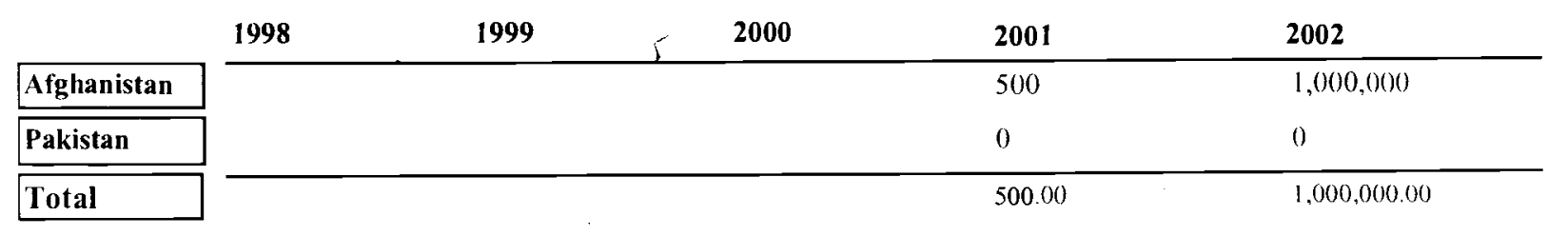

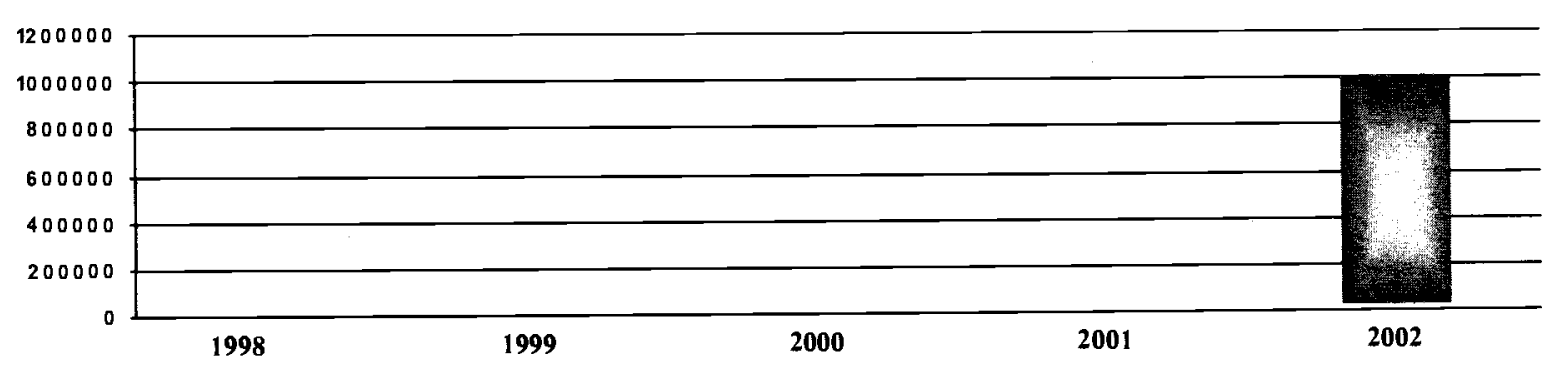

\begin{tabular}{|c|c|c|c|c|c|c|}
\hline \multicolumn{2}{|c|}{ Donors } & & llocation & \multirow[b]{2}{*}{ Province } & \multicolumn{2}{|c|}{ Targeted Provinces } \\
\hline Donors & $\%$ Funded & Allocation & $\%$ Funded & & Seetor & $\%$ Targeted \\
\hline Austc ARE & & Health & 100 & Baghlan & Health & 20 \\
\hline DFID & & & & Kunduz & Health & 40 \\
\hline Private Funds & & & & Takhar & Health & 40 \\
\hline
\end{tabular}

WHO Inkind

\section{Sub Offices}

\begin{tabular}{|c|c|c|c|c|c|}
\hline Sub Office & City / Town & Phone & Fax & E-mail & In Charge \\
\hline $\begin{array}{l}\text { Takhar.House } 1 \text { Street } 1 \text { Taloqan } \\
\text { ('ity }\end{array}$ & Taloqan & $\lcm{873762139352}$ & & talogan(umelrin.org.uk & Rose luz \\
\hline
\end{tabular}


MeRU (Medical Relief Unit)

\begin{tabular}{|c|c|c|c|}
\hline Membership & Other & Country of Affliliation & Japan \\
\hline Address & Communication & Key Staff & Position \\
\hline \multirow{3}{*}{$\begin{array}{l}\text { Saraki Mahbas Green \& White } \\
\text { Building. } \\
\text { In Front of Hamam Malobas, } \\
\text { Mazar-Aighanistan }\end{array}$} & Phone: & Tadahisa Kawashima & Chief of Operation \\
\hline & +8737627611 & Meyuki Tujii & Administrator \\
\hline & $\begin{array}{l}\text { E-mail: leqo5460(anifry.ne.jp } \\
\text { Web: }\end{array}$ & Kazoko Yasonaga & Field Coordinator \\
\hline
\end{tabular}

\begin{tabular}{|l|}
\hline Afghan \\
\hline Pakistani \\
\hline Expatriates \\
\hline Total \\
\hline
\end{tabular}

Personnel

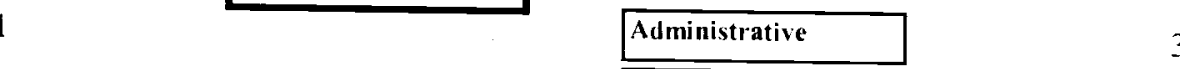

0

Support 8

Technical 4

Budget In US S

Total

\begin{tabular}{|c|c|c|c|c|}
\hline & 1998 & 2000 & 2001 & 2002 \\
\hline Afghanistan & & & 200,000 & 600,000 \\
\hline Pakistan & & & 0 & 0 \\
\hline Total & & & $200,000.00$ & $600,000.0 x$ \\
\hline
\end{tabular}

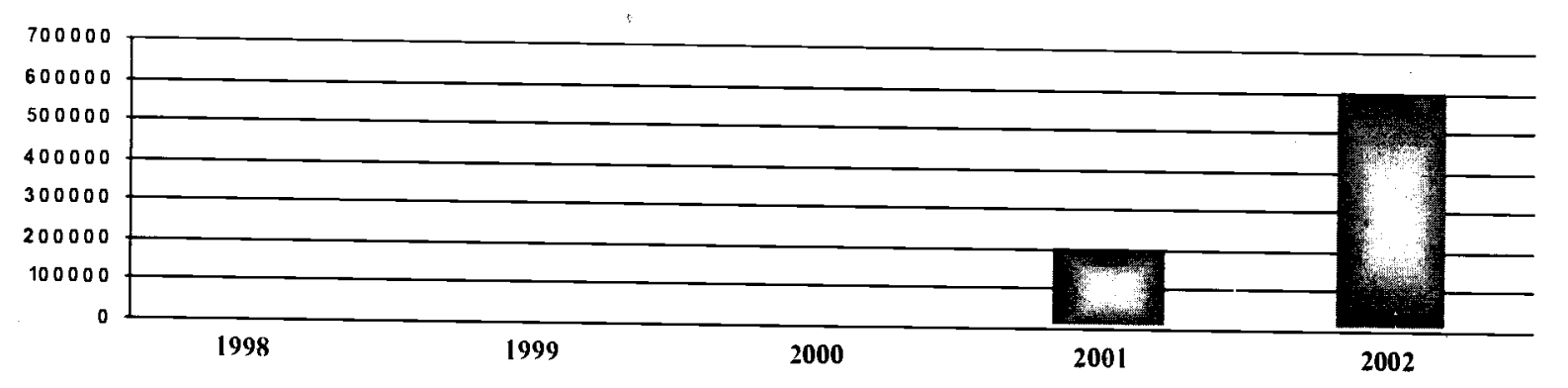

\begin{tabular}{|c|c|c|c|c|c|c|}
\hline \multicolumn{2}{|c|}{ Donors } & & llocation & \multirow[b]{2}{*}{ Province } & \multicolumn{2}{|c|}{ Targeted Provinces } \\
\hline Donors & "1/4 Funded & Allocation & $1 \%$ Funded & & Sector & $\%$ Targeted \\
\hline MoFA Japan & 20 & Emergency & 10 & Balkh & Health & 100 \\
\hline INFPA & 80 & Health & 90 & & & \\
\hline
\end{tabular}

Sub Offices 
MRA (Maihan Rehabilitation Agency)

\begin{tabular}{|c|c|c|c|}
\hline Membership & ANC'B & Country of Affiliation & Aighanistan \\
\hline Address & Communication & Key Staff & Position \\
\hline \multirow{4}{*}{$\begin{array}{l}\text { 3rd lloor Haje Said Plaza, } \\
\text { Talashi Chowk, } \\
\text { Jalalabad - Afghanistan }\end{array}$} & Phone: & Eng flakimuddin & Managing Director \\
\hline & Fax: & Agro.Sabruddin & Key Staff \\
\hline & E-mail: & & \\
\hline & Web: & & \\
\hline
\end{tabular}

\begin{tabular}{|l|}
\hline Afghan \\
\hline Pakistani \\
\hline \hline Expatriates \\
\hline Total \\
\hline
\end{tabular}

Personnel

\begin{tabular}{|c|c|c|c|c|c|}
\hline & & & & \multirow[b]{3}{*}{2001} & \multirow[b]{3}{*}{2002} \\
\hline & & & Budget In US S & & \\
\hline & 1998 & 1999 & 2000 & & \\
\hline Afghanistan & 10,000 & & & 15,000 & 20,000 \\
\hline Pakistan & () & & & 0 & 0 \\
\hline Total & $10,000,00$ & & & 15.000 .00 & $20,000.00$ \\
\hline
\end{tabular}
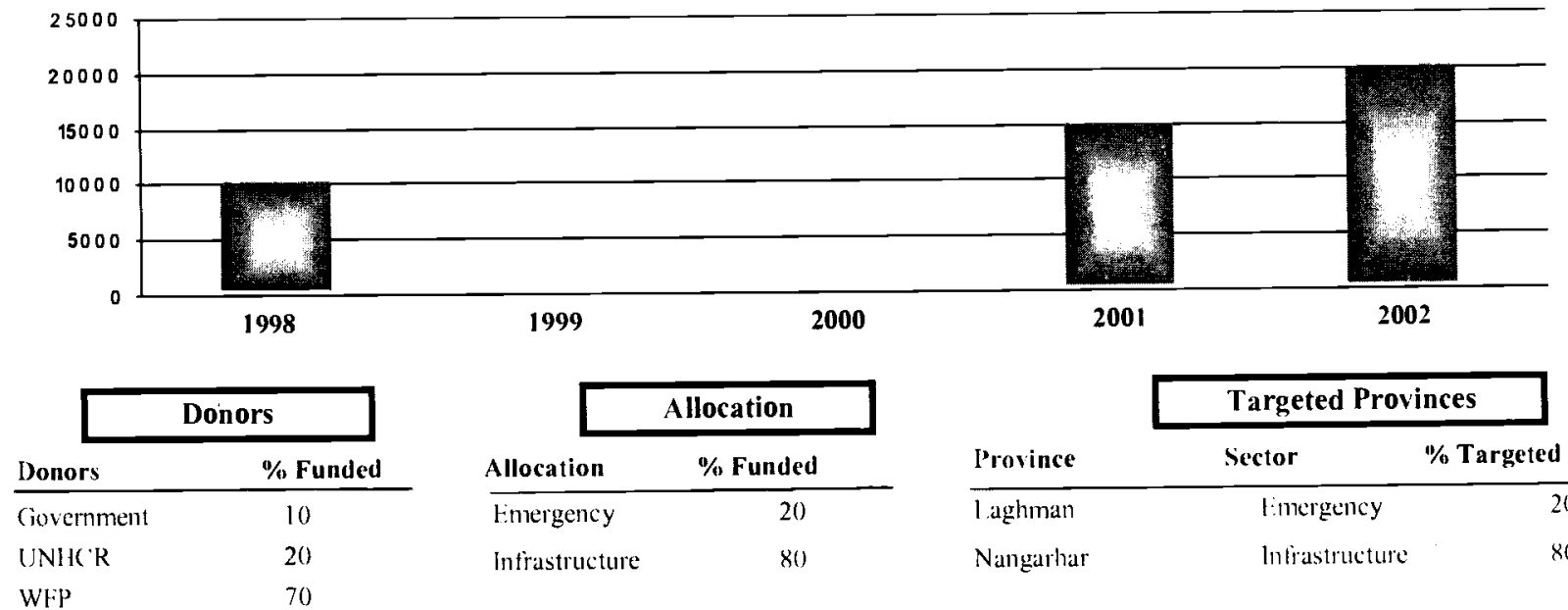

\begin{tabular}{lcr|} 
& \multicolumn{2}{c|}{ Targeted Provinces } \\
\cline { 2 - 2 } Province & Sector & $\%$ Targeted \\
\hline 1.aghman & limergency & 20 \\
Nangarhar & lnirastructure & 80
\end{tabular}

Sub Offices

\begin{tabular}{|c|c|c|c|c|c|}
\hline Sub Office & City / Town & Phone & Fax & E-mail & In Charge \\
\hline Wazir Akbar Khan St. 15 House 131 & Kabul & & & & Sarudd 1 n \\
\hline
\end{tabular}




\section{MRAA (Mailan Rehabilitation Association for Afghanistan)}

\begin{tabular}{|c|c|c|c|}
\hline Mcmbership & Other & Country of Affliliation & \begin{tabular}{|l} 
Afghanistan \\
\end{tabular} \\
\hline Address & Communication & Key Staff & Position \\
\hline \multirow{4}{*}{$\begin{array}{l}\text { ( hicken Street, } \\
\text { Shar-e-Now, } \\
\text { Kabul-Afghanistan }\end{array}$} & Phone: $\quad 35625$ & Ah.Jawid Arianzai & Director \\
\hline & Fax: & Eng. Aziz. & Enginecr \\
\hline & E-mail: & Mohd Munib & Financial ()tficer \\
\hline & Web: & & \\
\hline
\end{tabular}

\begin{tabular}{|l|}
\hline Afghan \\
\hline Pakistani \\
\hline Expatriates \\
\hline Total \\
\hline
\end{tabular}

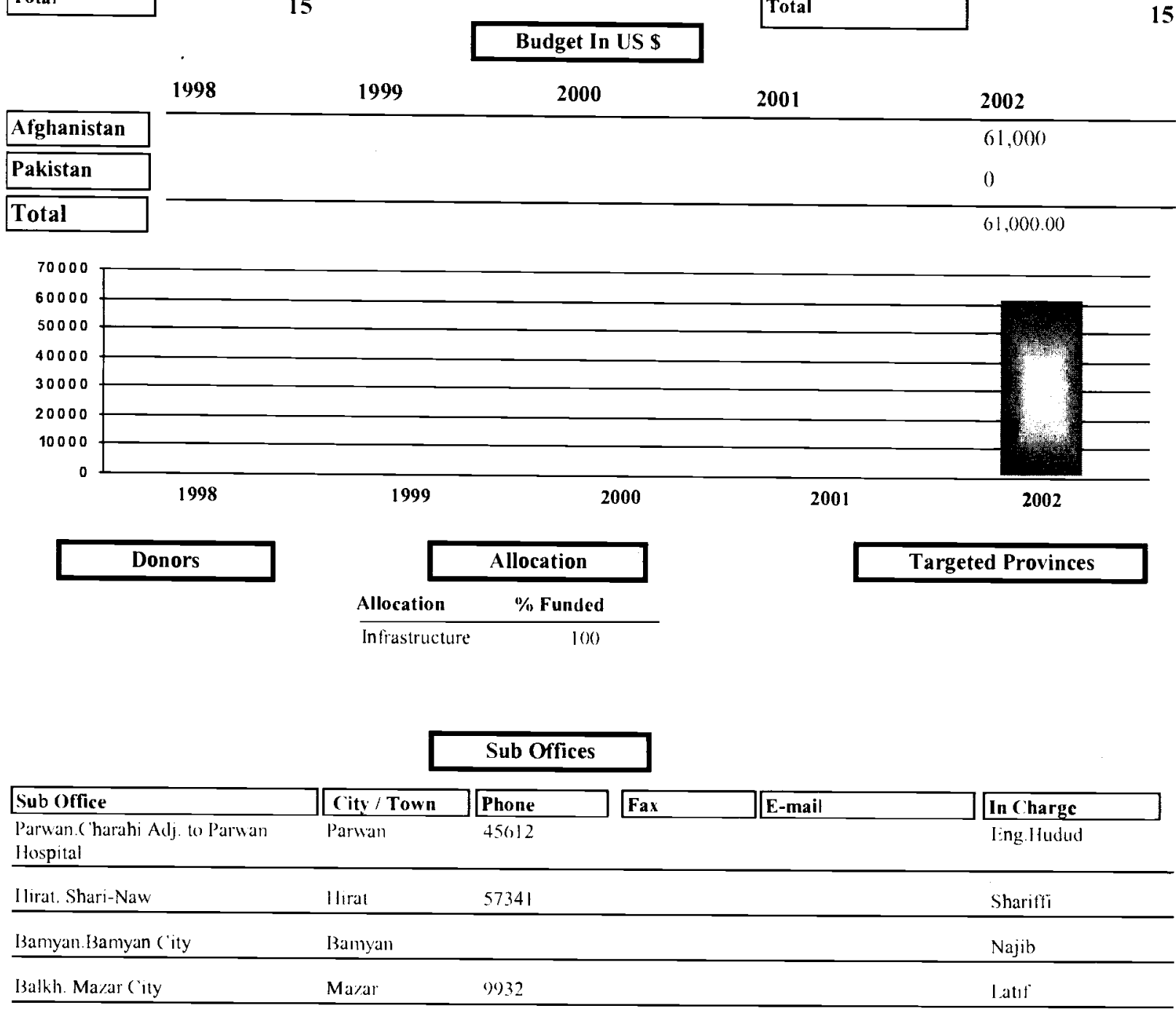

Personnel

15

0

0

15

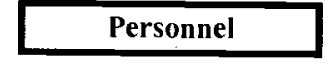

\begin{tabular}{|l|}
\hline Administrativc \\
\hline Support \\
\hline Technical \\
\hline Total \\
\hline
\end{tabular}




\section{MRCA Medical Refresher Courses for Afghans)}

\begin{tabular}{|c|c|c|c|}
\hline Memhership & AC'BAR & Country of Affliliation & France \\
\hline Address & Communication & Key Staff & Position \\
\hline \multirow{4}{*}{$\begin{array}{l}\text { Administrative Enclave, } \\
\text { Plot } 34 \text { A3 Phase } 5 \text { Hayatabad, } \\
\text { Peshawar-Pakistan }\end{array}$} & Phone: & Ah.Seyar /afar & (ieneral Director \\
\hline & 81281 & Ahmadullah Ahmadzai & Training Coordinator \\
\hline & E-mail: & Abdul Rahim Nasry & Administrative Manage \\
\hline & Web: & & \\
\hline
\end{tabular}

\begin{tabular}{|l|}
\hline Afghan \\
\hline Pakistani \\
\hline Expatriates \\
\hline Total \\
\hline
\end{tabular}

\section{2}

Personnel

\begin{tabular}{|l|}
\hline Afghanistan \\
\hline Pakistan \\
\hline
\end{tabular}
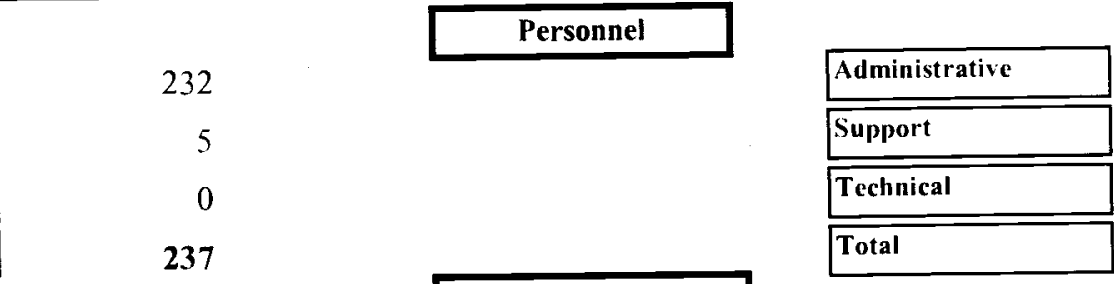

Budget In US \$

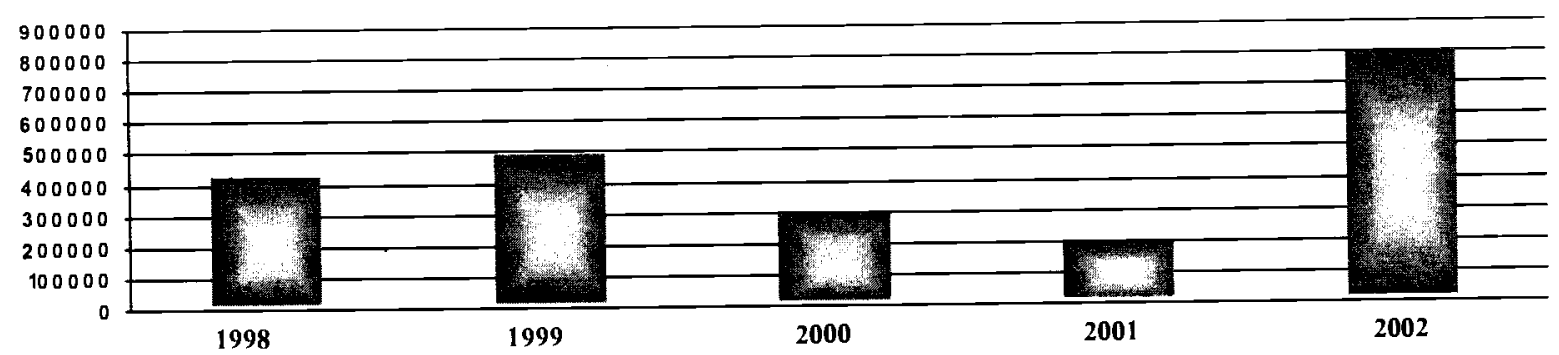

\begin{tabular}{lc}
\multicolumn{2}{c|}{ Donors } \\
Donors & \% Funded \\
\hline CORI) AID & 2 \\
ECHO & 18 \\
EU & 60 \\
French (jovt. & 20
\end{tabular}

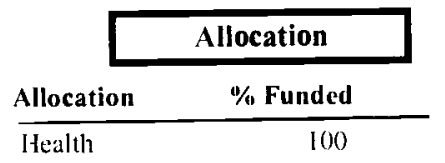

\begin{tabular}{lcr}
\cline { 2 - 3 } & \multicolumn{2}{c|}{ Targeted Provinces } \\
Province & Sector & $\%$ Targeted \\
\hline Kabul & Health & 20 \\
NWFP & Health & 62 \\
Parwan & Health & 18
\end{tabular}

French (jovt

\begin{tabular}{lllll}
$\mathbf{1 9 9 8}$ & $\mathbf{1 9 9 9}$ & $\mathbf{2 0 0 0}$ & $\mathbf{2 0 0 1}$ & $\mathbf{2 0 0 2}$ \\
\hline 70,000 & 60,000 & 40,000 & 35,000 & 240,000 \\
350,000 & 430,000 & 250,000 & 155,000 & 560,000 \\
\hline $420,000.00$ & $490,000.00$ & $290,000.00$ & $190,000.00$ & $800,000.00$
\end{tabular}

\begin{tabular}{|c|c|c|c|c|}
\hline & \multirow{2}{*}{ Sub Offices } & & \\
\hline & & & & \\
\hline Suh Office & \begin{tabular}{|l|} 
(ity / Town \\
\end{tabular} & Phone & E-mail & In Charge \\
\hline $\begin{array}{l}\text { Parwan. Behind ("harikar Civil } \\
\text { llospital }\end{array}$ & Charikar & & mrca-afg(ciyahoo.com & Nematullah Zarghon \\
\hline $\begin{array}{l}\text { House } 36 \text { Street B 2nd Part of Kart- } \\
\text { e-Parwan }\end{array}$ & Kabul & 070277435 & mrea_Afg(ayahoocon & M.Kazım \\
\hline
\end{tabular}




\section{MRORA (MarufRelief Organization for Reconstruction of Afghanistan)}

\begin{tabular}{|c|c|c|c|}
\hline Membership & SWABC & Country of Affiliation & Afghanistan \\
\hline Address & Communication & Key Staff & Position \\
\hline \multirow{3}{*}{$\begin{array}{l}\text { Madad Chowk Near Toopkhana, } \\
\text { Kandahar-Afghanistan }\end{array}$} & Phone: & Habibullah Barakzai & Director \\
\hline & Fax: & Mohd.Salim & Deputy Director \\
\hline & E-mail: & Mohd.Ibrahim & Site Lingineer \\
\hline
\end{tabular}

\begin{tabular}{|l|}
\hline Afghan \\
\hline \hline Pakistani \\
\hline Expatriates \\
\hline Total $\cdot$ \\
\hline
\end{tabular}

21

0

0

21
Personnel

\begin{tabular}{|l|}
\hline Administrative \\
\hline Support \\
\hline Technical \\
\hline Total \\
\hline
\end{tabular}

Budget In US \$

\begin{tabular}{|c|c|c|c|c|c|}
\hline & 1998 & 1999 & 2000 & 2001 & 2002 \\
\hline Afghanistan & 30,000 & 50,000 & 60,000 & 90,000 & 45,000 \\
\hline Pakistan & 0 & 0 & 0 & 0 & 0 \\
\hline Total & $30,000.00$ & $50,000.00$ & $60,000.00$ & $90,000.00$ & 45, \\
\hline
\end{tabular}

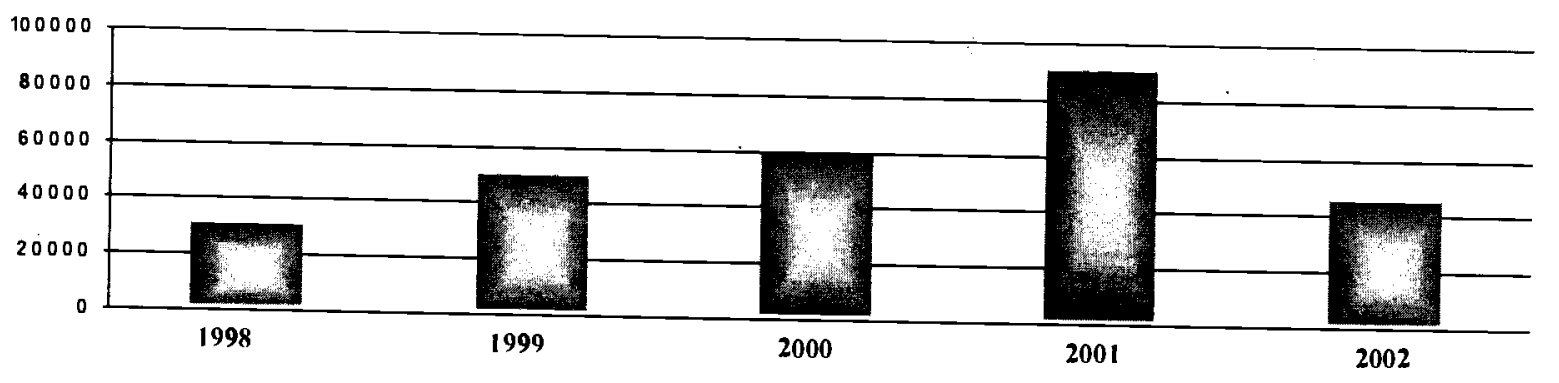

\begin{tabular}{lc}
\multicolumn{2}{c|}{ Donors } \\
\hline Donors & \% Funded \\
\hline FAO & 10 \\
INHCR & 15 \\
INICTE: & 25 \\
INOPS & 30 \\
WIPP & 20
\end{tabular}

\begin{tabular}{lc|}
\hline & \multicolumn{1}{c|}{ Allocation } \\
\hline Allocation & $\%$ Funded \\
\hline Agriculture & 15 \\
Education & 20 \\
Energency & 10 \\
Income Generatio & 5 \\
Infrastructure & 30 \\
Water Resources & 30
\end{tabular}

\begin{tabular}{lcc} 
& \multicolumn{2}{c|}{ Targeted Provinces } \\
\cline { 2 - 3 } Province & Sector & $\%$ Targcted \\
\hline Hilmand & Water Resources & 10 \\
Kabul & Infrastructurc & 60 \\
Kandahar & Infrastructure & 20 \\
Zabul & Agriculture & 10
\end{tabular}

Sub Offices

\begin{tabular}{|c|c|c|c|c|}
\hline Sub Office & City / Town & Phone & E-mail & In Charge \\
\hline Kabul Taimani sarak-1 & Kabul & & & Hamdullah \\
\hline $\begin{array}{l}\text { Ilitmand Near gorcrner housc } \\
\text { I ashikar ( iah }\end{array}$ & Lashkar Gah & & & Abdullah \\
\hline
\end{tabular}




\begin{tabular}{|c|c|c|c|}
\hline Membership & 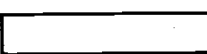 & Country of Affiliation & Afghanistan \\
\hline Address & Communication & Key Staff & Position \\
\hline \multirow{4}{*}{$\begin{array}{l}\text { House } 5 \text { Maded chock, } \\
\text { Kandahar-Afghanistan }\end{array}$} & Phone: & Abdul Ghani & Director \\
\hline & Fax: & Ahmad & Deputy Director \\
\hline & E-mail: & Mohd Nalime & Site Engineer \\
\hline & Web: & & \\
\hline
\end{tabular}

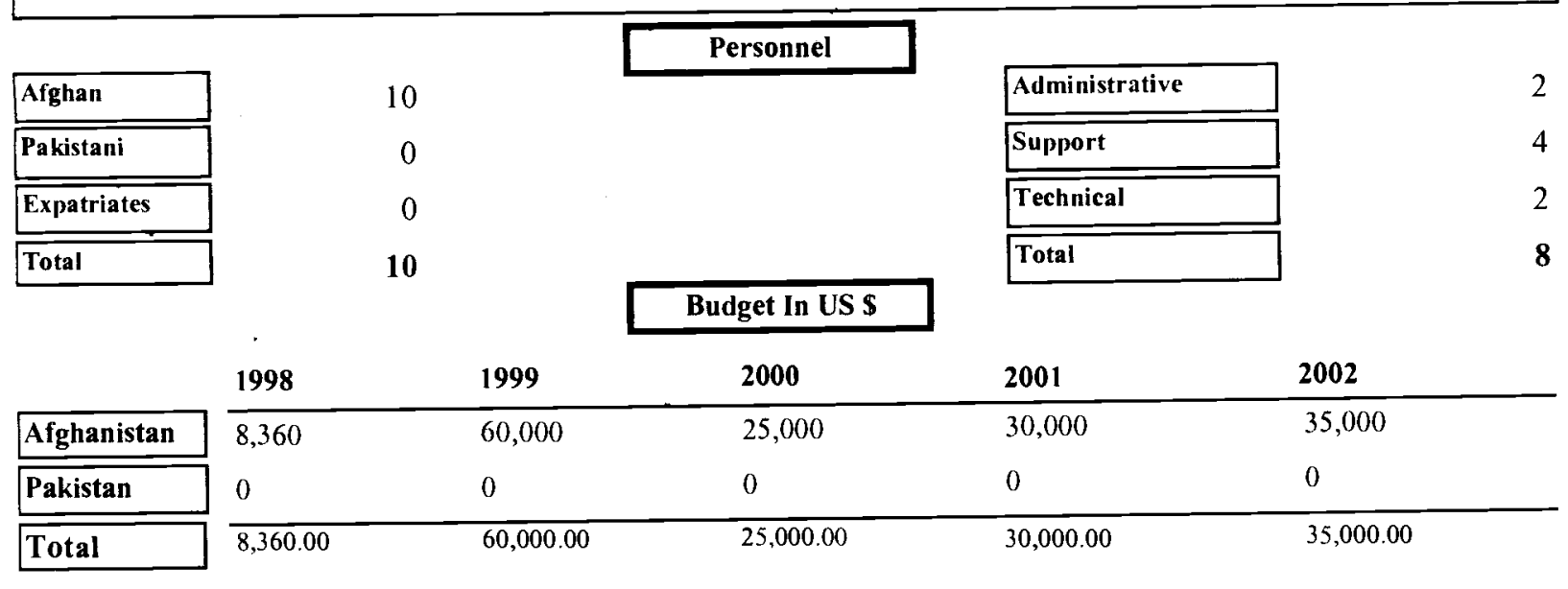

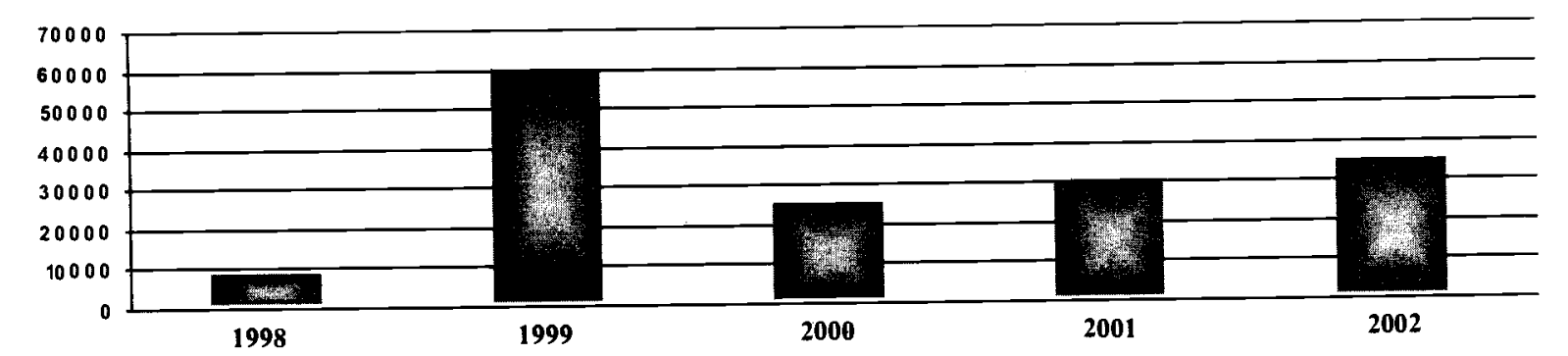

\begin{tabular}{lc}
\multicolumn{1}{c|}{ Donors } \\
Donors & \% Funded \\
\hline UNDCP & 35 \\
UNHCR & 30 \\
UNICEF & 25 \\
UNOPS & 20 \\
WFP & 40
\end{tabular}

\begin{tabular}{lc|}
\cline { 2 - 2 } & \multicolumn{2}{c|}{ Allocation } \\
Allocation & \% Funded \\
\hline Agriculture & 20 \\
Education & 35 \\
Emergency & 20 \\
Infrastructure & 30 \\
Water Resources & 25
\end{tabular}

\begin{tabular}{lcc}
\cline { 2 - 3 } & \multicolumn{2}{c|}{ Targeted Provinces } \\
\cline { 2 - 3 } Province & Sector & \% Targeted \\
\hline Farah & Water Resources & 10 \\
Hilmand & Agriculture & 30 \\
Hilmand & Water Resources & 5 \\
Kandahar & Water Resources & 5 \\
Kandahar & Infrastructure & 40 \\
Zabul & Education & 5 \\
Zabul & Water Resources & 5
\end{tabular}

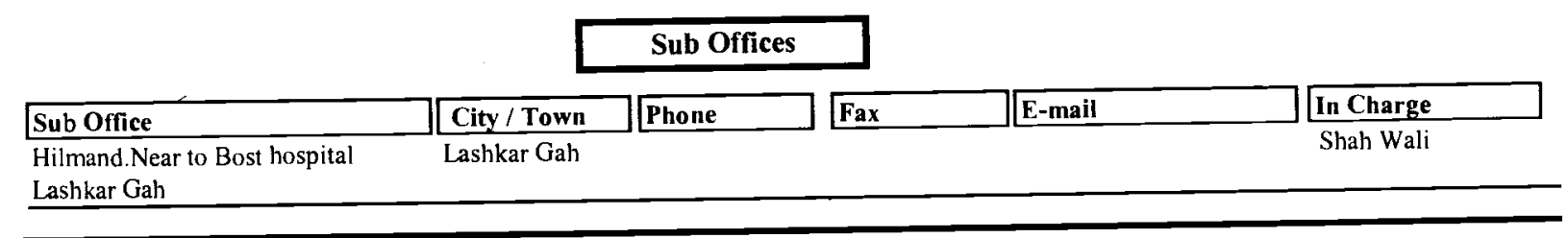




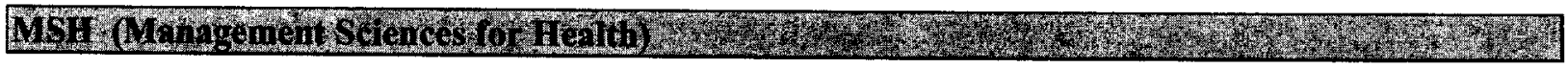

\begin{tabular}{|c|c|c|c|}
\hline Membership & & Country of Affiliation & USA \\
\hline Address & Communication & Key Staff & Position \\
\hline \multirow{4}{*}{$\begin{array}{l}\text { House } 22 \text { Tarabaz Khan Road, } \\
\text { Shabobo St. Shahr-e-Now, } \\
\text { Kabul-Afghanistan }\end{array}$} & Phone: & Waliam Newbrander & Chief of Party \\
\hline & Fax: & Laurency Loumonica & Health Services \\
\hline & E-mail: afghan@msh.org & Mubark Shah & Training Coordinator \\
\hline & www.msh.org & & \\
\hline
\end{tabular}

\begin{tabular}{|l|}
\hline Afghan \\
\hline \hline Pakistani \\
\hline \hline Expatriates \\
\hline Total \\
\hline
\end{tabular}

Personnel

82

Budget In US \$

\begin{tabular}{|l|}
\hline Administrative \\
\hline Support \\
\hline Technical \\
\hline Total \\
\hline
\end{tabular}

0

12

82

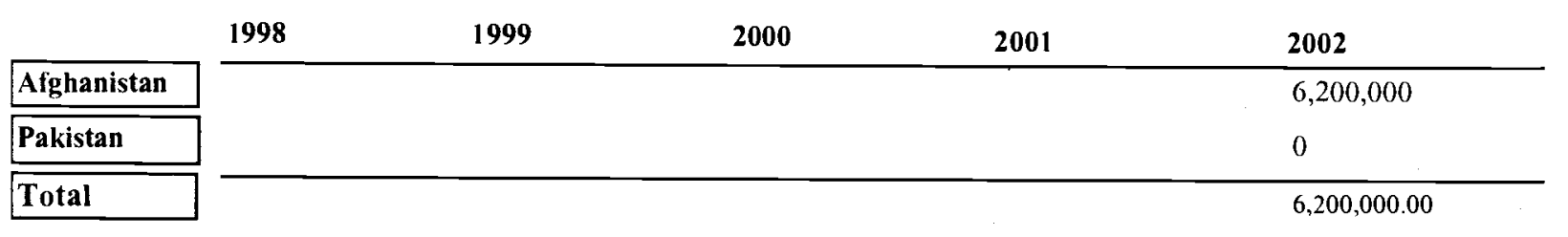

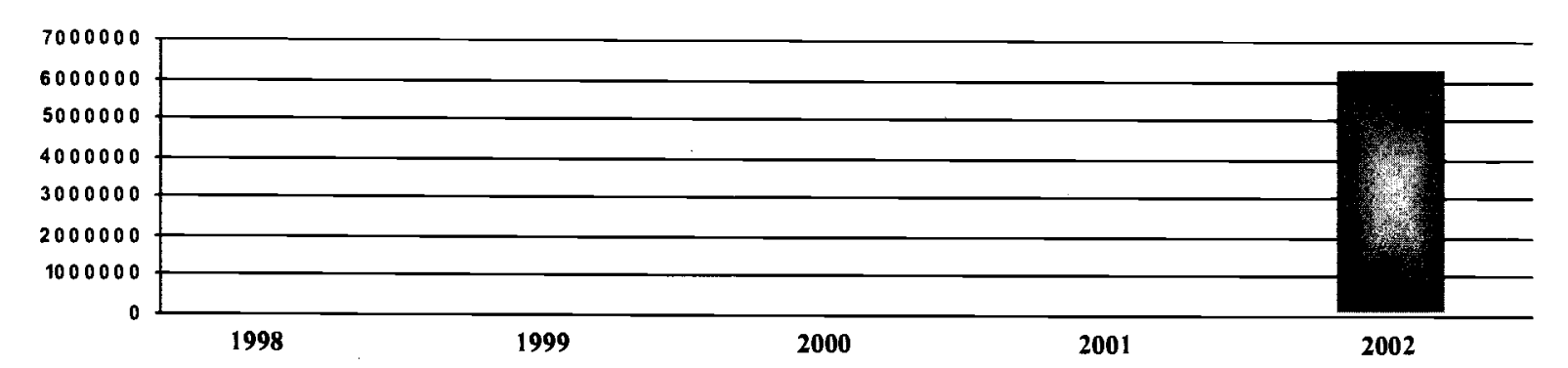

\begin{tabular}{|c|c|c|c|c|c|c|}
\hline \multicolumn{2}{|c|}{ Donors } & & llocation & \multirow[b]{2}{*}{ Province } & \multicolumn{2}{|c|}{ Targeted Provinces } \\
\hline Donors & $\%$ Funded & Allocation & $\%$ Funded & & Sector & $\%$ Targeted \\
\hline UNFPA & 4 & $\overline{\text { Health }}$ & 100 & All Provinces & 100 & 0 \\
\hline USAID & 96 & & & & & \\
\hline
\end{tabular}

Sub Offices

\begin{tabular}{|c|c|c|c|c|c|}
\hline Sub Office & City / Town & Phone & Fax & E-mail & In Charge \\
\hline $\begin{array}{l}\text { USA. } 165 \text { Allandale Road } \\
\text { Boston,MA } 02130-3400\end{array}$ & USA & & & & \\
\hline
\end{tabular}


NBR (Nawbahar Balkh Reconstruction)

\begin{tabular}{|c|c|c|c|}
\hline Membership & & Country of Affliliation & UN \\
\hline Address & Communication & Key Staff & Position \\
\hline \multirow{4}{*}{$\begin{array}{l}\text { Mazar (ity Qauny Market, } \\
\text { Mazar-Afghanistan }\end{array}$} & Phone: 3222 & Abdul Mohammad & Director \\
\hline & Fax: & Eng.A.Ghatar & Side Engineer \\
\hline & E-mail: & M.Nawroz & Officer \\
\hline & Web: & & \\
\hline
\end{tabular}

\begin{tabular}{|l|}
\hline Afghan \\
\hline \hline Pakistani \\
\hline Expatriates. \\
\hline Total \\
\hline
\end{tabular}

Personnel

14
0
0
14
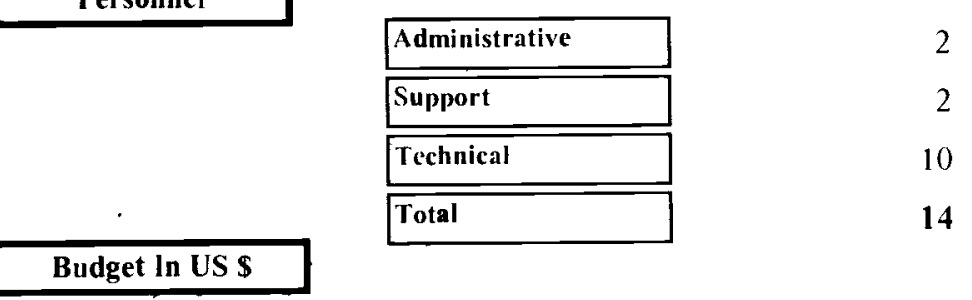

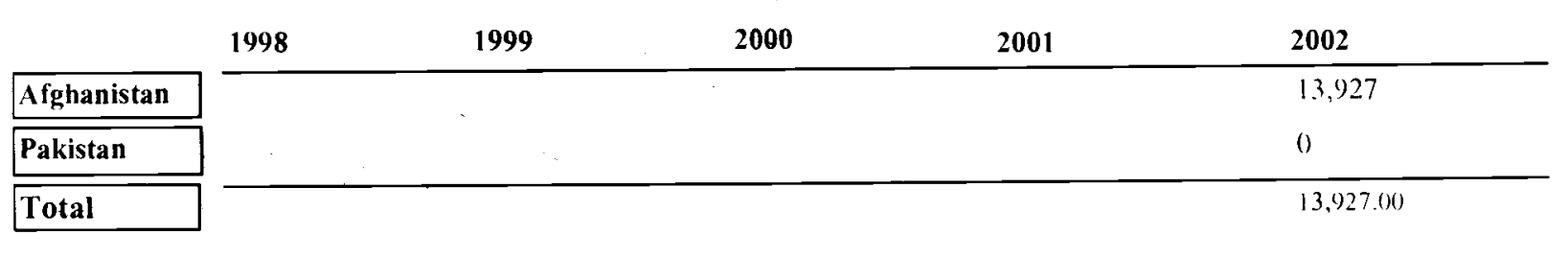
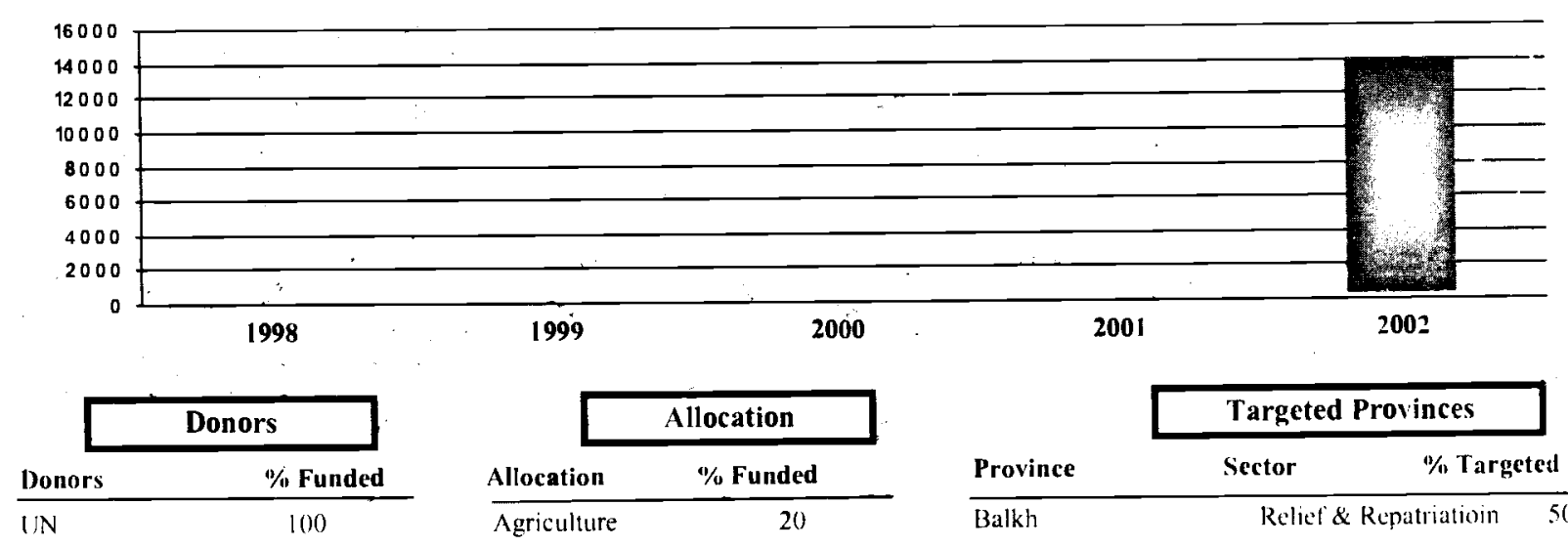

\begin{tabular}{lc|}
\hline \multicolumn{1}{c|}{ Allocation } \\
Allocation & $\%$ Funded \\
\hline Agriculture & 20 \\
Education & 10 \\
Emergency & 50 \\
Health & 5 \\
Huntan Rights & 5 \\
Infrastructure & 10
\end{tabular}

\begin{tabular}{lcc}
\multicolumn{1}{c|}{} & \multicolumn{2}{c|}{ Targeted Provinces } \\
\cline { 2 - 3 } Province & Sector & \multicolumn{2}{c}{$\%$ Targetesl } \\
\hline Balkh & Relicf \& Repatriatioin & 50 \\
Balkh & Intiastructure & 5 \\
Balkh & Relicf \& Repatratioin & 50 \\
Jawzjan & Relief \& Repatriatioin & 50 \\
& &
\end{tabular}

Sub Offices 


\section{NC (Nejat Center)}

\begin{tabular}{|c|c|c|c|}
\hline Membership & & Country of Affliliation & Afghanistan \\
\hline Address & Communication & Key Staff & Position \\
\hline \multirow{4}{*}{$\begin{array}{l}\text { House } 14 \text { K4 Main Street, } \\
\text { Phase } 3 \text { Hayat } \wedge \text { bad, } \\
\text { Peshawar-Pakistan }\end{array}$} & Phone: & M.Qasim Zamani & Director \\
\hline & 822467 & Tariq Suleman & Deputy Director \\
\hline & E-mail: nejat@brain.nct.pk & Abdul Baqi & Supervisor \\
\hline & Web: & & \\
\hline
\end{tabular}

\begin{tabular}{|l|}
\hline Afghan \\
\hline Pakistani \\
\hline Fxpatriates \\
\hline Total \\
\hline
\end{tabular}

\section{Personnel}

\begin{tabular}{|l|}
\hline Administrative \\
\hline Support \\
\hline Teehnical \\
\hline Total \\
\hline
\end{tabular}

Budget ln US \$

\begin{tabular}{|c|c|c|c|c|c|}
\hline & 1998 & 1999 & 2000 & 2001 & 2002 \\
\hline Afghanistan & 60,000 & 60,000 & 30,000 & 0 & 0 \\
\hline Pakistan & 30,000 & 30,000 & 24,000 & 24,000 & 24,000 \\
\hline Total & $90,000.00$ & $90,000.00$ & $54,000.00$ & $24,000.00$ & $24,000.00$ \\
\hline
\end{tabular}

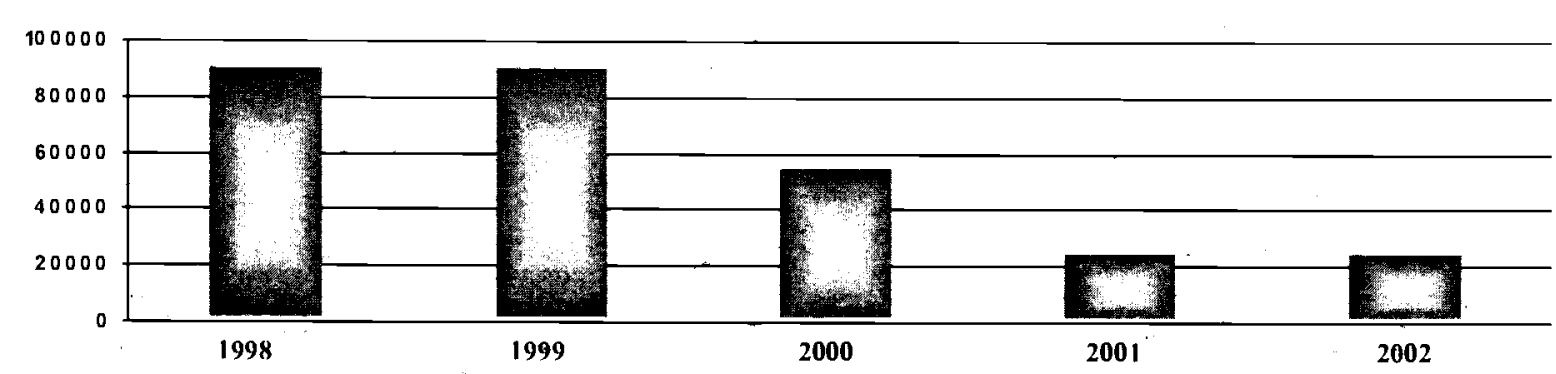

\begin{tabular}{|c|c|c|c|c|c|c|c|}
\hline \multicolumn{2}{|c|}{ Donors } & & llocation & \multirow[b]{2}{*}{ Province } & \multicolumn{3}{|c|}{ Targeted Provinces } \\
\hline Donors & $\%$ Funded & Allocation & $\%$ Funded & & Sector & $\% \mathrm{Ta}$ & \\
\hline (jT\% & 30 & Irug Rehab & 60 & Kabul & Drug & tation & 10 \\
\hline SVA & 40 & Other & 40 & & & & \\
\hline
\end{tabular}

\section{Sub Offices}

\begin{tabular}{|c|c|c|c|c|}
\hline Sub Office & ( ity / Town & Phone & E-mail & In Charge \\
\hline $\begin{array}{l}\text { l)arulaman Near I labibya l Iigh } \\
\text { School }\end{array}$ & Kabul & & & Arif \\
\hline Nangrarhar ( hahrahe Maraston & lalalabad & & & Snwar Khan \\
\hline
\end{tabular}




\begin{tabular}{|c|c|c|c|}
\hline Membership & Other & Country of Affiliation & Japan \\
\hline Address & Communication & Key Staff & Position \\
\hline \multirow{4}{*}{$\begin{array}{l}\text { Jada Koj Charahi Haji Ayob, } \\
\text { Hirat-Afghanistan }\end{array}$} & +81752410681 & Satayo Ono & Representative \\
\hline & +81752410682 & Nono Norioka & Preject Coordinator \\
\hline & nicco@kiwi.ne.jp & Aklko Matsumoto & Medical Coordinator \\
\hline & www.kyoto-nicco.org & & \\
\hline
\end{tabular}

\begin{tabular}{|r|r}
\hline Afghan & 15 \\
\hline \hline Pakistani & 0 \\
\hline Expatriates & 2 \\
\hline Total & 17 \\
\hline
\end{tabular}

Personnel

\begin{tabular}{|c|c|c|c|c|c|}
\hline & & & Budget In US \$ & & \\
\hline & 1998 & 1999 & 2000 & 2001 & 2002 \\
\hline Afghanistan & & & & & 300,000 \\
\hline Pakistan & & & & & 0 \\
\hline Total & & & & & $300,000.0$ \\
\hline
\end{tabular}

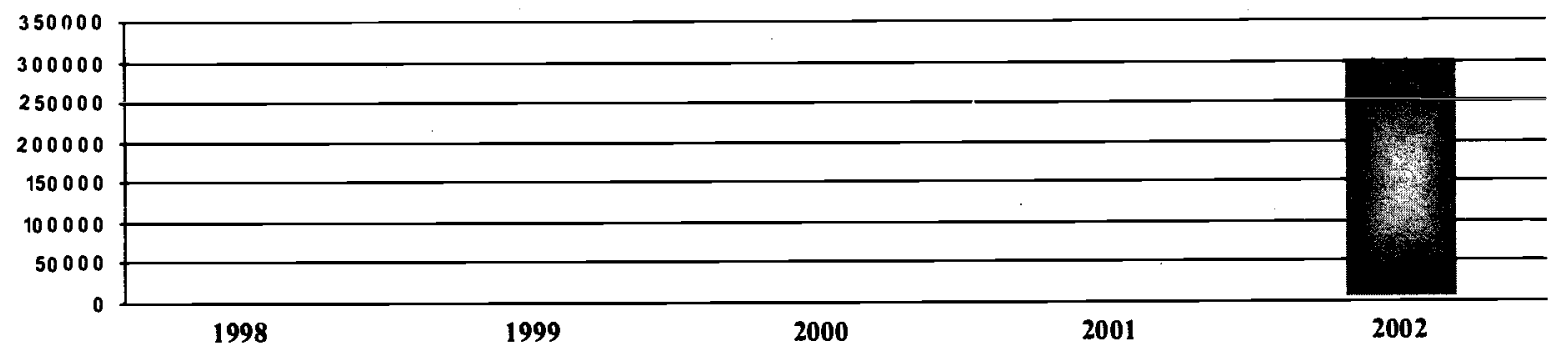

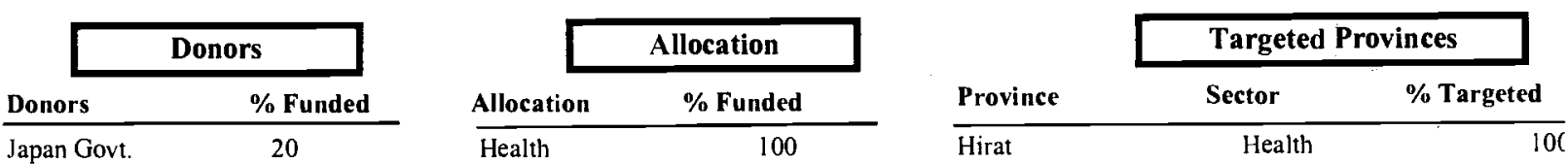

\section{Sub Offices}

\begin{tabular}{|c|c|c|c|c|c|}
\hline Sub Office & City / Town & Phone & Fax & E-mail & In Charge \\
\hline $\begin{array}{l}\text { 101Nishi-Rokkaku-Cho Shinmachi- } \\
\text { Nishi-Iru Nakagyo-Ku Kyoto }\end{array}$ & Japan & +81752410681 & & fzb0735 & \\
\hline
\end{tabular}




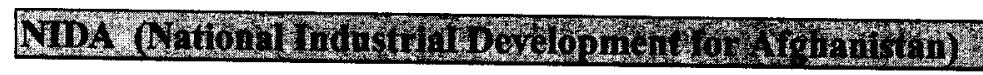

\begin{tabular}{|c|c|c|c|}
\hline Membership & Other & Country of Affliliation & Afghanistan \\
\hline Address & Communication & Key Staff & Position \\
\hline $\begin{array}{l}\text { House } 235 \text { St } 6 \text { Taimani, } \\
\text { Kabul-A fghanistan }\end{array}$ & $\begin{array}{l}\text { Phone: } 32427 \\
\text { Fax: } \\
\text { E-mail: } \\
\text { Web: }\end{array}$ & $\begin{array}{l}\text { Said Bashir Waizir } \\
\text { Said Wali Shinwari }\end{array}$ & $\begin{array}{l}\text { Director } \\
\text { Technical Assistant }\end{array}$ \\
\hline
\end{tabular}

\begin{tabular}{|l|}
\hline Afghan \\
\hline Pakistani \\
\hline Expatriates \\
\hline Total \\
\hline
\end{tabular}

17

0

0

17

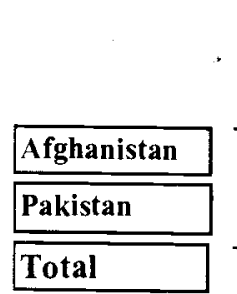

1998

1999

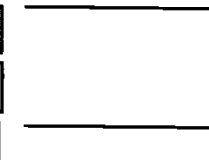

90000

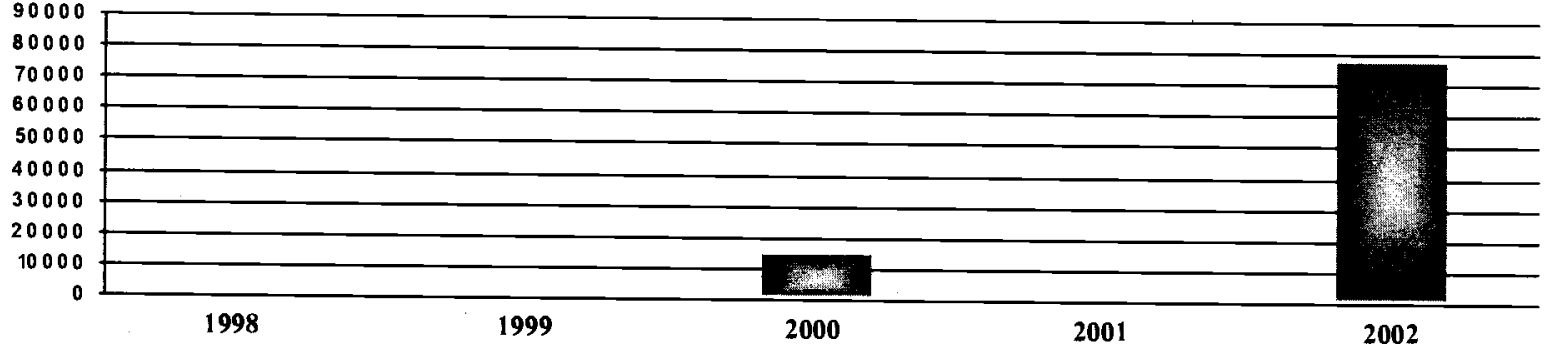

Personnel

Budget In US \$

\begin{tabular}{|l|}
\hline Administrative \\
\hline Support \\
\hline Technical \\
\hline Total \\
\hline
\end{tabular}

2002

77,000

0

$77,000.00$

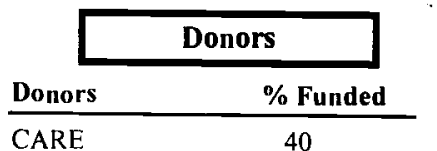

DFID

UNDP/OPS

UNHCR

WFP

\begin{tabular}{lc}
\multicolumn{1}{c}{} & \multicolumn{2}{c}{ Allocation } \\
Allocation & \% Funded \\
\hline Agriculture & 15 \\
Education & 20 \\
Infrastructure & 50 \\
Other & 15
\end{tabular}

Sub Offices

\section{Sub Office}

NWFP.St. 3 House 3 Nasir Bagh

Road

Nangarhar.Oppsite of Chawk

Mukhabrat

Bamyan. Yakawlang District

City / Town Phone

Peshawar 853744

\begin{tabular}{lcr}
\cline { 2 - 3 } & \multicolumn{2}{c|}{ Targeted Provinces } \\
\hline Province & Sector & \% Targeted \\
\hline Bamyan & Water Resources & 50 \\
Kabul & Infrastructure & 25 \\
Maidan & Water Resources & 25
\end{tabular}
E-mail In Charge Waheed Shah Eng.Bismullah 
NPO/RRAA (Norwegian Project Office Rural Rehabilitation Association for Afghanistan)

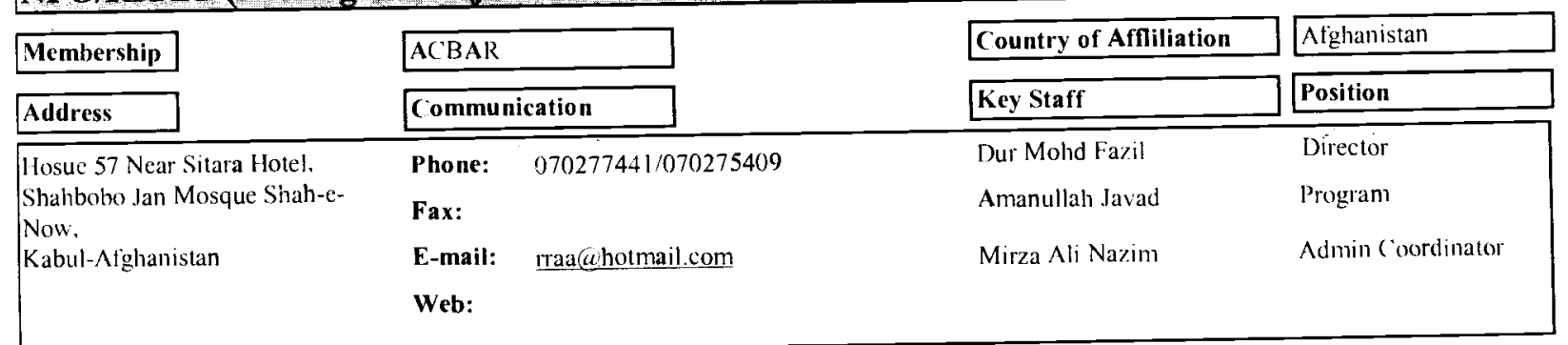

\begin{tabular}{|l|}
\hline Afghan \\
\hline \hline Pakistani \\
\hline Expatriates \\
\hline Total \\
\hline
\end{tabular}

\section{Personnel}

\begin{tabular}{|c|c|c|c|c|c|}
\hline & 1998 & 1999 & 2000 & 2001 & 2002 \\
\hline Afghanistan & $52,441,359$ & $46,689,373$ & $9,091,906$ & $22,302,449$ & $157,158,110$ \\
\hline Pakistan & $9,012,062$ & $9,140,336$ & $92,925,107$ & $322,403,224$ & $3,023,271$ \\
\hline Total & $61,453,421.00$ & $55,829,709.00$ & $102,017,013.00$ & $344,705.673 .00$ & 160.181 .381 .00 \\
\hline
\end{tabular}

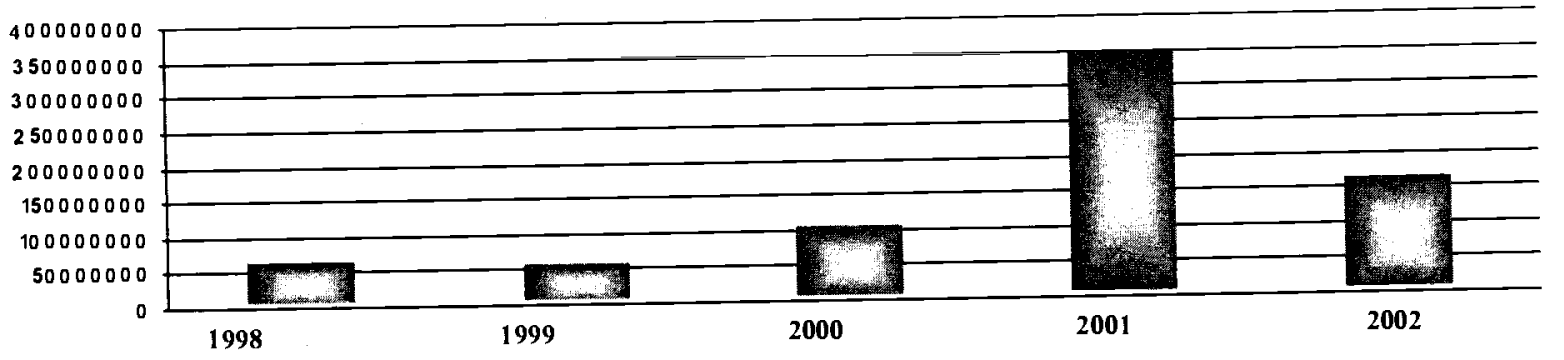

\begin{tabular}{|c|c|c|c|}
\hline \multicolumn{2}{|c|}{ Donors } & \multicolumn{2}{|c|}{ Allocation } \\
\hline Donors & $\%$ Funded & Allocation & $\%$ Funded \\
\hline $\mathrm{CA}$ & 20 & Agriculture & 10 \\
\hline ('WS & 7.3 & I:mergency & 0.44 \\
\hline DFII) & 10 & l lealth & 55 \\
\hline IRC & 23 & Infrastructure & 2 \\
\hline NCA & 24.96 & Social Programs & 10 \\
\hline $\begin{array}{l}\text { UNHC R } \\
\text { WIP }\end{array}$ & $\begin{array}{l}30 \\
1044\end{array}$ & Water Resources & 23 \\
\hline
\end{tabular}

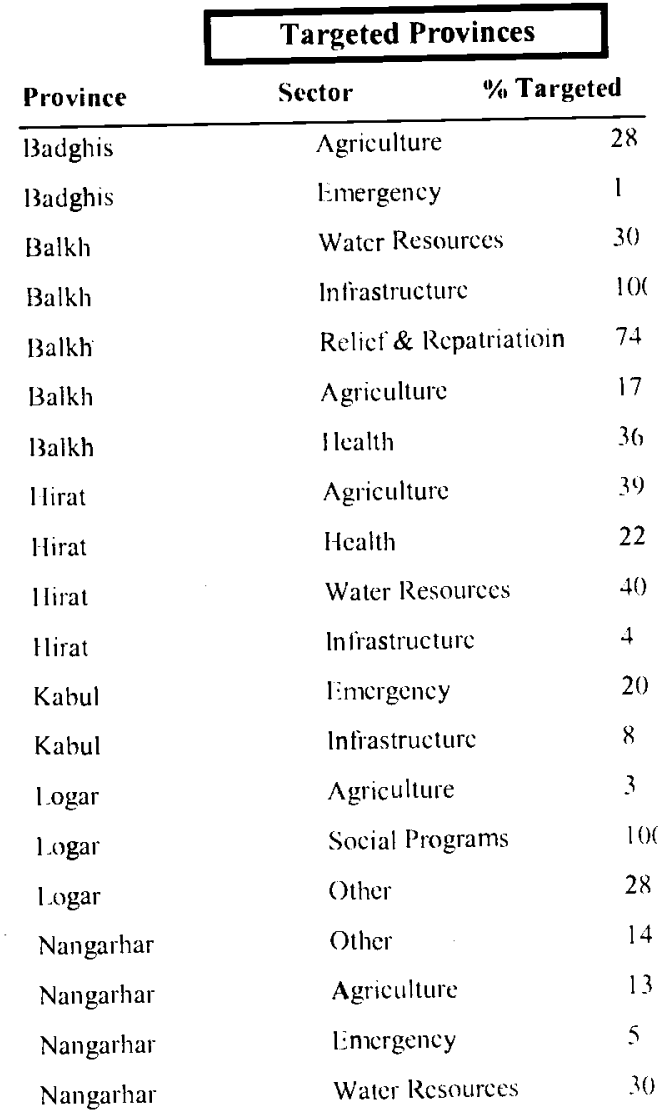




\section{Sub Offices}

\begin{tabular}{|c|c|c|c|c|c|}
\hline Sub Office & City / Town & Phone & Fax & E-mail & In Charge \\
\hline $\begin{array}{l}\text { NWFP. House } \mathrm{F} 2 / 34 \text { K.K.K Road } \\
\text { University Town }\end{array}$ & Peshawar & $851129 / 854497$ & 840107 & rraa@brain.net.pk & M.A.Nazim \\
\hline Parwan.Charikar City & Parwan & & & & Eng.Mirwais \\
\hline Parwan Bagram Town & Parwan & & & & Dauod \\
\hline Logar.Khushi Town & Logar & & & & \\
\hline Logar.Konjak Pul Alam & Logar & & & & \\
\hline $\begin{array}{l}\text { Nangarhar.Jalalabad-Kabul } \\
\text { Highway Hazratan Mosque }\end{array}$ & Jalalabad & & & & A.Qayum \\
\hline $\begin{array}{l}\text { Laghman, Opposite Qala-e-Serai } \\
\text { Mehterlam City }\end{array}$ & Laghman & & & & Fazil Rahaman \\
\hline Balkh.Kart-e-Bukhdi Mazar city & Balkh & 2629 & & & Riaz Akseer \\
\hline
\end{tabular}




\begin{tabular}{|c|c|c|c|}
\hline Membership & Other & Country of Affliliation & Afghanistan \\
\hline Address & Communication & Key Staff & Position \\
\hline \multirow{4}{*}{$\begin{array}{l}\text { Agriculture \& Gudam Sangai } \\
\text { Road, } \\
\text { Jalalabad-Afghanistan }\end{array}$} & Phone: & Noorulhaq & Director \\
\hline & Fax: & Matiwallah & Health \\
\hline & E-mail: & Atahwll Haq & Administrator \\
\hline & Web: & & \\
\hline
\end{tabular}

\begin{tabular}{|l|}
\hline Afghan \\
\hline \hline Pakistani \\
\hline \hline Expatriates. \\
\hline Total \\
\hline
\end{tabular}

11

Personnel

\begin{tabular}{|l|}
\hline Administrative \\
\hline Support \\
\hline Technical \\
\hline Total \\
\hline
\end{tabular}

Budget In US \$

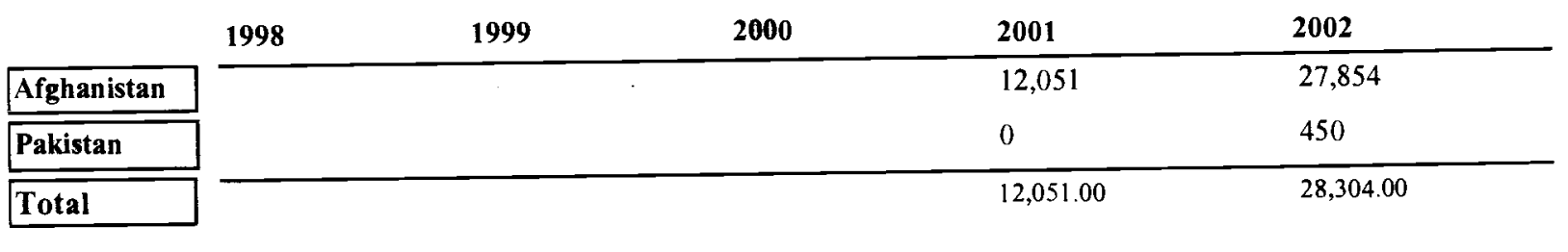

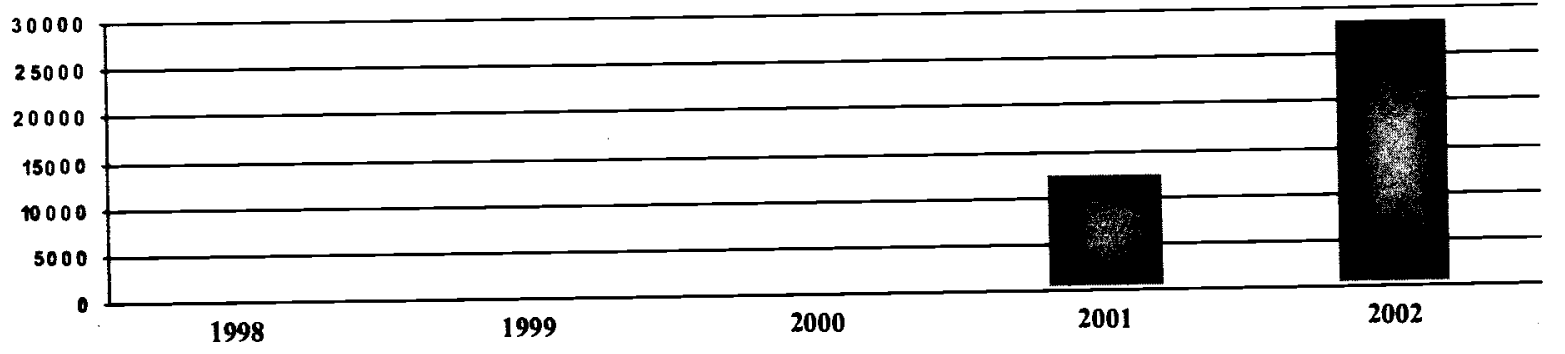

\begin{tabular}{lc|}
\hline \multicolumn{2}{c|}{ Donors } \\
Donors & $\%$ Funded \\
\hline UNAMA / WFP & 10 \\
UNHCR/UNICA & 50 \\
UNICEF & 10 \\
WFP/UNAMA & 30
\end{tabular}

\begin{tabular}{lc|} 
& \multicolumn{2}{c|}{ Allocation } \\
\hline Allocation & \% Funded \\
\hline Agriculture & 10 \\
Education & 20 \\
Emergency & 10 \\
Infrastructure & 60
\end{tabular}

\begin{tabular}{lcc} 
& \multicolumn{2}{c|}{ Targeted Provinces } \\
\cline { 2 - 3 } Province & Sector & \% Targeted \\
\hline Kabul & Education & 50 \\
Kapisa & Education & 20 \\
Logar & Infrastructure & 15 \\
Nuristan & Education & 15
\end{tabular}

Sub Offices

\begin{tabular}{|c|c|c|c|c|c|}
\hline Sub Office & City / Town & Phone & Fax & E-mail & In Charge \\
\hline Charai Qala Mosa 2nd Floor & Kabul & & & & \\
\hline
\end{tabular}




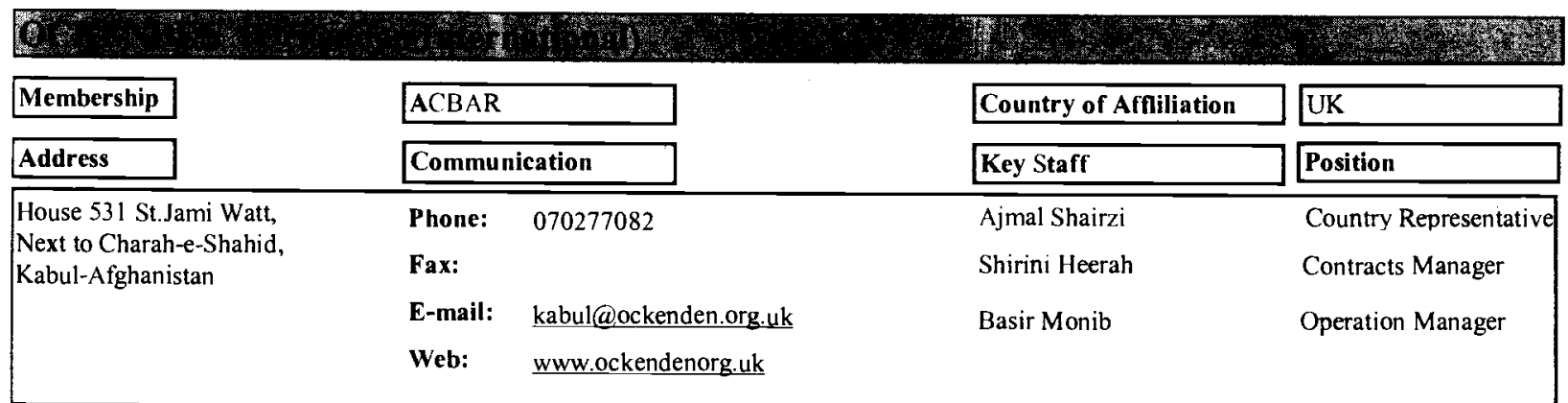

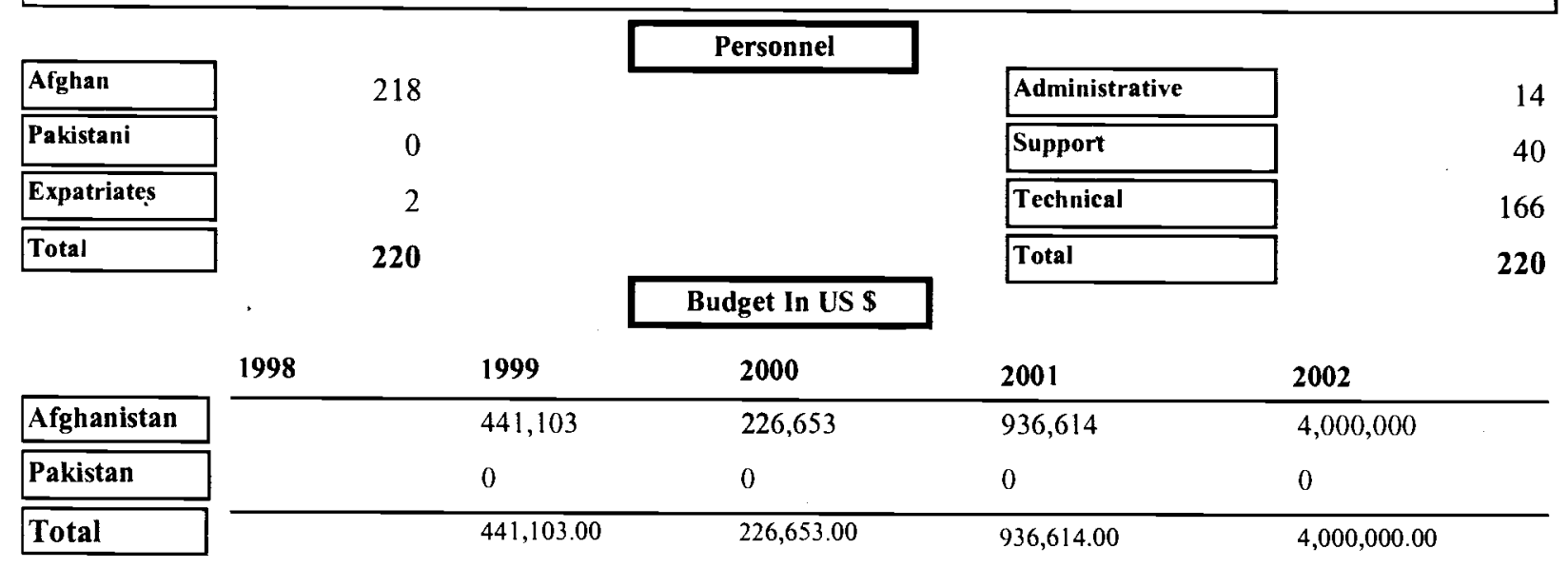

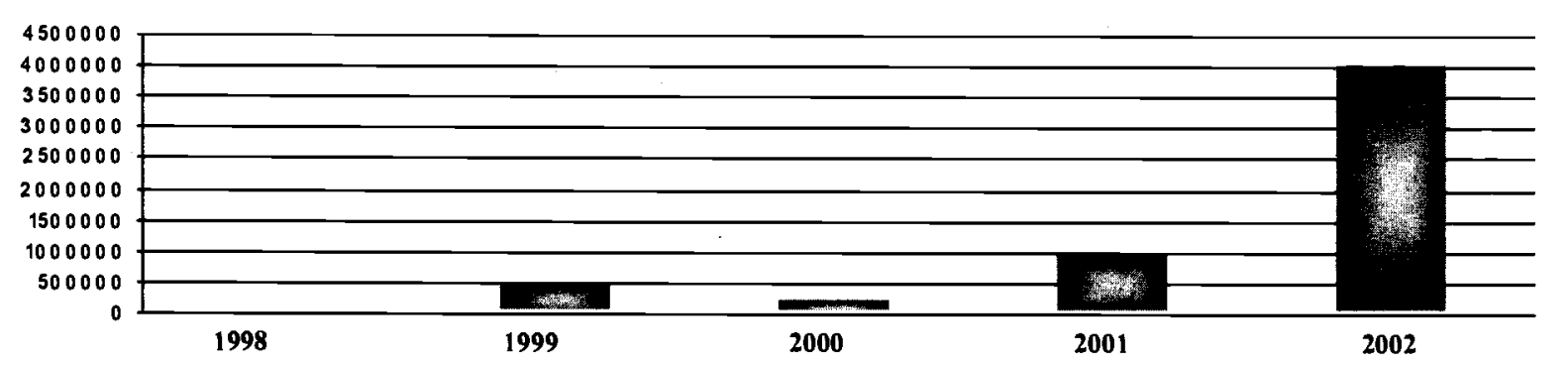

\begin{tabular}{|c|c|c|c|c|c|c|}
\hline \multicolumn{2}{|c|}{ Donors } & & location & \multirow[b]{2}{*}{ Province } & \multicolumn{2}{|c|}{ Targeted Provinces } \\
\hline Donors & $\%$ Funded & Allocation & $\%$ Funded & & Sector & $\%$ Targeted \\
\hline \multicolumn{2}{|l|}{ DFID } & Education & 17 & Badghis & \multicolumn{2}{|c|}{ Relief \& Repatriatioin } \\
\hline \multicolumn{2}{|l|}{ ECHO } & Infrastructure & 14 & Farah & \multicolumn{2}{|c|}{ Water Resources } \\
\hline \multicolumn{2}{|l|}{ EU } & Relief \& Repatria & 42 & Ghazni & \multicolumn{2}{|c|}{ Infrastructure } \\
\hline \multicolumn{2}{|l|}{ IOM } & Social Programs & 10 & Helmad & \multicolumn{2}{|c|}{ Infrastructure } \\
\hline & Water Resources & 17 & Hirat & \multicolumn{2}{|c|}{ Education } \\
\hline & & & & Nimroz & \multicolumn{2}{|c|}{ Agriculture } \\
\hline
\end{tabular}

\section{Sub Offices}

\begin{tabular}{|c|c|c|c|c|}
\hline Sub Office & City / Town & Phone & E-mail & In Charge \\
\hline $\begin{array}{l}\text { House } 250 \text { Jade-e-Mahtab Bagh-e- } \\
\text { Azadi Street }\end{array}$ & Hirat & 224059 & $\begin{array}{l}\text { ocken4@inmarsat.france } \\
\text { telecom.fr }\end{array}$ & Andjela Bajramociv \\
\hline $\begin{array}{l}\text { Zabth House Next to Haji Akhound } \\
\text { Mosque }\end{array}$ & Ghazni & +8707627500 & $\begin{array}{l}\text { ocken3@inmarsat.france } \\
\text { telecom.tr }\end{array}$ & Nasrullah Amid \\
\hline $\begin{array}{l}\text { Nimroz.Jada-e-Shamali Lasia-e- } \\
\text { Naswan }\end{array}$ & Zaranj & +882168980011 & nimroz@brain.net.pk & Nasir Ahmad \\
\hline $\begin{array}{l}\text { Helmand.Jada-e-Laghman Lashkar } \\
\text { Gah City }\end{array}$ & Lashkar Gah & +882168980011 & afgocken@brain.net.pk & Ghouse Mohd. \\
\hline House 132 St.7 District No.1 & Farah & +882168980077 & oifarah@brain.net.pk & Eng. Amin \\
\hline $\begin{array}{l}\text { Badghis.Jada-e-Marief Haji Mohd. } \\
\text { House }\end{array}$ & Qala-e-Naw & +870762867019 & $\begin{array}{l}\text { ocken2@inmarsat.france } \\
\text { telecom.fr }\end{array}$ & Eng. Ajmal Norzia \\
\hline $\begin{array}{l}\text { Apt. } 10848 \mathrm{~N} \text {-avar Building Vanak } \\
\text { Avenue Tehran } 19919\end{array}$ & Iran & +98218885105 & mosavi@safïneh.net & Nastaran Moossavi \\
\hline
\end{tabular}




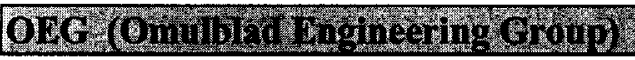

\begin{tabular}{|c|c|c|c|}
\hline Membership & Other & Country of Affliliation & Afghanistan \\
\hline Address & Communication & Key Staff & Position \\
\hline \multirow{4}{*}{$\begin{array}{l}\text { House } 2 \text { 3rd Floor Sediqyar } \\
\text { Market, } \\
\text { Hospital Road, } \\
\text { Mazar-Afghanistan }\end{array}$} & Phone: & Eng.M.Saleh & Director \\
\hline & Fax: & Eng.M.Qasim & Deputy Director \\
\hline & E-mail: & Mr.A.Rahman & Admin Officer \\
\hline & Web: & & \\
\hline
\end{tabular}

\begin{tabular}{|l|}
\hline Afghan . \\
\hline Pakistani \\
\hline Expatriates \\
\hline Total \\
\hline
\end{tabular}

\begin{tabular}{|l|r|}
\hline Administrative \\
\hline Support \\
\hline Technical \\
\hline Total \\
\hline
\end{tabular}

Budget In US \$

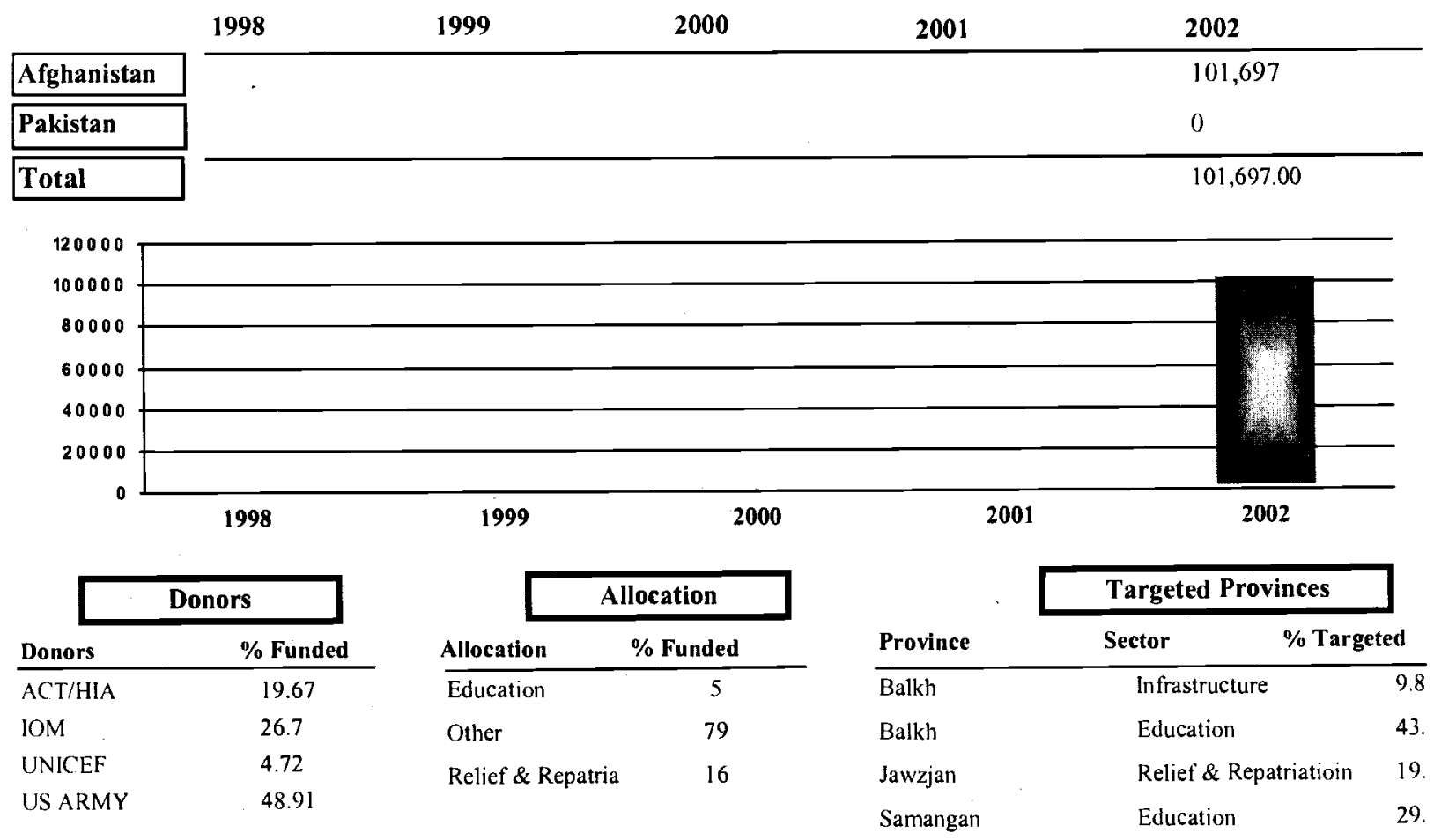

Sub Offices

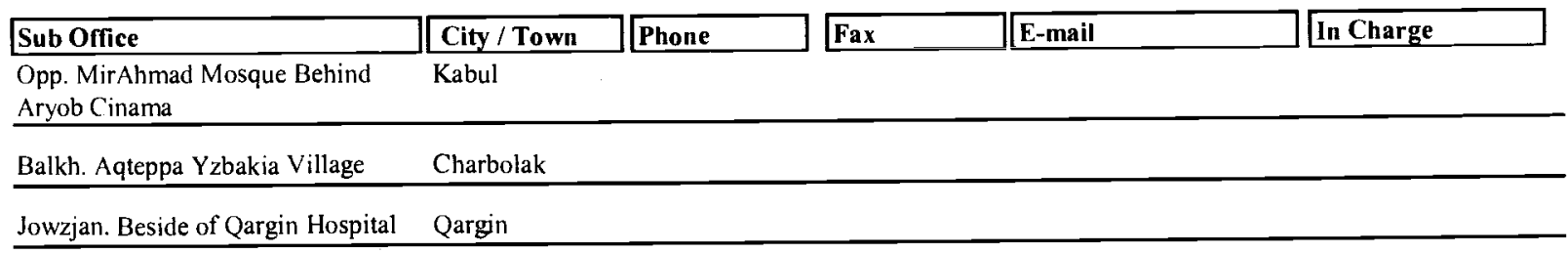


ORA (Orphans Refugees \& Aid)

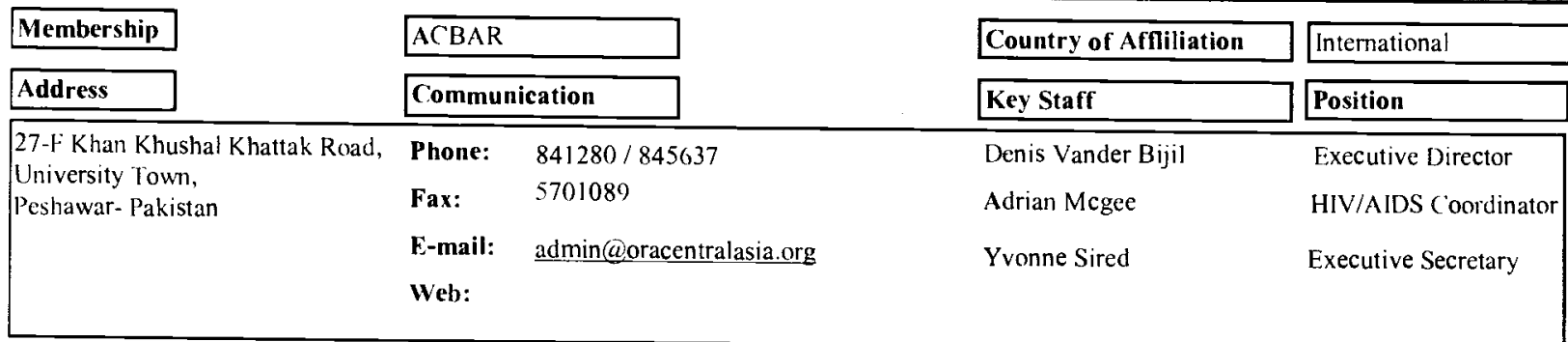

\begin{tabular}{|l|c|ll|}
\hline Afghan & 52 & Personnel & \\
\hline Pakistani & 12 & & \\
\hline Expatriates & 5 & & \\
\hline Total & 69 & & \\
\hline
\end{tabular}

\begin{tabular}{|c|c|c|c|c|c|}
\hline & 1998 & 1999 & 2000 & 2001 & 2002 \\
\hline Afghanistan & $4,603,000$ & 161,888 & $1,494,000$ & 55,000 & \\
\hline Pakistan & () & 283,864 & 243,790 & 324,697 & \\
\hline Total & $4,003,000.00$ & $445,752.00$ & $1,737,790.00$ & $379,697.00$ & \\
\hline
\end{tabular}

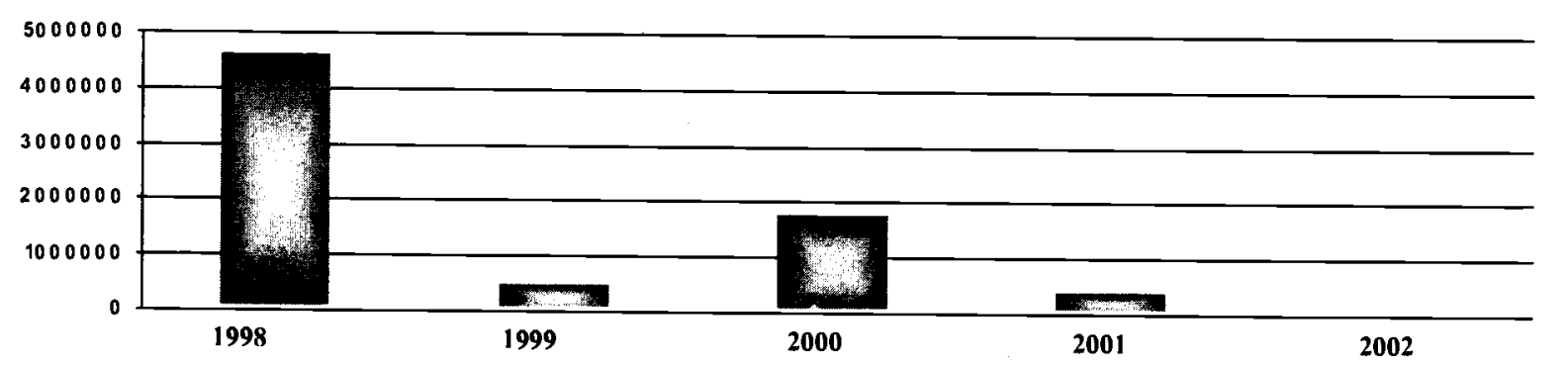

\begin{tabular}{|c|c|c|c|c|c|}
\hline \multicolumn{2}{|c|}{ Donors } & \multicolumn{3}{|c|}{ Allocation } & Targeted Provinces \\
\hline Donors & \% Funded & Allocation & $\%$ Funded & Province & $\%$ Targeted \\
\hline CMS & 3.8 & Education & 10.3 & Badakhshan & Education \\
\hline $\mathrm{DOH}$ & 5.7 & Health & 59.5 & Kabul & Health \\
\hline Dutch Embassy & 4.3 & Income Generatio & 24 & NWFP & Income Generation \\
\hline Global Sourcenet & 3.2 & Relief \& Repatria & 6.2 & NWFP & Education \\
\hline Metterdaad & 28.4 & & & & \\
\hline $\mathrm{NCA}$ & 10.4 & & & NWFP & Health \\
\hline $\mathrm{NOR} \wedge \mathrm{I})$ & 2.8 & & & & \\
\hline$O R \wedge($ ierm & 13.3 & & & & \\
\hline ()ther & 1.9 & & & & \\
\hline Icar Australia & 2.9 & & & & \\
\hline Tearfund & 17.3 & & & & \\
\hline UNDCP & 4.3 & & & & \\
\hline UNOC'IIA & 1.7 & & & & \\
\hline
\end{tabular}

Sub Offices

\begin{tabular}{|c|c|c|c|c|}
\hline Sub Office & City / Town & Phone & E-mail & In Charge \\
\hline NWFP.Street 4 Nasir Bagh Road & Peshawar & 8444 I 7 & & Hayatullah \\
\hline Badakhshan.Shahr-e-Now & Iayzabad & & & Mohd. Alam \\
\hline
\end{tabular}




\begin{tabular}{|c|c|c|c|}
\hline Membership & & Country of Affiliation & Afghanistan \\
\hline Address & Communication & Key Staff & Position \\
\hline \multirow{4}{*}{$\begin{array}{l}\text { Hotel Babari Room 9, } \\
\text { 4th Floor, } \\
\text { Mazar-Afghanistan }\end{array}$} & Phone: $\quad 3523$ & Najmudin & Director \\
\hline & Fax: & Saifuddin & Admin \\
\hline & E-mail: & & \\
\hline & Web: & & \\
\hline
\end{tabular}

\begin{tabular}{|c|c|c|c|c|}
\hline & & Personnel & & \\
\hline Afghan & 15 & & Administrative & 3 \\
\hline Pakistani & 0 & & Support & 2 \\
\hline Expatriates & 0 & & Technical & 10 \\
\hline Total & 15 & & Total & 15 \\
\hline & & Budget In US S & & \\
\hline
\end{tabular}

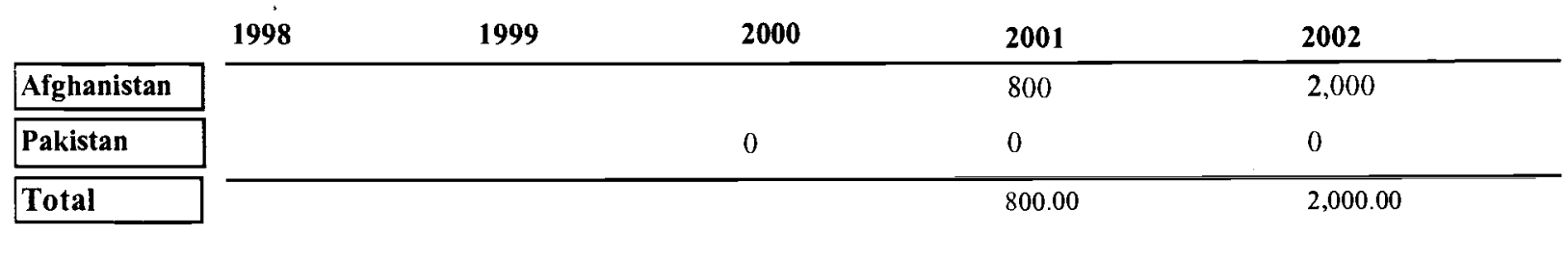

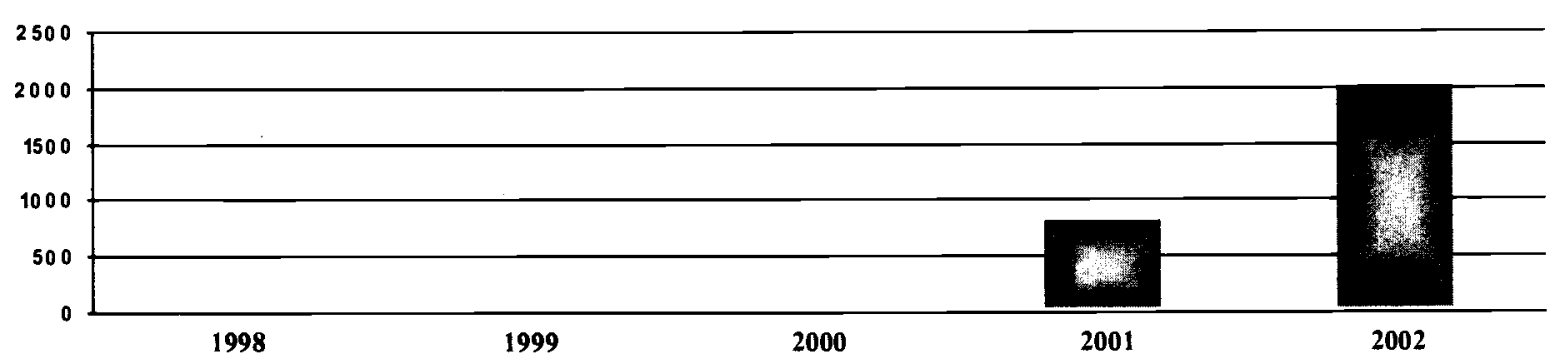

\begin{tabular}{|c|c|c|c|c|c|c|c|}
\hline \multicolumn{2}{|c|}{ Donors } & & ocation & \multirow[b]{2}{*}{ Province } & \multicolumn{3}{|c|}{ Targeted Provinces } \\
\hline Donors & $\%$ Funded & Allocation & $\%$ Funded & & Sector & $\%$ Targ & \\
\hline UNHCR & 50 & Education & 50 & Faryab & Relie & triatioin & 50 \\
\hline WFP & 50 & Relief \& Repatria & 50 & Mazar & Educ & & 50 \\
\hline
\end{tabular}

\section{Sub Offices}

\begin{tabular}{|c|c|c|c|c|}
\hline Sub Office & City / Town & Phone & E-mail & In Charge \\
\hline Jawzjan.Mudir Qayum Road & Jawzjan & 516 & & E. Shafee \\
\hline Faryab.Near Airpot Behind of Hanifa & Faryab & & & Sayfuddin \\
\hline
\end{tabular}




\begin{tabular}{|c|c|c|c|c|}
\hline Membership & ACBAR & & Country of Affliliation & GB \\
\hline Address & Commu & cation & Key Staff & Position \\
\hline \multirow{4}{*}{$\begin{array}{l}\text { 3rd Part Frist Park, } \\
\text { Faizabad New City, } \\
\text { Badskhshan-Afghanistan }\end{array}$} & Phone: & 00873762279436 & Eng.Salim & Program Coordinator \\
\hline & Fax: & 00873762279436 & Eng.Zafer & Team Leader \\
\hline & E-mail: & mohammad_salim@oxfam.org.uk & Eng.Hadi & Admin Manager \\
\hline & Web: & \multicolumn{2}{|l|}{ www.oxfam.org.uk } & \\
\hline
\end{tabular}

\begin{tabular}{|l|r|}
\hline Afghan \\
\hline Pakistani \\
\hline Expatriates \\
\hline Total \\
\hline
\end{tabular}

Personnel

\begin{tabular}{|c|c|c|c|c|c|}
\hline \multirow[t]{3}{*}{ Total } & \multicolumn{2}{|c|}{156} & & \multirow[t]{2}{*}{ Total } & \multirow{2}{*}{ 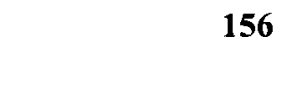 } \\
\hline & . & & Budget In US \$ & & \\
\hline & 1998 & 1999 & 2000 & 2001 & 2002 \\
\hline Afghanistan & $1,000,000$ & $1,500,000$ & & 118,120 & $1,245,120$ \\
\hline Pakistan & 0 & 0 & & 0 & 0 \\
\hline Total & $\overline{1,000,000.0}$ & $1,500,000.0$ & & $118,120.00$ & $1,245,120.00$ \\
\hline
\end{tabular}

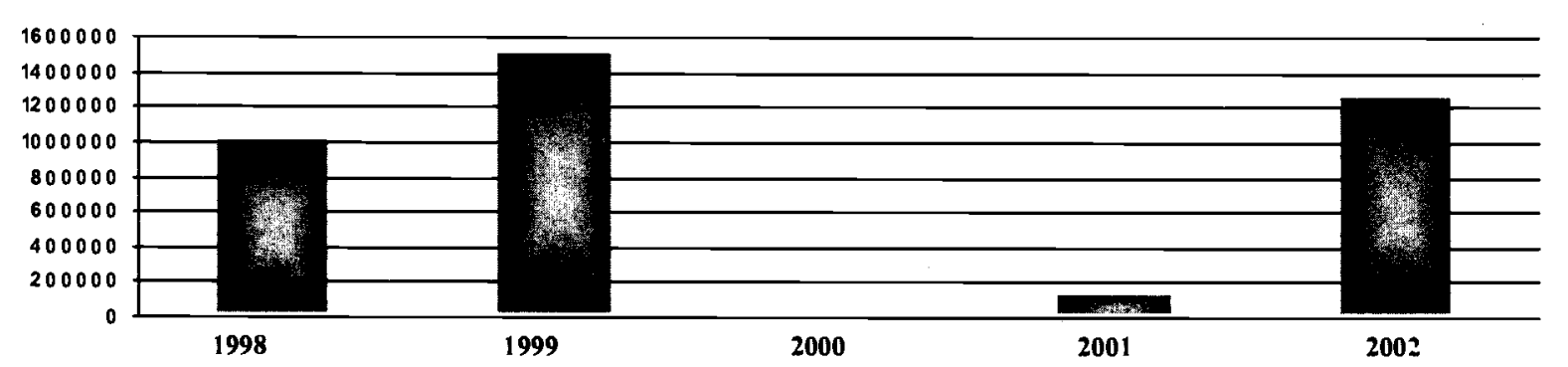

\begin{tabular}{|c|c|c|c|c|c|c|c|}
\hline \multicolumn{2}{|c|}{ Donors } & & ocation & \multirow[b]{2}{*}{ Province } & \multicolumn{3}{|c|}{ Targeted Provinces } \\
\hline \multirow{2}{*}{$\frac{\text { Donors }}{\text { OXFAM GB }}$} & \multirow{2}{*}{$\frac{\% \text { Funded }}{5}$} & \multirow{2}{*}{$\frac{\text { Allocation }}{\text { Agriculture }}$} & $\%$ Funded & & Sector & \multicolumn{2}{|c|}{$\%$ Targeted } \\
\hline & & & 20 & Badakhshan & Relie & triatioin & 85 \\
\hline \multirow[t]{8}{*}{ OXFAM US } & 95 & Education & 30 & Badakhshan & Educ & & 20 \\
\hline & & Emergency & 5 & Badakhshan & Infra & & 10 \\
\hline & & Environment & 2 & Badakhshan & Incor & ation & 20 \\
\hline & & Gender Issues & 10 & Badakhshan & Wate & & 90 \\
\hline & & Health & 15 & Badakhshan & Agric & & 20 \\
\hline & & Human Rights & 3 & & & & \\
\hline & & Income Generatio & 5 & & & & \\
\hline & & In frastructure & 10 & & & & \\
\hline
\end{tabular}

Sub Offices

\begin{tabular}{|c|c|c|c|c|}
\hline Sub Office & City / Town & Phone & E-mail & In Charge \\
\hline Badakhshan.3rd Part New City & Fayzabad & +873762279436 & $\begin{array}{l}\text { oxfam- } \\
\text { faizabad@ooxfam.org.uk }\end{array}$ & M.Salim \\
\hline $\begin{array}{l}\text { House } 319 / 322 \text { Main Darulaman } \\
\text { Road }\end{array}$ & Kabul & +873762945671 & $\begin{array}{l}\text { oxfam- } \\
\text { kabul@oxfam.org.uk }\end{array}$ & Martin Ocaga \\
\hline Near Ministry of Planing District 6 & Kandahar & +873762553310 & $\begin{array}{l}\text { oxfam- } \\
\text { kandahar@oxfam.org.uk }\end{array}$ & Willy Newman \\
\hline Niew Telecom Building & Hirat & +873762155987 & $\begin{array}{l}\text { oxfam- } \\
\text { herat@oxfam.org.uk }\end{array}$ & \\
\hline Bamyan.l'unjas District & :amyan & +873761015379 & $\begin{array}{l}\text { roerto bernardogoxfam. } \\
\text { org.uk }\end{array}$ & Roberto Bernard? \\
\hline
\end{tabular}



$\underline{\mathrm{k}}$

Oxfam Afg.in Pak. House 44 St. 59 Islamabad

4443776

4443776

agnprg@oxfam.org.uk Tariq Nazir

$18 / 3$

\section{PACTEC (eartiners In Aviation \& Communications Technology)}

\begin{tabular}{|c|c|c|c|}
\hline Membership & & Country of Afniliation & USA \\
\hline Address & Communication & Key Staff & Position \\
\hline \multirow{4}{*}{$\begin{array}{l}\text { St.13 Canel, } \\
\text { Wazir Akbar Khan, } \\
\text { Kabul-Afghanistan }\end{array}$} & 070276060 & John Woodberry & Director \\
\hline & Fax: & Todd Mcmichacl & Assistant Director \\
\hline & pacteckbl@ apactec.nt & & \\
\hline & www pactec.org & & \\
\hline
\end{tabular}

\begin{tabular}{|l|rll|}
\hline \multicolumn{1}{|c|}{} & 30 & Personnel \\
\hline Afghan & 5 & \\
\hline Pakistani & 6 & & Support \\
\hline Expatriates & 41 & & Technical \\
\hline Total & & \\
\hline
\end{tabular}

Budget In US \$

\begin{tabular}{|lllll} 
& 1999 & 2000 & 2002 \\
\hline Afghanistan & 1998 & & \\
\hline Pakistan & & & \\
\hline Total & & \\
\hline
\end{tabular}

1998

\begin{tabular}{lc}
\hline \multicolumn{2}{|c|}{ Donors } \\
Donors & $\%$ Funded \\
\hline ГC 110 & 100
\end{tabular}

1999

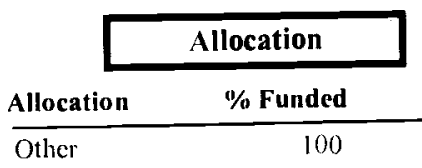

2001

2002

\section{Sub Offices}

\section{Targeted Provinces}


PARSA (Physiotherapy \& Rehabilitation Support for Afghanistan)

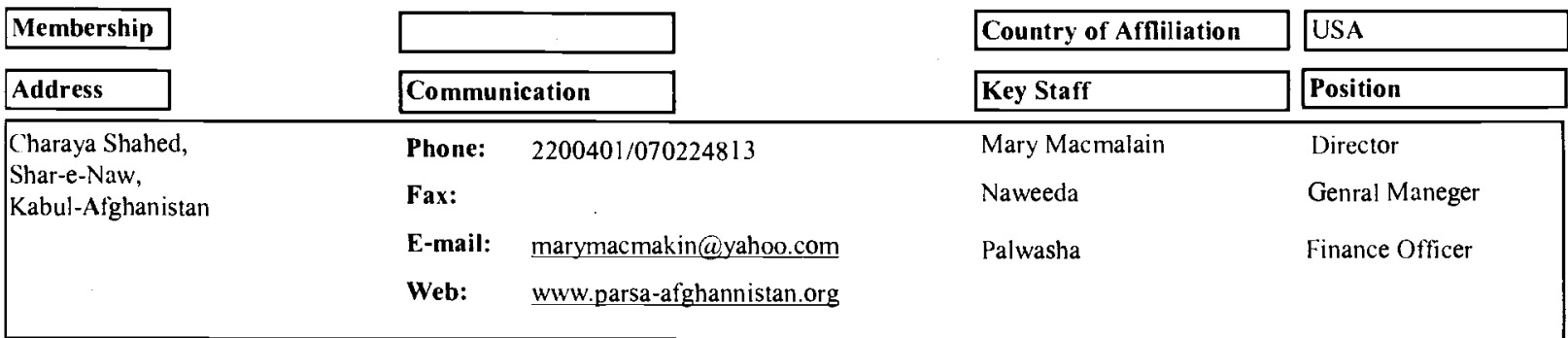

\begin{tabular}{|l|}
\hline Afghan \\
\hline Pakistani \\
\hline Expatriates \\
\hline Total \\
\hline
\end{tabular}

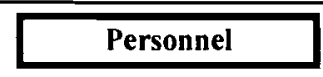

\begin{tabular}{|l|}
\hline Administrative \\
\hline Support \\
\hline Technical \\
\hline Total \\
\hline
\end{tabular}

Budget In US \$

\begin{tabular}{|l|llll}
\multicolumn{1}{l}{} & $\mathbf{1 9 9 8}$ & $\mathbf{2 0 0 0}$ & $\mathbf{2 0 0 1}$ & $\mathbf{2 0 0 2}$ \\
\cline { 3 - 5 } Afghanistan & & 181,000 & 225,000 & 360,000 \\
\hline Pakistan & & 0 & 0 & 0 \\
\hline Total & & $181,000.00$ & $225,000.00$ & $360,000.00$
\end{tabular}

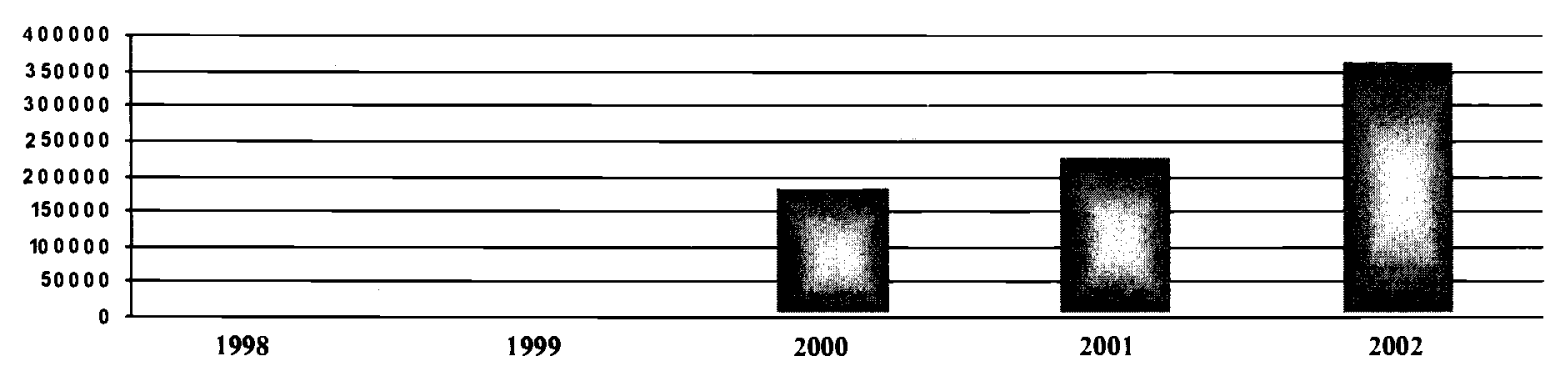

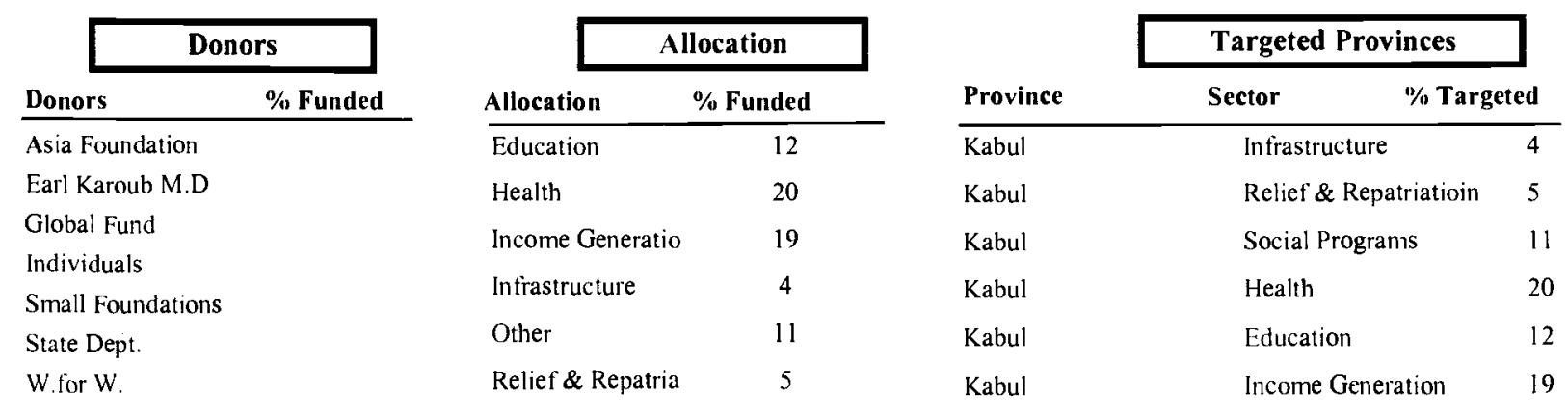

\begin{tabular}{|c|c|c|c|c|}
\hline & & Sub Offices & & \\
\hline Sub Office & City / Town & Phone & E-mail & In Charge \\
\hline Qulai Fatullah St. 2 & Kabul & 32455 & $\begin{array}{l}\text { marymacmakin@yahoo. } \\
\text { com }\end{array}$ & Nasima \\
\hline Pule Sokhta District 6 & Kabul & 32455 & $\begin{array}{l}\text { marymacmakin@yahoo. } \\
\text { com }\end{array}$ & Zahra \\
\hline Gozarqah District 7 & Kabul & 32455 & $\begin{array}{l}\text { marymacmakin@yahoo. } \\
\text { com }\end{array}$ & Saifur Rulradu \\
\hline Paghmar & Kabul & 32455 & $\begin{array}{l}\text { marymacmakin@yahoo. } \\
\text { com }\end{array}$ & Naheed \\
\hline Badakhshan.Faizabad & Faizabad & 32455 & $\begin{array}{l}\text { marymacmakin@yahoo. } \\
\text { com }\end{array}$ & Huda \\
\hline
\end{tabular}




\begin{tabular}{|c|c|c|c|}
\hline Membership & Other & Country of Affiliation & Afghanistan \\
\hline Address & Communication & Key Staff & Position \\
\hline \multirow{4}{*}{$\begin{array}{l}\text { Taimani St. } 3 \text { Across From lOMG, } \\
\text { House } 306 \text { Beside RAFA, } \\
\text { Kabul-Afghanistan }\end{array}$} & 070278048 & Monawar Khan & Director \\
\hline & & Shir Hassan & Program Officer \\
\hline & E-mail: & Eng.Rahmatulla & Administrator \\
\hline & Web: & & \\
\hline
\end{tabular}

\begin{tabular}{|c|c|c|c|c|c|}
\hline & & & Personnel & & \\
\hline Afghan & \multicolumn{2}{|c|}{14} & & Administrative & 2 \\
\hline Pakistani & \multicolumn{2}{|c|}{0} & & Support & 8 \\
\hline Expatriates & \multicolumn{2}{|c|}{0} & & Technical & 4 \\
\hline \multirow[t]{3}{*}{ Total } & & & & Total & 14 \\
\hline & . & & Budget In US S & . & \\
\hline & 1998 & 1999 & 2000 & 2001 & 2002 \\
\hline Afghanistan & & & 33,298 & 718,683 & $1,070,060$ \\
\hline Pakistan & & & 0 & 0 & 0 \\
\hline Total & & & $33,298.00$ & $718,683.00$ & $1,070,060.00$ \\
\hline
\end{tabular}

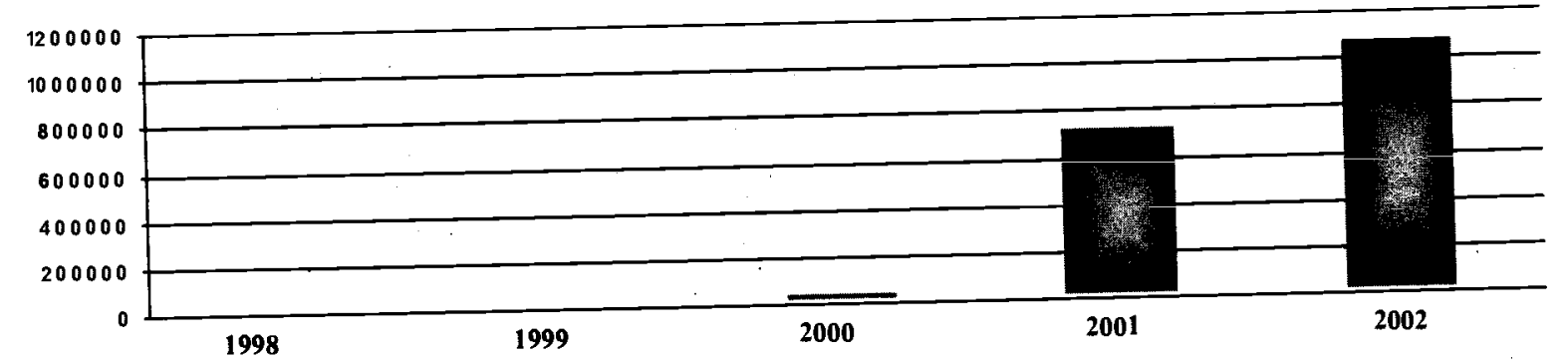

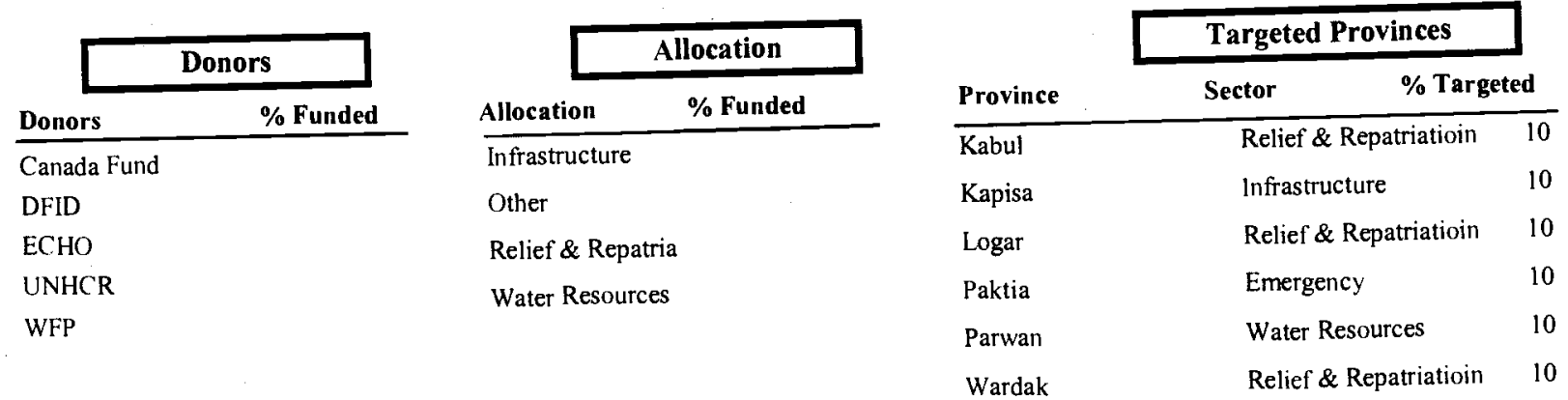

\begin{tabular}{l|l|l|l|}
\cline { 2 - 3 } & & & \\
\hline
\end{tabular}




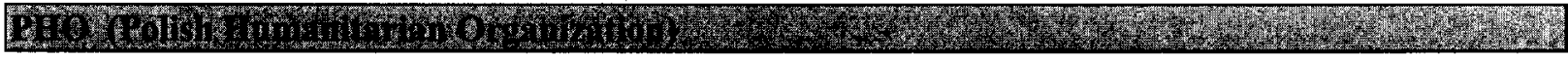

Membership

Other

Country of Affiliation

Poland

Address

Communication

Key Staff

77 Shahaboudin watt Road,

Charai-e-Haji Yagoub,

Phone: 070279554

Radoslaw Rzehak

Position

Shahr-e-Now,

Fax:

Katarzyna Pzczota

Head

Kabul-Afghanistan

E-mail: phoaf@pah.ngo.pl

Web: www.pah.ngo.pl

\begin{tabular}{|l|lll|}
\hline Afghan & \multicolumn{1}{c|}{ Personnel } & \\
\hline Pakistani & 5 & Administrative \\
\hline Expatriates & 0 & Support & 2 \\
\hline Total & 2 & & 2 \\
\hline
\end{tabular}

Budget In US S

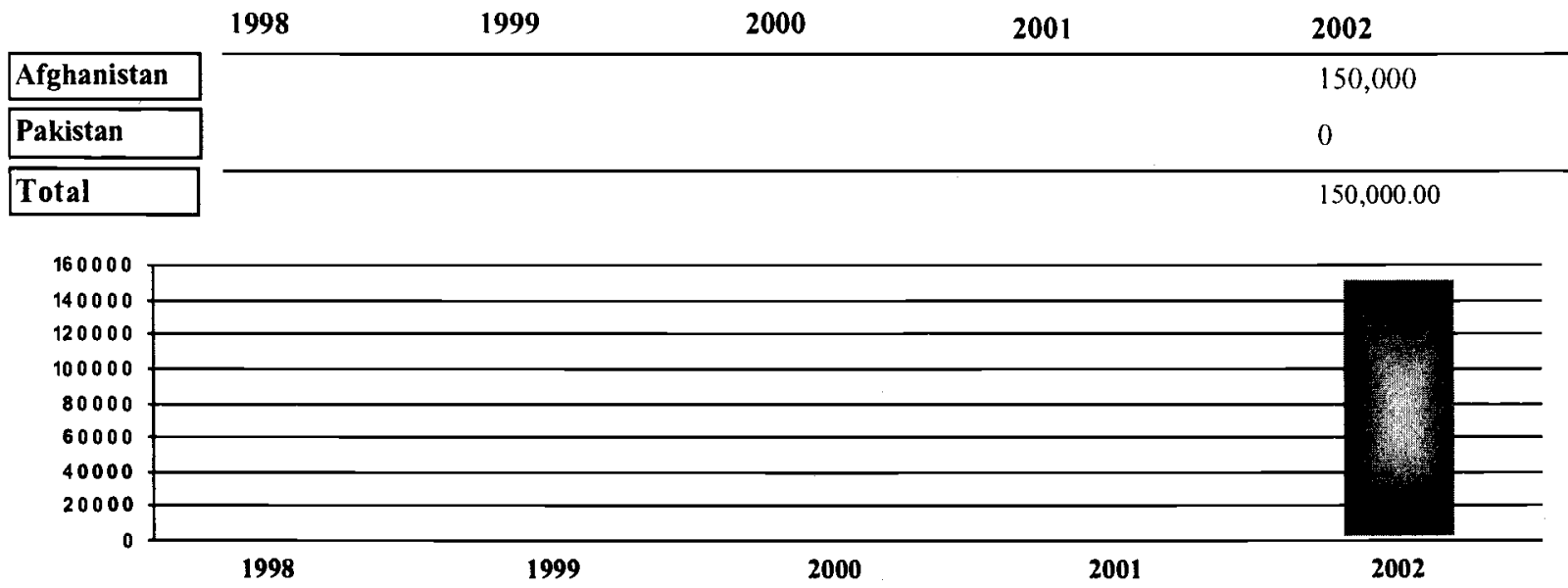

\begin{tabular}{|c|c|c|c|c|c|c|}
\hline \multicolumn{2}{|c|}{ Donors } & & llocation & \multirow[b]{2}{*}{ Province } & \multicolumn{2}{|c|}{ Targeted Provinces } \\
\hline Donors & $\%$ Funded & Allocation & $\%$ Funded & & Sector & $\%$ Targeted \\
\hline Private & 90 & Education & 90 & Kabul & Education & 10 \\
\hline UNOP & 10 & Infrastructur & 10 & & & \\
\hline
\end{tabular}


PRB (Pamir Reconstruction Bureau)

\begin{tabular}{|c|c|c|c|}
\hline Membership & ACBAR & Country of Affiliation & Afghanistan \\
\hline Address & Communication & Key Staff & Position \\
\hline \multirow{3}{*}{$\begin{array}{l}\text { House I Chaharrahi Sadarat, } \\
\text { Opp.Sadarat Main Gate, } \\
\text { Kabul- Afghanistan }\end{array}$} & $2200012 / 33262$ & Eng.M.Kabir & Executive Director \\
\hline & Fax: & Noor Hussain & Program Manager \\
\hline & E-mail: prbkabul@hotmail.com & Bahir Ahmad & Finance Manager \\
\hline
\end{tabular}

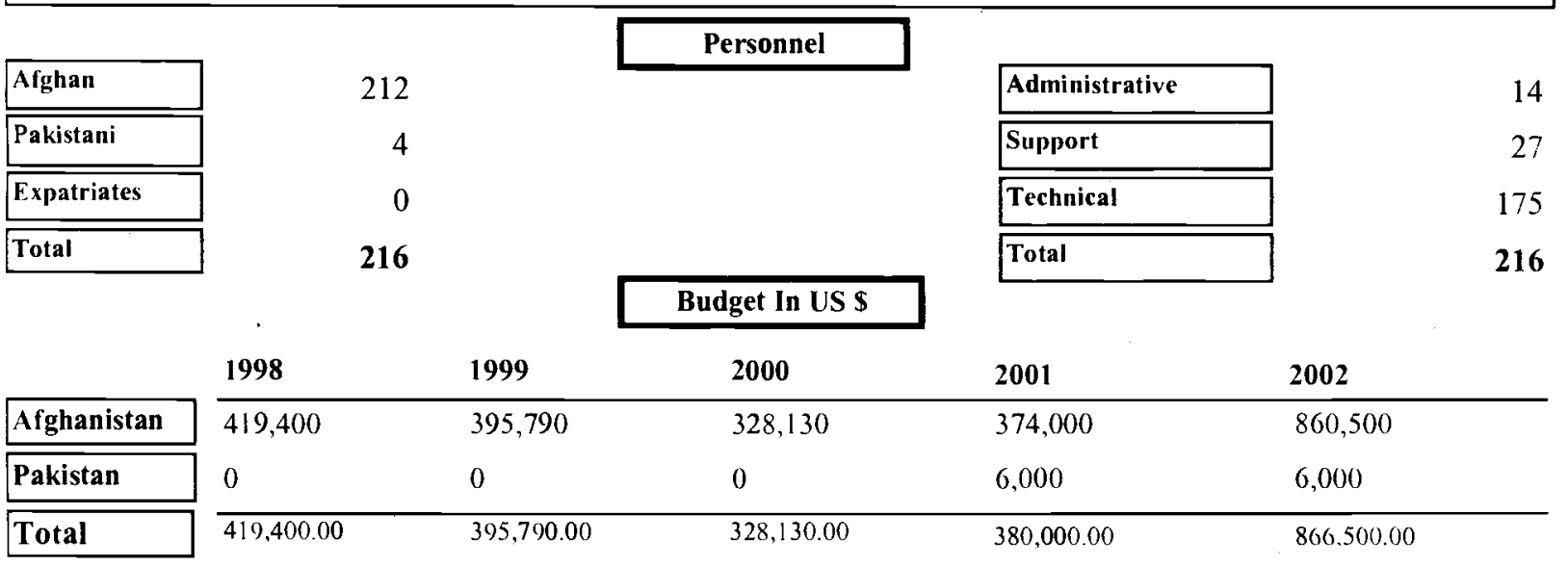

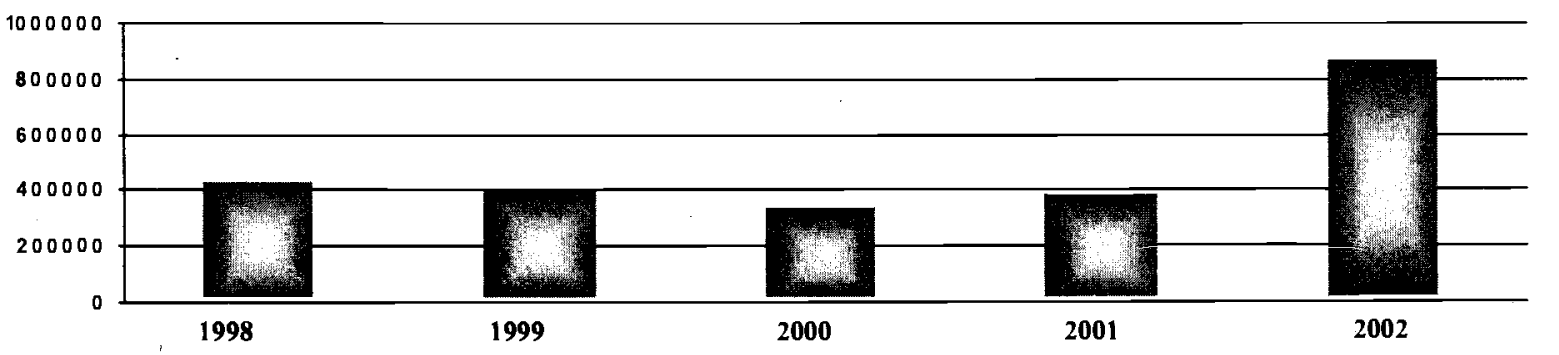

\begin{tabular}{|c|c|c|c|c|c|c|c|}
\hline \multicolumn{2}{|c|}{ Donors } & & ocation & \multirow[b]{2}{*}{ Province } & \multicolumn{3}{|c|}{ Targeted Provinces } \\
\hline Donors & $1 \%$ Funded & Allocation & $\%$ Funded & & Sector & $\%$ Targete & \\
\hline CIDA & 1.61 & Agriculture & 6.23 & Badakhshan & Infrastructure & & 29. \\
\hline DFID & 1.1 & Income Generatio & 1.09 & Badghis & Agriculture & & 0.1 \\
\hline FAO & 0.83 & Infrastructure & 81.80 & Baghlan & Agriculture & & 0.1 \\
\hline $\begin{array}{l}\text { IDRF } \\
\text { IRC }\end{array}$ & $\begin{array}{l}7.05 \\
1088\end{array}$ & Relief \& Repatria & 5.11 & Balkh & Water Resources & & 23 \\
\hline NCA & 2.43 & Water Resources & 3.36 & Faryab & Agriculture & & 2.5 \\
\hline PRB & 7.81 & & & Jawzjan & Agriculture & & 0.1 \\
\hline Private & 1.86 & & & Kabul & Education & & 43 \\
\hline UNDCP & 0.88 & & & Kunduz & Agriculture & & 0.1 \\
\hline UNOCHA & 8.34 & & & Peshawar & Education & & 0.7 \\
\hline UNOPS & 3.55 & & & Samangan & Agriculture & & 01 \\
\hline URF/KFW & 25.86 & & & & & & 0.1 \\
\hline WFP & 18.87 & & & Takhar & Agriculture & & 0.1 \\
\hline
\end{tabular}

Sub Offices

\begin{tabular}{|c|c|c|c|c|c|}
\hline Sub Office & City / Town & Phone & Fax & E-mail & In Charge \\
\hline $\begin{array}{l}\text { Balkh.Sarak-Awal-e-Takhnikoom } \\
\text { Beside Iniversity }\end{array}$ & Mazar & 41127 & & & Eng.Assadullah \\
\hline Badakhshan.Shahr-e-Now & Fayzabad & & & & Fazil Omar \\
\hline Takhar.Sarahi Sang 2nd Street & Taluqan & & & & Dr.Hedayatullah \\
\hline $\begin{array}{l}\text { NWFP.8-F(A) Rehman Baba Rd. } \\
\text { University Town }\end{array}$ & Peshawar & 5701641 & 841474 & prb@brian.net.pk & Dr.M.Zia \\
\hline
\end{tabular}


PSD (Parthners for Social Development)

\begin{tabular}{|c|c|c|c|}
\hline Membership & & Country of Affiliation & Afghanistan \\
\hline Address & Communication & Key Staff & Position \\
\hline \multirow{3}{*}{$\begin{array}{l}\text { Zakir House Ali Abad Bazaar, } \\
\text { Kerani Road, } \\
\text { Quetta-Pakistan }\end{array}$} & +4281853126 & Mirza Husain & Director \\
\hline & +4281838945 & M-A.Haideri & Asst. Director \\
\hline & E-mail: sameem@gta.paknet.com.pk & Feda Hassain & Admin Officer \\
\hline
\end{tabular}

\begin{tabular}{|c|c|c|c|c|}
\hline & & Personnel & . & \\
\hline Afghan & 32 & & Administrative & 3 \\
\hline Pakistani & 2 & & Support & 4 \\
\hline Expatriates & 0 & & Technical & 27 \\
\hline Total & 34 & & Total & 34 \\
\hline
\end{tabular}

\begin{tabular}{|c|c|c|c|c|c|}
\hline & 1998 & 1999 & 2000 & 2001 & 2002 \\
\hline Afghanistan & & 27,562 & 34,961 & 49,572 & 0 \\
\hline Pakistan & & 16,805 & 23,951 & 27,608 & 25,355 \\
\hline Total & & $44,367.00$ & $58,912.00$ & $77,180.00$ & $25,355.00$ \\
\hline
\end{tabular}

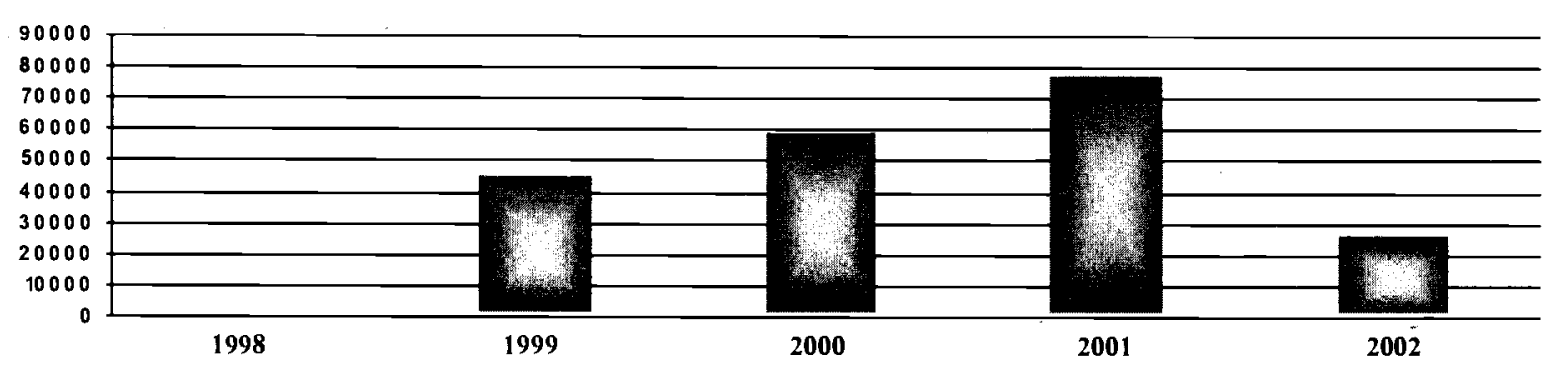

\begin{tabular}{|c|c|c|c|c|c|c|}
\hline \multicolumn{2}{|c|}{ Donors } & & Allocation & \multirow[b]{2}{*}{ Province } & \multicolumn{2}{|c|}{ Targeted Provinces } \\
\hline Donors & $\%$ Funded & Allocation & $\%$ Funded & & Sector & $\%$ Targeted \\
\hline \multirow[t]{2}{*}{ Self-Sustainable } & 100 & Education & 100 & $\overline{\text { Baluchistan }}$ & Education & 8 \\
\hline & & & & Ghazni & Education & 7 \\
\hline
\end{tabular}

Sub Offices

\begin{tabular}{|c|c|c|c|c|c|}
\hline Sub Office & \begin{tabular}{|l} 
City / Town \\
\end{tabular} & Phone & $\overline{\text { Fax }}$ & E-mail & In Charge \\
\hline $\begin{array}{l}\text { House } 42 \text { St.1 Bagha-Balla Road } \\
\text { Parwan } 2 \text { (howk }\end{array}$ & Kabul & & & $\begin{array}{l}\text { naveen } \\
\text { o.com }\end{array}$ & Abdullahi \\
\hline
\end{tabular}




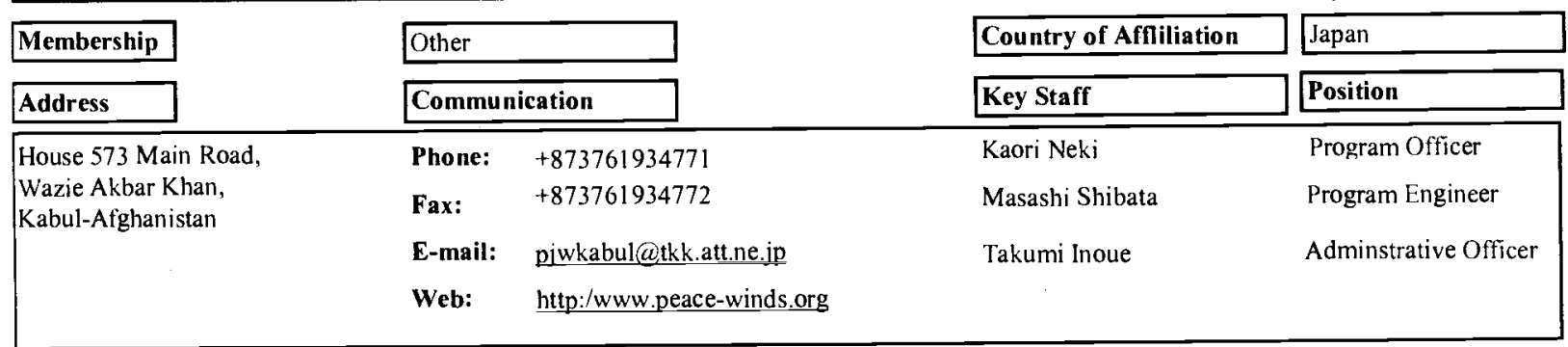

\begin{tabular}{|l|}
\hline Afghan \\
\hline \hline Pakistani \\
\hline Expatriates \\
\hline Total \\
\hline
\end{tabular}

\begin{tabular}{|l|}
\hline Administrative \\
\hline Support \\
\hline Technical \\
\hline Total \\
\hline
\end{tabular}

\begin{tabular}{|c|c|c|c|}
\hline & 1998 & 2000 & 2002 \\
\hline Afghanistan & & $2,331,000$ & $1,696,240$ \\
\hline Pakistan & & 0 & 0 \\
\hline Total & & $2,331,000.00$ & $1,696,240.00$ \\
\hline
\end{tabular}

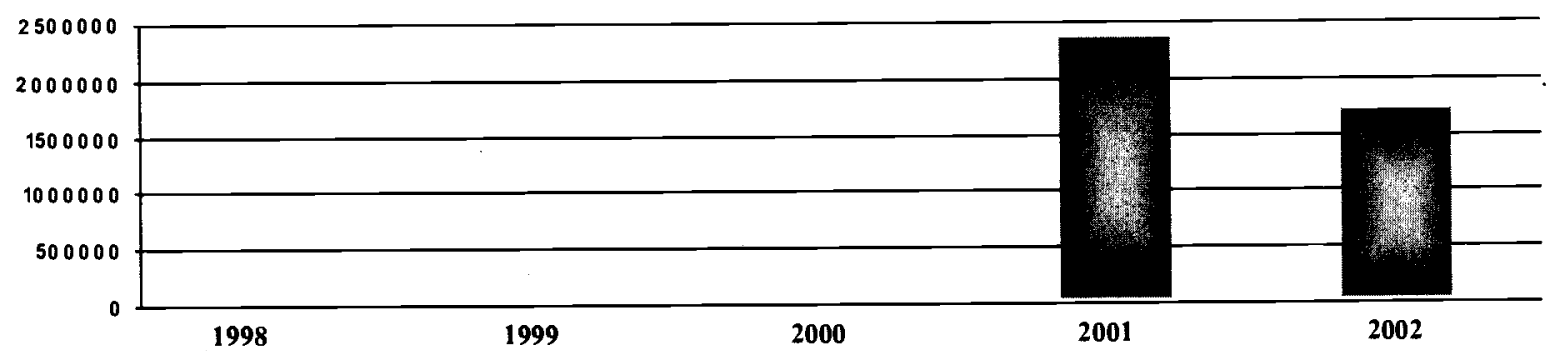

\begin{tabular}{|c|c|c|c|c|c|c|c|}
\hline \multicolumn{2}{|c|}{ Donors } & & location & \multirow[b]{2}{*}{ Province } & \multicolumn{3}{|c|}{ Targeted Provinces } \\
\hline Donors & $\%$ Funded & Allocation & $\%$ Funded & & Sector & $\%$ Target & \\
\hline \multirow{10}{*}{$\begin{array}{l}\text { Donations } \\
\text { Japan Govt. } \\
\text { Membership Fee } \\
\text { Other } \\
\text { UN Agencies }\end{array}$} & \multirow{2}{*}{$\begin{array}{l}14.5 \\
6.2\end{array}$} & Agriculture & 10 & Kabul & Veterinary & \multicolumn{2}{|r|}{0} \\
\hline & & \multirow{3}{*}{$\begin{array}{l}\text { Emergency } \\
\text { Income Generatio } \\
\text { Infrastructure }\end{array}$} & 20 & Kabul & \multicolumn{3}{|l|}{ Education } \\
\hline & $\begin{array}{l}24.7 \\
21.6\end{array}$ & & 10 & Kabul & \multicolumn{3}{|c|}{ Water Resources } \\
\hline & \multirow{2}{*}{33} & & 60 & Kabul & \multicolumn{3}{|c|}{ Infrastructure } \\
\hline & & & & Sari Pul & \multicolumn{3}{|l|}{ Other } \\
\hline & & & & Sari'Pul & \multicolumn{3}{|c|}{ Water Resources } \\
\hline & & & & Sari Pul & \multicolumn{3}{|l|}{ Agriculture } \\
\hline & & & & Sari Pul & \multicolumn{3}{|c|}{ Infrastructure } \\
\hline & & & & Sari Pul & \multicolumn{3}{|c|}{ Relief \& Repatriatioin } \\
\hline & & & & Sari Pul & \multicolumn{3}{|l|}{ Emergency } \\
\hline
\end{tabular}

Sub Offices

\begin{tabular}{|c|c|c|c|c|c|}
\hline Sub Office & City / Town & Phone & $\overline{F a x}$ & E-mail & In Charge \\
\hline Balkh.1st Street Kart-e-Sulh & Mazar & +873761856387 & +87376285461 & pwjmazar@zah.att.ne.jp & Takumi Inoue \\
\hline Sari Pul.New Town & Sari Pul & +873762285463 & +87376285463 & pwjsarep@zah.att.ne.jp & Takumi Inoue \\
\hline Punjab.House 1-A St.49 F8/4 & Islamabad & 2855349 & 285548 & pwjisb@comsats.ne.pk & Badar Mahmood \\
\hline
\end{tabular}




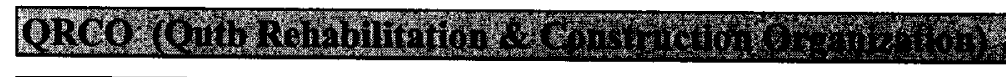

\begin{tabular}{|c|c|c|c|}
\hline Membership & Other & Country of Affiliation & Afghanistan \\
\hline Address & Communication & Key Staff & Position : \\
\hline \multirow{4}{*}{$\begin{array}{l}\text { St.Amir Alisher Nwai Road Km l, } \\
\text { Hirat-Afghanistan }\end{array}$} & Phone: $\quad 225444$ & Qutb Salahy & Director \\
\hline & Fax: & M.Qabol & Deputy \\
\hline & E-mail: & H.Gulam Sakhy & Deputy \\
\hline & Web: & & \\
\hline
\end{tabular}

\begin{tabular}{|l|lll|}
\hline Afghan & & \multicolumn{1}{c|}{ Personnel } & \\
\hline Pakistani & 8 & & 3 \\
\hline \hline Expatriates & 0 & & Administrative \\
\hline Total & 0 & & 4 \\
\hline & $\mathbf{8}$ & & Technort \\
\hline
\end{tabular}

\begin{tabular}{|c|c|c|c|c|c|}
\hline & 1998 & 1999 & 2000 & 2001 & 2002 \\
\hline Afghanistan & & & & & 110,000 \\
\hline Pakistan & & & & & 0 \\
\hline Total & & & & & $110,000.00$ \\
\hline
\end{tabular}

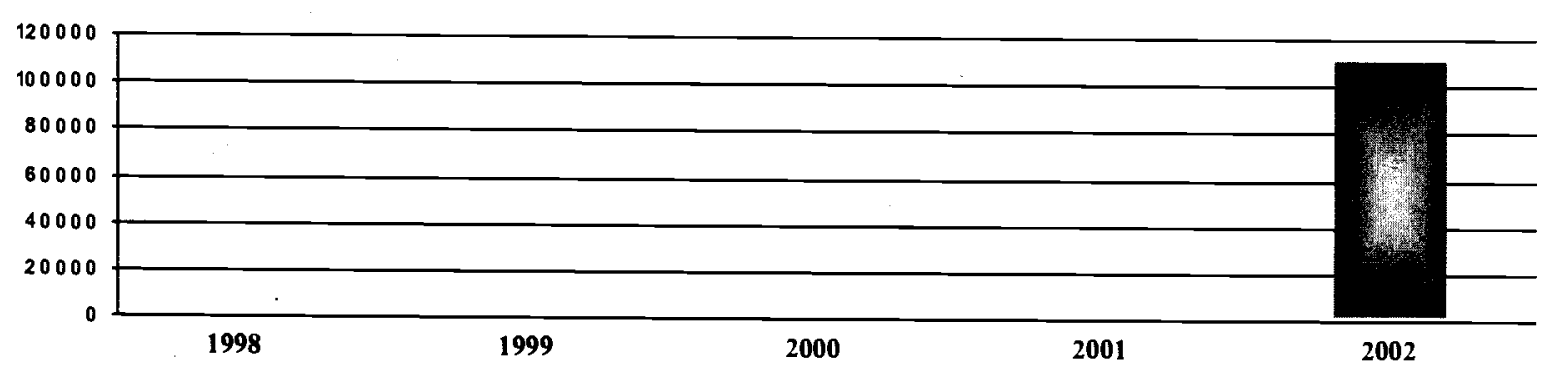

\begin{tabular}{|c|c|c|c|c|c|c|}
\hline \multicolumn{2}{|c|}{ Donors } & \multicolumn{2}{|c|}{ Allocation } & \multirow[b]{2}{*}{ Province } & \multicolumn{2}{|c|}{ Targeted Provinces } \\
\hline Donors & $\%$ Funded & Allocation & $\%$ Funded & & Sector & $\%$ Targeted \\
\hline $\mathrm{FAO}$ & 20 & Agriculture & 20 & Hirat & Infrastructure & 80 \\
\hline UNHCR & 80 & Infrastructure & 80 & Hirat & Agriculture & 20 \\
\hline
\end{tabular}

\section{Sub Offices}

\begin{tabular}{l|l|l|l|l|l|l|l|l|l|}
\hline Sub Office & City / Town & Phone & Eax Charge \\
\hline Hirat.Center of District Ghorian & Ghorian \\
\hline Hirat center of District Kosan & Kosan \\
\hline
\end{tabular}




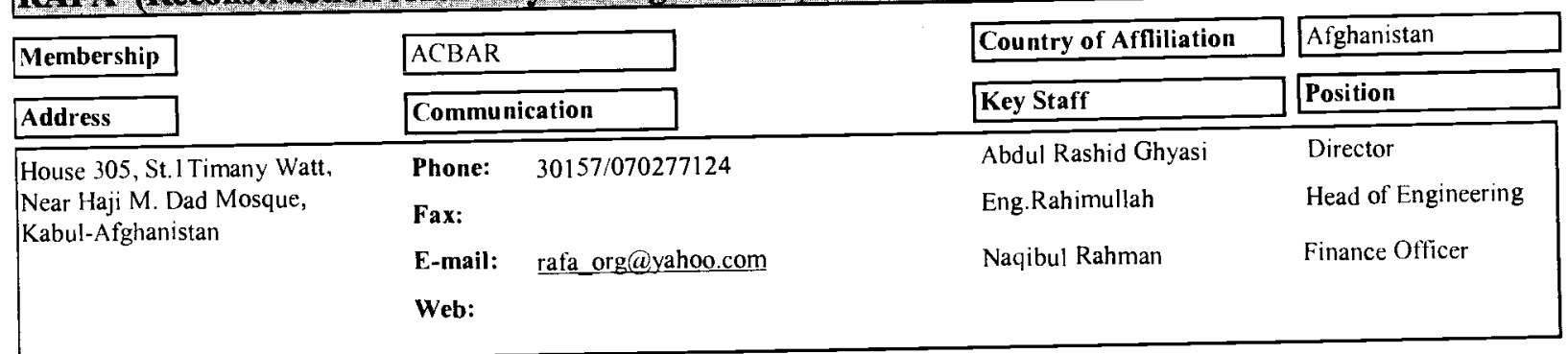

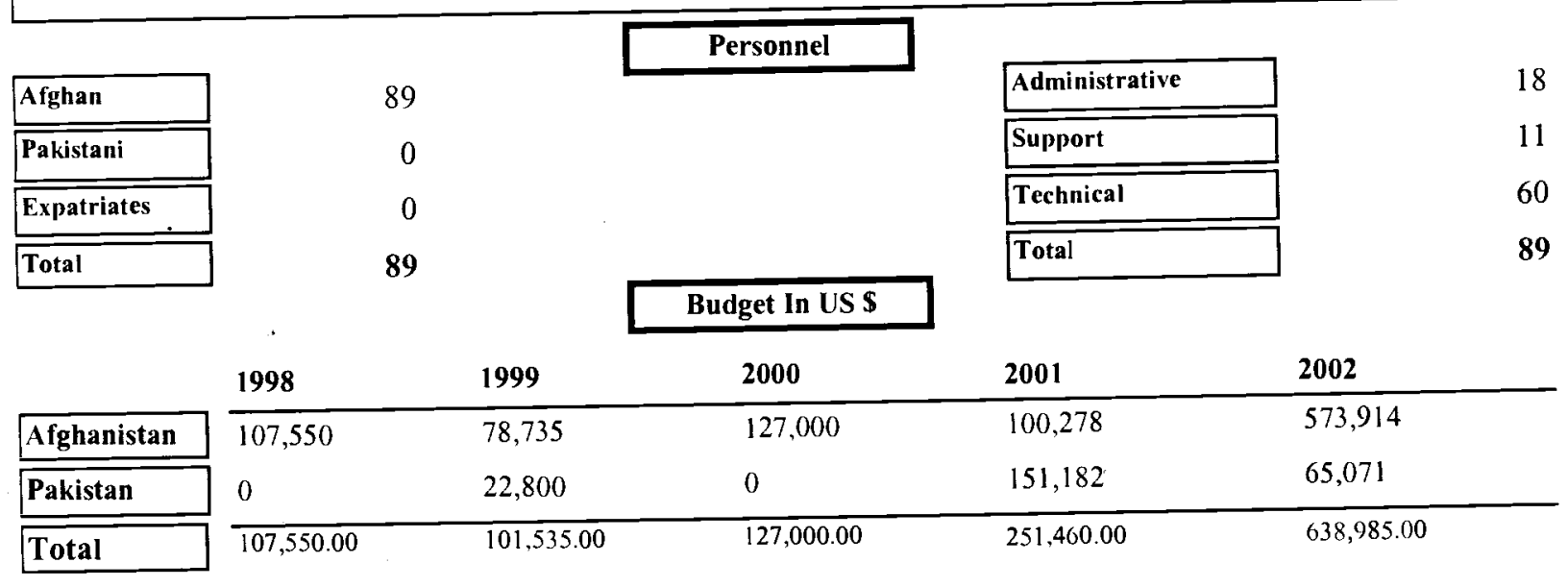

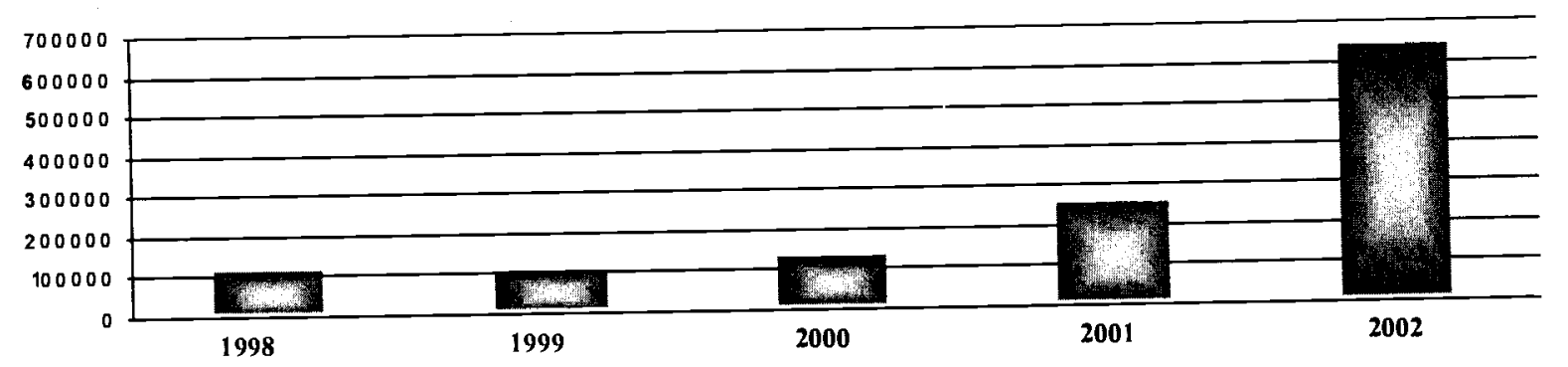

\begin{tabular}{|c|c|c|c|c|c|c|c|}
\hline \multicolumn{2}{|c|}{ Donors } & \multicolumn{2}{|c|}{ Allocation } & \multirow[b]{2}{*}{ Province } & \multicolumn{3}{|c|}{ Targeted Provinces } \\
\hline Donors & $\%$ Funded & Allocation & $\%$ Funded & & Sector & \multicolumn{2}{|c|}{$\%$ Targeted } \\
\hline Cordaid & 50 & Emergency & 6.3 & Baghlan & Water & rees & 4 \\
\hline FAO & 2 & Income Generatio & 3.8 & Kabul & Infras & & 11 \\
\hline IRC & 27.8 & Infrastructure & 11.2 & Kandahar & Wate & rees & 8 \\
\hline \multirow[t]{4}{*}{ UNICEF } & 10.2 & Relief \& Repatria & 53 & NWFP & Emer & & 10 \\
\hline & & Water Resources & 25.7 & Paktya & Wate & irces & 10 \\
\hline & & & & Parwan & Relie & Datriatioin & 53 \\
\hline & & & & Samangan & Wate & Irces & 3 \\
\hline
\end{tabular}

\begin{tabular}{|c|c|c|c|c|c|}
\hline & & Sub Offices & & & \\
\hline Sub Office & City/ Town & Phone & Fax & E-mail & In Charge \\
\hline $\begin{array}{l}\text { Kandahar.Opp.ICRC Office Shahr-e- } \\
\text { Now }\end{array}$ & Kandahar & & & rafa_org@yahoo.com & M.Yusof \\
\hline $\begin{array}{l}\text { Balkh.Haji Yasin Apartment Chine } \\
\text { Froshi St. }\end{array}$ & Mazar & & & rafa_org@yahoo.com & A.Hadi \\
\hline NWFP.Flat 402 Gul Haji Plaza & Peshawar & 850593 & 850593 & rafa@brain,net.pk & Safiullah \\
\hline Nangarhar.House 12 St. 2 & Jalalabad & & & rafa org@yahoo.com & A.Rashid \\
\hline
\end{tabular}




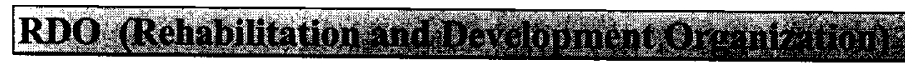

\begin{tabular}{|c|c|c|c|}
\hline Membership & ANCB & Country of Affliliation & Afghanistan \\
\hline Address & Communication & Key Staff & Position \\
\hline \multirow{4}{*}{$\begin{array}{l}\text { Latif House Qafila Road, } \\
\text { Tehkal Payan, } \\
\text { Peshawar-Pakistan }\end{array}$} & Phone: & Gul Noor & Director \\
\hline & Fax: & Ajmal Noor & Deputy Director \\
\hline & E-mail: rdo_org@hotmail.com & Najibullah & Administrative \\
\hline & Web: & & \\
\hline
\end{tabular}

\begin{tabular}{|r|}
\hline Afghan \\
\hline Pakistani \\
\hline Expatriates \\
\hline Total \\
\hline
\end{tabular}

Personnel

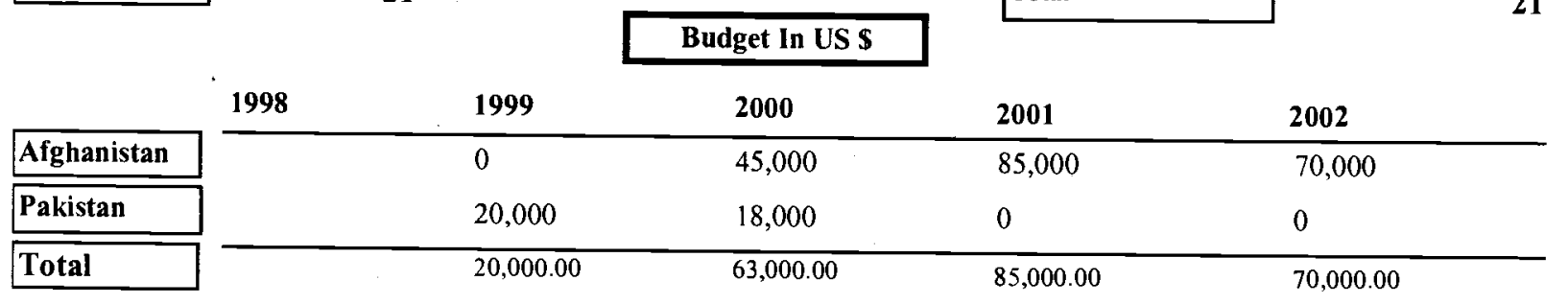

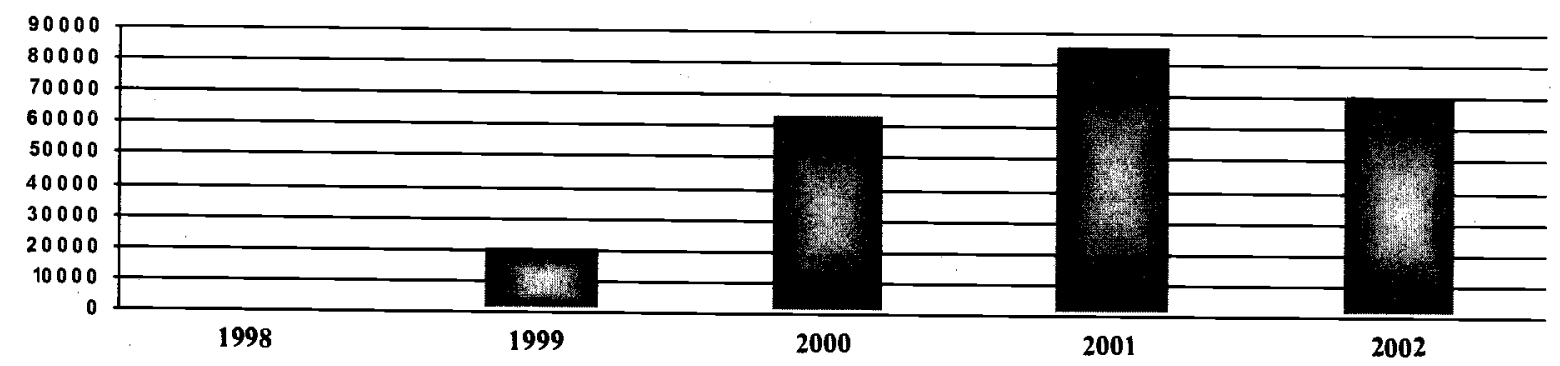

\begin{tabular}{|c|c|c|c|c|c|c|c|}
\hline \multicolumn{2}{|c|}{ Donors } & & location & \multirow[b]{2}{*}{ Province } & \multicolumn{3}{|c|}{ Targeted Provinces } \\
\hline Donors & $\%$ Funded & Allocation & $\%$ Funded & & Sector & $\%$ Targ & \\
\hline \multirow{7}{*}{$\begin{array}{l}\text { INTERSOS } \\
\text { Self Funding } \\
\text { UNHCR } \\
\text { WFP }\end{array}$} & \multirow{7}{*}{$\begin{array}{l}5 \\
5 \\
30 \\
60\end{array}$} & Agriculture & 18 & Kunar & Heal & & 12 \\
\hline & & Education & 10 & Kunar & Agri & & 18 \\
\hline & & Emergency & 5 & Nangarhar & Edu & & 10 \\
\hline & & Environment & 10 & Nangarhar & Relis & triatioin & 5 \\
\hline & & Health & 12 & Nangarhar & Envi & & 10 \\
\hline & & Infrastructure & 40 & Nangarhar & Eme & & 5 \\
\hline & & Relief \& Repa & 5 & Nangarhar & Infra & & 40 \\
\hline
\end{tabular}

\begin{tabular}{l|l|l|l|}
\hline & & \\
\end{tabular}




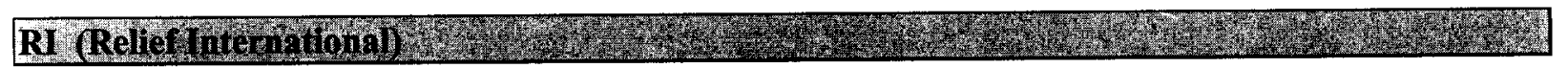

\begin{tabular}{|c|c|c|c|}
\hline Membership & ACBAR & Country of Affliliation & USA \\
\hline Address & Communication & Key Staff & Position \\
\hline \multirow{4}{*}{$\begin{array}{l}\text { Shirpoor \# } 9 \text { Butchery Street, } \\
\text { Kabul-Afghanistan }\end{array}$} & $33813 / 07077016$ & Eric James & Country Director \\
\hline & Fax: & Del-Aga Shkeeb & General manager \\
\hline & E-mail: kabul@ri.org & Durga Prasad & Finance/Admin \\
\hline & www.ri.org & & \\
\hline
\end{tabular}

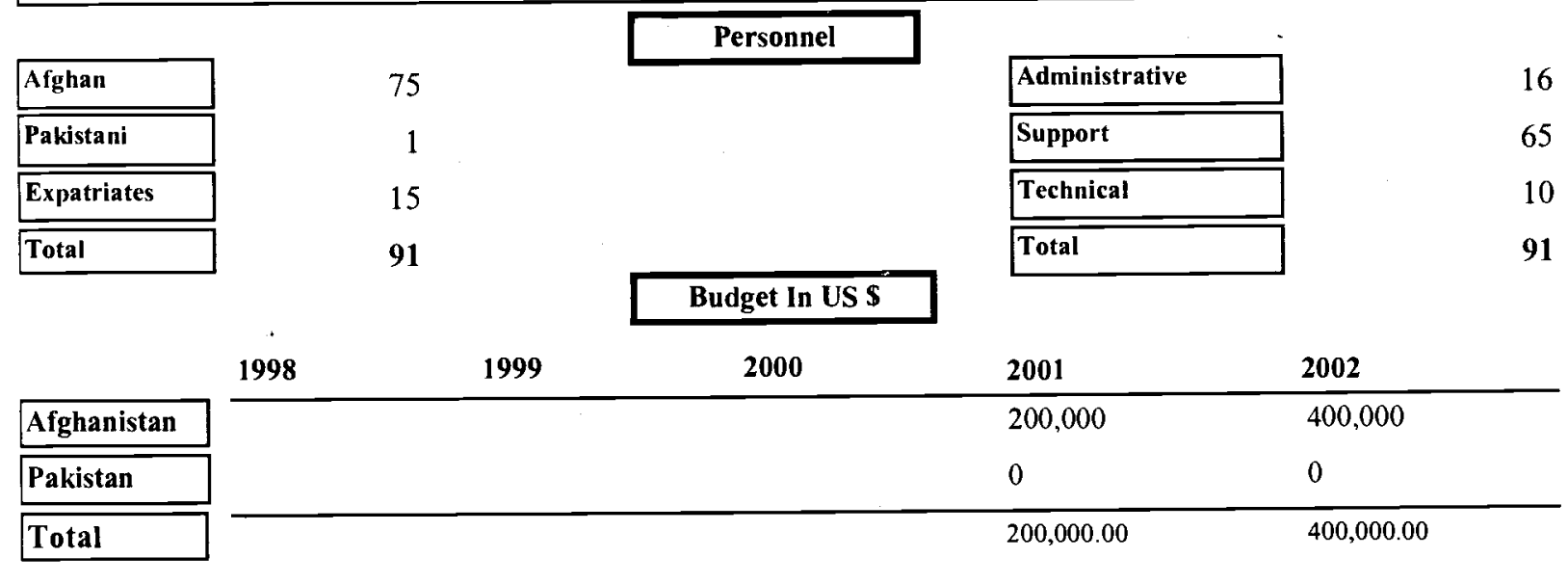

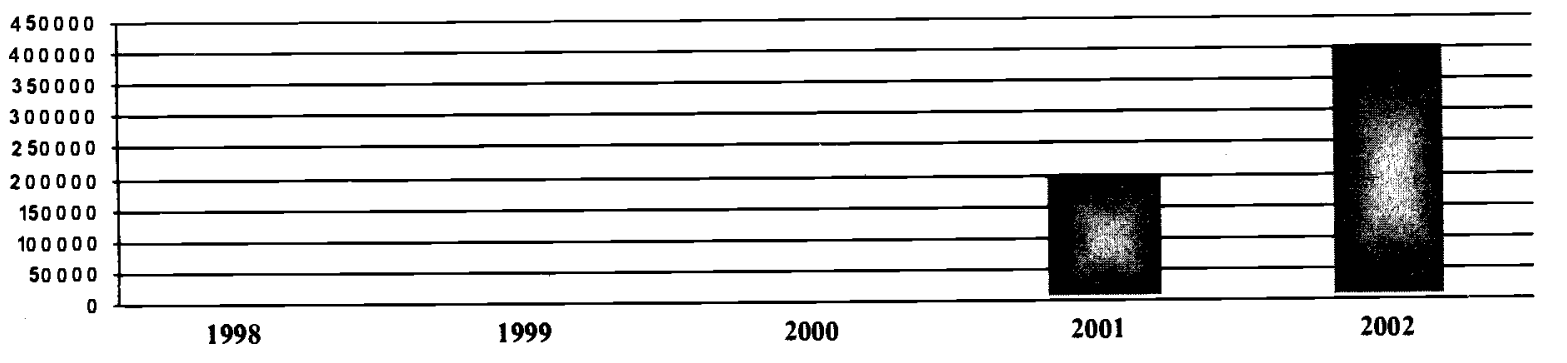

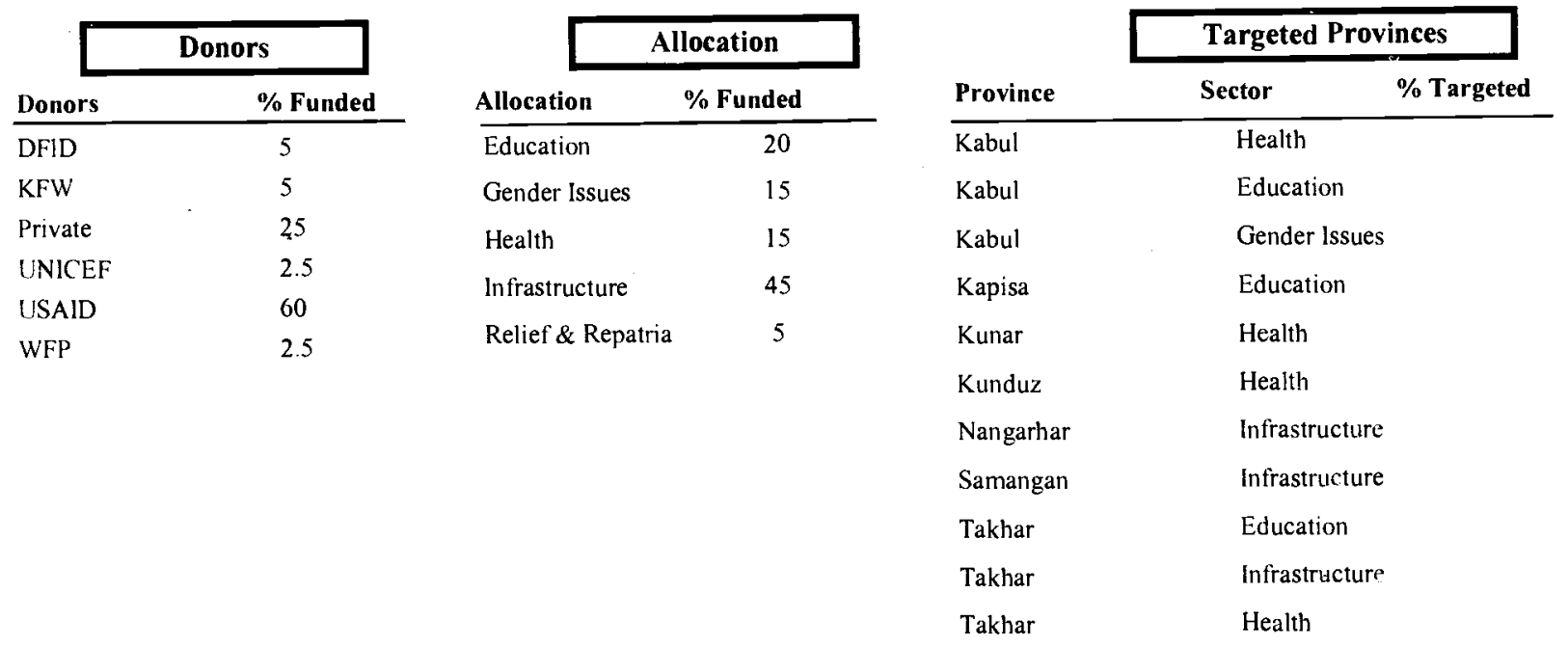

\section{Sub Offices}

\begin{tabular}{l|l|l|l|l|l|l|l|l|l|l|l|}
\hline Sub Office & City / Town & Phone & Sharge \\
Takhar.Street 3 Behind Municipal & Taluqan \\
Field & \\
\hline $\begin{array}{l}\text { Nangarhar.Street } 2 \text { House } 2 \\
\text { Chashma Khanjee }\end{array}$ & Jalalabad \\
\hline
\end{tabular}




\begin{tabular}{|llll|}
\hline Membership & Other & \multicolumn{1}{c|}{ Country of Affliliation } & Afghanistan \\
\hline Address & Communication & Key Staff & Position \\
\hline $\begin{array}{l}\text { Qala-e-Fatullah St.3, } \\
\text { House 409, }\end{array}$ & Phone: 2400610/0702276951 & Eng.Najmullah & General Director \\
Kabul-Afghanistan & Fax: & Shafi Gullah & Assistant \\
& E-mail: & Ahamd Haroon & Executive \\
& Web: & & \\
& & & \\
\hline
\end{tabular}

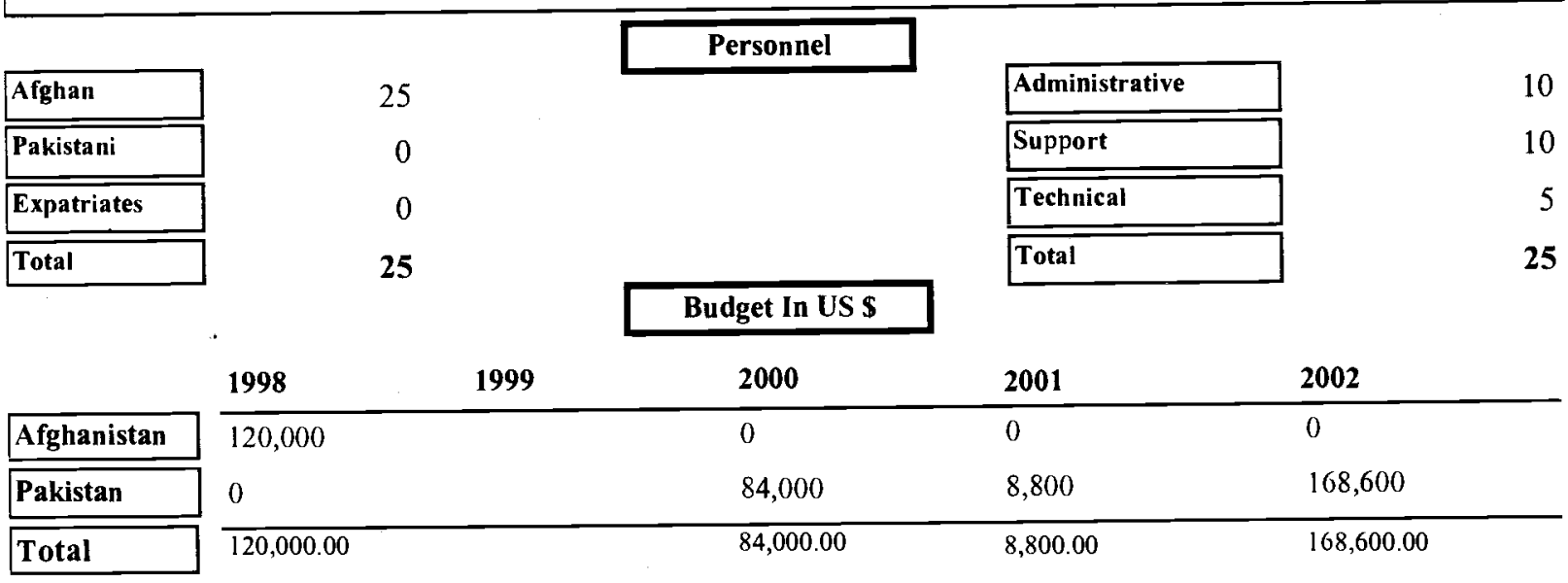

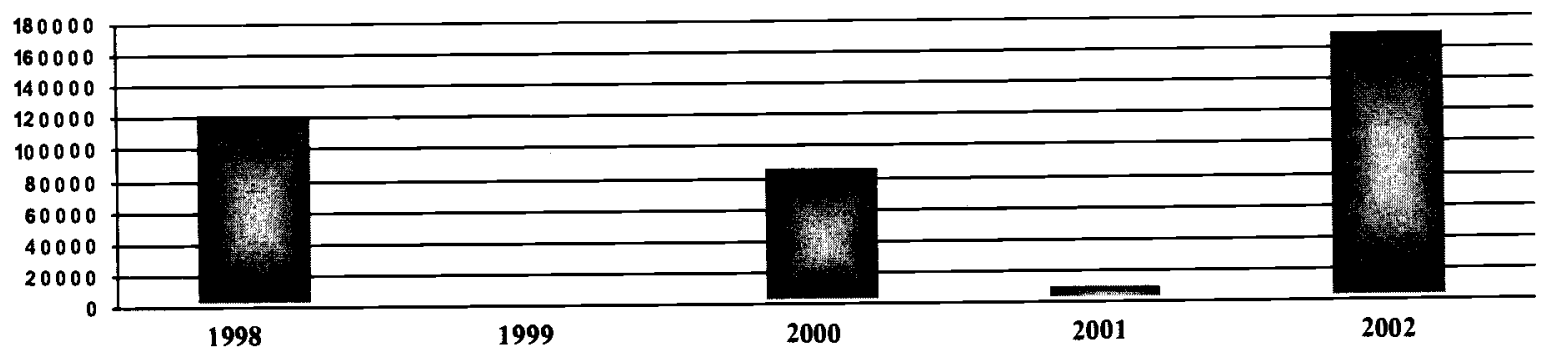

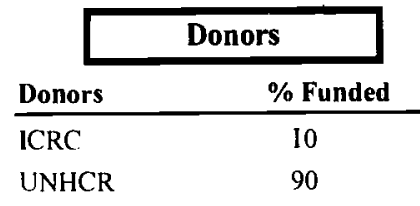

\begin{tabular}{lc|}
\hline \multicolumn{2}{|c|}{ Allocation } \\
Allocation & \% Funded \\
\hline Emergency & 10 \\
Gender Issues & 15 \\
Human Rights & 20 \\
Income Generatio & 20 \\
Infrastructure & 80
\end{tabular}

Sub Offices

\begin{tabular}{|c|c|c|c|c|c|}
\hline Sub Office & \begin{tabular}{|l|} 
City / Town \\
\end{tabular} & Phone & Fax & E-mail & In Charge \\
\hline Parwan.Cement Jabalussaraj & Jabalussaraj & & & & \\
\hline
\end{tabular}

\begin{tabular}{lcc} 
& \multicolumn{2}{c|}{ Targeted Provinces } \\
\cline { 2 - 3 } Province & Sector & \multicolumn{2}{c}{$\%$ Targeted } \\
\hline Kabul & Rapid Survey & 20 \\
Kabul & Income Generation & 66. \\
Kabul & Relief \& Repatriatioin & 50 \\
Logar & Relief \& Repatriatioin & $10 c$ \\
Parwan & Relief \& Repatriatioin & 10 \\
Wardak & Relief \& Repatriatioin & $10 c$
\end{tabular}

Wardak 0 0 5 


\begin{tabular}{|c|c|c|c|}
\hline Membership & ANCB & Country of Affiliation & Afghanistan \\
\hline \begin{tabular}{|l} 
Address \\
\end{tabular} & Communication & Key Staff & Position \\
\hline \multirow{4}{*}{$\begin{array}{l}\text { House } 2 \text { Karti Parwan St.1, } \\
\text { Kabul-Afhganistan }\end{array}$} & $2201414 / 070282009$ & Syad Ikram & Director \\
\hline & Fax: & Syad Abbas & Deputy Director \\
\hline & E-mail: $\quad \underline{\text { rssa.r@mailcity.com }}$ & Eng.Najib & Regional Manager \\
\hline & Web: & & \\
\hline
\end{tabular}

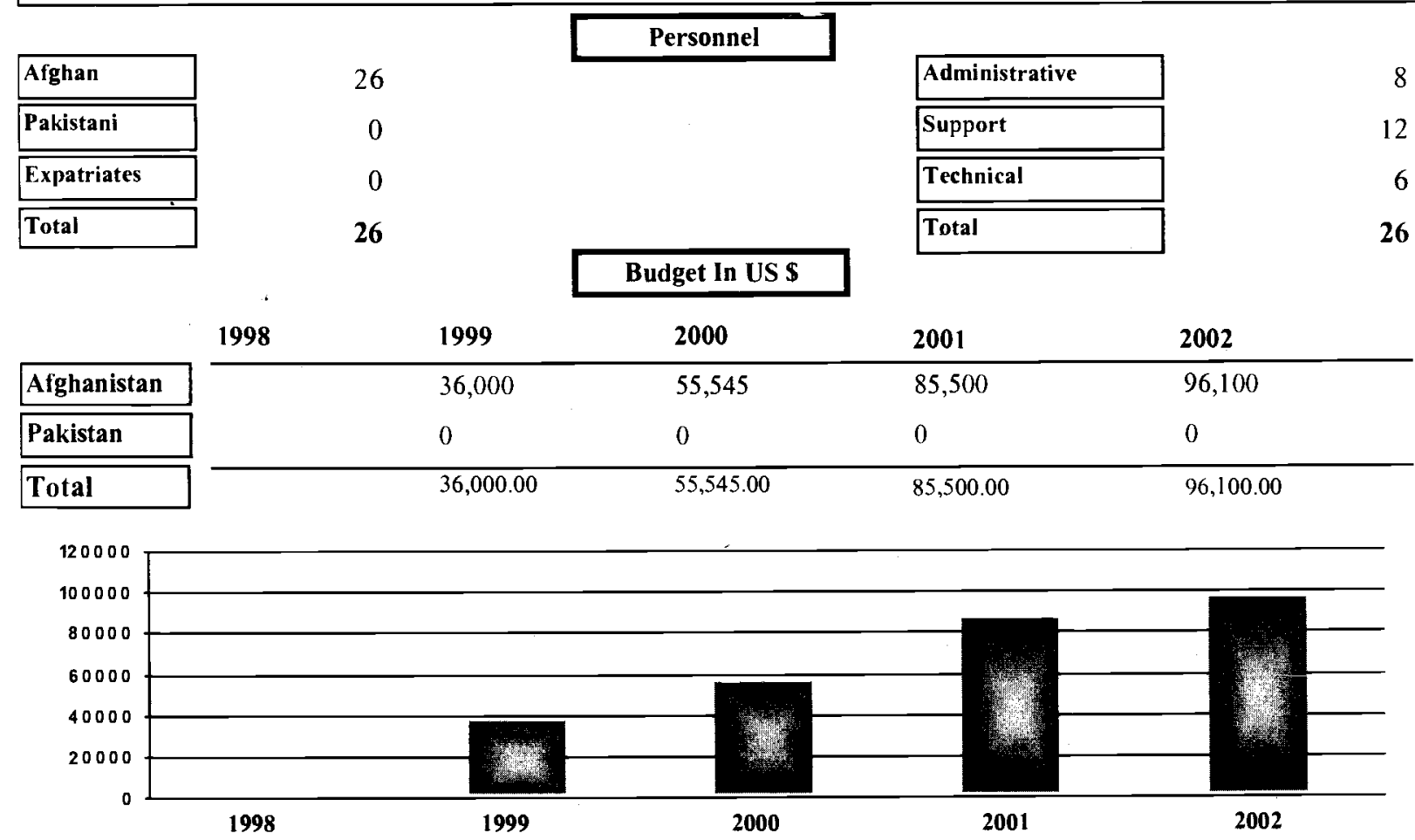

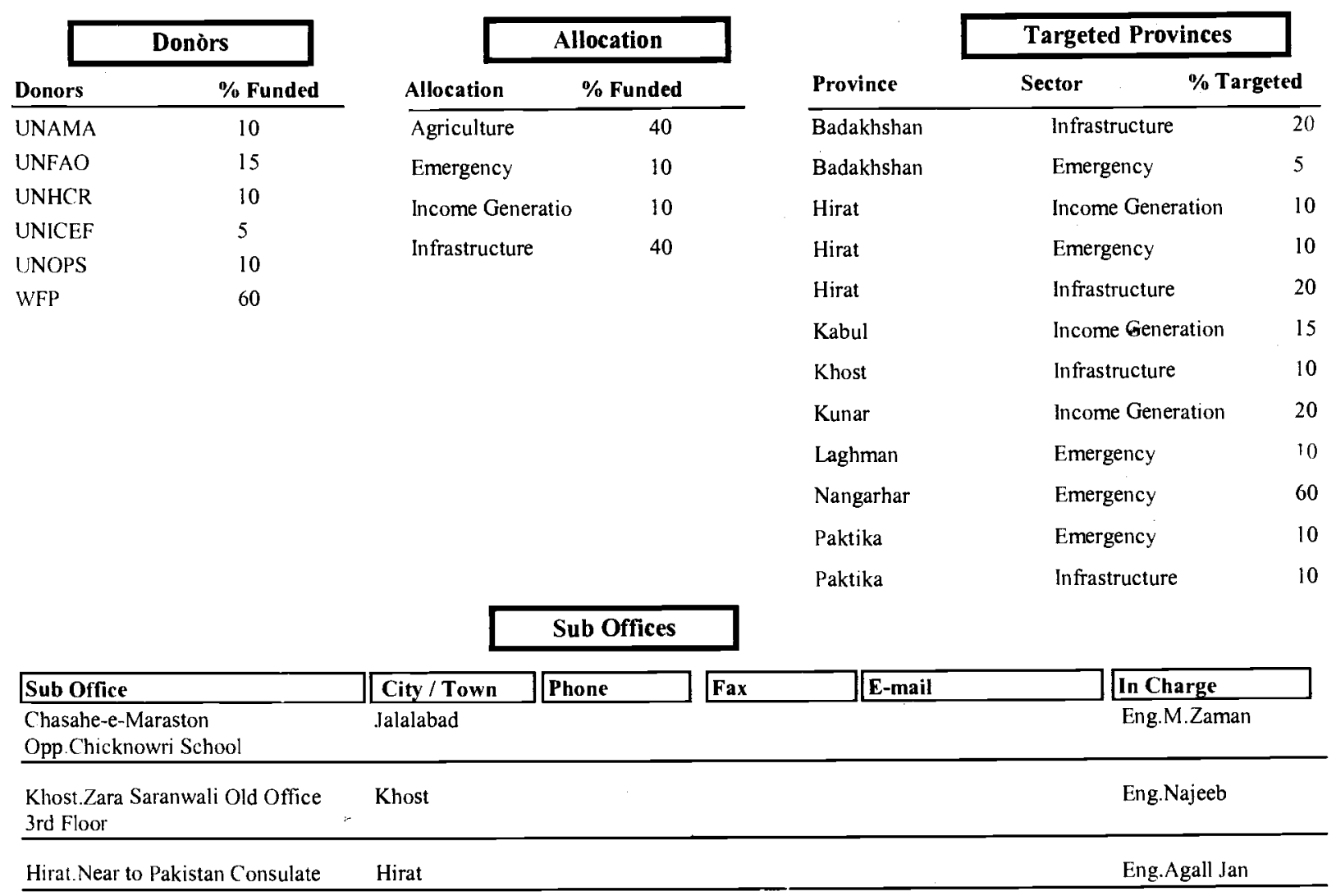




\begin{tabular}{|c|c|c|c|c|}
\hline Membership & & & Country of Affiliation & Switzerland \\
\hline Address & \multicolumn{2}{|c|}{ Communication } & Key Staff & Position \\
\hline \multirow{4}{*}{$\begin{array}{l}\text { House } 77 \text { Murad Abad Board, } \\
\text { Peshawar-Pakistan }\end{array}$} & Phone: & 842187 & Babir Shah Safi & Director \\
\hline & Fax: & 842187 & Hussain Rahimy & Deputy Director \\
\hline & E-mail: & swissaid@brain.net.pk & Mohd.Naseem & Project Manager \\
\hline & Web: & & & \\
\hline
\end{tabular}

\begin{tabular}{l|}
\hline Afghan \\
\hline Pakistani \\
\hline Expatriates \\
\hline Total
\end{tabular}

Personnel

\begin{tabular}{|l|}
\hline Administrative \\
\hline Support \\
\hline Technical \\
\hline Total \\
\hline
\end{tabular}

Budget In US \$

1998

1999

2000

2001

2002

\begin{tabular}{|l|}
\hline Afghanistan \\
\hline Pakistan \\
\hline Total \\
\hline
\end{tabular}

30,834

155,686

$186,520.00$
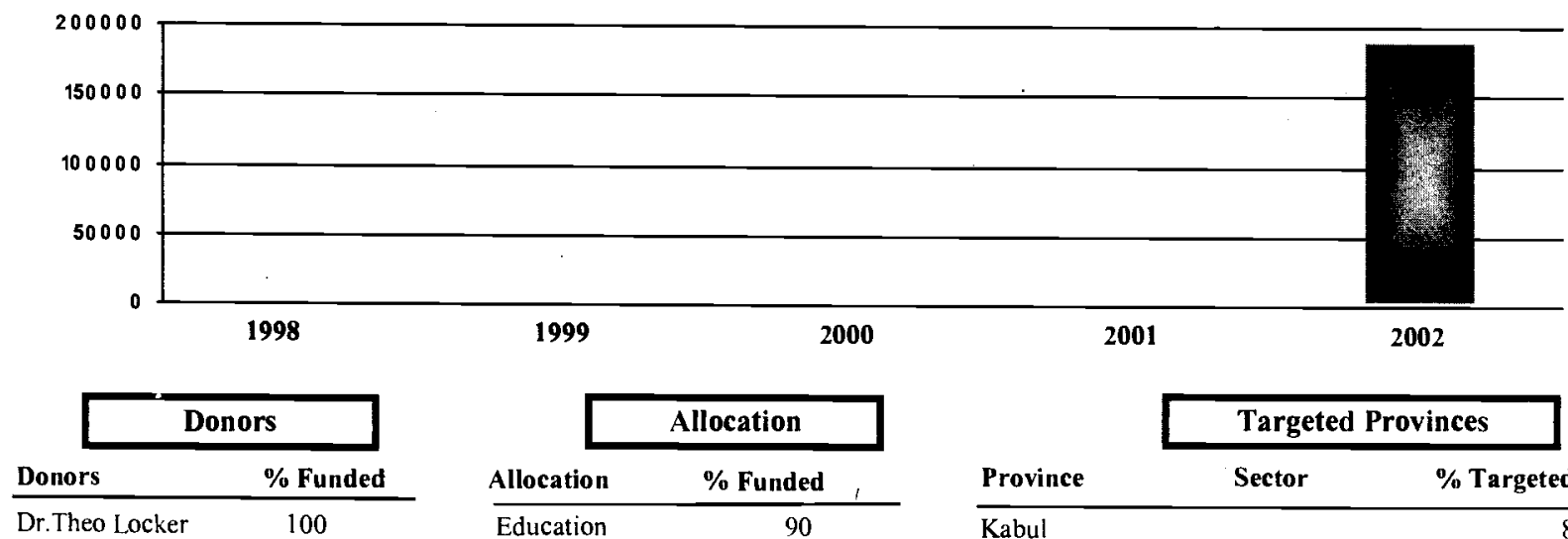

\begin{tabular}{lc|}
\hline & Allocation \\
\hline Allocation & \% Funded \\
\hline Education & 90 \\
Income Generatio & 7 \\
Relief \& Repatria & 3
\end{tabular}

\begin{tabular}{lrr} 
& \multicolumn{2}{c|}{ Targeted Provinces } \\
\cline { 2 - 3 } Province & Sector & \% Targeted \\
\hline Kabul & 8 \\
Nangarhar & 8 \\
NWFP & 84
\end{tabular}

Sub Offices

\begin{tabular}{|c|c|c|c|c|}
\hline Sub Office & City / Town & Phone & E-mail & In Charge \\
\hline Kabul.St-1 Karte-e-Parwan 2 & Kabul & & & Zulmay \\
\hline $\begin{array}{l}\text { Nangarhar. Rokhan Meena } \\
\text { St.1 House } 5\end{array}$ & Jalalabad & & & Fazle Hadi \\
\hline
\end{tabular}




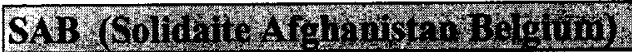

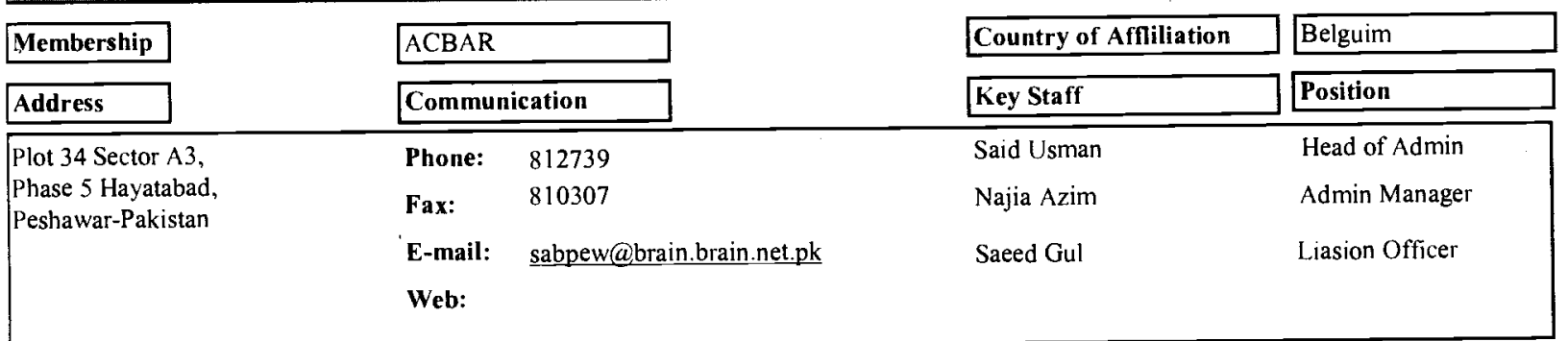

\begin{tabular}{|c|c|c|c|c|c|c|}
\hline & & & Personnel & & & \\
\hline Afghan & \multicolumn{2}{|c|}{70} & & Administrative & & 43 \\
\hline Pakistani & \multicolumn{2}{|c|}{0} & & Support & & 26 \\
\hline Expatriates & \multicolumn{2}{|c|}{1} & & Technical & & 2 \\
\hline \multirow[t]{3}{*}{ Total } & \multirow{2}{*}{\multicolumn{2}{|c|}{71}} & & Total & & 71 \\
\hline & & & Budget In US S & & \multirow{2}{*}{\multicolumn{2}{|c|}{2002}} \\
\hline & 1998 & 1999 & 2000 & 2001 & & \\
\hline Afghanistan & 0 & 0 & 0 & 0 & 0 & \\
\hline Pakistan & 400,000 & 150,000 & 400,000 & 150,000 & 30,000 & \\
\hline Total & $400,000.00$ & $150,000.00$ & $400,000.00$ & $150,000.00$ & $30,000.00$ & \\
\hline
\end{tabular}

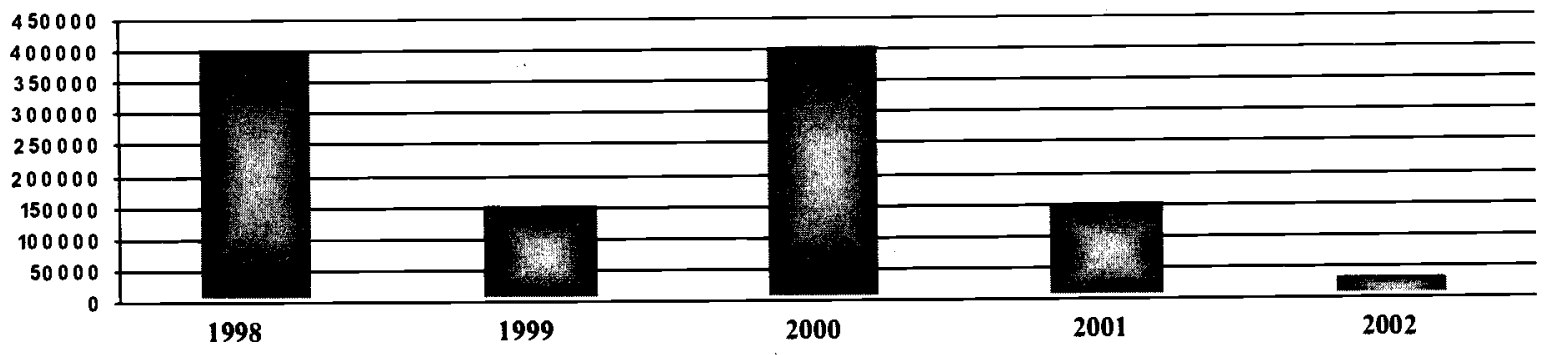

\begin{tabular}{|c|c|c|c|c|c|c|}
\hline \multicolumn{2}{|c|}{ Donors } & & llocation & \multirow[b]{2}{*}{ Province } & \multicolumn{2}{|c|}{ Targeted Provinces } \\
\hline Donors & $\%$ Funded & Allocation & $\%$ Funded & & Sector & $\%$ Targeted \\
\hline Belgium.Govt. & 19 & Education & 50 & NWFP & Edu & 10 \\
\hline $\mathrm{EU}$ & 70 & Income $\mathrm{Ge}$ & 50 & & & \\
\hline
\end{tabular}

Sub Offices

\begin{tabular}{|c|c|c|c|c|c|}
\hline Sub Office & City / Town & Phone & Fax & E-mail & In Charge \\
\hline $\begin{array}{l}\text { House } 311 \text { St. } 3 \text { Charrahee Haji } \\
\text { Yaqob Shahre Naw }\end{array}$ & Kabul & 070278263 & & & Shah Wali \\
\hline Nangarhar. Charahee Sehat Ama & Jalalabad & & & & Eng.Akram \\
\hline
\end{tabular}




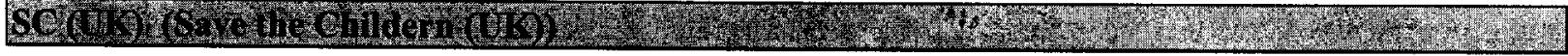

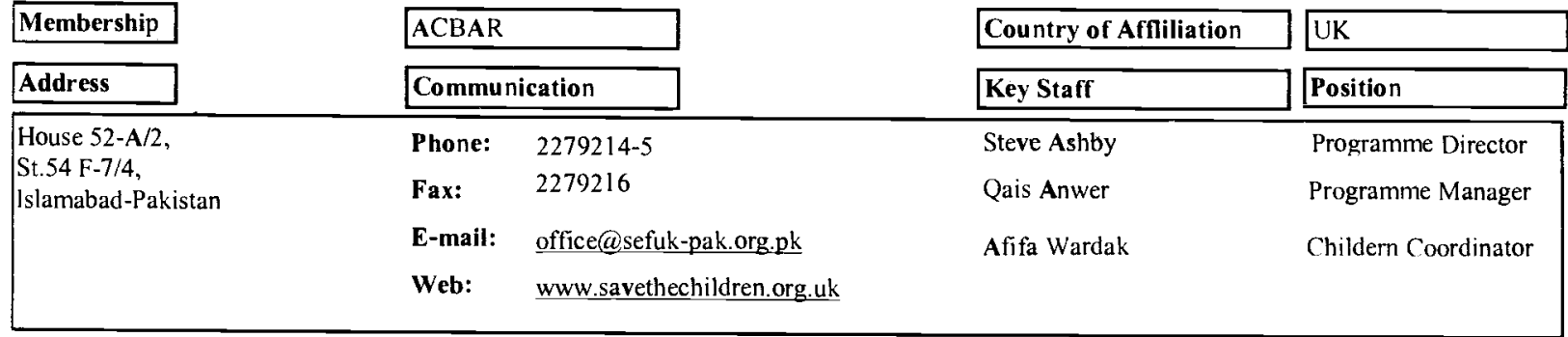

\begin{tabular}{|l|}
\hline Afghan \\
\hline \hline Pakistani \\
\hline Expatriates \\
\hline Total \\
\hline
\end{tabular}

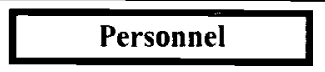

\begin{tabular}{|l|}
\hline Administrative \\
\hline Support \\
\hline \hline Technical \\
\hline Total \\
\hline
\end{tabular}

Budget In US \$

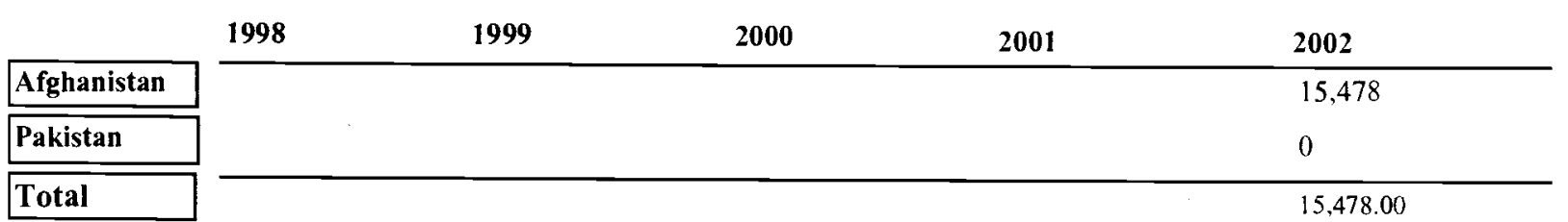

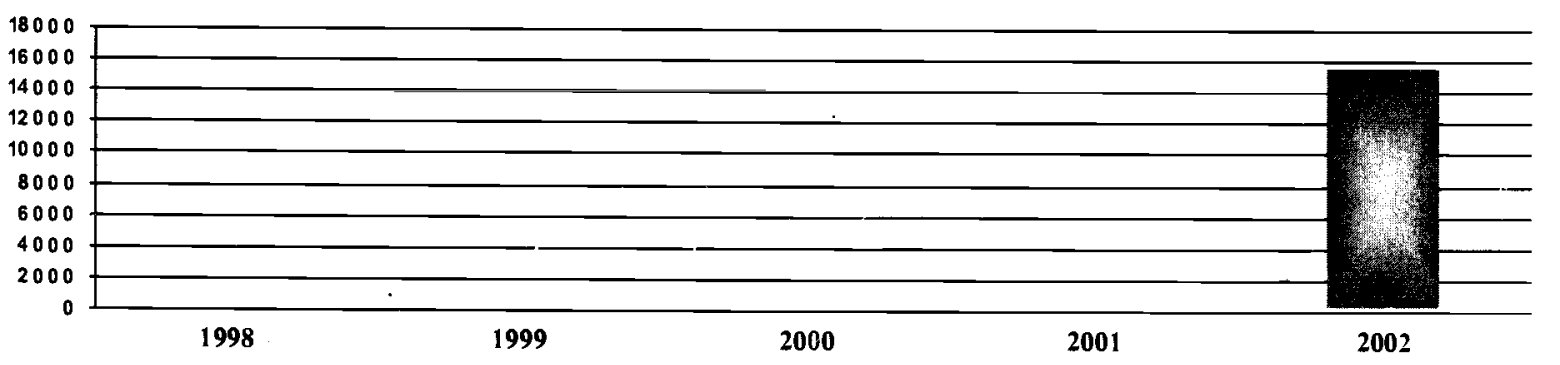

\begin{tabular}{|c|c|c|c|c|c|c|}
\hline \multicolumn{2}{|c|}{ Donors } & & location & \multirow[b]{2}{*}{ Province } & \multicolumn{2}{|c|}{ Targeted Provinces } \\
\hline Donors & $1 \%$ Funded & Allocation & "\% Funded & & Sector & $\%$ Targeted \\
\hline Parthenon Trust & 84.5 & Human Rights & 100 & NWFP & Prote & on 10 \\
\hline SCF-NZ & 15.5 & & & & & \\
\hline
\end{tabular}

\section{Sub Offices}

\begin{tabular}{|c|c|c|c|c|c|}
\hline Sub Office & City / Town & Phone & Fax & E-mail & In Charge \\
\hline $\begin{array}{l}\text { Kabul.House } 2127 \text { Street A(aleph) } \\
\text { Karte-se }\end{array}$ & Kabul & 070276372 & +87376294499 & $\begin{array}{l}\text { scukkbl@psh.paknet.co } \\
\text { m.pk }\end{array}$ & Robert folkes \\
\hline $\begin{array}{l}\text { NWFP.34 -B,Railway Road } \\
\text { University Town } \\
\end{array}$ & Peshawar & 5701510 & 841367 & $\begin{array}{l}\text { ganwar@scuk- } \\
\text { peshawar.org.pk }\end{array}$ & Qais Anwar \\
\hline
\end{tabular}




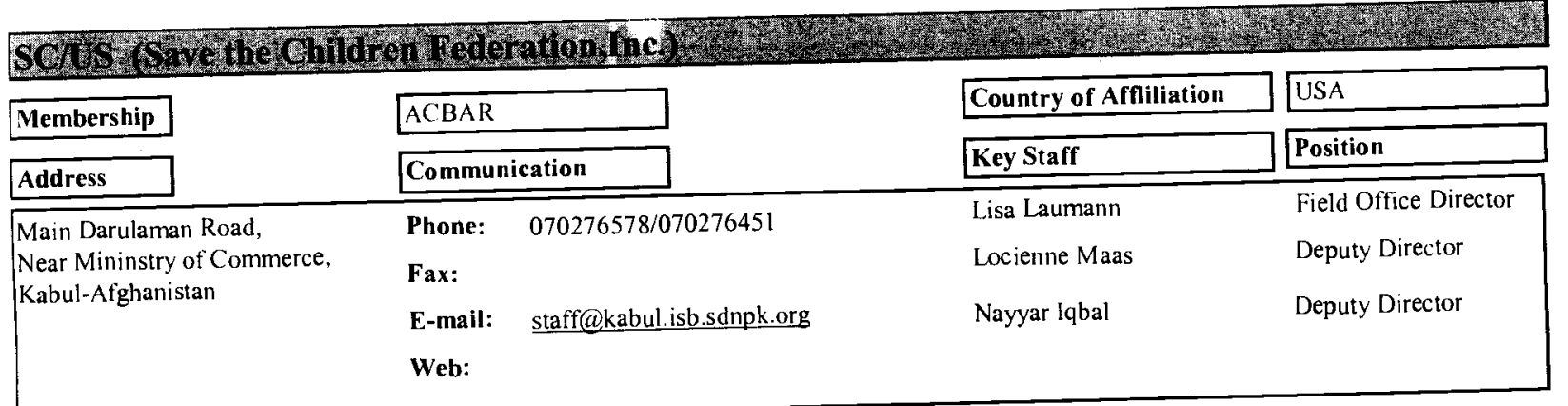

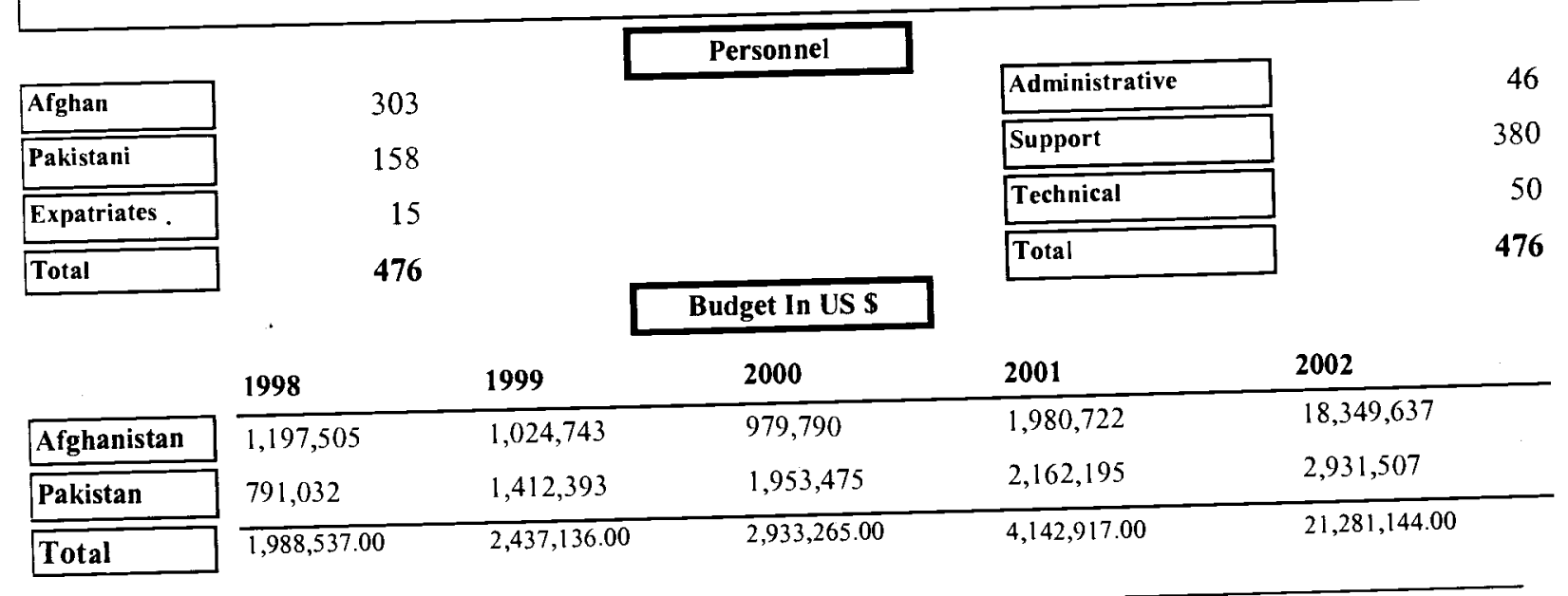

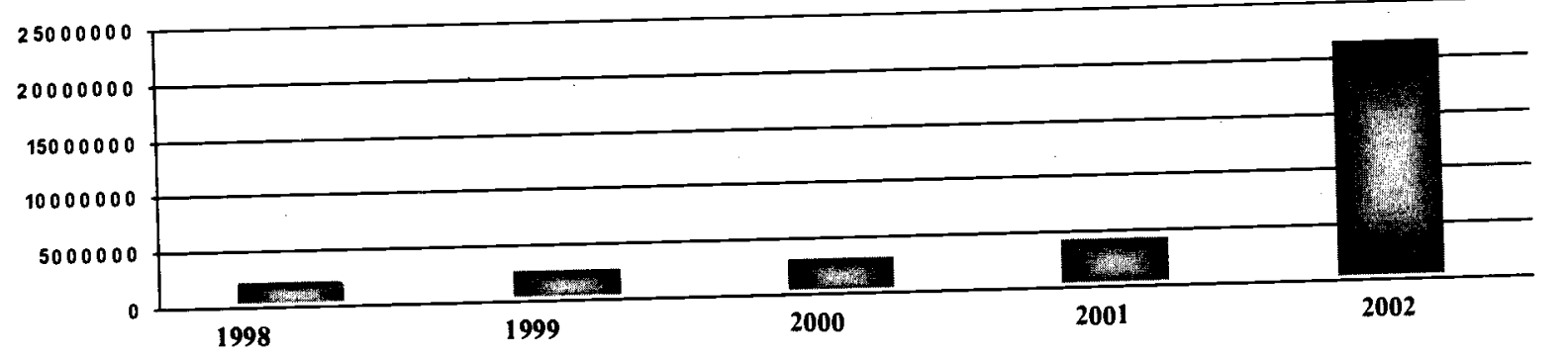

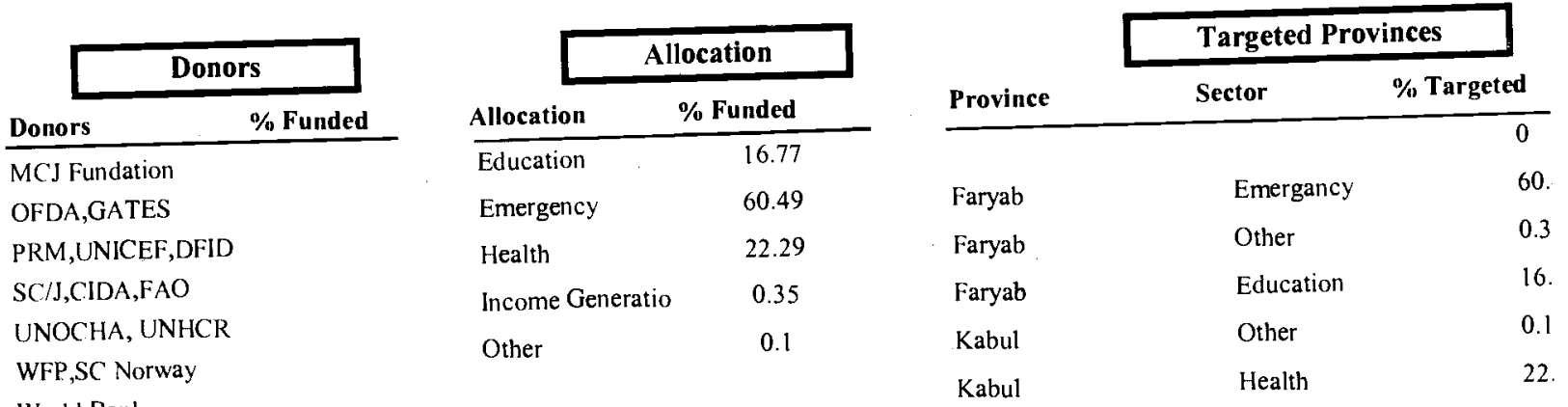

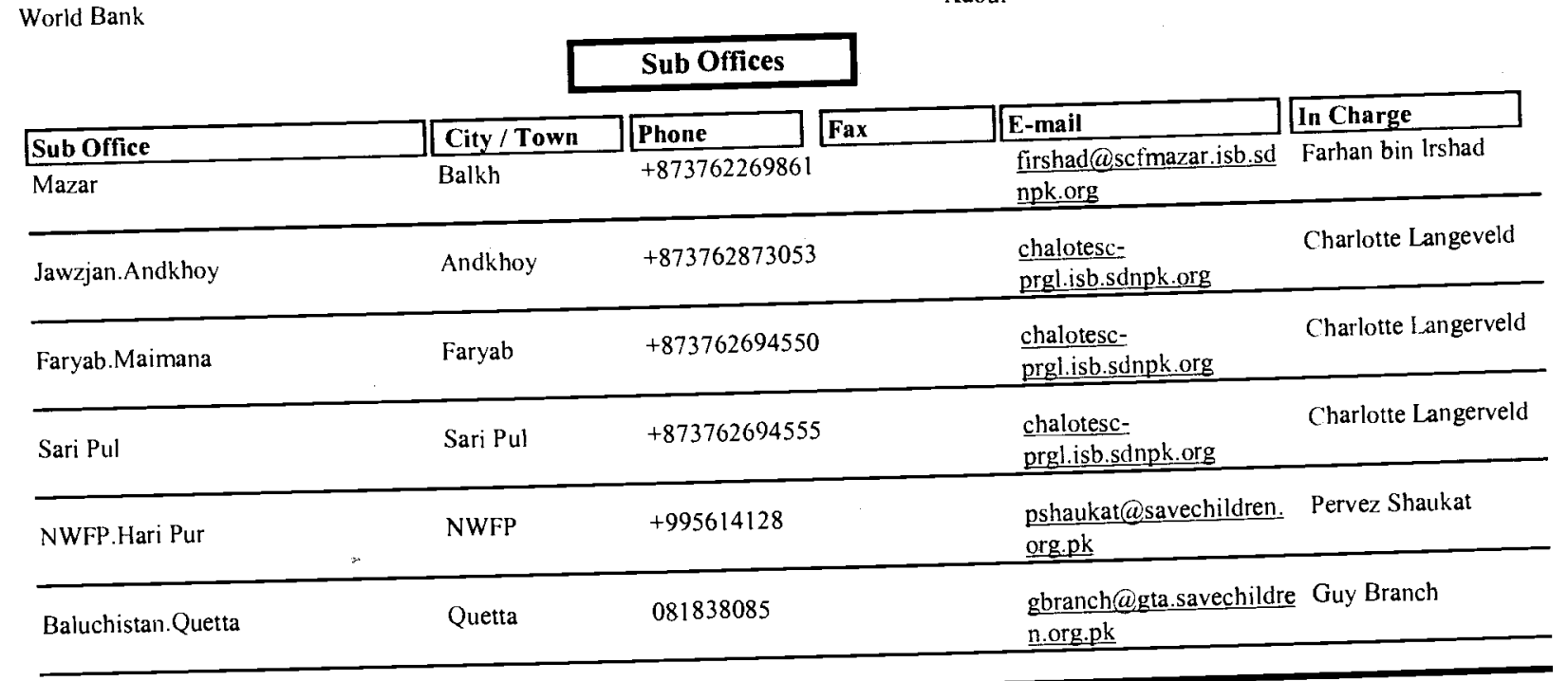




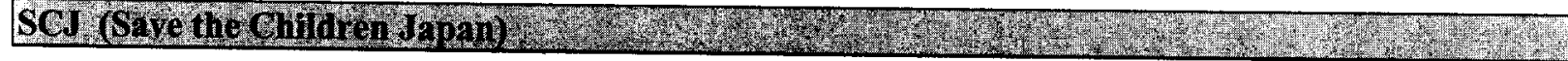

\begin{tabular}{|llll|}
\hline Membership & Other & Country of Affliliation & Japan \\
\hline Address & Communication & Key Staff & Position \\
\hline $\begin{array}{llll}\text { 149 Daramsal School Street, } \\
\text { Kat-e-Parwan, } \\
\text { Kabul- Afghanistan }\end{array}$ & Phone: $\quad 070279425$ & Yuichi Tanda & Resident Representativ \\
& Fax: & Hiroshi Miyashita & Program Coordinator \\
& E-mail: $\quad$ scj afg@vc.kcon.ne.jp & Nooko Kanatani & Kabul Manager \\
& Web: & & \\
\hline
\end{tabular}

\begin{tabular}{|l|}
\hline Afghan \\
\hline \hline Pakistani \\
\hline Expatriates \\
\hline Total \\
\hline
\end{tabular}

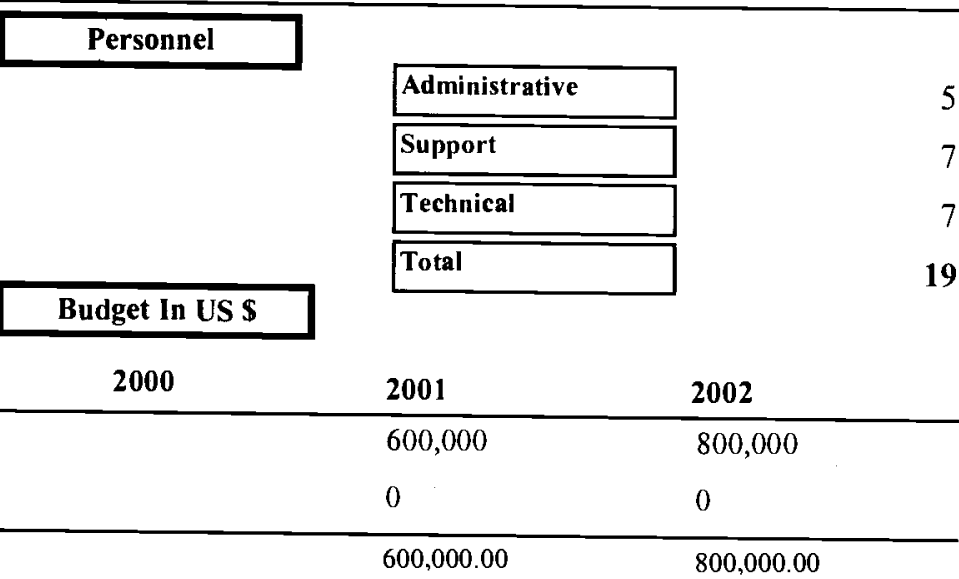

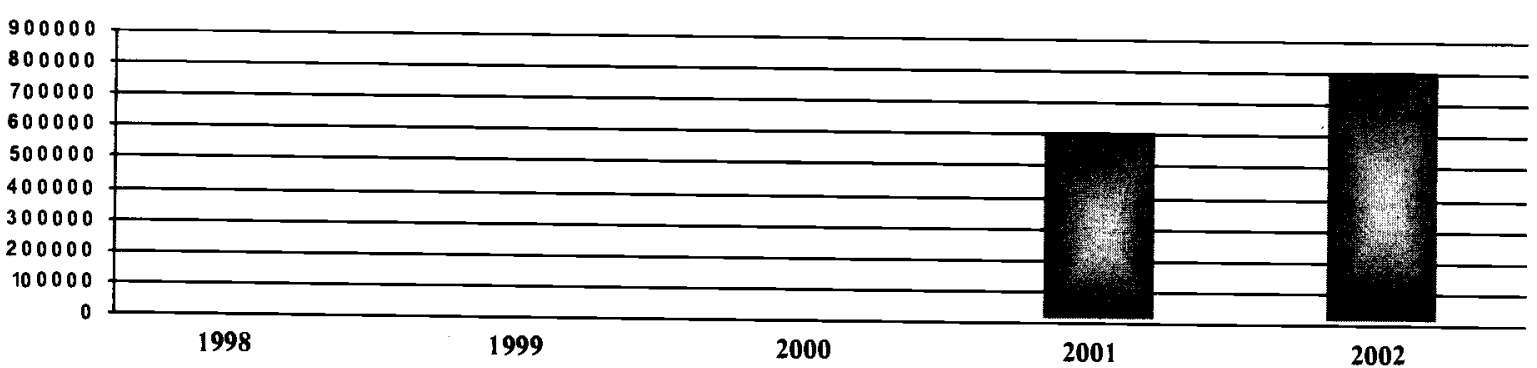

\begin{tabular}{|c|c|c|c|c|c|c|}
\hline \multicolumn{2}{|c|}{ Donors } & & llocation & \multirow[b]{2}{*}{ Province } & \multicolumn{2}{|c|}{ Targeted Provinces } \\
\hline Donors & $\%$ Funded & Allocation & $\%$ Funded & & Sector & $\%$ Targeted \\
\hline Japan Private & 96 & Education & 16 & Bamyam & Infra & \\
\hline \multirow[t]{3}{*}{ UNICEF } & 4 & Infrastructure & 72 & Kabul & Educ & \\
\hline & & Mines & 11 & Logar & Infra & \\
\hline & & Other & 1 & & & \\
\hline
\end{tabular}

Sub Offices

\begin{tabular}{|c|c|c|c|c|c|}
\hline Sub Office & City/ Town & Phone & Fax & E-mail & In Charge \\
\hline Sar Asia Center of Bamyan Province & Bamyan & & & & \\
\hline Punjab. House 30 Street $20 \mathrm{~F} 9 / 2$ & Islamabad & +923009508308 & 2875624 & scj-am@best.net.pk & \\
\hline
\end{tabular}


SDF (Sanayee Development Foundation)

\begin{tabular}{|c|c|c|c|}
\hline Membership & ACBAR & Country of Affliliation & Afghanistan \\
\hline Address & Communication & Key Staff & Position \\
\hline \multirow{4}{*}{$\begin{array}{l}\text { F10 Rehman Baba Road, } \\
\text { University Town, } \\
\text { Peshawar-Pakisan }\end{array}$} & Phone: & Raz Mohd. Dalili & Exective Director \\
\hline & +0918 & Sayed Farooq & Deputy Director \\
\hline & E-mail: & Shakoor Popalzai & Admin Manager \\
\hline & Web: & & \\
\hline
\end{tabular}

\begin{tabular}{|l|r|}
\hline Afghan \\
\hline \hline Pakistani \\
\hline Expatriates \\
\hline Total \\
\hline
\end{tabular}

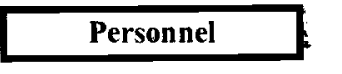

\begin{tabular}{|l|}
\hline Administrative \\
\hline Support \\
\hline Technical \\
\hline Total \\
\hline
\end{tabular}

Budget In US \$

\begin{tabular}{|c|c|c|c|c|c|}
\hline & 1998 & 1999 & 2000 & 2001 & 2002 \\
\hline Afghanistan & 0 & 102,000 & 120,000 & 440,000 & 650,000 \\
\hline Pakistan & 35,000 & 50,000 & 170,000 & 207,000 & 132,000 \\
\hline Total & $35,000.00$ & $152,000.00$ & $290,000.00$ & $647,000.00$ & $782,000.00$ \\
\hline
\end{tabular}

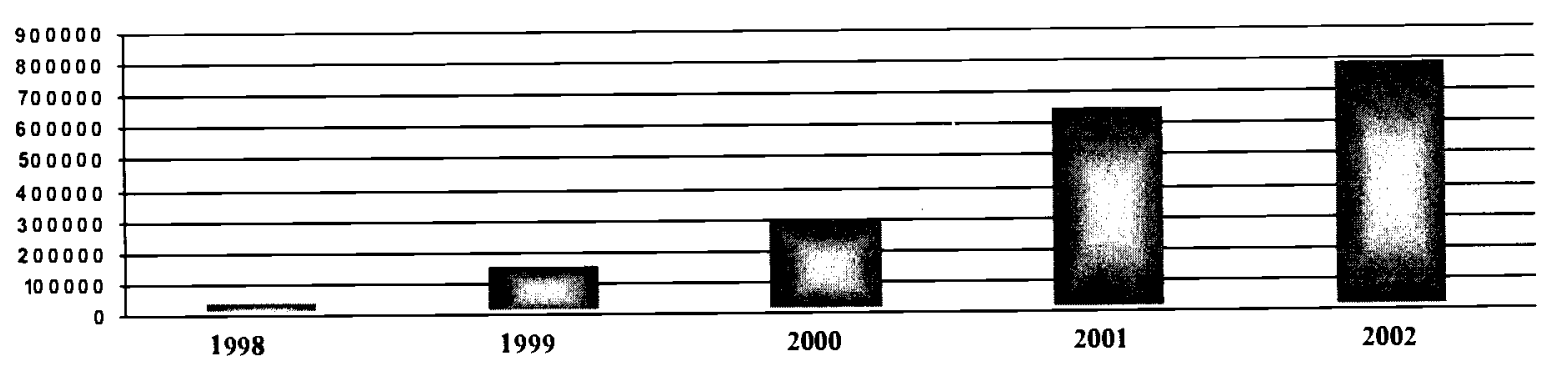

\begin{tabular}{lc}
\hline \multicolumn{2}{c|}{ Donors } \\
Donors & \% Funded \\
\hline Aus Aid & 5 \\
Children in Risk & 5 \\
EO/CA & 20 \\
NCA & 35 \\
Self Sustained & 10 \\
TRO CAIR & 25
\end{tabular}

\begin{tabular}{lc|}
\multicolumn{1}{c|}{ Allocation } \\
Allocation & \% Funded \\
\hline Education & 70 \\
Emergency & 10 \\
Environment & 5 \\
Health & 10 \\
Other & 5
\end{tabular}

\begin{tabular}{lcc} 
& \multicolumn{2}{c|}{ Targeted Provinces } \\
\cline { 2 - 3 } Province & Sector & \% Targeted \\
\hline Badghis & Emergency & 3 \\
Farah & Education & 3 \\
Ghazni & Emergency & 7 \\
Hirat & Education & 12 \\
Kabul & Education & 50 \\
Peshawar & Education & 25
\end{tabular}

\section{Sub Offices}

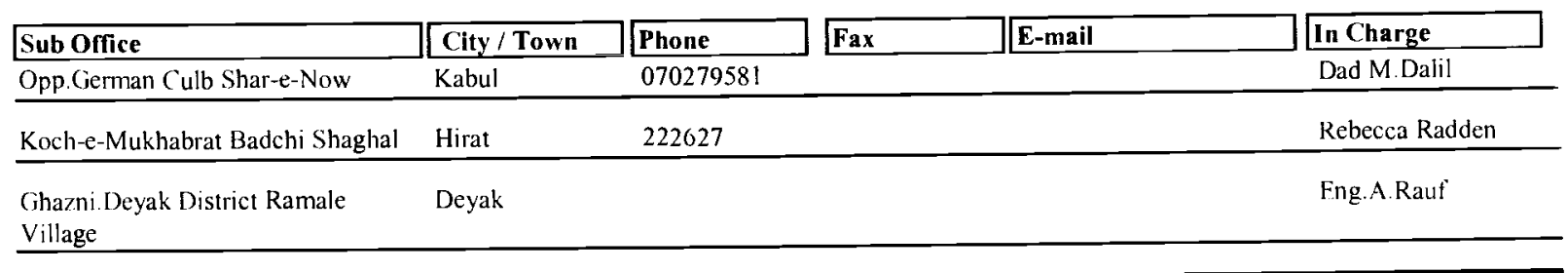




\begin{tabular}{|c|c|c|c|}
\hline Membership & ANCB & Country of Affliliation & Afghanistan \\
\hline Address & Communication & Key Staff & Position \\
\hline \multirow{4}{*}{$\begin{array}{l}\text { Hirat City Darb-a-Malik, } \\
\text { Amini Road, } \\
\text { Hirat-Atghanistan }\end{array}$} & Phone: & Gh.Farooq Sadder & Director \\
\hline & Fax: & Zai-Uddin Zai & Deputy Director \\
\hline & E-mail: & Najibullah Ariya & Administrator \\
\hline & Web: & & \\
\hline
\end{tabular}

\begin{tabular}{|l|}
\hline Afghan \\
\hline Pakistani \\
\hline Expatriates \\
\hline Total \\
\hline
\end{tabular}

Personnel

\begin{tabular}{|l|}
\hline Administrative \\
\hline Support \\
\hline Technical \\
\hline Total \\
\hline
\end{tabular}

16

0

0

16

Budget In US S

\begin{tabular}{|c|c|c|c|c|c|}
\hline & 1998 & 1999 & 2000 & 2001 & 2002 \\
\hline Afghanistan & & 82,000 & & 15,000 & 310,500 \\
\hline Pakistan & & 0 & & 0 & 0 \\
\hline Total & & $82,000.00$ & & $15,000.00$ & $310,500.00$ \\
\hline
\end{tabular}

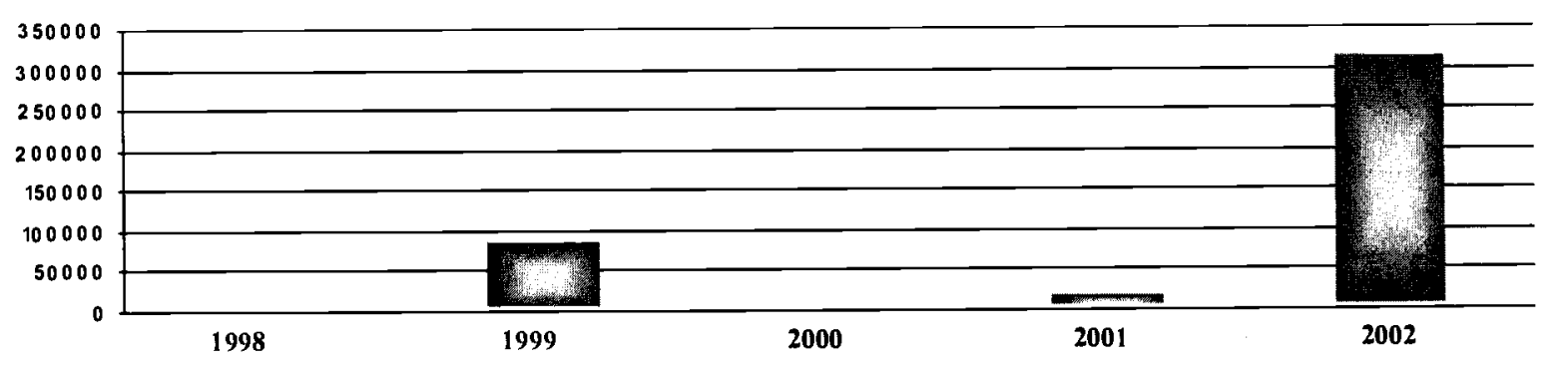

\begin{tabular}{|c|c|c|c|c|c|c|}
\hline \multicolumn{2}{|c|}{ Donors } & & llocation & \multirow[b]{2}{*}{ Province } & \multicolumn{2}{|c|}{ Targeted Provinces } \\
\hline Donors & \% Funded & Allocation & $1 / 1$ Funded & & Sector & $\%$ Targeted \\
\hline $\mathrm{BPRM} / \mathrm{IRC}$ & 4 & Infrastructure & 100 & Farah & Infrastructure & 44 \\
\hline OFDA/IRC & 70 & & & Ghor & Infiastructure & 33 \\
\hline UNAMA & 4 & & & Hirat & Infrastructure & 23 \\
\hline UNHCR & 3 & & & & & \\
\hline UNOPS & 19 & & & & & \\
\hline
\end{tabular}

Sub Offices

\begin{tabular}{ll|l|l|l|l|l|l|l|l|l|l|l|l|l|}
\hline Sub Office & City / Town & Phone & Earge \\
\hline Ghor.Center of Tulak District & Tulak \\
\hline Farah.Bazaar-Chawk-a-Zawel & Shindand \\
\hline
\end{tabular}




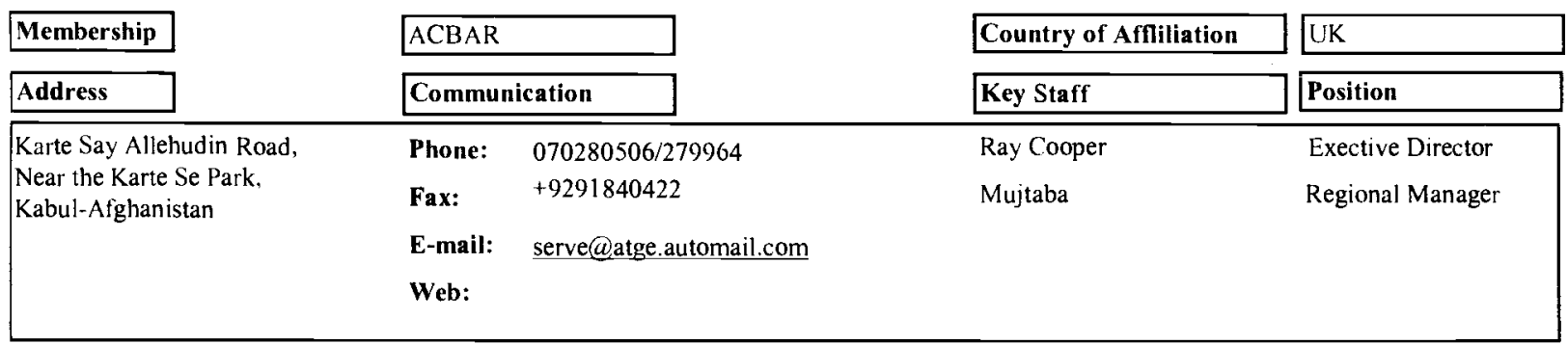

\begin{tabular}{|l|r|}
\hline Afghan & 175 \\
\hline \hline Pakistani & 1 \\
\hline Expatriates & 18 \\
\hline Total & 194 \\
\hline
\end{tabular}

Personnel

\begin{tabular}{|c|c|c|c|c|c|}
\hline \multirow[t]{3}{*}{ lotal } & \multirow{2}{*}{\multicolumn{2}{|c|}{194}} & \multirow[b]{2}{*}{ Budget In US S } & Total & \multirow[b]{3}{*}{2002} \\
\hline & & & & \multirow[b]{2}{*}{2001} & \\
\hline & 1998 & 1999 & 2000 & & \\
\hline Afghanistan & & 635,121 & 504,374 & 478,095 & $1,276,438$ \\
\hline Pakistan & & 0 & 0 & 0 & 0 \\
\hline Total & & $635,121.00$ & $504,374.00$ & $478,095.00$ & 1.276 .438 .00 \\
\hline
\end{tabular}
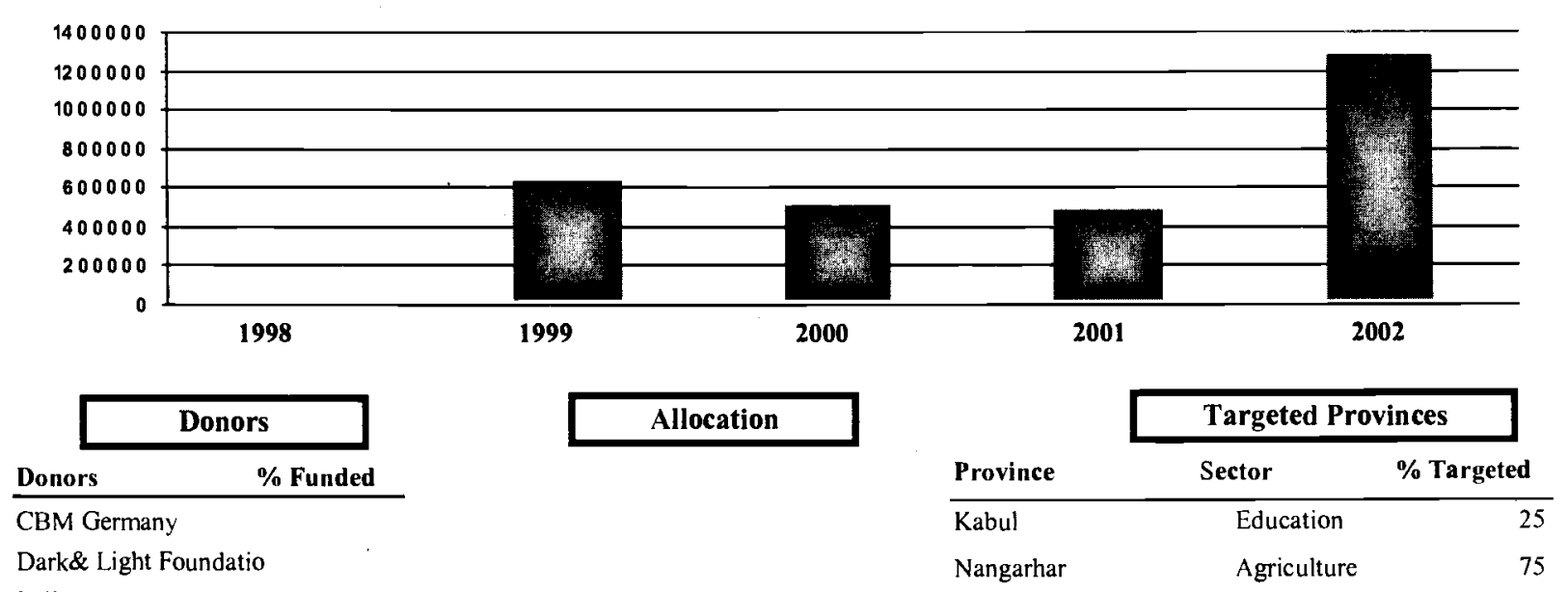

Individuals

Kinder Nothilfe

SC-S

Tear Fund

UNICEF

\section{Sub Offices}

\begin{tabular}{|c|c|c|c|c|c|}
\hline Sub Office & City / Town & Phone & Fax & E-mail & In Charge \\
\hline $\begin{array}{l}\text { Shahr-e-Naw Opp. The Ministry of } \\
\text { Interior }\end{array}$ & Kabul & 2200591 & & $\begin{array}{l}\text { serve@atge.automail.co } \\
\text { m }\end{array}$ & \\
\hline $\begin{array}{l}\text { Nangarhar.Regi Shah Morakhan } \\
\text { Area }\end{array}$ & Jalalabad & & & $\begin{array}{l}\text { serve@atge.automail.co } \\
\underline{\mathrm{m}}\end{array}$ & Wakil \\
\hline $\begin{array}{l}\text { NWFP. } 10 \text { School Road } \\
\text { UniversityTown }\end{array}$ & Peshawar & 840292 & 840422 & adminp@brain.net.pk & Akn Knrberg \\
\hline
\end{tabular}




\section{SFAO (Save The Forest Animals Organization)}

\begin{tabular}{|c|c|c|c|}
\hline Membership & ANCB & Country of Affliliation & Afghanistan \\
\hline Address & Communication & Key Staff & Position \\
\hline $\begin{array}{l}\text { Hirat Wcllayat Street, } \\
\text { Opp.Genraf Hospital, } \\
\text { Hirat-Afghanistan }\end{array}$ & $\begin{array}{l}\text { Phone: } 220223 \\
\text { Fax: } \\
\text { E-mail: } \\
\text { Web: }\end{array}$ & Mohd.Amin Ghori & Director \\
\hline
\end{tabular}

\begin{tabular}{|l|}
\hline Afghan \\
\hline Pakistani \\
\hline Expatriates \\
\hline Total \\
\hline
\end{tabular}

18

0

0

18

\begin{tabular}{|l|}
\hline Administrative \\
\hline Support \\
\hline Technical \\
\hline Total \\
\hline
\end{tabular}

Budget In US \$
3

\begin{tabular}{|l|}
\hline Afghanistan \\
\hline Pakistan \\
\hline Total \\
\hline
\end{tabular}

\section{8}

1999

2000
2,000
0

15,000 2002

$$
0
$$

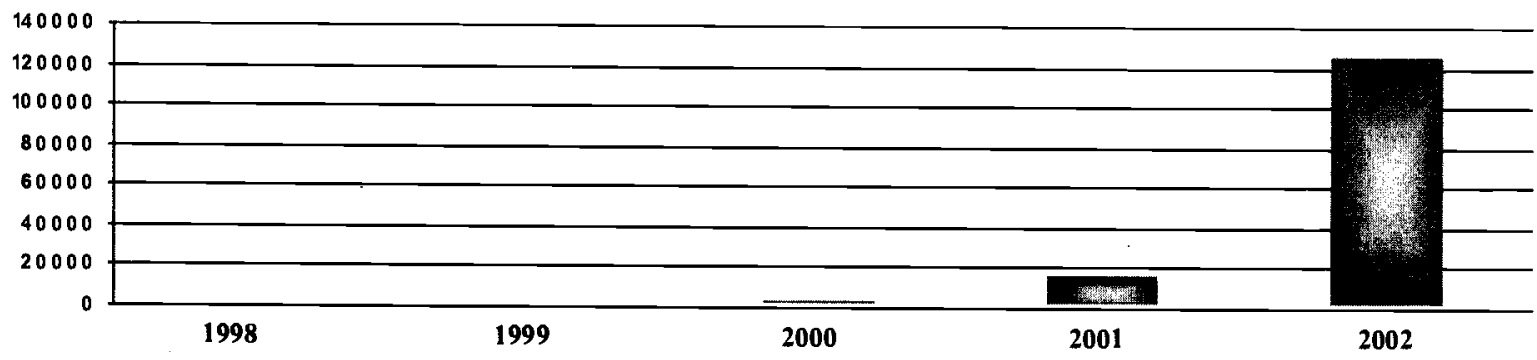

\begin{tabular}{lc|}
\cline { 2 - 2 } & \multicolumn{2}{c|}{ Donors } \\
Donors & \% Funded \\
\hline ATI & 50 \\
FAO & 5 \\
HELP & 20 \\
UNHCR & 15 \\
UNICEF & 10
\end{tabular}

\begin{tabular}{lc|}
\multicolumn{1}{c|}{ Allocation } \\
\hline Allocation & \% Funded \\
\hline Agriculture & 26 \\
Education & 15 \\
Infrastructure & 50 \\
Water Resources & 15
\end{tabular}

\begin{tabular}{lcc} 
& \multicolumn{2}{c|}{ Targeted Provinces } \\
\cline { 2 - 3 } Province & Sector & \% Targeted \\
\hline Badghis & Infrastructure & 50 \\
Badghis & Agriculture & 5 \\
Farah & Infrastructure & 20 \\
Ghor & Other & 5
\end{tabular}

Sub Offices

\begin{tabular}{ll|l|l|l|}
\hline Sub Office & City / Town & Phone & Fax & E-mail \\
\hline Kabul.Shar-e-Naw & Kabul & & Shabnam \\
\hline Kandahar. Chowk Shohada & Kandahar & Asadullah & \\
\hline
\end{tabular}


SGAA (Sandy Galls Afghanistan Appeal)

\begin{tabular}{|c|c|c|c|}
\hline Membership & ACBAR & Country of Affiliation & UK \\
\hline Address & Communication & Key Staff & Position \\
\hline \multirow{4}{*}{$\begin{array}{l}\text { 45 S.Jamaluddin Afghani Road, } \\
\text { University Town, } \\
\text { Peshawar- Pakistan }\end{array}$} & Phone: & Fiona Gall & Project Consultant \\
\hline & 843028 & Saminuddin Saber & Field Director \\
\hline & sgaa@brain.net.pk & Asif Bhatti & Liason Officer \\
\hline & Web: & & \\
\hline
\end{tabular}

\begin{tabular}{|c|c|c|c|c|c|c|}
\hline & & & Personnel & & & \\
\hline Afghan & \multicolumn{2}{|c|}{86} & & Administrative & & 18 \\
\hline Pakistani & \multicolumn{2}{|c|}{3} & & Support & & 22 \\
\hline Expatriates & \multicolumn{2}{|c|}{1} & & Technical & & 50 \\
\hline \multirow[t]{3}{*}{ Total } & \multirow{2}{*}{\multicolumn{2}{|c|}{90}} & & Total & & 90 \\
\hline & & & Budget In US\$ & & \multirow{2}{*}{\multicolumn{2}{|c|}{2002}} \\
\hline & 1998 & 1999 & 2000 & 2001 & & \\
\hline Afghanistan & 738,000 & 229,000 & 298,000 & 235,000 & 480,000 & \\
\hline Pakistan & 0 & 0 & 0 & 0 & 0 & \\
\hline Total & $\overline{738,000.00}$ & $229,000.0$ & 298.000 .00 & $235,000.00$ & $480,000.00$ & \\
\hline
\end{tabular}

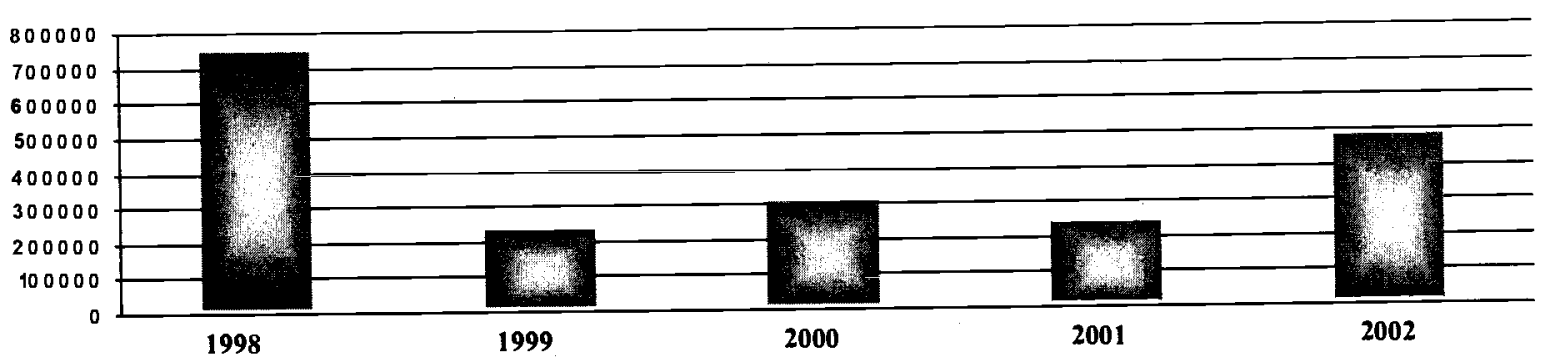

\begin{tabular}{|c|c|c|c|c|c|c|}
\hline \multicolumn{2}{|c|}{ Donors } & & llocation & \multirow[b]{2}{*}{ Province } & \multicolumn{2}{|c|}{ Targeted Provinces } \\
\hline Donors & $\%$ Funded & Allocation & $\%$ Funded & & Sector & $\%$ Targeted \\
\hline Community Fund UK & 25 & Health & 100 & Kabul & Health & 10 \\
\hline $\mathrm{EU}$ & 40 & & & Nangarhar & Health & 90 \\
\hline Princess Diana Fund & 25 & & & & & \\
\hline Private & 10 & & & & & \\
\hline
\end{tabular}

Sub Offices

\begin{tabular}{|c|c|c|c|c|}
\hline Sub Office & City / Town & Phone & E-mail & In Charge \\
\hline Nangarhar.Public Hospital 1 & Jalalabad & & & Samiuddin Saber \\
\hline $\begin{array}{l}\text { Khairkhana2 Opposite Hazarat Ali } \\
\text { Mosque }\end{array}$ & Kabul & & & Ms. Roquia \\
\hline
\end{tabular}




\section{SHA (Shafag Reconstruction Organization)}

\begin{tabular}{|c|c|c|c|}
\hline Membership & & Country of Afniliation & Afghanistan \\
\hline Address & Communication & Key Staff & Position \\
\hline \multirow{4}{*}{$\begin{array}{l}\text { East Rauza Opp.Sinam, } \\
\text { Derwaza-e-Tashqurghan, } \\
\text { Dr A.Ali Apt, } \\
\text { Mazar-Afghanistan }\end{array}$} & Phone: 41558 & Eng.Majib & Director \\
\hline & Fax: & Eng . Nabi & program Manager \\
\hline & E-mail: & Eng.Homayon & Site Engineer \\
\hline & Web: & & \\
\hline
\end{tabular}

\begin{tabular}{|l|}
\hline Afghan \\
\hline \hline Pakistani \\
\hline \hline Expatriates \\
\hline \hline Total $\cdot$ \\
\hline
\end{tabular}

43

0

0

43

Personnel

\begin{tabular}{|l|}
\hline Administrative \\
\hline Support \\
\hline Technical \\
\hline Total \\
\hline
\end{tabular}

Budget In US S

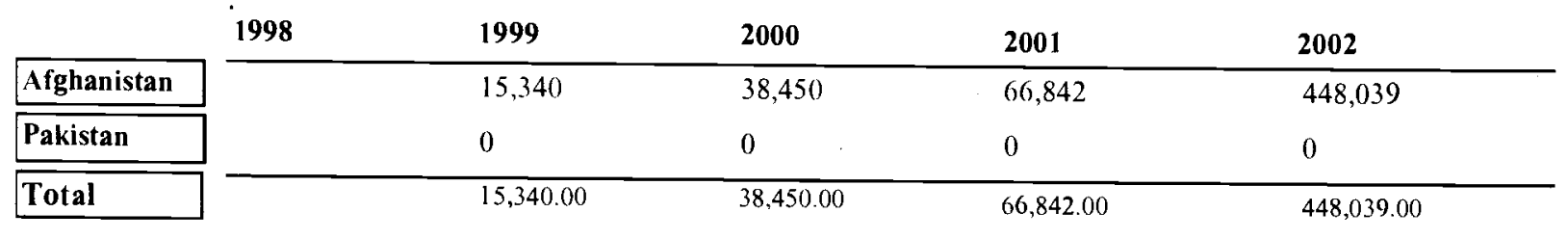

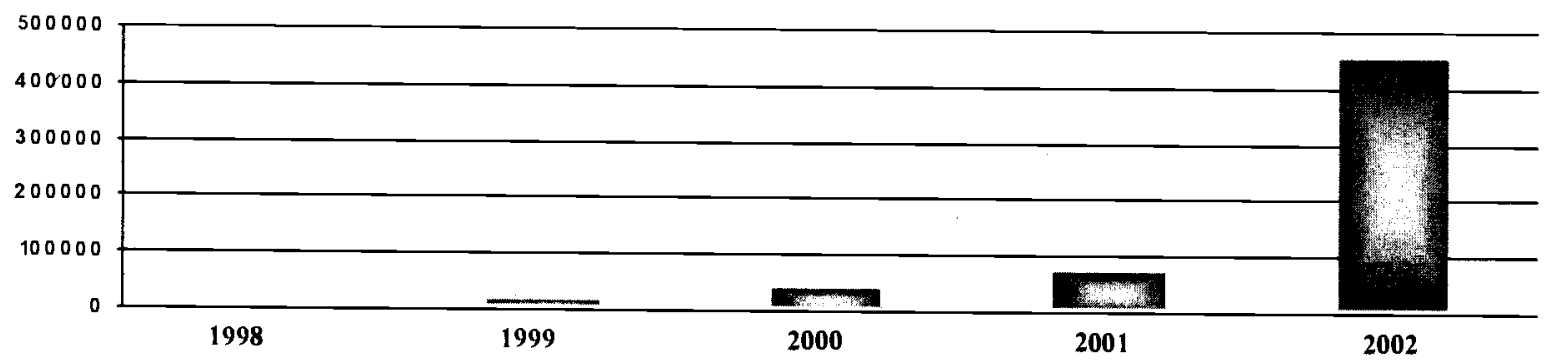

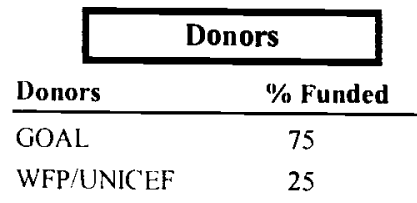

\begin{tabular}{|c|c|c|c|c|c|}
\hline & & Sub Offices & & & \\
\hline Sub Office & City / Town & Phone & Fax & E-mail & In Charge \\
\hline $\begin{array}{l}\text { Samangan. Takht Rustem Street Haji } \\
\text { Rafiq House }\end{array}$ & Samangan & & & & Eng. Hamidullah \\
\hline
\end{tabular}

\begin{tabular}{|c|c|c|c|c|}
\hline \multicolumn{2}{|c|}{ Allocation } & \multirow[b]{2}{*}{ Provinge } & \multicolumn{2}{|c|}{ Taroeted Provinces } \\
\hline Allocation & (1) Funded & & Sector & o/ Targated \\
\hline \multicolumn{2}{|c|}{ Inforastructure } & All Nart & & 1 \\
\hline
\end{tabular}

Relief \& Repatria 


\begin{tabular}{|c|c|c|c|}
\hline Membership & $\widehat{A C B A R}$ & Country of Affliliation & Afghanistan \\
\hline Address & Communication & Key Staff & Position \\
\hline \multirow{4}{*}{$\begin{array}{l}\text { Darul KhairNaimat Mahal, } \\
\text { Jamrud Road University Town, } \\
\text { Peshawar-Pakistan }\end{array}$} & Phone: & Ghulam Dastagir & Director \\
\hline & 5700882 & Ahmad wali & Deputy Director \\
\hline & sjawo@brain.net.pk & Abdul Ghaffar & Principal \\
\hline & Web: & & \\
\hline
\end{tabular}

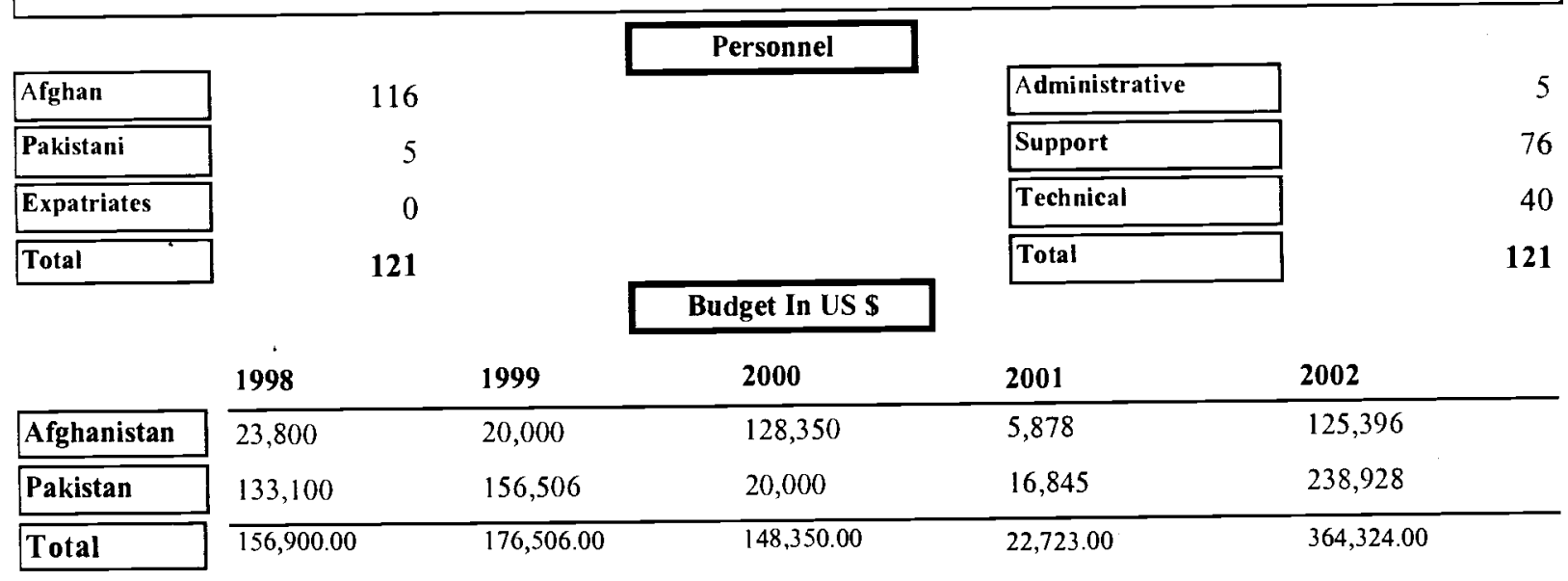

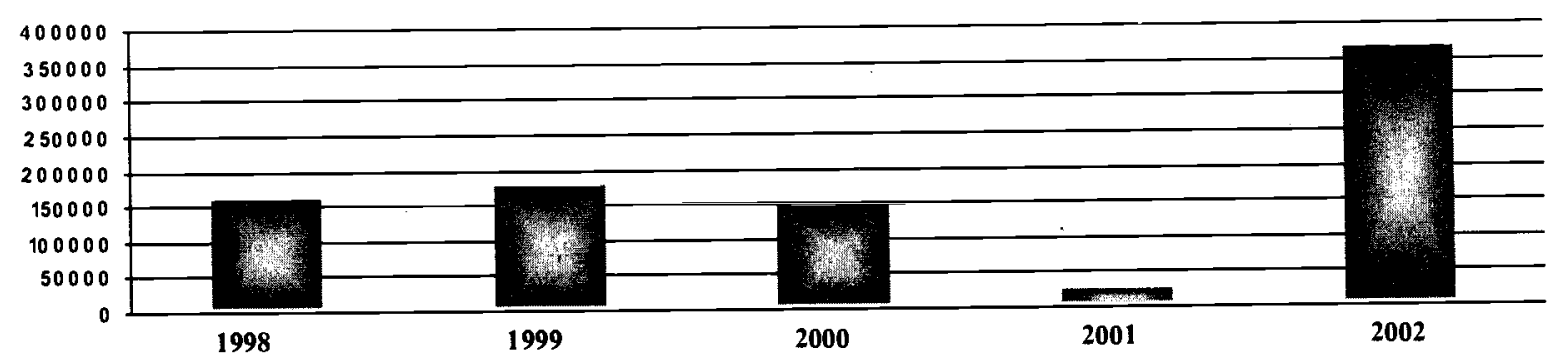

\begin{tabular}{|c|c|c|c|c|c|c|c|c|}
\hline \multicolumn{2}{|c|}{ Donors } & \multicolumn{3}{|c|}{ Allocation } & \multirow[b]{2}{*}{ Province } & \multicolumn{3}{|c|}{ Targeted Provinces } \\
\hline Donors & $\%$ Funded & Allocation & & nded & & Sector & \multicolumn{2}{|c|}{$\%$ Targeted } \\
\hline CARITAS Germany & 3 & Agriculture & & 7 & Kabul & Oth & & 3 \\
\hline Global Crisis Asst. & 3 & Education & & 20 & Kabul & Reli & \& Repatriatioin & 3 \\
\hline UNHCR & 67 & Income Ge & atio & 20 & NWFP & Infr & ructure & 47 \\
\hline \multirow[t]{4}{*}{ World Vision Int. } & 27 & In frastruct & & 47 & NWFP & Em & ency & 47 \\
\hline & & Other & & 3 & & & & \\
\hline & & Relief \& R & tria & 3 & & & & \\
\hline & & & \multicolumn{2}{|c|}{ Sub Offices } & & & & \\
\hline \multicolumn{2}{|l|}{ Sub Office } & City / Town & Phon & & E-mail & \multicolumn{3}{|c|}{ In Charge } \\
\hline \multicolumn{2}{|c|}{ Kolola Pushta Burji Barq Bus Stop } & Kabul & \multicolumn{2}{|c|}{070280561} & & \multicolumn{3}{|c|}{ Muneer } \\
\hline \multicolumn{2}{|c|}{$\begin{array}{l}\text { Nangarhar.Street } 3 \text { Angoor Bagh } \\
\text { Near Zakhira-i-Thail }\end{array}$} & Jalalabad & \multicolumn{3}{|c|}{3152} & \multicolumn{3}{|c|}{ Attiqullah } \\
\hline
\end{tabular}




\begin{tabular}{|c|c|c|c|}
\hline Membership & ACBAR & Country of Affiliation & Germaney \\
\hline Address & Communication & Key Staff & Position \\
\hline \multirow{4}{*}{$\begin{array}{l}\text { Shelter Germany, } \\
\text { Am aleten Bannhof 15, } \\
38122 \text { Bravschweig Gerrang }\end{array}$} & +495318853957 & Georg Taubmann & Excutive Director \\
\hline & +495318853959 & Greg Gilmore & Country Director \\
\hline & info@shelter.de & Len Stitt & Country Director \\
\hline & www.shelternow.org & & \\
\hline
\end{tabular}

\begin{tabular}{|l|r|}
\hline Afghan \\
\hline Pakistani \\
\hline Expatriates \\
\hline Total \\
22 \\
24 \\
\hline
\end{tabular}

\section{Personnel}

\begin{tabular}{|l|}
\hline Administrative \\
\hline Support \\
\hline Technical \\
\hline Total \\
\hline
\end{tabular}

Budget In US \$

\begin{tabular}{|llllll} 
& 1908 & $\mathbf{1 9 9 9}$ & $\mathbf{2 0 0 0}$ & $\mathbf{2 0 0 1}$ & $\mathbf{2 0 0 2}$ \\
\hline Afghanistan & 366,500 & 387,000 & 213,400 & 146,600 & 360,200 \\
\hline Pakistan & $3,593,000$ & 930,700 & 676,500 & 322,900 \\
\hline Total & $3,980,000.00$ & $1,144,100.00$ & $823,100.00$ & $683,100.00$ \\
\hline
\end{tabular}

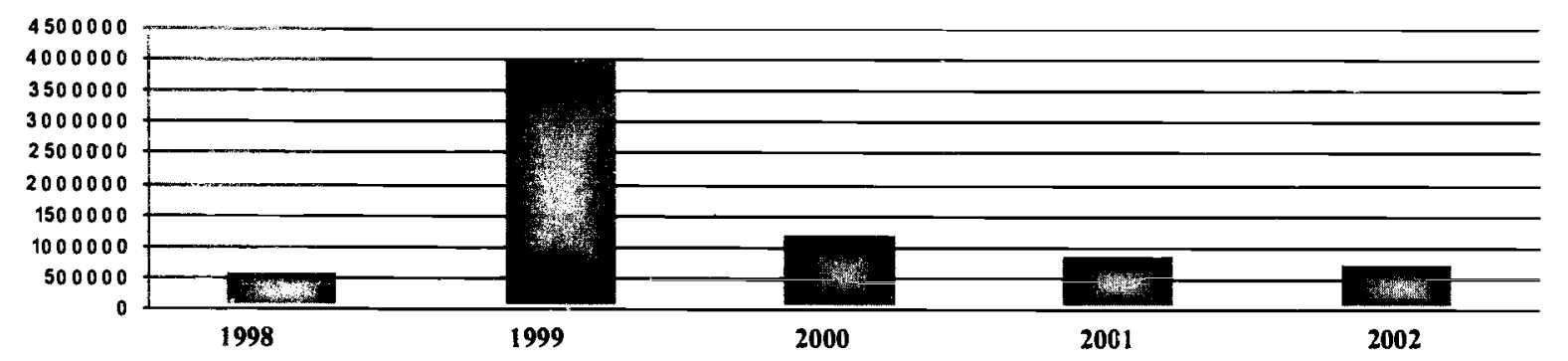

\begin{tabular}{lc}
\multicolumn{1}{c|}{ Donors } \\
Donors & \% Funded \\
\hline KNH & 30 \\
Other & 5 \\
Tear Fund AlS & 5 \\
Tear Fund UK & 10 \\
WFP & 50
\end{tabular}

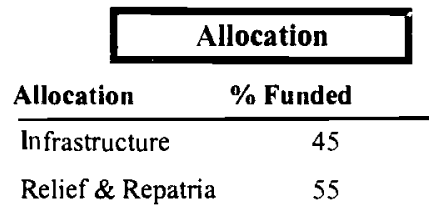

\begin{tabular}{lcc} 
& \multicolumn{2}{c|}{ Targeted Provinces } \\
\cline { 2 - 3 } Province & Sector & $\%$ Targeted \\
\hline Kabul & Infrastructure & 60 \\
Kandahar & Infrastructure & 5 \\
WFP & Infrastructure & 35
\end{tabular}

Sub Offices

\begin{tabular}{|c|c|c|c|c|c|}
\hline Sub Office & City / Town & Phone & Fax & E-mail & In Charge \\
\hline $\begin{array}{l}\text { NWFP.60E Canal Road I Iniversity } \\
\text { Town }\end{array}$ & Peshawar & 851130 & 840522 & sni@pes.comsats.net.pk & Greg Gilmore \\
\hline Street 4 Qaiae Fattullah & Kabul & +8816314267 & & gerogt@gmx.net & Georg Tavsmann \\
\hline $\begin{array}{l}\text { Pot } 27-28, \text { Samll Ind. Estate } \\
\text { Haytabad }\end{array}$ & Peshawar & 815318 & 03204291539 & farazsni@hotmail.com & Faraz Khan \\
\hline $\begin{array}{l}\text { Postbus } 1065,1780 \text { EB Denhelder } \\
\text { Netherlands }\end{array}$ & Holland & +31223632279 & +3122379 & info@shelterholland.nl & John Veldhous \\
\hline
\end{tabular}




\begin{tabular}{|c|c|c|c|c|}
\hline Membership & \multicolumn{2}{|l|}{$\widehat{A C B A R}$} & Country of Affliliation & France \\
\hline Address & Commur & cation & Key Staff & Position \\
\hline \multirow{4}{*}{$\begin{array}{l}\text { North-East Haji Yaqub Square, } \\
\text { Opp.Lucky Five Hotel, } \\
\text { Kabul-Afghanistan }\end{array}$} & Phone: & 070282704 & Bruno Marques & Head of Mission \\
\hline & & +873763221950 & France Machet & Regional Coordinator \\
\hline & E-mail: & solksbul@inmarsat.francetelecom.fr & Alexadre Coissac & Regional Coordinator \\
\hline & Web: & & & \\
\hline
\end{tabular}

\begin{tabular}{|c|c|c|c|c|c|c|}
\hline & & & Personnel & & & \\
\hline Afghan & \multicolumn{2}{|c|}{452} & & Administrative & & 48 \\
\hline Pakistani & \multicolumn{2}{|c|}{2} & & Support & & 302 \\
\hline Expatriates & \multicolumn{2}{|c|}{19} & & Technical & & 123 \\
\hline \multirow[t]{3}{*}{ Total } & & & & Total & & 473 \\
\hline & & & Budget In US \$ & & & \\
\hline & 1998 & 1999 & 2000 & 2001 & \multicolumn{2}{|l|}{2002} \\
\hline Afghanistan & $3,136,800$ & 904,260 & $2,000,000$ & $2,458,685$ & \multicolumn{2}{|l|}{$9,554,749$} \\
\hline Pakistan & 0 & 0 & 0 & 0 & \multicolumn{2}{|l|}{0} \\
\hline Total & $3,136,800.0$ & $904,260.0$ & $2,000,000.00$ & $2,458,685.00$ & $9,554,749.00$ & \\
\hline
\end{tabular}

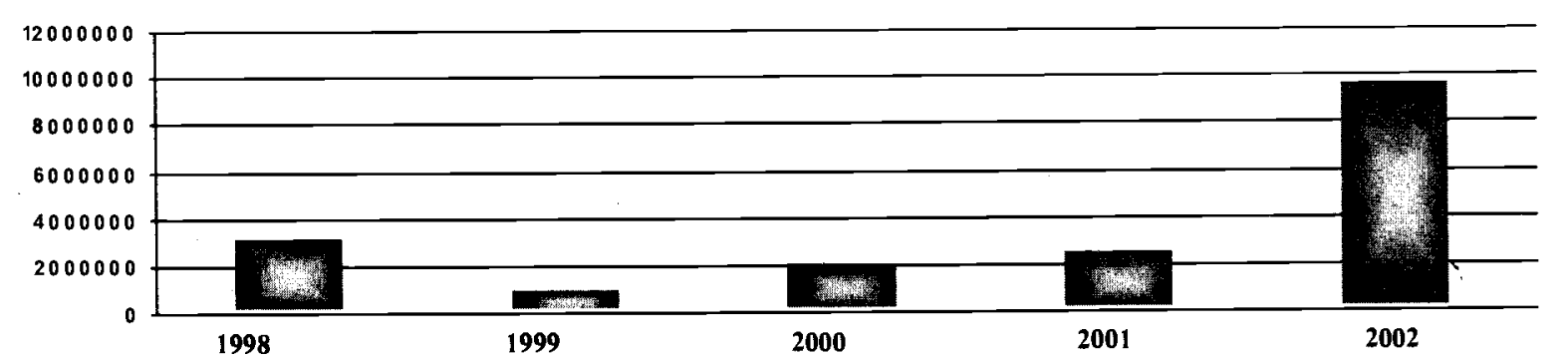

\begin{tabular}{|c|c|c|c|c|c|c|}
\hline \multicolumn{2}{|c|}{ Donors } & & location & \multirow[b]{2}{*}{ Province } & \multicolumn{2}{|l|}{ Targeted Provinces } \\
\hline Donors & $\%$ Funded & \multirow{2}{*}{$\frac{\text { Allocation }}{\text { Agriculture }}$} & $\%$ Funded & & Sector & $\%$ Targeted \\
\hline DFID & 3.85 & & 33 & Balkh & Relief \& Repatriatioin & 40 \\
\hline DG-Relex & 25.57 & Emergency & 28 & Balkh & Water Resources & 25 \\
\hline $\mathrm{ECHO}$ & 33.53 & Infrastructure & 30 & Balkh & Infrastructure & 25 \\
\hline $\begin{array}{l}\text { EURONAID } \\
\text { FAO }\end{array}$ & $\begin{array}{l}8.32 \\
0.18\end{array}$ & Other & 1 & Balkh & Agriculture & 10 \\
\hline ICARDA & 0.15 & Relief \& Repatria & 8 & Bamyan & Water Resources & 10 \\
\hline IFDC & 1.43 & & & Bamyan & Relief \& Repatriatioin & 35 \\
\hline OFDA & 13.36 & & & Bamyan & Infrastructure & 25 \\
\hline $\mathrm{SAH}$ & 3.07 & & & Bamyan & Agriculture & 30 \\
\hline UNAMA & 0.28 & & & Samangan & Relief \& Repatriatioin & 30 \\
\hline UNHCR & $\begin{array}{l}5.53 \\
3.56\end{array}$ & & & Samangan & Water Resources & 15 \\
\hline UNHCR/UNIC & $\begin{array}{l}3.56 \\
1.17\end{array}$ & & & Samangan & Infrastructure & 25 \\
\hline WFP & 1.17 & & & Samangan & Agriculture & 30 \\
\hline & & & & Wardak & Infrastructure & 10 \\
\hline & & & & Wardak & Water Resources & 20 \\
\hline & & & & Wardak & Agriculture & 70 \\
\hline
\end{tabular}

Sub Offices 


\begin{tabular}{|c|c|c|c|c|c|}
\hline Sub Office & City / Town & Phone & Fax & E-mail & In Charge \\
\hline $\begin{array}{l}\text { NWFP.32/F KKK Road University } \\
\text { Town }\end{array}$ & Peshawar & 5703978 & 844745 & solpesh@brain.net.pk & Fareed \\
\hline Wardak.Jalrez Khoja Saheb & Jalrez & +873763221949 & +87763221950 & $\begin{array}{l}\text { solkabul@inmarsat.franc } \\
\text { etelecom.fr }\end{array}$ & \\
\hline Bamyan City & Bamyan & +873762218786 & & $\begin{array}{l}\text { solbamya@inmarsat.fran } \\
\text { cetelecom.fi }\end{array}$ & Franc Machet \\
\hline Samangan Ruyi Du Ab & Samangan & +873762849495 & & $\begin{array}{l}\text { solroy@inmarsat.francet } \\
\text { elecom.fr }\end{array}$ & Chirstophe \\
\hline $\begin{array}{l}\text { Balkh.Dawaza-e Shadian Aq̣ab-e } \\
\text { Stadium }\end{array}$ & Mazar & +873762281662 & +87376228166 & $\begin{array}{l}\text { solmazar@inmarsat.fran } \\
\text { cetelecom.fr }\end{array}$ & Alexandre \\
\hline
\end{tabular}

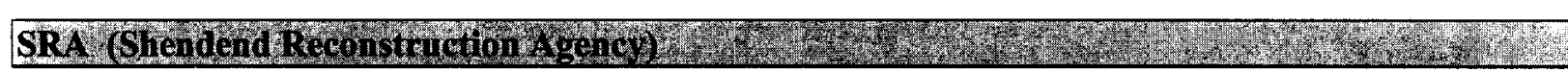

\begin{tabular}{|c|c|c|c|}
\hline Member̀ship & Other & Country of Affliliation & Afghanistan \\
\hline Address & Communication & Key Staff & Position \\
\hline \multirow{4}{*}{$\begin{array}{l}\text { Oppsite of Municpolity, } \\
\text { Homaun Market, } \\
\text { Hirat-Afghanistan }\end{array}$} & Phone: & Gulam Fidar & Program Manager \\
\hline & Fax: & Dr.Azim & Assistant Manager \\
\hline & E-mail: & Ashraf Khan & Adminstrator \\
\hline & Web: & & \\
\hline
\end{tabular}

\begin{tabular}{|l|rr|r|}
\hline Afghan & 10 & Personnel & \\
\hline Pakistani & 10 & Administrative \\
\hline Expatriates & 0 & Support & 2 \\
\hline Total & 0 & Technical & 4 \\
\hline
\end{tabular}

\begin{tabular}{|lllll}
\multicolumn{1}{l}{} & $\mathbf{1 9 9 9}$ & $\mathbf{2 0 0 0}$ & $\mathbf{2 0 0 1}$ & $\mathbf{2 0 0 2}$ \\
\hline Afghanistan & 50,000 & 35,000 & 85,000 \\
\hline Pakistan & 0 & 0 & 0 \\
\hline Total & $50,000.00$ & $35,000.00$ & $85,000.00$
\end{tabular}

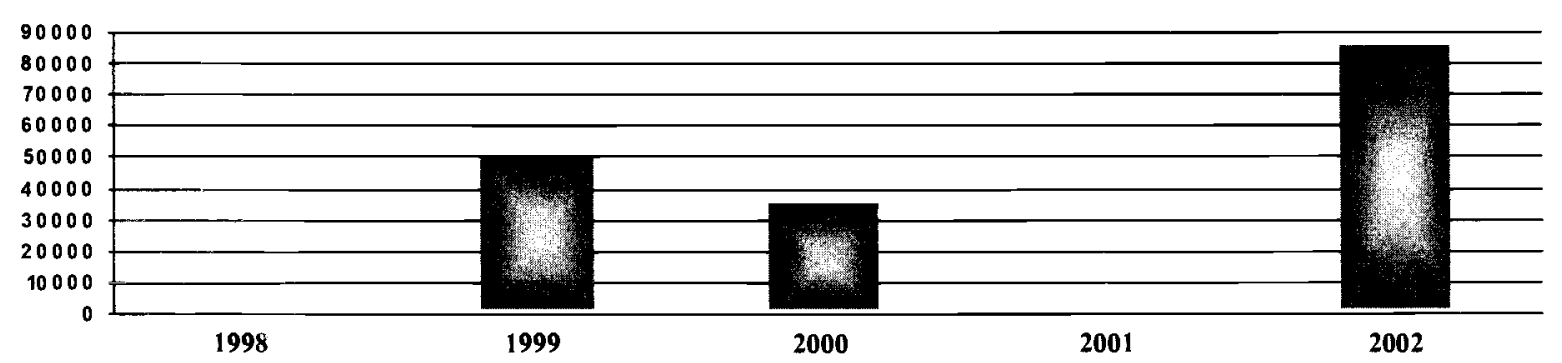

\begin{tabular}{|c|c|c|c|c|c|c|}
\hline \multicolumn{2}{|c|}{ Donors } & & location & \multirow[b]{2}{*}{ Province } & \multicolumn{2}{|c|}{ Targeted Provinces } \\
\hline Donors & \% Funded & Allocation & \% Funded & & Sector & $\%$ Targeted \\
\hline ATI & 25 & In frastructure & 100 & Badghis & In frastructure & 20 \\
\hline \multirow[t]{2}{*}{ UNOPS } & 75 & & & Farah & Infrastructure & 50 \\
\hline & & & & Hirat & In frastructure & 30 \\
\hline
\end{tabular}

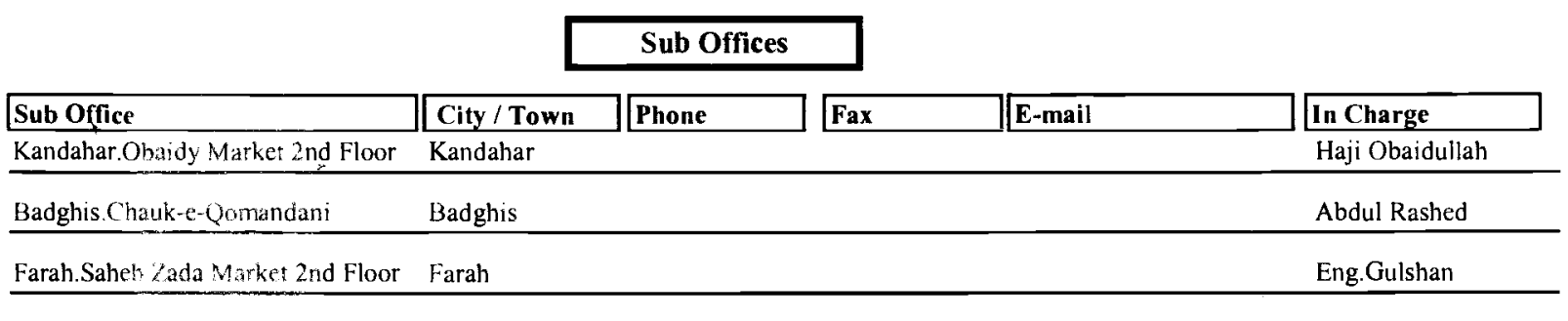




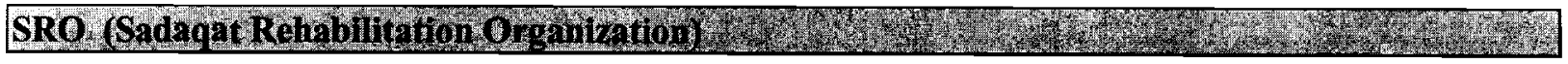

\begin{tabular}{|c|c|c|c|}
\hline Membership & $\mathrm{ANCB}$ & Country of Affliliation & Italia \\
\hline Address & Communication & Key Staff & Position \\
\hline \multirow{4}{*}{$\begin{array}{l}\text { Share Now Chahrahi Haji Yaqub, } \\
\text { Next to ACRU, } \\
\text { Kabul- Afghanistan }\end{array}$} & $070280966 / 070279797$ & Khair Mohd. Norzy & Director \\
\hline & Fax: & Dost Mohd. Norzy & Admin Assistant \\
\hline & E-mail: & Darioosh Osmany & Translater \\
\hline & Web: & & \\
\hline
\end{tabular}

\begin{tabular}{|l|r|}
\hline Afghan & 20 \\
\hline \hline Pakistani & 0 \\
\hline \hline Expatriates & 0 \\
\hline Total & 20 \\
\hline
\end{tabular}

Personnel

\begin{tabular}{|c|c|c|c|c|c|}
\hline \multirow[t]{3}{*}{ 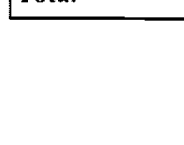 } & & & & \multirow[b]{3}{*}{2001} & \multirow[b]{3}{*}{2002} \\
\hline & & & Budget In US \$ & & \\
\hline & 1998 & 1999 & 2000 & & \\
\hline Afghanistan & & & & & 40,000 \\
\hline Pakistan & & & & & 5,000 \\
\hline Total & & & & & 45.000 .00 \\
\hline
\end{tabular}

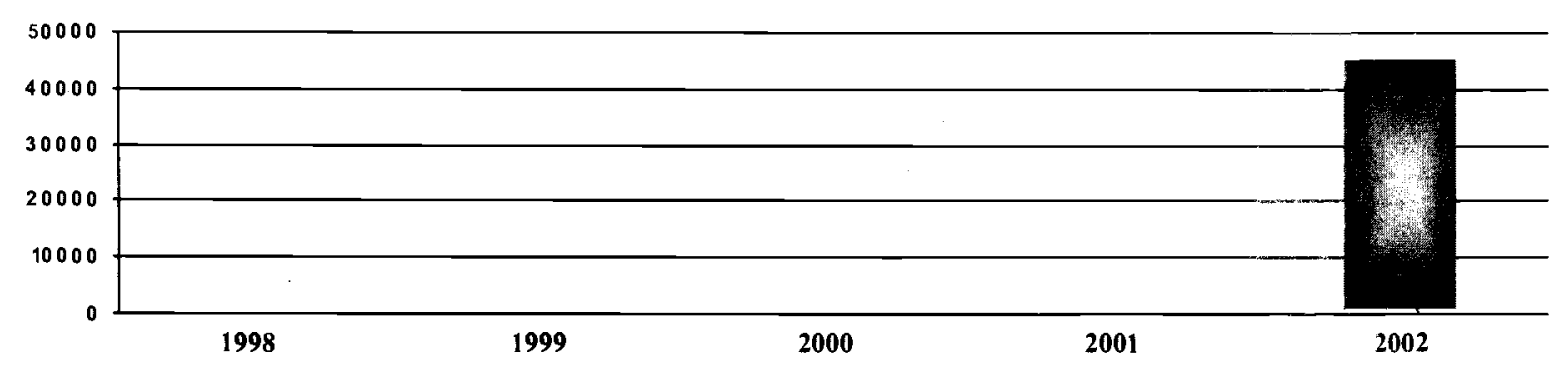

\begin{tabular}{|c|c|c|c|}
\hline \multicolumn{2}{|c|}{ Donors } & \multicolumn{2}{|c|}{ Allocation } \\
\hline Donors & $\%$ Funded & Allocation & $\%$ Funded \\
\hline ISAF & 90 & Infrastructure & 100 \\
\hline WFP & 10 & & \\
\hline
\end{tabular}

\begin{tabular}{lcc} 
& \multicolumn{2}{c|}{ Targeted Provinces } \\
\cline { 2 - 3 } Province & Sector & $\%$ Targeted \\
\hline Bamyan & Infrastructure & 8 \\
Hirat & Infrastructure & 10 \\
Kandahar & Agriculture & 7 \\
Mazar & Education & 10 \\
Uruzgan & Infrastructure & 18
\end{tabular}




\begin{tabular}{|c|c|c|c|}
\hline Membership & Other & Country of Affliliation & Afghanistan \\
\hline Address & Communication & Key Staff & Position \\
\hline \multirow{4}{*}{$\begin{array}{l}\text { Charahi Awal Simitry, } \\
\text { Beside IRC Office, } \\
\text { Hirat-Afghanistan }\end{array}$} & $227564 /+8821650268088$ & Eng.M.Naser & Director \\
\hline & Fax: & Eng.A.Khalii & Assistant Manager \\
\hline & E-mail: & M.Mostafa & Site Engineer \\
\hline & Web: & & \\
\hline
\end{tabular}

\begin{tabular}{|l|}
\hline Afghan \\
\hline \hline Pakistani \\
\hline \hline Expatriates \\
\hline Total \\
\hline
\end{tabular}

Personnel

\begin{tabular}{|l|}
\hline Administrative \\
\hline Support \\
\hline Technical \\
\hline Total \\
\hline
\end{tabular}

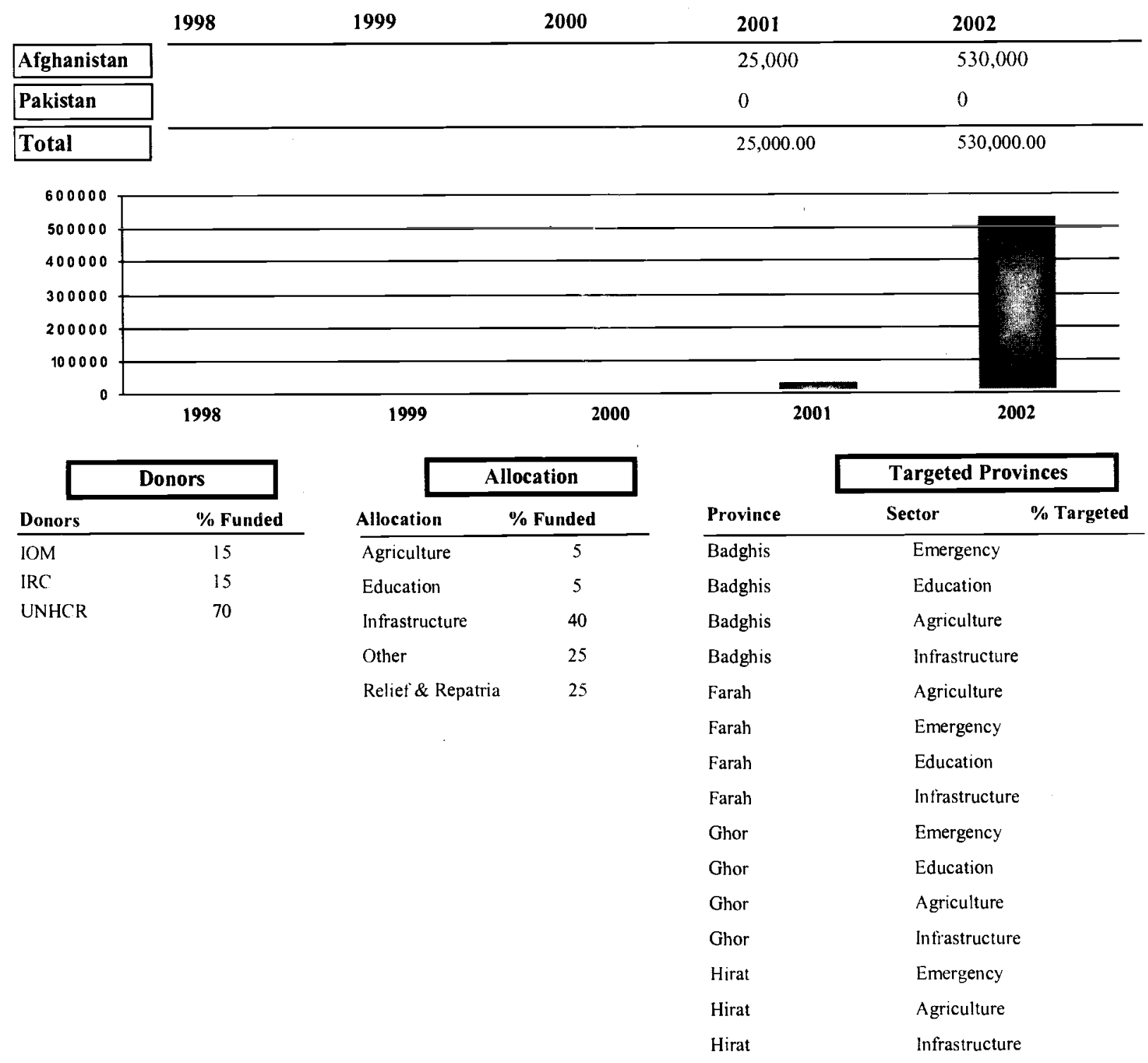

\section{Sub Offices}

\begin{tabular}{l|l|l|l|l|l|l|l|l|l|l|}
\hline Sub Office & City / Town Charge \\
Badghis. Kochi Perow in Front of & Badghis \\
WFP Office &
\end{tabular}


SRP (SharulkibRahabilitation Project),

\begin{tabular}{|c|c|c|c|}
\hline Membership & & Country of Afniliation & Afghanistan \\
\hline Address & Communication & Key Staff & Position \\
\hline \multirow{4}{*}{$\begin{array}{l}\text { Bandari Tafawsat East Rawza, } \\
\text { Dr. A.Ali Apartment, } \\
\text { Mazar- Afghanistan }\end{array}$} & Phone: & Zahir Shahrukhi & Director \\
\hline & Fax: & Najmuddin & Asst.Director \\
\hline & E-mail: & Sefatullah & Engineer \\
\hline & Web: & & \\
\hline
\end{tabular}

\begin{tabular}{|l|rr|r|}
\hline Afghan & \multicolumn{1}{c|}{ Personnel } & \\
\hline Pakistani & 16 & Administrative \\
\hline \hline Expatriates & 0 & Support \\
\hline Total & 0 & Technical & 10 \\
\hline
\end{tabular}

Budget In US \$

\begin{tabular}{|c|c|c|c|c|c|}
\hline & 1998 & 1999 & 2000 & 2001 & 2002 \\
\hline Afghanistan & & 7,700 & & 10,240 & 64,630 \\
\hline Pakistan & & 0 & & 0 & 0 \\
\hline Total & & $7,700.00$ & & $10,240.00$ & $64,630.00$ \\
\hline
\end{tabular}

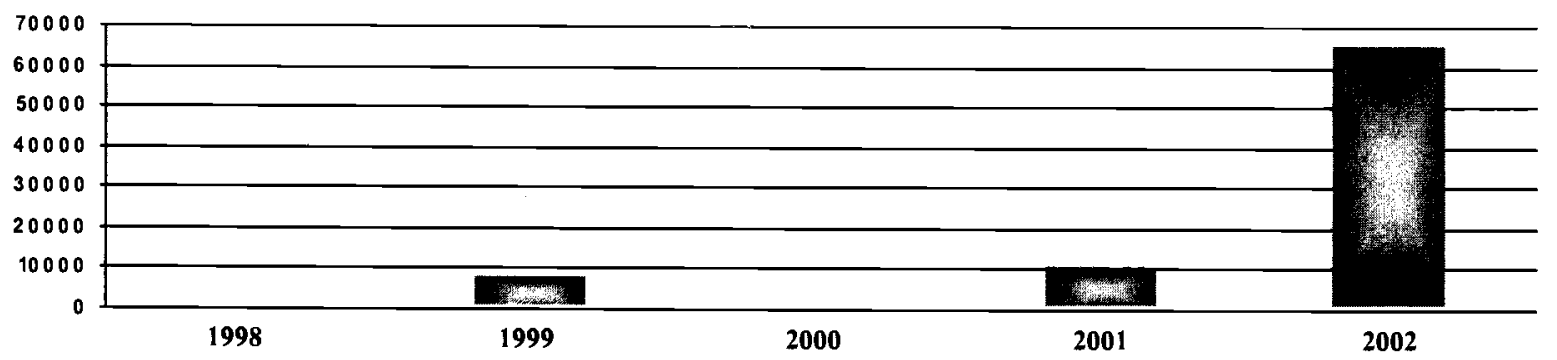

\begin{tabular}{|c|c|c|c|c|c|c|c|}
\hline \multicolumn{2}{|c|}{ Donors } & & location & \multirow[b]{2}{*}{ Province } & \multicolumn{3}{|c|}{ Targeted Provinces } \\
\hline Donors & $\%$ Funded & Allocation & $\%$ Funded & & Sector & $\%$ Targ & \\
\hline Goal Shelter & & Education & 50 & Samangan & Infra & & 50 \\
\hline UNICEF & 50 & Infrastructure & 80 & Samangan & Relie & triatioin & 80 \\
\hline WFP & 100 & Relief \& Repa & 100 & & & & \\
\hline
\end{tabular}

\section{Sub Offices}

\begin{tabular}{|l|l|l|l|l|l|l|l|l|l|l|l|l|l|l|}
\hline Sub Office & City / Town & Phone \\
\hline
\end{tabular}

Samangan. Beside Girls High School Khulm

Khulm

Samangan.Center of the District Samangan 


\begin{tabular}{|c|c|c|c|}
\hline Membership & $\overline{A N C B}$ & Country of Affiliation & Afghanistan \\
\hline Address & Communication & Key Staff & Position \\
\hline \multirow{4}{*}{$\begin{array}{l}\text { House } 131 \text { Street } 15, \\
\text { Wazir Akbar Khan, } \\
\text { Kabul-Atghanistan }\end{array}$} & 070275548 & Eng.A.Ghani & Director \\
\hline & & Eng.Gul Akbar & Regionar Manager \\
\hline & staar_af@yahoo.com & Eng.Faqirullah & Deputy Director \\
\hline & Web: & & \\
\hline
\end{tabular}

\begin{tabular}{|l|}
\hline Afghan \\
\hline \hline Pakistani \\
\hline Expatriates \\
\hline Total \\
\hline
\end{tabular}

Personnel

\begin{tabular}{|l|}
\hline Administrative \\
\hline Support \\
\hline Technical \\
\hline Total \\
\hline
\end{tabular}

Budget In US S

\begin{tabular}{l|lllll}
\multicolumn{1}{l}{} & $\mathbf{1 9 9 8}$ & $\mathbf{1 9 9 9}$ & $\mathbf{2 0 0 0}$ & $\mathbf{2 0 0 1}$ & $\mathbf{2 0 0 2}$ \\
\cline { 1 - 3 } Afghanistan & 110,000 & 80,000 & 90,000 & 120,000 & 150,342 \\
\cline { 1 - 3 } Pakistan & 0 & 35,000 & 0 & 0 & 0 \\
\cline { 1 - 5 } Total & $115,000.00$ & $90,000.00$ & $120,000.00$ & $150,342.00$
\end{tabular}
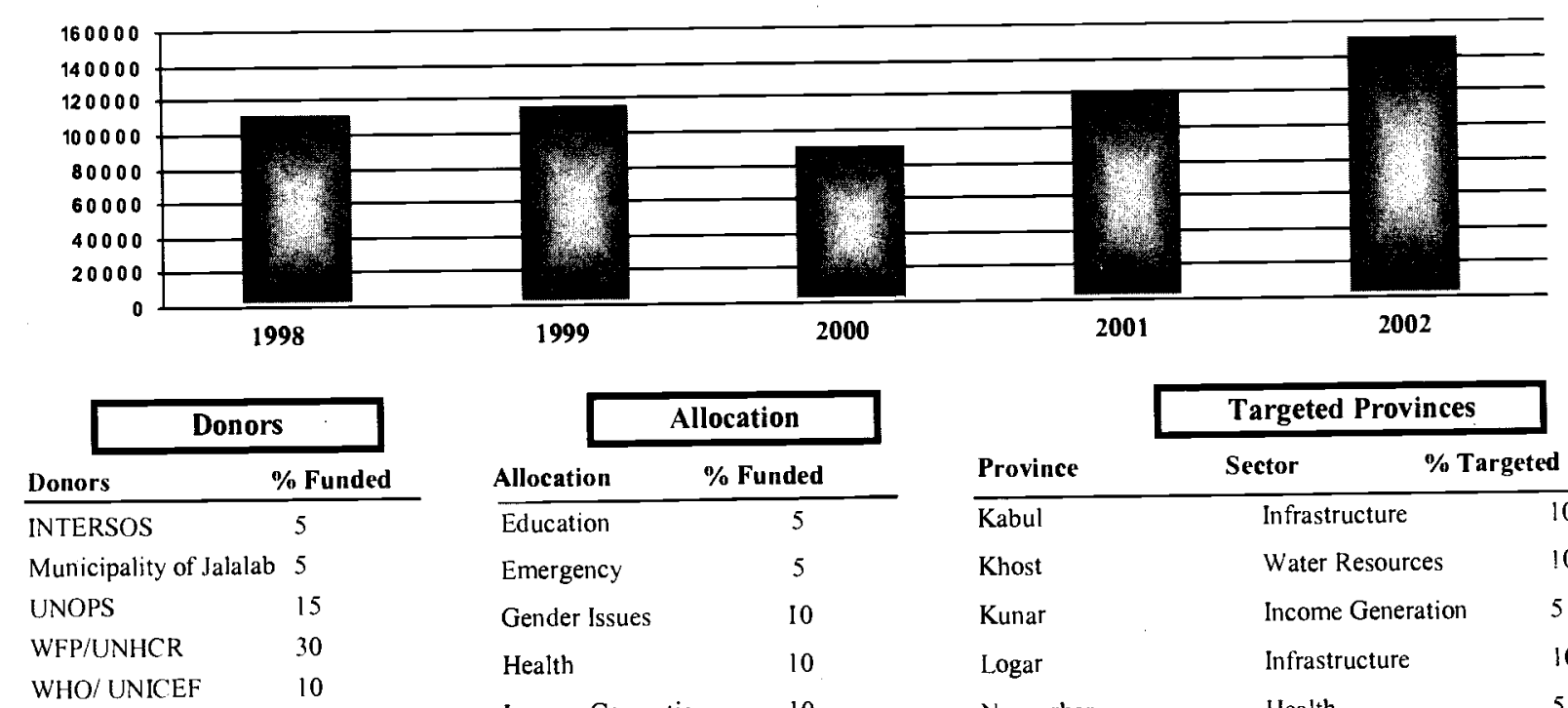

\begin{tabular}{lc|}
\multicolumn{1}{c|}{ Allocation } \\
\hline Allocation & \% Funded \\
\hline Education & 5 \\
Emergency & 5 \\
Gender Issues & 10 \\
Health & 10 \\
Income Generatio & 10 \\
Infrastructure & 40 \\
Other & 10 \\
Relief \& Repatria & 10
\end{tabular}

\begin{tabular}{lll} 
& \multicolumn{2}{c|}{ Targeted Provinces } \\
\cline { 2 - 3 } Province & Sector & \multicolumn{2}{c}{$\%$ Targeted } \\
\hline Kabul & Infrastructure & 10 \\
Khost & Water Resources & 10 \\
Kunar & Income Generation & 5 \\
Logar & Infrastructure & 10 \\
Nangarhar & Health & 5 \\
Paktika & Water Resources & 10 \\
Paktya & Water Resources & 10 \\
Parwan & Infrastructure & 10 \\
Wardak & Water Resources & 30
\end{tabular}

Sub Offices

\begin{tabular}{|c|c|c|c|c|c|}
\hline Sub Office & City / Town & Phone & Fax & E-mail & In Charge \\
\hline $\begin{array}{l}\text { Nangrahar.Chaparhar Hadda Near } \\
\text { ISRA }\end{array}$ & Jalalabad & & & staar-af@yahoo.com & Fiqirullah \\
\hline Kunar.Asadabad City & Kunar & & & & Ghazan \\
\hline Hilmand. Near Public Hospital & Hilmand & & & & Shafiq \\
\hline Paktika. Near Governer House & Paktika & & & & \\
\hline
\end{tabular}




\begin{tabular}{|c|c|c|c|}
\hline Membership & Other & Country of Affliliation & Afghanistan \\
\hline Address & Communication & Key Staff & Position \\
\hline \multirow{4}{*}{$\begin{array}{l}\text { Moh-e- Mobarak Road Taimani } \\
\text { St., } \\
\text { Kabul-Afghanistan }\end{array}$} & Phone: $\quad 07027943$ & Tenor Shah Ishaq Zai & Director \\
\hline & Fax: & Nooria & Assistant \\
\hline & E-mail: & Monawar & Admin Officer \\
\hline & Web: & & \\
\hline
\end{tabular}

\begin{tabular}{|l|}
\hline Afghan \\
\hline Pakistani \\
\hline Expatriates \\
\hline Total \\
\hline
\end{tabular}

Personnel

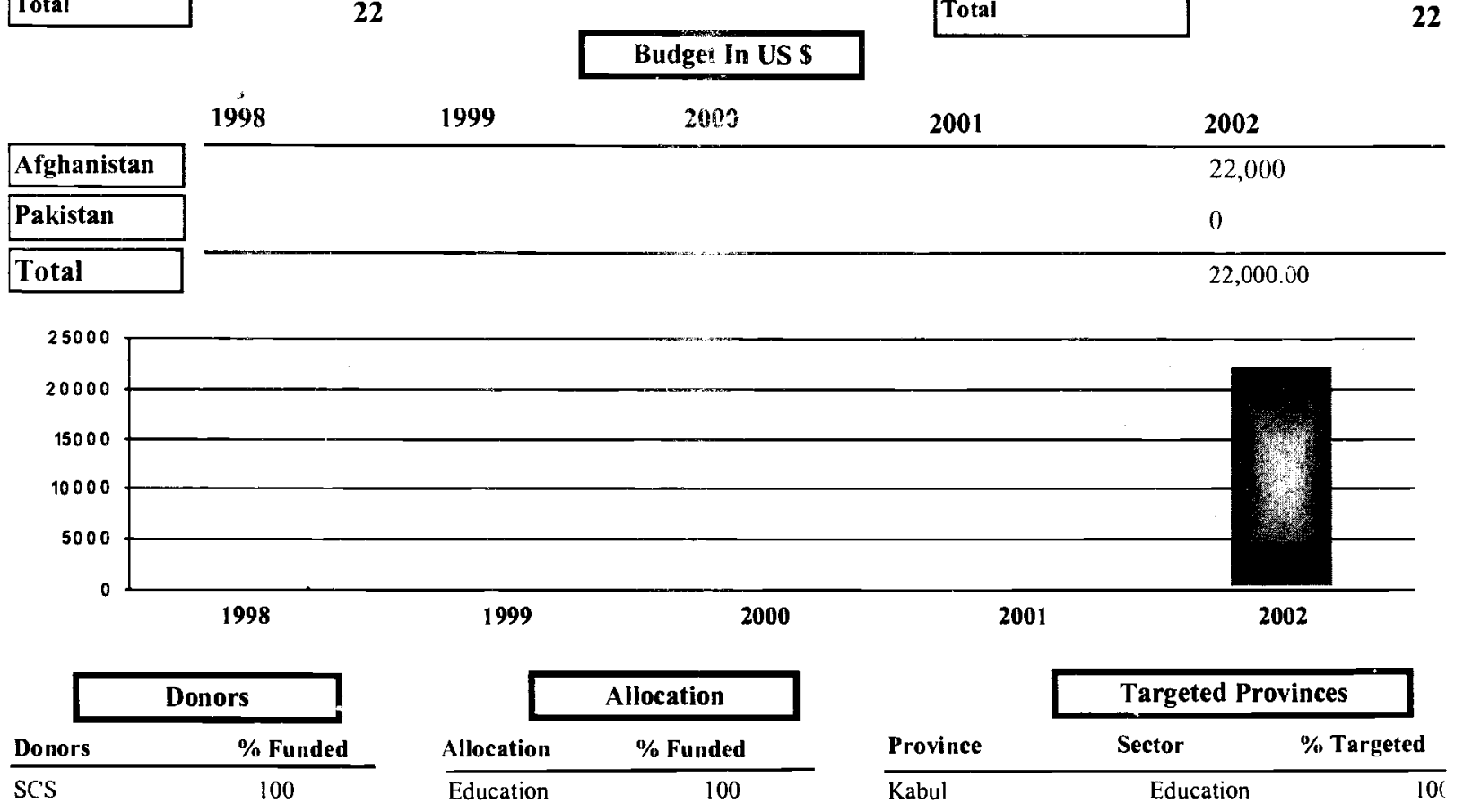

\section{Sub Offices}

\begin{tabular}{l|l|l|l|l|l|l|l|l|l|l|l|l|l|}
\hline Sub Office & City / Town & Phone \\
\hline $\begin{array}{l}\text { Nangrahar Chashma-e-Khanjee } \\
\text { Infornt of Health Net }\end{array}$ & Jalalabad \\
\hline
\end{tabular}




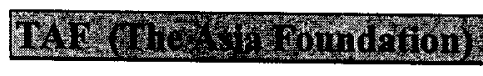

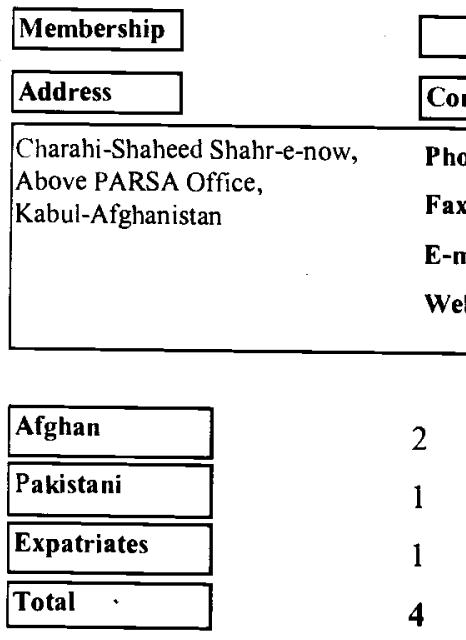

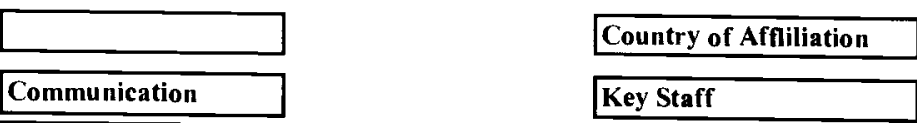

USA

Phone: 070277284/070276509

Key Staff

Position

Fax:

Jon summers

Representative

E-mail:

Aziz Rafiee

Program Manager

Web:

www.asiafound.org

Samima Durrani

Finance Officer

\section{Personnel}

Budget In US \$

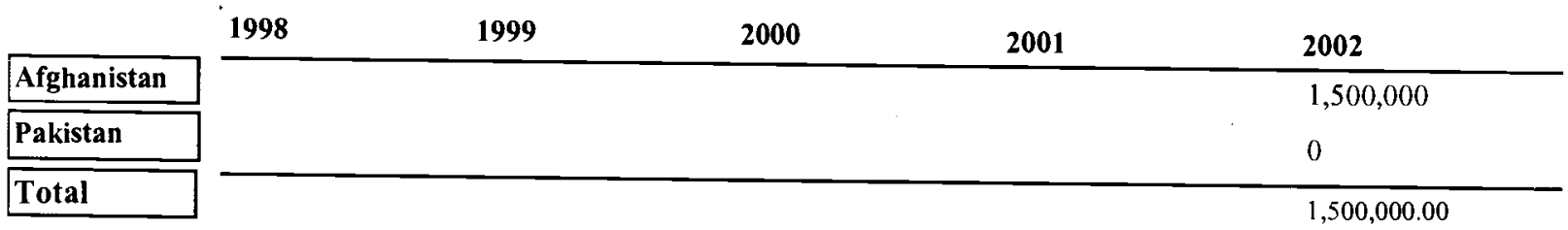

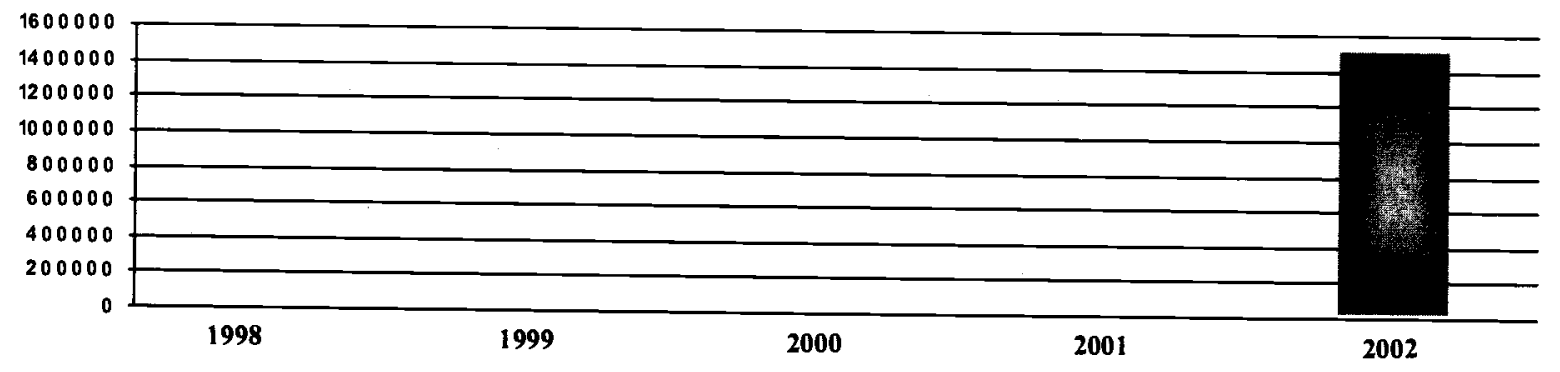

\begin{tabular}{lc|}
\cline { 2 - 2 } & \multicolumn{2}{c|}{ Donors } \\
Donors & \% Funded \\
\hline NGS & 7 \\
Private & 10 \\
USAID & 70 \\
USG & 13
\end{tabular}

\begin{tabular}{lc|}
\hline \multicolumn{2}{c|}{ Allocation } \\
\hline Allocation & \% Funded \\
\hline Education & 25 \\
Gender Issues & 5 \\
Human Rights & 5 \\
Income Generatio & 5 \\
Other & 60
\end{tabular}

\section{Sub Offices}

\begin{tabular}{lll} 
& \multicolumn{2}{c|}{ Targeted Provinces } \\
\hline Province & Sector & \% Targeted \\
\hline Balkh & Other & 5 \\
Hirat & Other & 5 \\
Kabul & Other & 30 \\
Kabul & Gender Issues & 5 \\
Kabul & Income Generation & 5 \\
Kabul & Health & 5 \\
Kabul & Education & 25 \\
Kandahar & Other & 5 \\
Kunduz & Other & 5 \\
Nangarhar & Other & 5 \\
Paktia & Other & 5
\end{tabular}

\begin{tabular}{|l|}
\hline Administrative \\
\hline Support \\
\hline Technical \\
\hline Total \\
\hline
\end{tabular}




\begin{tabular}{|c|c|c|c|}
\hline Membership & Other & Country of Affliliation & Afghanistan \\
\hline Address & Communication & Key Staff & Position \\
\hline \multirow{4}{*}{$\begin{array}{l}\text { House } 2 \text { Qala-e-Moosa } 2 \text { nd Street, } \\
\text { To the Right Kabir Pharmacy, } \\
\text { Kabul-Afghanistan }\end{array}$} & 070276628 & Najib Aziz Amiri & Persident in USA \\
\hline & Fax: & Ab.Raouf Aziz & Head of Kabul \\
\hline & E-mail: & Jaweed & Adminstrative \\
\hline & Web: & & \\
\hline
\end{tabular}

\begin{tabular}{|l|}
\hline Afghan \\
\hline \hline Pakistani \\
\hline Expatriates \\
\hline Total \\
\hline
\end{tabular}

Personnel

\begin{tabular}{|c|c|c|c|c|c|}
\hline Total & & & & Total & 20 \\
\hline & & & Budget In US \$ & & \\
\hline & 1998 & 1999 & 2000 & 2001 & 2002 \\
\hline Afghanistan & 10,000 & 64,000 & 54,000 & 25,000 & 27,000 \\
\hline Pakistan & 58,000 & 20,000 & 40,000 & 35,000 & 0 \\
\hline Total & $08,000.00$ & $84,000.00$ & $94,000.00$ & $60,000.00$ & $27,000.00$ \\
\hline
\end{tabular}
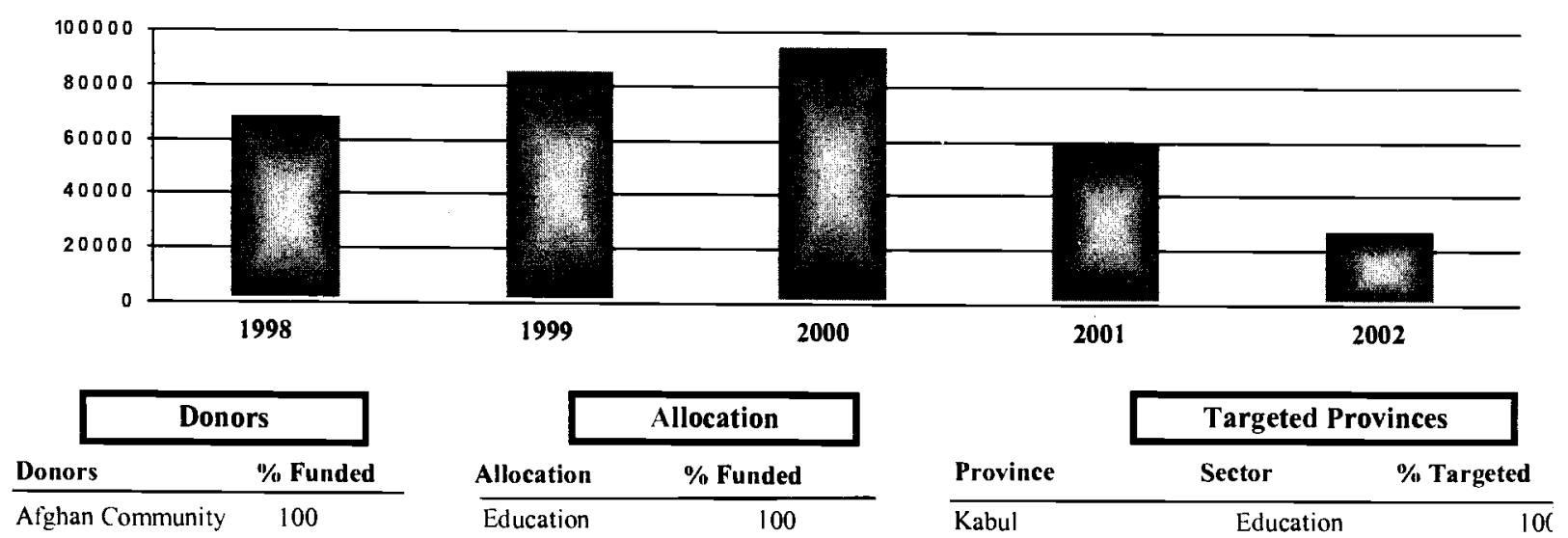

Sub Offices

\begin{tabular}{|c|c|c|c|c|}
\hline Sub Office & City / Town & Phone & E-mail & In Charge \\
\hline $\begin{array}{l}\text { USA. } 6320 \text { Augusta DR STE } 501 \\
\text { Spring Field VA }\end{array}$ & Veriginia & 70344230455 & & Najib Aziz \\
\hline $\begin{array}{l}\text { NWFP.Sector J-4 House } 71 \text { P. } 2 \\
\text { Hayatabad }\end{array}$ & Peshawar & 819019 & & Taran \\
\hline
\end{tabular}




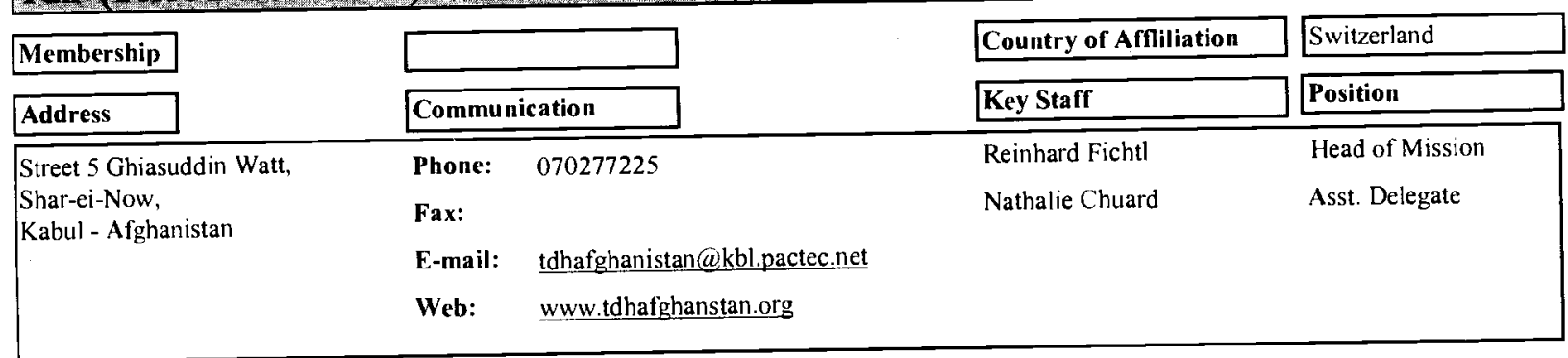

\begin{tabular}{|l|}
\hline Afghan \\
\hline Pakistani \\
\hline Expatriates \\
\hline Total \\
\hline
\end{tabular}

\begin{tabular}{|l|}
\hline Administrative \\
\hline Support \\
\hline Technical \\
\hline Total \\
\hline
\end{tabular}

Budget In US \$

\begin{tabular}{|c|c|c|c|c|c|}
\hline & 1998 & 1999 & 2000 & 2001 & 2002 \\
\hline Afghanistan & 230,000 & 300,000 & 600,000 & 900,000 & $1,100,000$ \\
\hline Pakistan & 0 & 0 & 0 & 0 & 0 \\
\hline Total & $230,000.00$ & $300,000.00$ & $600,000.00$ & $900,000.00$ & $1,100,000.00$ \\
\hline
\end{tabular}

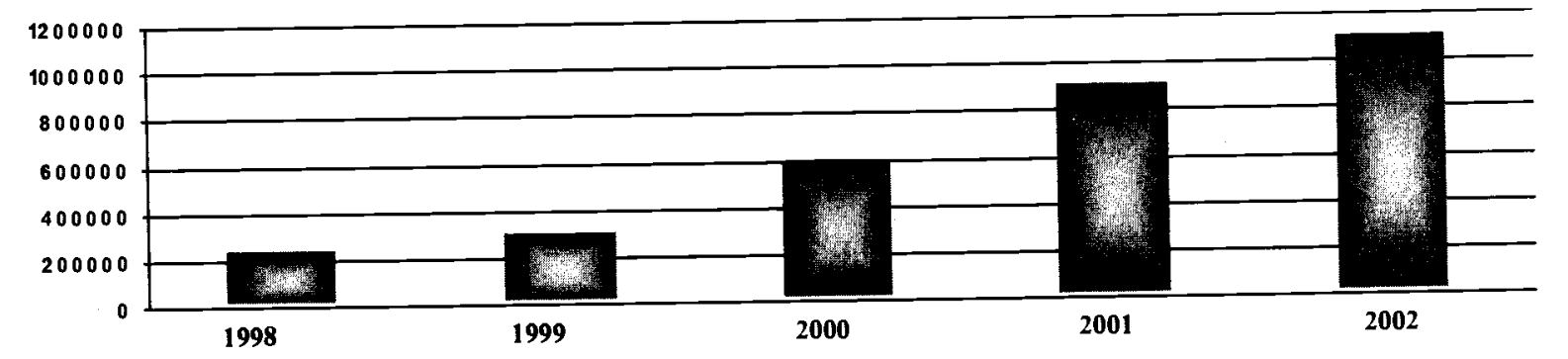

\begin{tabular}{l} 
Donors \\
Donors \\
\hline BMZ Germany \\
CDB \\
DFID \\
ECHO \\
MoFA Germany \\
SDC \\
TDH germany \\
TDH Italy \\
TDH Netherland \\
TDH Switzerland \\
UNICEF
\end{tabular}

\begin{tabular}{lc}
\multicolumn{1}{c|}{} & Allocation \\
\hline Allocation & \% Funded \\
\hline Education & 20 \\
Emergency & 30 \\
Health & 30 \\
Other & 20
\end{tabular}

\begin{tabular}{llr} 
& \multicolumn{2}{c|}{ Targeted Provinces } \\
\cline { 2 - 3 } Province & Sector & $\%$ Targeted \\
\hline Kabul & Health & 20 \\
Kabul & Other & 20 \\
Kandahar & Health & 10 \\
NWFP & Other & 10 \\
Takhar & Education & 40
\end{tabular}

Sub Offices

\begin{tabular}{|c|c|c|c|c|c|}
\hline Sub Office & City / Town & Phone & Fax & E-mail & In Charge \\
\hline Kabul.Wazir Akbar Khan Hospital & Kabul & 070277204 & & $\begin{array}{l}\text { tdhafghanistan@kbl.pact } \\
\text { ec.net }\end{array}$ & Noor Khanum \\
\hline Takhar.Rustaq Project Office & Rustaq & +87376169460 & & $\begin{array}{l}\text { tdhafghanistan@kbl.pact } \\
\text { ec.net }\end{array}$ & Roohullah \\
\hline NWFP .Peshawar & Peshawar & 5703814 & 852062 & tdhkabul@brain.net.pk & Matloob \\
\hline
\end{tabular}




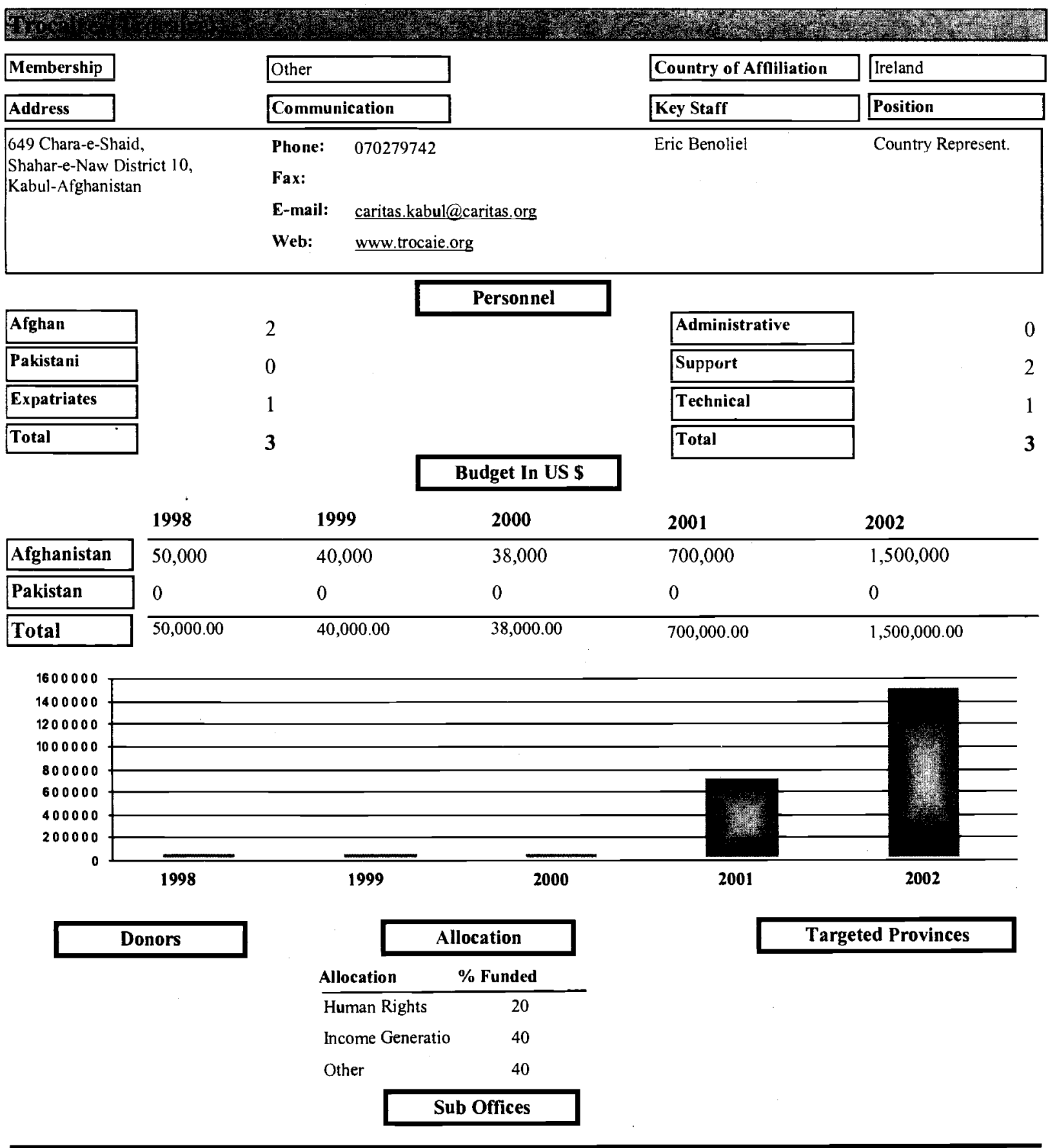




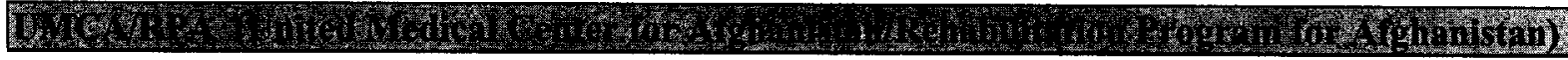

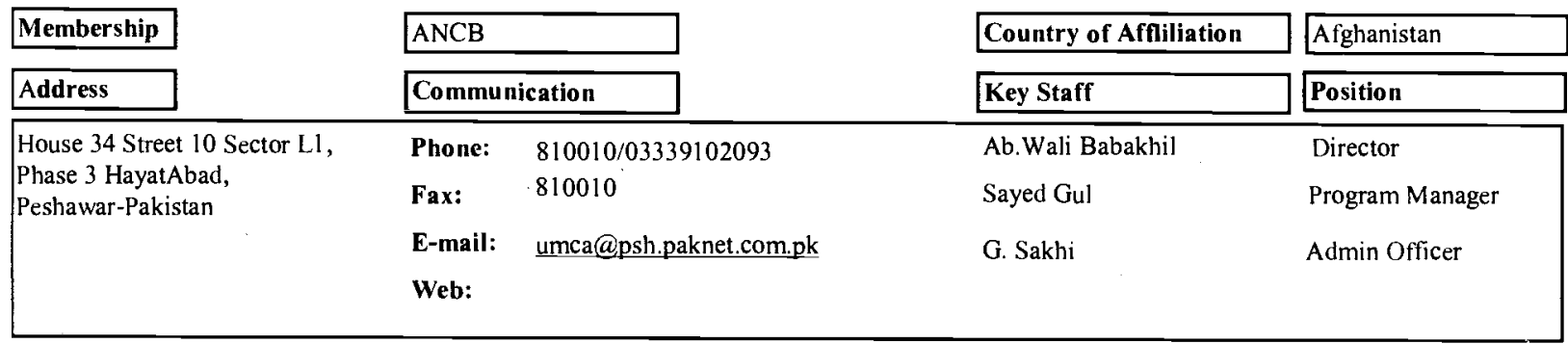

\begin{tabular}{|l|}
\hline Afghan \\
\hline Pakistani \\
\hline \hline Expatriates \\
\hline Total \\
\hline
\end{tabular}

Personnel

\begin{tabular}{|l|}
\hline Administrative \\
\hline Support \\
\hline Technical \\
\hline Total \\
\hline
\end{tabular}

1

43

Budget In US \$

\begin{tabular}{l|lllll}
\multicolumn{1}{l}{} & 1998 & $\mathbf{1 9 9 9}$ & $\mathbf{2 0 0 0}$ & $\mathbf{2 0 0 1}$ & $\mathbf{2 0 0 2}$ \\
\cline { 1 - 3 } Afghanistan & 16,313 & 18,012 & 24,571 & 18,750 & 3,400 \\
\hline Pakistan & 0 & 2,700 & 3,234 & $22,150.00$
\end{tabular}

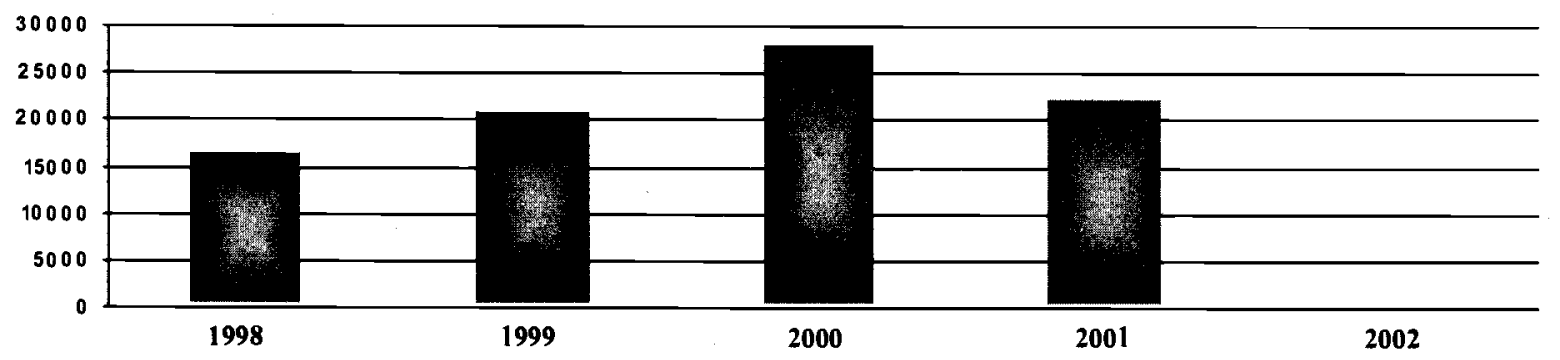

\begin{tabular}{lc}
\cline { 2 - 2 } & \multicolumn{2}{c|}{ Donors } \\
Donors & \% Funded \\
\hline D.P.J & 5 \\
INTERSOS & 29 \\
JOCF/Bellmark & 45 \\
NAC & 20 \\
WHO & 1
\end{tabular}

\begin{tabular}{lc|}
\multicolumn{1}{c|}{ Allocation } \\
Allocation & \% Funded \\
\hline Agriculture & 15 \\
Emergency & 5 \\
Health & 45 \\
Income Generatio & 25 \\
Other & 5 \\
Veterinary & 5
\end{tabular}

\begin{tabular}{lcr} 
& \multicolumn{2}{c|}{ Targeted Provinces } \\
\cline { 2 - 3 } Province & Sector & $\%$ Targeted \\
\hline Nangarhar & Veterinary & 10 \\
Nangarhar & Income Generation & 25 \\
Nangarhar & Agriculture & 15 \\
Nangarhar & Emergency & 5 \\
Nangarhar & Health & 45
\end{tabular}

\section{Sub Offices}

\begin{tabular}{|c|c|c|c|c|c|}
\hline Sub Office & City / Town & Phone & Fax & E-mail & In Charge \\
\hline $\begin{array}{l}\text { House } 5 \text { St. } 3 \text { ZaraSarandwali Zone } 4 \\
\text { Rege-Shahmurad Khan }\end{array}$ & Jalalabad & & & & Sayed Gul \\
\hline C/0 ANCB Office & Kabul & 070270221 & & & \\
\hline
\end{tabular}




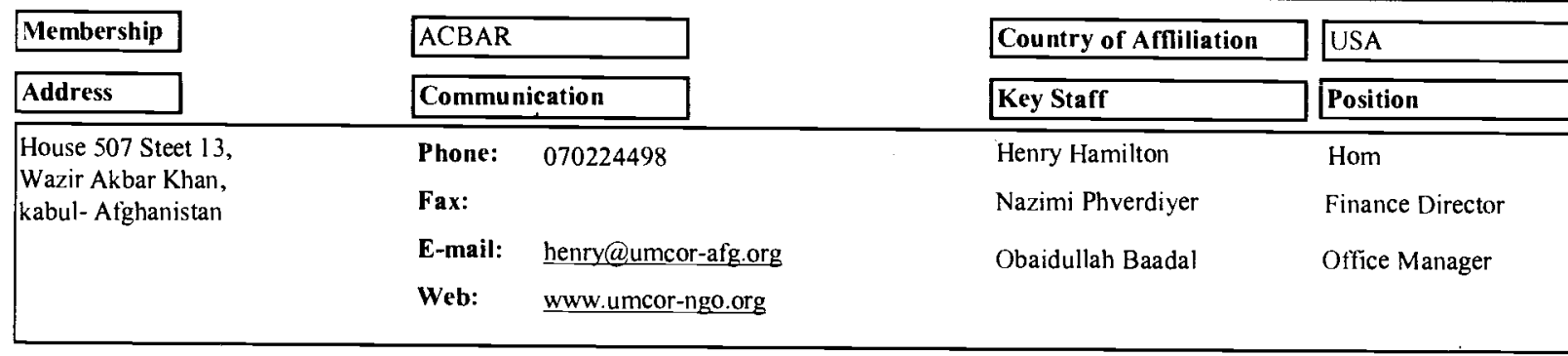

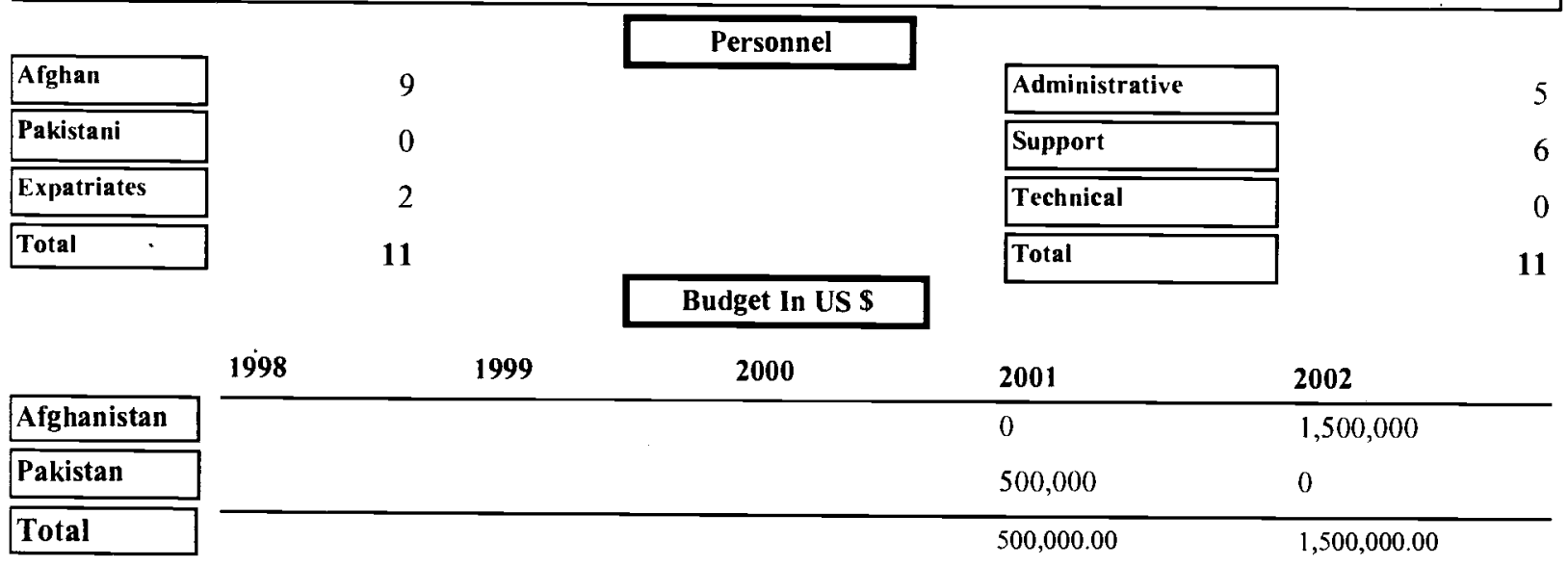

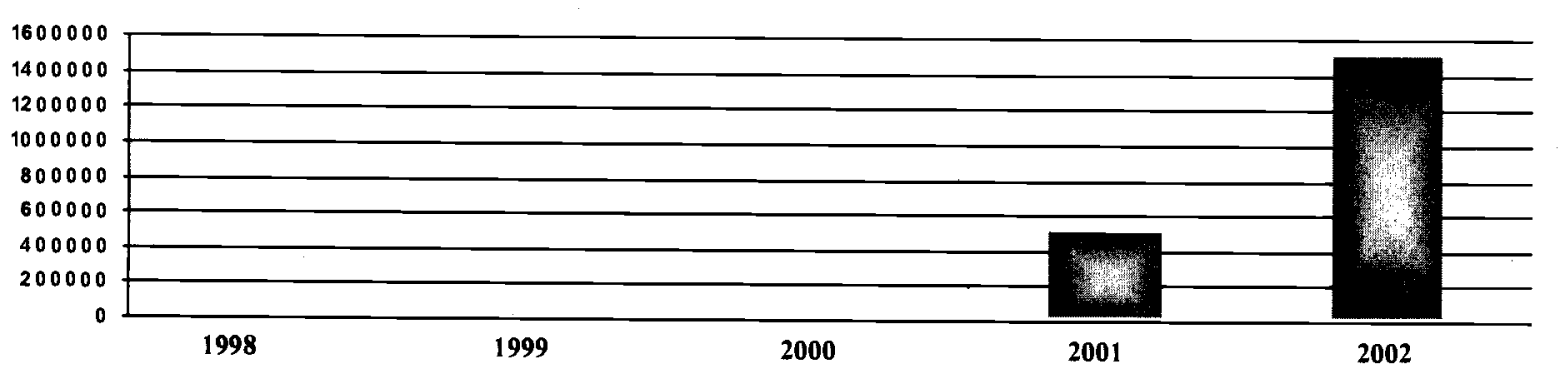

\begin{tabular}{|c|c|c|c|c|c|c|c|}
\hline & & & location & & Targe & inces & \\
\hline Donors & $\%$ Funded & Allocation & $\%$ Funded & Province & Sector & $\% \mathrm{~T}$ & \\
\hline Self Funding & 100 & $\overline{\text { Agriculture }}$ & 15 & $\overline{\text { Parwan }}$ & Inco & ation & 20 \\
\hline & & Education & 10 & Parwan & Wat & & 10 \\
\hline & & Environment & 5 & Parwan & Env & & 5 \\
\hline & & Income Generatio & 10 & Parwan & Edu & & 10 \\
\hline & & Infrastructure & 40 & Parwan & Infra & & 40 \\
\hline & & Water Resources & 20 & Parwan & Agri & & 15 \\
\hline
\end{tabular}

Sub Offices 


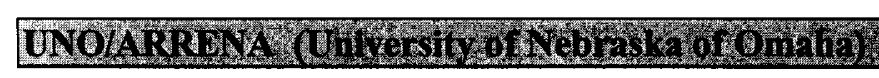

\begin{tabular}{|c|c|c|c|}
\hline Membership & Other & Country of Affliliation & USA \\
\hline Address & Communication & Key Staff & Position \\
\hline 56-C Old Bara Road, & 9216618 & Abdul Salam Azimi & Chief of Party \\
\hline $\begin{array}{l}\text { University Town, } \\
\text { U.P.O. Box } 967\end{array}$ & Fax: $\quad 840492$ & J.K.Hekmati & Liaison Officer \\
\hline Peshawar- Pakistan & $\begin{array}{l}\text { E-mail: unoatep-pes@yahoo.com } \\
\text { Web: }\end{array}$ & Hamidullah Anwari & Admin Officer \\
\hline
\end{tabular}

\begin{tabular}{|l|}
\hline Afghan \\
\hline Pakistani \\
\hline Expatriates \\
\hline Total \\
\hline
\end{tabular}

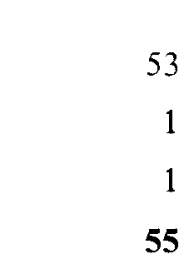

Personnel

\begin{tabular}{|l|}
\hline Afghanistan \\
\hline Pakistan \\
\hline
\end{tabular}

\begin{tabular}{|l|}
\hline Administrative \\
\hline Support \\
\hline Technical \\
\hline Total \\
\hline
\end{tabular}

1

2000

2001

2002

0

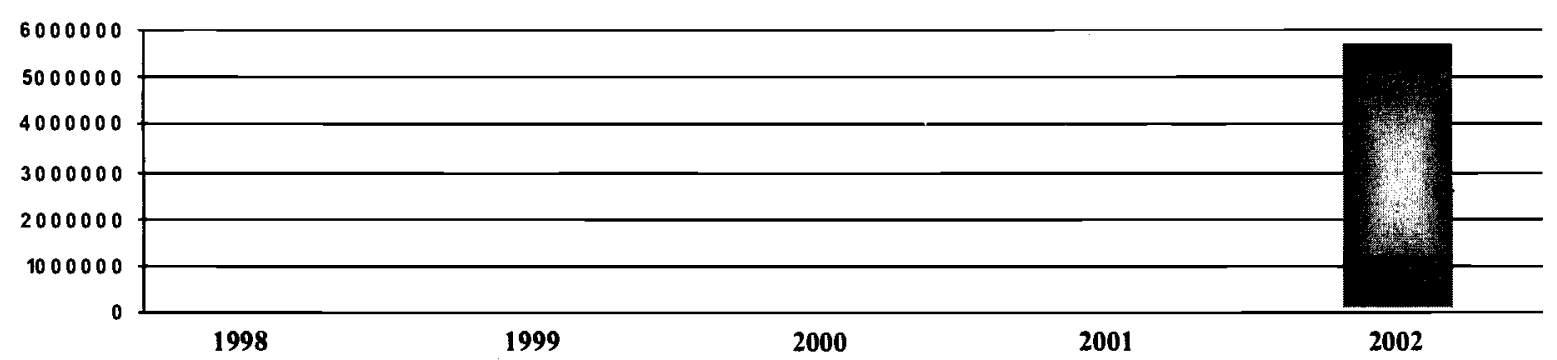

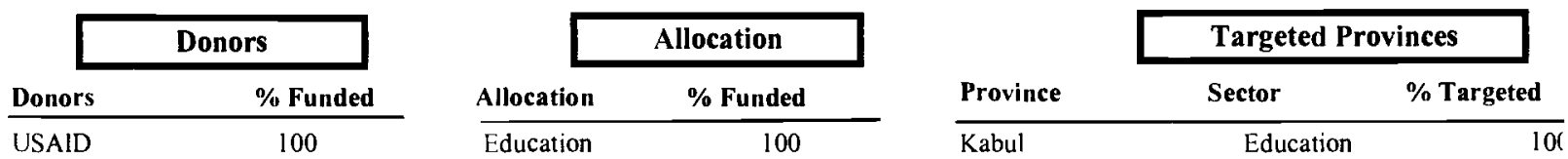

\begin{tabular}{|c|c|c|c|c|c|}
\hline & & Sub Offices & & & \\
\hline Sub Office & City / Town & Phone & $\longdiv { \text { Fax } }$ & E-mail & In Charge \\
\hline Shahr-Now Haji Yaqub St.3 & Kabul & 2200731 & 2200731 & $\begin{array}{l}\text { unoarrena_kab@yahoo.c } \\
\text { om }\end{array}$ & Mohd.Dawood \\
\hline Shahr-Now Taimani Road & Kabul & 070279659 & & & M.Y.Jabar Khil \\
\hline $\begin{array}{l}\text { NWFP. House } 6 \text { St. } 3 \text { Nasir Bagh } \\
\text { Road Baord Colony }\end{array}$ & Peshawar & 842257 & 840402 & & A.S.Durrani \\
\hline $\begin{array}{l}\text { NWFPHouse } 40 \text { S.A.Q Road } \\
\text { University Town }\end{array}$ & Peshawar & 851341 & & imdc@brain.net.pk & Kh.Faiz \\
\hline Ministry of Education First Stair & Kabul & 2101730 & & & J.K.Hekmati \\
\hline
\end{tabular}




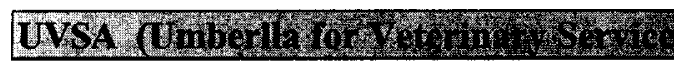

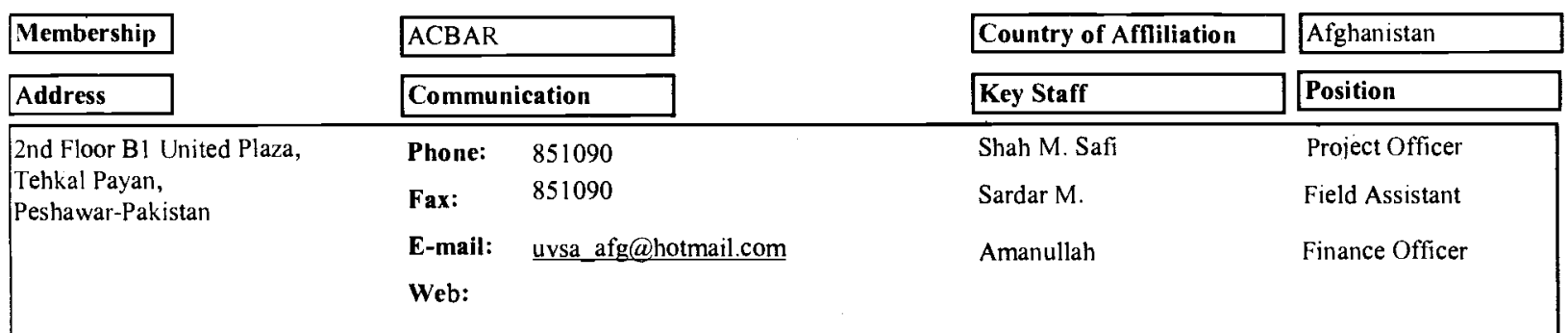

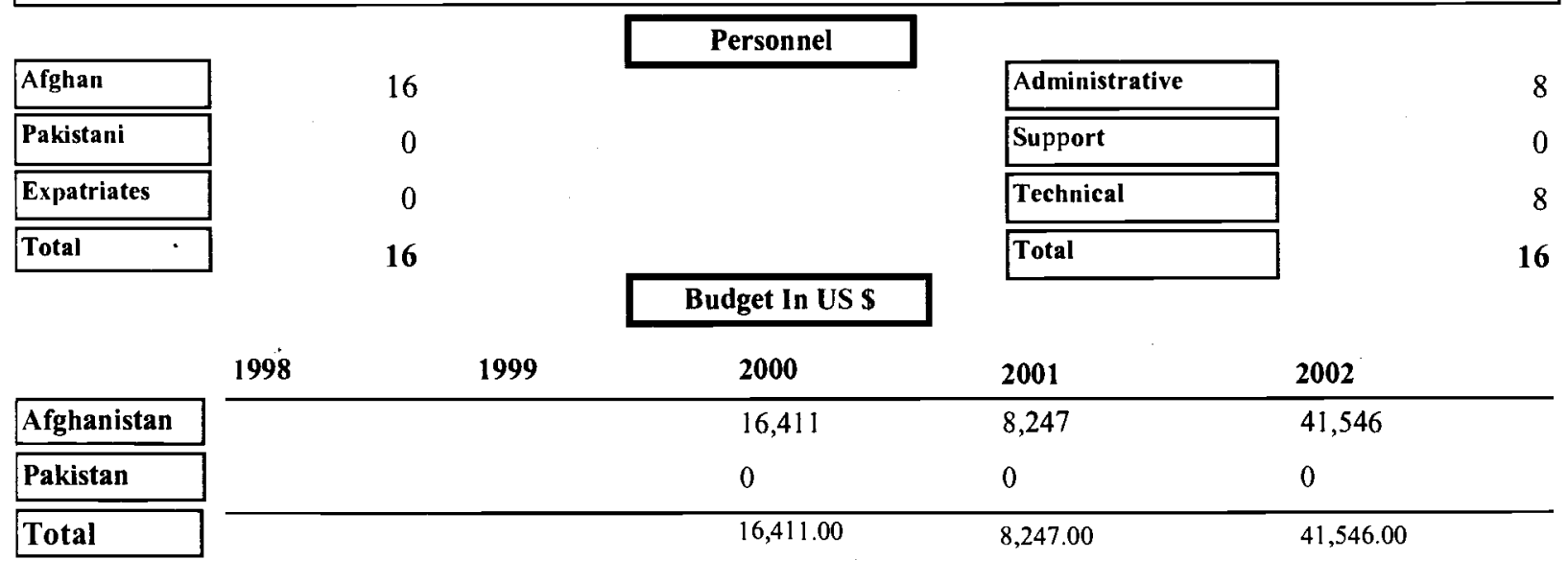

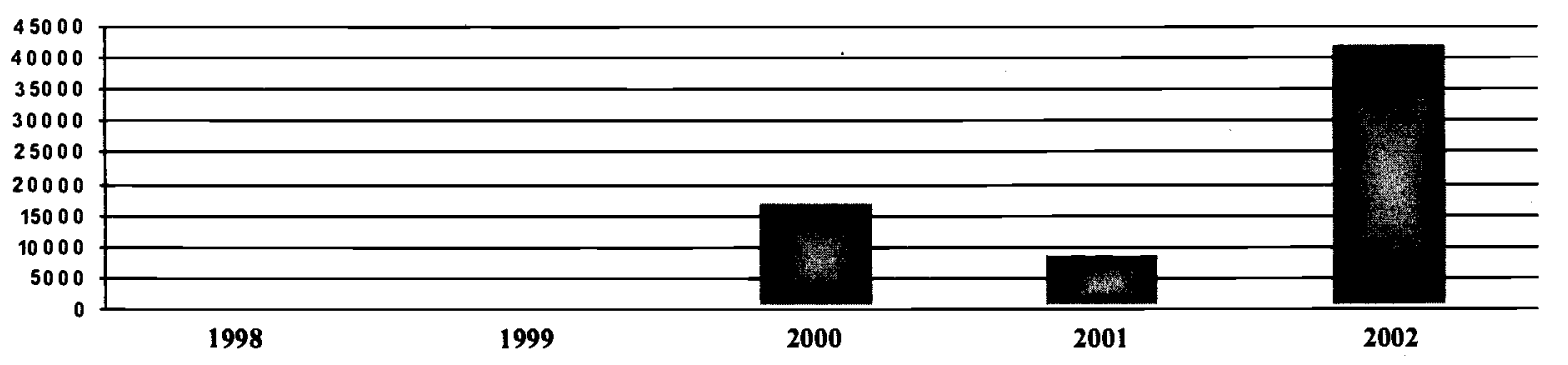

\begin{tabular}{|c|c|c|c|c|c|c|}
\hline \multicolumn{2}{|c|}{ Donors } & & llocation & \multirow[b]{2}{*}{ Province } & \multicolumn{2}{|c|}{ Targeted Provinces } \\
\hline Donors & $\%$ Funded & Allocation & $\%$ Funded & & Sector & $\%$ Targeted \\
\hline \multirow[t]{5}{*}{$\mathrm{FAO} / \mathrm{UN}$} & 100 & Veterinary & 100 & Balkh & Agriculture & 1 \\
\hline & & & & Hirat & Agriculture & 10 \\
\hline & & & & Kabul & Agriculture & 1 \\
\hline & & & & Kunduz & Agriculture & 1 \\
\hline & & & & Nangarhar & Agriculture & 4 \\
\hline
\end{tabular}

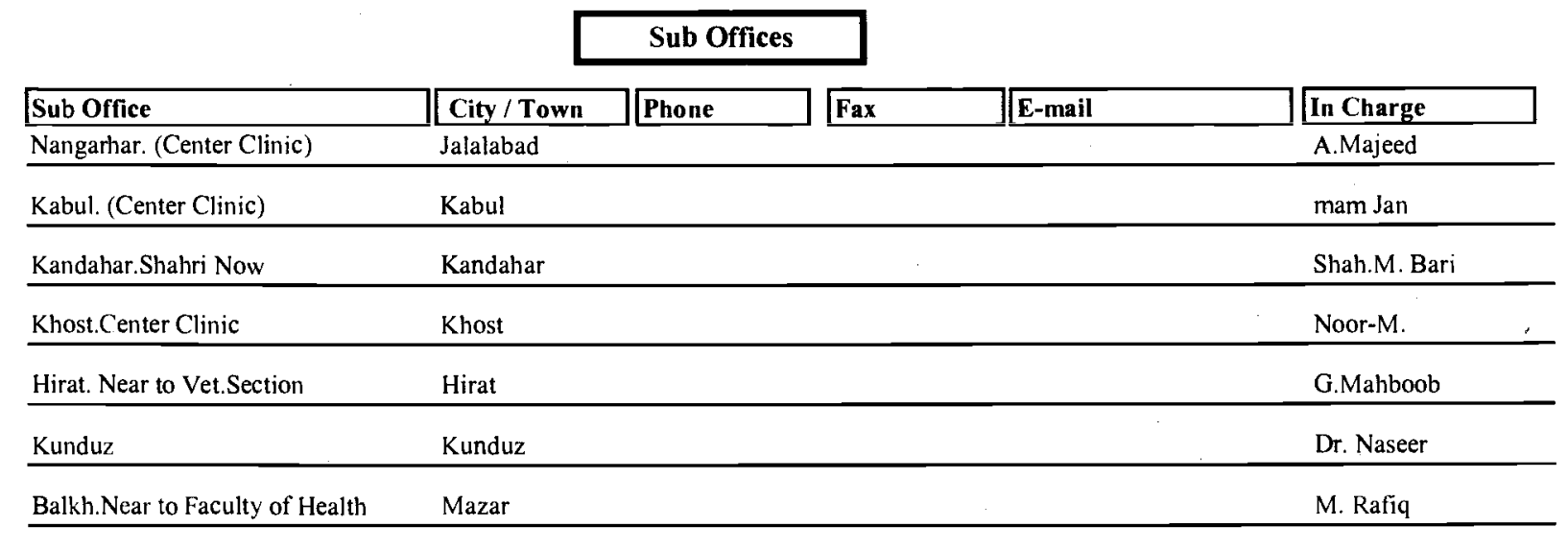




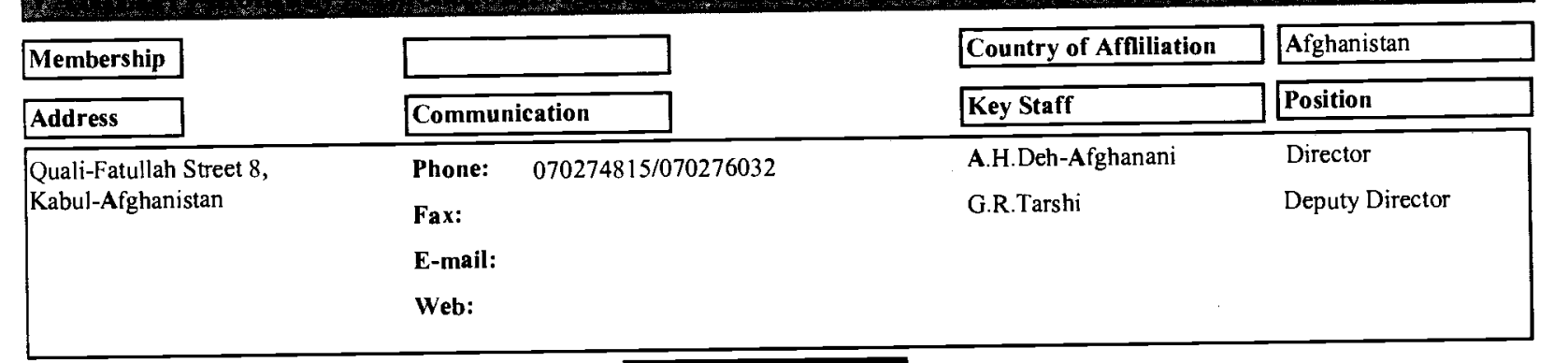

\begin{tabular}{|c|c|c|c|c|}
\hline & & Personnel & & \\
\hline Afghan & 20 & & Administrative & 5 \\
\hline Pakistani & 0 & & Support & 5 \\
\hline Expatriates & 0 & & Technical & 10 \\
\hline Total & 20 & & Total & 20 \\
\hline & & Budget In US \$ & & \\
\hline
\end{tabular}

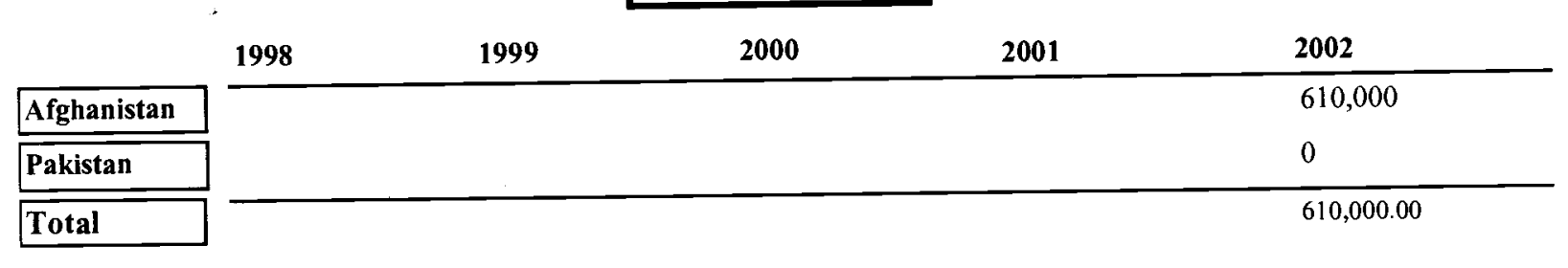
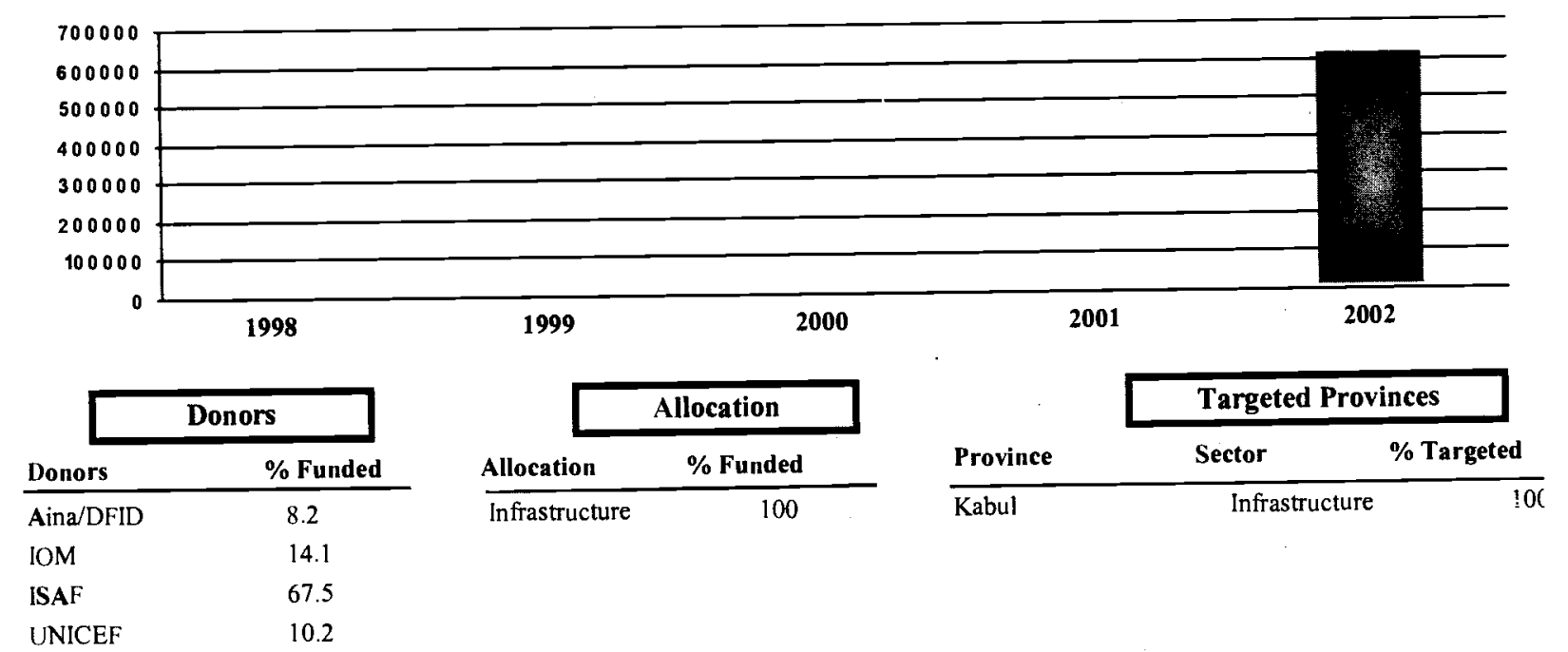

\section{Sub Offices}

\begin{tabular}{l|l|l|l|l|l|l|l|l|l|}
\hline Sub Office & City / Town Charge \\
\hline Qalai-Fatullah 10th Street & Kabul \\
\hline
\end{tabular}


WW Noice of Womein Organistalion)

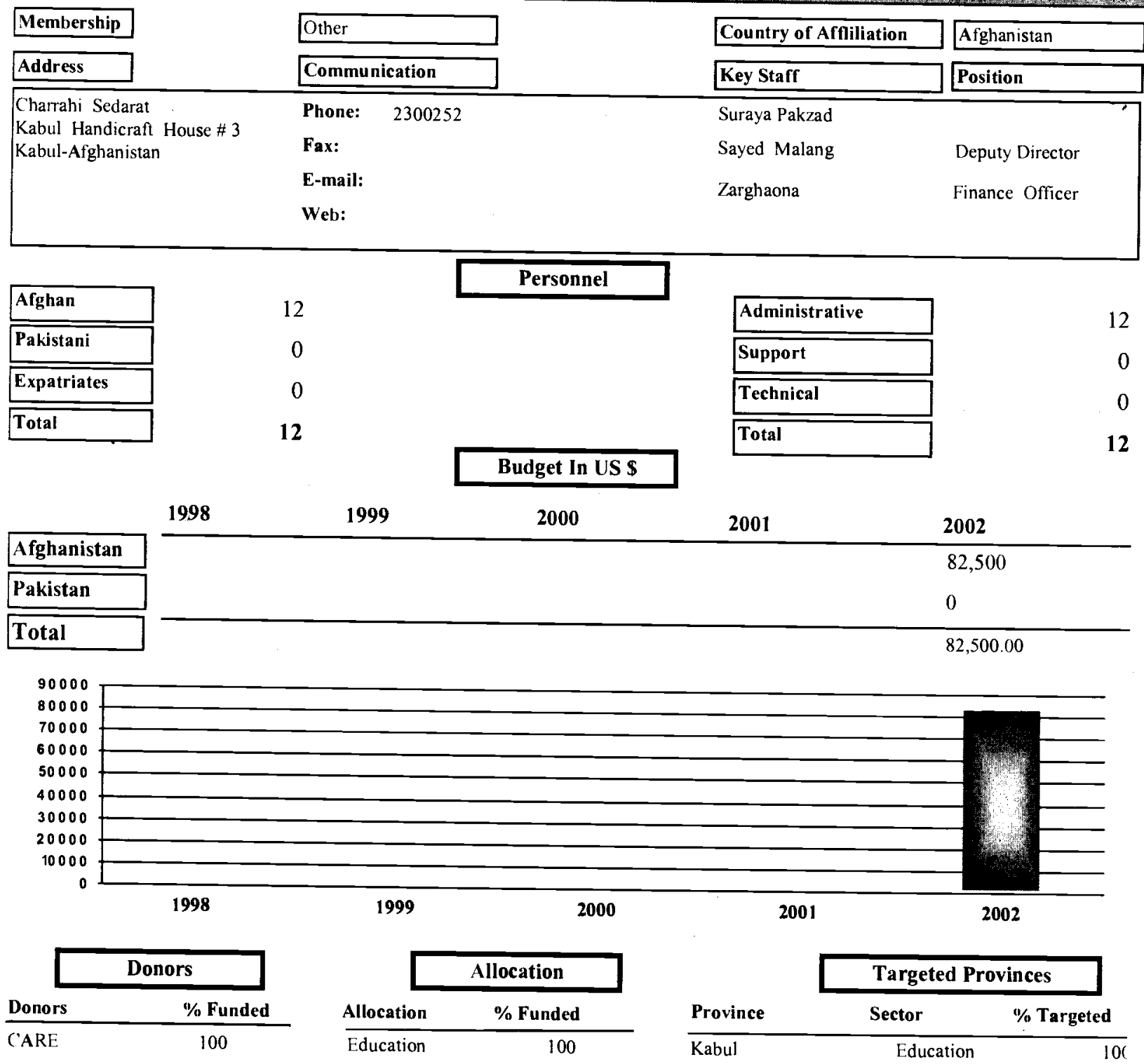




\begin{tabular}{|llll|}
\hline Membership & Other & \multicolumn{1}{|c|}{ Country of Affliliation } & Afghanistan \\
\hline & Communication & Key Staff & Position \\
\hline Address & Phone: 61466 & Fahima Kakat & Director \\
\hline $\begin{array}{l}\text { House 563 1st Line Street 13, } \\
\text { Wazir Akbar Khan, } \\
\text { Kabul - Afghanistan }\end{array}$ & Fax: & Kamela & Program Coordinator \\
& E-mail: & Naqibullah & Admin Manager \\
& Web: & & \\
& & & \\
\end{tabular}

\begin{tabular}{|c|c|c|}
\hline & & Personnel \\
\hline Afghan & 30 & \\
\hline Pakistani & 0 & \\
\hline Expatriates & 0 & \\
\hline Total & 30 & \\
\hline
\end{tabular}

\begin{tabular}{|l|}
\hline Administrative \\
\hline Support \\
\hline Technical \\
\hline Total \\
\hline
\end{tabular}

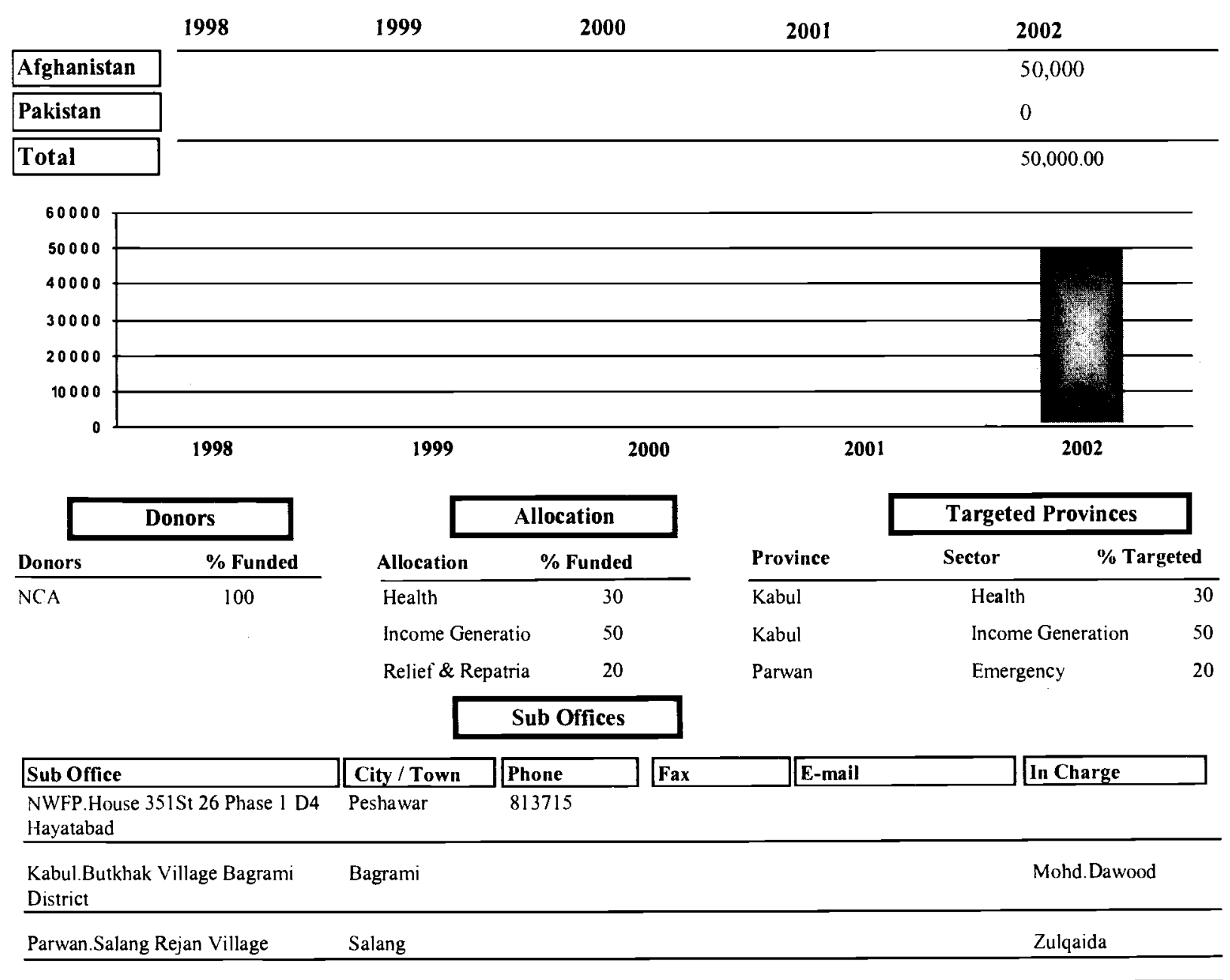




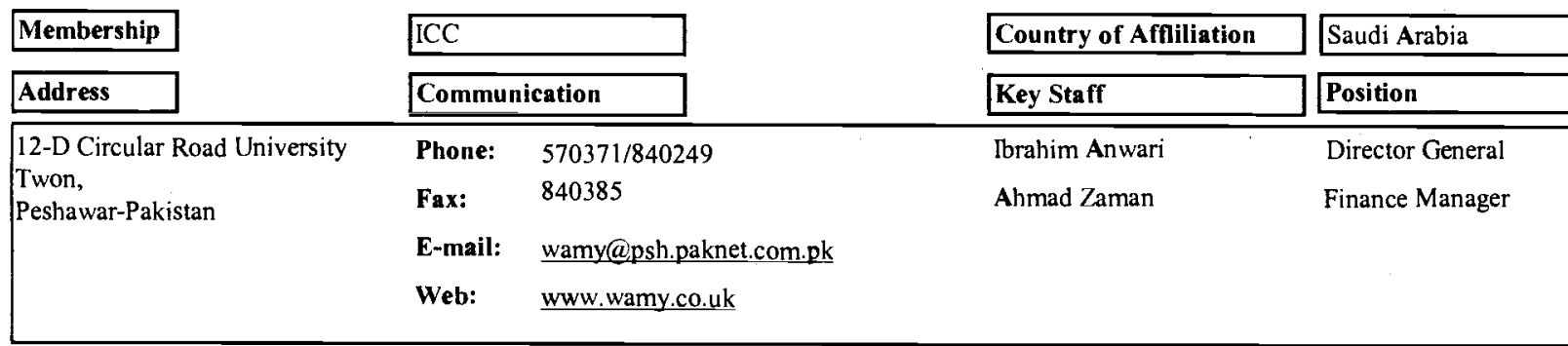

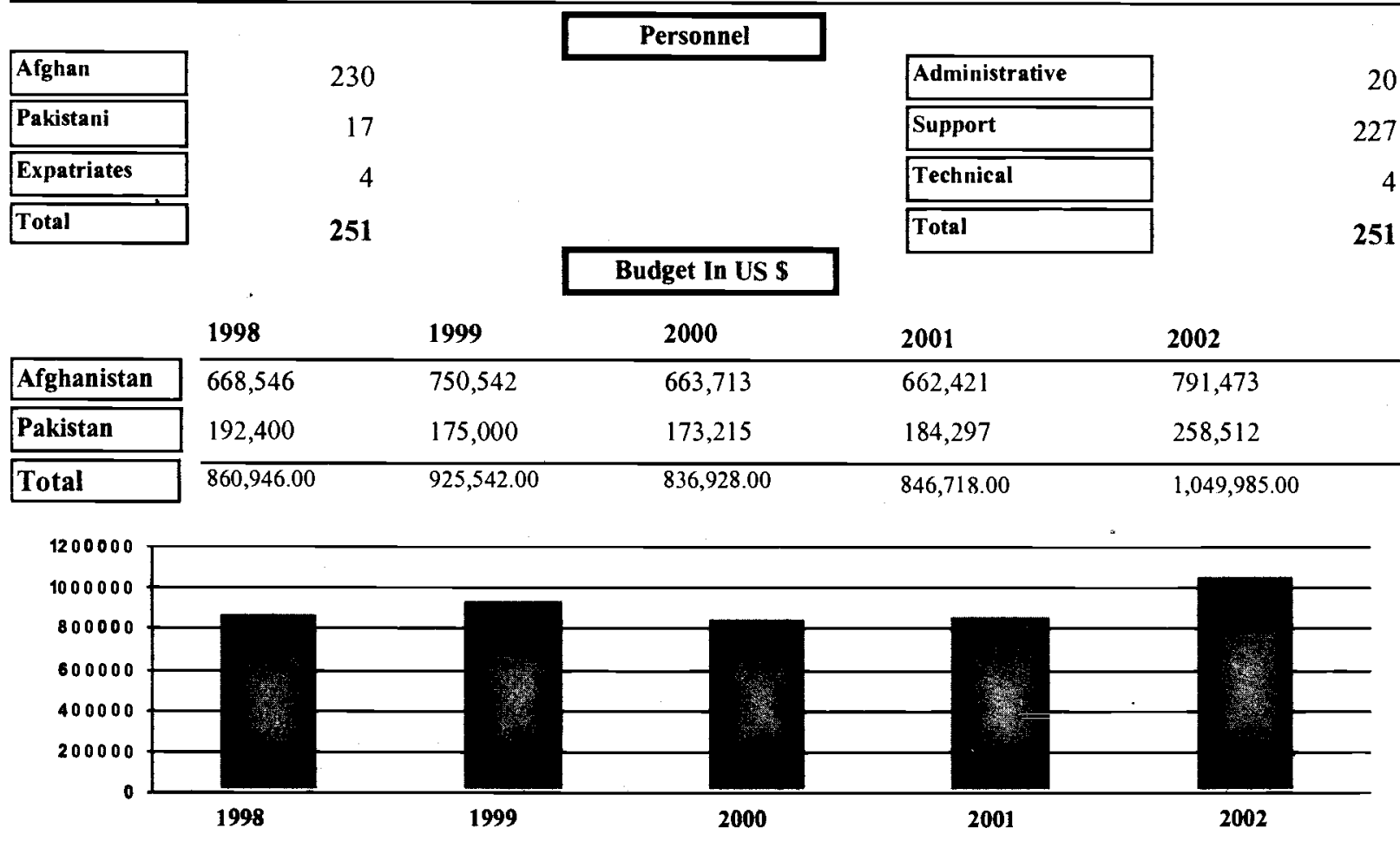

\begin{tabular}{|c|c|c|c|c|c|c|c|}
\hline Dono & & & location & & Target & inces & \\
\hline Donors & $\%$ Funded & Allocation & $\%$ Funded & Province & Sector & $\%$ Targ & \\
\hline UNHCR/WFP/MSF/W & 13 & Education & 20.07 & Hirat & Relic & triatioin & 10. \\
\hline WAMY & 87 & Health & 12.6 & Kabul & Educ & & 6.8 \\
\hline & & Other & 9.1 & Kandahar & Relie & triatioin & 0.7 \\
\hline & & Social Programs & 58.23 & Kunar & Educ & & 9 \\
\hline & & & & Logar & Educ & & 2.2 \\
\hline & & & & Nangarhar & Watc & & 27. \\
\hline & & & & NWFP & Relic & atriatioin & 28. \\
\hline & & & & Paktya & Relic & atriatioin & 9.7 \\
\hline & & & & Wardak & Educ & & 4.7 \\
\hline
\end{tabular}

Sub Offices

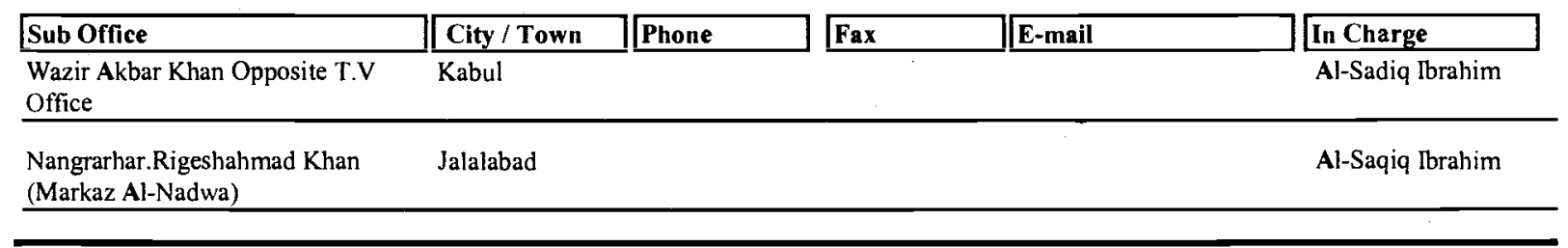




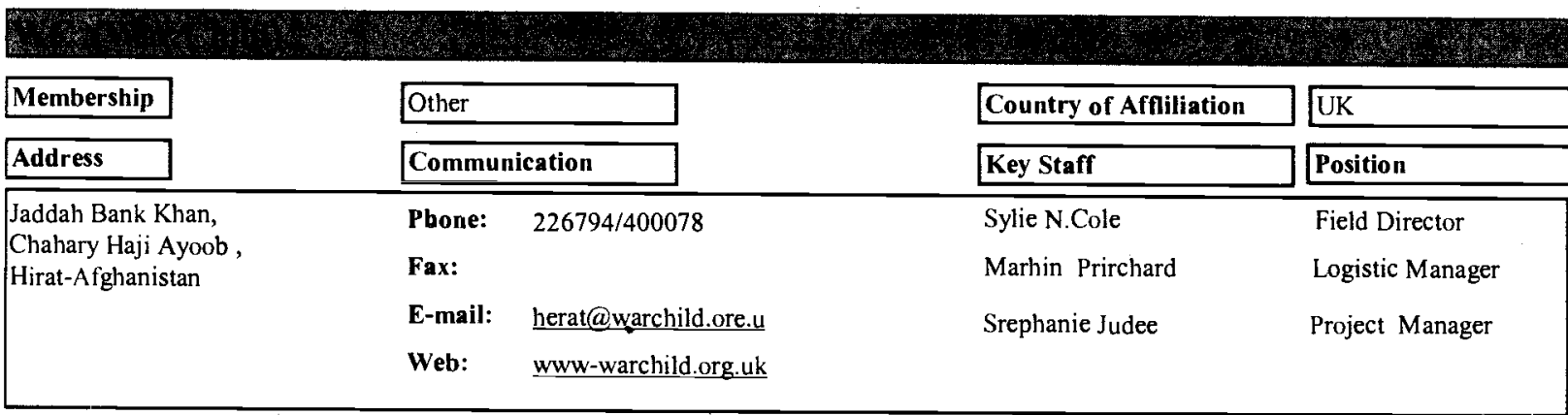

\begin{tabular}{|l|}
\hline Afghan \\
\hline \hline Pakistani \\
\hline \hline Expatriates \\
\hline Total \\
\hline
\end{tabular}

Personnel

Budget In US \$

\begin{tabular}{|l|}
\hline Administrative \\
\hline Support \\
\hline Technical \\
\hline Total \\
\hline
\end{tabular}

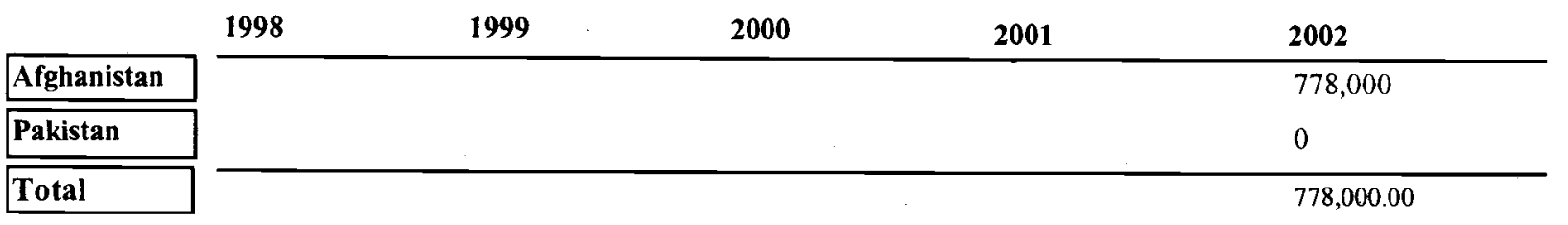

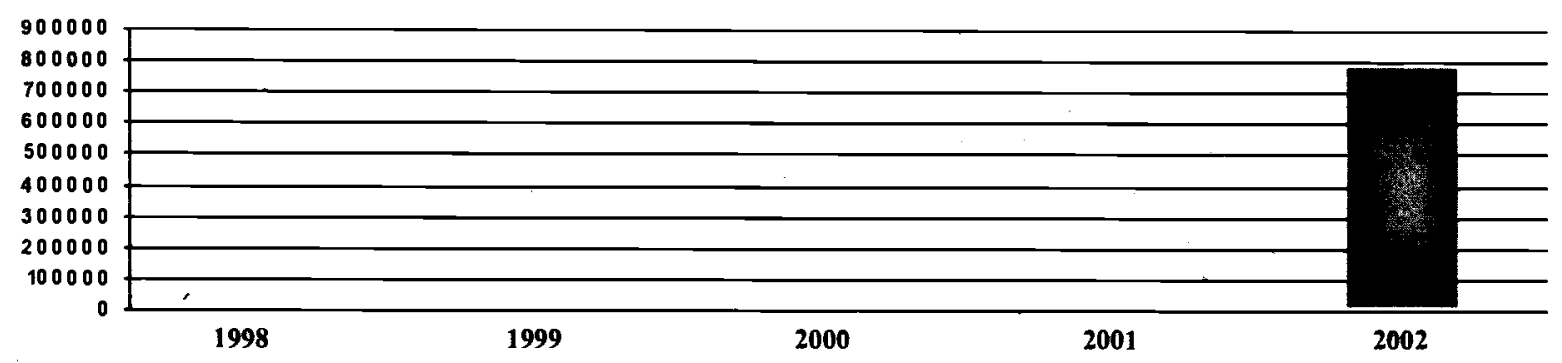

\begin{tabular}{|c|c|c|c|c|c|c|}
\hline \multicolumn{2}{|c|}{ Donors } & & llocation & \multirow[b]{2}{*}{ Province } & \multicolumn{2}{|c|}{ Targeted Provinces } \\
\hline Donors & $\%$ Funded & Allocation & $\%$ Funded & & Sector & $\%$ Targeted \\
\hline ATI & 5.75 & Agriculture & 8 & Hirat & Education & 2 \\
\hline DFID & 85.75 & Emergency & 90 & Hirat & Infrastructure & 1 \\
\hline Private & 4.75 & Infrastructure & 2 & Hirat & Gender Issues & 4 \\
\hline WFP & 3.75 & & & Hirat & Agriculture & 4 \\
\hline & & & & Hirat & Emergency & 85 \\
\hline
\end{tabular}

Sub Offices

\begin{tabular}{|c|c|c|c|c|c|}
\hline Sub Office & City / Town & Phone & Fax & E-mail & In Charge \\
\hline $\begin{array}{l}\text { Punjab.C/O: Goal House } 12 \text { Steet } 39 \\
\text { F 6/1 }\end{array}$ & Islamabad & 03008565854 & & shamid & \\
\hline
\end{tabular}




\begin{tabular}{|c|c|c|c|}
\hline Membership & ANCB & Country of Affiliation & Afghanistan \\
\hline Address & Communication & Key Staff & Position \\
\hline \multirow{4}{*}{$\begin{array}{l}\text { Shash Darak House } 96, \\
\text { Opposite of Bakary, } \\
\text { Kabul-Afghanistan }\end{array}$} & Phone: $\quad 24033$ & Eng.Anar Gul & Director \\
\hline & Fax: & Eng.Ali & Assistant \\
\hline & E-mail: & Mohd.Mahboob & Admin Officer \\
\hline & Web: & & \\
\hline
\end{tabular}

\begin{tabular}{|l|r|}
\hline Afghan \\
\hline \hline Pakistani \\
\hline \hline Expatriates \\
\hline Total \\
\hline
\end{tabular}

Personnel

\begin{tabular}{|l|}
\hline Administrative \\
\hline Support \\
\hline Technical \\
\hline Total \\
\hline
\end{tabular}

12

Budget In US \$

\begin{tabular}{l|lllll} 
& $\mathbf{1 9 9 8}$ & $\mathbf{1 9 9 9}$ & $\mathbf{2 0 0 0}$ & $\mathbf{2 0 0 1}$ & $\mathbf{2 0 0 2}$ \\
\cline { 1 - 3 } Afghanistan & 12,000 & 9,000 & 20,000 & 25,000 \\
\hline Pakistan & 0 & 0 & 0 & 0 \\
\hline Total & 0 & $9,000.00$ & $20,000.00$ & $25,000.00$
\end{tabular}

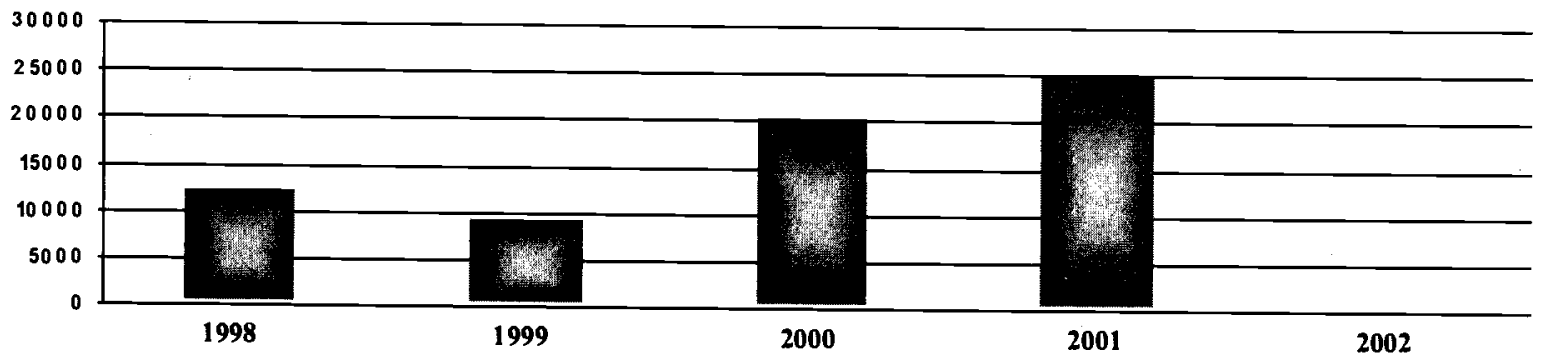

\begin{tabular}{|c|c|c|c|c|c|c|c|}
\hline \multicolumn{2}{|c|}{ Donors } & & llocation & \multirow[b]{2}{*}{ Province } & \multicolumn{3}{|c|}{ Targeted Provinces } \\
\hline Donors & $\%$ Funded & Allocation & $\%$ Funded & & Sector & $\%$ Tar & \\
\hline \multirow{6}{*}{$\begin{array}{l}\text { ICRC } \\
\text { UNHCR } \\
\text { UNICEF }\end{array}$} & & Agriculture & 100 & Nangarhar & Incor & ation & 80 \\
\hline & & Education & 100 & Nangarhar & Infra & & 10 \\
\hline & & Emergency & 90 & Nangarhar & Relie & triatioin & 10 \\
\hline & & Health & 100 & & & & \\
\hline & & Infrastructure & 80 & & & & \\
\hline & & Other & 80 & & & & \\
\hline
\end{tabular}

Sub Offices

\begin{tabular}{|c|c|c|c|c|}
\hline Sub Office & City / Town & Phone & E-mail & In Charge \\
\hline $\begin{array}{l}\text { Nangrarhar.Oppsite of RRD } \\
\text { Departmen }\end{array}$ & Jalal Abad & 2633.2828 & & \\
\hline NWFP.First Street 25 Hayatabad & Pakistan & 813935 & & \\
\hline
\end{tabular}




\begin{tabular}{|c|c|c|c|}
\hline Membership & ANCB & Country of Affiliation & Afghanistan \\
\hline Address & Communication & Key Staff & Position \\
\hline \multirow{4}{*}{$\begin{array}{l}\text { Qala-e-Fatehulla Road, } \\
\text { Across from M.Mostafa Mosque, } \\
\text { Kabul-Afghanistan }\end{array}$} & 070277708 & Eng.Habibulla & Director \\
\hline & Fax: & Eng.M.Farooq & Deputy Director \\
\hline & E-mail: & M.Akbar & Member \\
\hline & Web: & & \\
\hline
\end{tabular}

\begin{tabular}{|l|}
\hline Afghan \\
\hline Pakistani \\
\hline Expatriates \\
\hline Total \\
\hline
\end{tabular}

35

0

0

35

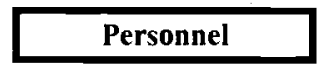

\begin{tabular}{|l|}
\hline Administrative \\
\hline Support \\
\hline Technical \\
\hline Total \\
\hline
\end{tabular}

Budget In US \$

\begin{tabular}{|c|c|c|c|c|c|}
\hline & 1998 & 1999 & 2000 & 2001 & 2002 \\
\hline Afghanistan & & 32,000 & 36,872 & 36,872 & 149,935 \\
\hline Pakistan & & 0 & 0 & 0 & 0 \\
\hline Total & & $32,000.00$ & $36,872.00$ & $36,872.00$ & $149,935.00$ \\
\hline
\end{tabular}

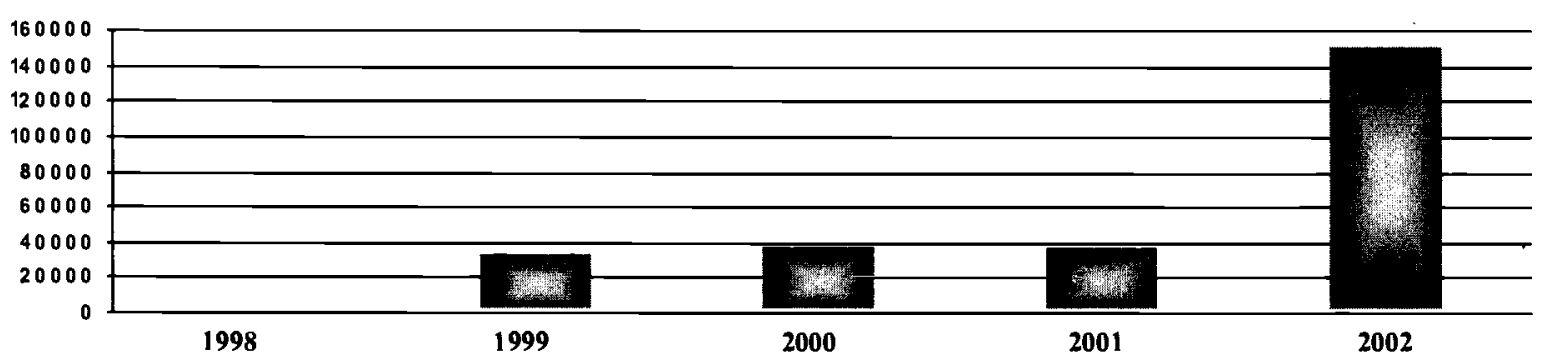

\begin{tabular}{lc}
\multicolumn{2}{c|}{ Donors } \\
\hline Donors & \% Funded \\
\hline CARE / PUI & 100 \\
UNHCR & 100 \\
WFP & 100
\end{tabular}

\begin{tabular}{lc|} 
& \multicolumn{1}{c|}{ Allocation } \\
\hline Allocation & \% Funded \\
\hline Education & 25 \\
Emergency & 25 \\
Environment & 25 \\
Infrastructure & 25
\end{tabular}

Sub Offices

\begin{tabular}{|c|c|c|c|c|}
\hline Sub Office & City / Town & Phone & \begin{tabular}{|l|l|} 
Fax & E-mail \\
\end{tabular} & In Charge \\
\hline Nangarhar.Gulab -Plaza & Nangarhar & & & Shir-Ahmad \\
\hline $\begin{array}{l}\text { Paktia.Gardiz City Back of Civil } \\
\text { Hospital }\end{array}$ & Paktia & & & Gul Ahmad \\
\hline Kapisa.Qala-e-Tawab & Mahmud Raqii & & & M.Haroon \\
\hline Bamiyan.Shibar District & Shibar & & & Eng. Asadulla \\
\hline $\begin{array}{l}\text { Parwan.Shirwan District Bagh r } \\
\text { Afghan }\end{array}$ & Parwan & & & Said Karim \\
\hline Ghazni.Angori & Jaghuri & & & Najibulla \\
\hline
\end{tabular}

\begin{tabular}{llc} 
Province & Sector & \% Targeted \\
\hline Bamyan & Infrastructure & 10 \\
Ghazni & Relief \& Repatriatioin & 10 \\
Kabul & Infrastructure & 10 \\
Kapisa & Relief \& Repatriatioin & 10 \\
Laghman & Relief \& Repatriatioin & 10 \\
Nangarhar & Relief \& Repatriatioin & 10 \\
Paktya & Education & 10 \\
Paktya & Water Resources & 10 \\
Parwan & Infrastructure & 10
\end{tabular}




\begin{tabular}{|c|c|c|c|}
\hline Membership & ANCB & Country of Affliliation & Afghanistan \\
\hline Address & Communication & Key Staff & Position \\
\hline \multirow{4}{*}{$\begin{array}{l}\text { Charhi-e- Ansari Kolala Pushta, } \\
\text { Road 2nd House } 165 \text { Shahre Now, } \\
\text { Kabul-Afghanistan }\end{array}$} & Phone: & Waheeda & Director \\
\hline & Fax: & Sakina & Assistant Director \\
\hline & E-mail: & Ajamal & Finance Officer \\
\hline & Web: & . & \\
\hline
\end{tabular}

\begin{tabular}{|l|}
\hline Afghan \\
\hline Pakistani \\
\hline Expatriates \\
\hline Total \\
\hline
\end{tabular}

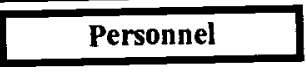

\begin{tabular}{|l|}
\hline Administrative \\
\hline Support \\
\hline Technical \\
\hline Total \\
\hline
\end{tabular}

Total

Budget In US \$

\begin{tabular}{|c|c|c|c|c|c|}
\hline & 1998 & 1999 & 2000 & 2001 & 2002 \\
\hline Afghanistan & 54,390 & 19,678 & 20,152 & 14,231 & 33,406 \\
\hline Pakistan & 0 & 0 & 0 & 0 & 0 \\
\hline Total & $54,390.00$ & $19,678.00$ & $20,152.00$ & $14,231.00$ & $33,406.00$ \\
\hline
\end{tabular}

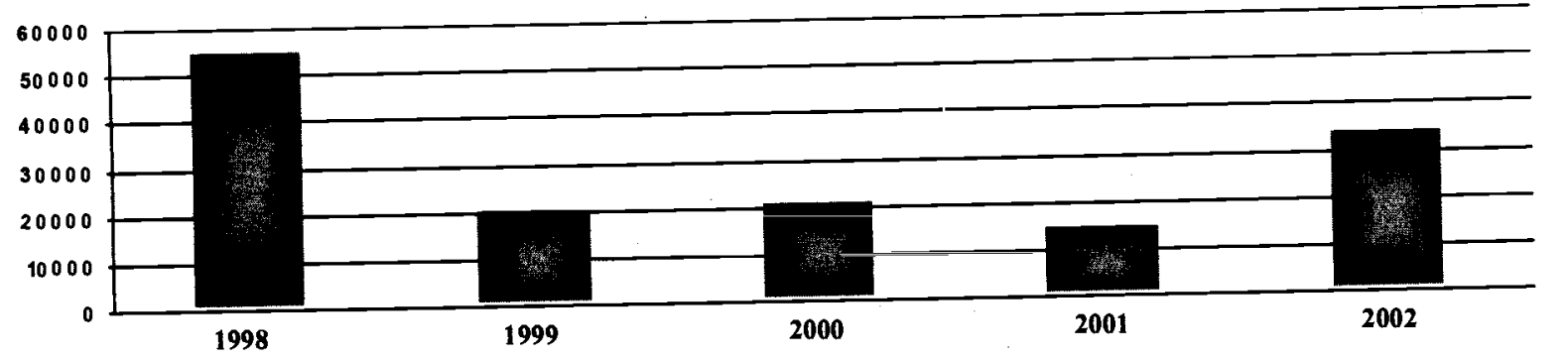

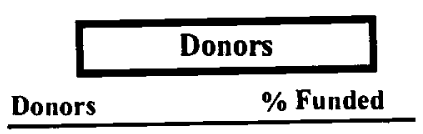

CARE

CARE/RAP

IRC / RAP

Private

\begin{tabular}{lc|}
\hline \multicolumn{2}{c|}{ Allocation } \\
\hline Allocation & \% Funded \\
\hline Agriculture & 6.3 \\
Education & 16.8 \\
Health & 7.2 \\
Income Generatio & 65.2 \\
Relief \& Repatria & 4.5
\end{tabular}

Sub Offices

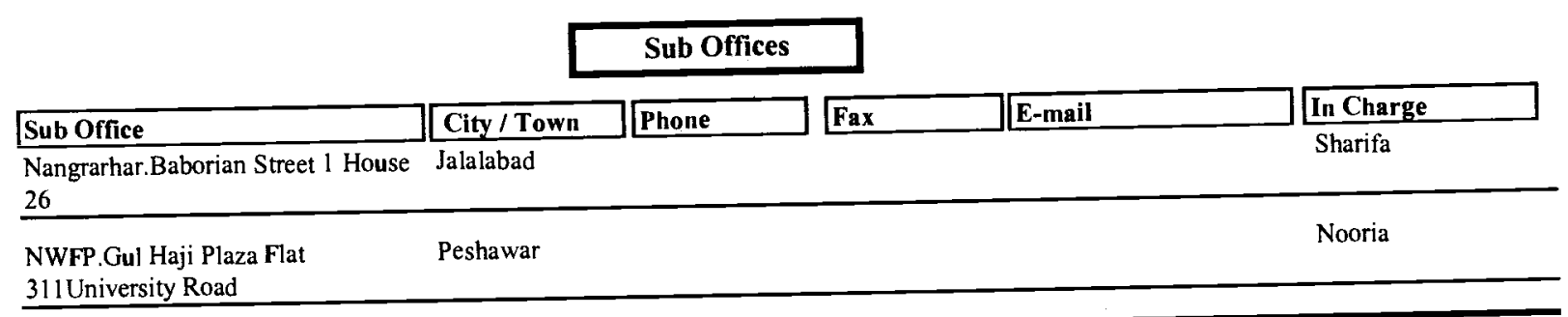

\begin{tabular}{lcc} 
& \multicolumn{2}{c|}{ Targeted Provinces } \\
\cline { 2 - 3 } Province & Sector & \multicolumn{2}{c}{$\%$ Targeted } \\
\hline Laghman & Relief \& Repatriatioin & 6.3 \\
NWFP & Relief \& Repatriatioin & 4.5 \\
NWFP & Health & 7.2 \\
NWFP & Income Generation & 29. \\
Wardak & Education & 16. \\
Wardak & Income Generation & 36
\end{tabular}




\begin{tabular}{|c|c|c|c|}
\hline Membership & ACBAR & Country of Affiliation & Partanership \\
\hline Address & Communication & Key Staff & Position \\
\hline \multirow{4}{*}{$\begin{array}{l}\text { House 1B Taimani St.41, } \\
\text { Kabul-Afghanistan }\end{array}$} & +8737629174469 & Garhan Strong & Operation Director \\
\hline & Fax: & Sabin Vunderber & Program Officer \\
\hline & E-mail: cart-uxe-5@wvi.org & Maroel Noronha & Constraction Officer \\
\hline & Web: & & \\
\hline
\end{tabular}

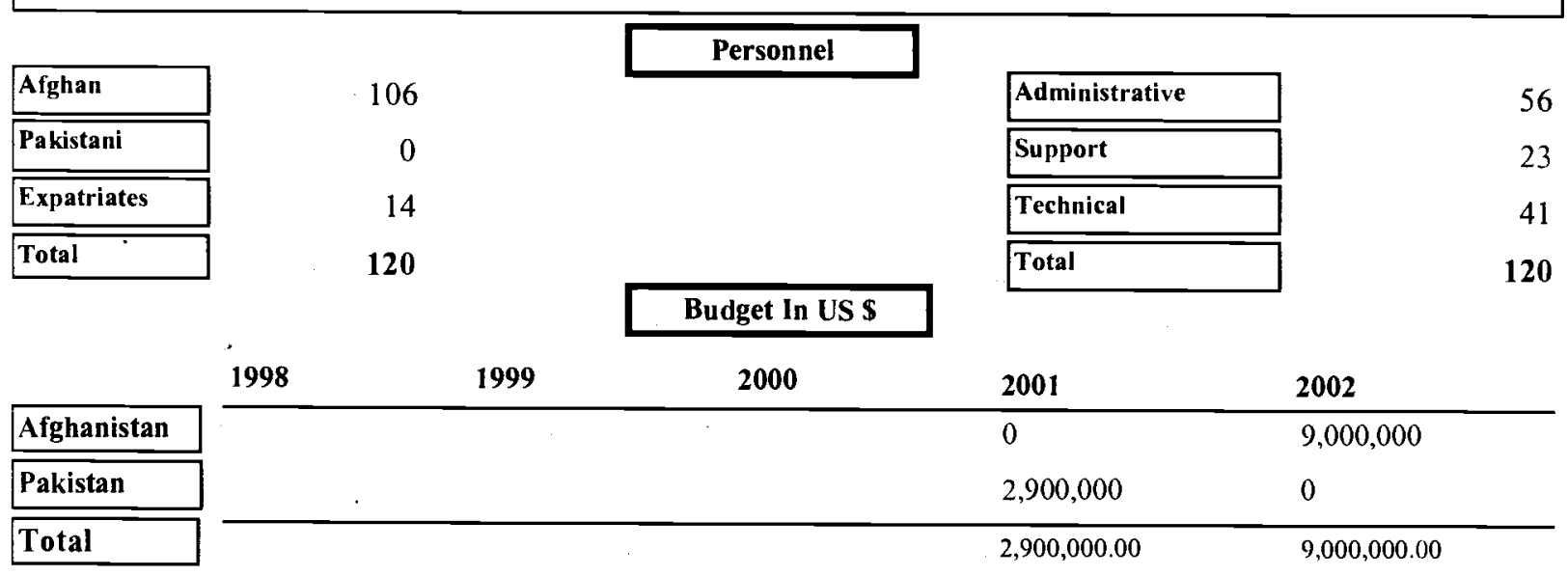

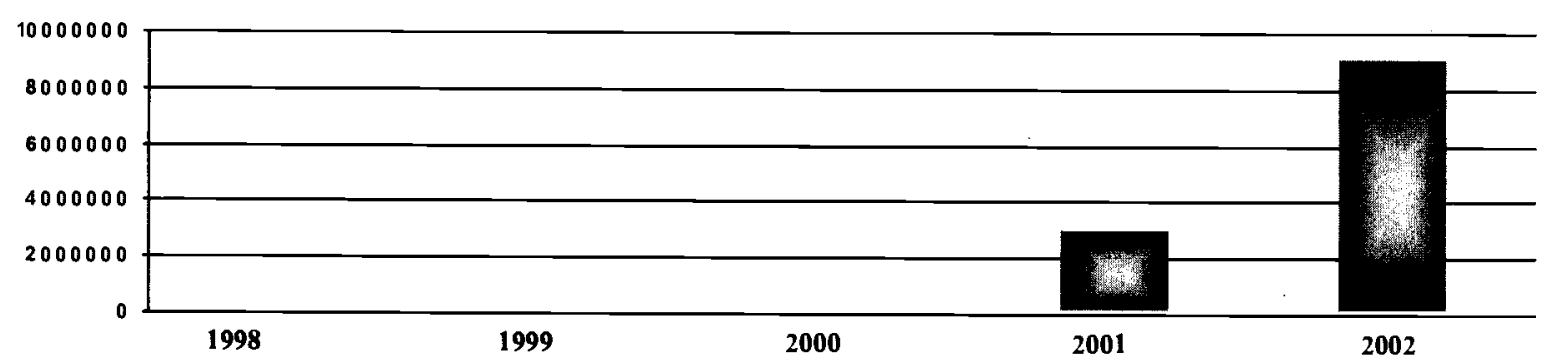

\begin{tabular}{lc}
\multicolumn{2}{c|}{ Donors } \\
Donors & $\%$ Funded \\
\hline Hong kong Gov & 34 \\
Other & 34 \\
UNICEF & 32
\end{tabular}

\begin{tabular}{lc|}
\hline \multicolumn{1}{c|}{ Allocation } \\
Allocation & \% Funded \\
\hline Agriculture & 10 \\
Education & 7 \\
Emergency & 25 \\
Health & 19 \\
Infrastructure & 12 \\
Relief \& Repatria & 27
\end{tabular}

\begin{tabular}{lll} 
& \multicolumn{2}{c|}{ Targeted Provinces } \\
\cline { 2 - 3 } Province & Sector & \% Targeted \\
\hline Badghis & Infrastructure & 1 \\
Badghis & Relief \& Repatriatioin & 7.2 \\
Badghis & Health & 12. \\
Badghis & Agriculture & 8.8 \\
Hilmand & Relief \& Repatriatioin & 3 \\
Hirat & Infrastructure & 4.5 \\
Hirat & Health & 5.2 \\
Hirat & Agriculture & 3.7 \\
Hirat & Relief \& Repatriatioin & 37 \\
Kabul & Infrastructure & 0.5 \\
Kabul & Relief \& Repatriatioin & 0.4 \\
Takhar & Relief \& Repatriatioin & 44
\end{tabular}

\section{Sub Offices}

\begin{tabular}{|c|c|c|c|c|}
\hline Sub Office & City / Town & Phone & E-mail & In Charge \\
\hline Badghis.Qala-Naw Town & Badghis & +873762974559 & & \\
\hline Badghis.Char Taq Town & Badghis & +873762974559 & & \\
\hline
\end{tabular}




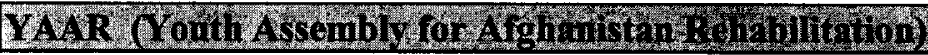

\begin{tabular}{|c|c|c|c|}
\hline Membership & ANCB & Country of Affiliation & Afghanistan \\
\hline Address & Communication & Key Staff & Position \\
\hline \multirow{4}{*}{$\begin{array}{l}\text { Qalai Fatulah St.8, } \\
\text { Kabul-Afghanistan }\end{array}$} & Phone: & Ihsanulah & Exective Director \\
\hline & Fax: & Mina & Admin \\
\hline & E-mail: & & \\
\hline & Web: & & \\
\hline
\end{tabular}

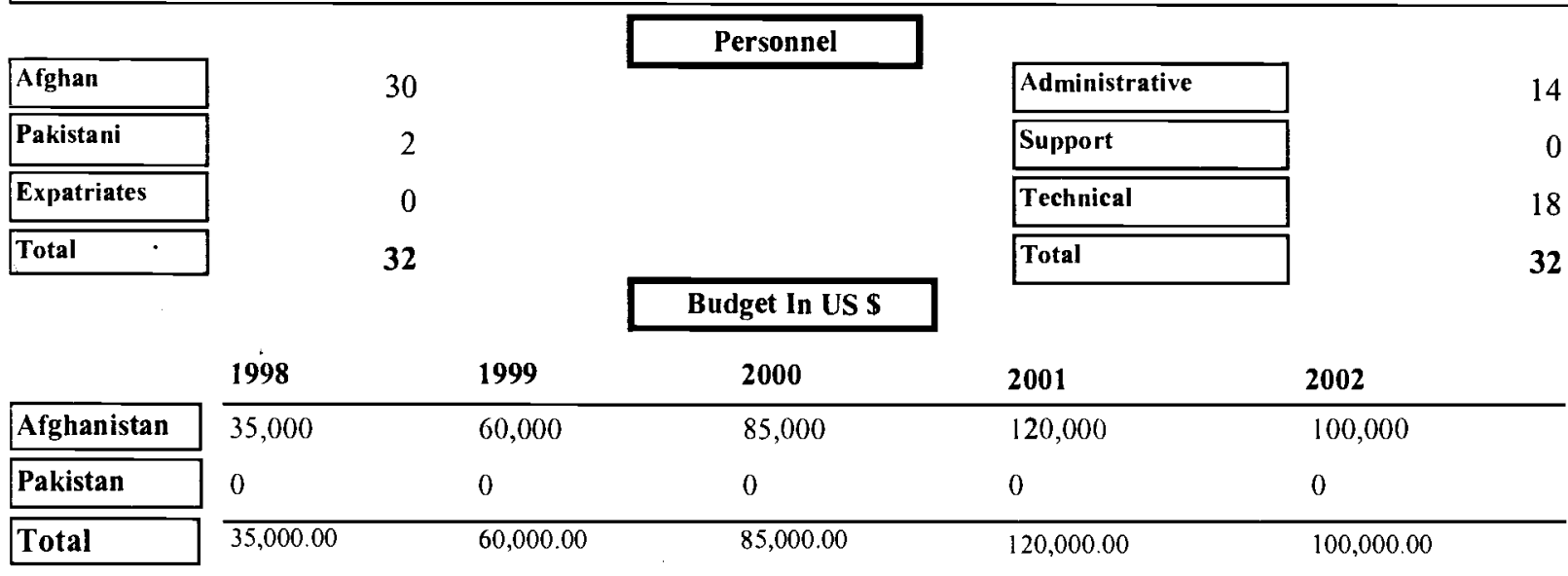

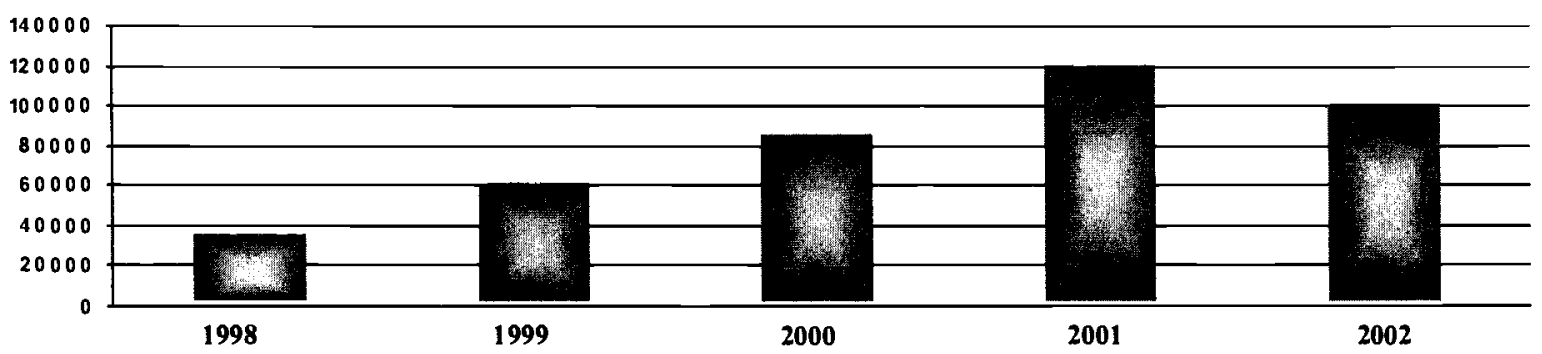

\begin{tabular}{lc|}
\cline { 2 - 2 } \multicolumn{1}{c|}{ Donors } \\
Donors & \% Funded \\
\hline IRC & 10 \\
UNDCP & 10 \\
UNHCR & 40 \\
UNOPS & 10 \\
WFP & 30
\end{tabular}

\begin{tabular}{lc|}
\cline { 2 - 2 } & \multicolumn{2}{c|}{ Allocation } \\
Allocation & \% Funded \\
\hline Agriculture & 10 \\
Education & 10 \\
Emergency & 40 \\
Environment & 5 \\
Gender Issues & 0 \\
Infrastructure & 20
\end{tabular}

\begin{tabular}{lll} 
& \multicolumn{2}{c|}{ Targeted Provinces } \\
\cline { 2 - 3 } Province & Sector & \% Targeted \\
\hline Hirat & Infrastructure & 20 \\
Hirat & Education & 10 \\
Hirat & Agriculture & 20 \\
Hirat & Health & 20 \\
Hirat & Emergency & 30 \\
Nangarhar & Agriculture & 20 \\
Nangarhar & Emergency & 20 \\
Nangarhar & Education & 30 \\
Nangarhar & Relief \& Repatriatioin & 30 \\
NWFP & Health & 30 \\
NWFP & Emergency & 20 \\
NWFP & Education & 50 \\
Paktika & Agriculture & 30 \\
Paktika & Water Resources & 40 \\
Paktika & Emergency & 30
\end{tabular}




\begin{tabular}{|c|c|c|c|c|}
\hline Sub Office & City / Town & Phone & E-mail & In Charge \\
\hline $\begin{array}{l}\text { Pakika.Sharana Near to Governer } \\
\text { House }\end{array}$ & Sharana & & & \\
\hline Nangrarhar.Torkham Stand & Jalalabad & & & Eng.Amir \\
\hline Hirat.Darab Iraq Haidari Azadari & Hirat & 220631 & & $\mathrm{Ab}$ Wahab \\
\hline $\begin{array}{l}\text { NWFP.House } 188 \text { St. } 23 \text { Sector D4 } \\
\text { Hayatabad }\end{array}$ & Peshawar & 817150 & 817150 & H.Shirshah \\
\hline
\end{tabular}




\begin{tabular}{|c|c|c|c|}
\hline Membership & ICVA & Country of Affiliation & Afghanistan \\
\hline Address & Communication & Key Staff & Position \\
\hline \multirow{4}{*}{$\begin{array}{l}\text { 3th Floor Haji Said Plaza, } \\
\text { Talashi Chowk, } \\
\text { JalalAbad - Afghanistan }\end{array}$} & Phone: & Haji Dad Mohd & Managing Director \\
\hline & Fax: & Dr.Said & Key staff \\
\hline & E-mail: & Zai-u-Rahman & Kkey staff \\
\hline & Web: & & \\
\hline
\end{tabular}

\begin{tabular}{|l|r|}
\hline Afghan & 20 \\
\hline \hline Pakistani & 0 \\
\hline \hline Expatriates . & 0 \\
\hline Total & $\mathbf{2 0}$ \\
\hline
\end{tabular}

\section{Personnel}

\begin{tabular}{|l|}
\hline Administrative \\
\hline Support \\
\hline Tecbnical \\
\hline Total \\
\hline
\end{tabular}

Budget In US S

\begin{tabular}{l|lllll}
\multicolumn{1}{l}{} & $\mathbf{1 9 9 8}$ & $\mathbf{1 9 9 9}$ & $\mathbf{2 0 0 0}$ & $\mathbf{2 0 0 1}$ & $\mathbf{2 0 0 2}$ \\
\cline { 1 - 5 } Afghanistan & 50,000 & 80,000 & 50,000 & 40,000 & 30,000 \\
\cline { 1 - 3 } & 0 & 0 & 0 & 0 & 0 \\
\hline Pakistan & 0 & $80,000.00$ & $50,000.00$ & $40,000.00$ & $30,000.00$
\end{tabular}

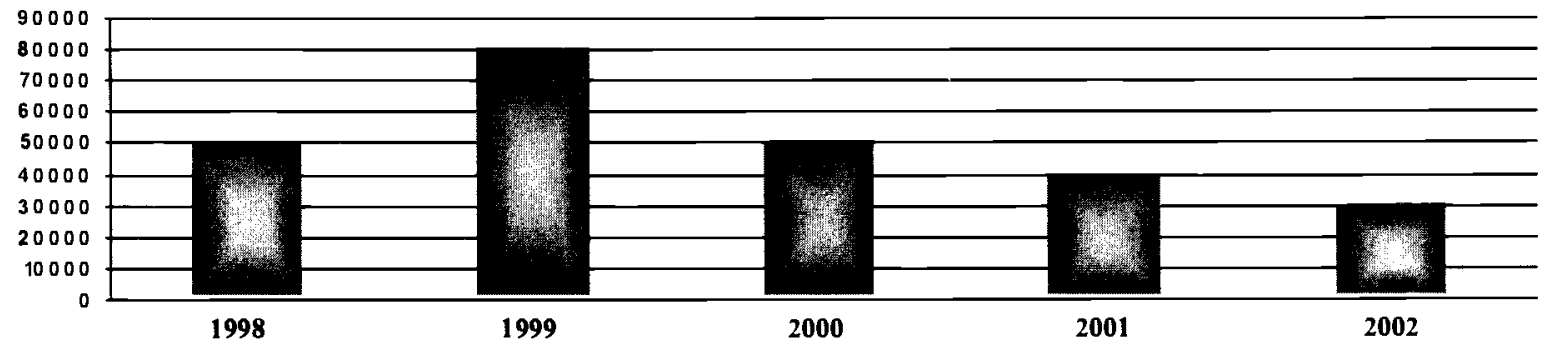

\begin{tabular}{|c|c|c|c|c|c|c|}
\hline \multicolumn{2}{|c|}{ Donors } & & llocation & \multirow[b]{2}{*}{ Province } & \multicolumn{2}{|c|}{ Targeted Provinces } \\
\hline Donors & $\%$ Funded & Allocation & $\%$ Funded & & Sector & $\%$ Targeted \\
\hline CIDA & 10 & \multicolumn{2}{|l|}{ Agriculture } & Bamyan & \multicolumn{2}{|c|}{ Agriculture } \\
\hline DIFID & 10 & \multicolumn{2}{|l|}{ Education } & Hirat & \multicolumn{2}{|c|}{ Agriculture } \\
\hline FAO & 40 & \multicolumn{2}{|l|}{ Emergency } & Kabul & \multicolumn{2}{|c|}{ Infrastructure } \\
\hline Health Net & 5 & \multirow{2}{*}{\multicolumn{2}{|c|}{ Health }} & Laghman & \multicolumn{2}{|c|}{ Agriculture } \\
\hline UNDP & 5 & \multirow{2}{*}{\multicolumn{2}{|c|}{ Income Generatio }} & 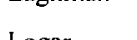 & \multirow{2}{*}{\multicolumn{2}{|c|}{ Agriculture }} \\
\hline UNOCHA & 5 & & & Logar & & \\
\hline UNOPS & 20 & \multicolumn{2}{|c|}{ Infrastructure } & Nangarhar & \multicolumn{2}{|c|}{ Agriculture } \\
\hline WFP & 5 & & & Paktia & Infra & \\
\hline
\end{tabular}

Sub Offices

\begin{tabular}{|c|c|c|c|c|}
\hline Sub Office & City / Town & Phone & E-mail & In Cbarge \\
\hline Laghman.Mihtarlam City & Mihtarlam & & & \\
\hline Kabul Wazir Akber Khan Street 15 & Kabul & 61484 & & \\
\hline Kandahar Chowk-e-Shaheedan & Kandahar & & & \\
\hline $\begin{array}{l}\text { Ghazni. 2nd Floor Jaghuri Hotel } \\
\text { Ghazni }\end{array}$ & Ghazni & & & \\
\hline
\end{tabular}

(Ghaznt 
YRO (Yama Rehabilitacion Organivation)

\begin{tabular}{|c|c|c|c|}
\hline Membership & Other & Country of Affliliation & UN \\
\hline Address & Communication & Key Staff & Position \\
\hline \multirow{4}{*}{$\begin{array}{l}\text { Mazar City Qawmy Market, } \\
\text { Mazar-Afghanistan }\end{array}$} & $40577 / 40516$ & Eng.A.Matin & Director \\
\hline & Fax: & Eng.A.Bashir & Site Engineer \\
\hline & E-mail: & Eng.Fawad & Site Engineer \\
\hline & Web: & & \\
\hline
\end{tabular}

\begin{tabular}{|l|}
\hline Afghan \\
\hline Pakistani \\
\hline Expatriates \\
\hline Total \\
\hline
\end{tabular}

Personnel

Budget In US \$

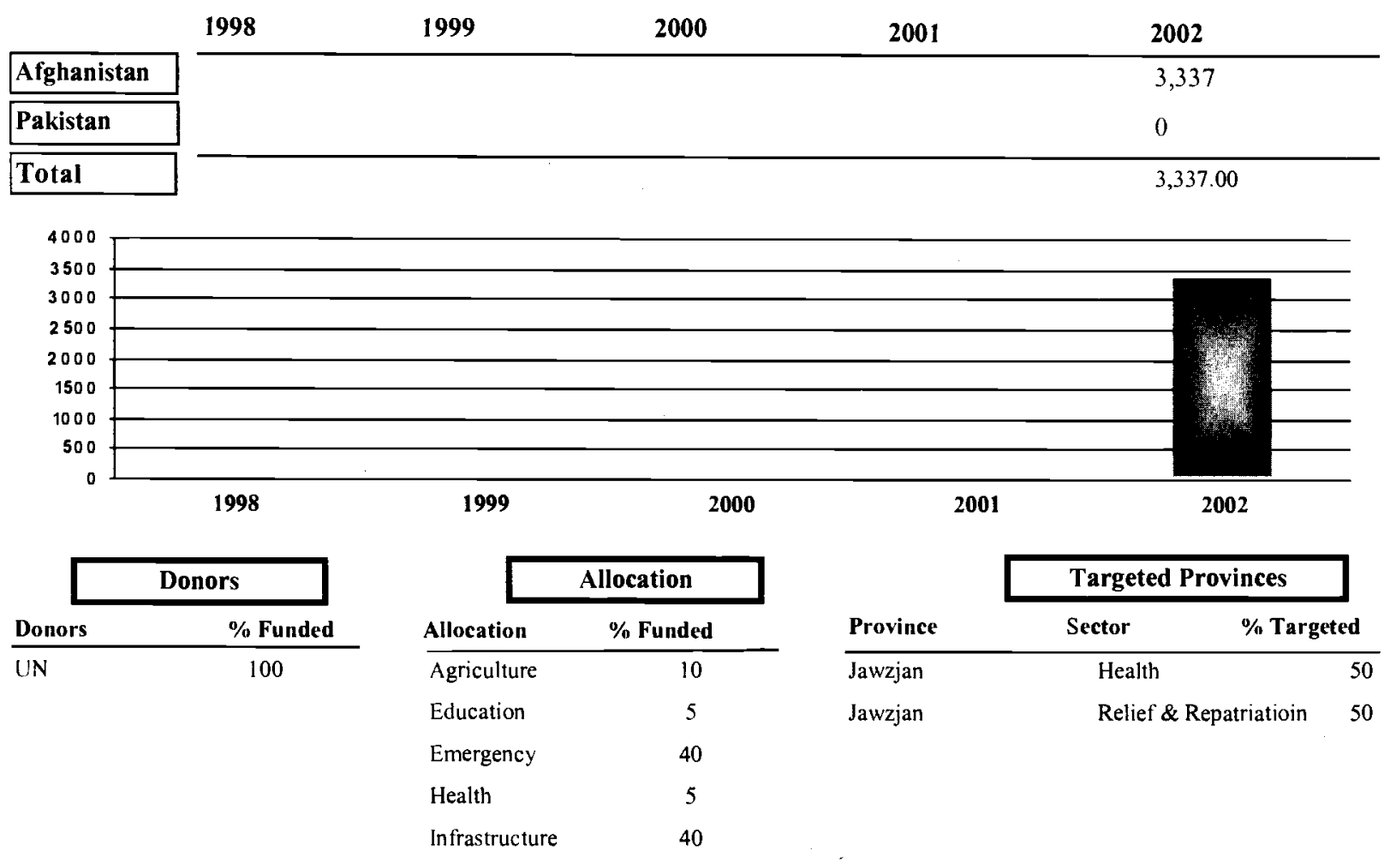

\section{Sub Offices}

\begin{tabular}{|l|l|l|l|l|l|l|l|l|l|}
\hline Sub Office & City / Town & Phone \\
\hline
\end{tabular}

Jawzjan.Shibirghan Yaka Bagh Shibirghan

Street 


\begin{tabular}{|c|c|c|c|}
\hline Membership & [ & Country of Affliliation & Afghanistan \\
\hline Address & Communication & Key Staff & Position \\
\hline \multirow{4}{*}{$\begin{array}{l}\text { Karte-Se Main Road, } \\
\text { Kabul-Afghanistan }\end{array}$} & \multirow{2}{*}{$\begin{array}{l}\text { Phone: } \\
\text { Fax: } \quad 051-2204073\end{array}$} & Edda Dohm & Head \\
\hline & & & \\
\hline & \multicolumn{2}{|l|}{ E-mail: } & \\
\hline & \multicolumn{3}{|l|}{ Web: } \\
\hline & \multirow[b]{2}{*}{6} & & \\
\hline Afghan & & Administrative & \\
\hline Pakistani & 1 & Support & \\
\hline Expatriates & 1 & Technical & \\
\hline Total & 8 & $\longdiv { \text { Total } }$ & \\
\hline
\end{tabular}

\begin{tabular}{|lllll}
\multicolumn{1}{l}{} & $\mathbf{1 9 9 8}$ & $\mathbf{2 0 0 0}$ & $\mathbf{2 0 0 1}$ & $\mathbf{2 0 0 2}$ \\
\cline { 1 - 3 } & & $\mathbf{1 9 9 8}$ & 20,000 & \\
\hline Afghanistan & 30,000 & 0 & \\
\hline Pakistan & 0 & $20,000.00$ &
\end{tabular}
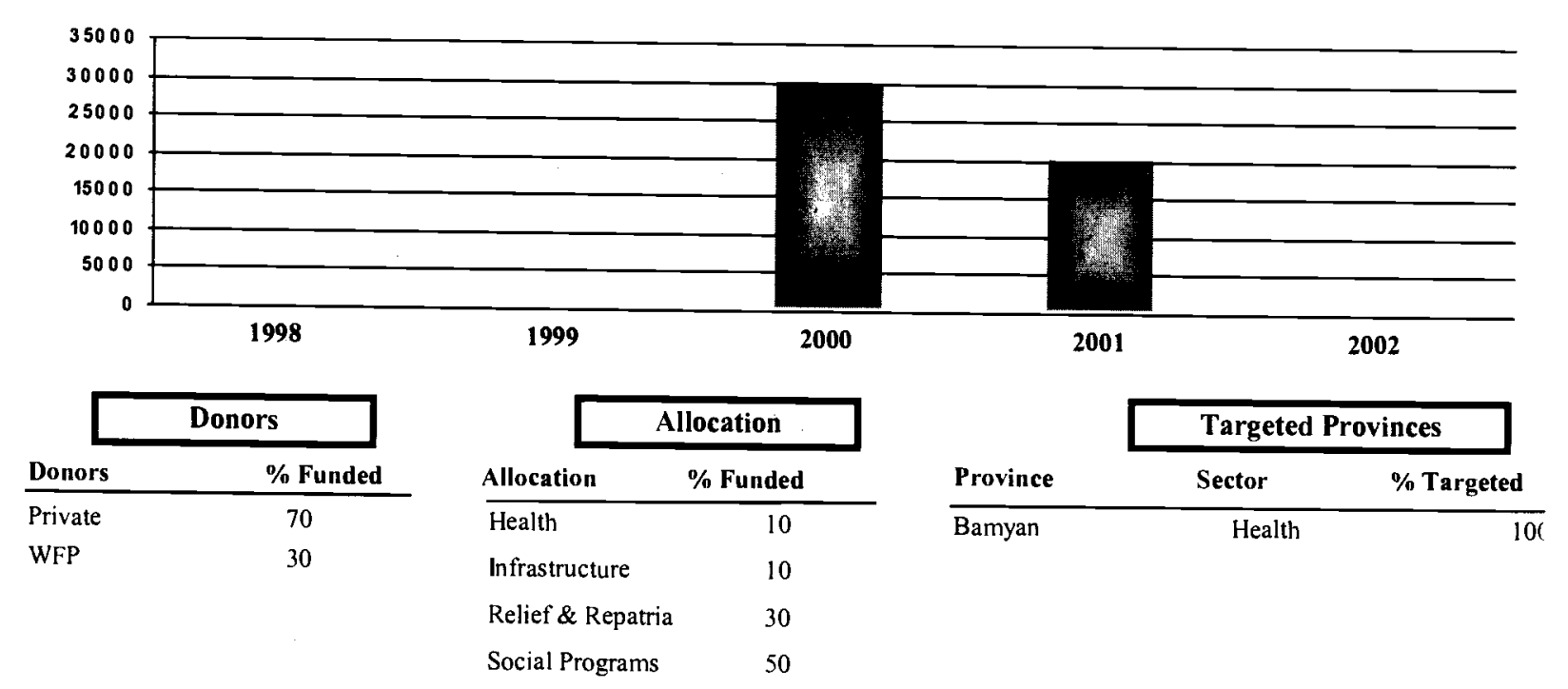

\begin{tabular}{|c|c|c|c|c|c|}
\hline & & Sub Offices & & & \\
\hline Sub Office & City / Town & Phone & Fax & E-mail & In Charge \\
\hline $\begin{array}{l}\text { Islamabad G } 7 / 2-4 \quad 149 \text { Chenab } \\
\text { Road }\end{array}$ & Islamabad & 2204375 & 2204073 & & Dohm \\
\hline
\end{tabular}




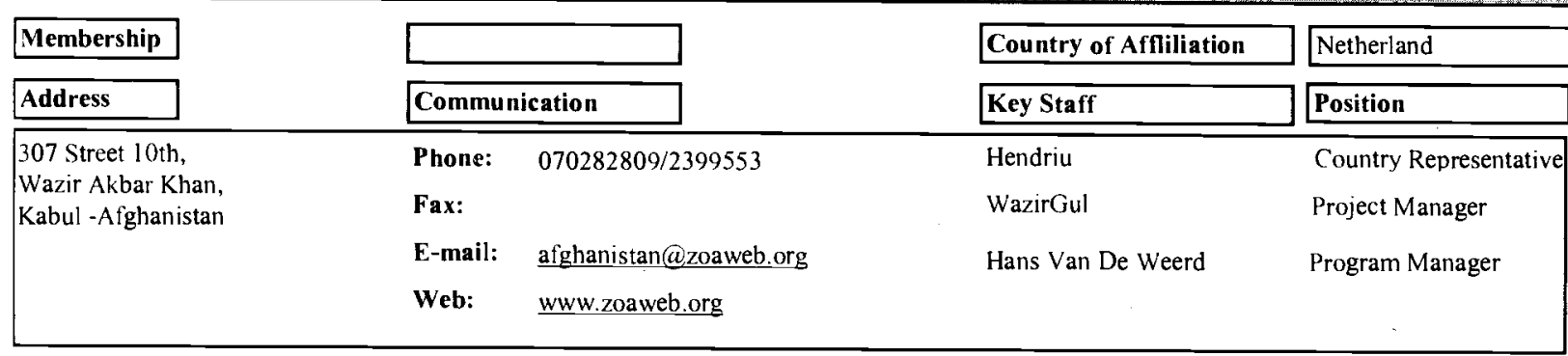

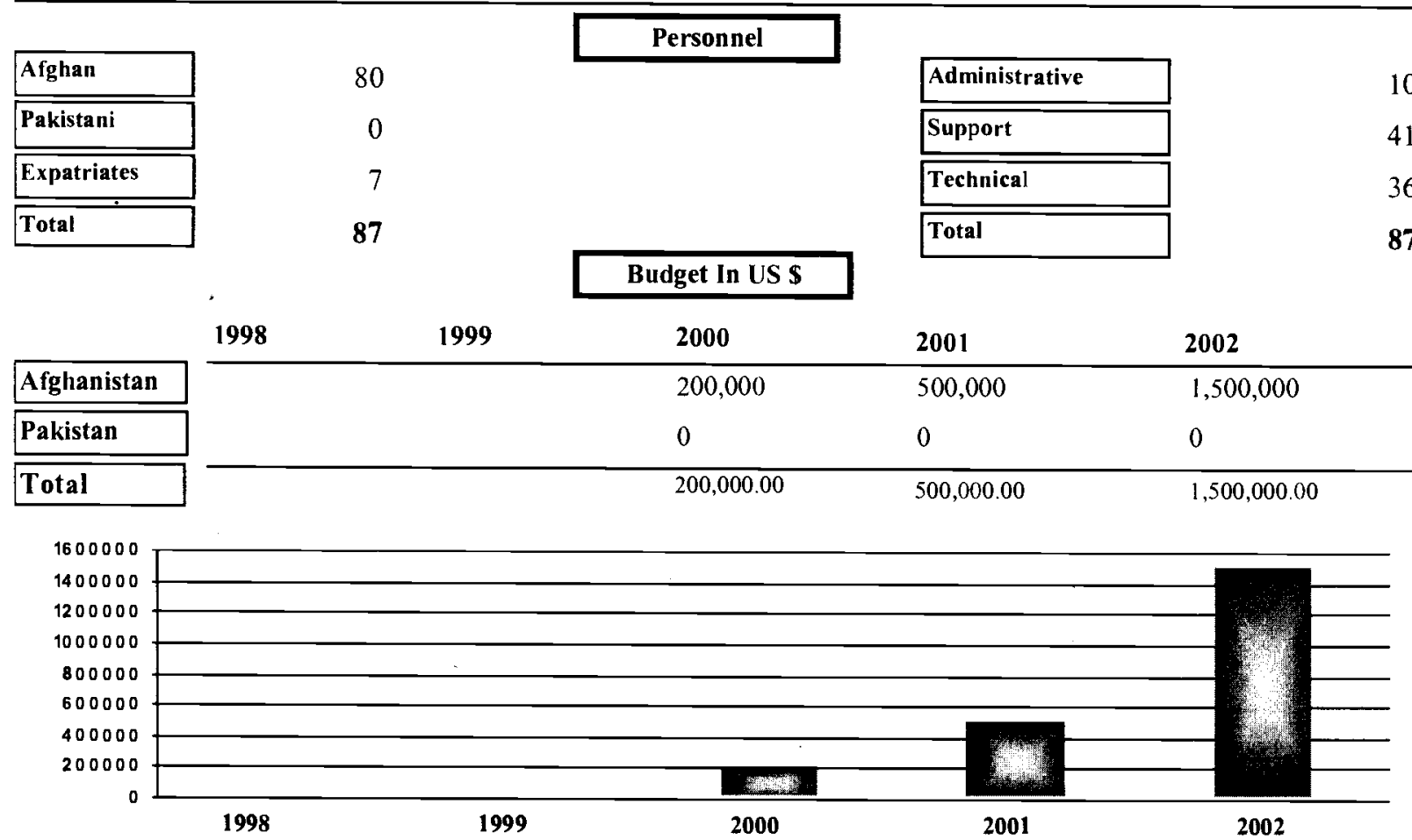

\begin{tabular}{|c|c|c|c|c|c|c|c|c|}
\hline \multirow{2}{*}{\multicolumn{2}{|c|}{\begin{tabular}{|c|}
\multicolumn{1}{|c|}{ Donors } \\
Donors \\
\end{tabular}}} & \multicolumn{3}{|c|}{ Allocation } & & \multicolumn{2}{|c|}{ Targeted Provinces } & \\
\hline & & Allocation & \multicolumn{2}{|c|}{$\%$ Funded } & Province & Sector & \multicolumn{2}{|c|}{$\%$ Targeted } \\
\hline CFGB & 7.5 & \multicolumn{2}{|c|}{ Agriculture } & 20 & Kabul & \multicolumn{2}{|c|}{ Water Resources } & 20 \\
\hline CRWRC & 7.5 & \multicolumn{2}{|l|}{ Health } & 15 & kabul & \multicolumn{2}{|c|}{ Relief \& Repatriatioin } & 15 \\
\hline Tear Fund & 5 & \multicolumn{2}{|c|}{ Income Generatio } & 10 & Kabul & \multicolumn{2}{|c|}{ Income Generation } & 10 \\
\hline $\begin{array}{l}\text { UNAMA } \\
\text { UNHCR }\end{array}$ & $\begin{array}{l}20 \\
35\end{array}$ & \multicolumn{2}{|c|}{ In frastructure } & 20 & Kabul & \multicolumn{2}{|c|}{ Health Care } & 15 \\
\hline W \& D & 10 & \multicolumn{2}{|c|}{ Relief \& Repatria } & 15 & Kabul & \multicolumn{2}{|c|}{ Infrastructure } & 20 \\
\hline \multirow[t]{8}{*}{ ZOA/CORD } & 15 & \multicolumn{2}{|c|}{ Water Resources } & 20 & Kabul & \multicolumn{2}{|c|}{ Agriculture } & 20 \\
\hline & & & & & Sari Pul & \multicolumn{2}{|c|}{ Relief \& Repatriatioin } & 15 \\
\hline & & & & & Sari Pul & Wat & r Resources & 20 \\
\hline & & & & & Pul & Ince & ne Generation & 10 \\
\hline & & & & & Pul & Hea & & 15 \\
\hline & & & & & & Infr & structure & 20 \\
\hline & & & & & Pul & Agr & :ulture & 20 \\
\hline & & & Sub O & ices & & & & \\
\hline Sub Office & & City / Town & Phone & & E-mail & & In Charge & \\
\hline $\begin{array}{l}\text { NWFP.28th } \\
\text { Town } \\
\end{array}$ & Road University & Peshawar & 841663 & & zoapesh & net.pk & Sabour & \\
\hline Balkh & & Mazar & +87376 & 177546 & & & Hans Van De & \\
\hline
\end{tabular}

